Wendelin BITZAN

\title{
The Sonata as an Ageless Principle
}

Nikolai Medtner's Early Piano Sonatas:

Analytic Studies on their Genesis, Style, and Compositional Technique

\section{Dissertation}

in Partial Fulfillment of the Requirements for the Academic Degree of

Doctor of Philosophy (PhD)

Doctoral Programme in Musicology

University of Music and Performing Arts Vienna

Department of Musicology and Performance Studies

Advisor

Univ.-Prof. Mag. Dr. Martin Eybl

Co-advisor

Prof. Dr. Christoph Flamm, Musikhochschule Lübeck

Vienna 2018 
For Xenia,

who means everything to me 
i $\quad$ Preface

ii $\quad$ Outline of the Topic and Basic Ideas...................................................................................

ii.i Sources and Preconditions of Research ..................................................................

ii.ii Goals and Methods of Approach ..............................................................................

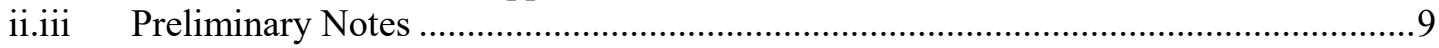

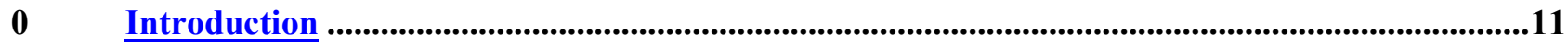

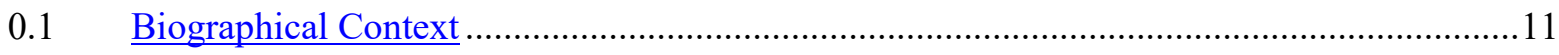

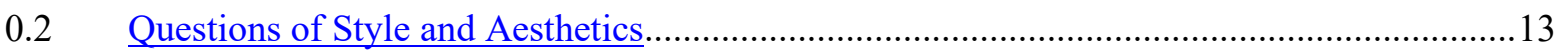

$0.2 .1 \quad$ Between Tradition and Modernism..........................................................................14

0.2 .2 National Identity …………………………………………………………….... 16

0.2.3 Symbolism and Russian Silver Age ................................................................21

$1 \quad$ The Sonata: Tradition and Innovation..........................................................................................27

$1.1 \quad$ European Piano Sonatas after Beethoven ……………………………………………....28

1.1.1 Sonata Hybrids and the Fantasy Idea .......................................................................30

1.1.2 Single-Movement Sonata Form ……………………………………………….. 31

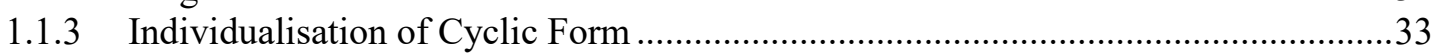

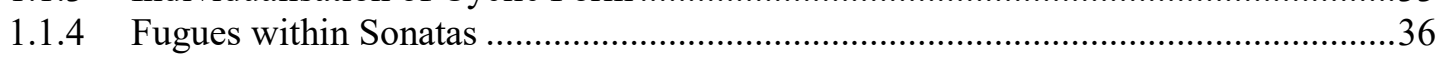

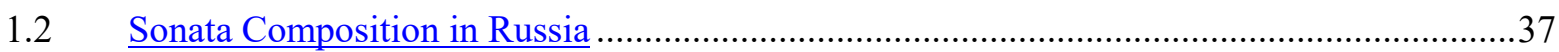

1.2.1 Russian Piano Sonatas ............................................................................................

1.2.2 Introductions to Individual Works .........................................................................4

1.2.3 Chamber and Orchestral Music..........................................................................49

$1.3 \quad$ Theories of Sonata Form: A Short Backview …………………………………………..55

1.3.1 European and North American Concepts................................................................58

1.3.2 Russian Music Theory ………………………………………………………….63

1.3.3 Sonata Form as Narrative and Drama ……………………………………………...69

$2 \quad$ Features of Medtner's Musical Language.........................................................................................73

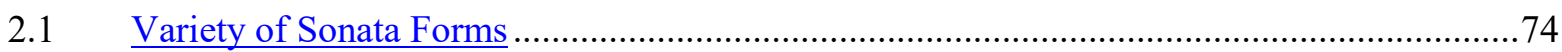

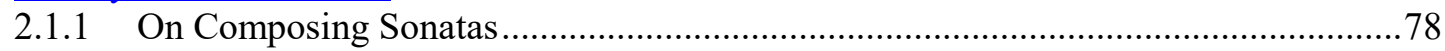

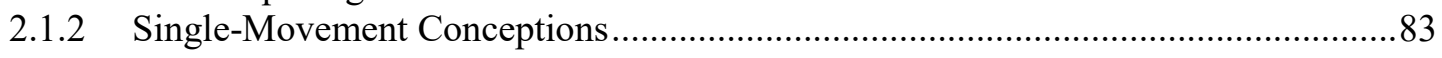

2.1.3 Monothematic Approaches ………………………………………………………85

2.1.4 Quaternary Sonata Form ..................................................................................... 87

2.1.5 Cyclic Form and Cross-Movement Relation...........................................................

2.2 Melodic Invention and Development............................................................................92

2.2.1 General Traits of Melody ...........................................................................92

2.2.2 Scales and Modes...................................................................................................94

2.2.3 Aspects of Meter and Rhythm .....................................................................................

2.2.4 Syntax and Construction of Themes ................................................................. 100

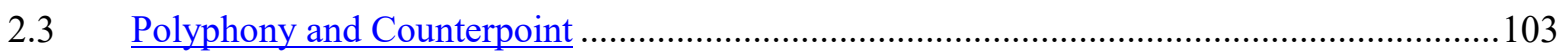

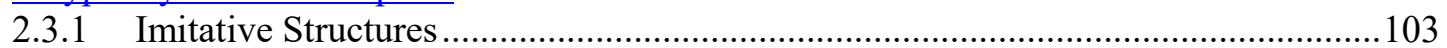

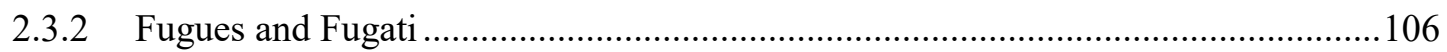

2.3.3 Invertible Counterpoint......................................................................................... 107

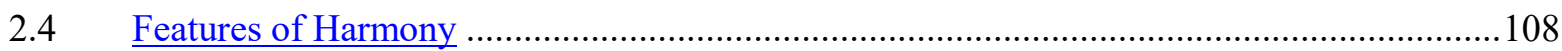

2.4.1 Particular Harmonic Functions …………………………………………………....108

2.4.2 Non-functional Progressions....................................................................................111

2.4.3 Harmonic Cycles and Schemata ............................................................................112

2.4.4 Design of Final Cadences .......................................................................................116

2.4.5 Key Semantics ............................................................................................. 118 


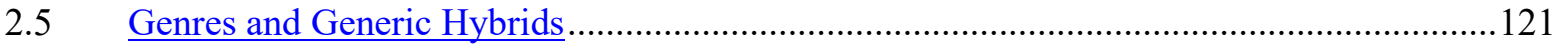

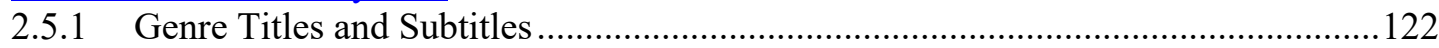

2.5.2 Musical Storytelling: The Skazki .................................................................... 124

2.5.3 Classification of Generic Hybrids .......................................................................125

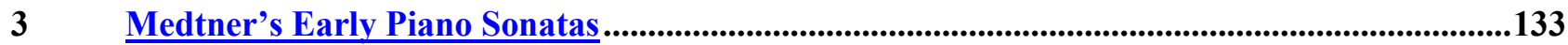

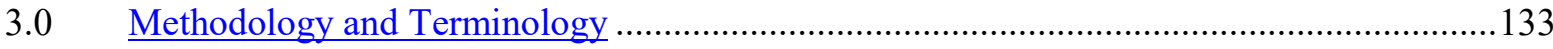

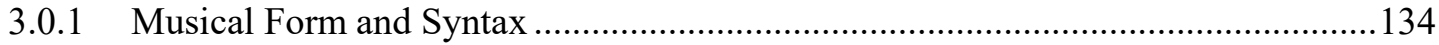

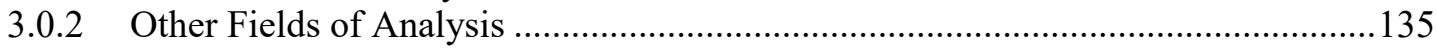

3.1 A Spiritual Organism in Music: Sonata in F minor, Op. 5 ….........................................136

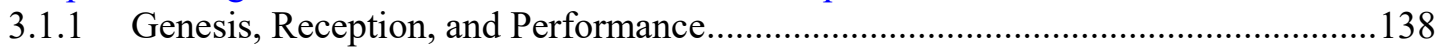

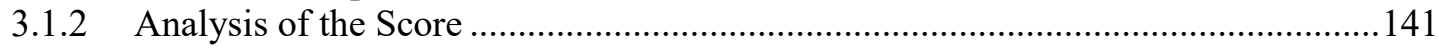

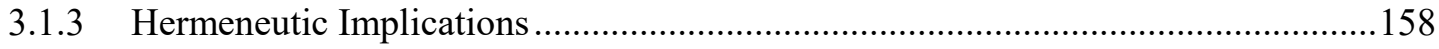

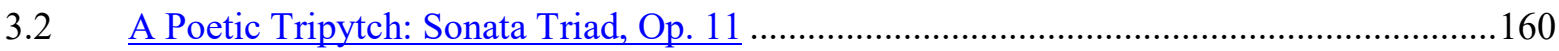

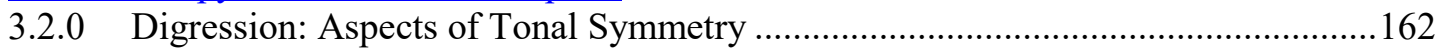

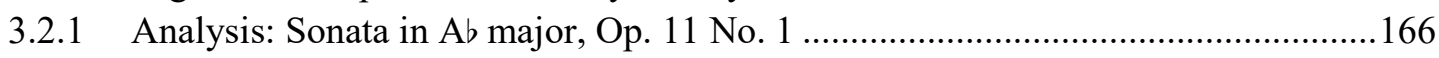

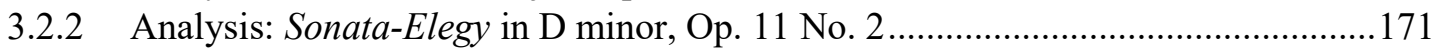

3.2.3 Analysis: Sonata in C major, Op. 11 No. 3 …....................................................... 178

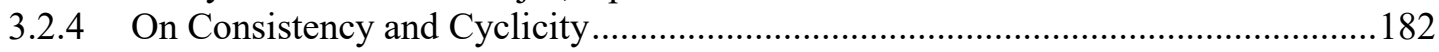

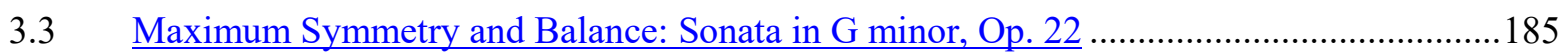

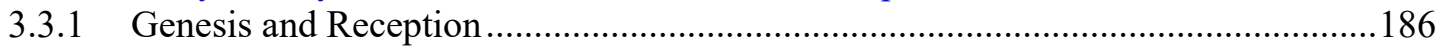

3.3.2 Digression: Tonal Symmetry and Architectural Balance.........................................190

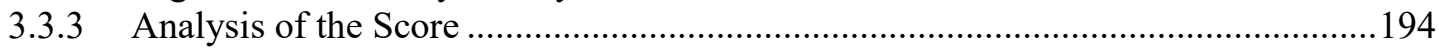

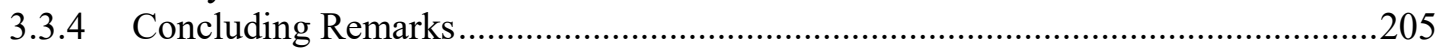

3.4 Narrative Tone, Ambiguous Structure: Sonata-Skazka in C minor, Op. 25 No. 1 ...............207

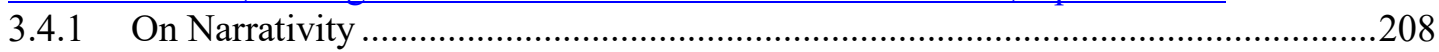

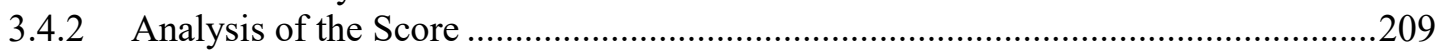

3.4.3 On Hybridity and Cyclicity ....................................................................2. 218

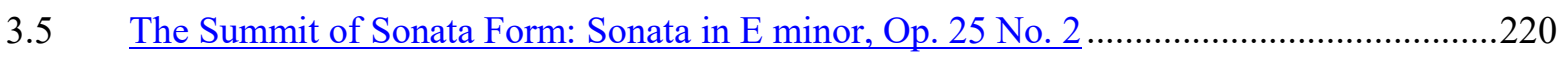

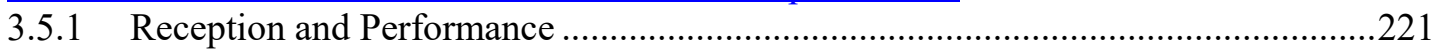

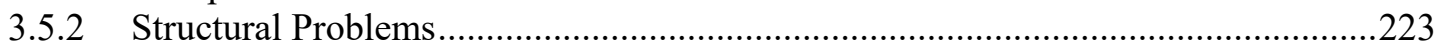

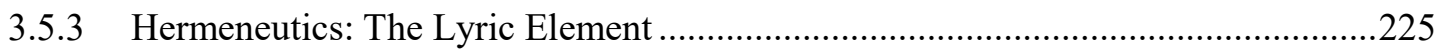

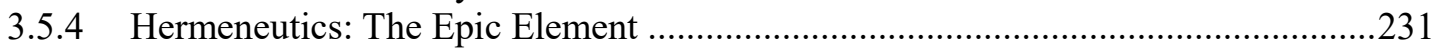

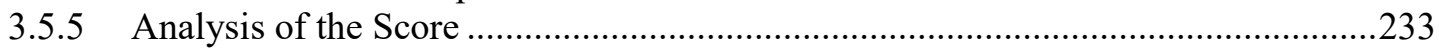

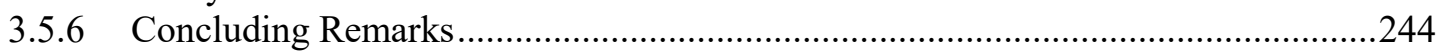

3.6 A Milestone of Symbolist Music: Sonata-Ballade in F\# major, Op. 27 ................................246

3.6.1 The Score on its Own..........................................................................................248

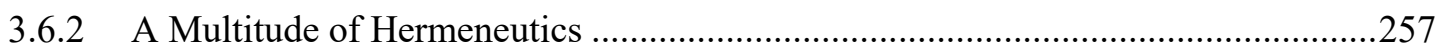

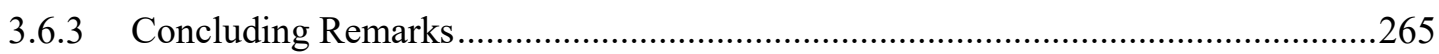

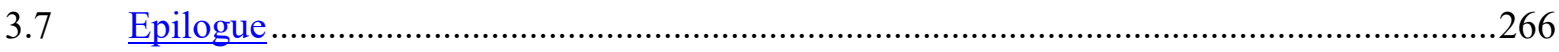

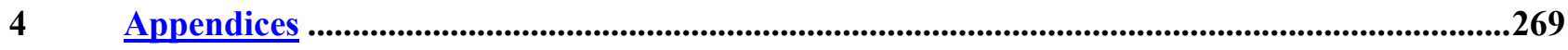

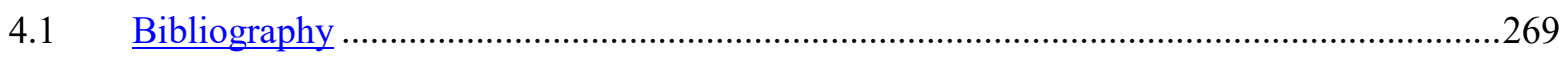

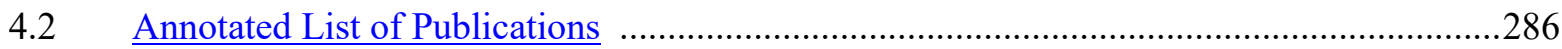

4.2.1 The Sonatas: Analysis and Musical Comment.......................................................286

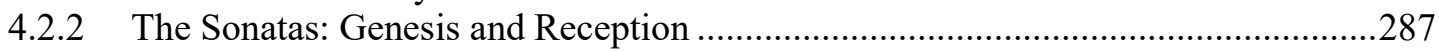

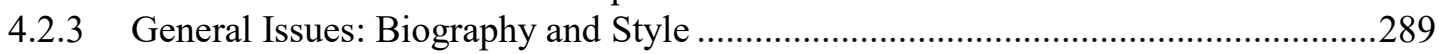

4.2.4 Encyclopedic Texts, Discography, Bibliography................................................291

4.2.5 Others of Medtner's and Other Composers' Works .............................................292

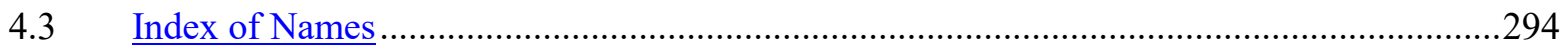

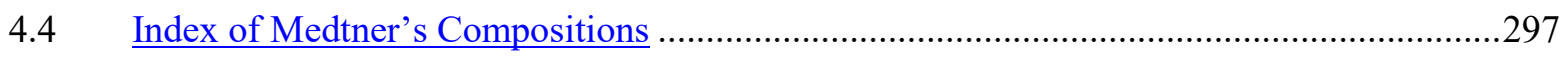

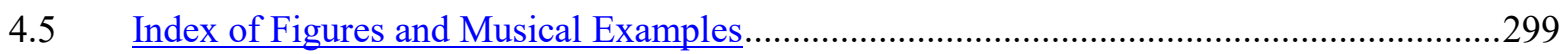


"Otzhivayut ne formï, a skhemï." (»It is not musical forms which obsolesce, but schemes.") — Nikolai Medtner in a letter to Alfred and Ekaterina Swan, 1933

Why Sonatas? - This crucial question needs to be posed at the start of an examination dedicated to early$20^{\text {th }}$-century music, relating the subject to cultural and historiographic perspectives. The sonata, as a genre and musical form, has been the predominant paradigm of Viennese Classicism, generating outstanding results on the fields of orchestral, chamber and piano music, and even having considerable impact on vocal composition. As a central formal vehicle of instrumental music, the sonata remained the foremost point of reference in composition throughout the $19^{\text {th }}$ century, regardless of new developments such as the fantasy, the symphonic poem and, in piano and chamber music, the increasing importance of miniature and aphorism. This, however, significantly changed during the first decades of the $20^{\text {th }}$ century. In the course of emerging >Modernist $\iota$ tendencies in music, composing sonatas was widely abandoned in Western Europe during the first half of the $20^{\text {th }}$ century - with a few notable exceptions, such as Paul Hindemith, Erwin Schulhoff, and Ernst Křenek, and with some composers, like Richard Strauss or Igor Stravinsky, making only brief reference to the genre during their early years. Meanwhile, the sonata continued to prevail and flourish in Soviet Russia, forming a somewhat self-contained space which had composers adhere to the traditional models for ideological reasons. After 1945, some avant-garde composers, such as Pierre Boulez, Bernd Alois Zimmermann, György Ligeti, and Michael Tippett, occasionally turned back to composing sonatas. However, the sonata never regained the fundamental significance it had enjoyed during the $18^{\text {th }}$ and $19^{\text {th }}$ centuries; and the few instances of its use during the past decades have tended to employ the genre independently from its history.

Musical culture is, like other disciplines of art, coined through the aesthetic interaction of form and content, the relationship of which has been subject to permanent change over time. Hence composers, when making decisions on the titles, genres, and forms of their creative output, can choose from a large variety of options. They associate their work with the historical backgrounds and semantics of these categories, andconsciously or not - place it within aesthetical, social, and political frameworks. The choice of a musical genre implies a superordinate cultural and narrative dimension: Once a composition is named a sonata, it relates to both the history of this genre and its current contexts and perspectives in artistic production, performance, and reception.

Since musical genres have always been subject to zeitgeist and fashion, they may become nearly extinct in the course of music history (which has happened, for instance, to the Renaissance madrigal or the thoroughbass vocal duet), with the possibility of being reanimated later. The sonata, though, has not >died out<, despite the aforementioned loss of relevance during the first half of the $20^{\text {th }}$ century, and it never completely disappeared from contemporary composers' catalogues of works. Instead of falling into oblivion, the sonata genre has, just like the string quartet, remained a hallmark of instrumental music throughout the $20^{\text {th }}$ century, and continues to 
pose an aesthetic challenge to composers - and be it only for the educational purpose of compositional studies. Yet when measured by its relevance in musical œuvres, in concert life, and reception, the sonata might well be understood as an entity which keeps on growing and developing without aging, and as such deserves every effort to be explored and surveyed in its various manifestations. Guided by the prepended quote from one of Nikolai Medtner's letters, claiming that musical forms generally do not obsolesce, the present study will gain central stimuli from the question whether the following assertion is applicable: Can the sonata, as a traditional species observed during a period of transformation and turmoil, be considered an ageless principle?

\section{ii OUTLINE OF THE TOPIC AND BASIC IDEAS}

The sonata output of Nikolai Karlovich Medtner (1880-1951), ${ }^{1}$ spanning eighteen compositions, can be regarded as essential within the composer's œuvre. Like his contemporaries Aleksandr Scriabin and Sergei Prokofiev, Medtner dealt with sonata form lifelong and, along with them, cast the genre from the $19^{\text {th }}$ into the $20^{\text {th }}$ century. However, his compositions never received as much attention as those of his famous compatriots. Medtner's piano works, although more frequently considered by performers in the past three decades, are still lacking a thorough appreciation in the domains of musicology and musical analysis. Instead, Medtner has been repeatedly referred to as a restorer of the formal paradigms of Classicism, and as a conservative figure in times of ongoing stylistic changes, especially on the field of sonata form. This point of view may prevent us from acknowledging Medtner's most flexible and innovative way of handling this traditional genre.

While composing largely autodidactical, Medtner attained a series of individual strategies in employing sonata form. Incorporating in his music a remarkable variety of outlines and conceptions of musical form, he turned to single-movement sonata form quite early in his career (in the Sonata Triad, Op. 11). Later, he would explore other creative solutions rather independent from the classical model. For instance, he implements sonata movements in cycles of character pieces (Forgotten Melodies, Opp. 38 and 39); he develops formal hybrids ranging between one-piece and multi-sectional conceptions (Op. 22, Op. 53 No. 2); and he extends the singlemovement sonata to an integrative entity of symphonic dimensions (Op. 25 No. 2). Besides his fourteen piano sonatas, Medtner created three violin sonatas, a Sonate-Vocalise for voice and piano, and a piano quintet, as well as three piano concertos. Furthermore, he composed a large number of piano character pieces, including a group of thirty-eight skazki (Märchen) as well as more than hundred songs for voice and piano, set to texts by Goethe, Eichendorff, Pushkin, Tyutchev, Fet, and others. Thus, all of Medtner's compositions involve a piano part. Many of these concise works - which prove the composer's command of formal and contrapuntal refinement in their scores - bear a descriptive attribute or subtitle. This feature allows for a possible perception of Medtner's music as Symbolist art, enriched with poetic, metaphysical, or spiritual aspects which point beyond the music.

1 Medtner's surname is also spelled Metner, if transcribed literally from the Cyrillic alphabet; the composer himself preferred the seven-letter form when using the Latin alphabet. Medtner's first name is usually transcribed Nikolai or Nikolay; other alternatives frequently found are Nikolaj (in German or Scandinavian languages), Nikolaï (in French) or, in historical writings, idiomatic transcriptions like Nicolas, Nicholas, Nikolaus etc. As for the patronymic name, I will maintain the English spelling Karlovich. 


\section{ii.i SOURCES AND PRECONDITIONS OF RESEARCH}

Measured by the total amount of writings related to Medtner (see bibliography in chapter 4.1), surprisingly little research has been carried out on his œuvre in Western musicology. It is still not quite clear why Medtner is almost completely neglected by many scholars, even by those focusing on Russian or Eastern European music. Richard Taruskin, in his book Defining Russia Musically (1997), refers to the composer only once, and with a rather pejorative assessment: »Medtner, the poor man's Rachmaninoff ${ }^{2}{ }^{2}$ The Sonata / Sonate articles from the New Grove Dictionary as well as from both editions of Die Musik in Geschichte und Gegenwart mention Medtner only in rough enumerations, and in one of the most wide-ranging German volumes on piano music, Harenberg Kulturführer Klaviermusik, he is completely omitted.

Outside Russia, there has been hardly any individual scholarship on Medtner's music up to the 1990s. Two memorial volumes with appreciative essays, most of them written by contemporaries and friends of the composer, were published after Medtner's death (edited by Holt 1955 and Apetyan 1981). A number of monographic studies have mainly focused on biographical issues, aesthetics, or aspects of performance, instead of providing comprehensive views of Medtner's music (Pinsonneault 1956, Swan 1967, Zetel 1981). The first thorough study to observe the genesis, structure, and reception of a large portion of Medtner's works was Elena Dolinskaya's Nikolai Metner. Monograficheskiy ocherk (1966; a revised and extended version was published in 2013), while other Russian contributions from that decade (Vasilyev 1962, Alekseyev 1969) merely gave overviews of Medtner's piano music, lacking a scholarly approach. A handful of meanwhile outdated academic studies, mainly DMA dissertations or MA theses, have dealt with the piano sonatas (Yagodkina 1959, Ginsburg 1961, Mochalova 1962, Loftis 1970, Kinley 1970, Keller 1971, Elmore 1972, Surace 1973); most of these produced rather poor analytic results and failed to embed the works into aesthetical and cultural contexts. Thanks to the contributions of Barrie Martyn-whose book Nicolas Medtner. His Life and Music (1995) represents the first comprehensive study in English language, making Medtner's biography and œuvre accessible to a wider public - and of Christoph Flamm, whose extensive study Der russische Komponist Nikolai Metner (1995) has advanced to the foremost resource in scholarly research on Medtner, the situation has significantly improved by the last decade of the $20^{\text {th }}$ century. Since then, the composer's catalogue of works, his biography and personal relationships, and his position within the cultural spheres of pre-revolutionary Russia and during emigration have largely been deduced. Some other Russianlanguage dissertations have appeared in the following years, incorporating interdisciplinary and historiographic perspectives (Moskalets 2004, Podporinova 2007), and a number of recent studies have notably focused on individual sonatas (Vasyutinskaya 2014, Emerson 2016 ${ }^{\mathrm{a}}$, Bertin 2018). However, untranslated Russian sources have not been taken into consideration by most Western researchers. With regard to Medtner's piano sonatas, a thorough examination and contextualisation of this corpus of works, drawing on recent approaches and methods of musical analysis, is still lacking. This niche is going to be closed by the present study.

2 Taruskin 1997, p. 318. 


\section{Musical Sources}

Virtually all of Medtner's compositions are available in score, many of them in several editions and reprints. The first editions of the sonatas appeared at various Russian, German, and English publishers (Belyayev, Yurgenson, Benjamin, Édition Russe de Musique, Zimmermann, and Novello). The Collected Edition of Medtner's works, edited by Aleksandr Goedicke, Aleksandr Goldenweiser et al. (Sobranie sochineniy. Sochineniya dlya fortep'yano, Vol. 1-4) was, at the instigation of the composer's widow Anna Medtner, published by the Soviet State Music Publishing House (Muzgiz) in 1959-60, ${ }^{3}$ providing corrections of misprints in the first editions, and adding some insightful notes and subtitlings derived from Medtner's sketches. The piano sonatas from the Collected Edition were, with minor changes, reprinted as The Complete Piano Sonatas, Series 1-2, at Dover Publications (1998), ${ }^{4}$ initiated by the (now inactive) International Medtner Foundation. This two-volume publication presented the corpus as a whole for the first time, including an introduction by Eugene Istomin, an editorial note by Marc-André Hamelin and performance notes by Geoffrey Tozer, as well as Robert Rimm's translations of the footnotes from the Soviet Collected Edition. The Dover edition may serve as a sufficient basis for performance and analysis. However, for the purpose of philological precision, I will for the most part refer to the Collected Edition in the course of this study, and occasionally consult the first editions and other consecutive prints in order to discuss discrepancies or certain editorial problems.

\section{Performances and Recordings}

Some of Medtner's sonatas belong to his most frequently performed compositions, such as the SonataReminiscenza, Op. 38 No. 1, an all-time favourite of audiences and performers, and the G minor Sonata, Op. 22. Others, like Opp. 5 and 56, his earliest and latest sonata, are hardly ever programmed. In addition to the sonatas, many pianists also include Medtner's skazki or some of his other character pieces in their recitals; the most frequently chosen ones are the Skazki, Op. 20 Nos. 1-2, Op. 26 Nos. 1-4, and Op. 51 No. 3. Among the performers programming Medtner's compositions in recent time are, to mention but a few: Boris Berezovsky, Ekaterina Derzhavina, Severin von Eckardstein, Jonathan Powell, Paul Stewart, Daniil Trifonov, Konstantin Shcherbakov, Yevgeny Sudbin, Aleksei Volodin, Aleksandr Karpeyev, Simon Callaghan, Benjamin Grosvenor, Dinara Klinton, Cahill Smith, Frank Huang, Caspar Vos, Lucas Debargue, Florian Noack, Darya Dadykina, and Vasily Gvozdetsky.

The piano sonatas have been discographically documented in three complete recordings so far. Australian pianist Geoffrey Tozer made the first one for Chandos Records (1992-98, 4-CD box set published in 1999); the renderings of Canadian pianist Marc-André Hamelin followed in turn on Hyperion Records

3 Digitised versions of most of the volumes of the Collected Edition, split up into PDF files comprising the individual works, are available online at the Petrucci Music Library: imslp.org/wiki/Category:Medtner,_Nikolay (accessed August 16, 2018). This note simultaneously serves as a disclaimer for possible copyright issues arising from the use of digitisations made accessible through this website, which I will not be held reliable for in any country.

4 The only case where the Dover edition deviates from the Soviet Collected Edition is the A minor Sonata, Op. 30. For a reason unknown to me, the volume relies on a re-release of the first edition (1917) of this work, edited by F. H. Schneider at Édition Russe de Musique (1922). 
(1996-98, 4-CD box set published in 1998); and live recordings of performances of students of the Moscow Conservatory (two concerts in 2009) were published as a 4-CD box set on SMC (published 2010). ${ }^{5}$ However, the most important advocate of Medtner's music, deserving to be singled out among all other performers mentioned here, is the English pianist Hamish Milne who played and recorded virtually every of Medtner's solo piano works over a period of roughly 30 years. In his journey through the sonatas, Milne only omitted Opp. 38 No. 1 and 56, while recording the twelve remaining works during 1977-2000, first collectively released on Brilliant Classics (as part of a 7-CD box set, 2010). ${ }^{6}$ Hungarian pianist Ádám Fellegi has recorded eleven of the fourteen sonatas for Naxos (3 CDs, published 1989-91), omitting Op. 30 and Op. 53 Nos. 1-2. Russian pianist Irina Mejoueva has recorded ten sonatas so far (Denon Japan, 1998-2003), omitting Op. 5, Op. 30, and Op. 53 Nos. 1-2. Japanese pianist Masahiro Kawakami has recorded seven sonatas so far, including Op. 11 Nos. 1-3, Op. 27, Op. 38 No. 1, Op. 39, and Op. 53 No. 2, published on Harmony and Momonga Records (2 CDs, 2001-04). Russian pianist Ekaterina Derzhavina has recorded Opp. 11 Nos. 1-3, and both Opp. 38 and 39, for Deutschlandradio (2-CD box published in 2008 on Phoenix Records), as well as the three violin sonatas with Nikita Boriso-Glebsky on Profil Edition (2-CD box, 2018); others of Derzhavina's broadcast recordings, including Opp. 25 No. 1 and 30, are still unpublished. The Canadian Paul Stewart has started an ongoing complete recording for Naxos, two discs of which are available so far, including Op. 5, Op. 11 Nos. 1-3, Op. 25 No. 1, Op. 38 No. 1, Op. 56, and the early Sonatina (published 2012-16); Stewart also recorded the violin sonatas with Laurence Kayaleh on Naxos (2 CDs, 2007-08). More selected sonatas have been recorded by Severin von Eckardstein, Nikolai Demidenko, Natasha Konsistorum, Geoffrey Douglas Madge, Evgeny Kissin, Malcolm Binns, Jürg Hanselmann, Uwe Balser, and some others. ${ }^{7}$

The only sonatas recorded by Medtner himself were the Sonata-Ballade, Op. 27, and Sonata tragica, Op. 39 No. 5, as part of a larger recording project funded by the composer's late patron, the Maharadjah of Mysore, and produced by His Master's Voice (1947). Other historical recordings of individual sonatas were done, starting in the 1940s and 1950s, by the Soviet-Russian pianists Emil Gilels, Maria Yudina, Maria Grinberg, Vladimir Sofronitsky, Benno Moiseivich, Yakov Flier, Evgeny Svetlanov, Grigory Ginzburg, Gleb Akselrod, and Sviatoslav Richter. Among the Western pianists to record some of Medtner's sonatas during the 1960s and 1970s were Edna Iles, Michael Ponti, Earl Wild, John Clegg, and Daniel Graham.

5 The pianists involved in this recording were: Sergei Neller, Ekaterina Shishkina, Dmitry Krutogolovy, Aleksandra Solomina, Anton Mikitsky, Anastasiya Zhuralvleva, Yuri Favorin, Sergei Yorov, Grigory Rymko, Ilya Kaigodorov, Aleksandr Shaikin, Mikhail Turpanov, Irina Chistyakova, and Varvara Tarasova, each of who performed one of the fourteen piano sonatas.

6 The somewhat conglomerate Brilliant Classics box added the two sonatas omitted by Milne from Geoffrey Tozer's complete recording.

7 In no particular order I mention the following pianists: Yevgeny Sudbin, Anna Vinnitskaya, Anna Zassimova, Konstantin Lifshitz, Dmitry Alekseev, Chisato Kusunoki, Veronika Ilinskaya, Irina Mejoueva, Irina Shishkina, Irina Feoktistova, Irina Ossipova, Olga Scheps, Adam Golka, Yura Margulis, Vladimir Viardo, Vladimir Pleshakov, John Corrigan, Dmitry Feofanov, Dmitry Paperno, Alexander Vaulin, Alexander Paley, Nigel Hill, Elena Margolina, Antony Rollé, Igor Nikonovich, Mikhail Lidsky, Veniamin Korobov, Boris Bekhterev, Gunnar Sama, Alessandro Taverna, Michael Preiser, and Florian Noack. 


\section{ii.ii GoAls AND Methods of ApPROACH}

Unlike music journalism and popular-scientific literature claim once in a while, Medtner has never been an obscure or sforgotten< composer. Instead, a small but devoted group of performers have continuously advocated his music since his death. Due to the significant increase in performances of Medtner's works since the 1980s, various attempts to capture the composer's position in music history and the individual qualities of his œuvre can be observed during the following decades. However, many of these efforts have emanated from a performer's perspective, tending to fall short of scholarly standards and to lack analytical depth, and their appearance was nearly exclusively limited to Great Britain, the United States, and Russia. To put it bluntly, a considerable portion of the previous research on Medtner has been produced by pianists inclined to write about a composer-pianist whose music they had already been focusing on as performers. And, admittedly, so am I - even if I would hardly dare playing Medtner in a public recital; but I believe there is an additional and yet unachieved quality which I can contribute through my research. Genuine musicological approaches, focusing on genre history or contexts of music aesthetics, are still underrepresented in Medtner scholarship, as are multi-perspective discussions of his works, incorporating a versatile application of recent methods of musical analysis. This poses a distinct desideratum for research.

In the present study I consider Medtner's piano sonatas in the context of their genesis, confront them with other composers' works, and provide multifaceted and comprehensive analyses of the scores. These are based on a backview to sonata composition and theory of sonata form in the $19^{\text {th }}$ and $20^{\text {th }}$ centuries, particularly focusing on Russian music and scholarship. Since Medtner strongly relied on the Austro-German musical tradition of the Classic and Romantic periods, comparisons to the formal principles of Beethoven, Schumann, Brahms, and Liszt appear most desirable. From a geographical perspective, valuable insights arise from viewing Medtner in the succession of Anton Rubinstein, Tchaikovsky, Taneyev, Arensky, and Glazunov. Another goal is to regard the piano sonatas in the aesthetic environment of their time, relating them to the works of his Russian contemporaries, such as Scriabin, Rachmaninov, Myaskovsky, Aleksandrov, Stanchinsky, Feinberg, and the early Prokofiev. In the light of the predominant assessments of music criticism, considering Medtner a rather conservative artist who strongly rejected modern styles and techniques of composition, his book Muza i moda. Zashchita osnov muzikal'nogo iskusstva (The Muse and the Fashion. A Defence of the Foundations of the Art of Music, published in 1935) serves as an instructive document to understand the composer's idiosyncratic position and motivations.

The study is subdivided in three large parts, each of which may also be read separately. Its methodology is organised so as to gradually focus on its core topic - the detailed analysis of Medtner's music - in two inductive steps, proceeding from the general to the specific. The first part does not yet deal with Medtner, but is devised to give an overview of sonata composition before and during his lifetime, putting his work in a larger historical context. I will point out stylistic features and lines of tradition among Western European and

Russian composers, and summarise the genre's reflection in music theory and scholarship of the $19^{\text {th }}$ and $20^{\text {th }}$ centuries. After that, the second part is dedicated to Medtner's style and its characteristic features, not yet concentrating on the piano sonatas, but providing a general approach to his musical language. A number of 
separate chapters will examine the composer's application of sonata form, as well as aspects of melody, rhythm, counterpoint, and harmony. Medtner's œuvre does not show fundamental stylistic changes in comparison of his earlier to his mature compositions as much as, say, Scriabin or Stravinsky. However, some subtle peculiarities arise in the music written after his emigration in 1921, when confronted with works still completed in his Russian native country; a survey of these is included later in this introduction. Finally, the third and most comprehensive part provides analyses of eight of Medtner's piano sonatas completed during 1903-14, combining aspects of their genesis and reception - such as history of edition, performance, recording, and review-with detailed examinations of the scores. The scope of these analyses will thus be confined to a group of compositions which emerged within a single decade, roughly delimited by the start of Medtner's career and the outbreak of World War I, whereas the general characterisation of his musical language is not bound to any particular period, genre, or instrumentation.

\section{ii.iii PRELIMINARY NOTES}

The information provided in Flamm's extensive catalogue of Medtner's compositions is utilised as a general basis for dates of composition, philological information on drafts and sketches, and the history of edition and reception. ${ }^{8}$ For many further details on editions, performances, and recordings, I am relying on the invaluable online resource medtner.org.uk, created and maintained with utmost devotion by Chris Crocker (2006-18). ${ }^{9}$

The titles of Medtner's sonatas tend to appear in multiple languages, depending on the country where publication, performance, and reception have taken place. In this study I will usually unify the nomenclature of pieces in English language where originally denominated by the term >sonata leave the titles as found in their original appearance if composed of ssonata and an additional adjective. Thus, I refer to the individual sonatas as follows: Sonata Triad, Op. 11; Sonata-Elegy, Op. 11 No. 2; SonataSkazka, Op. 25 No. 1; ${ }^{10}$ Sonata-Ballade, Op. 27; Sonata-Reminiscenza, Op. 38 No. 1; Sonata tragica, Op. 39 No. 5; Sonata-Vocalise, Op. 41 No. 1; Sonata romantica, Op. 53 No. 1; Grozovaya Sonata, Op. 53 No. 2; ${ }^{11}$ Sonata-Idyll, Op. 56; and Sonata epica, Op. 57.

\section{Romanisation of the Cyrillic Alphabet}

I am using the New Grove transliteration system throughout, ${ }^{12}$ with minor deviations. Thus, the letters of the Cyrillic script are romanised as follows: ай (as final sound) = ai; еe = eye (two syllables); ей (as final sound) $=e i$; $($ stressed vowel $\mathrm{e})=\ddot{e} ;$ ж $=z h ; з=z ;$ ий (as final sound) $=y$ as vowel (rather than $i y) ;$ й $=y$ as consonant;

8 See the catalogue of works (Werkverzeichnis) in Flamm 1995, pp. 351-571.

9 See the website medtner.org.uk, which comprises a list of works with information on editions and performances, as well as a number of recordings and many publications available in full text (accessed August 16, 2018).

10 The Russian version is preferred due to the difficulties in translating the term skazka; see chapter 2.5.2.

11 Since the common Italian variant used in the first edition, Sonata minacciosa, and the French variant, Sonate orageuse, do not quite match the twofold meaning of the Russian adjective sgrozovoy<, I decided to preserve the Russian denomination.

12 Established by Gerald Abraham for the New Grove Dictionary of Music and Musicians, Vol. 1 (1980), also used in Grove Music Online. 
$\mathrm{x}=k h ; ц=t s ; ч=c h$ (or $t c h$ when used as initial sound); $ш=s h ; щ=s h c h ; \mathrm{ы}=\ddot{i}$ (to distinguish from $y$ ); э (as initial sound $)=\dot{e}$; ю $=y u$; я $=y a$; ь (soft sign $)=$ ' (apostrophe); ъ (hard sign) $=$ '” (double apostrophe). In divergence from that system, common personal names are transliterated as most frequently used (unless included in citations from Russian original sources), such as Tchaikovsky (rather than Chaykovskiy), Mussorgsky (rather than Musorgskiy), Scriabin (rather than Skryabin), Rachmaninov (rather than Rakhmaninov), Medtner (rather than Metner), and Prokofiev (rather than Prokof'ev); alternative spellings are given in square brackets. As for the nomenclature of years, all dates - including Russian references to pre-revolutionary years - are given according to the Gregorian (new style / novizy stil') instead of the Julian calendar (ancient style / starïy stil').

\section{Acknowledgements}

The completion of this study, the most part of which has been written in a number of cosy Berlin coffee shops, would not have been possible without the help of many people to whom I would like to express my sincere thanks and deepest gratitude. In no particular order, I here acknowledge a number of persons among my teachers and advisors, colleagues, friends, and relatives:

- For their counsel, never-ceasing support, and valuable advice: Prof. Dr. Christoph Flamm (Lübeck); Prof. Dr. Martin Eybl (Vienna); and Prof. Dr. Gesine Schröder (Leipzig).

- For her invaluable help with translations, proofreading, and for the clarification of music-theoretical and terminological issues: Elena Chernova (Regensburg).

- For fruitful exchange of thoughts and materials, and for most delightful personal encounters related to research activities and music events: Chris Crocker (Oxfordshire); Vasily Gvozdetsky (Berlin); Darya Dadykina (Berlin); Dr. Aleksandr Karpeyev (London); Prof. Francis Pott (London); Prof. Dr. Roger Graybill (Boston, Massachusetts); Dr. Bradley Emerson (Austin, Texas); Dr. Nathan Uhl (Tempe, Arizona); Nicolò Rizzi (Milan); Dr. Nikola Komatović (Vienna); Dr. Benjamin Bertin (Montréal); Dr. Tatyana Shevchenko (Odessa); Ekaterina Derzhavina (Moscow); Severin von Eckardstein (Berlin); Luisa Splett (Berlin); Cornelius Gerhardt (Berlin); Prof. Linde Großmann (Berlin); Lidia Kalendareva (Berlin); Larissa Kolodiy (Berlin); Pearl von Herder (Berlin); Prof. Dr. Oliver Korte (Lübeck); Dr. Simon Moser (Offenburg); Aleksandra Savenkova (Vienna); Benjamin Vogels (Vienna); and Dr. Markus Neuwirth (Lausanne).

- For providing sources, scans of writings and theses, or access to Russian-language sources otherwise unavailable to me, and for initiating interlibrary loans: Prof. Dr. Amos Bitzan (Madison, Wisconsin); Dr. Ramón Wenzel (Perth); Prof. Dr. Konstantin Zenkin (Moscow); Prof. Evgeniya Vasyutinskaya (Krasnoyarsk); Dr. Natalia Nayko (Krasnoyarsk); Prof. Dr. Aleksei Krasnoskulov (Rostov-on-Don); Dr. Gottfried Eberle (Berlin); and Peter Seidle (Karlsruhe).

- Finally, the most important persons in my life - my family: Xenia, Cosima, and Lionel, as well as my dear parents, who have eagerly followed and supported my work at any time. 


\section{Introduction}

As a prologue to the three major parts of this study, the following two chapters intend to open a sociohistorical space for fundamental appreciation and insight into Nikolai Medtner's music. Even though my approach is not designed as a biographical study and primarily focuses on analysis and contextualisation of the body of examined works within genre history, the forthcoming discussion will benefit from a general clarification of Medtner's aesthetic position and attitude as a creative artist. I will thus delineate the preconditions of his work on the subsequent pages, shortly summarising the composer's familial background and early influences, embedding his activity into social and political contexts, and providing an overview of artistic and philosophical movements of his time.

\section{$0.1 \quad$ BiogRAPHICAL CONTEXT}

Nikolai Karlovich Medtner was born to a privileged and cultured Muscovite family on January 5, 1880. His father, Karl Petrovich Medtner (1846-1921), was a merchant and manager of a lace factory, with an strong affection for art and literature; his mother, Aleksandra Karlovna Medtner née Goedicke [Gedike] (18431918), a younger sister of the composer Fëdor Karlovich Goedicke and descendant of a family of German origin, was educated as a pianist and singer. Nikolai, born December 24, 1880, was the youngest brother to four elder siblings: Emil [Ėmiliy] Karlovich (1872-1936); Karl Karlovich (1874-1919); Aleksandr Karlovich (1877-1961); and Sofiya Karlovna (1878-1943). His junior brother, Vladimir Karlovich (18821899?), died at a young age.

Nikolai began studying the piano at the age of six, taught by his mother and uncle, and showed early ambitions towards composing as well. In 1892 he quit school and enrolled at the Moscow Conservatoire's junior department, in the same year when his cousin Aleksandr Fëdorovich Goedicke (1877-1957) took up his studies. He was instructed on the piano by Anatoly Ivanovich Galli and attended harmony classes with Anton Stepanovich Arensky and Nikolai Dmitrievich Kashkin. In the spring of 1894 Nikolai entered the senior department, studying the piano successfully with Paul Pabst. ${ }^{1}$ After his teacher's unexpected death in 1897, he continued his pianistic education with Vasily Lvovich Sapelnikov and, more influentially, with Vasily Ilyich Safonov, the institution's current director. Under the guidance of Safonov, who had also been the teacher of Aleksandr Nikolayevich Scriabin and Iosif Arkadievich Lhévinne, he developed to a promising young virtuoso. Breaking off the counterpoint class of Sergei Ivanovich Taneyev after half a year in 189798, Medtner did not receive a thorough education in composition or music theory at all; and besides some informal consultations with Taneyev, his attempts in composition were to most extent self-taught. In 1900 he

1 Dolinskaya 1966, p. 10, and Martyn 1995, p. 6, assert that Pabst had been a pupil of Franz Liszt. This seems doubtful as Pabst had first studied with his father in Königsberg and later with Anton Door in Vienna, probably having received only informal advice from Liszt during a stay in Weimar. 
graduated from the Conservatoire with a coveted gold medal in piano playing and took part in the $3^{\text {rd }}$ Vienna Rubinstein Competition, but only gained a honorary mention. Some months later he decided, to the dismay of his teachers and family, not to pursue a career as a concert pianist, but to devote himself fully to composing. His brother Emil was one of the few to support Nikolai in the difficult choice of his major occupation.

In 1896 the Medtners had become acquainted with the family of Anna Mikhailovna Bratenshi (18771965), a young violinist who was three years Nikolai's senior. After she had become close friends with the eldest brother Emil Karlovich, and her sister Elena had married Karl Karlovich, Nikolai started to develop strong feelings for Anna. Once the Medtner brothers' mother became suspicious of a growing relationship among the two adolescents, she prohibited contact between Anna and Nikolai. ${ }^{2}$ In turn, Emil, a lawyer by profession and a widely educated person, was offered a job in Nizhniy Novgorod, and asked Anna to come along and marry him. She agreed, not knowing that Nikolai's affection towards her had not ceased, even though he had been engaged to another girl in the meantime. Emil's and Anna's wedding took place in October 1902, and they left Moscow together. In this turbulent state of mind, Medtner sketched and composed his first published Piano Sonata, Op. 5 (see figure 0.1). It was not before the following summer that Anna and Nikolai finally revealed their attitude to each other, and in turn entrusted themselves to Emil who appeared full of understanding, but asked Nikolai not to bother their parents with this unfavorable connection. The desperate affair was going to be kept secret by the brothers, even after their mother gained insight into the true nature of this love triangle. Due to these circumstances, Anna and Nikolai would not be able to get married before Aleksandra Medtner's death in 1918. ${ }^{3}$
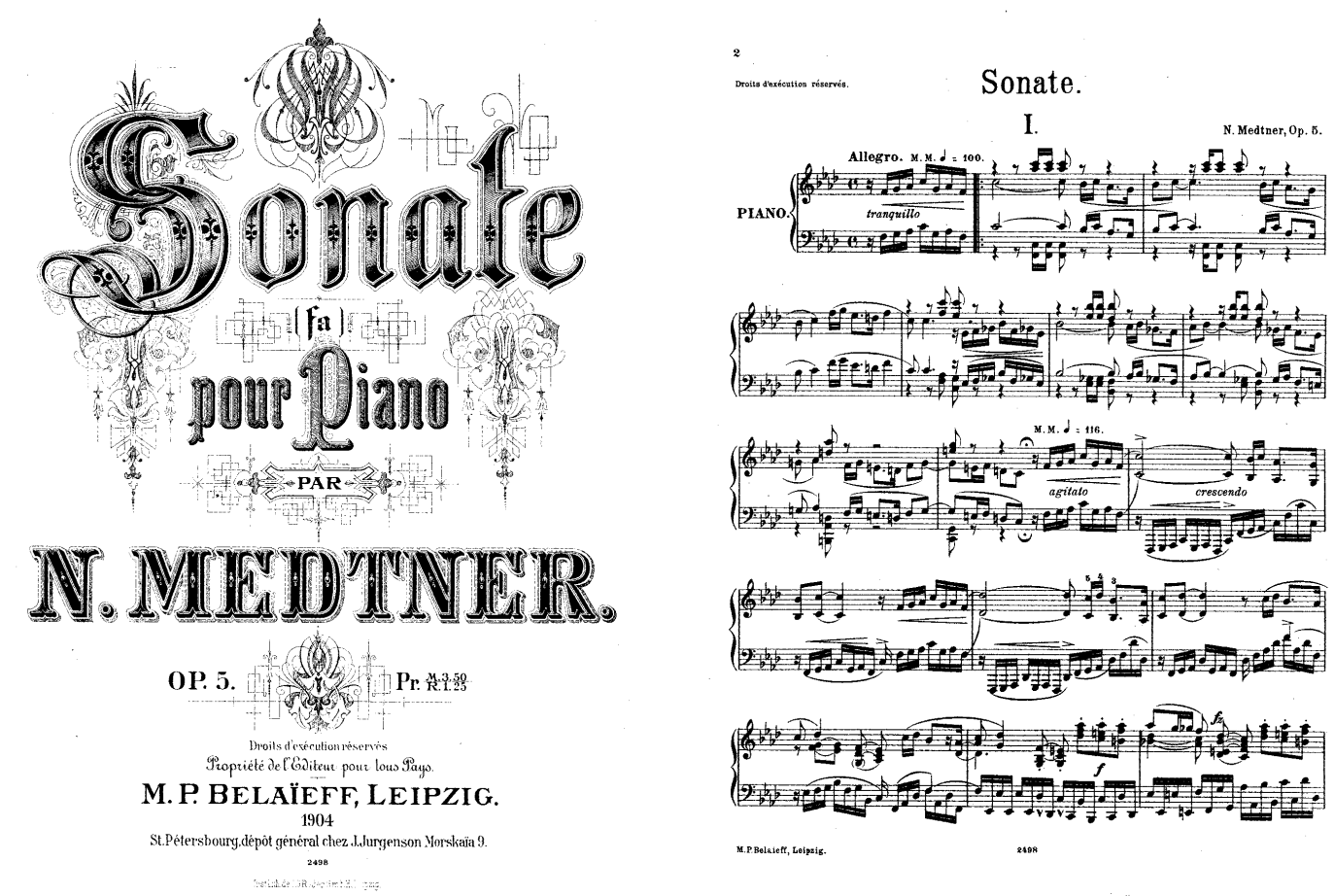

Figure 0.1: Medtner, Sonata, Op. 5, first edition (Belyayev 1904), pp. 1-2

2 See Swan 1967, p. 68ff., and Martyn 1995, p. 14f.

3 For a detailed account of these biographical implications see ibid., p. $27 \mathrm{f}$. 
Medtner's rising career saw him regularly appear in recitals in Moscow, Berlin, and Saint Petersburg, for the most part as performer of his own piano works which were published by Pëtr Yurgenson and, from 1910, in Sergei Kusevitsky's Édition Russe de Musique. After extensive travels and concert tours, and having already composed nine of his fourteen piano sonatas up to Op. 30, Medtner accepted a professoral position at the Moscow Conservatory where he had already taught in 1909-10, now directing a piano class during the years of 1915-1919. Still, he was uneasy with this occupation and would reject several other teaching positions in the future. As a result of the Russian Revolution and the outbreak of the Civil War in 1921, Medtner and his wife Anna emigrated to Berlin. In the following years they would frequently change their residence, continue living in Germany and France, and eventually move to England. As a composer, Medtner enjoyed only moderate success in Western Europe during the 1920s, and there were few advocates of his music; on the contrary, he was highly acclaimed on his first return to the Soviet Union in 1927 where he performed on an extended concert tour. In 1935, Medtner's life saw three significant events and changes: With the support of his close friend Sergei Vasilyevich Rachmaninov, he published a book named Muza i moda (The Muse and the Fashion) illustrating his personal music-aesthetical views; he converted from Protestantism to Russian Orthodox faith; ${ }^{4}$ and he finally settled in Golders Green near London where he composed his late works, Opp. 56-61. From 1947 Medtner was supported by an Indian maharadjah, Jaya Chamaraja Wadiyar of Mysore, who funded several recordings of his compositions, before the composer died of a heart disease on November 13, $1951 .^{5}$

\subsection{Questions of StYle AND Aesthetics}

Stylistic considerations in music are, as almost always when discussing artistic production, a controversial issue. In general, it seems hardly possible to outline a >personal style< without considering other developments ongoing at the same time. In order to characterise aspects of musical language, such as specific features of melody, harmony, or counterpoint (see introduction to part 2), the confrontation with other composers' music will be indispensably required. Yet this must not automatically imply an assessment of qualityand this is exactly what many of the past evaluations of Medtner's role in music history have suffered from: a lack of neutrality, and a tendency to judge his music as more or less valuable, compared to that of his contemporaries, which has lead some authors to diagnose an alleged >retrospectiveく or >restorative< style. From such assessments, two perilous aesthetic misleadings may arise:

- A work of art may be well done (id est, ingeniously conceived, or cunningly crafted from a technical point of view), but as its stylistic features seem outdated in comparison to other works, the work itself cannot be valued.

- A work of art is remarkable in itself and can be appreciated as such, but it would appear more remarkable if it were created earlier.

4 A possible parallel can be drawn to Arnold Schoenberg's conversion to Judaism in 1933, even if this was for the most part induced by his opposition towards Nazi Germany, whereas Medtner's transformation was rooted in his personal beliefs and the wish to correspond to his wife's faith. See Martyn 1995, p. 218.

5 More detailed accounts of Medtner's biography are found in Swan 1967, pp. 65-116; Flamm 1995, pp. xvii-xxiv; and throughout in Martyn 1995. 
The common basis to both notions is the conception of art history as a process of continuous improvement, developing from simple structures to ever-increasing complexity. Under this precondition, works which seemingly or obviously contradict the belief in the necessity of progress will be depreciated. Facing this risk, a stylistic evaluation of Medtner's œuvre must also take into consideration his aesthetic roots and cultural sphere; and, in order to be fair against his music and its peculiarities, an assessment free of any value judgment, measured by position in an alleged shistorical progress`, is required. This applies all the more when bringing to mind that Medtner himself stood remarkably faithful to his aesthetic values, and thus to his general idea of composing music, throughout his lifetime. He did not cease to carefully control his individual musical thought, and never made compromises, nor would he give in to influences from outside. At the same time, his decent personality restrained him from writing for the purpose of making a particular effect, or to meet the demands of audiences or critics. This attitude can be considered as profoundly honest—and the same may be expected of the evaluation and analysis of his music.

\subsubsection{BETWEEN TRADITION AND MODERNISM}

As with most polarising pairs of terms, this antagonism construes two extreme positions, suggesting a dual alternative which is not necessarily reflected in reality. In the discussion of Medtner's person and œuvre, the repeated attribution of >traditionalism<, as opposed to >modernism<, is evident already in contemporary writings and reviews, and continued after his death. However, being »firmly rooted in tradition $«{ }^{6}$ as Eric Blom put it, is not necessarily a negative ascription, as seen in two representative statements: The Russian musicologist Leonid Sabaneyev referred to Medtner as »a faithful soldier of the ancient musical faith $<^{7}$ and the German critic Rudolf Walther Hirschberg saw him as a »conscious anti-Modernist, Classicist, or neoRomantic, but by no means an epigone ${ }^{8}{ }^{8}$ Both authors thus tend to interpret Medtner's rejection of $>$ modernism $<$ as a certain quality — a confession or creed derived from artistic integrity, and a means of persistently demonstrating his commitment and indebtedness to his musical ancestry, which helped him resist the temptation of simply following momentary trends and fashions.

While still living in Russia, Medtner's musical language all in all matched the expectations of audiences and reviewers, regarding the question of how contemporary music should sound like-with a notable exception, the influential critic Vyacheslav Karatygin, who appeared particularly adverse towards Medtner. However, the largely positive reception of his music considerably changed after his emigration. During his time in Berlin and Paris in the 1920s and 1930s, from when Sabaneyev's and Hirschberg's assessments date, the composer himself became well aware of >not being modern<, and one of the most frequently quoted selftestimonies is his 1925 statement that he felt like being hundred years late: »I can add about myself [...] that

6 Blom 1954, p. 649.

7 Sabaneyev $1927^{\mathrm{a}}$, p. 143.

8 My translation of Hirschberg 1931, p. 100: »Ja, Medtner ist bewußt antimodern. Er ist klassizistisch oder neoromantisch eingestellt, aber er ist kein Epigone.« 
I was born [...] with a delay of a century «, ${ }^{9}$ an impression derived from the fact that he could not overcome himself and float with the current of modern trends. The inclination to define his own attitude in opposition to adverse tendencies was most symptomatic of Medtner's perception of his role in musical life, and grew more intense during the years of emigration. This caused him to ostentatiously confirm his >traditionalist attitude in a number of compositions of the 1930s which, by intentional simplicity and anti-complexity, cultivate a quasi-nostalgic tone. ${ }^{10}$ Turning away from the reternak principles of composition, as he considered was the case in the >Modernist tendencies of his time, seemed pointless and decadent to Medtner. Before broadly expressing his opinions on the music of his contemporaries in his 1935 book Muza i moda, this attitude had already become clear in a 1924 interview:

»I am not a modernist, you see. [...] This does not mean unwillingness to listen what the moderns have to say. I do listen and try to find something in it to arouse feeling and sympathy, but always fail to find these or anything that appeals. It all seems to be useless and futile. ${ }^{11}$

Another ascription circulating throughout writings on Medtner is the epithet \The Russian Brahms`, denoting both retrospectivity and an aesthetical affinity to Brahms's style and techniques of composition. The Russian music critic Grigory Prokofiev seems to have been the first to assume the alikeness of the two composers, noting »If we want to approximate him to any other composer, one should think of Brahms« and »I have already pointed out [...] Medtner's mental proximity to Brahms «; ${ }^{12}$ but it was indeed Karatygin who, having variously stated Medtner's indebtedness to both Schumann and Brahms, wrote in 1913 that »Glazunov and Taneyev are but Russian analogies to Brahms; though the single and typical >Russian German<, the Brahmsian of our country, is Medtner. ${ }^{13}{ }^{3}$ This proclamation seems to have been simplified in turn, with the abovementioned epithet ceaselessly protruding from writings of the successive decades, and constituting Medtner as a >Russian version « of the German who was nearly fifty years his senior.

This label has been subject to broad discussion. Of course, the definition of a role model in headline style as seen here, expressed in dependence from an idealised predecessor, is highly problematic. Not only is Brahms's complex artistic profile reduced to exemplary aspects of style and compositional technique; but also is Medtner considered a mere epigone of these, prompting Blom to remark that $\gg$ this designation is in itself contradictory«, and whereas »Medtner is undoubtedly a modern descendant of the Beethoven-Brahms

9 My paraphrase of a passage from Medtner's letter to Grigory Beklemishev of November 3, 1925: »Ot sebya v vide >avtobiograficheskoy< zametki mogu dodavit', chto rodilsya v $1879 \mathrm{~g}[\mathrm{odu}] \mathrm{s}$ opozdaniem na odno stoletie, chto zaklyuchayu iz togo obstoyatel'stva, chto nikakimi sud'bami ne mogu zastavit' sebya plit' s sovremennïmi muzikal'nïmi techeniyami i vse vremya prinuzhden plit' protiv techeniya.« See Apetyan 1973, p. 307.

10 See Flamm 2006, p. 3: »Besonders seit den 30er-Jahren zeigt sich ein >nostalgischer Zug«. However, this mainly applies to Op. 54, Op. 55, and Op. 56; the comparatively simple textures of this group of works was also motivated by Medtner's publisher Zimmermann's request for some easier, good-selling compositions. See also Flamm 1995, p. $516 f$.

11 Musical America, November 8, 1924, p. 24, as quoted after Brower 1925, p. 11; see also Yasser 1924.

12 My translation of two of Prokofiev's critiques, dating from 1907, in Flamm 1995, pp. 269 and 272: »Esli ego priblizhat' k kakomu-nibud' iz kompozitorov, to pridetsya vspomnit' Bramsa«; »Mne uzhe prishlos' kak-to ukazyvat' [...] na dukhovnuyu blizost' g[ospodina] Metnera Bramsu.«

13 Karatygin 1913 in Flamm 1995, p. 305: »Glazunov i Taneev—-tol'ko russkie ranalogiiく Bramsa. Edinstvennïy zhe tipichnïy 〉russkiy nemets〈, otechestvennïy bramsianets—eto Moskvich Metner.« See also Pott 2013, p. 3. 
line $[\ldots]$, he is not therefore more like Brahms than the latter is like Beethoven $« .{ }^{14}$ Neither of the two composers' reception can possibly profit from this unfortunate comparison, nor could any other. In the light of alleged analogies to Brahms - which were also assigned to Sergei Taneyev and Aleksandr Glazunov, clearly demonstrating the arbitrariness of this insinuation-, Dorothee Eberlein notes that the epithet $>$ Russian Brahms might just as well have been attributed to any other composer who showed Classicist tendencies in his music. ${ }^{15}$ Medtner himself rejected this obtrusive comparison, though rather subtly, in a 1920 letter to his brother Emil where he referred to Brahms as a »colossal master«, and just shortly after declared: »I am speaking merely of my muse, which everyone for some reason has decided to consider the sister or even the daughter of Brahms, which I cannot accept at all, and the longer, the less «. ${ }^{16}$

However, all these attributions or self-perceptions, regardless of whether they be allegations of >traditionalism Medtner's music. It will not be the goal of this study to assign certain features of his style to either >traditionalism or >modernism`, or to generally deduce these from a single historical role model or archetype. On the contrary, I will aim to describe the traits of Medtner's musical language (see part 2) as unbiasedly and neutrally as possible, and without judging their progressivity, relying only on evidence taken directly from the scores. In this respect, I will essentially follow the idea that one does not need to be >modern in order to be innovative, in compliance with Harold Truscott's proclamation that »contemporary implies a state of mind, not the use of a certain type of harmony rather than another «. ${ }^{17}$ For similar reasons, neither of the terms $>$ genius` or >masterpiece will be employed throughout this study other than in quotes.

\subsubsection{NATIONAL IDENTITY}

Growing up at the outermost temporal edge of the Russian Empire, in an atmosphere of social and political transformation which already saw the legitimacy of the Tsarist monarchy dwindle, Medtner was entrenched in the cultural sphere of his home country. A crucial part in the development of the young composer's aesthetic values played his eldest brother Emil, a lawyer, publicist, and music critic, who inflicted Nikolai with his affectation for German poetry and philosophy and, due to familial ancestry, claimed himself to be a general advocate of Germanic culture in Russia. The other most influential figure in the young Medtner's environment

14 Blom 1954, p. 649; see also Milne 1980, p. 23. For Medtner's claim that he was »Beethoven's pupil«, see chapter 1.1.

15 See Eberlein 1978, p. 106: »[Man] kann [...] zu dem Schluß kommen, wer in Rußland nur irgendwie klassizistische Züge in seinen Kompositionen zeigte, wurde [...] als eine Analogie zu Brahms empfunden«. This seems at least disputable as the epithet has never been given to Sergei Rachmaninov whose musical aesthetics might appear even more related to Classicism than Medtner's. On the other hand, the notion of sentimentality, or an alleged likeness to bourgeois salon music as often recognised in Rachmaninov's music, has not been attributed to Medtner.

16 Excerpt from a letter to Emil Medtner of June 7 and 20, 1920; see Apetyan 1981, p. 186: »On ogromnïy master!govoryu lish' o svoey muze, kotoruyu pochemu-to vse sgovorilis' schitat' rodnoy sestroy ili dazhe docher'yu Bramsovoy, chego ya nikak ne mogu priznat' i chem dal'she, tem men'she.« Translation quoted after Martyn 1995, p. 120.

17 Truscott 1961, p. 117, also expressing the following thoughts: »Medtner did not like contemporary music, and said so, but this has been construed at times to mean something he did not say. He did not say that he had no sympathy with what contemporary composers were trying to say, merely that he did not like their way of trying to say it. [...] Musicians a hundred years ago [...] would still have been puzzled by the content of this music, perhaps the more so because so much of its language would have been understandable.« 
was the Symbolist poet and theorist Andrei Bely (1880-1934, pen name of Boris Bugayev) who, through his close relationship with the Medtner brothers, provided a link to the Symbolist movement and its predominant ideas in the framework of the Russian Silver Age. Bely's exchange with Nikolai served as »an important and mutually fruitful friendship which left its marks in the œuvres of both $\iota^{18}$ Due to these influences, Medtner can be considered an artist of dual heritage, or a representative of both Russian and German cultures.

\section{German Legacy and Russianness}

Both of Medtner's parents had roots in Germany. The ancestors of his father Karl Petrovich Medtner, allegedly originating from a Danish family settling in Schleswig-Holstein around the turn of the $19^{\text {th }}$ century, had immigrated into Russia via the Baltic countries, while his mother Aleksandra Karlovna Medtner, née Goedicke, stemmed from the Gebhard family, a Thuringian dynasty of pastors and musicians, with acquaintances to high-ranking German intellectuals of the $19^{\text {th }}$ century. ${ }^{19}$

The role of Emil Medtner's worldview and largely ideological philosophy on Nikolai's artistic socialisation can hardly be overestimated. The elder literally placed his cultural hopes on his younger brother, seeing him as the heir of Austro-German musical tradition which he expected him to continue. In his manifesto Modernizm i muzika (Modernism and Music), Emil commented on Nikolai's approach in a way that »[...] he wholly associates himself to the Germanic line of creative thought from the $18^{\text {th }}$ century to Wagner and Brahms. Consequently, Medtner is categorised in the repertoire lists as a German composer and author of Goethe songs. $\ll^{20}$ Emil thus considered his brother's work an ideal case of contemporary composition, ${ }^{21}$ based on and supported by his own thought to an extent that »the bonds between the composer of philosophy and the composer of melody [were nowhere] closer than in the life of the composer-pianist Nikolai Medtner and his brother, Emil ${ }^{22}$ Rebecca Mitchell analyses the triangle relationship of Nikolai, Emil, and Anna Medtner as a source of philosophical thought which was reflective, and to some extent depreciative, of the developments of their time:

»By combining the writings of all three Medtners, a well-developed philosophical aesthetic emerges, addressing both questions of compositional specifics and metaphysical symbolism. [...] Committed to a vision of music as the unifying thread of contemporary culture, the Medtners sought to recapture an aesthetic sense based upon emotion, intuition, and a recognition of eternal laws that they believed underpinned all artistic expression, Nikolai was expected to resurrect those ideals in music. $\ll^{23}$

18 My translation of Flamm 1995, p. 69: »Zwischen Andrej Belyj und Nikolaj Metner [hat] eine bedeutende, wechselseitig befruchtende Freundschaft bestanden [...], die in den Werken beider ihre Spuren hinterließ.« See also ibid., p. 49ff., for a detailed examination of Bely's influence on Medtner. However, the friendship began to dwindle in the early 1910s, resulting in Bely eventually breaking off the connection to the Medtners in 1913. For more details see Ljunggren 2014, p. $101 \mathrm{ff}$.

19 See Martyn 1995, p. 1ff., and Flamm 1995, p. 2f.

20 Emil Medtner 1912 [under his pen name Vol'fing], p. 1983: »[...] primikkaya vsetselo k idushchey ot nachala XVII veka do Vagnera i Bramsa germanskoy tvorcheskoy linii. Sovershenno pravil'no takzhe N. Metner otnesen v repertuarnikh spiskakh k nemetskim kompozitoram, kak avtor Goethe-Lieder.« See also Flamm 1995, p. 45; Flamm $2002^{\mathrm{a}}$, p. 188; and Mitchell 2015, p. 134f.

21 See Flamm 1995, p. $45 \mathrm{ff}$.

22 Marsrow 2008, p. 89.

23 Mitchell 2015, p. 112. 
In his Nationalist attitude, Emil even anticipated that Nikolai would arise as a blend of Dionysian and Apollonian character, a notion derived from Nietzsche's philosophy which was highly popular in Russia at that time, ${ }^{24}$ and as »a perfect synthesis—both racially and musically_ of Russian and German temperaments « ${ }^{25}$ The dark sides of Emil's orientation were his fanatic nationalism, viewing Germanic culture as superior to Russian, ${ }^{26}$ and also a growing inclination to racist and anti-Semitic ideas, absorbed through the writings of Wagner and Chamberlain. Even though there is not a single indication that Nikolai shared the latter tendencies, ${ }^{27}$ he seems at least to have adopted Emil's idea of German cultural hegemony and was himself an ardent exponent of ranti-modernism< (see chapter 0.2.1). Due to Emil's influence, Nikolai elected Beethoven, Schumann, and Wagner as his musical idols; and while the latter, during emigration, gradually lost importance as a source of inspiration, it was Beethoven in particular who remained a principal point of reference throughout the composer's life.

Notwithstanding this clear orientation towards German musical legacy, some aspects of Medtner's musical language are unmistakably Russian, despite this fact was neglected or even denied by some scholars. Michel Calvocoressi wrote that »the German classical idiom is the natural vehicle of his musical thought, and $[\ldots]$ he could no more felt at home in the Russian vernacular than Borodin or Mussorgsky in the idiom of Brahms and Reger «, ${ }^{28}$ whereas Richard Anthony Leonard, somewhat maliciously, asserted that »Medtner (who had in fact German blood) was at times completely indifferent to his Russian heritage, and composed as if he was a nineteenth-century German $«{ }^{29}$ Yet many instances of a particular 〉Slavic tone $<$ can indeed be found in Medtner, though not so much in his sonatas but rather in the skazki and songs. ${ }^{30}$

To name but a few examples which express Russianness through a particular type of melody, intentionally devised as to sound like Russian folk song (narodnaya pesnya), the initial subject and theme of the B section from the Russian Skazka in F minor, Op. 42 No. 1 (1924) spring to mind, conveying a melancholic and wistful tone as found in many traditional melodies. As a striking resemblance of the melos of Orthodox

24 Emil had apparently made similar attributions towards Bely; see Ljunggren, p. 17: »[...] both had something Dionysian about them, but Nikolai was considerably more reserved than the volatile Belyi . As for the Dionysian side of Nikolai's character and music, another contextualisation might arise from his use of the term dithyrambos, a type of ancient Greek choral poetry associated with the praise of Dionysus, as a musical genre-for instance in the Three Dithyrambs, Op. 10, the finale of the $1^{\text {st }}$ Violin Sonata, Op. 21, or in the Danza ditirambica found in the $3^{\text {rd }}$ set of Forgotten Melodies, Op. 40 No. 6. For a general discussion of the Nietzschean Apollo vs. Dionysus polarity in Russian Symbolism, see Deppermann 1984, p. 89f.

25 Bertin 2018, p. 37. See also Alenskaya 2003: »Heir to two currents of western [sic!] music—Russian and German«.

26 Regarding Emil Medtner's view of the cultural-historical position of both countries see Ljunggren 1994, p. 20: »Germany [...] had been chosen to achieve spiritual hegemony«, while Russia »represented an immature cultural stage in need of German discipline. « See also Flamm 1995, p. 90: »Émilij Metner [sah] in seiner fanatischen Germanophilie nur in der Aneignung deutscher Kultur eine Zukunft der russischen [...] und [dürfte] das seinem Bruder eingeschärft haben«. However, Redepenning 2008, p. 67, somewhat attenuates this evaluation: »Nikolaj Metner [teilte] den Kulturpessimismus, nicht aber die penetrante Germanophilie seines Bruders «.

27 See Flamm 1995, pp. 37 and $71 \mathrm{ff}$.

28 Calvocoressi 1944 , p. 84, referring to Medtner as »musically non-Russian« and belonging to a group of »nonnationalist « Russian composers in differentiation to >The Five ( moguchaya kuchka) and other alleged »lesser nationalists« such as Lyadov and Glazunov.

29 Leonard 1956, p. 342.

30 Bertin 2018, p. 20, embraces the thought that the piano sonatas are Medtner's most >German< works, while the skazki stand for the Russian side of his personality, in analogy to the mazurkas representing Polishness in Chopin in comparison to his sonatas. 
chant, the serene variation theme from the $2^{\text {nd }}$ movement of the $2^{\text {nd }}$ Violin Sonata, Op. 44 (1923-26; see example 2.2.1) should be mentioned; ${ }^{31}$ or, as prominently found throughout Russian art music, allusions to church bells, such as in the B minor Skazka >Campanella<, Op. 20 No. 2 (1908-09). ${ }^{32}$ Other connections can be established by references to modal scales or stereotypes of dance, as seen in the Skazki, Op. 51 (1928), the dedication of which (»To Ivan the Fool and Cinderella«) directly hints to the world of Russian folk tales. ${ }^{33}$ These examples give proof of a tangible stylistic trait related to a national idiom, possibly derived from other composers' music which had earlier adhered to folklore earlier. Particularly often, a \Slavic tone $<$ is found in Medtner's settings of Russian poems, such as the Tyutchev song Sizhu zadumchiv $i$ odin (Absorbed and Alone), Op. 28 No. 6 (1913), or Pushkin's Ekho (The Echo), Op. 32 No. 1 (1915). As Hamish Milne observed, »his Russian songs crystallise the Russian melos as vividly as do the folk-song settings of, say, Balakirev or Lyadov «. ${ }^{34}$ Even more examples of obvious reference to Russian folklore occur in Medtner's works of the 1940s, such as the Chorovod (Russian Round Dance) for piano duo, Op. 58 No. 1 (1940) and the $3^{\text {rd }}$ Piano Concerto, Op. 60 (1941-42), which is essentially based on a narrative derived from Lermontov's poetry.

However, it would be misleading to assume a proximity of Medtner's music to Russian folklore in such a way as to expect discernible quotations of melodies. Iosif Yasser, in his extensive discussion of those influences, stated that even $»$ some of the avowed admirers of Medtner have been wary of recognising his music as specifically Russian in character and texture $\ll,{ }^{35}$ and traces passages from Medtner's instrumental music to phrases from similarly-sounding traditional tunes. Lastly, to put it straight, indisputable quotations from the world of Russian folk song are virtually non-existent in Medtner, particularly when compared to the way more obvious instances in the music of Tchaikovsky, >The Five «, or Stravinsky. Thus, the passages where Medtner sounds \Russian $\prec$ or \Slavic $<$ have comparatively little to do with authentic folklore, and may rather be considered a refined approximation, or mimetic adoption, of a distinctly national melodic idiom.

\section{Inspiration through Literature}

Since the Medtners were highly appreciative of Germanic culture, Johann Wolfgang Goethe, as the foremost representative of German Classicist literature, served as a kind of household deity in the family. After initial engagement with Mikhail Lermontov, a classic of Russian poetry whose lyrics affected Medtner's earliest published works, Opp. 1 and 3 (1901-1903), Goethe naturally provided a principal source of inspiration for the young composer's vocal music. Among Medtner's songs, Goethe holds the most prominent position,

31 See Yasser 1955, p. 63.

32 See Hamilton 2017, p. 29 and p. 49.

33 Alekseyev 1969, p. 251, mentions both these works to indicate that Medtner had remained an entirely Russian composer: »To nazvaniem p'esï [...], to posvyashcheniem tsikla [...] on kak bï khotel podcheknut', chto ostalsya russkim kompozitorom. «See also ibid., p. 256, again referring to the Russian Skazka, Op. 42 No. 1: »It is the narrative character of Medtner's music which most convincingly suggests the proximity to Russian folk song « (»Imenno v povestvovatel'nosti muzïki Metnera osobenno otchelivo skazalas' ee bliznost' k russkoy pesennosti«). See also Yasser 1955, p. 59f.

34 Milne 1980, p. 23.

35 Yasser 1955, p. 56f., referring to Medtner's adoption of Russian melos as »)ethnographic trimmings « (in quotation of the composer's own expression) which he would use »in some special cases only«. See also Yasser 1981, p. 203. 
with three opus numbers comprising twenty-seven songs exclusively dedicated to his poetry: Opp. 6, 15, and 18 (1903-1909). Goethe's works also affected some of Medtner's instrumental music, such as the Sonata Triad, Op. 11 (1904-08), and the three Nachtgesänge for violin and piano, Op. 16 (1907-08), both of which were ascribed with lyric mottos. ${ }^{36}$ Besides Goethe, Medtner also resorted to three poems by Heinrich Heine in his Op. 12 (1907), and to five poems of the young Friedrich Nietzsche, Opp. 19 and 19a (1909-10).

Christoph Flamm distinguishes three main stages in Medtner's vocal music, delimited by the choice of texts. ${ }^{37}$ After the period of »Germanic years « from 1904-09, also shaped by an extended journey to Munich in 1907, he somewhat abruptly turned to setting Russian poems from 1910 onwards, leaving Goethe behind for more than a decade. In the following period, he concentrated on the works of national poet Aleksandr Pushkin and the Romanticists Fëdor Tyutchev and Afanasy Fet, publishing six opus numbers devoted to these three (Opp. 24, 28, 29, 32, 36, and 37; 1911-18), ${ }^{38}$ until he left Russia in 1921. Literary references are also evident in the E minor Sonata, Op. 25 No. 2 (1910-12), which is inscribed with an epic motto by Tyutchev, and the Sonata-Ballade in F\# major, Op. 27 (1912-14), subtly alluding to a Fet poem (see the corresponding analyses in chapters 3.4 and 3.6). In succession, German poetry returns during the long period of »Years of wandering and inner emigration« from 1922-51, as seen in Op. 46 (1924), which employs poems by Goethe, Joseph von Eichendorff, and Adelbert von Chamisso, and with the Goethean sujets inherent in the Sonata-Vocalise and Suite-Vocalise, Op. 41 Nos. 1 and 2 (1922-27). However, non-Russian poets did not play such a dominant role in Medtner's music as before - except for Goethe, the occupation with whom alternates with settings of Russian poems, as in Opp. 45 and 52 (1924-29), which again resort to Pushkin and some Tyutchev. In Medtner's last songs, published posthumously as his Op. 61 (1954), a bundle of seven songs of various origin were disparately combined, set to texts by Eichendorff, Lermontov, Pushkin, and Tyutchev, and summing up Medtner's output to a total of 107 published songs.

The most important caesura in Medtner's creative life, roughly dividing his œuvre in two halves (Opp. 1-40; Opp. 41-61) is marked by his emigration from Russia in September 1921-a delayed reaction to the 1917 revolution and the start of the Russian Civil War. The decision to leave his home country coincided with personal consequences the family had to face in the post-revolutionary years, such as repression, loss of possessions due to expropriation, and destruction of their cultural environment. It is hardly imaginable that a composer of Symbolist orientation, with his innermost creative thought being connected to a quasi-religious conception of the nature of art, could have continued working under the instrumentalising and exploitative attitude of Soviet cultural policy. Nevertheless, a possible stylistic change due to the experience of revolution and emigration is not as clearly discernible in Medtner's music as one might expect. His rexile style< can however be delineated by a few observations on how his later compositions differ from the earlier works written in Moscow. First, the distinct Russian tone evident in the abovementioned examples from the Skazki

36 For an overview of all of Medtner's compositions inspired by Goethe, see Flamm 2002 ${ }^{\mathrm{a}}$, p. $194 \mathrm{f}$.

37 Flamm 1995, chapter »Lieder und literarische Inspiration«, pp. 163-209.

38 The only exception from these three poets is a song after Valery Bryusov, Tyazhela, bestsvetna i pusta (Heavy is the gravestone), Op. 28 No. 4 (1913). At the same time, the Bryusov song is one of the only two cases that Medtner turned away from classical to contemporary poetry, with the other example being his setting of Bely's Epitafiya »Zolotomu blesku veril« (»I believed in the golden shine«), originally titled Druzyam (To the Friends), Op. 13 No. 2 (1907). 
of the 1920s, Opp. 42 and 51, allows for the conclusion that »the national traits in Medtner's music became more and more apparent over the time. It is almost as if one feels how he is longing for his homeland while living in diaspora $\ll .{ }^{39}$ This aspect partly corresponds with an increasing interest in modal diatonic scales (see chapter 2.2.2). Second, there is a noticeable tendency to produce textures of greater clarity and simplicity in some of the piano works of the 1930s, namely Opp. 54-56 (as mentioned before in chapter 0.2.1). All in all, we might conclude that Medtner, while restlessly moving from one place to another through Germany, France, and England, chose to express the agony of his artistic isolation by subtle, yet significant and recurring allusions to the culture of the country he had left behind—-showing a trait of his musical language which had not played such a significant role before.

\subsubsection{Symbolism ANd Russian Silver AgE}

In order to assess Medtner's position in the context of artistic developments of his time, we will have to consider his relationship to the Symbolist movement as one of the major directions in European intellectual history of the early $20^{\text {th }}$ century, and in particular its manifestations within the Silver Age (serebryanïy vek) of Russian literature and music. In a short backview to the emergence, expansion, and decline of these currents, I will highlight a number of aesthetic preconditions for Medtner's creative activity.

The expressions fin de siècle (〉end of the century८, cf. also belle époque), and décadence, employed both as period terms and denominations of a cultural worldview, stand for an aesthetic climate in European art which served as a basis for movements such as Symbolism and Expressionism. The former, which will be primarily regarded here, originated in France, defining itself by rejection of the trends of Naturalism and Realism, which it aimed to replace with ideas of spirituality and personal imagination. In the domain of literature, French Symbolism was initiated through the poetry of Charles Baudelaire, and essentially formed by Paul Verlaine, Stéphane Mallarmé, and Arthur Rimbaud as its main exponents. These poets tended to make use of linguistic symbols as signifiers independent from their traditional semantics, and sought to create meaning by combining iconic fragments of Realist language to produce a newly conceived experience of poetry.

The ideas of the French Symbolists were in turn transferred to Russia, where the abovementioned poets were strongly absorbed, and a parallel movement was initiated by Dmitry Merezhkovsky's treatise On the Reasons for the Decline of Contemporary Russian Literature (1892). This development took place in the framework of the Russian Silver Age (a period term conceived in response to the Golden Age of Russian Poetry during c. 1800-50), which united a number of stylistic trends in literature at the turn of the $20^{\text {th }}$ century, gaining significant stimuli from the writings of Nietzsche, Schopenhauer, and Solovëv. The Russian Silver Age not only incorporated Symbolism, but also other tendencies in literature and the fine arts. In music, the term may be applied to the music of composers born between c. 1870-90, a generation which increasingly recognised their influential predecessors, namely Tchaikovsky and the Petersburgian school of `The Five«, as a

39 My translation of Alekseyev 1969, p. 251: »S techeniem vremeni natsionalnïe cherti muzïki kompozitora vïstupali vse bolee opredelenno. Chuvstvuetsya, chto, nakhodyas' vdali ot rodinï, on tyanulsya k ney.« 
>Classical period‘, or Golden Age, of Russian music. ${ }^{40}$ These sought to find new paths in composition as opposed to the aesthetic paradigms of the $19^{\text {th }}$ century, largely turning away from the genres of opera and ballet. Generally speaking, »music in Russian Symbolism advanced to the rank of a philosophical category «, ${ }^{41}$ and this statement aptly describes the artistic environment of the Medtner family. Yet, after being one of the foremost aesthetic forces in Russia during the first decade of the $20^{\text {th }}$ century, the Symbolist movement declined around 1911, giving way to the avant-garde movements of Futurism (represented by poets such as Vladimir Mayakovsky and Velimir Khlebnikov) and Akmeism (Osip Mandelstam, Anna Akhmatova, and others).

Among the Russian Symbolists, two generations of poets may be differentiated, with their periods of work partly overlapping. Important figures of the earlier generation were Fëdor Sologub, Konstantin Balmont, Innokenty Annensky, Zinaida Hippius, and Valery Bryusov; the latter, with his almanac Russian Symbolists (1894), advanced to become the spokesman of the movement. The works of the abovementioned authors were typically committed to philosophical and metaphysical sujets, tending towards a self-stylisation of the poet as a mystic medium. The younger group, with Aleksandr Blok and Andrei Bely as its main exponents, was significantly influenced by the ideas of the poet and religious philosopher Vladimir Solovëv. As a consequence, their poetry is characterised by spirituality and mysticism, particularly reflecting the prerevolutionary upheavals in social life and politics. An idea common to the Russian Symbolists is the belief to live at the verge of their era, or even contribute to a final epoch of artistic eschatology. Blok's and Bely's œuvre coincides with the atmosphere of the collapsing Russian Empire, expressed through a rich system of lyrical imagery, and indicating societal change and overthrow by the metaphoric depiction of natural phenomena, such as thunderstorms or blizzards.

In general, Symbolist works tend to share and exchange ideas from different art forms, and to create approximations between music, poetry, drama, and visual arts, forming a network of versatile mutual influences. This phenomenon may primarily become apparent at the surface - that is, in the titles of works; there are Symbolist paintings named like pieces of music, and musical works with titles derived from literature or the fine arts. In this context, the intellectual sphere of Symbolism produces a fruitful exchange between styles and disciplines, something which can be referred to as an early manifestation of sintermediality $<$. Two examples of works by Eastern European artists strongly affected with Symbolist ideas shall illustrate this tendency here. First, there was the predilection of Medtner's friend and creative stimulator, the poet Andrei Bely, to transfer principles of musical form to literature, which determined the choice of titles of four of his early epic works, named ssymphonies $<$. The earliest and most popular of these is the four->movement $<S e-$ cond $>$ Dramatic Symphony (published in 1902; see figure 0.2). Second, a considerable portion of the œuvre of the Lithuanian painter and composer Mikalojus Čiurlionis, who received his musical education in Warsaw and Leipzig, is characterised by intermedial tendencies — he created a number of painting cycles named $>$ sonatas`, including the diptych Stellar Sonata (1908), which comprises two separate `movements` titled Allegro and

40 See Redepenning 2008, p. 47: »Was die Musik betrifft, so paßt der Terminus \Silbernes Zeitalter insofern, als sich die Phase der sogenannten Petersburger Schule und Čajkovskijs im Rückblick wie ein >Goldenes Zeitalter auszunehmen und in eine >russische Klassik zu verwandeln begann.«

41 Deppermann 1984, p. 93: »Musik rückt im russischen Symbolismus in den Rang einer philosophischen Kategorie ein.« 
Andante (see figure 0.3). ${ }^{42}$ Also, the artistic visions of the late Aleksandr Scriabin, whose drafts for an interdisciplinary Mysterium (1903-15) aimed to synaesthetically merge the spheres of music, poetry, dance, light, and odour, delineate an utopia of multi-sensual inspiration much representative of Symbolist transdisciplinarity.

\section{PART ONE}

1. A season of sweltering grind. The roadway gleamed blindingly.

2. Cab-drivers cracked their whips, exposing their worn, blue backs to the hot sun.

3. Yard-sweepers raised columns of dust, their grime-browned faces loudly exulting, untroubled by grimaces from passers-by.

4. Along the pavements scurried heat-exhausted intellectuals and suspicious-looking citizens.

5. All were pale and over everyone hung the light-blue vault of the sky, now deep-blue, now grey, now black, full of musical tedium, eternal tedium, with the sun's eye in its midst.

6. Streams of white-hot metal poured down from the same spot.

7. None knew where they ran to or why, fearing to look truth in the eye.

1. A poet, writing a poem about love, was having difficulty with the choice of rhymes. And dropped an ink-blot, and, turning his eyes towards the window, took fright at the tedium of the sky.

2. The grey-blue vault smiled at him with the sun's eye in its midst.

1. Two men were arguing over a cup of tea about people great and small. Their cracked voices had grown hoarse with debate.

2. One sat with his elbows on the table. He raised his eyes to the window. He saw. He broke all threads of the conversation. He had caught the smile of eternal tedium.

3. The other was leaning his short-sighted, pock-marked face towards his antagonist, spattering him with spittle, as he finished bawling out his objection.

\footnotetext{
4. But the other did not bother even to wipe his face with handkerchief; he had withdrawn into the depths, plunged into the fathomless.

5. And the victor threw himself back in his chair, his good-natured, stupid eyes peering out at the silent one through golden spectacles.

6. He knew nothing of the removal of the final veils.

7. And in the sweltering streets, in the blinding whiteness, men in darkblue jackets drove by on water-carts.

8. They sat on barrels which gushed out water underneath.

1. High buildings towered like a spread of bristles, puffed up like fattened pigs.

2. One moment they would wink their countless windows at the timid pedestrian, the next they would flash him a blind wall as a sign of contempt, then they would sneer at his hidden thoughts with belching columns of smoke.

3. On these days and at these hours documents and memoranda were being composed in offices, and a cockerel led hens around the paved courtyard.

4. Two grey guinea-fowl were in the courtyard too.

5. A talented artist had painted a "miracle" on a large canvas, ${ }^{2}$ and twenty skinned carcases hung in the butcher's shop.

6. And everybody knew this, and everybody concealed it, fearing to turn their eyes towards the tedium

7. And yet there it was, shadowing everyone, a misty, invisible outline.

8 . Although the water-cart men were consoling each and everyone by spreading mud everywhere, and children bowled hoops along the 9. Although the light-blue vault laughed into everyone's eyes, the
terrible, grey-blue vault of the sky with the sun's eye in its midst.
}

Figure 0.2: Bely, Simfoniya 2-ya, dramaticheskaya (Second >Dramatic Symphony), beginning of $1^{\text {st }}$ part $(1902)^{43}$
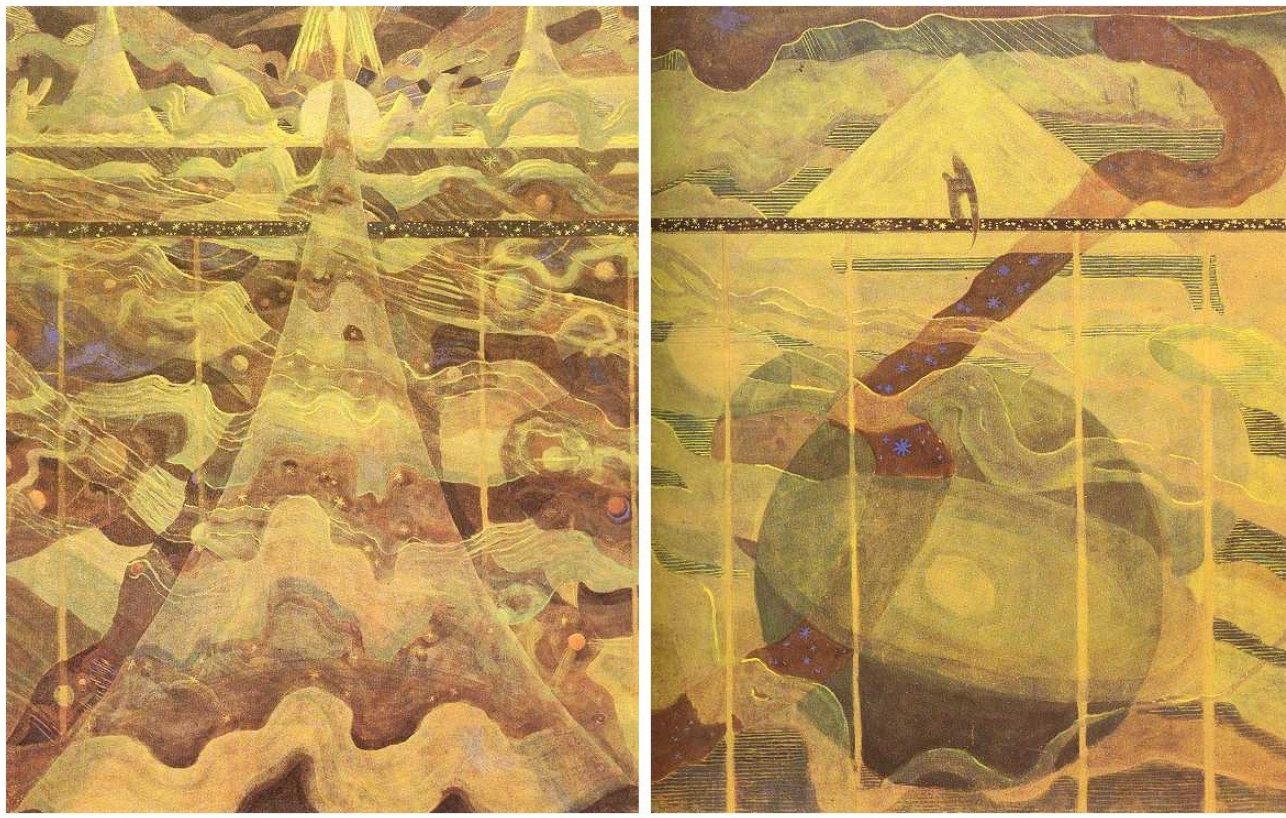

Figure 0.3: Čiurlionis, Žvaigždžiu sonata (Stellar Sonata), Allegro and Andante (1908)

42 Another work illustrative of these tendencies is, though rather belonging to the aesthetics of Futurism, the crossmedial stage composition Pobeda nad solntsem (The Victory over the Sun, 1913) which was collaboratively created by the four artists Kazimir Malevich, Mikhail Matyushin, Aleksei Kruchënïkh, and Velimir Khlebnikov.

43 Quoted from Bely 1902, pp. 19-20, in the 1986 translation by Roger Keys. 
Other elements central to Russian Symbolism are imagery of colours and synaesthetic perception, that is, the spontaneous association of sensory impressions from different fields, which may collectively act as means of artistic expression. Synaesthetic thought is vividly expressed in Vasily Kandinsky's famous aphorism »Colour is the keyboard, the eyes are the hammer, the soul is the strings $\ll .{ }^{44}$ However, synaesthesia is too vaguely defined, and too inconsistently conceived, to be considered a sustainable artistic category. It is rather a symptom, an indicator of Symbolist zeitgeist, and as such but one of several features of this interdisciplinary movement, which Leonid Sabaneyev conceived as a »demand for mystic, orgiastic, and even >satanic $<$ perceptions of $\operatorname{art} \ll{ }^{45}$ What is more, several Russian artists of the early $20^{\text {th }}$ century showed an affinity to the intellectual movements of theosophy, anthroposophy, mysticism, occultism, and to psychoanalysis. There were intense relationships and exchanges of thoughts between Andrei Bely and Rudolf Steiner, Emil Medtner and Carl Gustav Jung, Aleksandr Scriabin and Helena Blavatsky, and between the philosopher Ivan Ilyin, one of Nikolai Medtner's most devoted advocates, and Sigmund Freud. ${ }^{46}$

In the light of all these developments and tendencies, Dorothea Redepenning's assessment that $»$ Medtner showed hardly any interest in Symbolism $\aleph^{47}$ seems not quite accurate as it wouldn't seem viable to have escaped from this network of aesthetic inspiration conveyed by his friends and family. As Amanda Marsrow states, »there was perhaps no composer of the Silver Age more thoroughly integrated into the literary and philosophical milieu of Moscow's Symbolist circles « ${ }^{48}$ Even if Medtner himself showed no ambition to produce interdisciplinary or cross-medial works, and-apart from Muza i moda as his written contribution to aesthetic discourse - never quite transcended the realm of pure sound, his music features numerous allusions to other disciplines and art forms, continuously crossing borders on the field of musical genres (see also chapter 2.5). In this sense, a >scent of interdisciplinarity < is in fact inherent to Medtner's music. His personal approximation of Symbolism is not so much defined by the use of Symbolist poetry (there are only two poems by Andrei Bely and Valery Bryusov which he set to music), but by a subtle dimension of immersion into poetry, spirituality, or metaphysical thought, as seen in some of his instrumental works like the SonateBallade in $\mathrm{F} \#$ major, Op. 27 (see the corresponding analysis in chapter 3.6), or the Piano Quintet in C major, Op. posth. A statement by Elena Dolinskaya adequately grasps Medtner's relationship to Symbolism:

»Maybe it were only the creative efforts of a group of Russian Symbolist poets (Bryusov, Bely, and Vyacheslav Ivanov) which proved, to some extent and in a certain period, similar to Medtner's state of mind during the first decades of the $20^{\text {th }}$ century. [...] In particular, the Symbolists' subjectivist attitude apparently resonated with Medtner's creative quest during that time. $\aleph^{49}$

44 Vasily Kandinsky, Über das Geistige in der Kunst, Bern 1911, p. $91 \mathrm{f}$.

45 Leonid Sabaneyev, Geschichte der russischen Musik, Leipzig 1926, p. 167.

46 See Ljunggren 2014, pp. 107-133, for a detailed examination of the interactions between Russian artists and the protagonists and masterminds of these movements.

47 Redepenning 2008, p. 67: »Gleichfalls [wie Glièr, Štejnberg, Čerepnin und Grečaninov] kaum Interesse am Symbolismus zeigte der deutschstämmige Nikolaj Metner«.

48 Marsrow 2008, p. 93.

49 My translation of Dolinskaya 1966, p. 46: »I, pozhaluy, tol'ko tvorcheskie ustremleniya gruppï russkikh poètovsimvolistov (V[aleriy] Bryusov, A[ndrey] Belïy, Vya[cheslav] Ivanov) do nekotoroy stepeni i lish' na opredelennom etape okazalis' blizkimi nastroeniyam Metnera pervïkh desyatiletiy XX veka. [...] Spetsificheski sub'"ektivistskoe 
Even though the most intense period of Medtner's identification with Symbolist literature and philosophy seems to have been limited to the years of c. $1902-08,{ }^{50}$ he had thoroughly absorbed the idea that musical works meant more than they revealed on their outer surface, and implied a hermeneutic perspective which went beyond that of the audience and the performer. This quality, be it an apparent feature conveyed by descriptive titles or poetic epigraphs, or be it enigmatically hidden behind the musical score, is one of the most characteristic features of Medtner's music - though underestimated in previous scholarship - and as such constitutes a genuine aspect of Symbolism in music. Yet Flamm's 1995 evaluation, pointing out that »Medtner's position in the history of music, which originates from a hitherto neglected niche of Russian Symbolism, demands for a more explicit determination $«,{ }^{51}$ still proves valid a quarter of a century later. In this sense, future research will be much appreciated to further explore the fascinating interdependencies and intersections of Russian music, literature, and philosophy of the early $20^{\text {th }}$ century.

mirooshchushchenie poetov-simvolistov, vidimo, okazalos' $\mathrm{v}$ tot period vremeni $\mathrm{v}$ kakoy-to stepeni sozvuchnïm $\mathrm{i}$ tvorcheskim iskaniyam Metnera."

50 See Flamm 1995, p. 67ff., and Zetel 1981, p. 110f.

51 My translation of Flamm 1995, p. 142: »Metners musikhistorische Position, die einer bislang übersehenen Nische und Facette des russischen Symbolismus entspringt, [läßt sich noch] nicht klar genug bestimmen.« 


\section{The Sonata: Tradition and Innovation}

A sonata is, in the original meaning of the term, nothing more than a >piece that sounds $<$, understood as a composition to be played in contrast to something which is sung. ${ }^{1}$ However, over the centuries the term has developed a large and diverse space of generic contexts which, when not regarded in their specific temporal and stylistic environments, might oppose or even contradict each other. Today, a sonata is most frequently conceived as »a piece of music usually but not necessarily consisting of several movements, almost invariably instrumental and designed to be performed by a soloist or a small ensemble [, and] generally incorporat [ing] a movement or movements in [...] Sonata form $«{ }^{2}$ Here I intend to provide a brief history of sonata composition and theory of sonata form, condensed and customised to the primary purpose of delimiting the preconditions of Nikolai Medtner's contributions to this traditional genre, and relating to possible connections between his music and that of his predecessors. In this way, I aim to build a historical and theoretical framework as a basis for the subsequent discussion of Medtner's music.

The fact that the sonata figured as one of the foremost means of musical expression is evident in statements of composers and theorists already since the Baroque period, and grew even more distinct during Viennese Classicism. Throughout the $18^{\text {th }}$ century, it was primarily described as a species of instrumental music — that is, a genre - rather than in the sense of implying a particular musical form. Johann Mattheson wrote in 1713 that the Baroque sonata of his time was »a kind of instrumental composition, particularly for the violin, which consists of alternating Adagio and Allegro [movements], and recently seems to have aged a little [...], but to some extent has been freshly reanimated on the full-voiced keyboard. $\aleph^{3}$ Johann Walther, two decades later, similarly remarked that a »sonata [...] represents a serious and artificial piece of instrumental music, mainly for violins $«{ }^{4}$ also emphasising the alternation of slow and fast movements. From the middle of the $18^{\text {th }}$ century, an inclination to view the sonata's rank in analogy to genres of other domains or artistic disciplines arises in scholarly writings. Jean-Jacques Rousseau, in the French Encyclopédie, regarded the sonata as a piece composed in four or five movements of different character, occupying a similar position in instrumental music as the cantata among compositions for the voice, ${ }^{5}$ and Augustus Kollmann declared that a

1 See Rosen 1971, p. 30: »The original meaning of >sonataく was >played « as opposed to >sungく, and it only gradually acquired a more specific, but always flexible, sense.«

2 Mangsen, Irving, Rink, and Griffiths 2001, p. 617.

3 My translation of Mattheson 1713, p. 175: »Sonata ist eine Art Instrumental-insonderheit aber Violin-Sachen / die in abgewechselten Adagio und Allegro bestehet / nunmehro schier etwas zu veralten beginnen will / [...] auff dem vollstimmigen Clavier aber gleichsam von frischen wieder belebet worden ist $\ll$.

4 My translation of Walther 1732, p. 571: „Sonata oder suonata [ital.] von sonare oder suonare, lauten, klingen; ist ein vor Instrumente, insonderheit aber vor Violinen, gesetztes gravitätisches und künstliches Stück, so in abgewechselten adagio und allegro bestehet.«

5 My paraphrase of Rousseau 1765, p. 348: »Sonate, s. f. en Musique, est une piece de musique purement instrumentale, composée de quatre ou cinq morceaux de caracteres différens. La sonate est à-peu-près par rapport aux instrumens, ce qu'est la cantate par rapport aux voix.« 
sonata »may be compared in Instrumental Music, to what an Air is in Vocal Music. ${ }^{6}$ A paradigmatic example of the Classicists' perception of the significance of composing sonatas, now primarily perceived as a genre of piano music, was expressed in Daniel Gottlob Türk’s 1789 statement: »The sonata most reasonably deserves the principal position among compositions dedicated to the piano. Looking at what the ode stands for in poetry, just about that is represented by the true sonata in music. ${ }^{7}$ It was not until the doctrine of Türk's contemporary, Heinrich Christoph Koch, that the term >sonata transcended the mere description as a musical genre, and became subject to an elaborate theory of sonata form, understood both as the succession of a multi-movement layout and the structure of its first movement (see chapter 1.3.1).

\subsection{European Piano Sonatas AFter BeETHOVEN}

In this chapter I will not delineate a full genre history of $19^{\text {th }}$-century piano sonatas, which has been thoroughly accomplished by standard literature, ${ }^{8}$ but name a number of aspects and developments which account for the preconditions of Medtner as a composer of sonatas, and will be introduced as individual features of his own sonata œuvre (see chapter 2.1). Considering Ludwig van Beethoven as the progenitor of Medtner's formal aesthetics and a principal source of inspiration, it seems consequential that he claimed to be »Beethoven's pupil«, as reported by his student Panteleymon Vasilyev. However, this heritage, as Vasilyev emphasised, must not be regarded as mere imitation, but as an organic pervasion of his artistic ideas by the essence of Beethoven's artistic thought, ${ }^{9}$ deriving his formal idioms from the paradigms of Classicism. The scope of exploration will therefore start with Beethoven's music, while earlier developments will be excluded, acknowledging that Haydn's and Mozart's keyboard sonatas did not function as direct models for Medtner's contributions to the genre. After I have previously related to the dilemma of viewing Medtner as a >traditionalist (see chapter 0.2.1), we can depart here from the supposition that his Austro-German musical legacy served him as a general point of reference, rather than coining a stylistic or idealistic dependence, or even epigonism. As a professor and leader of a piano class at the Moscow Conservatory, Medtner also taught Beethoven's sonatas and thus passed his conviction on to his students. Even though he did not instruct them in composing, it would well merit separate research to examine to what extent this legacy flourished in the performances and compositions of Vasilyev, Abram Shatskes, Mark Gurvich, Nikolai Shtember, Nikolai Sizov, and others. ${ }^{10}$

6 Kollmann 1799, p. 9.

7 My translation of Türk 1789, p. 390: »Die Sonate verdient unter den Tonstücken, welche für das Klavier bestimmt sind, wohl mit dem mehrsten Rechte die erste Stelle. Was man in der Dichtkunst unter der Ode versteht, ungefähr eben das ist in der Musik die eigentliche, wahre Sonate."

8 See, among others, Newman 1969; Alekseyev 1982; Kämper 1987; Edler 2004; Schmidt-Beste 2006; and Protopopov 2010.

9 See Vasilyev in Apetyan 1981, p. 72f.: »Metner v odnoy iz besed so mnoy nazval sebya uchenikom Betkhovena. [...] Zdes' prikhoditsya govorit' ne o podrazhanii robkogo uchenika svoemu uchitelyu, a ob organicheskom proniknovenii, ob ispovedanii samoy suti togo yavleniya v iskusstve, kotoromu imya-Betkhoven.« See also Martyn 1995, p. 77.

10 Apart from the teaching delivered to his London student Edna Iles, surveyed in depth in Karpeyev 2014, Medtner's influence on his pupils at the Moscow Conservatory and during emigration is still widely unexplored. 

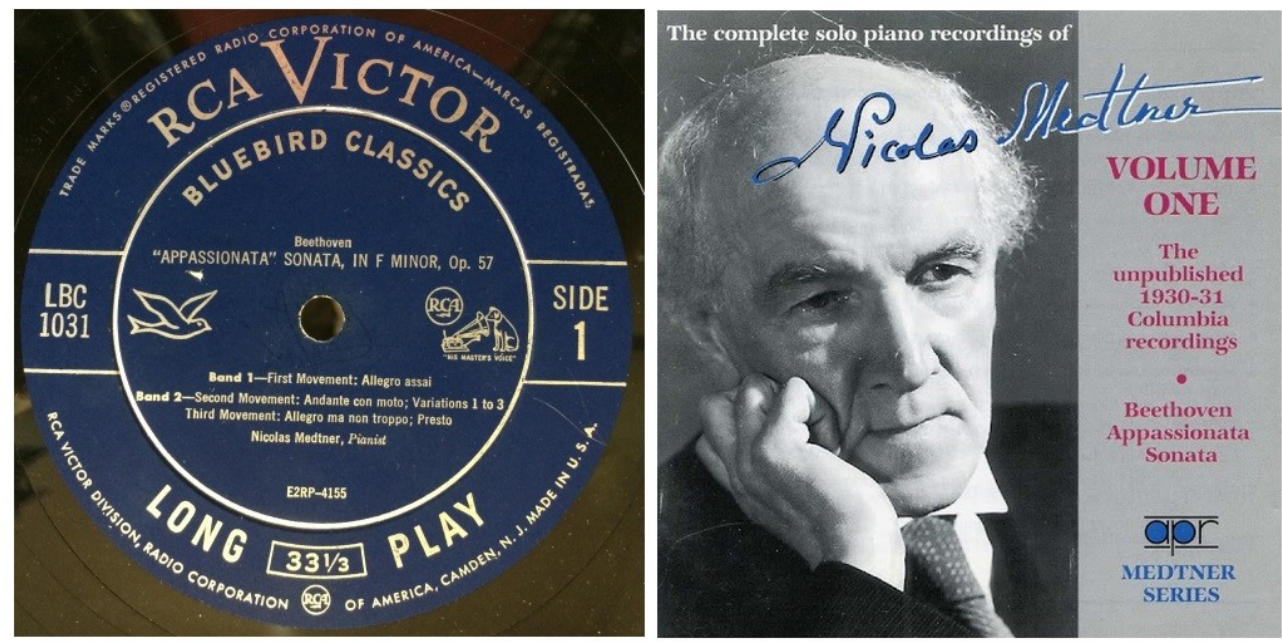

Figure 1.1: Medtner's recording of Beethoven's Sonata, Op. 57 (RCA Victor 1930, first released by APR 2004)

While Medtner's music clearly profits from being measured by Beethoven's model, other music—-for instance, many of Franz Schubert's sonatas, or Pëtr Tchaikovsky's symphonies - may not advantageously benefit from being exclusively judged by the parameters of Beethoven's sonatas, such as formal balance or organic discourse of motivic development. In this sense, the diligent reference to Classical models poses the risk of neglecting approaches from other aesthetic directions or lines of tradition. The forthcoming considerations will therefore attempt to grasp a broad variety of styles and national idioms, regardless of whether a dependency of the Viennese Classicist tradition is detectable or not. However, for a large number of $19^{\text {th }}$ century German and Austrian composers of symphonies and sonatas, Beethoven was considered a touchstone and, more often than not, an overpowering shadow. ${ }^{11}$ This has doubtlessly contributed to the fact that the piano sonata, understood in its traditional multi-movement design, nearly went extinct in Central Europe during the second half of the $19^{\text {th }}$ century. Besides the attempts of Franz Liszt and his followers to unify the sonata form and sonata cycle, only a few German composers produced piano sonatas during the 1860s and 1870s, such as Ferdinand Hiller, Xaver Scharwenka, and the Liechtenstein-born Josef Gabriel Rheinberger. In the meantime, multi-movement sonatas had significantly decreased in popularity and were no longer essentially programmed in piano recitals. ${ }^{12}$ For several composers, the goal of composing sonatas had somewhat changed in perception to being regarded as a retrospective study, and thus Richard Strauss, Eugen d'Albert, and Jean Sibelius only contributed a single work originating from their period of education before turning to other genres in succession. The newly increasing popularity of the genre in Russia around the turn of the $20^{\text {th }}$ century (see chapter 1.2.1) in fact amounts to its revitalisation after a prolonged period of relative neglection.

11 See Kämper 1987, p. 21: »Die Entwicklung der Klaviersonate hatte bei Beethoven einen Höhepunkt erreicht, der junge Komponisten entmutigen mußte."

12 See Edler 2004, p. 36: »Der bereits im ersten Jahrzehnt des 19. Jahrhundert[s] einsetzende Trend zur Abkehr von der Klaviersonate [...] hatte sich nach 1830 beschleunigt«; and ibid., p. 39: »Ein wesentlicher Grund für den Rückgang der Klaviersonate war ihre geringe Eignung für den Vortrag im öffentlichen Konzert und des privaten oder öffentlichen Salons«. 


\subsubsection{SONATA HYBRIDS AND THE FANTASY IDEA}

In the continuous struggle of composing sonatas in the succession of Beethoven, one possibility to provide an individual profile to the genre was to merge the genres of sonata and fantasy. This tendency, arising in the early $19^{\text {th }}$ century, had however been considerably prefigured by Beethoven's two Sonate quasi una fantasia, Op. 27 (1800-01), suggesting an improvisational character as a key component of their formal conception. Also, a piece such as the $1^{\text {st }}$ movement of his D minor Sonata `Tempest‘, Op. 31 No. 2 (1801-02), permeated by continuous shifts of tempo and improvvisando recurrences of its slow introductory measures, anticipates this tendency. In Beethoven, it seems as if the quasi fantasia idea figures as an alternative concept to the four-movement type of the grande sonate, which he had clearly favoured before; and after virtually all of Haydn's and Mozart's piano sonatas had been composed in three movements, with the four-movement outline appearing chiefly in their chamber and orchestral music, Beethoven boldly introduced the latter kind in his first published sonatas, Op. 2 (1795), and explicitly resorted to the title grande sonate in his Eb major Sonata, Op. 7 (1796-97), as something new and unexplored.

In addition to the possible derivation from Beethoven, one can observe a certain exchangeability of genre titles indicated by Robert Schumann’s word »Sonaten oder Phantasien—was liegt am Namen!« (»One can write sonatas or fantasies - who cares about the name! «). ${ }^{13}$ This flexible handling of genre had already gained recognition in Franz Schubert's four-movement Wanderer Fantasy in C major, D. 760 (1822), which could just as well have been named a sonata, and brings about a number of other multi-movement works in its succession I will here refer to as `sonata hybrids«—such as Felix Mendelssohn’s F\# minor Fantasy, Op. 28 (1833), bearing the alternative title of a Sonate écossaise, and Schumann's C major Fantasy, Op. 17 (183638). ${ }^{14}$ Other works to adhere to the concept of fantasy-sonata, or to combine the two denominations in an individual manner, were Ferdinand Ries’s Grande Sonate Fantaisie >L'infortunéeく in F\# minor, Op. 26 (1808); Carl Czerny's Grande Fantaisie en forme de Sonate in B minor, Op. 145 (1827); Stephen Heller's Phantasie in Form einer Sonate in D major, Op. 69 (1850); Ferdinand Hiller's G minor Fantasy, Op. 110 (1862); Felix Draeseke’s Sonata quasi Fantasia in C\# minor, Op. 6 (1862-67); and Joachim Raff’s Phantasie-Sonate in D minor, Op. 168 (1872). ${ }^{15}$ All of these works contributed to a development which Arnfried Edler has summarised as follows: »The affinity of the fantasy and sonata has, through the large multimovement works of Hummel and Schubert, entered the collective consciousness. ${ }^{16}$

13 Robert Schumann, Gesammelte Schriften über Musik und Musiker, ed. by Martin Kreisig, Leipzig ${ }^{5}$ 1914, Vol. 1, p. 395: »Also schreibe man Sonaten oder Phantasien (was liegt am Namen!), nur vergesse man dabei die Musik nicht, und das andere erfleht von eurem guten Genius« (parentheses are original).

14 Schubert's G major Sonata, D. 894 (1826) is also frequently referred to as a >Fantasy<. However, this subtitle is not an original denomination but rather that of Schubert's publisher Haslinger.

15 Similar conceptions are also variously found in Russian piano music, such as Scriabin’s Sonates-Fantaisies in G\# minor, an early one (1886) and his $2^{\text {nd }}$ Sonata, Op. 19 (1897); Feliks Blumenfeld's Sonate-Fantaisie in B minor, Op. 47 (1913); Anatoly Aleksandrov's Sonata-Fantasiya in C major, Op. 82 (1955); and Aleksandr Goldenweiser's Sonata-Fantasiya >Mournful Song« in Bb minor, Op. 37 (1959).

16 My translation of Edler 2004, p. 54: »Die Affinität der Fantasie zur Sonate war mit den großen mehrsätzigen Werken Hummels und Schuberts [...] in das allgemeine Bewußtsein eingegangen «. 
Fantasy-sonatas, in their ambition to blend the tight-knit conception of a sonata with the loose-knit design of a fantasy, have also presupposed syntheses of the fantasy with other genres of piano music, such as Mendelssohn’s Fantaisies ou caprices, Op. 16 (1829); Chopin’s Fantaisie-Impromptu in C\# minor, Op. 66 (1834), and Polonaise-Fantaisie in Ab major, Op. 61 (1846); as well as Tchaikovsky's Fantasy-Overtures, Romeo and Juliet (1869) and Hamlet, Op. 69 (1888), which are inspired by Shakespearean dramas. When mixtures of genres became more and more popular throughout the second half of the $19^{\text {th }}$ century, composers produced even more hybrid denominations, mostly in French language, such as Liszt's Valse-Impromptu in Ab major (1852); or Saint-Saëns's Valse-Caprice for piano and orchestra in Ab major, Op. 76 (1886). Similar titles were also chosen in Russia, such as Scriabin's Poème-Nocturne, Op. 61 (1911), or Rachmaninov's Études-Tableaux, Opp. 33 and 39 (1911-17). Even though Medtner did not refer to the fantasy genre or its derivatives - with the only exceptions of Rusalka, Op. 2 No. 1, which was sketched as a >Fantasia Fis-dur< (1897), and an early draft of the Piano Quintet in C major being titled >Fantasie für Streichquartett und Klavier (1904) - , ambiguous titles as seen in the abovementioned examples were probable trailblazers to his predilection for generic hybrids of all kinds (see chapter 2.5.3).

\subsubsection{Single-MOVEMENT SONATA Form}

A short backview may here illustrate the history of single-movement keyboard sonatas, as opposed to the multi-movement design which dominates the general perception of the genre. Early one-piece forms, as common in Baroque sonatas by Johann Kuhnau, Domenico Scarlatti, and others, have undergone a separate development as they appeared far before the multi-movement sonata cycle had been established, and thus cannot be considered a generic predecessor of the repertoire discussed here ${ }^{17}$ Classical piano sonatas were, as a rule, cast in multiple movements, and single-movement form were encountered only very rarely during the first half of the $19^{\text {th }}$ century. Where this did not happen due to projected multi-movement works left unfinished-for instance, in Franz Schubert's piano sonata fragments in C major, D. 613, and F minor, D. 625 (both of 1818); the String Quartet Movement in C minor, D. 703 (1820); or Robert Schumann's Allegro in B minor, Op. 8 (1831) - , these rare cases deserve special attention which might well attract a separate study. To give but a few examples for this tendency, Ferdinand Ries's Eb major composition `The Dream`, Op. 49 (1813), which is generally counted among his piano sonatas, and Ignaz Moscheles's Sonate mélancolique in $\mathrm{F} \#$ minor, Op. 49 (1814, rev. 1822), ${ }^{18}$ may be mentioned, both of which could also be regarded in the generic context of fantasy-sonatas.

17 If at all, Baroque sonata and suite movements might be regarded as a distant prefiguration of tonal symmetry as applied in Medtner's Op. 11 and Op. 22 (see the digressions in chapters 3.2.0 and 3.3.2). In that respect, the regular employment of the lower fifth region to the tonic as part of the second section of a bipartite form is characteristic of early- $17^{\text {th }}$-century compositions, before sonata forms of Viennese Classicism refrained from using keys other than the tonic in their recapitulation sections.

18 In Moscheles's sonata and Schumann's Op. 8, single-movement sonata form coincides with tonal symmetry of the respective secondary theme zones (see chapter 3.2.0). 
From the mid- $19^{\text {th }}$ century onwards, Franz Liszt, who had not shown any interest in composition of sonatas previously, experimented with single-movement sonata form in his piano and orchestral music, establishing a newly conceived category known as double-function form or, more recently, as $>$ two-dimensional sonata form $<.{ }^{19}$ This peculiar design incorporates multiple subdivisions, or >sub-movements $\triangleleft$, in one large, uninterrupted structure, juxtaposing sonata form with the multi-movement sonata cycle, and achieving inner coherence through the extensive use of thematic transformation. The first piano work to exemplify that strategy was Liszt's B minor Sonata (completed in 1853), preceded by the Fantasia quasi Sonata >Après une lecture de Dante $<$ which had been published as the last piece of the $2^{\text {nd }}$ volume of his Années de pèlerinage (1849). Some of Liszt's pupils and devotees, namely Julius Reubke (Sonata in Bb minor, 1856-57), Rudolf Viole (four of his eleven piano sonatas), and Hans von Bronsart (Märchen für Pianoforte >Melusine < in E major, Op. 9, of 1879), published works with similar features. After these contributions, the stwo-dimensional architecture seems to have nearly vanished from piano music, appearing less relevant to future sonata composers. However, the conception enjoyed significant popularity in orchestral music, such as in Liszt's piano concertos and symphonic poems, Richard Strauss's symphonic poems, as well as chamber music of the late- $19^{\text {th }}$ and early-20 $0^{\text {th }}$ centuries, such as Alexander Zemlinsky's and Arnold Schoenberg's early string quartets and chamber symphonies. Lisztian legacy is also apparent in a number of single-movement works by Russian composers, such as Nikolai Rimsky-Korsakov’s C\# minor Piano Concerto, Op. 30 (1882-83; see chapter 1.2.3) and Sergei Lyapunov's F minor Sonata, Op. 27 (1906-08; see chapter 1.2.2). In a similar sense as in the twelve Études d'exécution transcendante, Op. 11 (c. 1900), which added the sharp keys that Liszt had excluded from his cycle of the same name, Lyapunov's work is closely modelled on his ancestor's B minor Sonata.

The period between the stwo-dimensional piano sonatas of the Liszt school and Medtner's Sonata Triad, Op. 11 (1904-08), as the first notable instance of a remarkable series of single-movement forms arising in Russia, seems to have been nearly void of contributions of that type. From around 1910, the genre also found new consideration in Western Europe, but to a much lesser extent as opposed to Russian composers. The prominent case of Alban Berg's B minor Sonata, Op. 1 (c. 1909) — which he did not succeed in expanding to a multi-movement work and, upon Schoenberg's advice, eventually left it on its own — suggests that composers might still have been reluctant to conceive individual movements as complete works, long after single-movement form had been established as an alternative option for piano sonatas throughout Europe. Still, both of French composer Jean Huré's piano sonatas, one in F minor (1907) and another in A minor (1916), are cast in one single movement, as are five of six of Ferruccio Busoni's piano sonatinas (1910-20). Furthermore, there are Arnold Bax’s $1^{\text {st }}$ Sonata in F\# minor (1910, rev. 1921) and $2^{\text {nd }}$ Sonata in G major (1919); Sigfrid Karg-Elert’s massive Sonata patetica in C\# minor, Op. 105 (1914); Karol Szymanowski’s $3^{\text {rd }}$ Sonata in E major, Op. 36 (1917); and also two of Eugène Ysaÿe's six sonatas for solo violin, the ones in

19 Terminology according to Newman 1969 and Vande Moortele 2009. Other expressions attempting to grasp the hybrid character of that formal concept are »Mehrsätzigkeit in der Einsätzigkeit«, coined by Carl Dahlhaus, or »Binnensonate« (»interior sonata form«), as proposed by Heinemann 1993 in his analysis of Liszt’s B minor Sonata. 
D major 〉Balladeく, Op. 27 No. 3, and E major, Op. 27 No. 6 (1923). These appear to be the few remarkable instances of a tradition which otherwise nearly exclusively continues in Russia and the Soviet Union, being significantly shaped through the contributions of the young Medtner (see chapter 2.1.2). ${ }^{20}$

\subsubsection{INDIVIDUALISATION OF CYCLIC FORM}

The notion that a multi-movement work is supposed to establish a correlation between its individual sections also dates back to the early $19^{\text {th }}$ century. In this respect, the Lisztian turn to `two-dimensional sonata form was already preceded by a number of developments aiming to produce an intercommunity of material in multi-sectional compositions - a concept referred to as `thematic unity<, >thematicism〈, or ১Substanzgemeinschaft< (a common term in German-language scholarship). ${ }^{21}$ Works applying this strategy belong to the category of sonate cyclique, as introduced by Vincent d'Indy, ${ }^{22}$ the first scholar to discuss this conception as a paradigm of multi-movement form. In doing so, he frequently referred to the music of his teacher César Franck, whose late compositions appear most characteristic of his description of the >cyclic principle<. According to d'Indy, the essential quality of this design is that motives and themes be continuously quoted and transformed throughout a multi-movement work.

Several points of departure for the establishment of multi-movement cyclic form can be identified during the first decades of the $19^{\text {th }}$ century. Among Beethoven's symphonies, both the $5^{\text {th }}$ in $\mathrm{C}$ minor, Op. 67 , and the $6^{\text {th }}$ in F major >Pastorale`, Op. 68 (1807-08), employ quotations and reiterations of their most important themes, tending to recombine and synthesise them in the course of the final movement. In their succession, two other paradigmatic examples of cyclic form arose: Schubert's Wanderer Fantasy, D. 760 (1822), with its cyclic idea derived from a song; and Hector Berlioz's Symphonie fantastique in C major, Op. 14 (1830), the archetype of the Romantic program symphony, with an idée fixe and its derivatives pervading every movement. In order to adequately grasp cyclic conceptions in piano music of the late- $19^{\text {th }}$ and early$20^{\text {th }}$ centuries, we will have to be aware of parallel developments in orchestral and chamber music. After a first heyday of multi-movement cyclic form in symphonies of the 1840 s and 1850 s, these were largely superseded by Liszt's achievements on the field of single-movement form, corresponding with the emergence of the symphonic poem as a new genre. Yet the four-movement symphony resurged in the 1880s and 1890s, leading to a series of cyclic works which had direct influence on further developments in Russian music, and also, though indirectly, on Medtner's attempts to introduce cross-movement relations in his multi-movement

20 Apart from Medtner's, Scriabin's, and Prokofiev's contributions, this tendency is further exemplified by the works of Anatoly Aleksandrov, Samuil Feinberg, Konstantin and Oleg Eiges, Issay Dobrowen, Grigory and Aleksandr Krein, Anatoly Drozdov, Sergei Protopopov, Dmitry Melkikh, Viktor Kosenko, Aleksandr Mosolov, Boris Lyatoshinsky, and Aleksandr Goldenweiser.

21 >Thematicism`was, on the basis of Rudolf Réti's elaborations in The Thematic Process in Music (1951), introduced by Joseph Kerman in his book Contemplating Music (1985); >Substanzgemeinschaft< is a term by Hans Mersmann, first used in his work Angewandte Musikästhetik, Berlin 1926.

22 Indy 1909, pp. 234 and 378f. The author here defines some »éléments constitutifs de la forme cyclique«, subdivided in »modifications rhythmiques«, »mélodiques « und »harmoniques« as applied to a motivic nucleus (cellule). In German scholarship, cyclic sonata form has been discussed shortly after in the Formenlehre publications by Hugo Leichtentritt and Richard Stöhr (1911). 
sonatas (see chapter 2.1.5). During the $19^{\text {th }}$ century, we can thus identify two peak phases of cyclic sonata form, separated by chronology and geography, both of which I will illustrate here by mentioning a number of exemplary compositions:

- Germany, middle of the $19^{\text {th }}$ century: Mendelssohn's $3^{\text {rd }}$ Symphony in A minor >Scottish $<$ Op. 56 (completed 1842); Schumann's $4^{\text {th }}$ Symphony in D minor, Op. 120 (1841, rev. 1852); Liszt's Faust Symphony in C minor (1854); and also orchestral works of the 1860s and 1870s, including the hardly ever performed symphonies of Carl Reinecke, Joachim Raff, Max Bruch, and Josef Gabriel Rheinberger, many of which feature a distinct programmatic dimension.

- France, end of the $19^{\text {th }}$ century: Franck's Symphony in D minor (1885-86), and also most of his late chamber music; Camille Saint-Saëns's $3^{\text {rd }}$ Symphony in C minor >Organ`, Op. 78 (1888), dedicated to Liszt's memory; Vincent d'Indy's Symphonie sur un chant montagnard français for piano and orchestra in G major, Op. 25 (1886); as well as Ernest Chausson's Bb major Symphony, Op. 20 (1890); Paul Dukas's C major Symphony (1896); and Claude Debussy's String Quartet in G minor, Op. 10 (1893).

\section{Cyclic Techniques}

In derivation from d'Indy's description of the sonate cyclique, it seems convenient to classify a number of strategies of cyclic form in three hierarchic categories, so as to examine the way in which the interlocking of successive movements is achieved: ${ }^{23}$

(1) One or several cyclic ideas may be introduced in the first movement, then repeatedly recollected or quoted in the following movements - as prefigured by Berlioz's application of the idée fixe - and possibly merged and brought to a synthesis within the final movement.

(2) Thematic unity (`Substanzgemeinschaft $২$ ) of successive, or of the two exterior movements, may be achieved by a common diastematic structure - a motivic nucleus (cellule, as termed by d'Indy), or in the sense of Wagnerian leitmotives - and its transformation on motivic level.

(3) Actual thematic transformation may, as common in Liszt, be applied by the metamorphosis of an extended melodic contour which can be identified as a >cyclic themeく ( $\mathrm{d}$ 'Indy: thème générateur), typically corresponding with a change of character when restated. ${ }^{24}$

The following list presents some examples from piano and chamber music of the $19^{\text {th }}$ and early $20^{\text {th }}$ centuries, some of which might be assigned to more than one of the three categories:

23 I have first presented this classification in a paper on Russian symphonies; see Bitzan 2017, p. 62.

24 The metamorphosis of a theme means that it remains identical in its diastematic content, but may differ in rhythm and meter, dynamics, register and range, instrumentation, or in other parameters. >Thematic transformation as found in late- $19^{\text {th }}$-century music may thus be understood as the continuation of variative principles evident in earlier music, applied here with the particular purpose of producing a cross-movement coherence of musical material. For the significance of transformational techniques, see Réti 1951, p. 70: „Whenever a theme rises in the ear of a structurally trained composer, all kinds of possible transformations will at once automatically flash across his mind «; and ibid., p. 247, asserting that such techniques represent »one common underlying idea of structural thinking, which spreads through the ages and became the backbone of our musical evolution«. 
- Beethoven: Piano Sonatas in A major, Op. 101 (1813-16) and Ab major, Op. 110 (1821) incorporation of quotes from previous movements in the finales; synthesis of sonata and fantasy architectures.

- Brahms: Piano Sonata in F minor, Op. 5 (1853) - recollection of the $2^{\text {nd }}$ movement's initial theme in the $4^{\text {th }}$ Intermezzo movement ( $>$ Rückblick $\iota$ ) preceding the finale.

- Franck: Prélude, Choral et Fugue in B minor (1884) - restatement and final synthesis of the themes of every section within the fugue.

- Saint-Saëns: Violin Sonata in D minor, Op. 75 (1885) - recurrence of the $1^{\text {st }}$ movement's secondary theme near the ending of the final $4^{\text {th }}$ movement.

- Reger: Organ Suite in E minor, Op. 16 (1895) - introduction quoted near the end of the final Passacaglia movement.

- Enescu: String Octet in C major, Op. 7 (1900) - recombination of all significant themes from the $1^{\text {st }}$ and $2^{\text {nd }}$ sections in the final Mouvement de Valse subdivision.

- Medtner: Forgotten Melodies, $1^{\text {st }}$ cycle, Op. 38 (1919-20) - recollection of the opening ritornello from the initial Sonata-Reminiscenza in the last three pieces.

- Beethoven: Piano Sonata in C minor >Pathétique`, Op. 13 (1798-99) - free derivation of the rondo's refrain theme from the first secondary theme of the $1^{\text {st }}$ movement, with scale degrees 5-1-2-3 as a common nucleus (see example 1.2).

- Schubert: Wanderer Fantasy in C major, D. 760 (1822) - cyclic idea derived from the song Der Wanderer, D. 489 (1816), present as a rhythmic formula (. ..) in every movement.

- Schumann: Carnaval, Op. 9 (1834-35) - most pieces of the cycle commence with a variant of the nucleus $A b-C-B$ or $A-E b-C-B$, a soggetto cavato derived from the north-Bohemian city of Asch.

- Schumann: Piano Sonata in F minor, Op. 14 (1836, rev. 1853) - common descending contour of the initial themes of the $1^{\text {st }}, 2^{\text {nd }}$, and $3^{\text {rd }}$ movements, derived from an Andantino theme by Clara Wieck.

- Franck: Violin Sonata in A major (1886) - deduction of the initial themes of every movement from a motivic nucleus, consisting of an ascending third and a descending second or third.

- Scriabin: Piano Sonata in F minor, Op. 6 (1893) - interconnection of the primary themes of the $1^{\text {st }}, 3^{\text {rd }}$, and $4^{\text {th }}$ movements, and the secondary theme of the $2^{\text {nd }}$ movement, through the common nucleus $F-G-A b$ (see example 1.5 ).

- Schoenberg: Suite for Piano, Op. 25 (1921-23) - each movement is based on the same twelve-tone row which determines its initial melodic contour, most notably in the Prelude, Gavotte, and Gigue.

- Liszt: Piano Sonata in B minor (1849-53) - thematic transformation as a means of the constitutive >two-dimensional sonata form

- Brahms: Piano Sonatas in C major, Op. 1, and F\# minor, Op. 2 (1852-53) - intercommunity of the primary themes of the $1^{\text {st }}$ and $4^{\text {th }}$ movements of Op. 1 , and the $2^{\text {nd }}$ and $3^{\text {rd }}$ movements of Op. 2 (see example 1.3), both appearing as transformations of each other.

- Mussorgsky: Pictures of an Exhibition (1874) - multiple recurrences of the Promenade theme in several movements of the suite, transformed nearly beyond recognition in the piece Cum mortuis in lingua mortua.

- Tchaikovsky: Piano Trio in A minor, Op. $50(1881-82)$ - the $2^{\text {nd }}$ movement presents a set of variations on a cantabile subject which is eventually transformed into the theme of the final variation serving as the $3^{\text {rd }}$ movement (see also chapter 1.2.3 and example 1.11). A similar procedure is found in the $3^{\text {rd }}$ movement of Brahms's Clarinet Sonata in Eb major, Op. 120 No. 2 (1894), the Allegro non troppo section of which simultaneously represents a concluding variation and final movement.

- Myaskovsky: Piano Sonata in D minor, Op. 6(1907-10) - transformation of the $1^{\text {st }}$ movement's fugal subject to the $4^{\text {th }}$ movement's final culmination (see also chapter 1.2.2 and example 1.9).
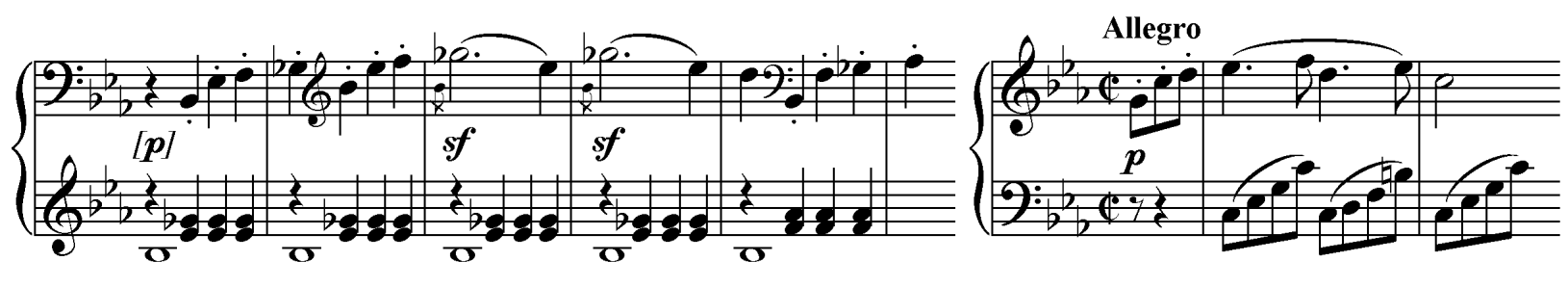

Example 1.2: Beethoven, Piano Sonata, Op. 13, $1^{\text {st }} \mathrm{mvt}, \mathrm{mm} .52-56 / / 3^{\text {rd }} \mathrm{mvt}, \mathrm{mm} .1-2$ 


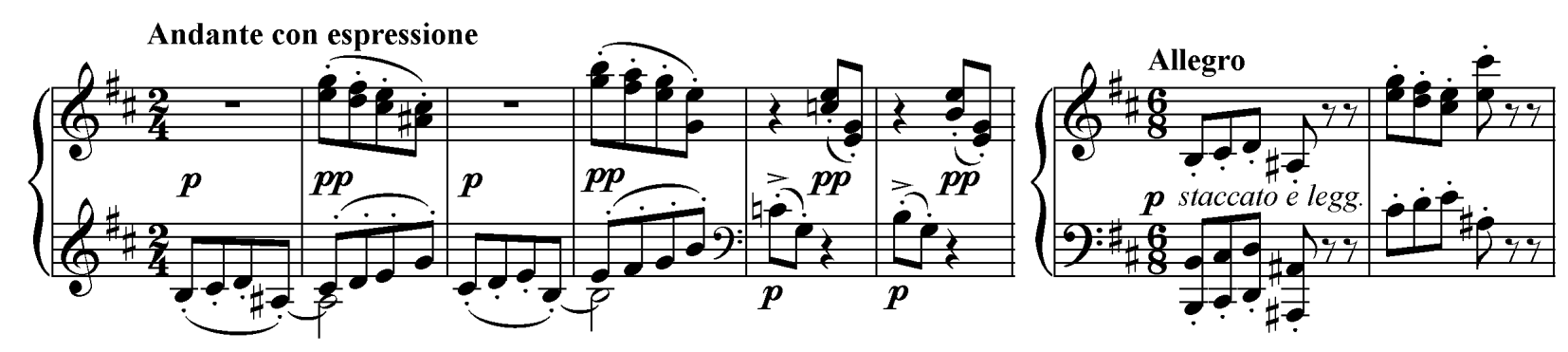

Example 1.3: Brahms, Piano Sonata, Op. 2, $2^{\text {nd }} \mathrm{mvt}, \mathrm{mm} .1-5 / / 3^{\text {rd }} \mathrm{mvt}, \mathrm{mm} .1-2$

\subsubsection{Fugues WITHIN SONATAS}

In the light of Medtner's predilection to incorporate extended imitative passages in his piano sonatas, it seems desirable to have a brief look on earlier sonatas and multi-movement cycles which enclose fugues or fugati. This feature may be described as unification of two otherwise antagonistic principles of musical form and compositional technique - sonata and fugue - , being occasionally brought to a synthesis in compositions which might be referred to as superpositions of the >galant style< and >learned style <. ${ }^{25}$ The phenomenon seems to originate in the finales of some of Haydn's string quartets, such as three of the six works from his Op. 20 (1772) and the F\# minor Quartet, Op. 50 No. 4 (1787), as well as in Mozart's string quartets and symphonies, such as the G major Quartet, K. 387 (1782) and C major Symphony >Jupiter`, K. 551 (1788). Yet fugues are more significantly implemented in Beethoven's late sonata cycles and thenceforward. In most cases, these figure as the final movements of sonatas, or as culminations of these - such as in the $\mathrm{B} b$ major Piano Sonata 〉Hammerklavier`, Op. 106 (1817-18), and Ab major Sonata, Op. 110 (1821), as well as in the first version of the $\mathrm{B} b$ major String Quartet, Op. 130 (1826), which originally comprised the Große Fuge later published as Op. 133. A notable exception from the traditional application of fugues as final apotheoses is Beethoven’s C\# minor String Quartet, Op. 131 (1826), which commences with an Adagio distantly echoing the theme of the $\mathrm{C} \sharp$ minor Fugue from Bach’s Well-tempered Clavier, Vol. 1. Further examples include Mendelssohn's Organ Sonatas, Op. 65 No. 2 in C minor and No. 6 in D minor (published in 1845); Brahms's E minor Cello Sonata, Op. 38 (1862-65); and the final Scherzo from Giuseppe Verdi's E minor String Quartet (1873), all of which incorporate fugal writing as their concluding movements or sections. A third strategy is to insert fugal passages into middle sections or developments of movements, as seen in the $4^{\text {th }}$ movements of Schumann's Eb major Piano Quartet, Op. 47 (1842), and Bruckner's $5^{\text {th }}$ Symphony in Bb major (1875-76). This approach turns out to be the one by which Medtner was particularly attracted (see chapter 2.3.2).

Hardly coincidentally, all three piano sonatas by Karol Szymanowski also incorporate fugues as their final movements or sections: the $1^{\text {st }}$ in C minor, Op. 8 (1905); the $2^{\text {nd }}$ in A major, Op. 21 (1910); and also the single-movement $3^{\text {rd }}$ Sonata in E major, Op. 36 (1917). Even more remarkably, an astonishing quantity of

25 The German theorist August Halm referred to sonata and fugue as »two cultures of music« as examined in his book of the same title, Von zwei Kulturen der Musik (1913). 
Russian chamber and orchestral works written at the turn of the $20^{\text {th }}$ century would make use of fugues to conclude their multi-movement outlines, such as Sergei Taneyev's String Quartet in C major, Op. 5 (189495) and String Quintet in C major, Op. 16 (1903-04); Aleksandr Scriabin's $1^{\text {st }}$ Symphony in E major, Op. 26 (1899-1900), closing with a triumphant choral fugue; and Aleksandr Glazunov's E minor Piano Sonata, Op. 74 (1901). ${ }^{26}$ Moreover, there are three peculiar cases of Russian piano sonatas which resort to fugal writing in their $1^{\text {st }}$ movements, posing a possible influence to Medtner in his contrapuntal writing: Mily Balakirev's $\mathrm{B} b$ minor Sonata (completed in 1905; see example 1.7); Nikolai Myaskovsky's $1^{\text {st }}$ Sonata in D minor, Op. 6 (1907-09), the fugal subject of which is reused and transformed in every of the subsequent movements (see example 1.9); and Aleksei Stanchinsky's compact $2^{\text {nd }}$ Sonata in G major (1912). In the course of exploring other tendencies in early-20 $0^{\text {th }}$-century Russian piano music, these three sonatas will be briefly introduced in the course of chapter 1.2.2.

\subsection{SONATA COMPOSITION IN RUSSIA}

The history of the sonata genre in Russia may be described as a process of assimilation and steady individualisation. First cyclic chamber works in sonata form are found in the œuvres of Mikhail Glinka, Aleksandr Alyabiev, and Nikolai Afanasyev (see also chapter 1.2.3), while piano sonatas were comparatively rare apart from besides the contributions of Dmytro Bortniansky, Lev Gurilëv, and Iosif Genishta, all of who produced sonatas in a Classicist style imported to Russia from Western Europe between the 1780s and 1840s. ${ }^{27}$ So it was not before the mid- $19^{\text {th }}$ century that the genre found its first notable consideration in Russia, embodied in the works of Anton Rubinstein who, having received major parts of his education in Germany, introduced the piano sonata in the Russian Empire. Rubinstein may thus be considered the first notable proponent of sonata composition in Russia; however, his four piano sonatas (1848-77), written during a period when hardly any prolific Western European composer seriously dealt with multi-movement sonata cycles, strongly rely on approaches of the first half of the $19^{\text {th }}$ century. He nonetheless had considerable influence on the following generation of Russian composers, and with the piano sonatas of Mily Balakirev, Pëtr Tchaikovsky, and Aleksandr Glazunov, the simported genre still sticked to the traditional scheme, mostly without gaining a central position in their composers' œuvres.

After Nikolai and Anton Rubinstein had founded the Saint Petersburg and Moscow Conservatories in 1862 and 1866, Western musical tradition and academic paradigms of musical form were particularly maintained in the curriculum of the Moscow-based institution. The Rubinstein brothers did not primarily appear as teachers of composition, but rather gained reputation as leaders of their respective piano classes. However, Nikolai's influence strongly coined the Muscovite school through his pupil Sergei Taneyev, and remained significant for teachers such as Tchaikovsky and Anton Arensky, who continued to adhere to Western

26 For more detailed comment on Taneyev's and Glazunov’s polyphonic writing see Protopopov 1987, pp. 189ff. and $210 \mathrm{ff}$.

27 Thus, Rubinstein's E minor Sonata, Op. 12 (c. 1847) was by no means »the first piano sonata to be composed by a Russian«, as stated by Howard 1996, p. 3. For an overview on the earlier sonata production by Alyabiev, Genishta, and others, see Newman 1969, p. $702 \mathrm{ff}$. 
paradigms of musical form. On the contrary, the five composers of the Petersburgian group >The Mighty Handful (moguchaya kuchka) did, due to their ambition to produce music rooted in Russian folklore and their opposition towards academism, not primarily resort to chamber and piano music, even though sonata form is present in their symphonies and chamber music. Nevertheless, it seems as if the notion of the Moscow Conservatory remaining a bastion of conservativism or even epigonism, while Saint Petersburg was supposed to be the more progressive institution, does not hold true with regard to instruction in musical form and other theoretical subjects; and nor did the Muscovites completely refrain from drawing inspirations from folk song, as evident in a comparison of Tchaikovsky's music with that of the kuchkistï. Also, the latters' stylistic influence, namely that of Balakirev and Rimsky-Korsakov, is discernible in the sonata cycles of Aleksandr Glazunov, Sergei Lyapunov, and Feliks Blumenfeld, whose œuvres stand for a otherwise conservative direction in Russian music. Arensky, on the other hand, fully orientated himself towards Tchaikovsky and the Moscow school despite being educated in Saint Petersburg. Regardless of the fact that many of the graduates of both Russian conservatories were composer-pianists, some of them preferred the miniature form over writing sonatas, as is the case with Lyadov, Arensky, Rebikov, Catoire, Georgy Conus, IppolitovIvanov, and Glière; and neither did Taneyev publish a piano sonata, even though he was a profound and much respected pianist.

It was not before the 1890s that Russian piano sonatas, as well as sonata cycles scored for chamber and symphonic ensembles, started to display specific traits of originality and, at the same time, developed a certain >Russianness $<$ in style and sound. We can thus state that when Aleksandr Scriabin first tackled the genre, closely followed by Nikolai Medtner, an independent sonata tradition that he could have drawn on hardly existed in Russia. ${ }^{28}$ Both composers showed a strong predilection for single-movement sonata form. Soon after, Nikolai Myaskovsky and Sergei Prokofiev, two composers trained in Saint Petersburg, also started to significantly contribute to the genre of piano sonata, which developed to remarkable heights during the 1910 s. ${ }^{29}$ Yet the traditional three-to-four-movement outline remained a compulsory subject to composers such as Blumenfeld, Sergei Rachmaninov, and Stanchinsky, who published works of that kind before the Russian revolution; and so did Prokofiev, Myaskovsky, and Anatoly Aleksandrov, when returning to the multi-movement design, a paradigm of instrumental music fully compatible with the guidelines of Stalinist cultural policy, in their sonatas of the 1930s and 1940s.

The general observations outlined above will now be examined in more detail, tracing the most important stylistic developments in Russian sonata cycles until the mid-20 $0^{\text {th }}$ century (chapter 1.2 .1 ). To put these observations in context, the overview is followed by a number of short introductions to individual piano sonatas written between the 1870s and the end of World War I, which deserve attention for being contributions by the generation of Medtner's teachers and direct contemporaries, preceding or accompanying his first creative

28 Martyn 1995, p. 23, claims that none of Scriabin's first three sonatas (1892-97) or Glazunov's two sonatas (1901) seems to have influenced Medtner in composing his F minor Sonata, Op. 5 (completed in 1903), ignoring the fact that Scriabin's $1^{\text {st }}$ Sonata in F minor, Op. 6, shows advanced techniques of cross-movement motivic relation which might well have had an effect on Medtner. See also chapter 3.1.

29 A comprehensive timetable of Russian piano sonatas from 1850-1930 is found in Flamm 1995, p. $214 \mathrm{f}$. 
period, and marking the premises of his own composing (chapter 1.2.2). This section will refer to works by Tchaikovsky, Balakirev, Scriabin, Lyapunov, Myaskovsky, Stanchinsky, Rachmaninov, Blumenfeld, Prokofiev, and Aleksandrov, supplemented by some musical examples. After that, a summary of parallel developments in Russian chamber and orchestral music will further illuminate the music-historical environment by briefly introducing a number of compositions, particularly remarkable for aspects of musical form, which also originate from the abovementioned period (chapter 1.2.3). Here, some popular and lesser-known works by Borodin, Tchaikovsky, Rimsky-Korsakov, Arensky, Taneyev, Glazunov, Catoire, Rachmaninov, Prokofiev, and Myaskovsky are included. ${ }^{30}$

\subsubsection{RUSSIAN PIANO SONATAS}

As mentioned above, the first Russian advocates of the piano sonata were Anton Rubinstein and Pëtr Tchaikovsky, two personalities who gained international acclaim as composers and performers of their own works. Whereas Rubinstein's conservativism and orientation towards Western musical heritage was formed during his years in Berlin, studying with Siegfried Dehn and Theodor Kullak, Tchaikovsky, after abandoning a projected career as a lawyer, in the first place continued his predecessor's direction. Rubinstein's style has been marked as eclectic and little innovative already by contemporary critics, ranking him significantly lower as a composer than as a pianist. His comprehensive œuvre includes four piano sonatas in E minor, Op. 12; C minor, Op. 20 (both c. 1848-54); F major, Op. 41 (1855); and A minor, Op. 100 (1877), the third of which has gained narrow popularity outside Russia. The piano sonatas of Tchaikovsky, who is chiefly regarded as a symphonic and operatic composer despite having created one of the most popular piano concertos of the repertoire, have suffered similar verdicts. His two four-movement works in $\mathrm{C} \sharp$ minor, Op. posth. 80 (1865, published 1900) and G major, Op. 37 (1878; for a short introduction see chapter 1.2.2) were harshly criticised for alleged deficiencies in the command of musical form, and could never prevail in recital programmes of the past and present.

From approx. 1856, the Petersburgian >Five` represented an opposed position to the Rubinsteins' academism, uniting the diverse approaches of their members who were not professionally educated as musicians, and propagating their common orientation on Russian national culture and folk song. However, the kuchkistï did not completely turn away from Western musical tradition, with their orchestral and chamber music regularly resorting to sonata cycles. Even so, their piano music did not particularly focus on the sonata genre, apart from Mily Balakirev's early Bb minor piano sonata, Op. 3 (c. 1850, reworked to his Op. 5 in 1855-56, and partly transformed into a large-scale virtuosic sonata in 1900-05; see chapter 1.2.2 and example 1.7), ${ }^{31}$ and Mussorgsky's fragment of a C major Sonata for piano four-hands (1860). In 1885, the so-called

30 This overview is by no means intended to provide independent research on the respective works, and neither will the discussion go into analytic detail. For this reason, the references given mainly refer to standard publications on genre history and piano music, not taking into account a larger body of relevant research literature on the individual composers and works.

31 See Leonard 1957, p. 77f.: »The works of Balakirev's second creative period, which began late in the eighteennineties, were nearly all in the classic forms. [...] To this period also belongs the Piano Sonata in B flat minor, published in $1905 \ll$, not commenting on the complicated genesis of that work. 
>Belyayev circleく was formed out of the collaboration of Nikolai Rimsky-Korsakov and the influential publisher and patron Mitrofan Belyayev. A member of this group was Rimsky-Korsakov's Petersburgian pupil Aleksandr Glazunov, whose œuvre represents a middle position between the nationalism of the kuchka and the Moscow school. As a rather conservative symphonist, he resorted to the piano sonata only temporarily, composing his three-movement $\mathrm{B} b$ minor and E minor Sonatas, Opp. 74 and 75 (1901; see example 1.4) $)^{32}$ in direct succession. Other figures from Glazunov's environment were Sergei Lyapunov with his massive F minor Piano Sonata, Op. 27 (1906-08), and Feliks Blumenfeld, whose Sonate-Fantaisie in B minor, Op. 46 (1913) also shows a certain affinity to the large-scale works of the ^New German Schook (for further notes on both works see chapter 1.2.2).

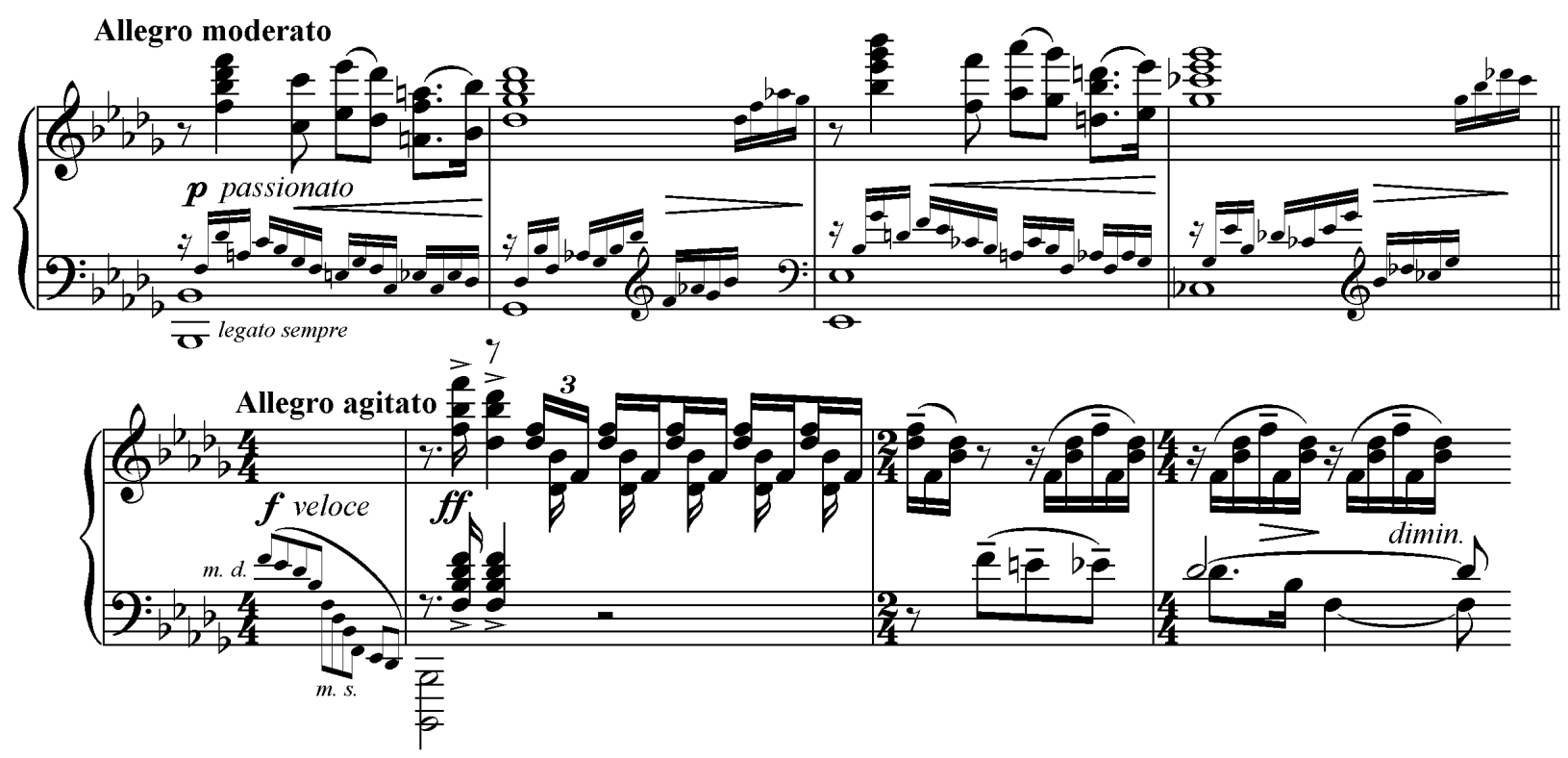

Example 1.4: Glazunov, $1^{\text {st }}$ Piano Sonata, Op. 74, $1^{\text {st }}$ mvt, mm. 7-10 // Rachmaninov, $2^{\text {nd }}$ Piano Sonata, Op. $36,1^{\text {st }} \mathrm{mvt}, \mathrm{mm} .1-3$

Around the turn of the $20^{\text {th }}$ century, a number of Muscovite composer-pianists successfully attempted to explore new aspects and dimensions of the sonata genre. Innovative tendencies particularly arose in the following domains: (1) some remarkable and original developments on the field of single-movement form, which must be regarded in the literary and philosophical climate of Russian Symbolism and the Silver Age; (2) the continuation of the tradition of fantasy-sonatas since the early $19^{\text {th }}$ century. The œuvres of the generation of composers born in the 1870s and 1880s, most of them trained by Anton Arensky and Sergei Taneyev, turned out especially fruitful in this respect. Aleksandr Scriabin's short creative period, focusing almost exclusively on piano music, brought about ten sonatas during 1892-1913, spanning a bridge from late-Romantic tonality in the succession of Chopin and Liszt to his idiosyncratic late style, the harmony of which is characterised by

32 Alekseyev 1982, p. 77, refers to Glazunov's piano sonatas as still representing a »lyrical-pathetic, Romantic manifestation of the genre«, although preceded by Scriabin’s early sonatas (»Sonatï [...] kak i nezadolgo pered tem napisannïe rannie sonatï Skryabina, prinadlezhat k tipu romanticheskikh, liriko-pateticheskikh proizvedeniy ètogo zhanra $)$. 
mystic spirituality and the use of the so-called >Prometheus chord , noticeably stretching and finally leaving behind traditional tonality. ${ }^{33}$ Scriabin's multi-movement $1^{\text {st }}, 2^{\text {nd }}$, and $3^{\text {rd }}$ sonatas were still composed in the 1890 s - yet they already expand the conventional scheme by a number of peculiar devices, such as the incorporation of a funeral march instead of an affirmative finale, as in the $4^{\text {th }}$ movement of the F minor Sonata, Op. 6 (1893; see example 1.5), or by extraordinarily closing the first of two movements in a key other than the tonic, as seen in the Sonate-Fantaisie in G\# minor, Op. 19 (1897). These were followed by the B minor Fantasy, Op. 28 (1900), marking Scriabin's first attempt to attain single-movement form in an individual work (see chapter 1.2.2), and irreversibly turning to this concept from the $5^{\text {th }}$ Sonata, Op. 53 (1907), onwards. ${ }^{34}$ At the same time, Sergei Rachmaninov dealt with the sonata genre in his two three-movement contributions, the D minor Sonata, Op. 28 (1907) and Bb minor Sonata, Op. 36 (1913, rev. 1931; see also chapter 1.2.2 and example 1.4). The former of these is only rarely performed due to its length and complexity, while the latter has invariably entered the standard repertoire of pianists.
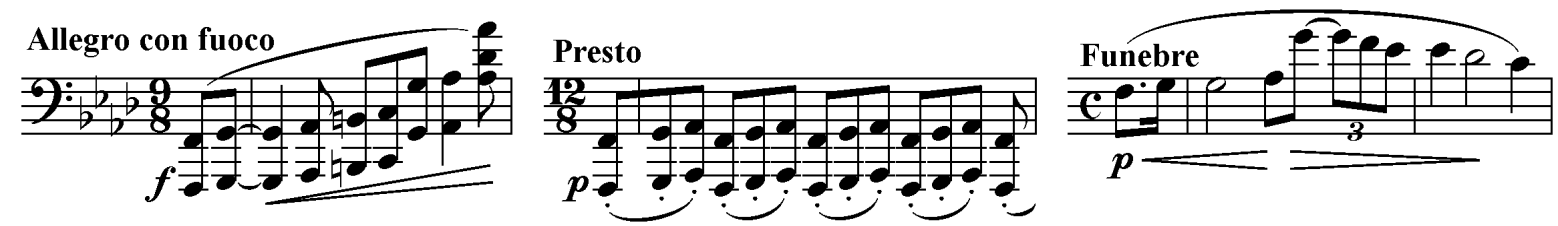

Example 1.5: Scriabin, $1^{\text {st }}$ Piano Sonata, Op. 6, $1^{\text {st }} \mathrm{mvt}, \mathrm{m} .1 / / 3^{\text {rd }} \mathrm{mvt}, \mathrm{m} .1 / / 4^{\text {th }} \mathrm{mvt}, \mathrm{mm} .2-3$ (motivic reduction)

Furthermore, some other composers from the Moscow school significantly contributed to the piano sonata repertoire. Aleksei Stanchinsky, another pupil of Taneyev, departed from the model of Scriabin's sonatas in his two works in F major and G major (both of 1912; see also chapter 1.2.2), preceded by an early singlemovement sonata in Eb minor (1905). The young Boris Pasternak composed an equally Scriabinesque, single-movement Sonata in B minor (1909) before eventually turning to literature; and in a similar manner, the short Sonata-Ballade, Op. 18 (1925) of Ukrainian composer Boris Lyatoshinsky shows echoes of Scriabin's harmony and formal manners. Still awaiting its public discovery is the exciting œuvre of Samuil Feinberg, including twelve highly complex piano sonatas composed between 1915-62, the earliest of which already being remarkable examples of single-movement form; see example 1.6 for a short excerpt of the $1^{\text {st }}$ Sonata in $\mathrm{F} \#$ minor, Op. 1 (1915). ${ }^{35}$ As Feinberg's sonatas tended to expand harmony and tonality in a highly individual manner, they paved the way for even more advanced experiments carried out in the sonatas of Muscovite composers of the 1920s, written in the period between the Russian revolution and the increasing restrictions

33 See Schibli 1983, p. 187ff., and Delson in Kuhn $2008^{\text {b }}$, p. $188 \mathrm{ff}$.

34 See Münch 2004, p. 164ff., for a confrontation on a number of scholars' evaluations of Scriabin's single-movement conceptions. The author however fails to draw a stringent conclusion from the cited perspectives.

35 Referring to this sonata incipit, Aleksandr Alekseyev notes that Feinberg's themes typically seem to depart from polyphonic writing or features of fugal design, in contrast to the alleged derivation of many of Medtner's themes from vocal phrasing (my paraphrase of Alekseyev 1974, p. 40: V otlichie ot tem Metnera, svyazannïkh s pesennïmi istokami i neredko razvivayushchikhsya $\mathrm{v}$ melodicheski raspevnïe postroeniya, $\mathrm{v}$ ètoy i mnogikh drugikh tipichnikh temakh Feynberga zametna preyemstvennost' ot formoobrazovaniya fugi«). 
imposed to the cultural life of the early Soviet Union. Examples are the six sonatas of Nikolai Roslavets (1914-28), only two of which have survived in full, the three works of Sergei Protopopov (1920-28) which feature a progressive style, hard to grasp in their rhythmic and harmonic language, and the four surviving sonatas of Aleksandr Mosolov (all written in 1924-25).

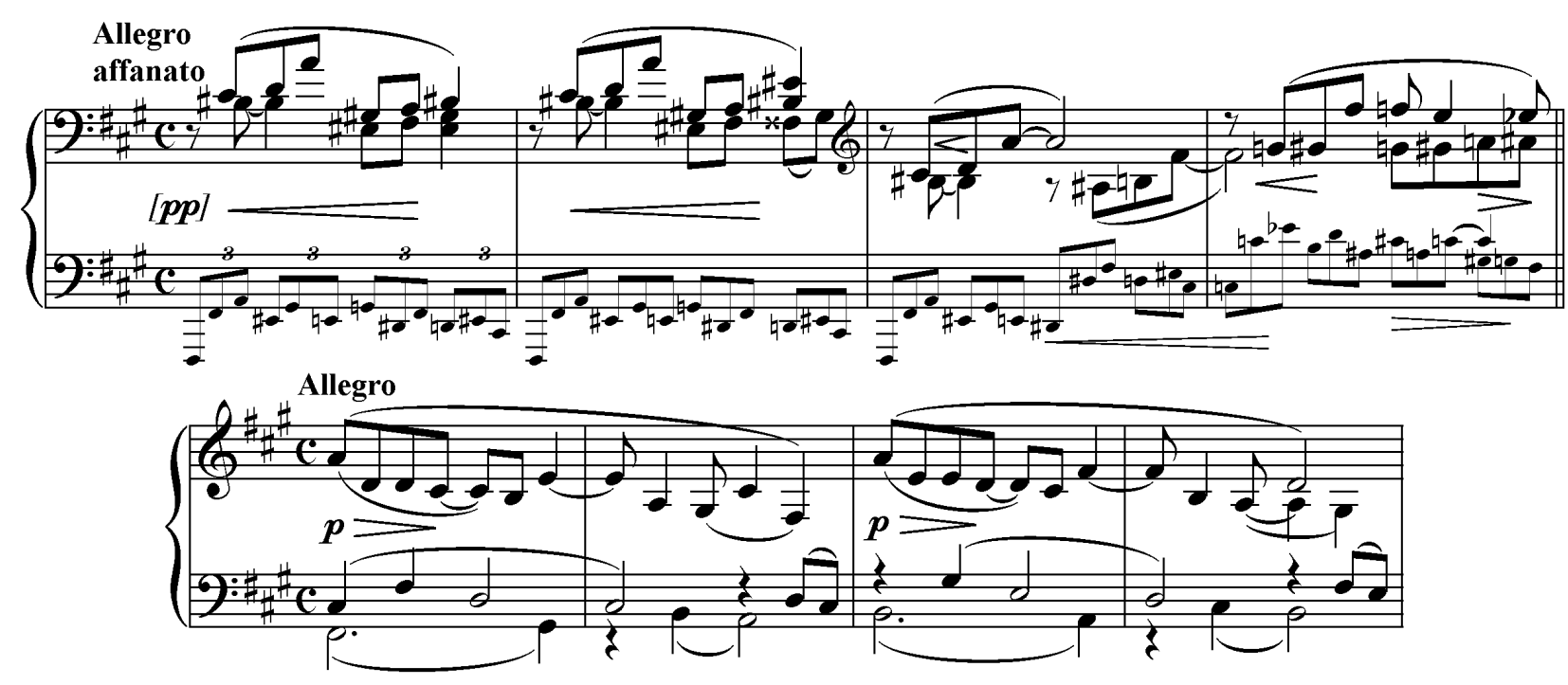

Example 1.6: Myaskovsky, $2^{\text {nd }}$ Piano Sonata, Op. 13, mm. 23-26 // Feinberg, $1^{\text {st }}$ Piano Sonata, Op. 1, mm. 1-4

Meanwhile, some of the graduates of the Saint Petersburg / Petrograd Conservatory found their individual paths after the 1917 revolution without necessarily drawing on the achievements of their predecessors. The pupils of Rimsky-Korsakov and Glazunov were, on the one hand, influenced by the nationalist attitude of the former, yet then again they seemed inspired by the latter's productive way of assimilating the Western tradition in order to attain their own treatment of sonata form. In Igor Stravinsky's case, these preconditions resulted in a highly individual musical language, absorbing Russian national folklore as well as French impressionism and avant-garde experimental styles. After having completed an early four-movement $\mathrm{F} \#$ minor Sonata (1903-04), still under Rimsky-Korsakov's guidance, he resorted to the genre only one more time during his neo-Classical period, publishing another compact three-movement sonata (1924) which shows traits of a burlesque study. A way more dominant role in the further advancement of the genre must be attributed to Sergei Prokofiev whose nine sonatas, composed between 1909-47, spanned his whole creative period. In the succession of his first single-movement Sonata in F minor, Op. 1 (1909), he attained diverse formal strategies in his following contributions, varying between another remarkable example of single-movement form in the $3^{\text {rd }}$ Sonata in A minor, Op. 28 (1917; see chapter 1.2.2) and full-scale works in three or four movements, such as the percussive $2^{\text {nd }}$ Sonata in D minor, Op. 14 (1912). Prokofiev's flexible musical language, characterised by its rhythmic poignancy, sharp dissonance, and Classicist lyricism, allowed him to cleverly position himself towards the guidelines of Stalinist cultural policy. Of particular significance are his $6^{\text {th }}, 7^{\text {th }}$, and $8^{\text {th }}$ sonatas, written during World War II (1939-44), of which the three-movement $7^{\text {th }}$ Sonata in Bb major, Op. 83 (1942), ranges among the most frequently performed works of Russian piano music. 
Stylistic backturns can also be found among other composers, especially during the time after the Soviet authorities had enforced the ideological directives of Socialist Realism in 1932. These conditions accounted for the fact that strategies of Soviet composers were particularly targeted towards traditional musical genres, while these had been largely abandoned in Western Europe and North America. However, this development has already attracted more detailed examinations than I am able to acknowledge in the framework of this study. ${ }^{36}$ In any case, a striking affinity to composing multi-movement sonatas can be observed among composers who did not leave Russia. The fourteen works of the Muscovite Anatoly Aleksandrov, written over a period of nearly sixty years from 1914-71, moved from a moderately progressive early period-with the single-movement Sonata-Skazka in F\# minor, Op. 4 (1914) and $2^{\text {nd }}$ Sonata in D minor, Op. 12 (1918), showing a clear indebtedness to Medtner and Scriabin - towards a series of retrospective three-movement works of a catchy late-Romantic idiom, fully compatible with the political doctrine. A similar twist is evident in the œuvre of Nikolai Myaskovsky, a prolific composer whose first four sonatas approached a tentative modernism, most remarkably in the single-movement $2^{\text {nd }}$ Sonata in F\# minor, Op. 13 (1912; see example 1.6), and $3^{\text {rd }}$ Sonata in C minor (1920). Then, after being accused of $>$ formalism $\iota$, his remaining five sonatas of 194449 attain a cheerfully innocent tone, yet still demonstrating his skilful craftsmanship. Similar observations apply to plenty of other Soviet piano sonatas after 1945, such as those of Myaskovsky's pupil Dmitry Kabalevsky ( $2^{\text {nd }}$ and $3^{\text {rd }}$ Sonatas, Opp. 45 and 46, of 1945-46), Oleg Eiges (twelve sonatas between 1928-83), Evgeny Golubev (ten sonatas between 1930-77), and the Polish-born Mieczysław Weinberg (six sonatas between 1940-60). Likewise, Dmitry Shostakovich turned back to the untarnished B minor of his threemovement $2^{\text {nd }}$ Sonata, Op. 61 (1942) long after having published his $1^{\text {st }}$ Sonata, Op. 12 (1926), an experimental single-movement work. ${ }^{37}$

\subsubsection{INTRODUCTIONS TO INDIVIDUAL WORKS}

\section{Pëtr Ilyich Tchaikovsky: $2^{\text {nd }}$ Piano Sonata in G major, Op. 37 (1878)}

This lengthy grande sonate, with its pianistic textures appearing monumental and bulky, has prompted a reviewer to the unflattering judgment that »had he rescored it for orchestra, it would have made an acceptable Tchaikovsky symphony ${ }^{38}$ The composer himself described the work, which was written simultaneously to Evgeny Onegin and the Violin Concerto, Op. 35, as »somewhat dry and complex«. Notwithstanding this criticism, the four-movement sonata is doubtlessly a mature and challenging concert piece, and was dedicated to Tchaikovsky's colleague at the Moscow Conservatory, the pianist Karl Klindworth. The initial Moderato e risoluto commences with a prominent dotted rhythm which is heard throughout the $1^{\text {st }}$ movement; ${ }^{39}$ its

36 See, for example, Gojowy 1980, p. 97ff;; Roberts 1993, p. 101ff.; and Sitsky 1994, p. 38ff.

37 A continuation of this overview, also including works composed after 1945 by Rodion Shchedrin, Sofiya Gubaidulina, Galina Ustvolskaya, Boris Tishchenko, Alfred Schnittke, and Nikolai Kapustin, is found in Bitzan 2012.

38 Newman 1969, p. 712.

39 Frolova 1955 , p. 25 , notes that similar instances of march-like rhythm occur in Tchaikovsky's $5^{\text {th }}$ and $6^{\text {th }}$ Symphonies. For considerations on the tonal cyclicity of the sonata and its large-scale harmonic progression, see also Roitershtein 1966, p. 140. 
primary theme is shaped as a small ternary, comprising a middle episode in $G$ minor which also initiates the recapitulation section. The overall structure of this large movement suffers from a number of clearly discernible formal borders, while organic transitions are rare; many of its themes are developed in rather mechanical sequences. This deficiency is however counterbalanced by the accomplished brightness of textures and beauty of melodic inspiration, such as in the $2^{\text {nd }}$ Andante non troppo movement in E minor, where a touching initial theme unfolds above a descending bass. A capricious Scherzo in 6/16 time follows, succeeded by an Allegro vivace finale which recalls some motives of the $1^{\text {st }}$ movement, and even surpassing it in virtuosic brilliance.

\section{Mily Alekseyevich Balakirev: Piano Sonata in Bb minor, Op. 5 (completed 1900-05)}

Some parts of this work were already sketched in 1850-56, in two approaches of writing a piano sonata, figuring as Op. 3 (dedicated to his friend César Cui) and Op. 5, before the final four-movement version, occasionally referred to as his $2^{\text {nd }}$ Sonata, took its shape no earlier than in 1905 as a nearly completely different work. In the ultimate four-movement version, only the scherzo-like $2^{\text {nd }}$ movement, a D major Mazurka, was maintained from the previous stages of the work, whereas the Allegro assai feroce which had previously served as an $1^{\text {st }}$ movement was abandoned in favour of an opening Andante, a newly composed, tonally indecisive Intermezzo forming the $3^{\text {rd }}$ movement, and a lively finale. The initial movement presents a hybrid of sonata form and fugato - a most surprising move for a non-academic like Balakirev to incorporate a scholarly contrapuntal genre, with only a distant prefiguration in the sketched epilogue of the Op. 3 Sonata. The widely spun fugal theme is introduced in the alto, soprano and tenor voices (see example 1.7), ${ }^{40}$ but soon breaks off after its first exposition in order to append a nocturne-style continuation, functioning as a secondary theme zone. The movement may not be considered a proper fugue any more legitimately than the opening of the prologue from Mussorgsky's Boris Godunov (1868-70, rev. 1872) - it lacks any further development of the subject after the theme entry of the bass voice appears truncated, just like many of the entries in succession. The development section is represented by an altered version of the fugal exposition, modulating to $\mathrm{F} \#$ minor and $\mathrm{D} b$ minor, before an unchanged echo of the exposition enters as a recapitulation.

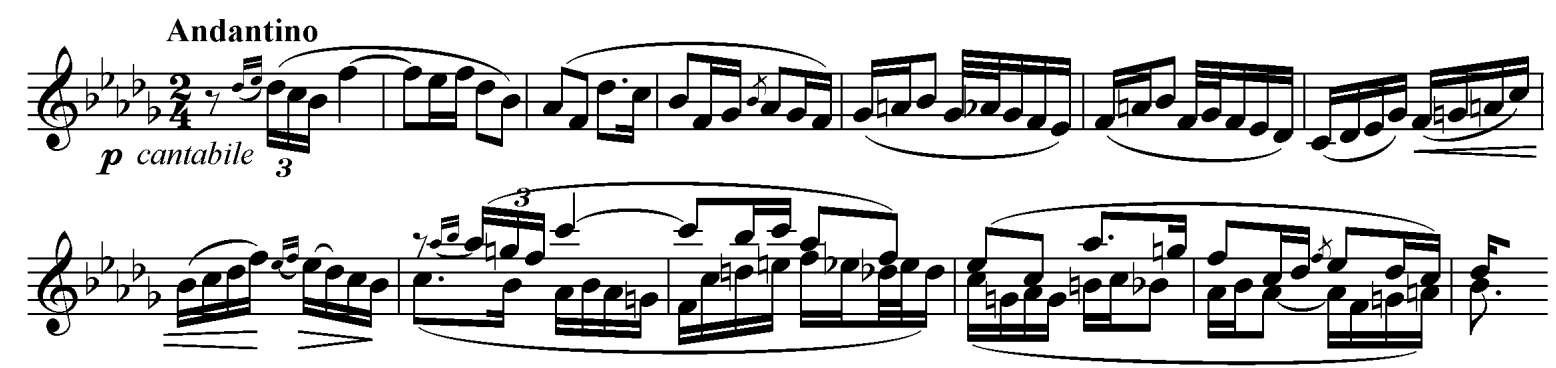

Example 1.7: Balakirev, Piano Sonata, 1905 version, $1^{\text {st }} \mathrm{mvt}, \mathrm{mm} .1-12$

40 Takenouchi 2004, p. 6, notes a kinship in tone and melodic contour between Balakirev's B b minor fugal subject and the primary theme from the $1^{\text {st }}$ movement of Medtner's Sonata romantica in the same key, Op. 53 No. 1 (1929-30). 


\section{Aleksandr Nikolayevich Scriabin: Fantasy in B minor, Op. 28 (1900)}

This composition represents the first independent single-movement sonata form to be written by a Russian composer, even though it was not named a sonata. Its unusual conception does not include a development section, ${ }^{41}$ and the fact that Scriabin himself neglected the work even more suggests it should be not counted among his piano sonatas. ${ }^{42}$ An indecisive Moderato primary theme unfolds at its outset, encircling the dominant harmony, and commencing with an ascending and descending minor second from the $5^{\text {th }}$ scale degreea possible yet distant prefiguration of the initial theme of Medtner's Sonata-Elegy in D minor, Op. 11 No. 2 (1905-06; see chapter 3.2.2). The clear melodic contour and periodicity of the D major secondary theme, marked Più vivo, is more specific, changing its character to a triumphant B major during the recapitulation section before being restated a third time within the coda, now in pianissimo and altered to B minor, before the work comes to an affirmative conclusion.

\section{Aleksandr Nikolayevich Scriabin: $5^{\text {th }}$ Piano Sonata, Op. 53 (1907)}

Composed seven years after the Fantasy, Op. 28, Scriabin's first actual single-movement sonata unites contrasting sections in different tempo and character to form a large-scale entity - which, however, might have been named a fantasy as well. ${ }^{43}$ Like hardly another of Scriabin's works, it stands for the transitional stage between the sphere of traditional harmony and the composer's experimental late style, giving an impressive effect through its dense textures and erratic melody. However, the composition is by no means atonal—most of the music bears the key signature of $\mathrm{F} \#$ major, and tonic or dominant qualities of chords remain discernible even if enriched by multiple added notes or occasional fourth-chord harmony. Among various opposing approaches to grasp the sonata's overall form, its internal structure is aptly described as a superposition of a sonata movement with a free chain form, ${ }^{44}$ comprising an Impetuoso introduction, a primary theme marked Presto con allegrezza, and a large expositional space with three more subjects. Many of the central ideas are assigned a certain >Leitmotiv< character through their idiosyncratic performance indications, recurring throughout the sonata, before the music closes with a triumphant coda in Eb major. A close proximity to the sonata's orchestral neighbour work, the simultaneously composed Poème de l'extase, Op. 54 (1905-08), is established by motivic intercommunity. Moreover, an epigraph taken from Scriabin's epic poem of the same name precedes the score of the sonata.

\section{Sergei Mikhailovich Lyapunov: Piano Sonata in F minor, Op. 27 (1906-08)}

The score of the composer's only sonata suggests subdivisions in multiple sections, being connected by attacca transitions, but the work in fact figures as a single-movement >two-dimensional sonata form <, and as such is strongly indebted to the influence of Liszt's B minor Sonata. Just like Tchaikovsky's G major Sonata,

41 This outline is called a >Type 1 Sonata by Hepokoski and Darcy 2006, p. $343 \mathrm{ff}$.

42 See Schibli 1983, p. 83, and Bartels 1995, p. 171f.

43 The formal outline of Scriabin's $4^{\text {th }}$ Sonata in F\# major, Op. 30 (1904), is ambivalent between single-movement form and a two-sectional structure, consisting of an introductory Andante and a Prestissimo volando sonata movement following attacca.

44 See Mauser 2004, p. 88: »Ein Sonatenhauptsatz mit ausgedehnten Themenkomplexen [...] verbindet sich mit einem Reihungsprozeß, der [...] dem architektonisch gebundenen Prinzip eine parataktische Reihung [...] unterschiebt.« 
it is dedicated to Karl Klindworth, a former pupil of Liszt who had been Lyapunov's piano teacher at the Moscow Conservatory. However, the stylistic influence of the music of Balakirev, who was one of Lyapunov's main authorities during his later period in Saint Petersburg, is even more evident in the sonata. Regarding its motivic interrelations, the work appears slightly less complex than the Lisztian model. ${ }^{45} \mathrm{~A}$ powerful Allegro appassionato subject dominates the beginning, but is soon superseded by a lyrical subordinate idea in 6/4 time, also in F minor and marked Cantabile ed espressivo, which gradually gains importance as the music proceeds, and is eventually transformed into a $\mathrm{G} \#$ minor scherzando subject in the last third of the work (see example 1.8). The overall sonata form remains noticeable throughout the 25 -minute composition, although a proper developmental process is missing. Instead, an E major cantilena is introduced as a middle section which returns at the end, transformed to a chorale-like apotheosis in F major.

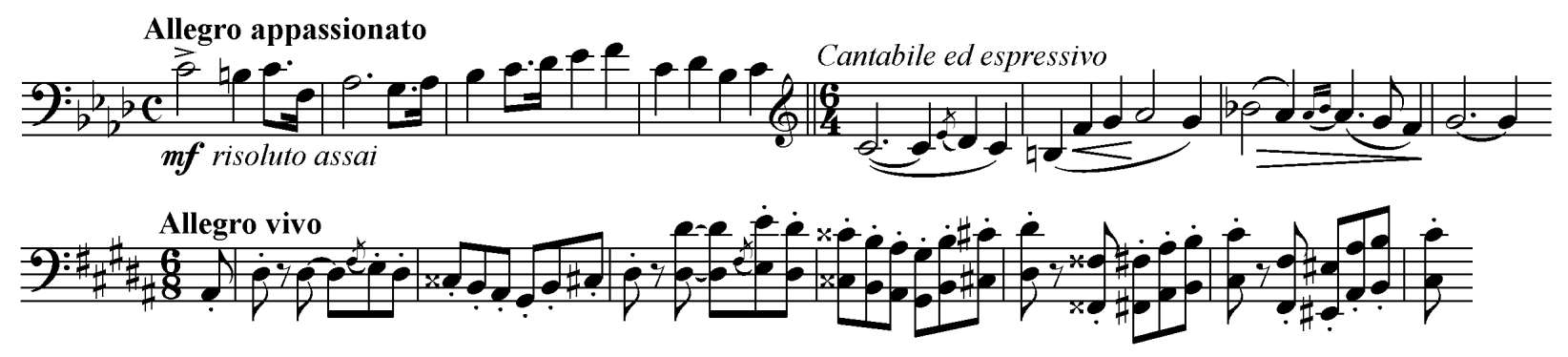

Example 1.8: Lyapunov, Piano Sonata, Op. 27, mm. 1-4// mm. 52-55 // mm. 360-365 (motivic reduction)

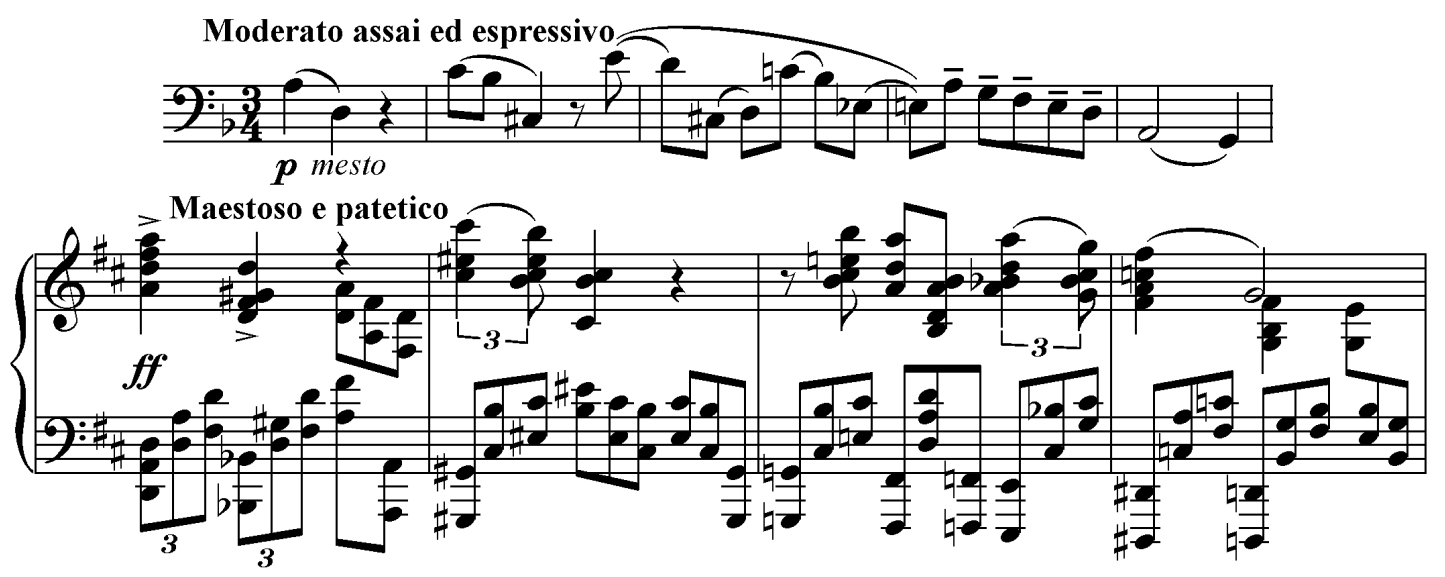

Example 1.9: Myaskovsky, $1^{\text {st }}$ Piano Sonata, Op. 6, $1^{\text {st }} \mathrm{mvt}, \mathrm{mm} .1-5 / / 4^{\text {th }} \mathrm{mvt}, \mathrm{mm} .219-222$

\section{Nikolai Yakovlevich Myaskovsky: $1^{\text {st }}$ Piano Sonata in D minor, Op. 6 (1907-09)}

Myaskovsky's first sonata, dedicated to the poet and renowned Pushkinist Modest Hofmann, is one of only two four-movement works among his nine contributions to the genre. As a distinctly cyclic work, it is indebted to the large-scale, final-oriented designs of the late $19^{\text {th }}$ century, and as such it was appreciated by Glenn Gould as »perhaps one of the most remarkable pieces of its time « ${ }^{46}$ A three-part fugue indicated

45 To identify the sonata's clear indebtedness to Liszt, one needs not dismiss it, like Newman 1969, p. 703f., as an epigonal work.

46 Tim Page (ed.), A Glenn Gould Reader, London 1987, p. 179. 
Moderato assai, commencing in ascending order of its theme entries, functions as a slow introductory movement to the following Allegro affanato, which is written in a regular sonata form. The fugal subject, encircling the descending fifth $A-D$ and its upper and lower semitones, forms the basis for all thematic work and serves as a cyclic link to the successive movements. It figures as the secondary theme of the $2^{\text {nd }}$ movement, is then recalled in the middle section of the $\mathrm{F} \#$ major Largo espressivo, and eventually returns as a final apotheosis, marked Maestoso e patetico, within the $4^{\text {th }}$ movement (see example 1.9).

\section{Aleksei Vladimirovich Stanchinsky: $2^{\text {nd }}$ Piano Sonata in G major (1912)}

Another sonata to substantially incorporate contrapuntal writing is this compact work by the Muscovite composer Stanchinsky. The $1^{\text {st }}$ of its two movements, Lento espressivo, is a fully developed three-part fugue, the subject of which appears, in its wide interval leaps, in instantaneous combination with a countersubject, and remains in $\mathrm{G}$ major without a single accidental for eleven measures. ${ }^{47}$ Later on, a section in $\mathrm{F} \#$ minor and an $\mathrm{A} b$ major stretto appear, leading to a richly ornamented fortissimo recapitulation of the initial theme. The movement unexpectedly closes in E major, a possible reflection of the non-tonical ending of the $1^{\text {st }}$ movement from Scriabin's $2^{\text {nd }}$ Sonata, Op. 19, and launches into a lively, equally Scriabinesque Presto finale, written in an irregular 11/8 time. After Stanchinsky's tragic death in 1914, aged only twenty-six and probably by suicide, Medtner dedicated his Three Piano Pieces, Op. 31 (1914), which include a funeral march, to the memory of the young composer whose acquaintance he had made only shortly before.

\section{Sergej Vasilyevich Rachmaninov: $2^{\text {nd }}$ Piano Sonata in Bb minor, Op. 36 (1913, rev. 1931)}

This work has advanced to a core piece of the pianistic repertoire, but not without some detours. Two decades after completing the lengthy first version of his $2^{\text {nd }}$ Sonata, Rachmaninov decided to apply significant cuts, demonstrably motivated by the comparison with Chopin's $2^{\text {nd }}$ Sonata, Op. 35 (1839-40), also in Bb minor, on which he remarked: »It lasts 19 minutes, and all has been said. ${ }^{48}$ The revised version is much more compact and compelling in its thematic statements; yet Vladimir Horowitz later compiled a third edition as a mixture of both previous versions, which was authorised by Rachmaninov. The three movements, played attacca after each other, are cyclically interconnected by motivic cross-references and quotes. A motto-like initial idea, the descending arpeggio of the tonic fourth-sixth chord $D b-B b-F$, is introduced at the beginning of the $1^{\text {st }}$ movement, anticipating the contour of both its primary and secondary themes. ${ }^{49}$ The $2^{\text {nd }}$ movement, a G major Lento, commences with a Non allegro introduction in swaying tonality, followed by a theme and three variations. The same introduction, transposed down a whole-tone, also precedes the $\mathrm{B} b$ major finale, a lively piece with no clearly defined primary theme, combining traits of a scherzo and sonata form.

47 See Sitsky 1994, p. 29f.

48 Swan 1944, p. 8, recalling a talk with Rachmaninov. See also Wehrmeyer 2000, p. 85.

49 Bryantseva 1962, p. 10, proposes a narrative implication to this beginning, which allegedly resembles $\gg$ a sombre breeze of wind, sounding a bell« (»Sumrachnoe dunovenie vetra donosit gulkiy udar kolokola«). 
Feliks Mikhailovich Blumenfeld: Sonate-Fantaisie in B minor, Op. 46 (1913)

Blumenfeld, having studied with Rimsky-Korsakov in Saint Petersburg and later accepting a professorship at the Moscow Conservatory, inscribed his only piano sonata with the name of the befriended composer Nikolai Tereshchenko, and would dedicate his Etude-Fantaisie in F minor, Op. 48 (1916), to Medtner shortly thereafter. The sonata appears as a traditional three-movement work at first glance, but many of its formal features fully justify the hybrid title of a fantasy-sonata. The $1^{\text {st }}$ movement presents a truncated sonata form, with its exposition, which comprises two primary themes in the tonic key and a D minor secondary theme zone, being followed by a short development and a restatement of the secondary theme in G\# minor, while a recapitulation of the strong initial subject is left out. Although closing with a double bar line, the $1^{\text {st }}$ movement needs to rely on the dramaturgy of the following ones so as to achieve overall coherence. A stwodimensional sonata form $<$, however, is not intended - clear diastematic links to the $2^{\text {nd }}$ and $3^{\text {rd }}$ movements are missing, apart from a distant resemblance of the finale's embellished Allegro con fuoco theme to the second primary theme of the $1^{\text {st }}$ movement. The sonata curiously denies harmonic resolution at its ending, closing with an augmented triad above $B$.

\section{Sergei Sergeyevich Prokofiev: $3^{\text {rd }}$ Piano Sonata in A minor, Op. 28 (1917)}

Just like his $4^{\text {th }}$ Sonata in C minor, Op. 29, Prokofiev's $3^{\text {rd }}$ Sonata is largely based on earlier sketches from the composer's youth, as suggested by the indication »From Old Notebooks« (»Iz starikh tetradey«). The work was dedicated to the poet Boris Verin. As one of only two of Prokofiev's single-movement sonatas, it appears as the more remarkable work compared to the youthful, post-Romantic, and rather conventional $1^{\text {st }}$ Sonata in F minor, Op. 1 (1909). After the introduction of a furious Allegro tempestoso primary theme, sonata form is handled with a certain amount of liberty, allowing the exposition's secondary theme to mutate to a gently flowing interior episode, marked Tranquillo, semplice e dolce. ${ }^{50}$ This passage makes the music calm down completely, vaguely wavering in tonality between A minor and $\mathrm{C}$ major, before abruptly starting anew. The secondary theme zone is not independently restated in the recapitulation section, but its subject reappears, in diminution and cunningly hidden in a staccato figuration of the left hand's tenor voice (see example 1.10), ${ }^{51}$ during the final section. Similar superpositions of themes had occurred earlier in the recapitulation sections of Medtner's Sonatas, Op. 11 No. 2 and Op. 22 (1905-10), but it is unlikely that Prokofiev was directly influenced by these works.

50 Kholopov 1990 , p. 285 , hints to the sequence of the notes $E-C-B-E$, prominently found at the onset of that theme, as a probable example of a soggetto cavato, derived from the name of Lisa Esche, a fellow student of Prokofiev at the Saint Petersburg Conservatory.

51 Westfall 2008, p. 94, refers to the juxtaposition of themes in his analysis of the sonata, but does not mention this particular, and structurally significant, passage. 


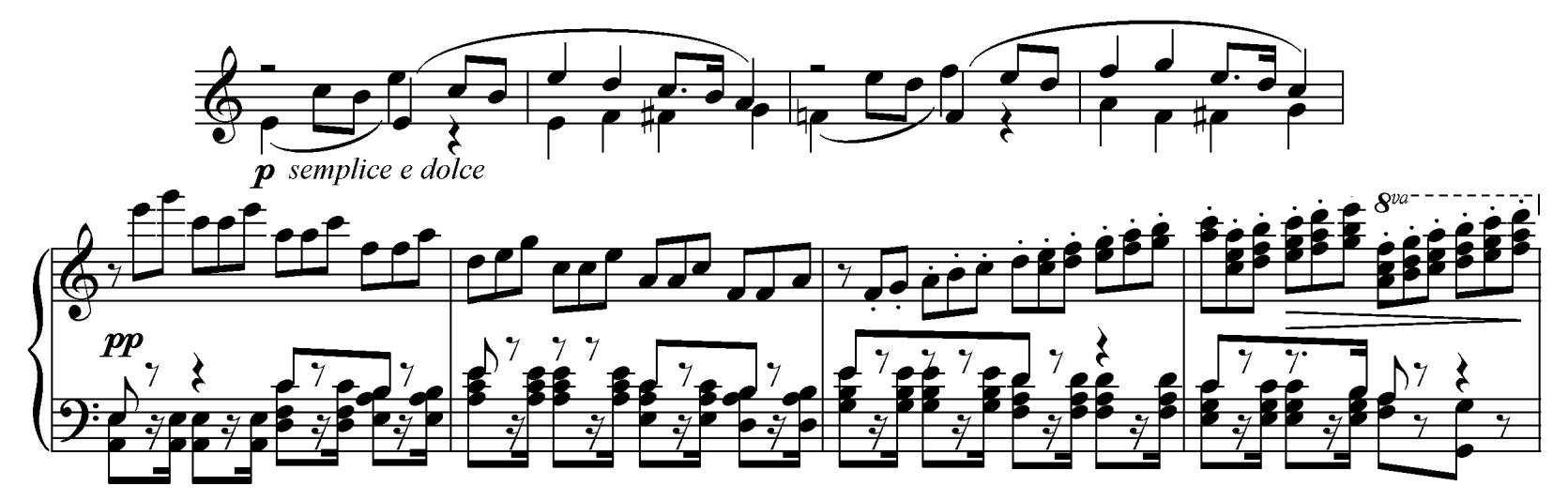

Example 1.10: Prokofiev, $3^{\text {rd }}$ Piano Sonata, Op. 28, mm. 58-61 (motivic reduction) // mm. 199-202

\section{Anatoly Nikolayevich Aleksandrov: $2^{\text {nd }}$ Piano Sonata in D minor, Op. 12 (1918)}

Of Aleksandrov's fourteen sonatas, the earliest appear as the most interesting ones, even if they represent a stage of the composer's development when he had not fully shaken off the influence of Scriabin and Medtner. The $2^{\text {nd }}$ Sonata is in many respects modelled on Medtner's Sonata-Elegy in D minor, Op. 11 No. 2 (1905-06), the opening theme of which has much in common with Aleksandrov's initial Allegro agitato idea - both subjects encircle the $5^{\text {th }}$ scale degree with ascending and descending minor seconds (see chapter 3.2.2 and example 3.2.20). So it is not surprising that the younger composer dedicated his work to Medtner whose music had been one of his main sources of inspiration before entering the Moscow Conservatory. ${ }^{52}$ Aleksandrov's formal scheme extends Medtner's compact outline, but appears more conventional in the treatment of themes and motives. In its general tonal plan, the work employs a tonal symmetry of scalar thirds: The exposition introduces its secondary theme in F major, while this subject is later recapitulated in $\mathrm{B} b$ major, and followed by a third restatement in D major during the coda, closing the circle. Near the end of his long life, Aleksandrov set another monument to Medtner in his late piano cycle My soul. Elysium of Visions, Op. 110 (Dusha moya. Elizium teney, 1979), which includes a narrative Skazka in D minor as its $4^{\text {th }}$ piece, inscribed with the line "pamyati N. K. Metnera«.

\subsubsection{CHAMBER AND ORCHESTRAL MusiC}

The surprising fact that none of Medtner's most important teachers, neither Taneyev nor Arensky, has completed a solo piano sonata, ${ }^{53}$ all the more lets him appear, along with Scriabin, as a revivifier of the genre. However, both Taneyev and Arensky were remarkably successful as composers of chamber music, and as

52 Alekseyev 1974, p. 37, points out that the first edition of the work was inscribed with four lines from a Heine poem (»Herz, mein Herz, sei nicht beklommen, / und ertrage dein Geschick, / neuer Frühling gibt zurück, / was der Winter dir genommen«) translated to Russian (»Serdtse, serdtse, bïl kak bïlo, / Ne sklonyaysya pred sud'boy, / Vsë nazad pridët s vesnoy, / Chto zimoy tï skhoronilo«). This might have been a possible reflection of the Goethe epigraph in Medtner's Sonata Triad, Op. 11. See also Pevzner 2013, p. 88.

53 The influence of these two scholars' academic and private teaching delivered to Medtner was limited to a rather short period in 1892-93 (Arensky) and 1897-98 (Taneyev, further infrequent consultations in 1901-02). It should however be mentioned that Taneyev left two unfinished sketches to piano sonatas, one early fragment in $\mathrm{Eb}$ major (1874-75) and another in F\# minor (1899-1900). See Wehrmeyer 1996, p. 305. 
such must be acknowledged for their use of sonata form and multi-movement cyclic design in their duo sonatas, trios, quartets, and quintets, scored for strings with and without piano, as well as in their piano concertos. In this respect, a work like Taneyev's noteworthy G minor Piano Quintet, Op. 30 (1910-11), deserves attention for its epic length and elaborate thematic construction. Some others of the two composers' works will be briefly addressed in the following paragraphs, as well as other late- $19^{\text {th }}$ and early- $20^{\text {th }}$-century works by Russian composers notable for their unconventional approach to musical form.

When looking at the origins of sonata composition in Russia during the $19^{\text {th }}$ century, a habit of composing chamber works in multi-movement cycles is hardly noticeable before the 1850s. Mikhail Glinka's rare excursions to chamber music, such as the Trio pathétique in D minor (c. 1827) and the fragment of a viola sonata (1825), can hardly be considered a substantial portion of his œuvre, and neither do the contributions of Aleksandr Alyabiev (Violin Sonata in E minor) and Iosif Genishta (Cello Sonatas in A major, Op. 7, and D major, Op. 13), written during the 1820s and 1830s, show significant autonomy. Instead, it was Anton Rubinstein again who, with his prolific output of no less than ten string quartets, five piano trios, three violin sonatas, and another three sonatas for viola or cello with piano, must be credited as the first notable Russian composer of chamber music ${ }^{54}$-although he only insignificantly departed from his stylistic inspirers, such as Mendelssohn and Schumann. One of the first Russian chamber works to gain considerable popularity was Nikolai Afanasiev’s A minor String Quartet \The Volga ( published in 1866).

More remarkably, Russian composers took interest in orchestral composition, essentially starting with Anton Rubinstein's six symphonies (1850-86). While he resorted to ideas of cyclic form less obviously than his German and French contemporaries, his second contribution to that genre, a program symphony in C major named >The Ocean<, Op. 42 (completed in 1851 as a four-movement work, and extended seven movements by two revisions of 1863-80), was remarkably successful throughout Europe-and also influenced Tchaikovsky whose career as an orchestral composer began shortly after with his $1^{\text {st }}$ Symphony in G minor $>$ Winter Daydreams`, Op. 13 (1866). The kuchkistï, namely Balakirev, Borodin, and Rimsky-Korsakov, made occasional use of `thematicism ‘ and transformational techniques in Liszt's succession, as seen in their orchestral works of the 1860s and 1870s. Noticeable cross-references between movements were established in Borodin's $1^{\text {st }}$ Symphony in Eb major (1867), the main subjects of which are formed from the common interval of a descending fourth; and likewise in Rimsky-Korsakov’s Antar in F\# minor, Op. 9 (composed 1868 as his $2^{\text {nd }}$ Symphony, and revised 1875-91, now under the title of a symphonic suite), making use of a motto-like initial phrase which is invariably quoted throughout the four movements. Cyclic conceptions are more essentially considered in Tchaikovsky's later symphonies, most notably in the $4^{\text {th }}$ and $5^{\text {th }}$, Opp. 36 and 64 (1877-88), while Glazunov, through Balakirev's influence, started to employ thematic transformation only in his symphonies of the 1890s. While the traditional four-movement outline was continuously maintained in Russian orchestral compositionaccounting for an unbroken line of tradition through the late- $19^{\text {th }}$ to the $20^{\text {th }}$ century, much more than is the case with piano sonatas - , single-movement forms, such as symphonic poems, programmatic overtures, and solo concertos of the Lisztian type, were considered by most of the abovementioned composers as well.

54 For a thorough overview of Rubinstein's sonata production see Newman 1969, p. 704ff. 


\section{Chamber Works}

As one of the foremost contributions to Russian chamber music, Tchaikovsky's Piano Trio in A minor, Op. 50 (1881-82), may be singled out for its biographical inflections - it was dedicated »to the memory of a great artist« (»pamyati velikogo khudozhnika«), referring to his mentor Nikolai Rubinstein who had died in 1881 during the period of composition — as well as for its formal approach. The lugubrious $1^{\text {st }}$ movement Pezzo elegiaco, lasting about 18 minutes, is followed by an equally extensive set of variations in $\mathrm{E}$ major. Its theme is transformed to various guises and characters, such as a fugue, waltz, and mazurka, before the final variation serves as a $3^{\text {rd }}$ movement, presenting the theme in a brilliant, march-like A major (see example 1.11). In turn, Sergei Rachmaninov would dedicate his lengthy Trio élégiaque in D minor, Op. 9 (1893), to Tchaikovsky's memory, taking over his predecessor's formal outline, ${ }^{55}$ the >elegiac attribute of the title, and even the exact wording of the dedication. It seems quite possible that Medtner, who likewise resorted to elegies and elegy-hybrids in his piano œuvre, was inspired by these epitaph compositions (see chapter 3.2.2). This exclusive sub-tradition within Russian chamber music is further continued by Anton Arensky's three-movement $2^{\text {nd }}$ String Quartet in A minor, Op. 35 (1894), also composed shortly after Tchaikovsky's death, and revering his memorial with a set of variations on the Legend from his Children's Songs, Op. 54 No. 5, which forms the $2^{\text {nd }}$ Moderato movement. The exterior parts of this quartet, which attains a singular position for the fact that it is scored for two cellos instead of a second violin part, resort to Russian national tunes: The initial theme of the $1^{\text {st }}$ movement is derived from the Orthodox chant Nadgrobnoe rïdanie tvoryashche pesn': alliluia, referenced as Thème réligieux in the preface of Arensky's score, ${ }^{56}$ whereas the $3^{\text {rd }}$ movement presents a fugato based on the folk song Slava na nebe solntsu vïsokomu. This melody had already been used by Beethoven as a thème russe in the $3^{\text {rd }}$ movement of his E minor >Razumovsky< String Quartet, Op. 59 No. 2 (1806), and gained immense popularity through its application in the choral prologue of Mussorgsky's Boris Godunov (1868-70).

A remarkable approach to single-movement form is represented by Georgy Catoire's $2^{\text {nd }}$ Violin Sonata >Poème ‘ in A major, Op. 20 (composed as early as 1906, and published in 1910; see example 1.12 for short excerpts). This delicate and elaborate work of roughly 20 minutes, closing in D major instead of the tonic key, echoes César Franck's chromaticism and somewhat prefigures the Impressionist harmony of Szymanowski's violin cycles of the 1910s. It was dedicated to Aleksandr Goldenweiser and premiered by the violinist Aleksandr Medtner, Nikolai's brother, and Lev Conus. ${ }^{57}$ Catoire (also spelled Katuar), who had studied with Otto Tiersch and Karl Klindworth in Berlin during the 1880s, was friends with the Medtner family, and from their mutual appreciation stemmed the dedication of his $1^{\text {st }}$ Violin Sonata in B minor, Op. 15 (1904) to Nikolai Medtner, who re-dedicated his G minor Piano Sonata, Op. 22 (c. 1901-10), to Catoire (see chapter 3.3.4 for more information on the two composer's relationship and the possible relevance of the latter's theoretical writings).

55 The same structure was adopted by Glazunov for his $1^{\text {st }}$ Piano Concerto in F minor, Op. 92 (1910-11).

56 See Protopopov 2010, p. 225f., for comments on the role of this liturgical chant (»tserkovnïy napev«) for the movement's formal development and tonal plan.

57 See Zassimova 2001, pp. 49 and 279. 


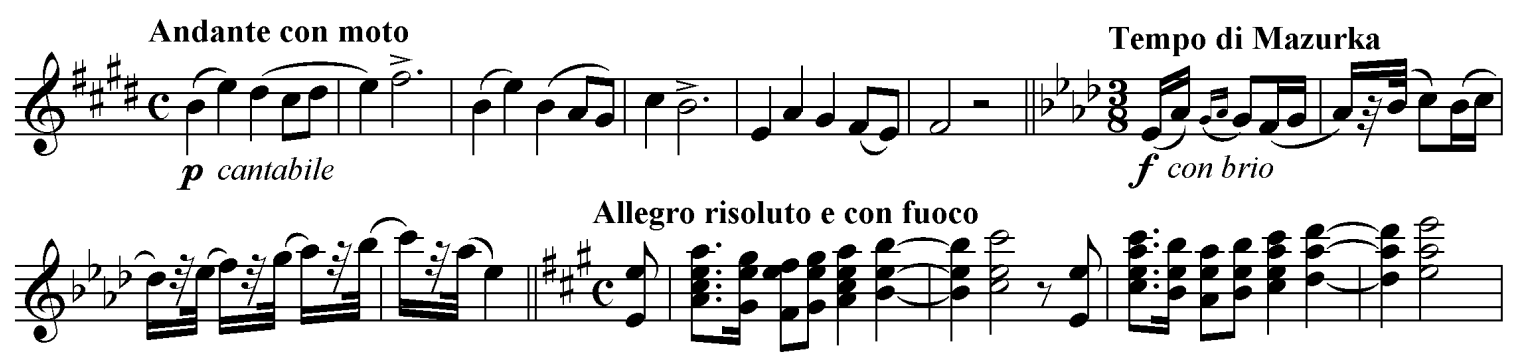

Example 1.11: Tchaikovsky, Piano Trio, Op. 50, $2^{\text {nd }} \mathrm{mvt}$, mm. $1-6 / / 10^{\text {th }}$ variation, $\mathrm{mm} .1-4 / /$ final variation, $\mathrm{mm} .2-5$
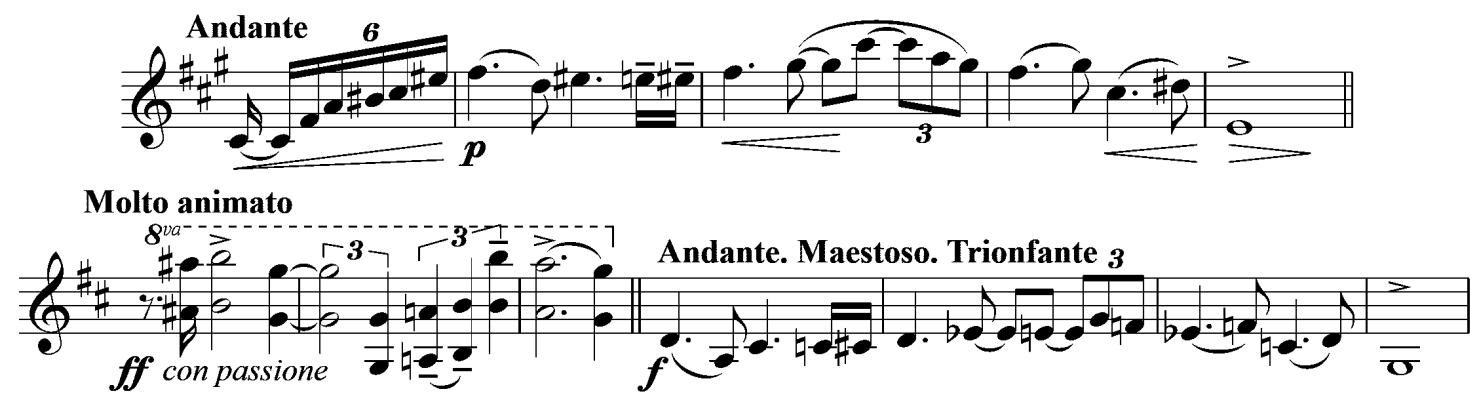

Example 1.12: Catoire, $2^{\text {nd }}$ Violin Sonata, Op. 20, mm. 8-11/ mm. 302-304 // mm. 327-330 (violin part)

\section{Symphonic Works}

Out of the large body of Russian symphonies and symphonic poems, I will here select four works to be briefly introduced, either for their extraordinary position in the ouvres of their composers, or for their formal peculiarity. Aleksandr Borodin's $2^{\text {nd }}$ Symphony in B minor (1869-76), dedicated to his wife Ekaterina Borodina, is widely regarded as his most successful orchestral work, admired also by Liszt who helped it being performed in Western Europe. Its $1^{\text {st }}$ movement commences with an Allegro theme in a primeval unison of the Phrygian scale, alternating between the major and minor third, a tonal feature which is maintained throughout the four movements. A vivacious F major Scherzo, figuring as the $2^{\text {nd }}$ movement, is followed by the lyrical core of the work, an $\mathrm{D} b$ major Andante with its folkloristic melody introduced by the clarinet and French horn. Most remarkable for its energetic and syncopated rhythm and formal ambiguity, oscillating between sonata form and a free sequence of dance-like themes, is the thrilling finale in B major, one of the brilliant examples of an intuitive, non-academic approach of composition leading to fully convincing results.

In this respect, Borodin's work poses the greatest possible contrast to Sergei Taneyev's Symphony in C minor, Op. 12 (1898), which had been published as No. 1 but was in fact his fourth contribution to the genre, succeeding two fragments from his years of study and the $3^{\text {rd }}$ Symphony in D minor (1884), all of which remained unpublished during the composer's lifetime. Taneyev's career as a symphonist had developed out of the influence of his teacher Tchaikovsky, and particularly drew on the latter's achievements with regard to cyclic form; ${ }^{58}$ and this architectural peculiarity, transforming the contour of the $1^{\text {st }}$ movement's initial

58 The cyclic principle can be exemplarily observed in Tchaikovsky's $5^{\text {th }}$ Symphony in E minor, Op. 64 (1888), where a sombre clarinet introduction is eventually transformed into the finale's hymnic initial theme. Taneyev, for his part, passed on these techniques on to his pupil Scriabin, whose five-movement $2^{\text {nd }}$ Symphony in C minor, Op. 29 
Allegro molto directly to the finale's Allegro energico theme,${ }^{59}$ may be considered the work's most appealing quality. Another remarkable transformational link maps the $1^{\text {st }}$ movement's secondary theme to a cunning canon at the finale's concluding culmination (see example 1.13). The symphony thus appears most deliberately conceived throughout, and its thematic and contrapuntal density, cross-movement interrelations, and tonal organisation make it a prime example of musical brainpower. All these features have constituted Taneyev's legendary reputation as a composer and scholar. The symphony is dedicated to Aleksandr Glazunov, only three years after the latter had dedicated his $5^{\text {th }}$ Symphony in Bb major, Op. 55 (1895) to Taneyev. For a possible role model effect of its contrapuntal combinatoriality for Medtner's $1^{\text {st }}$ Piano Concerto, Op. 33 (1914-18), see chapter 2.3.1.

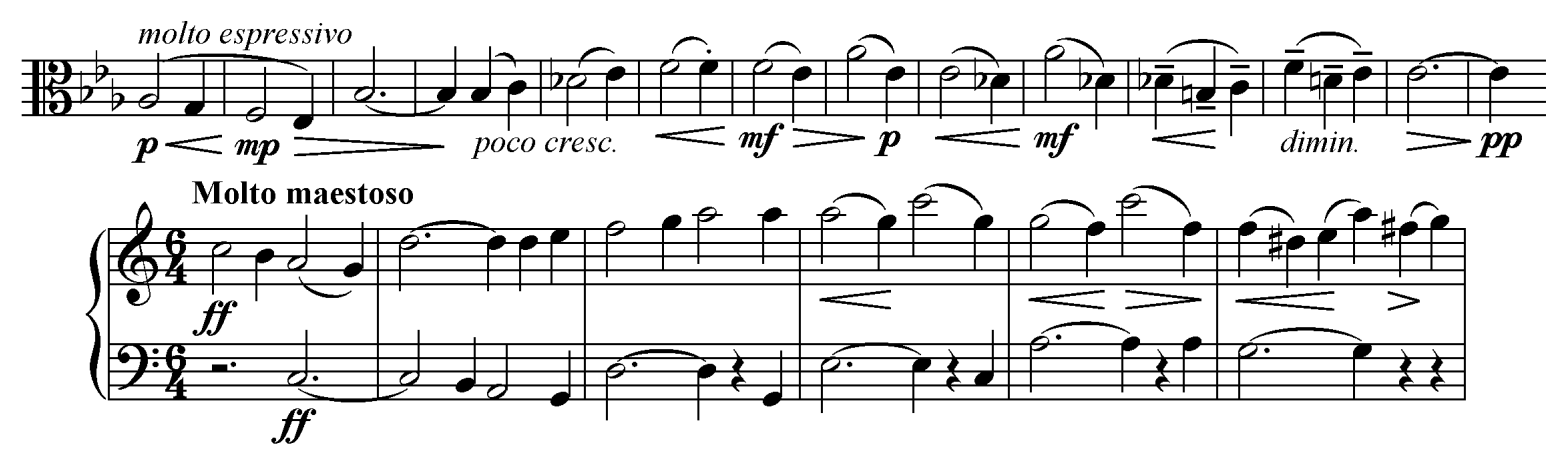

Example 1.13: Taneyev, Symphony, Op. 12, $1^{\text {st }} \mathrm{mvt}, \mathrm{mm} .57-69$ (violas and cellos) // $4^{\text {th }} \mathrm{mvt}$, mm. 299-304 (tutti)

One of the comparatively few symphonic poems by a Muscovite composer is Sergei Rachmaninov's Isle of the Dead, Op. 29 (1908), a twenty-minute orchestral tableau inspired by Arnold Böcklin's painting Die Toteninsel..$^{60}$ It was composed shortly after the publication of Rachmaninov's $2^{\text {nd }}$ Symphony in E minor, Op. 27 (1906-07), and is dedicated to the composer and publisher Nikolai Struve. A five-note ostinato $A-C-B-$ $E-A$, slowly unfolding in $5 / 8$ meter, gradually ascends to several large climaxes and is permeated by recurring quotes of the Gregorian plainchant Dies irae, Rachmaninov's haunting idée fixe which is present in most

(1901), is an equally impressive example of a transformational multi-movement cycle. The latter work invites for a few considerations on its number of movements: While Beethoven's $6^{\text {th }}$ Symphony $>$ Pastorale $<$, Op. 68, and Berlioz's Symphonie fantastique, Op. 14, were devised as five-part works in derivation from their inherent programmes, most of the successive instances of symphonies with more than four movements seem to extend the traditional scheme by insertion of one or two additional movements. See, for example, Schumann's $3{ }^{\text {rd }}$ Symphony in Eb major, Op. 97 >Rhenish (1850), the regular slow movement of which is followed by a sombre Eb minor piece (Feierlich); or Tchaikovsky's $3^{\text {rd }}$ Symphony in D major, Op. 29 (1875), incorporating an Alla tedesca dance in addition to its regular Scherzo, a device prefigured in Beethoven's six-movement String Quartet in Bb major, Op. 130. On the other hand, an independent introductory movement may add up to the regular four-part outline of a sonata cycle, as seen in Scriabin's $1^{\text {st }}$ and $2^{\text {nd }}$ Symphonies, Opp. 26 and 29, or in Brahms's $3^{\text {rd }}$ Piano Sonata in F minor, Op. 5 (1853), the finale of which is preceded by a short Intermezzo.

59 Boris Asafiev described this relationship as follows: »The first theme [of the finale] revives the symphony's main theme, but in binary [instead of ternary] meter, giving it a more decisive character in place of the original elasticity.« Asafiev, Izbrannïe trudy, Vol. 2, Moscow 1954, p. 314; transl. to German in Wehrmeyer 1996, p. 289. For a more detailed examination of cyclic aspects and theme transformation in this symphony, see Bitzan 2017, p. 68ff.

60 Despite the extra-musical inspiration, it is doubtful if The Isle of the Dead can be identified as true program music. See Wehrmeyer 2000, p. 87, for more thoughts on Rachmaninov's attitude concerning this matter (»Er war im Grunde kein Programmkomponist, zumindest nicht im strikten Sinne«). 
of his major works. Apart from a more agitated middle passage in Eb major, the work does not ultimately brighten to a major key and, unlike Rachmaninov's other orchestral works, returns to the sombre atmosphere of its beginning. A similar tone of resignation is perceptible in Nikolai Myaskovsky's $3{ }^{\text {rd }}$ Symphony, also in A minor, Op. 15 (1914); this early example from the impressive body of the composer's twenty-seven symphonies (1908-50) was dedicated to Boris Asafiev. Written in only two movements of Mahlerian dimensions - an outline employed only for one of Myaskovsky's other symphonies_-, the large second part, indicated Deciso e sdegnoso, finally ebbs away in a scarcely audible pianissimo. Maybe it is more than pure coincidence that one of Medtner's gravest works, the A minor Piano Sonata, Op. 30, also completed in 1914 shortly before the outbreak of World War I, is composed in the same tonality.

\section{Concertos}

Without the ambition of giving a full account of solo concerto composition in Russia, I have chosen three compact works for some introductory notes. Nikolai Rimsky-Korsakov’s Piano Concerto in C\# minor, Op. 30 (1882-83), is an atypical work within the composer's œuvre in many respects: It is one of his few compositions with a solo part, composed in response to Balakirev's proposal, and despite the fact that he was not a professional pianist himself; and more than any other of Rimsky-Korsakov's compositions, it adheres to the Western conception of cyclic single-movement form, making extensive use of thematic transformation, as seen in the concertos of Franz Liszt, to whom it was duly dedicated. The $1^{\text {st }}$ subdivision introduces a theme derived from the Russian folk song Sobiraytes-ka, brattsï-rebyatushki, ${ }^{61}$ which is processed quasimonothematically throughout the piece, and transformed to the F major Andante mosso and $\mathrm{D} b$ major Allegro con fuoco of the $2^{\text {nd }}$ subdivision and final passage (see example 1.14).

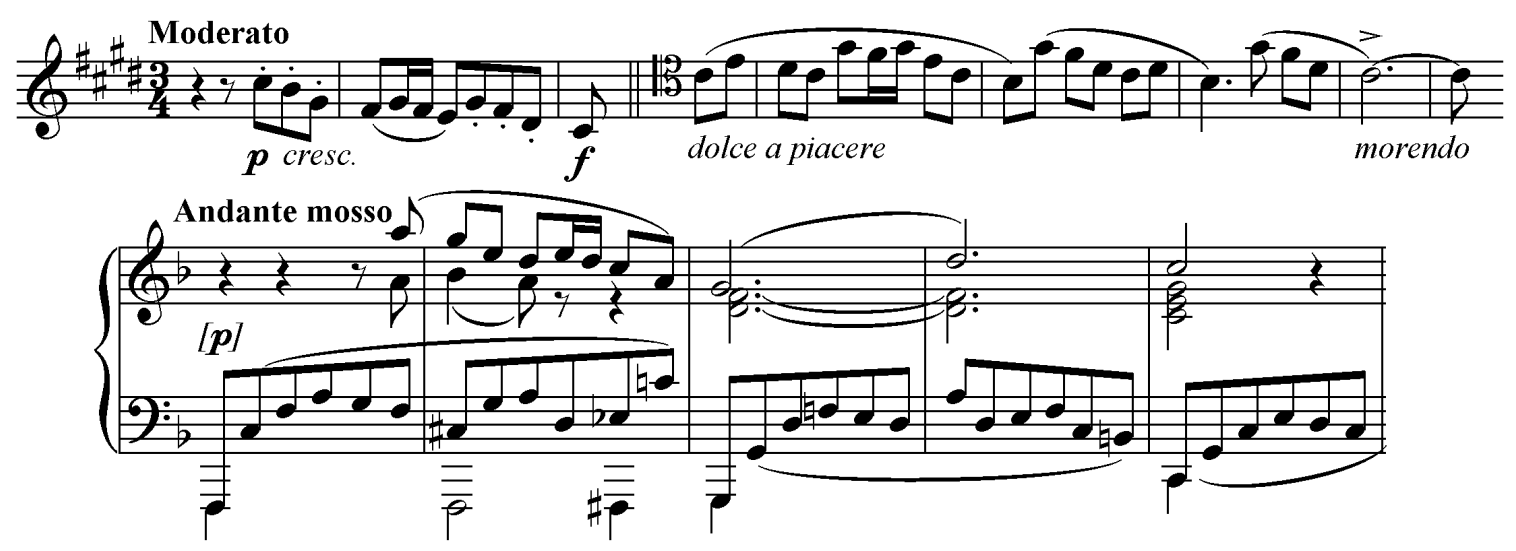

Example 1.14: Rimsky-Korsakov, Piano Concerto, Op. 30, mm. 1-2 (tutti) // mm. 6-9 (bassoon) // mm. 150-154 (piano)

61 The tune was taken from Mily Balakirev's collection of Russian folk songs Sbornik russkikh narodnïkh pesen (1866), where it figures as No. 18, belonging to the protyazhnaya genre. 
With obvious inspiration drawn from his teacher's work, Aleksandr Glazunov later approached the concerto genre in five compositions of his middle and late period. The Violin Concerto in A minor, Op. 82 (1904), is the first and most successful of these, dedicated to the violinist Leopold Auer who quickly popularised it in a number of countries. It features a single-movement form with four subdivisions, also in a Lisztian mood, but with less obvious >thematicism<. The initial Moderato subject appears related in character and contour to the intimate theme of the $2^{\text {nd }}$ Andante subdivision in $\mathrm{D} b$ major, before the lively melody of the final subdivision in A major, representing a caccia topos with horn fifths integrated in the double stops of the soloist's part, concludes the concerto in a virtuoso manner.

Of Sergei Prokofiev's five piano concertos, his $1^{\text {st }}$ in Db major, Op. 10 (1911), was still written during his studies with Anatoly Lyadov and dedicated to Nikolai Tcherepnin, his professor in conducting at the Saint Petersburg Conservatory. If we imagine that Medtner commented on this concerto-which he did not-, he might well have taken some interest in the formal experiment shown here, even if he otherwise appeared largely dismissive of Prokofiev's music. A single-movement form of roughly 15 minutes, divided in three subdivisions, recalls the Lisztian `two-dimensional sonata form<, with the slower middle section in G\# minor appearing yet unrelated to the Allegro brioso outer sections. Prokofiev himself described the work's formal outline as follows: »It is composed in sonata form with an Andante inserted before the development, which is designed as a Scherzo, and a solo cadenza preceding the recapitulation section. $\ll^{62}$ The concerto thus seems not so dissimilar from the architecture of Medtner's G minor Sonata, Op. 22, which was completed shortly before in 1910 .

\subsection{THEORIES OF SONATA Form: A SHORT BACKVIEW}

Ever since the sonata arose as a species of instrumental music and as a paradigm of musical form, its terminology has been subject to massive changes and controversial discussion. Whether it be the language used in composition treatises and textbooks of musical form, or the vocabulary applied for the purpose of examining sonatas and sonata movements in analytic literature - the terms introduced by one author were not necessarily found in the publications of another, and were even likely to contradict each other. Theories of sonata form, which started to develop in the late $18^{\text {th }}$ century, were sometimes designed as to oppose to their predecessors or contemporaries, and greatly differed in dependence of their time of development, area, and intended receiver; this applies to historical writings as well as to current approaches. In particular, Englishlanguage sonata terminology has significantly changed and advanced during the second half of the $20^{\text {th }}$ century, turning away from established normative terms such as, for instance, >sonata-allegro< or >firstmovement form replaced by more flexible vocabulary. In this respect, the term >sonata principle $<$, as introduced by Edward

62 Semyon Shlifstein: Sergei Prokofiev. Autobiography, Articles, Reminiscences, transl. Rose Prokofiev, Honolulu 2000 , p. 30 . 
Cone, ${ }^{63}$ was symptomatic of a general tendency in post-1945 music theory, allowing the analysis of sonatas to let a pluralistic combination of formal, thematic, and harmonic processes simultaneously take effect, while the mechanism of introducing material in a contrasting key (during expositions) and recapitulating it in the tonic key was retained as a >principal device of sonata form. In a similar way, Charles Rosen's proposal to refer to >sonata forms $<$ instead of using the singular ${ }^{64}$ was owed to the sonata's many possible generic contexts and derivations such as concerto, aria, and solo instrumental music. Some decades later, the >sonata principle is still being conceived as an essential embodiment of Classicist style, relying on tonal contrast and thematic development as its main analytic categories. Yet, in order to grasp the recent and historical modifications in applying sonata terminology, we will need to delineate the origins of their application, and delve into the terminological jungle of theories of musical form and composition. For this purpose, the table on the following page confronts the various expressions applied to sonata movements and their subdivisions in writings and treatises from the first half of the $19^{\text {th }}$ century - the period during which the foundations of modern analytic vocabulary were essentially shaped.

In the light of this variety of possibilities, a study focusing on sonatas, or at least compositions named >sonata< by their authors, needs to carefully specify its verbal means (see chapter 3.0 for a general delineation and clarification of the terminology applied in my analyses). In order not to simply adopt analytical vocabulary from other authors, I am required to ask where it originates and how it found its way into common methodology of examining musical works. With the following chapter, I take account of this demand for a historical retraceability of analytical terms - while acknowledging that it might at first look like a digression from the overall goal of this study and its focus on the music itself.

While it might seem advisable to depart from the latest developments on the field of musical form, approaches originating from the same time as the music being discussed should be additionally taken into consideration. That is, in Medtner's case, the historical development of sonata theories emerging in Russia and Western Europe during the $19^{\text {th }}$ and early $20^{\text {th }}$ centuries. I will now proceed with a short account of scholarship on musical form during this period, with special regard to its approaches to sonata forms and the sonata genre, and then consider some particular developments in music theory from Russia and the Soviet Union.

63 See Cone 1968, p. 76f.: »The formal design that is ideal for the Classical style [...] is of course the sonata-allegro. [...] Let us recall for a moment that the principle underlying both the fugue and the [Baroque] concerto was the recurrence of the theme at every important point of harmonic arrival. The corresponding principle for the Classical style - let us call it the sonata principle for want of a better term - is somewhat more complex."

64 See Rosen 1980, preface, p. 1f.: »The [...] plural [...] is meant to emphasize that what was eventually to become the canonical type of sonata form developed along with other forms, which influenced each other and were, in fact, interdependent. [...] The variety of [...] sonata forms extends beyond the domains of symphony, chamber music, and solo sonata. Without aria and concerto the history of sonata forms is simply quite unintelligible.« 


\begin{tabular}{|c|c|c|c|c|}
\hline AUTHOR ${ }^{65}$ & NAME OF MVT & SECTIONS & STRUCTURE OF $1^{\text {ST }}$ SECTION & FURTHER TERMINOLOGY \\
\hline $\begin{array}{l}\text { Koch } \\
1793\end{array}$ & erstes Allegro & $\begin{array}{l}\text { binary: erster / zweiter } \\
\text { Theyl; erster, zweiter, } \\
\text { lezter Hauptperiode }\end{array}$ & $\begin{array}{l}\text { melodische Theile, } \\
\text { subdivided in cadences: } \\
\text { Grundabsatz, Quintabsatz, } \\
\text { Schlusssatz }\end{array}$ & \\
\hline $\begin{array}{l}\text { Galeazzi } \\
1796\end{array}$ & melodia & $\begin{array}{l}\text { binary: prima / seconda } \\
\text { parte }\end{array}$ & $\begin{array}{l}\text { motivo principale; secondo } \\
\text { motivo; passo di mezzo; } \\
\text { periodo di cadenza; coda }\end{array}$ & $\begin{array}{l}\text { second section: } \\
\text { modulazione, ripresa, } \\
\text { replica }\end{array}$ \\
\hline $\begin{array}{l}\text { Kollmann } \\
1799\end{array}$ & long movement & $\begin{array}{l}\text { binary: first / second } \\
\text { section }\end{array}$ & first / second subsection & $\begin{array}{l}\text { second section: third / } \\
\text { fourth subsection }\end{array}$ \\
\hline $\begin{array}{l}\text { Momigny } \\
1806 \\
\end{array}$ & $\begin{array}{l}\text { morceau / } \\
\text { Allegro }\end{array}$ & $\begin{array}{l}\text { ternary: première, } \\
\text { seconde, troisième partie }\end{array}$ & première / seconde période & $\begin{array}{l}\text { reprise refers to a section } \\
\text { as well as to repetition }\end{array}$ \\
\hline $\begin{array}{l}\text { Reicha } \\
1814 \\
\end{array}$ & \multirow[t]{2}{*}{$\begin{array}{l}\text { grande coupe } \\
\text { binaire }\end{array}$} & \multirow[t]{2}{*}{$\begin{array}{l}\text { binary: première / } \\
\text { seconde partie }\end{array}$} & le thème, idées & $\operatorname{coda}$ \\
\hline $\begin{array}{l}\text { Reicha } \\
1824\end{array}$ & & & $\begin{array}{l}\text { première idée mère, pont, } \\
\text { seconde idée mère; idées } \\
\text { accessoires }\end{array}$ & $\begin{array}{l}\text { subdivisions of seconde } \\
\text { partie: première section } \\
\text { (développement principal } \\
\text { / arrêt), seconde section }\end{array}$ \\
\hline $\begin{array}{l}\text { Birnbach } \\
1827\end{array}$ & Hauptform & $\begin{array}{l}\text { ternary: erster / zweiter } \\
\text { (Mittelsatz) / dritter Theil }\end{array}$ & $\begin{array}{l}\text { Hauptgedanke / erster } \\
\text { Gedanke; zweites Thema / } \\
\text { Gedanke; Passage }\end{array}$ & $\begin{array}{l}\text { Koda refers to a closing } \\
\text { zone or an actual coda }\end{array}$ \\
\hline $\begin{array}{l}\text { Czerny } \\
1832\end{array}$ & erster Satz & \multirow[t]{2}{*}{$\begin{array}{l}\text { binary: erster / zweiter } \\
\text { Theyl; first / second part }\end{array}$} & $\begin{array}{l}\text { Grundidee / Hauptthema, } \\
\text { Mittelsatz / Mittelgesang, } \\
\text { Schlusssatz }\end{array}$ & $\begin{array}{l}\text { second section: } \\
\text { Entwicklung / } \\
\text { Durchführung }\end{array}$ \\
\hline $\begin{array}{l}\text { Czerny } \\
1848\end{array}$ & first movement & & $\begin{array}{l}\text { principal / middle subject, } \\
\text { final melody }\end{array}$ & $\begin{array}{l}\text { second section: } \\
\text { development }\end{array}$ \\
\hline $\begin{array}{l}\text { Marx } \\
1845\end{array}$ & Sonatenform & $\begin{array}{l}\text { ternary: erster, zweiter, } \\
\text { dritter Theil }\end{array}$ & $\begin{array}{l}\text { Hauptsatz / Hauptpartie, } \\
\text { Seitensatz / Seitenpartie, } \\
\text { Gang, Schlusssatz }\end{array}$ & $\begin{array}{l}\text { sections: Durcharbeitung, } \\
\text { Reprise; connecting } \\
\text { section: Zwischensatz }\end{array}$ \\
\hline $\begin{array}{l}\text { Lobe } \\
1850\end{array}$ & erstes Allegro & $\begin{array}{l}\text { ternary: erster / zweiter } \\
\text { Theil, Repetition }\end{array}$ & $\begin{array}{l}\text { Themagruppe, Gesang- } \\
\text { gruppe, Schlussgruppe }\end{array}$ & $\begin{array}{l}\text { second section: } \\
\text { Mittelsatzgruppe; } \\
\text { third section: Repetition }\end{array}$ \\
\hline
\end{tabular}

Table 1: Comparison of sonata terminology in writings of European authors, 1793-1850

65 The referenced treatises indicated by the names of authors and years of their first publications are: Heinrich Christoph Koch, Versuch einer Anleitung zur Composition, Vol. 3, Leipzig 1793; Francesco Galeazzi, Elementi teoricopratici di musica, Vol. 2, part 4, Rome 1796; Augustus Frederic Kollmann, An Essay on Practical Musical Composition, London 1799; Jérôme-Joseph de Momigny, Cours complet d'harmonie et de composition, Paris 1806; Anton Reicha, Traité de la mélodie, Paris 1814; id., Traité de haute composition musicale, Paris 1824; Heinrich Birnbach, »Über die verschiedene Form grösserer Instrumentaltonstücke aller Art und deren Bearbeitung«, Berlin 1827; Carl Czerny, translator's appendix to Reicha's Vollständiges Lehrbuch der musikalischen Composition, Vol. 1, Vienna 1832; id., School of Practical Composition, Vol. 1, London 1848; Adolf Bernhard Marx, Die Lehre von der musikalischen Komposition, Vol. 3, Leipzig 1845; Johann Christian Lobe, Lehrbuch der musikalischen Komposition, Leipzig 1850. See the bibliography for detailed references. 


\subsubsection{EUROPEAN AND NORTH AMERICAN CONCEPTS}

Johann Mattheson's approach to transfer structural categories of rhetoric to musical phenomena, condensed in his term Klangrede, already included a differentiation between the binary and ternary design of movements - or forma bipartita, as found in suite movements or arias, as opposed to the forma tripartita of sonata or symphony movements. This terminology was adopted by Heinrich Christoph Koch for his conception of interpunctische Form, which may be considered the first notable theoretical manifestation of sonata formreferred to as erstes Allegro - , and was developed to a means of construction of sonata movements in the third volume of his Versuch einer Anleitung zur Composition (1793). In Koch, the first movement of a symphony or sonata generally features a binary, yet tripartite, formal design, with its erster Theyl (first subdivision) comprising a single Periode (basic unit of melodic development), moving away from the tonic key; after that, the zweyter Theyl comprises two Perioden, the second of which returns to the tonic. ${ }^{66}$ Koch's perception of sonata form was essentially derived from the tonal plan of a composition, being further structured by Grundabsätze (authentic cadences) and Quintabsätze (half cadences), and not primarily depended on the invention or development of themes.

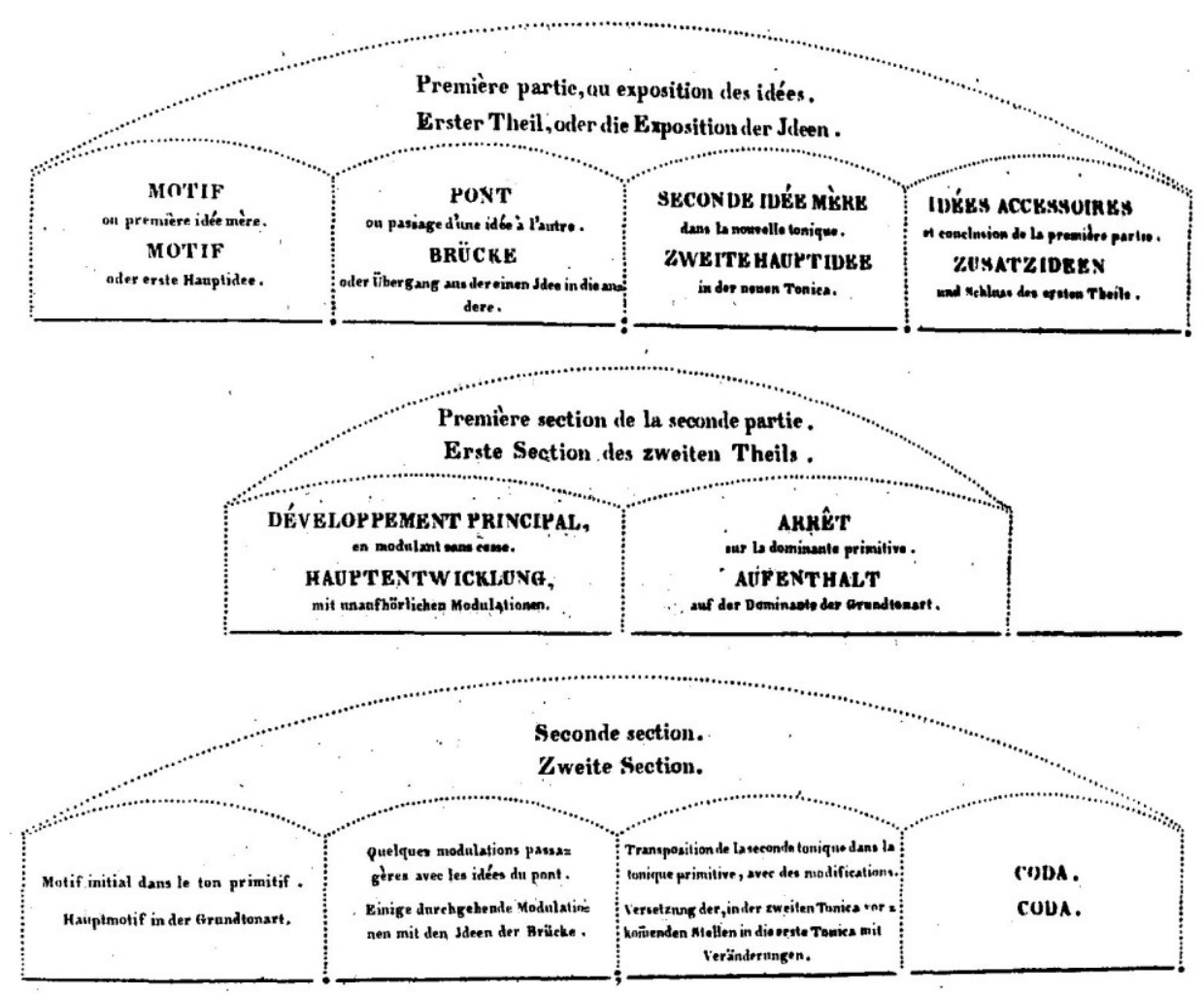

Figure 1.15: Reicha's scheme of sonata form (grande coupe binaire); Reicha 1824, p. 1165

66 Koch 1793, p. 304f.: »Das erste Allegro der Sinfonie [...] hat zwey Theile, die der Tonsetzer bald mit, bald aber auch ohne Wiederholung vortragen läßt. Der erste derselben [...] bestehet nur aus einem einzigen Hauptperioden«; ibid., p. 307: »Der zweyte Theil des ersten Allegro bestehet aus zwey Hauptperioden«; ibid., p. 311: »Der lezte Periode unsers ersten Allegro, der vorzüglich der Modulation in der Haupttonart gewidmet ist, fängt am gewöhnlichsten wieder mit dem Thema [...] an«; and ibid, p. 318: »Die Sonate nimmt alle Formen an, die schon vorhin bey der Sinfonie beschrieben worden sind.« 
In the composition manuals of most European scholars of the following decades, such as Francesco Galeazzi, Anton Reicha, and Carl Czerny, other binary conceptions of sonata form were outlined (see the table above for details on their terminology). Most of them were devised in dependence of a progression of keys to be applied to the succession of themes. Even though Jérôme-Joseph Momigny had already assumed three sections as subdivisions of an Allegro, Anton Reicha, one of the leading scholars of his day, still maintained the binary approach. In his Traité de haute composition musicale (1824), Reicha elaborated on his concept of grande coupe binaire (see figure 1.15), the première partie of which is supposed to introduce all the thematic ideas, ${ }^{67}$ comprising the idée mère (primary theme), a transitional passage named pont, and the seconde idée mère (secondary theme) ${ }^{68}$ The seconde partie, subdivided in a première and seconde section in analogy to Koch's zweiter Theyl, is then dedicated to the further development of the themes, as well as the recapitulation of both idées mères. In contrast to Koch, Reicha's formal scheme already included a solid description of thematic dualism. In turn, Carl Czerny, who in the first instance appeared as the German translator of Reicha's treatises, was clearly influenced by the latter's ideas in developing his own theories of sonata form. In the supplementary chapter to the first volume of his translation (»Über die Formen und den Bau jedes Tonstückes«/»On the Forms and Architecture of Every Composition«), Czerny gave an overview of the most popular musical forms of his time, including sonata form as »the most important [of all forms], because most of the other forms may be included in it $\ll{ }^{69} \mathrm{He}$ then provided a detailed description of every movement of a sonata, still assuming a binary subdivision for the first movement. ${ }^{70}$ Czerny was to specify his views later in his Schule der praktischen Tonsetzkunst, Op. 600 (1848), translated and distributed under the title School of Composition, which turned out to be immensely influential, prompting Charles Rosen to state: »Except for a few small and unimportant details, sonata form will be for all eternity what Czerny said it was. $\ll^{71}$

\section{Ternary Sonata Form}

The first substantial theoretical foundation of ternary sonata form arose in Heinrich Birnbach's extended article »Über die verschiedene Form grösserer Instrumentaltonstücke aller Art« (1827-28), introducing the term Hauptform for the first movement of sonata cycles. ${ }^{72}$ In Birnbach, as well as in other $19^{\text {th }}$-century German scholarship, a paradigm change in the models employed for sonata composition can be observed, now

67 Reicha defines the grande coupe binaire alongside with the alternate concept of grande coupe ternaire, a less complex structure which might be conceived as an extended three-part song form (small ternary). Czerny, after previously translating the coupes of Reicha's Traité de la mélodie (1814) as >Umkreis` or >Umfang^ (>circle`), later refers to the grande coupe binaire as »grosser zweiteiliger Rahmen« in his translation of the Traité de haute composition musicale; see Reicha 1824, p. $1158 \mathrm{ff}$.

68 Ibid., p. 1159: »La première partie sert à l'exposition des idées inventées. La seconde partie se subdivisé en deux sections dont la première sert au développement des idées, et la seconde à leur transposition."

69 Czerny 1832, p. 317: »Die Sonaten Form ist unter allen die wichtigste, weil sie nicht nur alle übrigen Gattungen in sich einschließen kann, sondern auch fast allen Jnstrumental - ja sogar manchen Vocal Compositionen als Vorbild dienen kann «; translation given according to Czerny 1848, p. 33.

70 Ibid.: »Die Sonate besteht gewöhnlich aus 4 oder 5 von einander unabhängigen Sätzen. 1ter Satz, bestehend aus einem sich meistens wiederhohlenden [...] ersten Theil und aus einem (längeren), eine kunstmässige und mannigfache Durchführung gestattenden zweiten Theil.« (italics original)

71 Rosen 1980, p. 365.

72 See Birnbach 1827, p. 270, section »Hauptform eines grössern Tonstücks«. 
paying greater attention to the design of thematic subjects and their relation, eventually leading to one of the most influential descriptions of sonata form - that of Adolf Bernhard Marx, which would show a significant effect on most of the successive theories of musical form during the $19^{\text {th }}$ and $20^{\text {th }}$ centuries. Marx, in the third volume of his Lehre von der musikalischen Komposition (1845), incorporated a full description of how a sonata's first movement should be structured, responding not to Czerny but rather preserving Birnbach's ternary approach. ${ }^{73}$ Moreover, Marx developed a refined syntax theory which also was largely absorbed by later authors, based on phrase-building clauses such as Satz (any short or extended melodic phrase), Periode (the combination of an opening Vordersatz and closing Nachsatz to form a thematic subject, bordered by cadences), and Gang (connecting passages without substantial thematic content).

Among the various definitions throughout the first half of the $19^{\text {th }}$ century, virtually all scholars and theorists primarily described the sonata, or symphony, as a multi-movement cyclic genre rather than a specific design of musical form (see also the statements cited at the outset of part 1). This changed when Marx introduced the term Sonatenform as a formal archetype clearly attached to its generic context, and being further differentiated in the early $20^{\text {th }}$ century by Hermann Grabner's and Guido Adler's denominations Sonatenhauptsatzform and Sonatensatzform. Ternary sonata form, according to Marx and his successors, essentially required an independent middle section in order to elaborate on the material of first section, and to be properly distinguished from rondo form. Also, Marx claimed that the first section should contain a modulating transition, connecting its first to its second subject. Yet the designations of the three sections, habitually referred to as exposition, development (derived from Reicha's développement), and recapitulation, were established as an invariable English-language coupling only in $1895,{ }^{74}$ whereas its German equivalents (Exposition, Durchführung, and Reprise) did not evolve in this particular meaning until the early $20^{\text {th }}$ century. ${ }^{75}$ Even then, this terminological trinity seemed not absolutely convincing-for the theme-processing and modulating middle section, Arnold Schoenberg has suggested, in analogy to the German Durchführung, the term elaboration ${ }^{76}$ and the third section may also be referred to, in derivation from French or Italian music theory, as re-exposition or counter-exposition, as opposed to the terms ripresa or Reprise, meaning only >repetition< which does not accurately describe what typically happens in that section.

\section{Tendencies of the $20^{\text {th }}$ Century}

German-speaking music theory of the late $19^{\text {th }}$ century largely adopted Marx's terminology, with the notable exception of Hugo Riemann who, in his Katechismus der Kompositionslehre (1889), referred to sonata form

73 Marx 1845, p. 221, discusses whether to stick to the binary concept with an disambiguation between Durcharbeitung and Reprise, but ends up accepting both passages as individual parts, thus relying on a fully developed ternary outline.

74 Prout 1895, p. 132: »The modern [sonata form] becomes a modified ternary, the three parts being (I.) the exposition, or the announcing of the first and second subjects; (II.) the development of these subjects [...]; (III.) the recapitulation of the first and second subjects.«

75 The coupling of the three German terms first appears in Alfred Richter's Die Lehre von der Form in der Musik (1904) and is fully established in Hugo Leichtentritt's Musikalische Formenlehre (1911).

76 Schoenberg 1967, p. 200: »The customary term, 〉developmentく, for this section, is a misnomer. It suggests germination and growth which rarely occur. The thematic elaboration and modulatory >working out $<$ (Durchführung) [...] seldom lead to the >development $<$ of anything new.« 
as >die vierte Form $`$ ( $>$ the fourth form $<$ ) without using a particular denomination. ${ }^{77}$ In the newly evolving textbook genre of Formenlehre, theorists such as Ludwig Bussler and Salomon Jadassohn described the sonata in interdependency or derivation from the sonatina, a perspective also prefigured in Marx's Kompositionslehre. Further significant contributions to scholarship in musical form, dedicated to the theory of the sonata as a first-movement construction and cyclic genre, include Ebenezer Prout's extensive volume $A p$ plied Forms (1895), published as a follow-up to his general introduction Musical Form (1893). Prout deduced the genesis of multi-movement sonata form, as opposed to the Baroque single-movement outline, from the compositions of Carl Philipp Emanuel Bach. In three chapters, each dedicated to one of the main sections of sonata form, Prout outlined a large body of standard variants and possible deviations, explored in greater detail as any of his predecessors did, and chiefly exemplified by the music of Haydn and Beethoven. He also introduced a series of special options, such as tonal variants of the secondary theme's recapitulation (see chapter 3.2.0). On the contrary, Vincent d'Indy, in the second volume of his Cours de composition musicale (1909), drew on the dramatic and architectonic conceptions of French scholars of the $19^{\text {th }}$ century, particularly focusing on cyclicity, thematic relation, and symmetry of formal sections in his analyses of Beethoven's piano sonatas and string quartets. With his choice of considered repertoire, d'Indy went beyond most other approaches of his time, examining sonatas by German and Russian composers of the $19^{\text {th }}$ century, as well as recently composed music by Camille Saint-Saëns, Gabriel Fauré, and himself, exclusively dedicating a chapter to the discussion of cyclic multi-movement forms. ${ }^{78}$ By this means, d'Indy's Cours is much more than its title suggests as it transcends the demands of a composition manual, like it would have been understood in the $19^{\text {th }}$ century, towards modern analytical literature.

Other writings of the early $20^{\text {th }}$ century have emphasised the functional logic of musical form and conceived the development of structural archetypes as a kind of organic development, evolving from the simple to the more complicated forms, as apparent in the writings of Hugo Riemann, Hugo Leichtentritt, and other German authors. While Heinrich Schenker's theory of musical form, as delineated in Der freie Satz (1935), had focused on »linear-contrapuntal views of the sonata as the unfolding of a fundamental structure (Ursatz) «, ${ }^{79}$ the successive treatises and textbooks significantly concentrated on the syntax and elaboration of themes and motives. In the writings of the Viennese scholars Erwin Ratz and Arnold Schoenberg, ${ }^{80}$ the principle of >entwickelnde Variation ( >developing variation $८$ ) is proclaimed as a predominant paradigm of syntactical and formal construction. The approach of the theorists of the Second Viennese School—and particularly to sonata form as it is presented in Schoenberg's Fundamentals of Musical Composition (1967)—was

77 However, in the revised and extended version of this treatise, published under the title Grosse Kompositionslehre (1902), Riemann eventually adopts the term Sonatenform.

78 A striking deficiency of d'Indy's Cours is that he omits stwo-dimensional sonata form cyclic sonata, and his engagement with Liszt is confined to the symphonic poems.

79 Hepokoski and Darcy 2006, p. 5, paraphrasing from Schenker's Der freie Satz, Vienna 1935, transl. by Ernst Oster as Free Composition, New York 1979.

80 Ratz's Einführung in die musikalische Formenlehre (1951) and Schoenberg's Fundamentals of Musical Composition (posthumously published 1967) figure among the most notable publications on musical form of the mid-20 $0^{\text {th }}$ century. Other than its title suggests, Schoenberg's book is not a compositional treatise but, following Ratz's Formenlehre, a comprehensive theory of musical form directed towards the analysis of Classical music. 
essentially based on the idea that musical development arises from small motivic cells through processes of growth, variation, and derivation, determining the continuous evolvement of the successive from the previous. Later German approaches, such as the Formenlehre textbooks by Günter Altmann, Lemacher and Schroeder, and Clemens Kühn, ${ }^{81}$ continued Ratz's and Schoenberg's tradition, further differentiating between >Reihungsformen $<$ ( $>$ chain forms $\triangleleft$ ) such as the small binary and ternary, variation, and rondo, and $>$ Entwicklungsformen $\triangleleft$ ( $>$ developing forms $<$ ), including fugue and sonata forms.

Under the influence of European scholars who emigrated to the United States, as did Schoenberg and Schenker, North American theorists of the second half of the $20^{\text {th }}$ century have tended to merge different embodiments and generic contexts of sonata form into terminological containers such as the >sonata idea< or >sonata principle<, the latter being »one of the most deeply rooted [methodologies and axioms] within English-language scholarship «. ${ }^{82}$ As it captures both formal and harmonic contexts, the term $>$ sonata principle $<$ is capable of simultaneously describing the thematic structure of a movement and its internal dramaturgy of modulation. The analytical writings and systematisations published during the 1950s and 1960s, namely those of Donald Francis Tovey, Leon Stein, Wallace Berry, and Charles Rosen, ${ }^{83}$ are no longer pure textbooks of musical form, but elaborated analytical prose, mainly focusing on Viennese Classicism, while a number of publications since approx. 1960 introduced a more critical view towards the history of sonata form. While German Formenlehre largely insisted on its pedagogical motivation, rarely striving for relevance in research, American publications now aimed to include empirical concerns for an evidence-based evaluation of compositions and theories, as seen in the writings of Leonard Ratner and William Newman. ${ }^{84}$ The latter author pioneered with his hitherto unparalleled three-volume history of sonata composition which also incorporated trends around the turn of the $20^{\text {th }}$ century. In the succession of Fred Lerdahl's and Ray Jackendoff's influential Generative Theory of Tonal Music (1983) and their introduction of the term >grouping structure`, American music theory has again contributed to the perception and analysis of sonata form in two significant publications: William Caplin's Classical Form. A Theory of Formal Functions (1998), enhancing the terminological domain of Schoenberg and Ratz for a versatile contemporary application, and James Hepokoski's and Warren Darcy's Elements of Sonata Theory (2006), which introduces an elaborate classification of sonata forms in five types, as well as a newly devised terminology of subdivisions, cadential events, and functional elements in the course of sonata movements (for details and perspectives see chapter $\underline{3.0}$ and the successive analyses of Medtner's sonatas, Opp. 11 and 22).

81 Günter Altmann, Musikalische Formenlehre, Berlin 1960; Heinrich Lemacher and Hermann Schroeder, Formenlehre der Musik, Cologne 1962; and Clemens Kühn, Formenlehre der Musik, Kassel 1987.

82 Hepokoski 2002, p. 92, providing a critical reading of several approaches to the >sonata principle<.

83 Donald Francis Tovey, Forms of Music, London 1956; Leon Stein, Structure and Style, Princeton 1962; Wallace Berry, Form in Music, Englewood Cliffs 1966; Charles Rosen, The Classical Style, New York 1971.

84 William Newman, A History of the Sonata Idea, Vols. 1-3, New York 1959-69 (including a rough account of Medtner's piano sonatas in Newman 1969, pp. $721 \mathrm{ff}$.); and Leonard Ratner, Classic Music: Expression, Form, and Style, New York 1980. 


\subsubsection{RUSSIAN MUSIC THEORY}

After multi-movement sonata cycles had entered Russian piano and chamber music around the middle of the $19^{\text {th }}$ century, music theory started to reflect the genre with a delay of some decades. The demand for textbooks of musical form only existed since the foundation of the Saint Petersburg and Moscow Conservatories in the $1860 \mathrm{~s}$, and this was, in the first place, met by the adaptation and translation of Western treatises. Influential theorists in Russia during that time were Adolf Bernhard Marx, Hugo Riemann, Ludwig Bussler, Ebenezer Prout, and later also Ernst Kurth, all of who were widely absorbed by Russian translations of their respective publication. Meanwhile, writings of Russian scholars mainly focused on harmony and instrumentation, the earliest publications being the textbooks of Tchaikovsky and Rimsky-Korsakov. ${ }^{85}$ These had long-lasting success despite being designed as guidelines to traditional harmony, and were firmly rooted in the pedagogical traditions of the $19^{\text {th }}$ century rather than exploring contemporary harmonic innovation. On the other hand, instruction in musical form was part of compositional treatises, corresponding to a general tendency in the history of music theory - and the only textbook of musical form available in Russia for decades was comprised in a composition manual by the Bohemian Josef Hunke, ${ }^{86}$ whereas determined Formenlehre publications only appeared around the turn of the century. Thus, musical form was, during the time considered, taught with a focus on compositional technique rather than analysis of completed works - and this paradigm still remained effective after the much-noticed translations of Prout's Musical Form and Applied Forms had appeared in Russia (1896; c. 1910). ${ }^{87}$ In the framework of these developments, a focal point of the following considerations will be the possible influences Medtner gained from the theoretical thought of his Muscovite teachers, contemporaries, and fellow composers.

A short glance at the first independent treatises on musical form published by Russian scholars reveals their close orientation towards Western paradigms, as apparent in Anton Arensky's compact Rukovodstvo $k$ izucheniyu form instrumental'noy $i$ vokal'noy muziki (Guide to the Study of Form of Instrumental and Vocal Music, 1894), which discussed sonata form only very briefly, and departed from the ideal-typical model without mentioning special cases. Arensky's book at least deserves attention for having introduced the terminological trinity to be used henceforth in Russian theory for the analysis of sonata form, the stopmost of musical forms ${ }^{88}$ - ékspozitsiya, razrabotka, and repriza. Similarly, Viktor Belyayev's Kratkoe izlozhenie ucheniya o kontrapunkte i ucheniya o muzikal'nïk formakh (Short Account of the Doctrines of Counterpoint

85 Pëtr Tchaikovsky, Rukovodstvo k prakticheskomu izucheniyu garmonii (Guide to the Practical Study of Harmony), Moscow 1872; and Nikolai Rimsky-Korsakov, Prakticheskiy uchebnik garmonii (Practical Textbook of Harmony), Saint Petersburg 1886. These were followed by Anton Arensky's Kratkoe rukovodstvo k prakticheskomu izucheniyu garmonii (Short Guide to Practical Harmony), Moscow 1891; Georgy Conus's Posobie $k$ prakticheskomu izucheniyu garmonii (Manual to the Practical Study of Harmony), Moscow 1894; and Mikhail Ippolitov-Ivanov's Uchenie ob akkordakh (Doctrine of the Chords), Moscow 1897.

86 Josef Hunke [Gunke], Polnoe rukovodstvo k sochineniyu muzïki (Complete Guide to Musical Composition), Moscow 1863; originally published in Russian.

87 For a more detailed discussion of the influence of translated Western textbooks and the general orientation of early Russian treatises on musical form, see Bitzan 2018.

88 Arensky 1894, p. 67: „Vïsshaya iz instrumental'nïkh form est' forma sonatnogo allegro; ona sostoit iz sleduyushchikh trekh chastey: 1) èkspozitsiya (izlozhenie), 2) razrabotka, 3) repriza (povtorenie). « The author probably borrowed the term >exposition<, which was not established in Russian theory so far, from Riemann's writings. 
and Musical Forms, 1915), only gave a brief description of sonata form, at least differentiating between the nomenclature of formal sections and thematic subjects. Both treatises exclusively resort to Beethoven's music for exemplifying aspects of sonata form.

\section{Taneyev's View of Sonata Form}

The institutional foundation of musical form as a theoretical subject was essentially shaped through the teaching of Nikolai Hubert who led a class in >Form and Fugue $<$ at the Moscow Conservatory, advancing to the institution's director after the death of Nikolai Rubinstein in 1881. After Hubert deceased in 1888, the subject was not formally taught for a couple of years until Sergei Taneyev filled the vacancy, having himself studied with Hubert, and introduced contemporary theoretical thoughts by Riemann and Bussler as part of his teaching. ${ }^{89} \mathrm{He}$ also appeared as translator of Bussler's Musikalische Formenlehre (1878, two Russian versions published in 1883-84), ${ }^{90}$ while his own writings focused on polyphony and counterpoint. ${ }^{91}$ However, Taneyev had been working on a treatise of musical form, based on the teaching materials for his newly established class in musical form, taught at the Conservatory during 1897-1905. Yet his notes were left incomplete during his lifetime and later compiled and edited by Fëdor Arzamanov in a publication titled $S$. $I$. Taneyev: prepodavatel' kursa muzikal'nykh form (Taneyev: Teacher of a Class in Musical Form, 1963). This reveals that Taneyev, as a professor, had not only shaped a whole generation of younger composers with regard to their studies in counterpoint, but also on the field of musical form. As for his attitude to sonata form, Ellon Carpenter summarised Taneyev's position as follows:

»Had Taneev written his proposed book on form, he might be known today not only as a master of polyphony but also as a master of form. [...] Taneev emphasised particularly the sonata form, which, in his view, embodied all the elements contributing to the artistic unity of a successful musical composition-thematic transformation and development, a reliance on tonality and a tonal scheme, and a logical structure. The sonata form provided an important compositional model, Taneev felt, primarily because of the delicate interrelation between thematic content and tonality inherent to the form. $\ll^{92}$

As seen in this evaluation, the sonata, as genre and musical form, appears to have played an equally central role for the theorist and for the composer Taneyev, a notion further confirmed by statements of Arzamanov and Vladimir Protopopov: »The degree of technical maturity of a composer is verified best of all by the ability to have command of the sonata form«, and »Sonata form was of elementary importance for Taneyev's

89 All information on curricula of the Moscow Conservatory is given according to Kyuregyan 2013, p. 187f.

90 The subdivisions of the sonata exposition were, in probable derivation from Marx, first outlined in the translations of Bussler's Formenlehre, titled glavnaya partiya (primary theme zone), pobochnaya partiya (secondary theme zone), and zaklyuchitel'naya partiya (closing zone). This terminology was almost invariably adopted by Russian scholarship until today.

91 Sergei Taneyev, Podvizhnoy kontrapunkt strogogo pis'ma (Convertible Counterpoint in the Strict Style), Leipzig 1909; and Uchenie o kanone (Doctrine of the Canon), posthumously published, Moscow 1929. As these textbooks were developed from a historiographic point of view, mostly concerned with Renaissance and Baroque contrapuntal style, their influence on Taneyev's students such as Scriabin, Rachmaninov, and Medtner is hard to discern in detail and has been subject to speculation; see also chapter 2.3.

92 Carpenter in McQuere 1983, p. 265. See also Carpenter 1988, p. 428ff. 
musical creation «. ${ }^{93}$ In Arzamanov's account of Taneyev's teaching, the one-year course first addressed musical motives and thematic structures, the period, and the small binary and ternary, before tackling the essentials of sonata form. Musical examples are almost without exception taken from Beethoven's piano sonatas and string quartets. The chapter on sonata form, occupying almost half of the publication, comprises extensive reflections of the role of large-scale harmonic progression (here referred to as Teoriya modulatsionnogo plana $)^{94}$ and includes graphical visualisations of modulation in Beethoven's music. Taneyev's teaching has obviously devoted much time to developmental techniques, as visible in a symmetrical diagram highlighting the modulation scheme of the middle section of sonata form (Khodoobraznie predlozheniya, in analogy to 'gang-like sections`; see figure 1.16). ${ }^{95}$ The following passage, titled »Voprosy skvoznogo razvitiya « (»Questions of continuous development«), includes thoughts on monothematism and thematic unity within a sonata movement, employed in order to achieve what Taneyev calls bolshaya svyazannost' (great coherence). ${ }^{96}$ By means of these elaborations, Taneyev introduced autonomous analytical elements within Russian discourse on musical form for the first time.

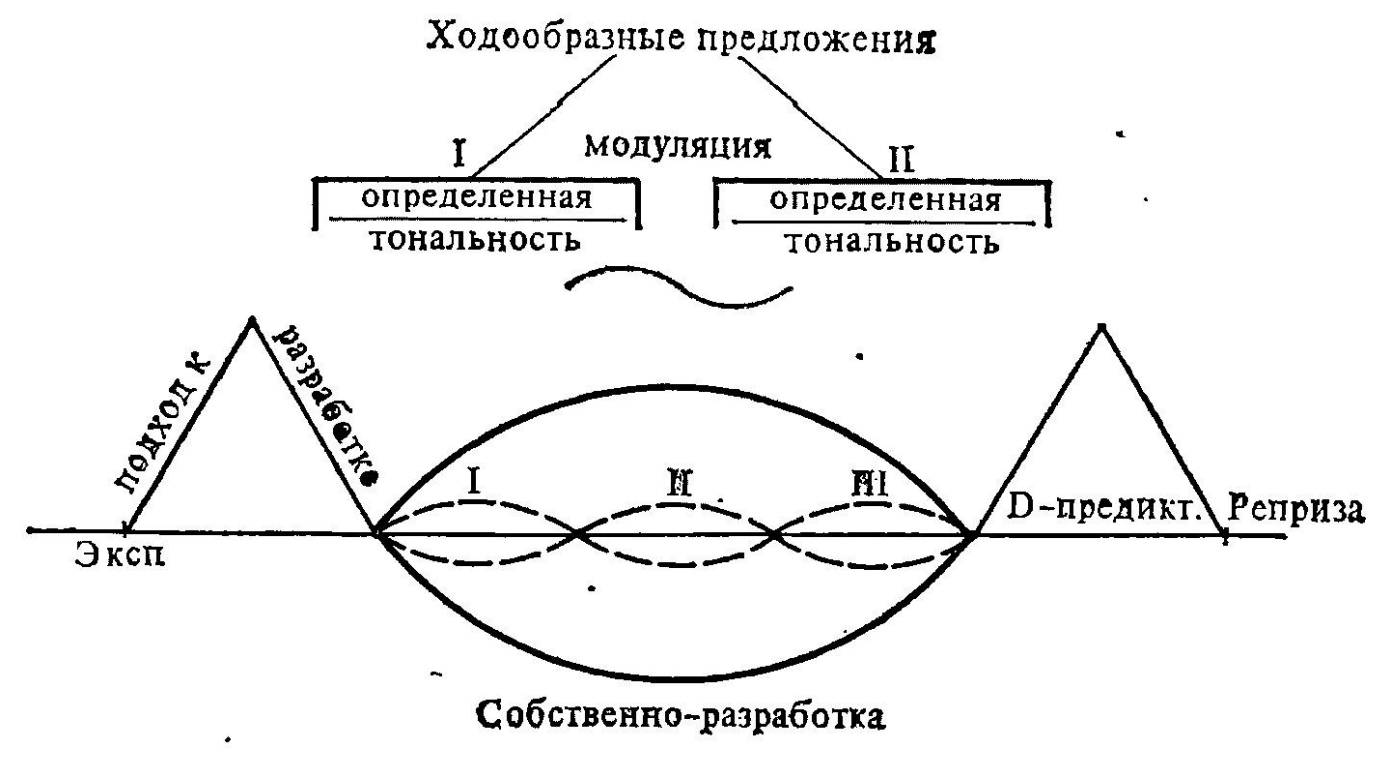

Figure 1.16: Taneyev's scheme of the development section (Khodoobraznïe predlozheniya); Arzamanov 1963, p. 49

93 Fëdor Arzamanov, Zavetï S. Taneeva, Moscow 1956, p. 36, quoted here according to Carpenter in McQuere 1983, p. 362; Protopopov 2010, p. 184: »Sonatnaya forma dlya Sergeya Ivanovicha Taneeva [...] bïla osnovnoy v muzikal'nom tvorchestve«. The memories of Hartmann 1956, p. 14f., shed light on Taneyev's understanding and teaching of sonata form, including his perception of the sonata movement as a >dual (bipartite) structure.

94 See Arzamanov 1963, p. 66f.; the common German term is used in derivation from Arnold Schoenberg's Structural Functions of Harmony (1954, transl. as Die formbildenden Tendenzen der Harmonie, 1957). It was also applied by August Halm for the analysis of Bruckner's symphonies.

95 Ibid., p. 49. The term khod, indicating a connecting passage, is obviously used in analogy to Marx's formal category of Gang, whereas D-predikt refers to the retransition to the recapitulation section, frequently based on a dominant pedal. See also Carpenter 1988, p. 441ff., for more remarks on Taneyev's modulatory diagrams. Moreover, Belyayev 1927, in a short contribution to the Beethoven centenary, elaborates on Taneyev's analytical thought on modulation in some movements from Beethoven's piano sonatas. However, the examples discussed here are limited to slow movements and rondos and do not include sonata forms.

96 Arzamanov 1963, p. 98ff. 


\section{Soviet Conceptions}

After the Russian revolution, the curricula of the Moscow Conservatory included classes dedicated to traditional musical form, taught by Georgy Catoire and Leonid Polovinkin, as well as metrotechtonic analysis after Georgy Conus, and theory of lad rhythm after Boleslav Yavorsky. ${ }^{97}$ Catoire, who occupied a particular influential position within early Soviet music theory, ${ }^{98}$ published one of the most widely recognised harmony treatises of his time, Teoreticheskiy kurs garmonii (Theoretical Course of Harmony, 1924), the merit of which is to have introduced Riemann's conception of functional harmony in Russia. ${ }^{99}$ In succession, Catoire was unable to complete his second theoretical work, Muzikal'naya forma (Musical Form), before his death in 1926, and it was posthumously edited and published in two volumes (1936-37) by his pupils Dmitry Kabalevsky, Lev Mazel, and Polovinkin. This book is considered the most comprehensive description of musical forms by a Russian scholar, and Catoire's significance for the orientation of the subject, as it was taught at the Moscow Conservatory during the successive decades, was widely accepted-even if he attained a rather retrospective view on genres and formal stereotypes of the $18^{\text {th }}$ and $19^{\text {th }}$ centuries, drawing on Arensky's and Taneyev's achievements. Interestingly, Catoire related to temporal symmetry in sonata form in the second volume of this treatise, arguing that the appearance of a sonata movement's secondary theme at the culmination of its development section is indicative of a forthcoming >mirror recapitulation` (>zerkal'naya repriza $),{ }^{100}$ but referring only to Beethoven's piano sonatas and not Medtner's. Catoire also briefly dealt with non-tonic recapitulations of secondary themes as seen in some of Beethoven's major-mode sonata movements, ${ }^{101}$ a feature also evident in some of Medtner's piano sonatas (see chapters 3.2.0 and 3.3 .4 for detailed elaboration on tonal symmetry of thirds).

Another publication which may hardly be overestimated in its relevance for the further development of Soviet Russia's theoretical thought is the first volume of Boris Asafiev's book Muzikal'naya forma kak protsess (Musical Form as a Process, 1930). Even if Asafiev's influential theory of >intonation< was unfolded only in its second volume (1947), his elaboration on traditional forms and genres are already permeated by this concept, understood as a general means of providing sense to tonal relations in music. Instead of presenting a textbook or composition manual, as his predecessors had done, Asafiev approached his subject from an aesthetic and philosophical point of view, and derived his terminology partly from that of Ernst Kurth. While denying the abstractive potential of formal models, the author at the same time declared sonata

97 See Kyuregyan 2013, p. 189.

98 Carpenter 1983, p. 274: »Catoire made such fundamental contributions to Soviet music theory that a student of his [Sergei Evseyev] later commented, >Practically no new book on questions of music theory manages without mention of and reference to works of Catoire««.

99 See Carpenter in McQuere 1983, p. 274, and Bolshakova 2008, p. 15.

100 Catoire 1936, p. 48f.: »V ètikh sluchayakh pobochnaya partiya provoditsya obïchno v kontse razrabotki, predstavlyaya ee kul'minatsiyu, chto yavlyaetsya v svoyu ochered' priblizheniem k tak nazïvaemoy >zerkal'noy reprize<, t. e. takoy reprize, v kotoroy snachala provoditsya pobochnaya partiya, a zatem glavnaya«. For a more detailed account of Catoire's view of sonata form, see Carpenter in McQuere 1983, p. 292.

101 Catoire 1936, ibid.: »U Betkhovena èto imeet mesto chashche vsego v tekh sluchayakh, kogda v èkspozitsii pobochnaya partiya davalas' ne v tonal'nosti dominantï i ne v parallel'nom mazhore. Tak, esli v èkspozitsii mazhornoy sonatï pobochnaya partiya bïla $\mathrm{v}$ tonal'nosti III mazhornoy stupeni, $v$ reprize ona mozhet nachat'sya $\mathrm{v}$ VI mazhornoy stupeni (op. 31 No. 1, op. 53).« 
form to be the highest possible expression in music, coining the dramaturgical processuality of its parts as a succession of »impulse, disorder, and reinstatement of balance «. ${ }^{102}$ Asafiev was much concerned with symmetrical aspects of musical form, even if he did not transfer his corresponding thoughts into a theoretical system. This was achieved by another contemporary scholar, Georgy Conus (also spelled Konyus), whose theory of metrotechtonism had already had considerable impact on Aleksandr Scriabin's view of musical form, and gained increasing relevance in Russia during the 1920s and 1930s. Metrotechtonism was, at that time, deemed a revolutionary technique of examining musical form, and developed to one of the leading academic paradigms of analysis. Just like Catoire and Medtner, Conus had studied with Arensky and Taneyev, but soon departed from their doctrine to develop his idiosyncratic method which was fully elaborated by 1919 and first published in $1924,{ }^{103}$ even if the author never wrote a proper guide or textbook to it. Metrotechtonic analysis strongly relies on counting measures, and its numeric graphs are obsessively focused on the correlating length and equal proportions of opposite sections, essentially incorporating ideas of temporal symmetry - even if these are not precisely termed. For a metrotechtonic approach to Medtner's G minor Sonata, Op. 22 (c. 1901-10), see chapter 3.3.4.

Before leaving behind the further progression of Russian music theory, with its development after 1945 not appearing directly relevant for the scope of this study, we will briefly consider Igor Sposobin's textbook Muzikal'naya forma (first published in 1947). This publication gained widespread recognition throughout the Soviet Union and the whole Communist world, and still remains in use in its multiple successive editions and translations until today. Sposobin provided a comprehensive account of sonata form in a chapter of more than thirty pages, unifying the characteristics of most of the earlier treatises. After his predecessors had based their discussions of formal archetypes nearly exclusively on the music of the Viennese Classics, Sposobin now introduced a large number of examples by Russian composers of the $19^{\text {th }}$ and early-20 $0^{\text {th }}$ centuries, also including a passage from Medtner's abovementioned G minor Sonata, Op. 22: In the course of discussing different types of musical opening (»tipi izlozheniya vo vstupleniyakh«), Sposobin quoted the sonata's first measures to exemplify a >medium< type of sonata introduction »with a more fragmented appearance of short elements «. ${ }^{104}$

In view of the large number of Russian piano sonatas composed between 1900-20, including a series of innovative and pioneering developments, one might expect contemporary music theory to relate to these peculiarities after due time; yet this is not the case. Compared to the significant contributions on the fields of single-movement form and fantasy-sonata, as seen in the ouvres of Scriabin and Medtner, Russian Formenlehre proved reluctant to reflect these novelties, while still adhering to the traditional paradigm of sonata form as part of a multi-movement cycle; and neither were the Lisztian stwo-dimensional sonata form sonate cyclique discussed in early Soviet scholarship, despite the relevance of their aftermath in Russian

102 Asafiev $1930^{\mathrm{b}}$, p. 127.

103 See Carpenter in McQuere 1983, p. 293. Conus published metrotechtonic analyses of some of Beethoven's sonatas in his following books and essays: Kritika traditsionnoy teorii v oblasti muzikal'noy formï, Moscow 1932; and Nauchnoe obosnovanie muzikal'nogo sintaksisa: $k$ izucheniyu voprosa, Moscow 1935. A number of Conus's earlier texts and analyses are published in Golovinsky 1965, pp. 69-109. For thoughts on the general usefulness and applicability of metrotechtonic analysis, see Carpenter 1983, p. 308f., and Wehrmeyer 1991, pp. 44-62.

104 Sposobin 1947, p. 42: »Sredinnïy [tip], s bolee otrïvochnïm provedeniem kratkikh èlementov«. See also ibid., p. 219. 
piano, chamber, and orchestral music. Instead, a more holistic method of musical analysis was enforced at the Moscow Conservatory after World War II, abandoning the term muzikal'naya forma in favour of integrative classes in analiz muzïkal'nykh proizvedeniy (analysis of musical works); this also appeared as the title of several forthcoming textbooks. Under the guidance of scholars such as Vladimir Protopopov and Yuri Kholopov, Russian theory of musical form extended its scope towards $20^{\text {th }}$-century music and the history of European music scholarship, combining pedagogical motivation with an increasing interest in scientific approaches and recent Western concepts in musicology and music theory. This tendency resulted in the reinstatement of muzikal'naya forma as an academic subject at the Moscow Conservatory, as initiated by Kholopov and his followers.

\section{The Idea of Sonatnost'}

Much earlier than North American theorists came to the conclusion that >sonata form tive an expression, which led to the constitution of the term >sonata principle < during the 1960 s, Soviet music theory had come up with an idea which might well be considered as a conceptual equivalent: sonatnost', a term that would literally translate to something like >sonata-ness` (the state of a piece of music showing traits of sonata form) — or, in German, Sonatenhaftigkeit_, but more aptly parallels the integrative meaning of >sonata principle<. Asafiev seems to have introduced sonatnost' in the first volume of Musical Form as a Process (1930), where it is used in several places, at times along with variatsionnost', and most notably in a passage where he claims the generally fast tempo of a >sonata-allegro to be a precondition of contrasting thematic dualism in the course of the movement. ${ }^{105}$ The relevance of sonatnost' was to be proved by later Russian music theory, where it developed to a standard phrase to signify certain formal aspects of a piece of music, whether it be denominated a sonata or not. Since the term was used so widely and self-explanatory, today's theorists are not even likely to be capable of naming its origin-sonatnost' has clearly become an analytic commonplace. Yet the applicability of the term has been recently questioned as too vague, colloquial, and in need of further explanation what exactly is meant by its usage; Tatyana Kyuregyan even rejects to refer to it as a musical term. As an alternative, Sergei Lebedev has proposed to resort instead to the expressions $>$ sonatnïy printsip $<$ (the literal translation of $>$ sonata principle $<$ ), or $>$ forma $s$ chertami sonatnoy $<$ (an outline with traits of sonata form). ${ }^{106}$

105 Asafiev $1930^{\text {b }}$, p. 186 : $\gg$ From the fact that a sonata form is usually an allegro, and not a slower tempo, the organic unity of this formal concept and the tempo can be deduced: The contrasting thematic correlations resulting from the sonata principle can only be unterstood within the borders of a certain tempo [of performance], and otherwise they will not take effect « (my translation of: »V tom, chto sonatnoe allegro obïchno est' allegro, a ne medlennoe dvizhenie, proyavlyaetsya organicheskaya svyaz' dannogo vida formovaniya s tempom: vïzïvaemïe sonatnost'yu konstrastno-tematicheskie sootnosheniya vosprinimayutsya kak takovie $v$ granitsakh opredelennïkh skorostey. Inache oni raspilyayutsya $)$.

106 Lebedev is associate professor at the department of interdisciplinary studies in musicology at the Moscow Conservatory, with his research specialising in history of notation and musical terminology. I quote his suggestions from an exchange of emails of August 28, 2018, between Lebedev and my colleague Elena Chernova, to whom I am grateful for her support. 
Sonatnost' was also variously applied to Medtner's music, for instance in Oleg Sokolov's study O sonatnosti $v$ proizvedeniyakh Metnera (On the Sonata Principle in Medtner's Works, 1968), ${ }^{107}$ and is used as a means to exemplify sonata-ish outlines in compositions of other genres (see also chapter 2.1.2). Despite Medtner's obsession with sonata form and the exploration of its maximal variety, the concept underlying every of his individual approaches to traditional form can still be addressed as sonatnost', regardless of how far he departed from the ideal-typical model. ${ }^{108}$ Once he assigned the generic denomination >sonata< to one of his compositions, we can doubtlessly assume that the corresponding formal outline - be it a single-movement design, or a multi-movement cycle incorporating sonata form in one or several of its parts - makes distinct use of at least one of the principle's prefigurations in the domains of traditional syntax, harmony, modulation and large-scale harmonic progression, motivic development, or thematic dualism.

\subsubsection{SONATA Form AS NARRATIVE AND DRAMA}

As an alternative to the >official definition of sonata forms and sonata cycles by outlining their structural features - such as the proportions of their parts and subdivisions, succession of cadences, or thematic content-, these may also be viewed as representations of a basic narrative, as a realisation of an underlying story or discourse, which is transported through the music. Even if »music in itself [...] does not and cannot convey any fact or action, nor can it express the simplest conceptual thought $\ll,{ }^{109}$ its interpretation as a processual succession of signifiers, or semiotic entities, certainly can. As a possible means of superordinate hermeneutics, the relations between literary narrative and classic or romantic instrumental music $[\ldots]$ might draw on the study of plot structure or narrative syntax, as initiated by Russian Formalism «. ${ }^{110}$ In this sense, topic theory and narratological approaches in musicology have variously referred to musical forms as embodiments of storytelling, and sonatas may likewise be understood as charged with topical content, for instance in relation to epic literature or drama, taking over »not only the expression of sentiment but the narrative effect of dramatic action, of intrigue and resolution «. ${ }^{111}$ The dramaturgy of movements within a sonata

107 See Sokolov 1968 in Kuhn 2008 a , p. 161: »The principles of sonata form are not only manifest in Medtner's sonatas and concertos, but also in his skazki and lyric piano pieces.«

108 I would like to thank Nikola Komatović for his suggestions regarding the application of sonatnost', which helped me elaborate on and clarify these thoughts.

109 Stein 1962, p. 172.

110 Maus 1991, p. 1f., referring to Vladimir Propp's Morphology of the Folktale (1928). The author (ibid., p. 8ff.) introduces a narrative analysis of the $3^{\text {rd }}$ movement from Beethoven's E major Sonata, Op. 14 No. 1, including reference to Tovey and Schenker. Further basic reading on musical narrativity is provided by Robert Hatten, »On Narrativity in Music: Expressive Genres and Labels of Discourse in Beethoven«, in: Indiana Theory Review, Vol. 12 (1991), pp. 75-91, elaborating on more examples from Beethoven's piano sonatas and string quartets; Jerrold Levinson, »Music as Narrative and Music as Drama«, in: Mind \& Language, Vol. 19 (2004), pp. 428-444, addressing the $1^{\text {st }}$ movement of Schubert's A minor Sonata, D. 845; and Byron Almén / Robert Hatten, »Narrative Engagement with Twentieth-Century Music: Possibilities and Limit«, in: Michael Leslie Klein / Nicholas Reyland (eds.), Music and Narrative since 1900, Bloomington 2013, pp. 59-85. For the general preconditions of narratological interpretation of music, see also Eero Tarasti, A Theory of Musical Semiotics, Bloomington 1994.

111 This quote from Rosen 1980, p. 9f., is coined to the symphony genre, but also applicable to the sonata. The author proceeds as follows (ibid., p. 10): »The sonata has an identifiable climax, a point of maximum tension to which the first part of the work leads and which is symmetrically resolved. It is a closed form, without the static frame of 
cycle can thus be endowed with a narrative implication; or, more commonly, movements in sonata form may be treated as narrative instances on their own. In particular, Hepokoski's and Darcy's Sonata Theory outlines a general narrative conception of the sonata trajectory, locating the most significant point of its dramaturgy at the tonic key's final confirmation in the recapitulation section - the point of culmination of the overall tonality, as represented by the ESC (»essential structural closure«):

»Since a central component of the sonata genre is its built-in teleological drive $[\ldots]$ the sonata invites an interpretation as a musically narrative genre. A sonata dramatizes a purely musical plot that has a beginning (P) $[\ldots]$, a middle $[\ldots]$, and a generic conclusion of resolution and confirmation (the ESC and subsequent music). It is in the nature of the sonata to set up a quest narrative. [...] A sonata is [...] a narrative raction< because it drives through a vectored sequence of energized events toward a clearly determined, graspable goal, the ESC. $\ll^{112}$

Alternatively, sonata form may be paralleled to the structure of $18^{\text {th }}$-century drama, which is outlined as early as in the theory of Reicha's grande coupe binaire, described as follows: »La première partie [...] est l'exposition du morceau; La première section [de la seconde partie] en est l'intrigue, ou le noeud; La seconde section en est le dénouement. « ${ }^{113}$ As Rosen, Newman, and other authors have later related, the three sections can be regarded in even closer analogy to the parts of the classic Aristotelian drama, or the five stages of standard dramatic theory: ${ }^{114}$ While the musical exposition corresponds to the narrative exposition (protasis) and rising action (epitasis), the development section, mostly associated with dramatic action and conflict, may be mapped to the climax (peripeteia), and the recapitulation, as an embodiment of formal and tonal resolution, equals the falling action (retarding moment) and dénouement (katastrophe) - just like the nearfinal confutatio in Quintilian's rhetoric. The climax of sonata form can, on the contrary, also be defined as the tonal contrast established within a movement's exposition, serving as a dramatic agent in Caplin's theory: »At the heart of the tonal drama in the exposition of a full-movement form [...] lies the conflict between the tonic key and its rival subordinate [secondary] key. ${ }^{115}$ In another alternative reading, the dramatic climax may be located »at the shift to the dark or subdominant side in the tonal orbit of the coda, and it often reaches a secondary peak [...] at the start of the recapitulation. ${ }^{116}$

In Medtner's music, it is primarily the piano character pieces, first of all his skazki, which are most likely to incorporate narrative contexts in terms of musical >storytelling` (see also chapter 3.4.1). Some of them might even be symptomatic of a general tendency in early- $20^{\text {th }}$-century music, when $\gg$ the disparity between story and discourse [...] enhances its narrativity even though its directional qualities are weakened by musical prose $\ll{ }^{117}$ However, Byron Almén's general account of musical narrativity—which is, like musical

ternary form; it has a dynamic closure analogous to the denouement of eighteenth-century drama, in which everything is resolved, all loose ends are tied up, and the work rounded off.«

112 Hepokoski and Darcy 2006, p. $251 \mathrm{f}$.

113 Reicha 1824, p. 1162.

114 As described by the German writer and literary theorist Gustav Freytag in his book Technik des Dramas (1863).

115 Caplin 1998, p. 125.

116 Newman 1963, p. 149f., having elaborated on the nature of the >sonata drama just before this statement (p. 149): »Where does the dynamic curve [...] reach its climax, or what may be called its catastasis in the protasis, epitasis, and catastrophe of the sonata drama? «

117 Rigbi 2013, p. 144, exemplifying this hypothesis on music by Mahler, Schoenberg, and Reger. 
semiotics, an independent field of research which cannot be explored in detail here - seems easily applicable to many of Medtner's compositions, apparently matching the composer's intention of creating music of descriptive or picturesque character:

»Perhaps, then, musical narrative really is a conceptual phenomenon, a phenomenon to be enlisted in the presence of texts, descriptive titles, and programs that lend their >literary $<$ qualities to musical signification. ${ }^{118}$

This definition seems to resonate with Medtner's notion that »it is impossible to talk about music«, which instead »talks itself «, ${ }^{119}$ and with his statements on the relationship between his musical language and extramusical content. ${ }^{120}$ There are also other works besides the skazki, such as the three cycles of Forgotten Melodies, Opp. 38, 39, and 40, which can be assigned a particular semantic layer through their biographical context. As Nicolò Rizzi notes, each of these opuses, with their recurring motives acting »like narrative >subjects $<$ or $>$ objects $<,[\ldots]$ capable of expressing, evoking, or signifying a particular narrated content « ${ }^{121}$ may be associated with a narrative instance — such as reminiscence (the biographical past), tragedy (present), or rebirth (future), ${ }^{122}$ suggesting an underlying plot to these three cycles, suitably depicting the composer's inner conflicts in the period directly preceding his emigration from Russia. Even more, some of Medtner's sonatas, in addition to their paradigmatic relevance within his œuvre, may become the staging ground for narration, and thus be charged with subliminal meaning. Most notably, this applies to his >genre sonatas $<$ or \Symbolist sonatas`, such as the Sonata-Skazka in C minor, Op. 25 No. 1 (1910-11), and Sonata romantica in Bb minor, Op. 53 No. 1 (1929-30), the implications of which will be further discussed in chapter 2.5.3. The extended trajectories of many of Medtner's sonatas seem to invite narrative readings and perspectives. This observation particularly applies to movements which are, for their structural ambiguity or irregularity as compared with the standard models of sonata form, difficult to access by means of >ordinary< terminology. The SonataReminiscenza in A minor, Op. 38 No. 1 (1919-20), is particularly characteristic of this tendency, figuring as an outstanding example of descriptive piano music. ${ }^{123}$ It shows an enigmatically codified variant of sonata form on its surface, but becomes way more comprehensible with the help of narrative and topical approaches.

118 Almén 2008, p. 12. For his further elaborations, the author adheres to four narrative archetypes introduced in 1957 by Northrop Frye: romance, tragedy, irony, and comedy. See ibid., p. ix.

119 Medtner 1935, p. 9: O muzïke govorit' nedostupno. Ona sama govorit i zagovarivaet imenno togda, kogda slova bessil'no umolkayut«, quoted after Swan's translation, p. 6.

120 See Markson 2017, p. 8ff., for a discussion of the terminology used in Medtner's Muza i moda for the indication

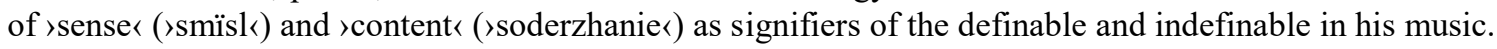

121 Rizzi 2018, p. 6.

122 Ibid., p. 22: »We can interpret the three cycles [...] as a triptych of reminiscence, tragedy, and rebirth«, particularly signified by Medtner's use of the poetic sub-genres of canzona, danza, and ditirambo.

123 For various narrative interpretations of the Sonata-Reminiscenza, see Podporinova 2009, p. 31f.; Rowen 2015 , p. 209ff.; and Emerson 2016 . 
- This page intentionally left blank - 


\section{Features of Medtner's Musical Language}

The goal of this part is to explore traits of musical form, melodic invention and development, rhythm and meter, polyphony, and harmony in Nikolai Medtner's music so as to gain a general overview of his style of composition. In addition, I will pay special attention to genre titles, the permeability of which figures as a distinct attribute of the composer's creative thought. The corpus of musical examples is thus not limited to the piano sonatas, but extends to all genres used by Medtner in order to provide a classification of peculiarities of the composer's music, systemised by the abovementioned parameters. Thus, the whole second part can, on the one hand, be read independently from the other parts of this study. However, it also functions as a counterpart to the comprehensive analyses of individual piano sonatas found in the third part, with which the following findings will be connected by numerous cross-references.

Discussing the features of a composer's >personal style poses a general methodological problem: If we encounter a stylistic phenomenon which is considered typical or characteristic from a subjective view, how can we ensure that this find is significant? Is it sufficient to quote examples by one particular composer (or virtually take random samples of his music) in order to delineate his >personal style ——or do we require comparison and confrontation with other composers' works written at the same time (so as to find criteria for exclusion)? Is the mere quantity of occurrences of certain phenomena indicative of their representativeness? And if so, how do we find evidence that a phenomenon does not exist in the music of a particular composer, or can $n o t$ be considered typical?

There seems to be no universally valid solution to these questions, and it is therefore up to the individual researcher to find a consistent way of dealing with problems and challenges associated with discerning a spersonal style «. A possible means of objectifying analytical results, however, is provided by some tools of digital musicology. Musical corpus research makes analytic results accessible to computational modelling, enabling the researcher to give empiric proof of aspects such as chord frequency, probability of progression from one chord to another, or pitch distribution, in relation to an examined corpus of works. In 2017-18 I have contributed harmonic analyses of Medtner's complete skazki to a corpus research project at École Polytechnique Fédérale de Lausanne (EPFL), and am looking forward to the results of the first computational examination of this dataset.

For the time being, my approach to describe Medtner's musical language must rely on intuitively-found results, the representativeness of which I try to substantiate by highlighting historical deductions of the respective phenomena. This complies with the premise that certain models of melodic and harmonic invention, as well as syntactic and formal archetypes, can be conceived as historical schemata, or topics in a certain semantic context, rather than isolated patterns. These are effective during the Baroque, Classical, and Romantic eras, being subject to continuous alteration and individualisation, and providing a superordinate perspective for their actual occurrence in Medtner's music. Furthermore, I believe that a certain feature does not need to occur very often to be considered noteworthy. In addition to phenomena which gain significance by their regular prevalence throughout Medtner's œuvre, there are also some >iconic< examples emerging as individually characteristic traits by their appearance in only one or two cases. 


\subsection{VARIETY OF SONATA FORMS}

The domain of musical form arises as the most fascinating aspect of Medtner's musical language. The particular devotion to sonata form, a cornerstone of Austro-German musical heritage, appears most consequent in Medtner's case as he was closely connected to this tradition from his early childhood. His family's predilection for Beethoven and Goethe, in particular that of Nikolai's eldest brother Emil who favoured German culture, poetry, and music before those of all other nationalities, predominantly influenced the young composer in choosing the formal vehicles of his musical expression.

Most notably, Medtner's fourteen piano sonatas, which he did not assign sequential numbers, represent a variety of highly individual outlines and dramaturgies. In his lifelong dedication to the sonata genre, Medtner found a distinctive way of dealing with traditional forms in every of his sonatas, imbuing it with new life over and over again, and never resorting to an earlier approach for a second time. This applies to the piano sonatas as well as the three violin sonatas, the unique Sonata-Vocalise, the Piano Quintet, and the three piano concertos. Apparently, the quantity of sonatas in Medtner outnumbers both Scriabin's (ten piano sonatas) and Prokofiev's (nine piano sonatas, four chamber works) output in those genres. Moreover, if regarded in their overall variety, Medtner's sonatas do not only surpass those of his Russian contemporaries in quantity, but also in terms of their flexibility in form and syntax. Still, points of reference for his work can be found throughout the music of the $19^{\text {th }}$ century - as in Schubert, Schumann, Brahms, and others, we will find single-movement forms, multi-movement cyclic conceptions, and sonata hybrids in Medtner as well. Thus, the following chapters are organised in loose analogy to the structure of chapter 1.1, presenting the composer's formal choices as special cases originating from the general tendencies observed before.

In total, Medtner's œuvre comprises 22 works and cycles that realise the >sonata principle< (see chapter 1.3.1), an overview of which is given on the following two pages. Two compositions from his early years, a sonata-allegro fragment and a sonatina, are listed for the sake of completeness, as is the Suite-Vocalise, Op. 41 No. 2, which is not actually a sonata. Fragments and incomplete works are not included. 


\section{Sonata Cycles in Medtner's Major Compositions}

Piece, Subtitle, DedicAtee, DAting

Sonata Movement in B minor, U/F $1.7(1897)^{1}$

Sonatina for Piano in G minor, U/F 1.10 (1898)

Piano Sonata (No. 1) in F minor, Op. 5 (1895-1903)

Sonata Triad (Sonatnaya triada), Op. 11

In memory of Andrei Mikhailovich Bratenshi

- Piano Sonata (No. 2) in Ab major, Op. 11 No. 1 (1904-06)

- Piano Sonata (No. 3) in D minor, Op. 11 No. 2 (1905-06) Sonata-Elegy (Sonata-elegiya)

- Piano Sonata (No. 4) in C major, Op. 11 No. 3 (1904-08)

Violin Sonata No. 1 in B minor, Op. 21 (1908-10)

Dedicated to Anna Mikhailovna Medtner

Piano Sonata (No. 5) in G minor, Op. 22 (1901-10)

Dedicated to Georgy Lvovich Catoire

Two Piano Sonatas, Op. 25

- Piano Sonata (No. 6) in C minor, Op. 25 No. 1 (1910-11) Märchen-Sonate (Sonata-skazka)

Dedicated to Aleksandr Fëdorovich Goedicke

- Piano Sonata (No. 7) in E minor, Op. 25 No. 2 (1910-12)

Motto from Tyutchev's >Night Wind $<$ poem

Dedicated to Sergei Vasilyevich Rachmaninov

Piano Sonata (No. 8) in F\# major, Op. 27 (1912-14)

Sonata-Ballade (Sonata-ballada)

\section{MVTS TEMPO INDICATIONS}

$1 \quad$ Allegro (unpublished)

$2 \quad 1^{\text {st }}$ mvt: Allegretto, ma non troppo

$2^{\text {nd }}$ mvt: Scherzo

$4 \quad 1^{\text {st }}$ mvt: Allegro

$2^{\text {nd }}$ mvt: Intermezzo (Allegro)

$3^{\text {rd }}$ mvt: Largo divoto

$4^{\text {th }}$ mvt: Finale (Allegro risoluto)

1 Allegro non troppo

1 Andante molto espressivo

1 Allegro moderato, con passione innocente

$3 \quad 1^{\text {st }}$ mvt: Canzona (Canterellando)

$2^{\text {nd }}$ mvt: Danza (Allegro scherzando)

$3^{\text {rd }}$ mvt: Ditirambo (Festivamente)

1 Tenebroso, sempre affrettando - Allegro assai - Interludium (Andante lugubre) Allegro assai

$3 \quad 1^{\text {st }}$ mvt: Allegro abbandonamente

$2^{\text {nd }}$ mvt: Andantino con moto

$3^{\text {rd }}$ mvt: Allegro con spirito

1 Introduzione (Andante con moto) - Allegro Tempo dell'introduzione -

Allegro molto sfrenatamente - Largamente

$3 \quad 1^{\text {st }}$ mvt: Allegretto

$2^{\text {nd }}$ mvt: Introduzione (Mesto) -

$3^{\text {rd }}$ mvt: Finale (Allegro)

- Limit of the scope of this study -

Piano Sonata (No. 9) in A minor, Op. 30 (1914)

1 Allegro risoluto - Allegro molto

Dedicated to Lev Ėduardovich Conus

Piano Concerto No. 1 in C minor, Op. 33 (1914-18)

1 Allegro - Tranquillo, meditamente-

In memory of Aleksandra Karlovna Medtner

Tempo primo - Coda (Allegro molto)

Forgotten Melodies (Zabïtie motivi), $1^{\text {st }}$ cycle, Op. 38

- Piano Sonata (No. 10) in A minor, Op. 38 No. 1 (1919-20) Sonata-Reminiscenza (Sonata-vospominanie)

1 Allegretto tranquillo - Andante con motoSvegliando, con moto

Forgotten Melodies (Zabïtie motivi), $2^{\text {nd }}$ cycle, Op. 39

- Piano Sonata (No. 11) in C minor, Op. 39 No. 5 (1920) Sonata tragica (Tragicheskaya sonata)

$1 \quad$ Allegro risoluto

- Medtner's final emigration in 1921 -

1 The catalogue numbers of the B minor Sonata Movement and Sonatina, as well as WoO (work without opus) numbers of the Piano Quintet, Op. posth., and some other works are given in accordance with Flamm 1995, pp. 548f. and 537ff. 
Piece, Subtitle, Dedicatee, Dating

Sonata for Voice and Piano in C major, Op. 41 No. 1 (1922)

Sonata-Vocalise (Sonata-vokaliz)

Dedicated to Anna Mikhailovna Medtner

Suite for Voice and Piano in F minor, Op. 41 No. 2 (1927)

Suite-Vocalise (Syuita-vokaliz)

Dedicated to Florestine Fortier

Violin Sonata No. 2 in G major, Op. 44 (1923-26)

Dedicated to Aleksandr Fëdorovich Goedicke

Piano Concerto No. 2 in C minor, Op. 50 (1923-26)

Dedicated to Sergei Vasilyevich Rachmaninov

Two Piano Sonatas, Op. 53

- Piano Sonata (No. 12) in B-flat minor, Op. 53 No. 1 (1929-30) Sonata romantica (Romanticheskaya sonata)

Dedicated to Archibald Martin Henderson

- Piano Sonata (No. 13) in F minor, Op. 53 No. 2 (1929-31)

Sonate orageuse (Grozovaya sonata)

alternative title: Sonata minacciosa

Dedicated to Alfred Laliberté

Piano Sonata (No. 14) in G major, Op. 56 (1935-37)

Sonata-Idyll (Sonata-idilliya)

Dedicated to Lev Ėduardovich and Olga Nikolayevna Conus

Violin Sonata No. 3 in E minor, Op. 57 (1936-38)

Sonata epica (Épicheskaya sonata)

In memory of Emil Karlovich Medtner

Piano Concerto No. 3 in E minor, Op. 60 (1941-42)

Ballade (Ballada)

Dedicated to Jaya Chamaraja Wadiyar, Maharadjah of Mysore

Piano Quintet in C major, Op. posth., WoO 5 (c. 1904-1948)

MVTS TEMPO INDICATIONS

2

Motto (Geweihter Platz by Goethe)

Sonata: Allegretto cantabile e con moto

$5 \quad 1^{\text {st }}$ mvt: Introduzione (Allegretto espressivo) $2^{\text {nd }}$ mvt: Song of the Nymphs (Andante)

$3^{\text {rd }}$ mvt: Secrets (Molto sostenuto)

$4^{\text {th }}$ mvt: Procession of the Graces (Allegretto)

$5^{\text {th }}$ mvt: What the Poet Speaks (Tranquillo)

$3 \quad 1^{\text {st }}$ mvt: Introduzione (Maestoso) Allegro appassionato - Cadenza I $2^{\text {nd }}$ mvt: Tema con variazioni (Andante con moto) - Cadenza II -

$3^{\text {rd }}$ mvt: Finale (Rondo. Allegro risoluto)

$3 \quad 1^{\text {st }}$ mvt: Toccata (Allegro risoluto)

$2^{\text {nd }}$ mvt: Romanza (Andante con moto)

$3^{\text {rd }}$ mvt: Divertimento (Allegro risoluto)

$1^{\text {st }}$ mvt: Romanza (Andantino con moto) $2^{\text {nd }}$ mvt: Scherzo (Allegro) -

$3^{\text {rd }}$ mvt: Meditazione (Andante con moto) $4^{\text {th }}$ mvt: Finale (Allegro non troppo)

Allegro sostenuto - Andantino meditamente, rubato - Fuga (Sempre al rigore di tempo) Coda (Sempre animato)

$2 \quad 1^{\text {st }}$ mvt: Pastorale (Allegretto cantabile) $2^{\text {nd }}$ mvt: Allegro moderato e cantabile

$4 \quad 1^{\text {st }}$ mvt: Introduzione (Andante) - Allegro

$2^{\text {nd }}$ mvt: Scherzo (Allegro molto vivace)

$3^{\text {rd }}$ mvt: Andante con moto

$4^{\text {th }}$ mvt: Finale (Allegro molto)

1 Con moto largamente -

Interludium (Allegro molto sostenuto) Finale (Allegro molto, svegliando, eroico)

$3 \quad 1^{\text {st }}$ mvt: Molto placido

$2^{\text {nd }}$ mvt: Andantino con moto

$3^{\text {rd }}$ mvt: Finale (Allegro vivace) 
The formal conceptions of Beethoven's sonatas may be identified as ancestors of many of Medtner's compositions, such as the $\mathrm{C}$ major Sonata >Waldstein<, Op. 53, which serves as a model to a number of works orientated towards their finale (at times including an introductory or intermediate movement, as in Medtner's Opp. 27 and 56). Still, a considerable number of Medtner's sonatas seems to be rather independent from historical paradigms of musical form. As Yuri Keldïsh states, the works are »very different in their musical form and character; Medtner employs the sonata cycle freely, withdrawn from the usual number and order of movements for a classical sonata ${ }^{2}{ }^{2}$ There are multiple instances of single-movement sonata form, encompassing hybrids between one-piece and multi-part designs; there are examples of what might be regarded as Medtner's free appropriation of the Lisztian >two-dimensional (double function) form, although under different preconditions (Op. 22, with an interlude transplanted into its development section, and Op. 53 No. 2 , where multiple sections are merged to a >through-composed, comprehensive form); and there is the unique construction of the E minor Sonata, Op. 25 No. 2, which may be described as an integrative, symphonic, single-movement form. Some compositions include large variation movements or sections (Op. 33; Op. 44, the inner movement of which is bordered by two large cadenzas); other works or movements encompass fugues or fugatos as part of their developments or concluding sections (Op. 5, $4^{\text {th }}$ movement; Op. 27, $3^{\text {rd }}$ movement; Op. 53 No. 2). In general, we can distinguish five main conceptions of sonata form in Medtner, appearing in their individual shapes and outlines:

(1) Traditional multi-movement forms Piano Sonatas, Op. 5, Op. 25 No. 1, Op. 53 No. 1, Op. 56

Violin Sonatas, Op. 21, Op. 44, Op. 57

Piano Quintet, Op. posth.; ${ }^{\text {nd }}$ Piano Concerto, Op. 50

(2) Multi-movement forms with introductory or final-directed movements

Piano Sonatas, Op. 27, Op. 56; Sonata-Vocalise, Op. 41 Nr. 1; $3^{\text {rd }}$ Piano Concerto, Op. 60

(3) One-piece single-movement forms ${ }^{3}$

Sonata Triad, Op. 11, Nos. 1-3; Piano Sonatas, Op. 30, Op. 38 No. 1, Op. 39 No. 5

(4) Multi-part single-movement forms

Piano Sonatas, Op. 22, Op. 53 No. 2; $1^{\text {st }}$ Piano Concerto, Op. 33

(5) Integrative symphonic single-movement form

Piano Sonata, Op. 25 No. 2

Other possible classifications may be applied according to the sonatas' musical character, or their narrative or hermeneutic implications, as suggested by Tatyana Shevchenko. ${ }^{4}$ From this perspective, three different types of piano sonatas arise: works without any super-musical dimension (Op. 5, Op. 11 Nos. 1 and 3, Op. 22, Op. 30); works with a rather general, unspecific emotional content (Op. 25 No. 2, Op. 38 No. 1, Op. 39 No. 5, Op. 53 Nos. 1 and 2); and works attributed with a narrative or hybrid genre (Op. 11 No. 2, Op. 25 No. 1,

2 My translation of Keldïsh 1976, col. 565f.: »Ego 13 [sic!] sonat ochen’ raznoobraznïy po forme i kharakteru muzïki. M[etner] svobodno traktuet sonatnïy tsikl, otstupaya ot obïchnogo dlya klassich[eskoy] sonatï kolichestva i raspolozheniya chastey.«

3 Chernaya-Oh 2008, p. 14, refers to these as >sonata-poems`, in possible derivation from the projected title of Scriabin's Op. 53.

4 Shevchenko 2017, p. 12, with my minor modifications. 
Op. 27, Op. 56). Ivan Ilyin, on the contrary, has proposed another categorisation in three groups: sonatas in »lyric form« (Op. 11, Op. 25 No. 1, Op. 38 No. 1, as well as the $2^{\text {nd }}$ and $3^{\text {rd }}$ Concertos, Opp. 50 and 60), in »dramatic form«(Op. 5, Op. 27, Op. 30), and in »tragic form«(Op. 22, Op. 39 No. $5,1^{\text {st }}$ Concerto, Op. 33). ${ }^{5}$

\subsubsection{ON COMPOSING SONATAS}

When observing Medtner as a composer of sonatas, we have to take into account the comments of his contemporaries, of fellow composers and music critics of his time, as well as later assessments, in order to comprehend what was being thought about the transfer of a traditional genre to the $20^{\text {th }}$ century. Yet this examination needs to start with a platitude: Sergei Taneyev is said to have stated that Medtner "was born with sonata form «, ${ }^{6}$ a label which does not mean much apart from qualifying the young composer as an early champion of the genre. ${ }^{7}$ The obtrusive statement is found in nearly every place where Medtner's sonatas are discussed. Regardless of what it is supposed to mean, Taneyev demonstrably highly valued his pupil's first piano compositions, as evident from a number of other assessments. Aleksandr Goldenweiser remarked that »after Beethoven no one equalled Medtner in his command of sonata form « $;^{8}$ and already in 1927 , when Medtner had not yet composed his last three piano sonatas, Leonid Sabaneyev made the following appreciative statement:

»Metner is a genuine classic in this sphere [of sonata form]. Over his compositions hovers the spirit of Beethoven's last Sonatas. Further it its difficult to characterise these compositions. They are as a rule written in broad form, massive in exposition, profound in content [...]. Metner's sonatas are creations of the same category as Bach's and Brahms'—one must go to meet this music, it will not come to meet us`, as Liszt said of Beethoven. «?

Even though Sabaneyev had emigrated to France just shortly before, his euphoric tone is indicative of positive evaluations in early-Soviet music journalism of that time. Yet, in saying little more than attributing Medtner's sonatas to the legacy of Beethoven, his statement appears just as disputable as many others. A more critical voice was that of Boris Asafiev who, in 1930, attested Medtner's knowledge »about the dramaturgy of sonata form, [...] proceed[ing] extremely logical while structuring his compositions, capturing the listener's attention at the very beginning.« However, Asafiev also remarked that »his contrasts lack poignancy, and the vitality characteristic of sonatas won't arise in an organic way. This is an explanation for the almost permanent loss of dramatic tension throughout his development sections, along with his natural strive to compensate this deficit by [...] highlighting those philosophical and poetic inspirations that the musical

5 Ilyin 1955, p. 184, not clarifying whether these denominations are genuine >formal« attributes rather than general characters.

6 The quotation seems to originate from Anna Medtner's memories, as provided in her essay of 1955, p. 18, extended and reprinted in Anna Medtner 1981, p. 37. Other authors to refer to that statement are Vasilyev 1963, p. 27; Swan 1967, p. 68; and Martyn 1995, p. 26: »The precise occasion of Taneyev's remark, which Medtner greatly valued throughout his life, has not been recorded.«

7 More information on Taneyev's role in educating Medtner is found in Keller 1971, p. 18f.

8 My translation of a statement from a 1918 concert note by Goldenweiser, quoted after Apetyan 1981, p. 12: »Posle Betkhovena nikto ne vladel sonatnoy formoy tak, kak Metner.«

9 Sabaneyev $1927^{\mathrm{a}}$, p. $138 \mathrm{f}$. 
ideas originate from. $\ll^{10}$ This statement is a hard one to judge as it appears as a general verdict of Medtner's developmental strategies, not giving any specific examples. Medtner's philosophical depth and spirituality, on the other hand, was praised by a number of other authors. One may agree or not to what Russian philosopher Ivan Ilyin, who apparently regarded his close friend Medtner as a sort of messiah of sonata form, somewhat biasedly wrote in 1955 :

»When our sickly generation is gone, $[\ldots]$ one of the musical thinkers of the future will write a history of the sonata. He will find, to begin with, that at the time of the greatest crisis and decadence, when unscrupulous inventors committed unheard-of offences and blasphemies in art, the form of sonata was given a new artistic meaning and depth and revealed to the world in fresh brilliance. This was done by Medtner. [...] Each sonata is a spiritual organism in which everything is mutually interconnected and grows out of a single kernel, a single problem indicated by the first two themes. $\ll^{11}$

Amazingly, the qualities Ilyin saw in Medtner's music seem to be reflected in his own ornamental style of writing. More prosaically, Eric Blom remarked in his Grove article of 1954: »The form in which Medtner expresses himself most completely is that of the sonata. He does not adhere very close to the classical model, which he bends to his creative fancy with considerable freedom, but its fundamental principles serve him as the ideal mould for all his larger works. Perhaps the sonata form is occasionally apt to be his master rather than his servant. $\ll^{12}$ The notion of Medtner being somewhat delivered to his favourite genre deserves consideration as it might be useful to explain his own spiritual, quasi-religious perspective towards traditional musical forms and genres as expressed in his book Muza i moda (The Muse and the Fashion, 1935). As for possible comparisons to other composers, William Newman draws an interesting parallel in his extensive 1969 study of sonata composition after Beethoven:

»Medtner's sonatas have somewhat the same strengths and failings as those of another neglected master before him, [the Liechtenstein-born Josef Gabriel] Rheinberger [...]. The identifications of Medtner with >sonata form and Brahms [...] do have significance if they pertain to his extraordinary ability, like Rheinberger's, to evolve, transform, develop, and permutate an idea [...]. This ability may well be his greatest, though hardly his only, strength. [...] The >failings that Medtner shares with Rheinberger are failings only while we insist that ideal >sonata form ‘ must reflect Beethoven's example in logic, tightness, and dynamism. According to that example, Medtner's forms [...] are too prolix to be called $>$ tight $<$ [...], to free to be called $>$ logicak, and to philosophical and homogeneous (or devoid of dramatic contrast) to be called $>$ dynamic $<.{ }^{13}$

Newman's perspective suggests that there had been previous attempts to dismiss specific features of lateRomantic sonata composition, measured by the model of Beethoven, but he does not state if this critique was directed towards Rheinberger or Medtner. It might probably have been the former, as I am not aware of any

10 My paraphrase of Kuhn's German translation of Asafiev 1930 a , p. 351: »Medtner versteht etwas von der Dramaturgie der Sonatenform und geht beim Aufbau seiner Sonaten überaus logisch zu Werke. Schon zu Beginn [...] gelingt es ihm, die Aufmerksamkeit des Hörers zu fesseln. [...] Dennoch fehlt den Kontrasten die Schärfe, und auch die Dynamik des Sonatencharakters will sich nicht auf organische Weise einstellen. So erklärt sich auch der fast ständige Verlust an dramatischer Spannung in seinen Durchführungen, begleitet vom natürlichen Bestreben des Komponisten, diesen Mangel [...] durch Hervorhebung jener philosophischen und poetischen Anregungen wettzumachen, die zur Entstehung der musikalischen Gestalten geführt hatten.«

11 Ilyin 1955, p. 180ff.

12 Blom 1954, p. 649f.

13 Newman 1969, p. 726f. 
such claim towards Medtner. The alleged likeness with Rheinberger, the ingenuity of whose sonata conceptions do not seem to rank equal with Medtner's, thus seems a bit arbitrary. More recently, a number of younger Russian scholars have tended to apply a holistic view towards sonata form in Medtner, seeking a foundation for the use of the traditional genre in his artistic personality. An exemplary statement in this respect, outlining the peculiarity of the genre by adhering to the established term sonatnost' (〉sonata-ness $\triangleleft$ ), is made by Yuliya Moskalets in her 2004 thesis:

»[Medtner's] predilection for this genre allows for the supposition that sonata form was the most adequate vehicle to express his ideas and ambitions. The process of accomplishing unity and harmony through the genesis and transformation of original thoughts, taking shape in the semantics of sonata form, was central to the composer's artistic ideas. [...] Medtner's personality was reflected in the sonata genre, uniting in itself the rational and emotional, the intuitive and the conscious, as well as his German roots and $>$ Russian artistic education $\lessdot .{ }^{14}$

Remarkably, none of the scholars and reviewers quoted above have argued that sonatas might not have been an appropriate genre to deal with in the early $20^{\text {th }}$ century. This is a prejudice that Medtner himself seemed to sense, or at least felt the need to defend his music against in Muza i moda, ${ }^{15}$ even if contemporary Soviet musicology was, naturally, anything but adverse towards traditional genres. The idea that, while the $20^{\text {th }}$ century advanced, composing sonatas was something outdated and belonged to a somewhat reactionary postRomanticism, seems to have arisen only after World War II, probably in the environments of serialism and the Darmstadt school. So in a way Medtner had premonitions of later- $20^{\text {th }}$-century views condemning his style as basically retrospective, which he did not live to experience. Scholars specialising in Russian music have long tended to emphasise Medtner's alleged conservativism in harmonic language, especially when compared with >modernist ‘ contemporaries such as Bartók, Stravinsky, and Prokofiev (all of who composed sonatas as well) rather than appreciating his achievements on the field of musical form. Those unjust confrontations have somewhat contributed to Medtner's relative neglection in performance and research during the decades preceding the 1990s.

\section{Medtner's Own View of Sonata Form}

In general, Medtner's creed of the architecture, balance, growth, and development of musical syntax and form is presented in the chapter »About the form« from the posthumously published volume The Daily Work of the Pianist and Composer (1963). ${ }^{16}$ The composer's own idealistic view of sonata form is briefly expressed in the chapter The Balance of Simplicity and Complexity from Muza i moda, deducing the genesis of

14 My translation of Moskalets 2004ª , p. 116f.: »Takoe pristrastie [Metnera] k zhanru [sonati] daet osnovanie predpolozhit', chto imenno sonata yavilas' dlya kompozitora naibolee adekvatnoy formoy vïrazheniya svoikh idey i stremleniy. Protsess dostizheniya edinstva i garmonii cherez stanovlenie, preobrazovanie i transformatsiyu nachal'nïkh obrazov, zalozhenniy v semantike sonatï, bïl sozvuchen tvorcheskim ustanovkam kompozitora. [...] V zhanre sonatï nashel otklik sam sklad lichnosti Metnera, osobïm obrazom sochetavshiy v sebe ratsional'noe s èmotsional'nïm, intuitivnoe s soznatel'nïm, nemetskie korni s >russkim khudozhestvennïm vospitaniem<.«

15 This is reflected already in the subtitle of the book, meant to be »a defence of the foundations of the Art of Music «.

16 Medtner 1963, p. 41ff., chapter »K forme«. References and quotes from this passage are found in Viktor Bobrovsky's volume On the Variability of Formal Functions ( $O$ peremennosti funktsiy muzikal'noy formi), Moscow 1970, p. $215 f$. 
sonata form from (ternary) song forms, and further from period-shaped themes and their phrases. In addition, he demands a converse relation of simplicity and complexity for the thematic construction and formal outline in song and sonata form:

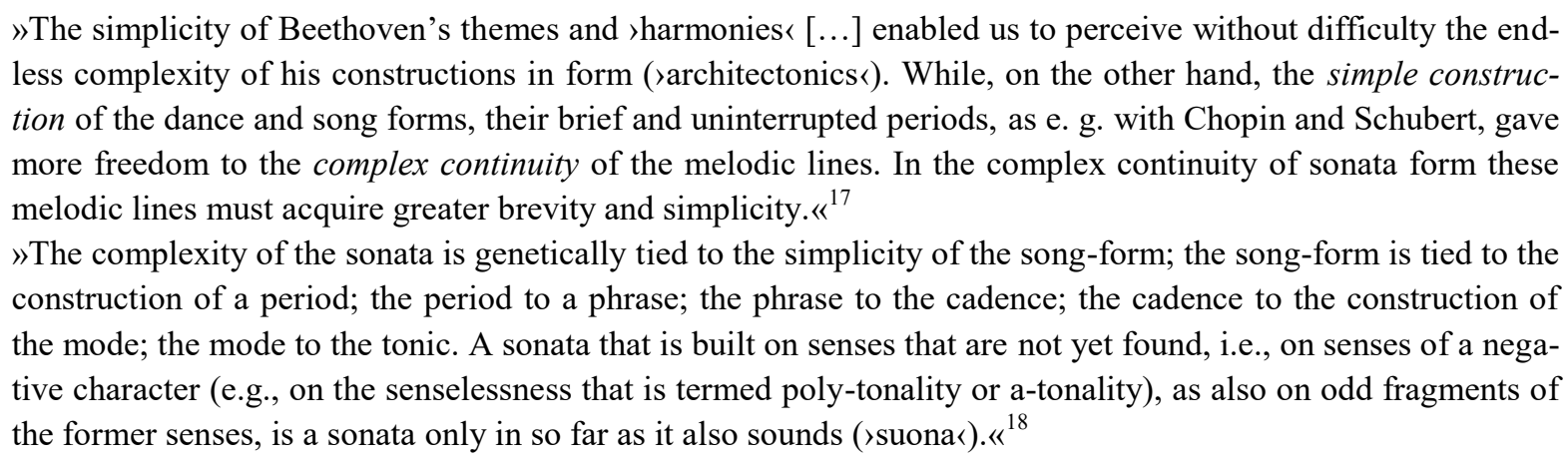

In accordance with his rejection of musical modernism of any kind, Medtner only accepts works as >real sonatas if their harmony is restrained to tonality, while any tendencies transgressing the traditional order of major and minor keys are considered ınegative of historical evolution of sonata form, as found in Beethoven's works:

»The efflorescence of harmony was followed by an efflorescence of the song form, from which gradually the sonata form also blossomed forth. The greatest representative of this form, Beethoven, conceived his sonatas and symphonies as one song, which [...] illumined to us the whole complexity of his architectonic constructions. ${ }^{19}$

While this deduction appears logical from the perspective of viewing musical forms as organisms, it neglects the historical rootedness of sonata form in Baroque suite movements and Italian orchestral overtures - $\mathrm{a}$ fact that seems not to have interested Medtner. What concerned him, though, was the question if composing sonatas was still an adequate option for a $20^{\text {th }}$-century composer. In a letter to Alfred and Ekaterina Swan of August 10, 1933, the composer comments on the notion of sonata form having come to an end, referring to a previous remark by Alfred Swan related to the Grozovaya Sonata, Op. 53 No. 2, which he generally appreciated. The following paragraph is a central statement for the present study, giving proof of Medtner's commitment to traditional musical form without fearing the risk of composing >outdated or even >old-fashioned music:

»I cannot understand your recent recognition that sonata form has outlived its era. It is not forms which obsolesce, but schemes. By the way, schemes have no viability at all, be they new or old. $\ll^{20}$

There is nothing known of a possible reaction by Swan; but while this quote shows Medtner's poignancy of argument and terminological distinction, it is also of crucial importance for understanding his view of the sonata as an ageless genre. He felt no need to change the foundations and formal paradigms of his creative

17 Medtner 1935, p. 19, quoted after Swan's 1951 translation, p. 16; italics are original.

18 Ibid., p. 51f., quoted after Swan's translation, p. 49.

19 Ibid., p. 67, quoted after Swan's translation, p. 63.

20 My translation of Apetyan 1973, p. 452: »Ne mogu ponyat' Vashego nedavnego priznaniya, chto sonatnaya forma otzhila svoy vek. Otzhivayut ne formi, a skhemi. Vprochem, skhemï voobshche ne obladayut nikakoy zhiznesposobnostyu, nezavisimo ot togo, novï li oni ili starï.« 
invention as long as they were conceived as mere envelopes which, in every of his sonata compositions, were consistently filled and varied with individual musical thought. Sonata form understood as a pure scheme, reproducing fixed patterns and orders of formal sections, were not of any interest to Medtner. Instead, he regarded »sonata form and the sonata cycle as evolutionary formal processes leading to new and individual solutions throughout, and resisting a schematic compliancy to musical form, $[\ldots]$ which required him to constantly find new parameters to ensure the structural consistency and logic of the respective work. $\ll^{21}$

\section{Medtner as a Performer of Sonatas}

Medtner extensively dealt with sonatas as a pianist as well. While his own compositions stood in the centre of attention of his performing activity, Beethoven's sonatas were also of great importance throughout his pianistic career, and the influence of these works on his own creative output cannot be overestimated. Christoph Flamm argues that they acted as a $»$ model and sublime ideal, especially those he himself performed as a pianist « ${ }^{22}$ Beethoven’s >Waldstein $<$ and >Appassionata $<$ sonatas, Opp. 53 and 57, which Medtner frequently programmed and even recorded (see figure 1.1), both belonged to the cornerstones of his pianistic repertoire, appearing in recitals from $1896-1936 .{ }^{23}$ His performances also included the piano sonatas in D major, Op. 10 No. 3; E minor, Op. 90; the 32 Variations in C minor, WoO 80; and the >Hammerklavier< Sonata in Bb major, Op. 106, as well as the violin sonatas in A major, Op. 12 No. 2, G major, Op. 30 No. 3, and one of the Op. 102 cello sonatas. However, the Beethoven work most frequently performed by Medtner is the $4^{\text {th }}$ Piano Concerto, Op. 58, appearing on his programmes 15 times from $1910-44 ;{ }^{24}$ and he duly wrote cadenzas to the $1^{\text {st }}$ and $3^{\text {rd }}$ movement of that concerto (WoO 1, 1910; published in 1911). In his earlier years, Medtner had also performed Schumann's $1^{\text {st }}$ Sonata in F\# minor, Op. 11 (in three recitals from 1898-1903), Brahms's G minor Piano Quartet, Op. 25, and one of his Op. 120 viola sonatas, as well as Grieg's $3^{\text {rd }}$ Violin Sonata in C minor, Op. 45. Another sonata-like work regularly performed by Medtner's was Chopin's F minor Fantasy, Op. 49, appearing six times from 1918-36.

21 My translation of Flamm 1995, p. 213: »Es ist die Betrachtung des Sonatensatzes und -zyklus als evolutionäre[r] Formprozess, der zu stets neuen und individuellen Lösungen führt und sich einer schematischen $>$ Formerfüllung kraß widersetzt. Wesentlich ist dabei, dass aufgrund des weitgehenden Wegfalls formstabilisierender Schemata [...] neue Parameter gefunden werden müssen, die den strukturellen Zusammenhalt und die gedankliche Logik des Werkes stützen.«

22 Ibid.: »Vorbilder und gleichzeitig hehres Ideal waren die Sonaten Beethovens, und unter diesen wohl besonders diejenigen, welche Metner als Pianist selbst in Konzerten aufführte."

23 Op. 53 appeared ten times in Medtner's recitals, Op. 57 eight times. He recorded Op. 53 in 1922 (Welte-Mignon) and Op. 57 in 1946 (His Master's Voice); another recording of Op. 57 was made by Columbia Records during his US tour in 1930, but not commercially released until 2004 (see figure 1.1). These examples represent some of the rare cases among Medtner's recordings of others than his own compositions (the only other one is a Scarlatti sonata, also recorded in 1922). All information given according to Flamm 1995, p. $631 \mathrm{f}$.

24 Other piano concertos in Medtner's repertoire were rare. Flamm 1995, ibid., only mentions two early performances of Tchaikovsky's $1^{\text {st }}$, Op. 23, as well as one performance of Beethoven's $3^{\text {rd }}$, Op. 37, and Schumann's Concerto, Op. 54. 


\subsubsection{Single-Movement CONCEPTIONS}

As a composer of single-movement piano sonatas, Medtner appears as a pioneer in Russian music, ${ }^{25}$ revivifying the diverse developments on that field in $19^{\text {th }}$-century European music (see chapter 1.1.2), even though he does not particularly rely on these. His first approaches to the conception, the sketches to the Sonata Triad, Op. 11, originate from 1904-a couple of years before writing such works became quite popular among early-20 $20^{\text {th }}$-century Russian composers. Aleksandr Scriabin's B minor Fantasy, Op. 28 (1900) figures as the first example of an independent single-movement sonata form in Russia; however this work was not named a sonata (see chapter 1.2.2). We can thus state that, by the time Medtner published his Ab major Sonata, Op. 11 No. 1, in 1906, his contemporaries had not come up with their earliest pieces in that design. Scriabin's $5^{\text {th }}$ Piano Sonata, Op. 53, dates from late 1907, the young Sergei Prokofiev's Op. 1 was not completed before 1909, and Georgy Catoire's $2^{\text {nd }}$ Sonata for violin and piano >Poèmeく in A major, Op. 20 (see chapter 1.2.3), was published in 1910. However, a work qualifying as a possible predecessor to the Sonata Triad can be found in Medtner's own œuvre: The Skazka in C minor, Op. 8 No. 2, also features sonata form and will be briefly examined later in the present chapter. There are seven examples of one-piece single-movement sonata forms in Medtner altogether - the three works of the Sonata Triad, Op. 11; the A minor Sonata, Op. 30; the Sonata-Reminiscenza and Sonata tragica from the Forgotten Melodies, Opp. 38 and $39 ;{ }^{26}$ and the SonataVocalise, Op. 41 No. 1, if we disregard the brief motto movement (Geweihter Platz) by which it is preceded. In addition, there are three instances of larger, multi-part single movement conceptions, including the $G$ minor Sonata, Op. 22; the E minor Sonata, Op. 25 No. 2; and the Grozovaya Sonata in F minor, Op. 53 No. 2. This means that, out of fourteen piano sonatas, only a comparatively small number of five works have multiple movements.

Medtner apparently shared his love for one-piece single-movement sonata form with Scriabin, who turned away from the multi-movement design from his $5^{\text {th }}$ sonata onwards. This conception is, though, not quite typical of Prokofiev, who employed single-movement form only in his $1^{\text {st }}$ Sonata in F minor, Op. 1 $(1909)^{27}$ and $3^{\text {rd }}$ Sonata in A minor, Op. 28 (1917). When looking at further contributions to single-movement sonata form written in Russia during the first two decades of the century, we find that works vary considerably in dimension and length. There are, on the one hand, the compact formal schemes of Medtner's Op. 11, of Scriabin's $6^{\text {th }}$ to $10^{\text {th }}$ Sonata (Opp. 62, 64, 66, 68, and 70, of 1912-13), as well as the $1^{\text {st }}$ and $2^{\text {nd }}$ Sonatas of Anatoly Aleksandrov (Opp. 4 and 12; 1914-18) and Samuil Feinberg (Opp. 1 and 2; 1915-16). On the other hand,

25 Newman 1969 , p. 722, wrongly claims that Medtner »seems to have followed Scriabin in preferring « singlemovement form.

26 The Sonata-Reminiscenza in A minor, Op. 38 No. 1, is Medtner's most popular and most performed composition, despite the fact that its sonata form is quite complicated. In deviation from the traditional scheme, the exposition features two rotations, with the second one omitting the primary theme and introducing a different secondary theme, while the recapitulation launches a new third subject before restating both secondary themes. The whole structure is framed by a self-contained ritornello, appearing at the outset and ending as well as at the border between the exposition and development section, transposed a fifth upward to E minor.

27 Prokofiev's Op. 1 was originally meant to become a multi-movement work, but eventually left on its own; the same applies to Medtner's Ab major Sonata, Op. 11 No. 1 (1904-06) and Alban Berg's B minor Sonata, Op. 1 (c. 1909). 
we encounter works of larger dimensions, such as Sergei Lyapunov's Op. 27 (1906-1908), Nikolai Myaskovsky's $2^{\text {nd }}$ and $3^{\text {rd }}$ Sonatas (Opp. 13 and 19; 1912-20), as well as Medtner's own remarkable G minor Sonata, Op. 22 (completed in 1910) and A minor Sonata, Op. 30 (1914). Multi-part single-movement form, as seen in Medtner's Op. 22, does not necessarily imply an adherence to the Lisztian stwo-dimensional sonata form<. If any work by Medtner is indebted to this conception, it certainly is his $1^{\text {st }}$ Piano Concerto in C minor, Op. 33 (1914-18). ${ }^{28}$

The distinction between one-piece and multi-part single-movement sonata form is only a gradual one. When it comes to the incorporation of slower passages ( $>$ Inselregionen $<)^{29}$ within a large sonata movement, as in Medtner's G minor Sonata, Op. 22, the criteria of the classification proposed above may dwindle-and even more so if there are several changes of tempo in the course of a movement. This aspect lets singlemovement structures appear related to the genre of the piano fantasy, more akin to the spirit of free improvisation than to the classical model of sonata form. Works such as Medtner's Op. 22 or Op. 53 No. 2 may just as well be seen as part of a tradition commencing in the early $19^{\text {th }}$ century with the approximation of the sonata and fantasy genres, a tendency established by Beethoven's piano sonatas of 1800-02, as well as a couple of other works in their succession (see chapter 1.1.1).

In the context of discussing Medtner's single-movement sonatas, the second Skazka from his Op. 8 (1904-06), a piece the young Sergei Prokofiev was much impressed of, ${ }^{30}$ merits a few additional considerations. After Medtner had just established the genre of skazka (Märchen), he already transcended the borders of this character piece by stretching its formal dimensions. This piece figures within the skazki corpus as one of the longest and most complex, and appears outstanding in many aspects of its formal design, most obviously for the fact that it presents a full-scale sonata movement. However, the composer would not name it a sonata, saving this term for the Sonata Triad, Op. 11. Panteleymon Vasilyev remarked: »On his way to the command of sonata form and creative self-consciousness, Medtner directs our attention towards his second Skazka in C minor (1905). This is a veritable sonata where both themes, their presentation, and the overall construction appear highly original. ${ }^{31}$ Looking at the piece in detail, a few peculiarities regarding Medtner's use of sonata form reveal themselves. A restless primary theme in $8 / 8$ time (grouped in $3+3+2$ quavers) and a cantabile secondary subject in G minor (m. 32ff.) form the exposition. Where a closing zone might have been expected, both themes are contrapuntally combined, still in G minor, yet with a polymodal air (p. 57ff.).

28 See Alekseyev 1969, p. 290: »A slow and a scherzando section are introduced during the development section of this large single-movement work, so that it resembles the two-dimensional cyclic forms of Liszt's concertos « (my translation of: »Ėto bol'shoe odnochastnoe sochinenie, v razrabotku kotorogo vvedenï medlennïy i skertsoznïy razdelï, chto sblizhaet ego po forme s odnochastno-tsiklicheskimi kontsertami Lista.«)

29 I use this term in my own analyses and teaching and believe that it sprang from my own invention.

30 See Flamm 2006, p. 3: »The young Prokofiev was particularly amazed by the skazka's bitonal harmony and rhythmic energy« (»So hat der junge Prokof’ev die [...] bitonalen harmonischen Schärfen und die rhythmische Energie des Märchens [...] begeistert aufgenommen«). There are indeed parallels in tone and texture, discernible when comparing Medtner's Skazka to works such as Prokofiev's Etudes, Op. 2 Nos. 3 and 4 (1909), both also written in C minor, or to the Toccata, Op. 11 (1912).

31 My translation of Vasilyev 1962, p. 14: »Na puti ovladeniya sonatnoy formoy i samostoyatel'nogo tvorcheskogo osoznaniya ee Metnerom ne mozhet ne obratit' nashego vnimaniya vtoraya c-moll'naya >Skazka< iz op. 8, sochineniya v 1905 g. Ėto samaya nastoyashchaya sonata, gde i temï, i ikh izlozhenie, i vsya postroyka gluboko originalnï.« 
This leads to further polyphonic wizardry during the development section where a three-part canon of the secondary subject emerges, combining the upper voices at a distance of one measure, and adding another voice in augmentation in the bass (m. 140ff.: grandisonante; see example 2.1.1). After a virtuosic culmination, the recapitulation omits the primary theme so as to start with the secondary instead (m. 187ff.) - a possible foreshadow of architectural balance later found in the G minor Sonata, Op. 22. There is no need for an independent restatement of the primary theme as it is heard later, again combined with the secondary theme (m. 213ff.).
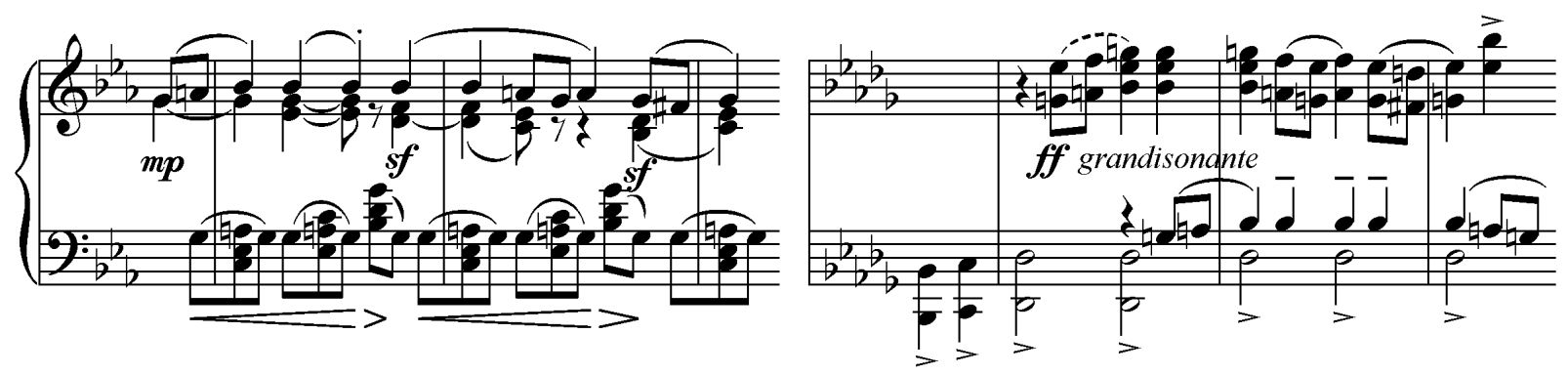

Example 2.1.1: Medtner, Skazka, Op. 8 No. 2, mm. 58-59// mm. 140-142

More variants of sonatnost', conceived as single-movement sonata forms appearing in Medtner's character pieces or other genres, include, for instance, the E minor Skazka, Op. 14 No. 2 (〉March of the Paladin<, 1904-07), where the development of three independent themes is superimposed with traits of a fugue, and the A minor Elegy, Op. 59 No. 1 (1940-41). ${ }^{32}$ An example of multi-part single-movement sonata form is also found in the abovementioned $1{ }^{\text {st }}$ Piano Concerto in $\mathrm{C}$ minor, Op. 33, a highly intriguing piece in terms of form and strategy of thematic development, which however appears curiously neglected by scholars, despite the fact that it would well deserve a more detailed discussion. ${ }^{33}$

\subsubsection{MONOTHEMATIC APPROACHES}

Some of Medtner's piano sonatas show a special design of their main subjects which is usually referred to as monothematic sonata form. This notion is for the most part based on a common motivic source of both the primary and secondary themes, or in the derivation of the latter from the former-which does not mean that no other subjects are introduced and developed in the course of the movement. This variant of sonata form has a distinct of tradition of its own, starting with many first movements from Joseph Haydn's sonata cycles and chamber works. Prominent examples are the $1^{\text {st }}$ movements of the C major Sonata, Hob. XVI:50 (1794-95), and of the C major String Quartet `Emperor`, Hob. III:77 (1797). Other monothematic sonata

32 More elaboration on aspects of sonata form inherent in that work are found in Sokolov in Kuhn 2008 ${ }^{\mathrm{a}}$, p. 166ff. The author also asserts, rather inappropriately, that the B minor Skazka, Op. 34 No. 1 ( $>$ The Magic Violin $<$ ), is composed in a loose sonata form.

33 See Sarest 2014 for an extended analysis of Op. 33, focusing on metrotechtonic aspects. Further recommended reading: Asafiev $1930^{a}$, p. 292f, who suggests that Medtner had been inspired by Georgy Catoire's Piano Concerto in Ab major (1909); and Dolinskaya 2013, pp. 153-164. 
movements are, to name but a few popular examples, the $1^{\text {st }}$ movements of Muzio Clementi's F\# minor Sonata, Op. 25 No. 5 (1790); of Schumann’s A minor Piano Concerto, Op. 54 (1841); and of Antonín Dvořák’s G minor Piano Concerto, Op. 33 (1876).

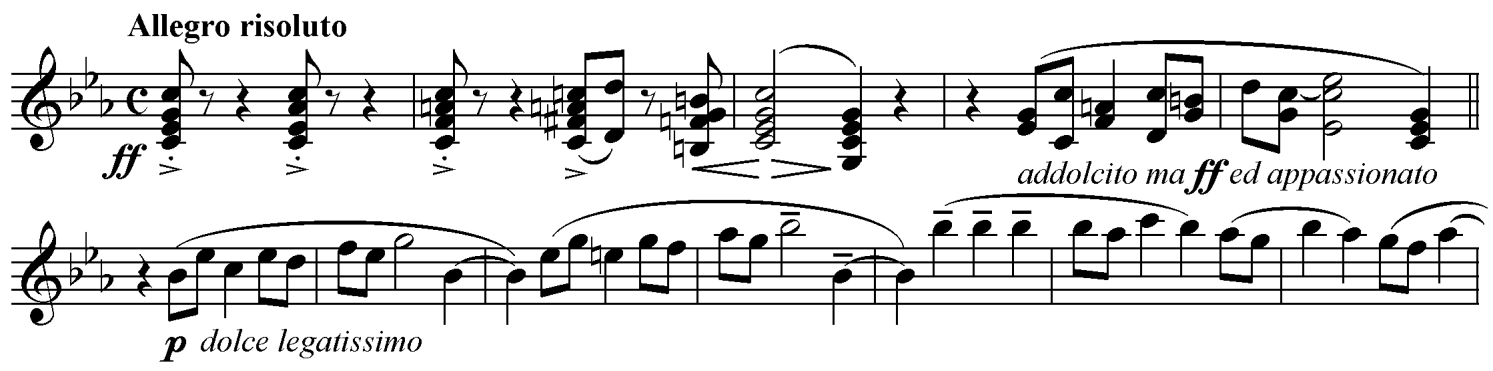

Example 2.1.2: Medtner, Sonata tragica, Op. 39 No. 5, mm. 1-5 // mm. 53-59 (motivic reduction)

Let us have a short look at two of Medtner's sonatas where monothematic form seems most apparent:

(1) In his single-movement Sonata tragica in C minor, Op. 39 No. 5, the melodic contour most convincingly acting as a secondary theme (m. 53ff.) presents a transposition of the primary theme's contrasting idea (m. 4f.), followed by a variant of the very first three measures (see example 2.1.2 for a comparison). Other instances of that subject are reiterated throughout the whole work, making monothematism a fairly plausible notion, and causing the sonata's recapitulation section to turn out much shorter than the exposition.

(2) In the Grozovaya Sonata in F minor, Op. 53 No. 2, the idea introduced at the very beginning determines, as a sort of motivic nucleus, the primary and secondary subjects ( $\mathrm{mm}$. 1ff. and 54ff.; see example 2.1.3), both of which can be identified as thematic transformations of one another. Also, the theme of the closing zone (m. 125ff.) and a fugato section arising amidst the sonata as part of an intense developmental procedure (m. 210ff.; see example 2.3.4) are derived from the initial idea. Thus, a considerable part of the work's motivic material is derived from a single idea which permeates this massive single-movement sonata, with its figurations and transformations being further developed in every significant subject.

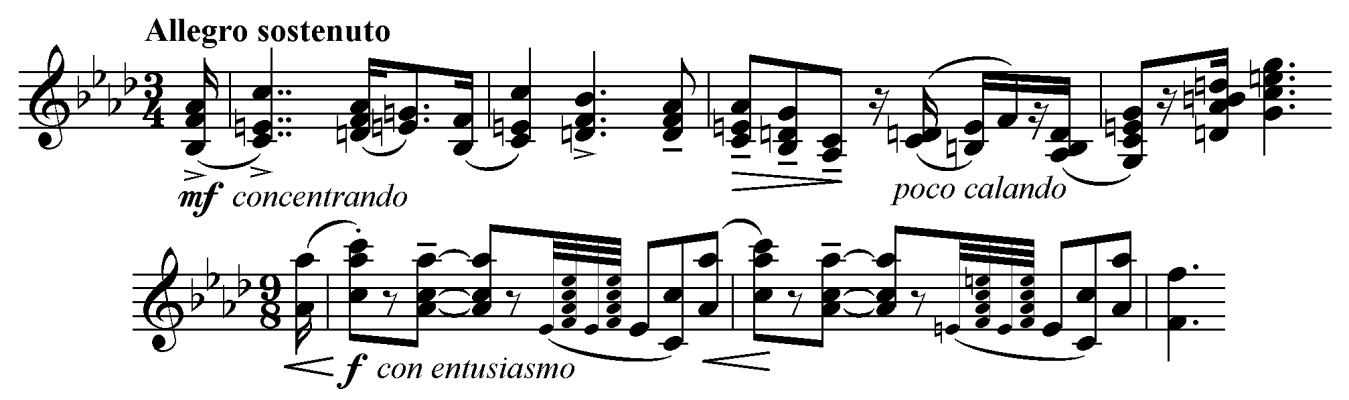

Example 2.1.3: Medtner, Grozovaya Sonata, Op. 53 No. 2, mm. 1-4// mm. 54-55 (motivic reduction) 


\subsubsection{QUATERNARY SONATA FORM}

At times, sonata movements are enhanced with a comprehensive coda which makes them transcend the border from tripartite to quadripartite sonata form, with the coda functioning as an independent fourth section. This can be achieved through analogy, or balance, of the development and coda sections: while the latter appears as a second developmental passage, it complements the recapitulation section in a similar way as the middle development section accumulates to the exposition (first type of coda). Alternatively, a more independent coda may be formed by attaching a supplementary passage, less closely related to the preceding sections, but counterbalancing the exposition and recapitulation with regard to its length and poignancy (second type of coda). ${ }^{34}$ In both cases, the coda as the movement's concluding section gains additional weight, and is likely to function as an overall climax in terms of in dramatic tension and density of motivic processing.

Of Medtner's seventeen movements in sonata form written for solo piano, no less than ten feature substantial codas, figuring as »the perhaps most encapsulating musical events for Medtner $«{ }^{35}$ The majority of the codas are unmistakably heralded by a corresponding indication in the score, while the others are at least made recognisable by an acceleration of tempo. Here is an overview of where codas occur: in Op. $5,1^{\text {st }}$ and $4^{\text {th }}$ movements (tempo acceleration); in Op. 11 Nos. 2 and 3 (both with explicit codas); in Op. 22 (tempo acceleration); in Op. 27, $1^{\text {st }}$ movement (explicit coda); in Op. 30 (explicit coda); in Op. 39 No. 5 (explicit coda); in Op. 53 No. 1, $4^{\text {th }}$ movement (explicit coda); and in Op. 53 No. 2 (explicit coda). Where codas are not explicitly indicated in the score, as in Opp. 5 and 22, Medtner tends to resort to the second type as described above-with the only exception of Op. 39 No. 5, which represents the second type as well. The $1^{\text {st }}$ movement of the Sonata-Skazka, Op. 25 No. 1, is a disputable case as it features a clearly separated concluding section, restating its secondary theme as a final climax, which might be referred to as a coda. However, I tend not to consider it as such since it lacks both characteristic attributes, the indication of a coda and an acceleration of tempo, at least one of which is employed by every other coda in Medtner's piano sonatas; instead, I prefer naming it a >conclusion< (see chapter 3.4.2).

One of the most remarkable of Medtner's codas, though perhaps the most conventional one, is that of the $1^{\text {st }}$ movement from his Piano Sonata in F minor, Op. 5. A thrilling culmination of dense thematic work, it is constructed in close analogy to many of Beethoven's codas-namely those of the $1^{\text {st }}$ movements of the >Waldstein $<$ and >Appassionata Sonatas, Opp. 53 and $57,{ }^{36}$ both of which are excellent paradigms of quaternary sonata form. Given the fact that Medtner frequently performed these sonatas as a pianist, it seems more

34 These two types correspond with what Hartmut Fladt refers to as »architectural development initiation« (a development section starting with a variant of the primary theme) or »logical development initiation« (drawing on the material of the closing zone). Equivalent considerations may apply to the onset of codas. This terminology seems to be unpublished; yet there are historical theories of sonata form including similar thoughts, such as Carlo Gervasoni's treatise La scuola della musica, Piacenza 1800, p. 467.

35 Bertin 2018, p. 59. Loftis 1970, p. 90ff., elaborates on Medtner's codas in greater detail, assuming that these occur in every of his piano sonata movements except for the $3^{\text {rd }}$ movement (Meditazione) of the Sonata romantica, Op. 53 No. 1, which clearly is too diffuse a touchstone for defining the mere existence of a coda.

36 Keller 1971, p. 8f, discusses the proportions of both of Beethoven's sonata movements in detail, also elaborating on possible motivic similarities between the finales of Medtner's Op. 5 and the >Appassionata<; see ibid., p. 29. 
than likely that he would craft his very first published sonata movement after Beethoven's model. James Pitts notes that, much like the $1^{\text {st }}$ movement of Beethoven's Op. 57 in the same key, the sections of Medtner's movement show a nearly even proportion in numbers of measures $(64+63+67+67)$ :

»The first movement of Medtner's first sonata, Op. 5, has divisions of almost identical length. [...] This is an extreme and unusual case of almost exact 1:1:1:1 proportion. Although most cases are not quite so mathematically simple, several of Medtner's sonatas exhibit similar proportions, with a coda of substantial weight. $\ll^{37}$

Whereas this $1^{\text {st }}$ movement appears highly balanced in structure, the finale of the same sonata is much more complicated as it features a doubly interrupted recapitulation section, and incorporates quotes from the previous movements as well as a feigned recurrence of its primary theme (for more details see the analysis in chapter 3.1). To highlight another remarkable example of quaternary sonata form, let us now have a brief look at the Sonata-Elegy in D minor, Op. 11 No. 2, which might serve as a preview to its more detailed discussion following in chapter 3.2.2. In the second of his seminal one-piece single-movement sonatas, Medtner produces a deliberate interdependency of the development and coda sections, the first of which is indicated $»$ V protivopolozhnost' Kode« (»In antagonism to the coda«). The coda itself (m. 79ff.) then presents a transformation and elaboration of the corresponding measures at the beginning of the development section (m. 41f.; see example 3.2.25). The resulting proportions of the four sections are by no means equal $(38+12+28+36$ measures), due to the fact that the secondary theme dominates both the very short development section and coda, and thus needn't be independently recapitulated. Yet the close correspondences of the second and fourth sections, as well as the first and third, make the Sonata-Elegy appear as a particularly balanced example of the first type of quaternary form.

\subsubsection{CYCLIC Form AND CROSS-MOVEMENT RELATION}

As for the tendency to apply a unifying design to multi-movement sonata cycles, Medtner draws on developments starting from the early $19^{\text {th }}$ century with works such as Beethoven's and Berlioz's symphonies, as well as Schubert's Wanderer Fantasy, D. 760. Thus, Medtner's approaches to cyclic form contribute to a line of tradition which includes composers such as Liszt, Franck, Saint-Saëns, and Vincent d'Indy, as well as Schumann, Brahms, and Max Reger. A work like the abovementioned F minor Sonata, Op. 5, features a versatile cyclic interlocking of its four movements by using two of the three possible techniques (outlined in chapter 1.1.3): There are various back-references and quotes from earlier movements, as well as a metamorphosis of the secondary subjects of both the $1^{\text {st }}$ and $4^{\text {th }}$ movements - these are antithetic instances of the same melody, producing a stark contrast in harmony and voicing, comparable to thematic transformations in the sense of Liszt's piano concertos and symphonic poems of the 1850 s.

Transformational procedures are not outstandingly typical of Medtner, but nevertheless found in all of his preferred genres. The cycles of Forgotten Melodies, the chamber works, and even some sets of songs

37 Pitts 1999, p. 4f. 
make intermittent use of >thematicism unity to multi-movement or multi-sectional compositions. Even some of Medtner's single-movement works show certain aspects of cyclic form, such as the Sonata tragica, Op. 39 No. 5, and the $1^{\text {st }}$ Piano Concerto, Op. 33, which substantially employs thematic transformation of its initial idea to form the variation theme arising at the beginning of its inner subdivision (see example 2.1.4).

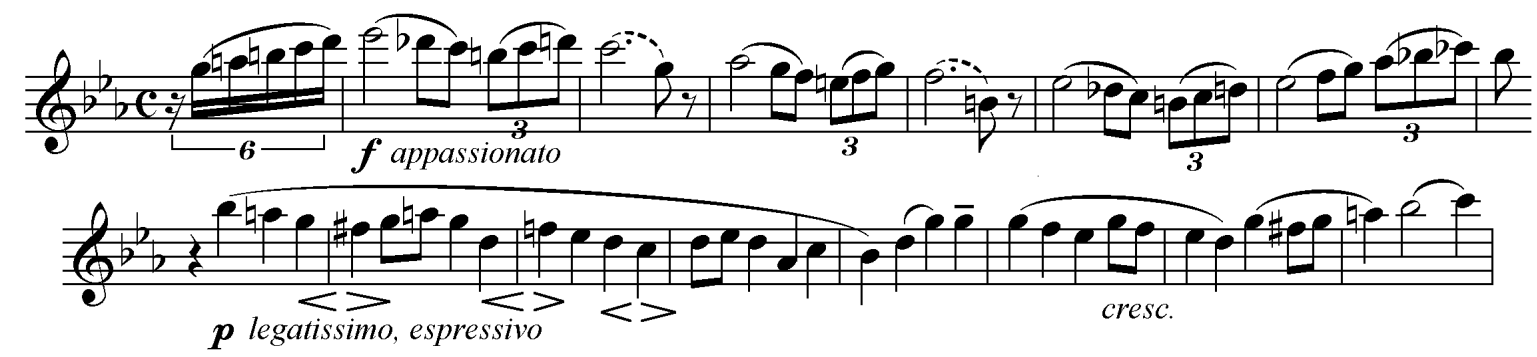

Example 2.1.4: Medtner, $1^{\text {st }}$ Piano Concerto, Op. 33, mm. 4-9 (violins) // mm. 262-269 (top voice of piano part)

One of the most popular strategies related to cyclic multi-movement form is to produce a retrospective synthesis of a work's significant themes in the final movement - a technique first seen in Beethoven's symphonies, and referred to as a >reservoir of themes $<$ by Christoph Flamm. ${ }^{38}$ Medtner applies this technique in every but one of his five multi-movement piano sonatas. ${ }^{39}$ However, while themes are mostly recollected successively as a conclusion, their contrapuntal combination or juxtaposition, as modelled in a work like Franck's Prélude, Choral et Fugue for piano (1884), does not occur in Medtner as often as one would expect. Examples are the $2^{\text {nd }}$ subdivision of the E minor Sonata, Op. 25 No. 2, and the finale of the SonataBallade in $\mathrm{F} \#$ major, Op. 27. The latter movement is a remarkable instance of a >reservoir of themes` as its stretto conclusion brings the initial 〉ballade themeく of the $1^{\text {st }}$ movement to a final synthesis with the so-called $>$ Muza motif - the cyclic idea of the $2^{\text {nd }}$ and $3^{\text {rd }}$ movements from which the finale's secondary theme is derived. A likewise impressive finale is found in the Sonata romantica in Bb minor, Op. 53 No. 1, the $4^{\text {th }}$ movement of which echoes the primary and secondary themes of the $2^{\text {nd }}$ (Scherzo) movement, and also recollects the initial ideas of the $1^{\text {st }}$ (Romanza) and $3^{\text {rd }}$ movements (Meditazione). Beyond the sonata genre, another remarkable example is represented by the $1^{\text {st }}$ cycle of Forgotten Melodies, Op. 38 (1919-20), a multifaceted set of eight interdependent pieces. It commences with the single-movement Sonata-Reminiscenza in A minor, introducing a ritornello which frames the whole opus as a motivic >reminiscence $<$, being varied and restated in the $6^{\text {th }}$ and $7^{\text {th }}$ movements (Canzona serenata and Danza silvestra), while the opening sonata's attribute is echoed in the title of the $8^{\text {th }}$ and last movement, Alla reminiscenza.

38 Flamm 1995, p. 218: »Das Finale [erweist sich] als Sammelbecken für Motive und Themen aller vorangegangenen Sätze und somit als eine Art zyklische Summe des Sonatenganzen. « This statement, referring to Medtner's Op. 5, may be transferred to his other multi-movement sonatas except for Op. 56. See also Flamm 2006, p. 10, where the same strategy is referred to as »resümierende[r] Themenreigen«.

39 See Keller 1971, p. 338f., for an overview of such techniques in Medtner. The author aptly describes the importance of cyclic techniques in stating that the composer was »continually concerned with structural unification in the multi-movement sonatas«, even if he misapprehends the structure of the two Op. 25 sonatas. 


\section{Bipartite Cycles}

A special type of multi-movement cyclic form in Medtner is the combination of an shorter (or introductory) first movement with a longer (or cardinal) second movement, so as to form the shortest possible multimovement correlation, directed towards its ending. A first example of this strategy within the corpus of Medtner's sonatas is found in the Sonata-Vocalise in C major, Op. 41 No. 1, which features a compact setting of Goethe's poem Geweihter Platz, ${ }^{40}$ named a >motto<. This song serves as an introduction to the successive main part, a textless single-movement sonata for voice and piano. Although the smotto might be omitted in performance, it shows a close cyclic interrelation with the sonata in the respect that it prefigures some of its motivic material and determines its semantic sphere as related to the content of Goethe's poem. A second case is Medtner's last piano sonata, the Sonata-Idyll in G major, Op. 56: A short and gentle Pastorale precedes a vigorous movement in sonata form nearly doubling its length. This sonata is extraordinary for its nearly complete omission of dramatic elements and stark contrasts of subjects, as incorporated in most others of Medtner's sonatas. Yet its $2^{\text {nd }}$ movement is a persuasive example of sonatnost', comparable in tone and character to the outer movements of the $2^{\text {nd }}$ Violin Sonata in the same key, Op. 44. Also, the succession of the G major Canzona matinata, Op. 39 No. 4, from the $2^{\text {nd }}$ cycle of Forgotten Melodies, and the successive Sonata tragica form a pair of similar teleology, the C minor tonic of the latter being preceded by a shorter piece in its dominant key. Unlike often experienced in recitals, where the Sonata tragica is performed individually on a regular basis, the incorporation of the Canzona matinata was mandatory in Medtner's opinion. ${ }^{41}$ This is fully convincing in view of the recurrence of its contrasting subject (m. 37ff.; see example 2.1.5), transposed from $F \#$ minor to $G$ minor, within the sonata’s exposition (m. 79ff.) - a cross-reference obscured to the listener if the Canzona is left out.

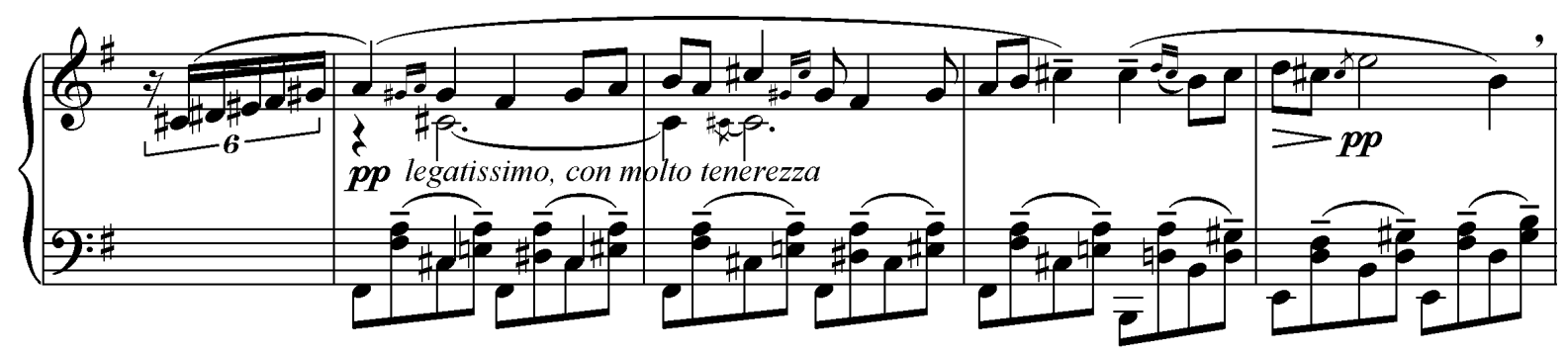

Example 2.1.5: Medtner, Canzona matinata, Op. 39 No. 4, mm. 37-40

Medtner makes use of bipartite trajectories in other genres as well. The diptych of the two Skazki, Op. 8 (1904-06) also incorporates a shorter piece in slow tempo and an extended Allegro, both in the key of

40 That Goethe poem must have been of crucial importance for the period after Medtner's emigration, as he did not only set the text for a second time a few years later, published as his Op. 46 No. 2 (1924), but also modelled the Suite-Vocalise, Op. 41 No. 2 (completed in late 1927 and belatedly paired with its sibling, the Sonata-Vocalise, in one opus), on the same poem, which is discernible in the titles of the suite's movements. See Flamm 1995, p. 206: »Offensichtlich bilden die einzelnen Sätze [der Suite-Vocalise] die Stationen des Gedichtes nach."

41 See the annotation in the Collected Edition, Vol. 3, p. 170: »To be performed in no other way than with the [Canzona] matinata« (»Ispolnyat' ne inache, kak s Matinat'oy«). 
$\mathrm{C}$ minor, and can be considered the earliest example of a two-part cycle in his auvre. ${ }^{42}$ The interrelation is particularly close as both skazki commence with three identical introductory measures, written in $4 / 8$ time in Op. 8 No. 1, and in alla breve (pesante, recitato) in No. 2. Moreover, this phrase reappears as a mutual closure to both pieces, serving as a framing agent. In Medtner's Twelve Goethe Songs, Op. 15 (1908-09), the successive pair of Meeresstille and Glückliche Fahrt (Nos. 7-8) forms a bipartite micro-cycle, reproducing the original coupling of the poems: The latter song, to be played attacca afterwards, responds to the former by means of its tonality (F\# minor - F\# major) and thematic substance. ${ }^{43}$ In analogy to the Skazki, Op. 8, the two late Elegies, Op. 59 (1940-41), are interconnected through their mutual opening phrase which is transposed from the A minor of the first piece to the $\mathrm{Eb}$ minor of the second, while the semiquaver movement is augmented to quavers (see example 2.1.6). However, other than in Op. 8, the tonalities of these two pieces, both of which show an exactly equal length of 108 measures, form a polar contrast as their roots $A$ and $E b$ are directly opposed in the circle-of-fifths - the same opposition of keys as seen in the prelude to the $1^{\text {st }}$ act of Richard Wagner's Tristan and Isolde.
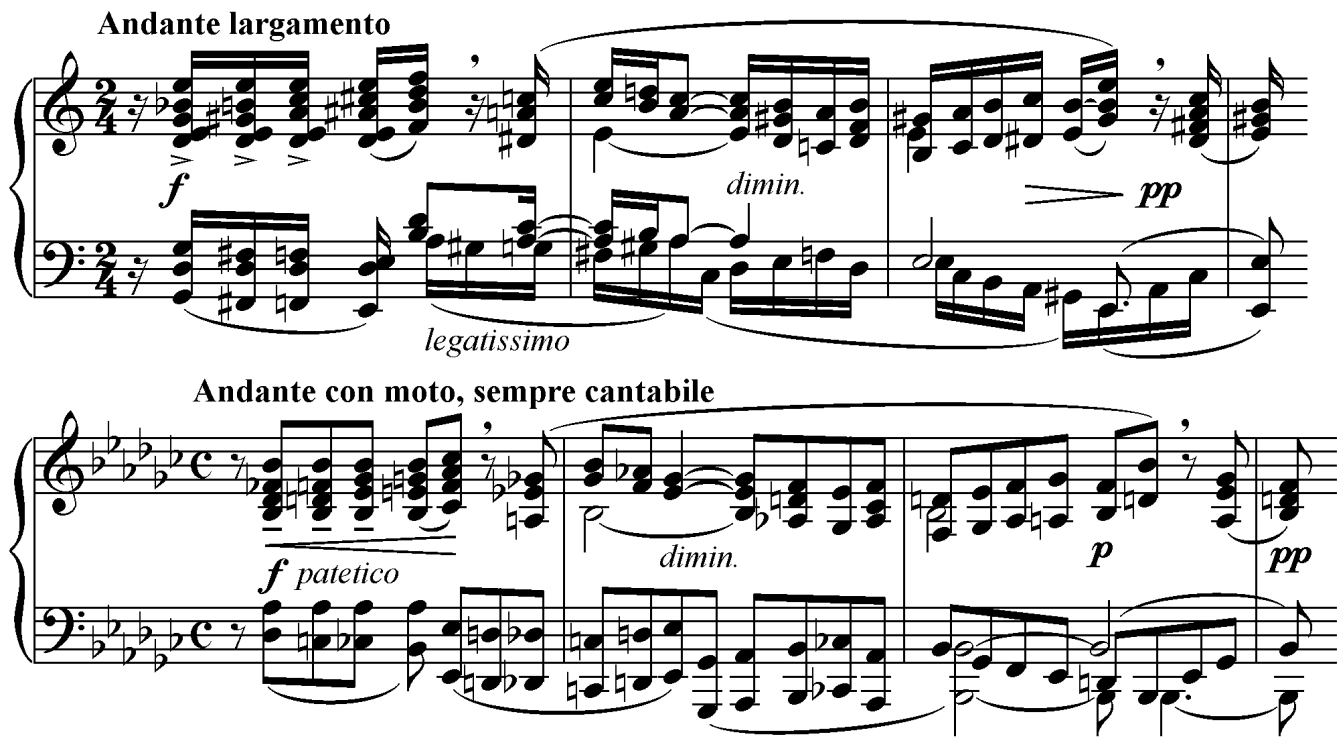

Example 2.1.6: Medtner, Elegy, Op. 59 No. 1, mm. 1-3 // Elegy, Op. 59 No. 2, mm. 1-3

Another coupling typical of Medtner is the succession of two shorter pieces opposed in character, Canzona and Danza, which also tends to combine a slower cantabile piece with a fast and lively movement. A pair of this kind is comprised in the $1^{\text {st }}$ Violin Sonata in B minor, Op. 21, where Canzona and Danza are represented by the $1^{\text {st }}$ and $2^{\text {nd }}$ movements, and followed by a Ditirambo as the final movement. After that, we find similar structures in the Forgotten Melodies, Op. 38 (1919-20), Nos. 4-5 (Canzona fluviala and Danza rustica) and 6-7 (Canzona serenata and Danza silvestra), as well as in the Canzonas with Dances for violin and piano, Op. 43 (1924-25).

42 See Dolinskaya 2013, p. 120. The author also considers the Introduzione of the E minor Sonata, Op. 25 No. 2, and the successive Allegro as a similar pair of sections, even if there follows a second subdivision of nearly equal length.

43 See Flamm 1995, p. 169f. 


\subsection{Melodic InVENTION AND DEVELOPMENT}

In virtually all of Medtner's music, the generative moment of motives and phrases seems to be derived either from the specific demands of piano technique, or from the cantilena of the human voice transferred to the keyboard. Like in the works of other composer-pianists, such as Medtner's predecessors Chopin, Liszt, and Scriabin, motivic and melodic invention mostly expresses itself as a function of pianistic texture. On the contrary, Medtner did not as much rely on aspects of instrumental colours or timbres, or their possible analogies on the keyboard, as on genuine techniques of piano articulation, such as cantabile, leggiero, martellato, and other common characters. The few exceptions from that predisposition (see, for example, the solo and tutti contrast in the development and coda sections of the Sonata-Elegy, Op. 11 No. 2, or the quasi violoncello indication at the entrance of the secondary theme from the $1^{\text {st }}$ movement of the Sonata-Skazka, Op. 25 No. 1) do not contradict the general tendency. Since Medtner's only orchestral works are his three piano concertos, and he otherwise appeared reluctant to deal with symphonic or chamber instrumentation, ${ }^{44}$ it may seem sufficient to deduce the features of his melodic invention mainly from the conditions of piano playing.

\subsubsection{General TRAits of MELODY}

I will now attempt to identify some general characteristics of Medtner's melos, supported by a number of examples from works of different genres. These observations do by no means claim to describe exclusive features of Medtner's style; they are naturally found in the music of his predecessors, contemporaries, and some of his successors as well. The findings rather serve as a single module in the overall goal of exemplifying the composer's musical language through various elements and parameters of his music, and as such must be regarded in the context of other peculiarities examined in the following chapters.

The most typical features of Medtner's melodic style seem to be cantability and small-interval movement, particularly when looking at main themes and subjects constitutive of the respective musical forms and genres. The general range of melodies may be extensive; yet, in the individual progression from one tone to another, intervals of major and minor seconds are preferred. This is a quality Medtner shares with other Russian composers of his time, most obviously Rachmaninov, whose melodic invention has often been portrayed as derived from Orthodox chant - which appears plausible due to the composer's deep-rooted religious belief and indebtedness to the spiritual sphere of Tsarist Russia before his emigration. ${ }^{45}$ For Medtner, this motivation seems less apparent as he converted from Protestant to Orthodox faith only in 1935, and was primarily committed to the metaphysical and spiritual ideas of Russian Symbolism during his early years. However, a familiarity with Russian folk and church music may be taken for granted, and it seems not fallacious to draw a parallel between some of his smoothly crafted melodies to znamennïy razpev, the unison liturgical chant of Orthodox church music, as well as to the technique of protyazhnaya pesnya (>elongated song ‘),

44 The young Medtner had projected a number of orchestral works, but none of these grew beyond the draft stage. Later, two of his pieces published as part of the $3^{\text {rd }}$ set of Forgotten Melodies, the Danza sinfonica and Danza ditirambica, Op. 40 Nos. 2 and 6, were sketched as symphonic dances but soon abandoned. See Flamm 1995, p. 478.

45 See, for example, Wehrmeyer 2000, p. 87 f. 
the melismatic cantilena of ancient Russian folk song. Barrie Martyn goes as far as to perceive echoes of the Orthodox chant Christ is risen in Medtner's Sonata epica for violin and piano, Op. 57, and the Piano Quintet, Op. posth. ${ }^{46}$ Yet one of the most remarkable instances of liturgically-inspired melos seems to be the unaccompanied Andante con moto theme from the $2^{\text {nd }}$ movement of the $2^{\text {nd }}$ Violin Sonata in G major, Op. 44 (see example 2.2.1). ${ }^{47}$

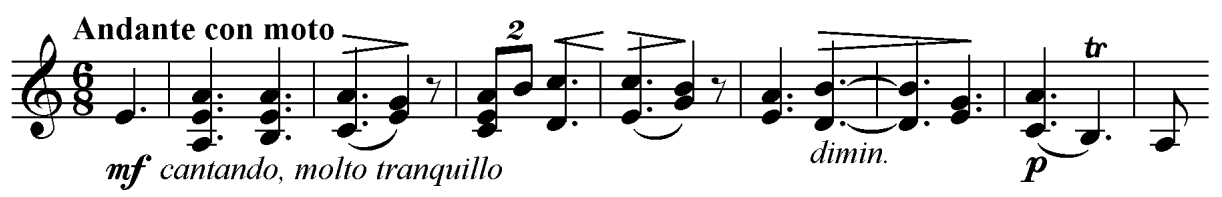

Example 2.2.1: Medtner, $2^{\text {nd }}$ Violin Sonata, Op. 44, $2^{\text {nd }}$ mvt, mm. 1-7 (violin part)

In Medtner scholarship, this predilection for $\gg$ conjunct melodic motion $\aleph^{48}$ is sometimes referred to as $>$ melismatic style $<$ or >vocalise style $<$. This type of melody is naturally found in Medtner's vocalise compositions (Op. 41 Nos. 1 and 2, as well as textless phrases included in a number of his songs, such as Op. 6 No. 3, Op. 36 No. 6 , Op. 37 No. 1, Op. 52 No. 6, and Op. 61 No. 6$),{ }^{49}$ but there also are numerous piano cantilenas much representative of this type of melody. An apposite instance is the initial theme of the $\mathrm{B} b$ minor Skazka, Op. 20 No. 1 (1908-09), a piece much reminiscent of Rachmaninov in several respects; and even more, the secondary theme from the $1^{\text {st }}$ movement of the $2^{\text {nd }}$ Piano Concerto in C minor, Op. 50, resembles the appealing cantabile of many of its dedicatee's melodies. More characteristic examples include the abovementioned subject from the Canzona matinata and Sonata tragica, Op. 39 Nos. 4 and 5 (see example 2.1.4), and the ample cantilena of the introductory theme from the E minor Sonata, Op. 25 No. 2 (see example 3.5.4).

Another distinctive feature is the multiple repetition of the same note in a melodic line, particularly often at the beginnings of themes. As Sarah Kinley has noted, one of the »peculiarities of Medtner's style« is represented by »repeated melody notes in groups of three «. ${ }^{50}$ To substantiate that observation, I might add that the exact number of repetitions may considerably vary, and that the most likely environment for this feature to occur seems to be the anacrusis of pieces and themes in binary meter - a somewhat restricted condition which can be exemplified by a number of subjects from throughout Medtner's piano sonatas, as seen in the list below. ${ }^{51}$ Many other passages can be found to support this assumption. However, some of these do

46 See Martyn 1995, pp. 227f. and 250; this notion might have been taken over from Pinsonneault 1956, p. 27. Martyn finds another possible reference to Orthodox chant in the Lermontov song Nishchiy »U vrat obiteli svyatoy« (The Beggar $»$ At the Gate of the Holy Abode«), Op. 3 No. 1 (1903); see ibid., p. 21.

47 Yasser 1955, p. 63, also discusses this theme as a melody »which sounds almost like a representative specimen of the znamennyi raspév«.

48 Elmore 1972, p. 16ff.

49 I have earlier proposed an algorithm how to examine the interval contour of a melody, judging its $>$ smoothness $<$ by means of a statistic analysis of conjunct and disjunct motion, discussing vocalise compositions by Rachmaninov, Medtner, and Reinhold Glière. For the Medtner examples, including excerpts from Op. 41 Nos. 1 and 2 as well as from some songs, see Bitzan 2014, p. 5ff.

50 Kinley 1970, pp. 15f. See also ibid., p. 25f.: »Triple repetition of a note in a melodic line is also a favourite melodic tendency of Medtner «, which appears as imprecise as the first quote.

51 See also Yagodkina 1959, p. 56, for a number of occurrences of themes commencing with four identical pitches. 
not figure as substantial themes, such as the first two measures of the Lyric Fragment in C minor, Op. 23 No. 1 (1910), which commence with sixteen semiquaver repetitions of $\mathrm{Eb}-\mathrm{a}$ structure which turns out as an accompanying figure once a more distinctive melody enters (m. 3ff.). Bradley Emerson refers to a large number of motives with repeated pitches as possible references to Medtner's so-called `Muza motif $\iota$ as introduced in the Sonata-Ballade, Op. 27, and the Pushkin song Muza (The Muse), Op. 29 No. 1 (see chapter 3.6.2), ${ }^{52}$ although it may seem at least doubtful that the corresponding semantic context applies to every of the cases from the following list.

- $\quad$ F minor Sonata, Op. 5, $1^{\text {st }}$ movement: transitional idea (mm. 14f., 25ff., 148ff.) - four notes $(A b, G, C)$, starting with an anacrusis.

- $\quad$ Skazka in C minor, Op. 8 No. 2 (1904-06): secondary theme (mm. 32ff., $187 \mathrm{ff}$.), also set in an extended canon (m. 121ff.; see example 2.1.1) - five notes ( $B b, E b$, and others), starting from the downbeat, preceded by two upbeat quavers.

- C major Sonata, Op. 11 No. 3: tertiary theme, arising in the development section (m. 91f.: see example $3.2 .34, \mathrm{~m} .204 \mathrm{ff}$.) - four notes $(E, G)$, starting with an anacrusis.

- G minor Sonata, Op. 22: an episode forming the middle section of the primary theme (m. 18ff.: see example 3.34, m. 383ff.), being quoted also in the development section (m. 165ff.) - seven notes (Eb and others), starting from the downbeat, preceded by three upbeat quavers.

- $\quad$ Sonata-Skazka in C minor, Op. 25 No. $1,1^{\text {st }}$ movement: secondary theme (mm. 26, 79, 101) - three notes $(D, E, G)$ starting from the downbeat.

- E minor Sonata, Op. 25 No. 2: first initial subject of the $2^{\text {nd }}$ subdivision (m. 285f.: see example 3.5.10), also inverted (m. 289f.) and processed as a fugato (m. $311 \mathrm{ff}$.) - four notes ( $B$ and $E$ ), starting with an anacrusis.

- $\quad$ Sonata-Ballade in F\# major, Op. 27: occurrences of the >Muza< motif in the $2^{\text {nd }}$ (mm. 37f., 44ff.: see examples 3.6.6 and 3.6.7) and $3^{\text {rd }}$ movements (mm. 49f., 314f.: see examples 3.6.8 and 3.6.9) - three notes $(A \#, B b, C \#)$, starting with an anacrusis.

- $\quad$ Sonata tragica in C minor, Op. 39 No. 5: primary theme (m. 1ff.: see example 2.1.2), the most impressive instance of which is a solo-voice episode in the development centre (m. $151 \mathrm{ff}$.) - four notes $(C$ or $E$ b), starting from the downbeat.

\subsubsection{SCALES AND MODES}

As a rule, Medtner's musical material is basically diatonic, except for occasional passages where he would resort to other types of heptatonic or octatonic scales_-but even then, he is likely to return to an unmistakably diatonic environment after a couple of measures. Altered pitches and chords are, as one would expect from an early- $20^{\text {th }}$-century composer, employed to a considerable extent, as is the frequent use of highly chromaticised harmony; yet these firmly rest upon an underlying major/minor tonality in virtually every case, which is left behind only temporarily. There are, however, a number of characteristic tendencies regarding the treatment of modal diatonic and non-diatonic scales in Medtner, appearing at times idiosyncratically remote from their traditional usage. 
Medtner has an obvious $»$ predilection for harmonising on the ascending minor scale $\left(6^{\text {th }}\right.$ and $7^{\text {th }}$ scale degrees raised persistently) ${ }^{53}$ In other words, he favours the melodic-minor mode, a scale with minor third, major sixth, and major seventh, which he uses not only in its traditional upward direction but also in descending melodies, resulting in a material distinguishable from the major mode only by the $3^{\text {rd }}$ scale degree. A paradigmatic example is found in the initial measures of the Sonata tragica in C minor, Op. 39 No. 5 (see example 2.1.2); for other prominent passages see the beginning of the development section of the Sonata-Elegy in D minor, Op. 11 No. 2 (m. 40f.), and a charming episode located in the middle of the Sonata-Vocalise in C major, Op. 41 No. 1 (m. 143ff.). Besides the traditional possibilities associated with the melodic-minor scale, including the application of leading-tones without an augmented second between the $6^{\text {th }}$ and $7^{\text {th }}$ scale degrees, Medtner also draws consequences in harmony, frequently employing chord with the sharpened sixth as a characteristic component of cadences. This means that, in a minor-mode context, subdominant chords tend to the major (see chapter 2.4.1). Another implication of the melodic-minor scale is that its $3^{\text {rd }}$ to $7^{\text {th }}$ degrees comprise four major seconds, or five out of six notes of a whole-tone (hexatonic) scale - a material not typically used by Medtner, which is however found in certain places, mostly in patterns of large-scale sequences. Examples include a striking passage from the Grozovaya Sonata, Op. 53 No. 2, where major triads and dominant seventh chords with the roots $E-B b, D-A b$, and $C$ alternate (m. 67ff.; see example 2.2.2), ${ }^{54}$ or the Maestoso ma a tempo episode from the Interludium of the G minor Sonata, Op. 22 (m. 222ff.).

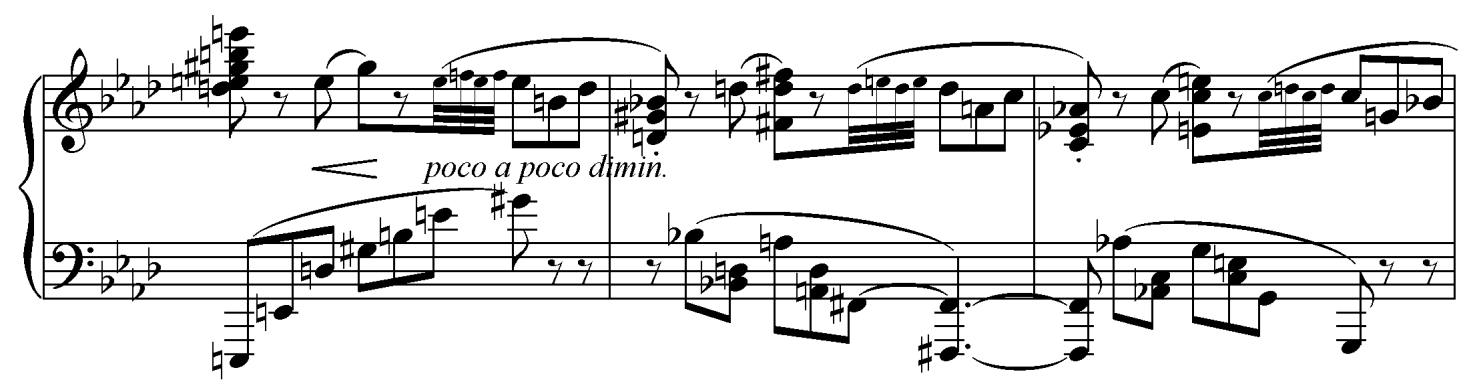

Example 2.2.2: Medtner, Grozovaya Sonata, Op. 53 No. 2, exposition, mm. 67-69

\section{Diatonic Modes}

If the $7^{\text {th }}$ degree of the melodic-minor scale is not raised, thus dispensing with a leading-tone, the material is equivalent to the Dorian mode which is prominently used by Medtner in many places. There are numerous occurrences of passages, sections, or even whole pieces written in that mode, appearing as the most popular modal key in Medtner's music. The Phrygian mode is also frequently found, while Lydian and Mixolydian occur much more rarely. While the Dorian mode, or other inflections and derivations from the melodicminor scale, continuously appears throughout Medtner's œuvre, other modal scales seem to occur less regularly in his early period, and only gain importance during the years of emigration.

53 Swan $1927^{\mathrm{a}}$, p. 48.

54 See Pitts 2004, p. 33f., emphasising that this sequence is constructed from a pivotal tritone progression. 
(1) Dorian mode

F minor Skazka >Song of Ophelia<, Op. 14 No. 1 (1906-07): $:{ }^{55}$ initial theme, starting with a major IV

Sonata-Ballade in F\# major, Op. 27: $2^{\text {nd }}$ movement, initial theme (m. 1ff.), including a leading-tone

A minor Skazka, Op. 51 No. 2 (1928): written with a key signature of one sharp throughout

Sonata-Reminiscenza in A minor, Op. 38 No. 1: primary theme (m. 13ff.; see example 2.2.3)

$3^{\text {rd }}$ Piano Concerto in E minor, Op. 60: introduction to the $1^{\text {st }}$ subdivision (m. $7 \mathrm{ff}$.)

(2) Phrygian mode

B minor $S k a z k a>$ Campanella<, Op. 20 No. 2 (1908-09): ostinato figure $F \# E-D-C \# C$ recurring throughout Sonata-Skazka in C minor, Op. 25 No. 2: transition connecting the $2^{\text {nd }}$ (m. 79ff.) to the $3^{\text {rd }}$ movement A minor Sonata, Op. 30: beginning of the coda (m. 507ff) ${ }^{56}$ referring back to the secondary theme $1^{\text {st }}$ Improvisation in Bb minor, Op. 31 No. 1 (1914): conclusion of the variation theme (m. 27ff.) A minor Skazka, Op. 34 No. 3 (1916): main theme (m. 5ff.), resembling the Gregorian chant Dies irae C minor Skazka, Op. 42 No. 2 (1924): subtitled `frigiyskiy lad«, with a key signature of four flats

(3) Lydian mode

Piano Quintet in C major, Op. posth.: $1^{\text {st }}$ movement, primary theme (m. 13ff.; example 2.2.4)

Piano Quintet in C major, Op. posth.: $1^{\text {st }}$ movement, >Muza motif (m. 71ff.; examples 3.6.12 and 3.6.15)

(4) Mixolydian mode

B minor Skazka >The Magic Violin<, Op. 34 No. 1 (1916): theme of final section (m. 149ff.; example 2.2.5)

Danza rustica in C major, Op. 38 No. 5 (1922): initial theme (m. 5ff.)

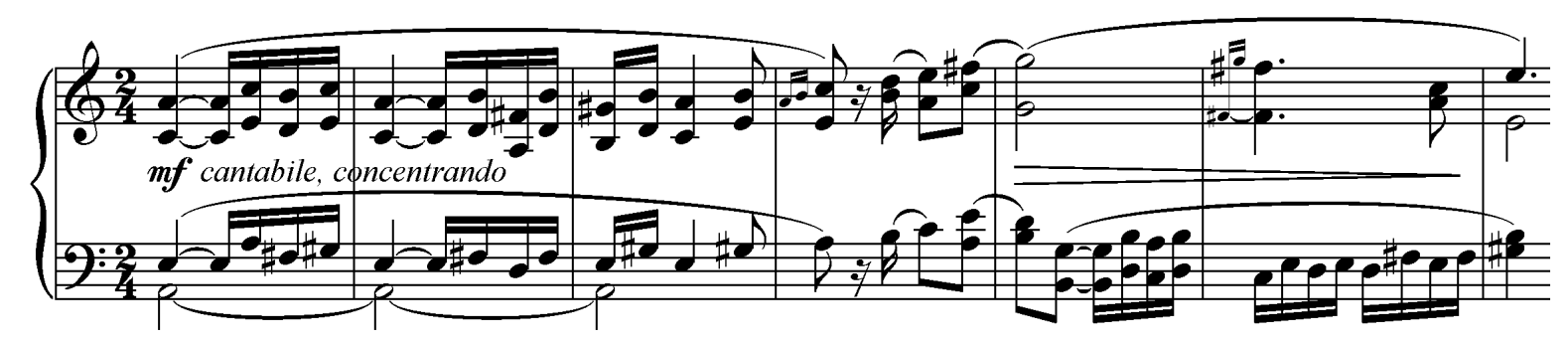

Example 2.2.3: Medtner, Sonata-Reminiscenza, Op. 38 No. 1, exposition, mm. 17-23

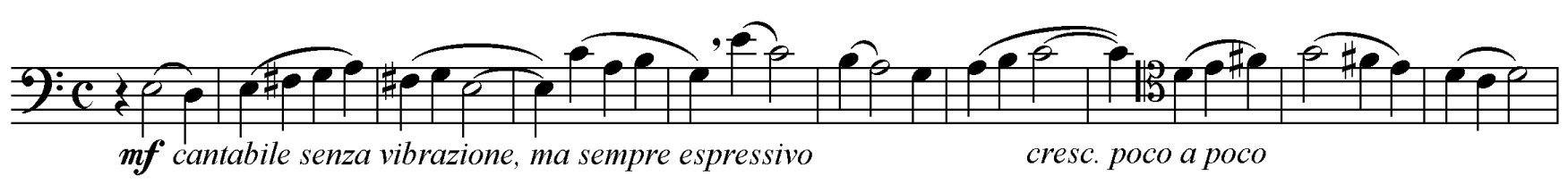

Example 2.2.4: Medtner, Piano Quintet, Op. posth., ${ }^{\text {st }} \mathrm{mvt}$, mm. 13-22 (cello part)

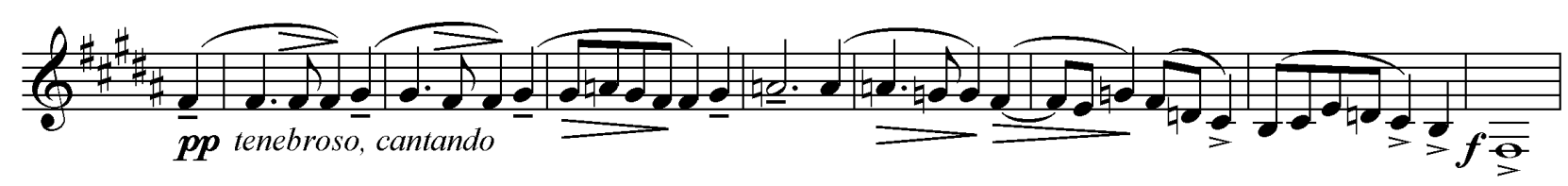

Example 2.2.5: Medtner, Skazka, Op. 34 No. 1, final section, mm. 149-156 (motivic reduction)

55 See Alekseyev 1969, p. 266: »Here occurs a Dorian-mode colouring« (»V p’ese vstrechaetsya doriyskaya ladovaya okraska «).

56 Elmore 1972, p. 26, gives a somewhat confusing account of the several transpositions of that subject. In fact, the Phrygian mode is not clearly discernible before its final manifestation in the coda. 


\section{Non-Diatonic Scales}

There are two manifestations of non-diatonic scales variously occurring in Medtner. The following examples are quoted from introductions, development sections, or codas, where harmonic progressions have significantly diverged from the movements' respective tonal centre - or a stable tonic has not yet been established. The acoustic scale, a heptatonic variant of the major mode with augmented fourth and minor seventh, is alternatively conceived as a synthetic scale derived from the superposition of Lydian ( $1^{\text {st }}$ to $5^{\text {th }}$ degrees) and Mixolydian modes $\left(5^{\text {th }}\right.$ to $8^{\text {th }}$ degrees$)$, and correspondingly named $>$ Mixolydian- $\sharp 11<$ or $>$ Lydian dominant $<$ scale. Two of its most impressive instances in Medtner are a climactic passage from the $2^{\text {nd }}$ subdivision of the E minor Sonata, Op. 25 No. 2 (m. 512ff.), and an episode from the $1^{\text {st }}$ movement's development section of the Sonata-Ballade, Op. 27. Here, dense processing of the transitional theme establishes a culmination, preceding the retransition, and sounding all in D-acoustic major (m. 124ff.; see example 2.2.6).

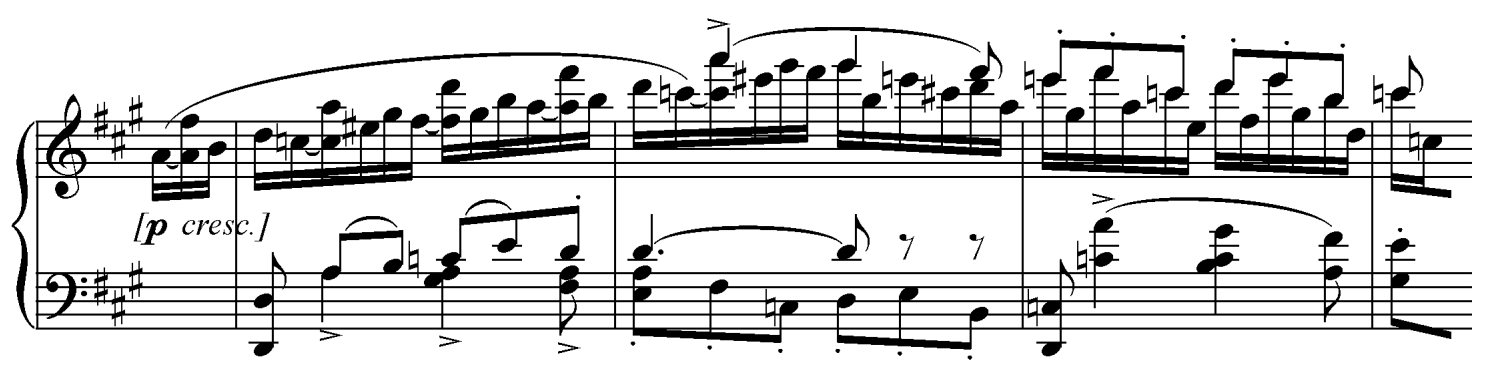

Example 2.2.6: Medtner, Sonata-Ballade, Op. 27, $1^{\text {st }}$ mvt, development, mm. 126-128

The other significant type of non-diatonic, non-heptatonic material found in Medtner is the symmetrical octatonic scale, constructed from alternating half-tone and whole-tone steps - an old acquaintance known from the music of Liszt, Mussorgsky, Tchaikovsky, Scriabin and, most significantly, Rimsky-Korsakov. ${ }^{57}$ A passage showcasing that scale in exemplary manner is heard in the introduction to Medtner's B minor Skazka >The Magic Violin< (1916), Op. 34 No. 1, where an ascending sequence of major triads is shifted upward by minor thirds, and polyrhythmically combined with a $\mathrm{F}^{7}$ arpeggio in the left hand (m. 5f.; see example 2.2.7) ${ }^{58}$ Other noteworthy examples, also constructed from sequences of major triads or half-diminished seventh chords shifting by minor thirds, are found in the development sections of the G minor Sonata, Op. 22 (m. 181ff.: $\mathrm{G}^{7 / 55}-\mathrm{B}^{7 / 55}$ ), and A minor Sonata, Op. 30 (m. 316ff: D major - Ab major - B major - F major).

57 In the theory of Boleslav Yavorsky, octatonism is referred to as >duplex chain $<$ or $>$ duplex diminished mode , derived from his concept of symmetrical single and double tritone systems, while in the school of Yuri Kholopov it is, among other symmetrical modes, called the >diminished scaleく or `Rimsky-Korsakov scaleく. See Kholopov 1975, p. 406f.

58 See Chernaya-Oh 2008, p. 22, as well as Pitts 1999, p. 40ff. The latter author gives some further examples of octatonic scales, taken from the Sonata-Ballade, Op. 27, the A minor Sonata, Op. 30, the Sonata tragica, Op. 39 No. 5 , and the $3^{\text {rd }}$ Piano Concerto, Op. 60. 


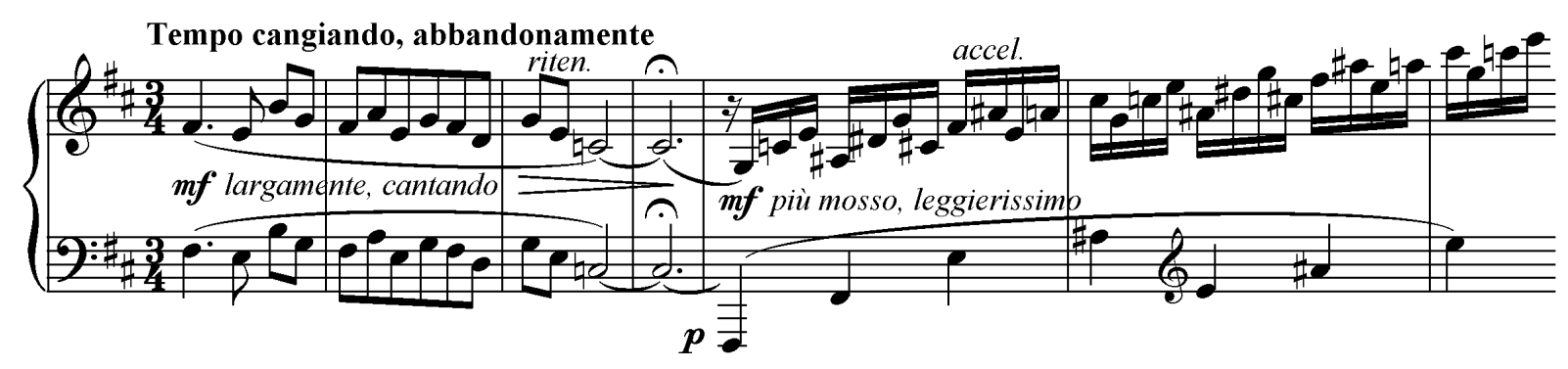

Example 2.2.7: Medtner, Skazka, Op. 34 No. 1, introduction, mm. 1-7

\subsubsection{ASPECTS OF METER AND RHYTHM}

Medtner's pianistic textures show a remarkable predilection for rhythmic density and complexity, especially when compared to the works of his contemporaries. Shifting and irregular accentuation (sometimes resulting in the illusion of virtual time signatures), asymmetrical divisions of note values and measures, as well as polyrhythmic and polymetric structures, are omnipresent in his music. The following observations aim to exemplify these tendencies in quoting but a few characteristic passages.

A rather simple instance of shifting accents is found in a passage from the C minor Skazka, Op. 8 No. 1 (1904-06), where the phrasing gives the illusion of $3 / 8$ time against the actual $2 / 4$ signature (m 9ff.). In addition, the beamed groups of three quavers in the melody and accompaniment are deliberately set askew by one quaver. More sophisticatedly, the violin part at the beginning of the $2^{\text {nd }}$ movement (Danza) from the $1^{\text {st }}$ Violin Sonata in B minor, Op. 21, suggests a 5/8 meter superposed to the denoted 2/4 time as evident in the piano part (m. 1ff., set in canon against the pianist's right hand from $\mathrm{m}$. 61ff.; see example 2.2.8). A similar situation can be observed in the $2^{\text {nd }}$ movement (Scherzo) of the Sonata epica in E minor, Op. 57: The initial theme unfolds a $4 / 4$ theme in patterns of two measures, each in a palindromic grouping of $4+3+2+3+4$ quavers, while the accentuation of the violin part slightly diverges from that of the piano.

On the contrary, when looking at the accompaniment of the secondary theme from the $1^{\text {st }}$ movement of the Sonata-Ballade, Op. 27, we find shifting accents of a much more complex type: In a $\mathrm{D} \#$ minor passage heard at the first occurrence of that subject (m. 35f.), the dotted rhythms, comprising halves of the $6 / 8$ measures, are combined with the same pattern in the left hand-but delayed by one quaver, giving a particular out-of-phase impression. Some measures later, in an A\# minor variant of the same subject (m. 44f.), the melody is provided with a new polymetric accompaniment which subdivides the $3 / 8$ units in duplets of dotted quavers, delayed by a semiquaver (see example 3.6.2 for both passages). 


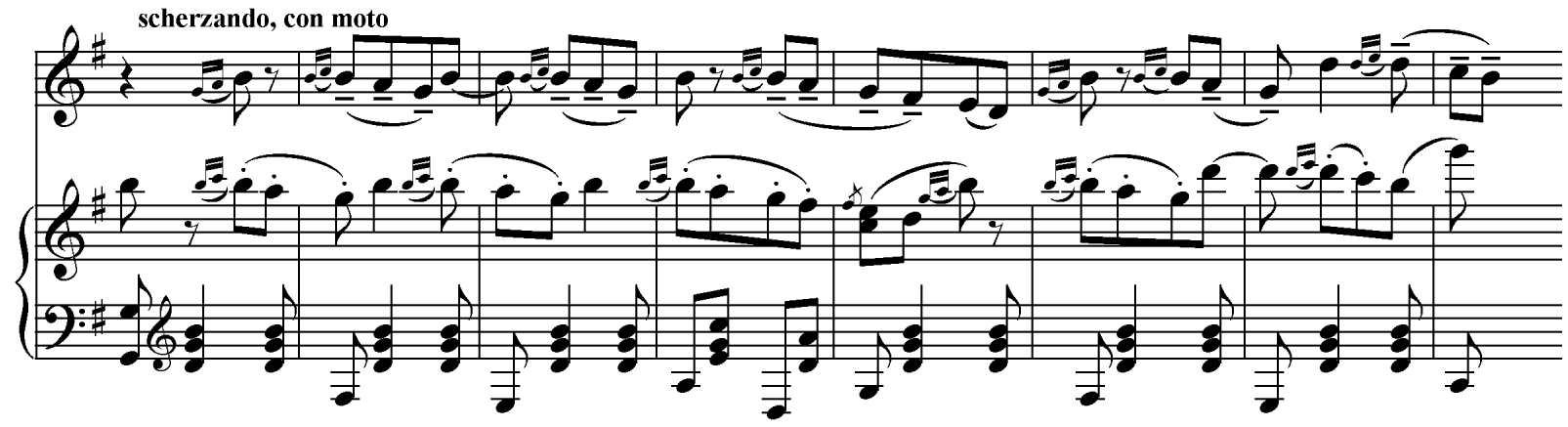

Example 2.2.8: Medtner, $1^{\text {st }}$ Violin Sonata, Op. 21, $2^{\text {nd }}$ mvt, mm. 61-68

An early and frequently quoted example of Medtnerian polyrhythm is found in the E major Prologue from the Stimmungsbilder, Op. 1 (1901). ${ }^{59}$ Its $4 / 4$ time is continuously subdivided in triplets of minims which represent the principal melody, supported by a heterophonic unison of $3+3+2$ quavers in the tenor voice. Figurations of quavers in the left hand, and of quaver triplets in the right hand's upper voice, produce units of twelve ternary quavers per measure, simultaneously fractured in groups of six, four, and three notes. In a similar manner, a passage from the $3^{\text {rd }}$ movement of the F minor Sonata, Op. 5, employs concurrent subdivisions of a crotchet in three, four, and six notes (m. 24f.; see example 3.1.7). Even more intense polyrhythm is found in the concluding section of the G minor Sonata, Op. 22: The Languido passage of m. 397ff. shows a three-versus-four subdivision of the right and left hands, being further refined in the course of the Molto appassionato coda (m. 413ff.: see example 2.2.9) where each of the ternary crotchets is again subdivided in quaver triplets, resulting in a nine-versus-four polyrhythmic design.

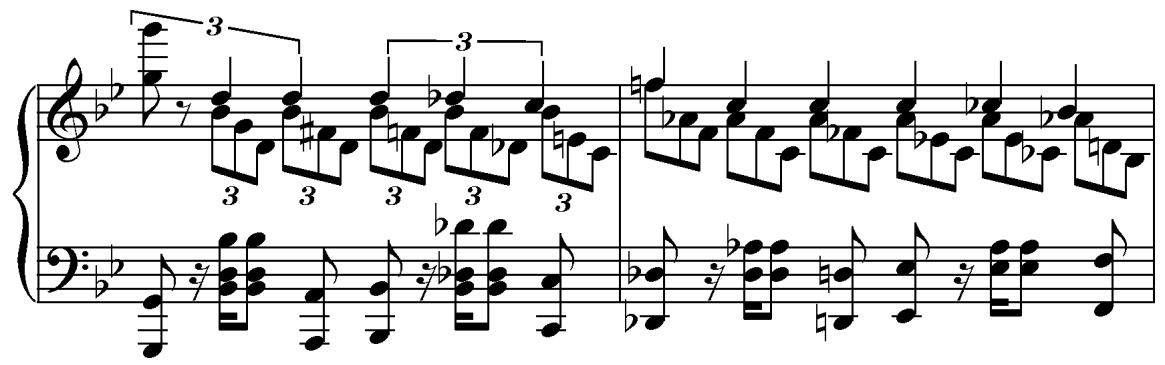

Example 2.2.9: Medtner, Sonata, Op. 22, coda, mm. 413-414

Medtner also occasionally achieves polymeter by asymmetrical division of time signatures, such as the $15 / 8$ time of the $1^{\text {st }}$ subdivision of the E minor Sonata, Op. 25 No. 2, which is in fact a ternary variant of 5/4 time. In a passage from the secondary theme zone, a grouping of $3+3+2+2+2$ quavers arises ( $\mathrm{mm} .99$ and 102), giving the impression of beats of diverging length. However, asymmetrical divisions of that kind do not necessarily require prime-number-based time signatures, as seen in the Goethe songs Im Vorübergehn, Op. 6 No. 4 (1903), with its initial vocal melody commencing in mm. 4f. and 32f., and Meeresstille, Op. 15 No. 7

59 This piece also exists in a version for voice and piano, based on Lermontov's poem Angel (The Angel), Op. ${ }^{\text {bis }}$ (transposed to Db major and finally completed in 1908). 
(1908-09). Both of these pieces show a grouping of $3+3+2$ quavers in $4 / 4$ or $8 / 8$ time (for the latter see example 2.2.10; the rhythm of the piano accompaniment lasts throughout the piece). Polymeter can thus, in Medtner, appear in three different guises: (a) constructed from uneven beat durations, as seen in the abovementioned examples; (b) by superposition of different meters of which only one is notated - such as the ambivalent notion of $3 / 2$ (or even $7 / 8+5 / 8$ ) against the denoted $6 / 4$ time - as conceived in the violin part of the $1^{\text {st }}$ movement of the Sonata epica, Op. 57 (m. 54ff.: Allegro); (c) or from irregular metric divisions combined with shifting accents, resulting in the illusion of two different time signatures being heard simultaneously, as in the passage from Op. 27 quoted above. Another striking example is found in a passage from Danza silvestra (Sylvan Dance), Op. 38 No. 7 (1920): In 4/8 time, the right hand is organised in syncopated rhythms of quavers and semiquavers, while the left has triplets of crotchets (m. 113f.; see example 2.2.11). The eightversus three division resulting from this superposition is further subdivided in eight-versus-twelve by introducing semiquavers within the ternary crotchets (m. $115 \mathrm{f}$.). ${ }^{60}$

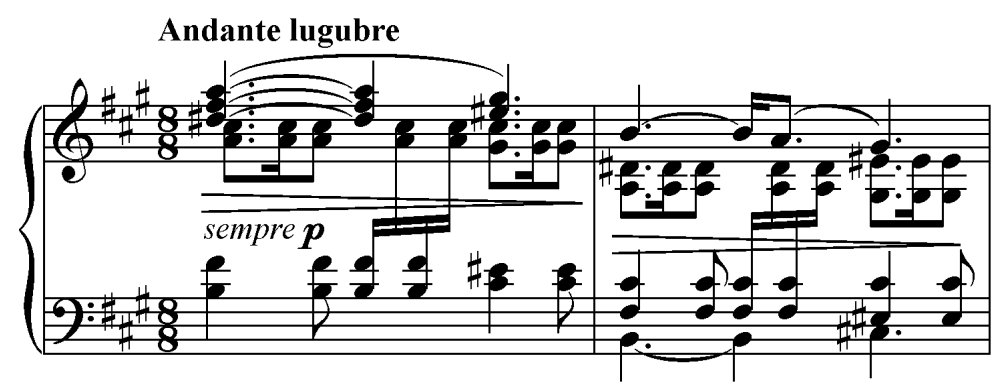

Example 2.2.10: Medtner, Twelve Goethe Songs: Meeresstille, Op. 15 No. 7, mm. 1-2 (piano part)

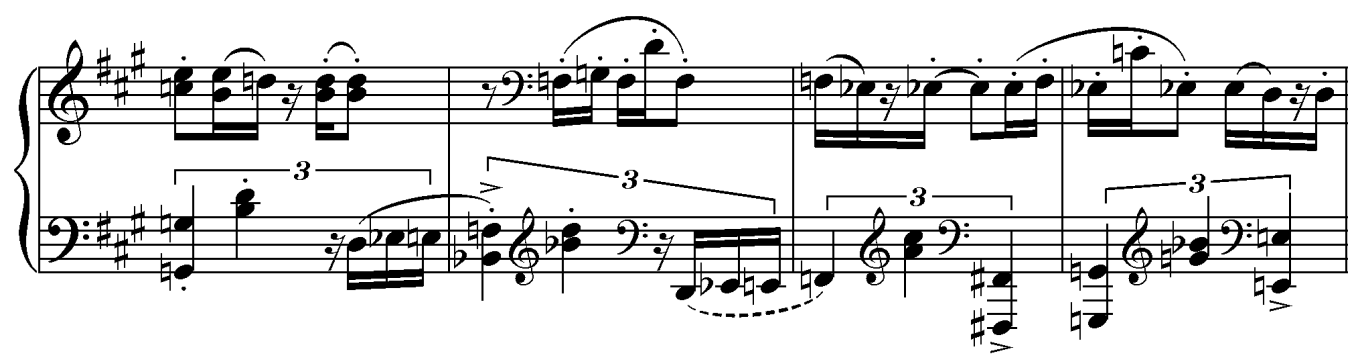

Example 2.2.11: Medtner, Forgotten Melodies, $1^{\text {st }}$ cycle: Danza silvestra, Op. 38 No. 7, mm. 113-116

\subsubsection{SyNTAX AND CONSTRUCTION OF THEMES}

Somebody with only a rough knowledge of Medtner's music might assume that simple structures, such as eight-measure periods, sentences, and other theme types structured in square numbers of measures, form the basis of Medtner's syntactical thinking. While this holds true for some other composers of his generation, including Scriabin and Rachmaninov, traditional syntax is, in Medtner, subject to a wide variety of deviations

60 According to Alekseyev 1969, p. 262, this intricate polymeter suggests the image of the bizarre fluttering of forest birds $\gg[$ Poliritmicheskie sochetaniya] prizvanï sozdat' vpechatlenie prichudlivogo tantsa-porkhaniy obitateley lesnïk chashch «). 
from the standard models as determined in the theories of Arnold Schoenberg, Erwin Ratz, and William Caplin. With reference to the terminology of Caplin's Classical Form, I will now list a number of ideal-typical examples in Medtner which indeed adhere to the Classical schemes. Many of these are found in primary and secondary themes from sonata movements. However, this collection must not obstruct the view from the many other examples that do not fit to these models at all. In fact, the majority of Medtner's themes, especially vocal subjects from his songs and those from the skazki written in a folkloristic tone, feature asymmetric phrases and flexible grouping of measures, and lack clear repetitions and variants of their basic ideas. Thus, they largely seem to reject a classification according to analytical models - and rightly so, as it was Medtner's permanent effort to never reproduce, but to freely adopt traditional patterns in his individual and creative way.

(a) Period

Pushkin song Zimniy vecher (Winter Evening), Op. 13 No. 1: initial theme

Goethe song Selbstbetrug, Op. 15 No. 3: initial theme

$1^{\text {st }}$ Improvisation in $\mathrm{B} b$ minor, Op. 31 No. 1: initial variation theme

B minor Skazka, Op. 34 No. 1: initial theme

Danza fluviala in E minor, Op. 38 No. 4: initial theme

Sonata-Vocalise in C major, Op. 41 No. 1: first secondary theme $\left(\mathrm{S}_{\mathrm{I}}\right)$

D minor Romantic Sketch >The Organ Grinder<, Op. 54 No. 6: theme of middle section

Theme and Variations in $C \sharp$ minor, Op. 55: initial theme

Piano Quintet in C major, Op. posth.: secondary theme (Quasi Hymn) of the $3^{\text {rd }}$ movement

(b) Sentence

C minor Skazka, Op. 8 No. 1: initial theme

$\mathrm{A} b$ major Sonata, Op. 11 No. 1: first secondary theme ( $\mathrm{S}_{\mathrm{I}}$; see example 3.2.12)

C major Sonata, Op. 11 No. 3: secondary theme (see example 3.2.32)

G minor Sonata, Op. 22: first secondary theme ( $\mathrm{S}_{\mathrm{I}}$; see example 3.3.6)

$1{ }^{\text {st }}$ Piano Concerto in C minor, Op. 33: initial theme

$2^{\text {nd }}$ Violin Sonata in G major, Op. 44: variation theme of the $2^{\text {nd }}$ movement

A major Skazka, Op. 51 No. 3: initial theme

(c) Compound theme (periods and sentences interlocked)

F minor Sonata, Op. 5: primary theme of the $4^{\text {th }}$ movement

E minor Sonata, Op. 25 No. 2: primary theme of the $1^{\text {st }}$ subdivision

Sonata-Ballade in F\# major, Op. 27: primary theme of the $1^{\text {st }}$ movement

(d) Small ternary (A-B-A)

G minor Sonata, Op. 22: first primary theme ( $\mathrm{P}_{\mathrm{I}}$, see example 3.3.5)

F minor Skazka, Op. 26 No. 3: initial theme (see example 2.2.12)

(e) Small ternary with repetition, or counter-bar-form (A-A-B-A)

F minor Sonata, Op. 5: secondary theme of the $1^{\text {st }}$ movement

Tyutchev song Polden' (Midday), Op. 61 No. 6 [Op. $59^{\text {bis }}$ : initial theme

With regard to the early piano sonatas, Marina Skalkina notes that »the processuality [of motivic work] found its expression in the construction of many sonatas' primary themes to which an active intra-thematic development is inherent ${ }^{61}{ }^{61}$ As for the motivic construction of themes, whether they are regularly formed or

61 My translation of Skalkina 2009, p. 212: »Protsessual'nost' nashla svoe vïrazhenie v stanovlenii glavnïkh tem mnogikh sonat, kotorïm prisushche aktivnoe vnutritematicheskoe razvitie.« 
not, we can observe a general tendency: Most of Medtner's material is arranged in such a way that the consecutive emerges from the preceding in organic sequence, while the diastematic content of initial motives is often used as a `nucleus` or `core`, determining the developmental possibilities of themes right from the beginning. In this respect, the formative potential of Medtner's material follows the model of Beethoven, Schumann, and Brahms, and as such can be described by adopting terms devised for the analysis of these composers' works: >contrastive deduction $<$ and $>$ developing variation $<{ }^{62}$

Let us have a look at a paradigmatic example for the abovementioned techniques: the initial theme of the F minor Skazka, Op. 26 No. 3, of c. 1912 (see example 2.2.12). This melody commences with a fourmeasure basic idea, ascending in conjunct melodic motion to the $5^{\text {th }}$ scale and descending again before closing with a perfect authentic cadence (m. 4). ${ }^{63}$ Where a regular period or sentence structure might have been expected, Medtner now appends derivative phrase from measures 2-3 of the basic idea (m. 5-6) and its stepwise descending sequence, unfolding over a chromatically descending bass, and shifted forward in the $3 / 4$ time by one crotchet (m. 7-8). This is followed by a free inversion of the basic idea (m. 9-12), which Medtner finally replicates with the original basic idea in altered harmonisation to conclude on a PAC again (m. 13-16), forming a small ternary of sixteen measures which shows an asymmetric, and entirely unpredictable, inner structure. Instead of introducing a contrasting idea or continuation phrase, all motivic processing is derived from the material of the first phrase.

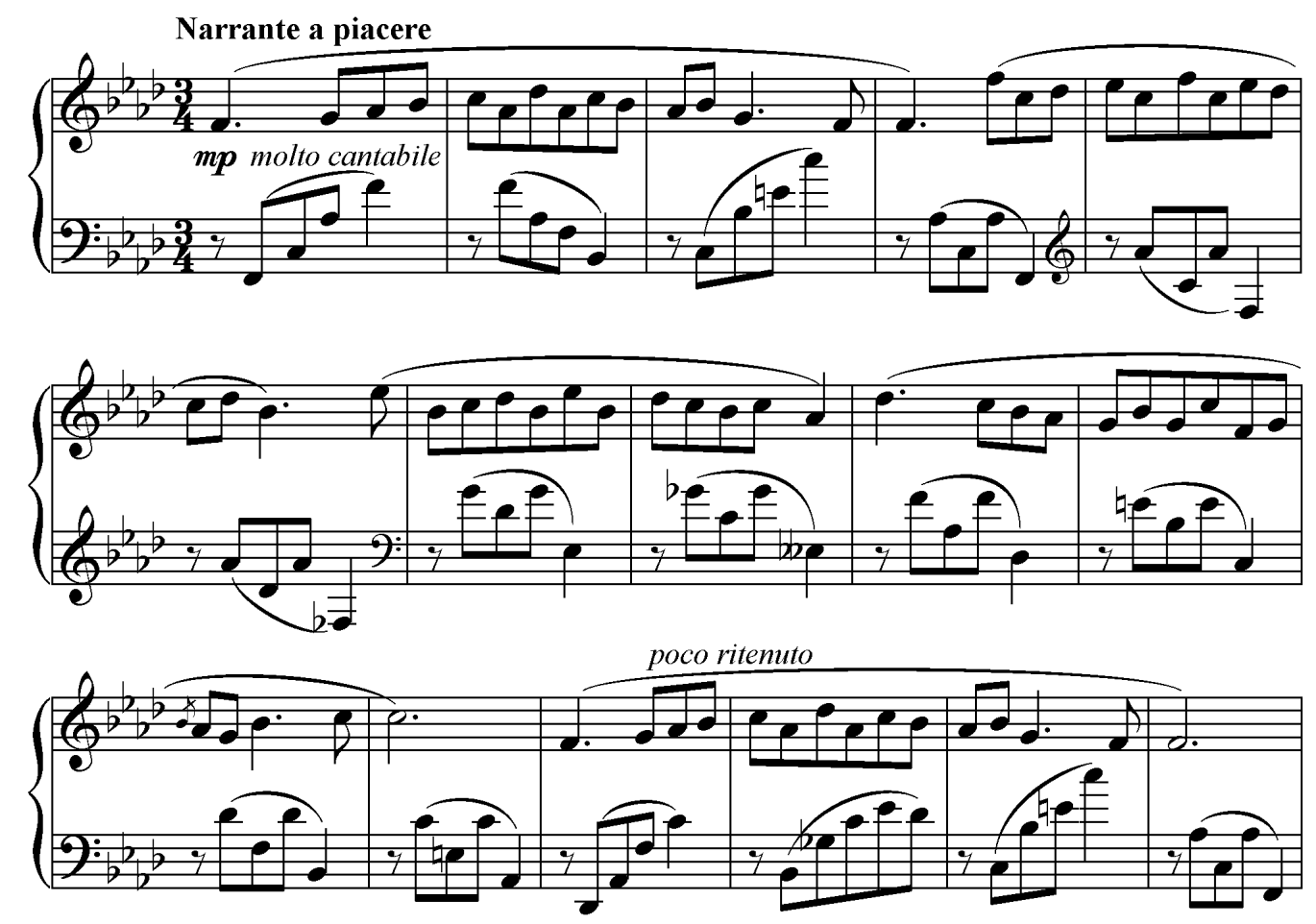

Example 2.2.12: Medtner, Skazka, Op. 26 No. 3, mm. 1-16

62 In accordance with the terminology of Arnold Schmitz (>kontrastierende Ableitung `) and Arnold Schoenberg (>entwickelnde Variation ‘).

63 This melody has a curious counterpart in the B minor Skazka >The Magic Violin«, Op. 34 No. 1, the initial theme of which shows exactly the same rhythm during its first measures (see example 2.2.7). 


\subsection{POLYPHONY AND COUNTERPOINT}

Medtner is widely regarded as an expert contrapuntist, and most of his scores are devised with an intense polyphonic refinement, including an astonishing variety of imitative and other contrapuntal techniques. This applies to his mature style as much as to his early compositions, and we can thus state that concentrated application of polyphonic techniques is evident throughout Medtner's whole creative period. The question whether this aspect should be considered a tribute to or heritage of his teacher Sergei Taneyev, and particularly his scholarship on counterpoint and fugue, has been discussed in various places. ${ }^{64}$ It appears to me as a rather impulsive conclusion to deduce any contrapuntally refined passage from works of a Taneyev pupil to the teacher's expertise, be it in the piano textures of Scriabin, Rachmaninov, or Medtner-as if these three composers' genuine affinity to counterpoint would not deserve an appreciation of its own. ${ }^{65}$ While a certain familiarity with Renaissance and Baroque polyphonic writing can be taken for granted among all of Taneyev's students, it is clearly an overstatement to attribute every single imitation or fugato to his influence. I will not further elaborate on this question here, but rather highlight a number of examples representative for Medtner's ambition to devise textures of contrapuntal density in every of his preferred musical genres.

\subsubsection{IMITATIVE STRUCTURES}

Canons and strettos, or imitations of melodic lines in two or more other voices, mostly entering one after another, belong to the most popular features of contrapuntal writing. Here is a list of some of the most remarkable imitational passages in Medtner's music, starting with an astonishingly ingenious three-part example from the early C minor Skazka, Op. 8 No. 2, and followed by detailed examinations of passages from the $1^{\text {st }}$ Piano Concerto, Op. 33, and the E minor Sonata, Op. 25 No. 2.

- $\quad$ Skazka in C minor, Op. 8 No. 2 (1904-06): processing of the secondary theme during the development section (m. 140ff.: see example 2.1.1) - the soprano and tenor voices present a canon at the lower sixth at two crotchets distance, with an additional third voice in the bass adding an augmentation of the theme, another sixth below.

- Piano Sonata in Ab major, Op. 11 No. 1: the second occurrence of the $\mathrm{S}_{\mathrm{I}}$ theme within the exposition's (m. 64ff.) and recapitulation's secondary theme zones (m. 187ff.: see example 3.2.13) - canon at the upper fifth at a distance of two crotchets. ${ }^{66}$

- Sonata-Elegy in D minor, Op. 11 No. 2: continuation of the primary theme (m. 5f.) - canon at the upper fourth at one crotchet's distance; the corresponding passage in the recapitulation (m. 54ff.) extends this structure to several consecutive canons at the lower fifth and upper fourth, at distances of one and two crotchets.

64 See Abraham in Holt 1955, p. 87; Keller 1971, p. 334; and Tozer 1999, p. 8.

65 According to Anatoly Aleksandrov, Taneyev in fact acknowledged his student's natural talent for contrapuntal writing after Medtner had abandoned his counterpoint class at the Moscow Conservatory: »Until now I believed that one could not become a real composer without a thorough study of counterpoint. Now, as illustrated by your example, I see that I was wrong. « (My translation of Apetyan 1981, p. 94: »Do sikh por ya dumal, chto nastoyashchim kompozitorom nel'zya sdelat'sya, ne izuchiv osnovatel'no kontrapunkt. Teper' na Vashem primere vizhu, chto oshibalsya v ėtom.«). See also Dolinskaya 1966, p. 12.

66 See Protopopov 1987, p. 287. 
- Skazka in E minor >March of the Paladin<, Op. 14 No. 2 (1904-07): culmination of the B section and its main subject - canon at the upper fifth at two crotchets distance, combined with the primary theme of the A section in the bass (m. 65ff.); a few measures later, the B theme joins in an 1:2 augmentation canon at the upper fifth with simultaneous theme entries (m. 69ff.). ${ }^{67}$

- $\quad 1^{\text {st }}$ Violin Sonata in B minor, Op. $21,2^{\text {nd }}$ movement: re-entry of the initial theme at the end of the A section (m. 61ff.) - canon at the lower octave (right-hand and violin parts) at a distance of one crotchet, with shifting accentuation of 5/8 against 2/4 time (see example 2.2.7).

- Skazka in C\# minor, Op. 35 No. 4 (1916-17): recapitulation of the A section (m. 73ff.) - the initial theme is presented in a 2:1 diminution canon at the upper octave at two measures distance, both voices ending simultaneously at the beginning of $\mathrm{m} .77$.

- Russian Skazka in F minor, Op. 42 No. 1 (1924): recapitulation of the B section (m. 111ff.) - canon at the upper octave at one measure distance.

- Dance Skazka in C major, Op. 48 No. 1 (1925): middle of the third section (m. 294ff.) - three-part canon of a staccato motive in repeated notes, entering in the upper minor ninth and upper fourth at two measures distance, and then inverting the intervals to the lower major seventh and lower fourth (m. $303 \mathrm{ff}$.).

- Sonata-Idyll in G major, Op. 56: beginning of the $1^{\text {st }}$ movement - the three entries of the introductory theme follow a comparatively simple imitative scheme, with the successive voices entering in the upper forth and lower seventh (mm. 2 and 4).

In the $1^{\text {st }}$ Piano Concerto in C minor, Op. 33 (1914-18), there is a cunning proportional canon located at the culmination of the work's $1^{\text {st }}$ subdivision, presenting this section's secondary theme in three different voices. While the violins and violas enter with the subject in its original motion of quavers, freely imitated by the piano two octaves higher and delayed by two crotchets, the cellos and basses join an octave below, nearly simultaneously with the first voice, with a 2:1 augmentation of the theme (m. 157ff.; see example 2.3.1). Furthermore, at the beginning of the $3^{\text {rd }}$ subdivision, the concerto's majestic initial theme is recapitulated in another canon at the octave, introduced by the piano part and freely answered one measure later by the strings (m. 533ff.; see example 2.3.2). This passage, if any, might indeed be a direct reflection of Taneyev who similarly devises the concluding stretto of the finale from his C minor Symphony, Op. 12 (1896-98). The secondary theme from the work's $1^{\text {st }}$ movement is here transformed to a final hymn, also set in a canon at the octave between the treble and bass voices (m. 299ff.: Molto maestoso; see example 1.12 in comparison).

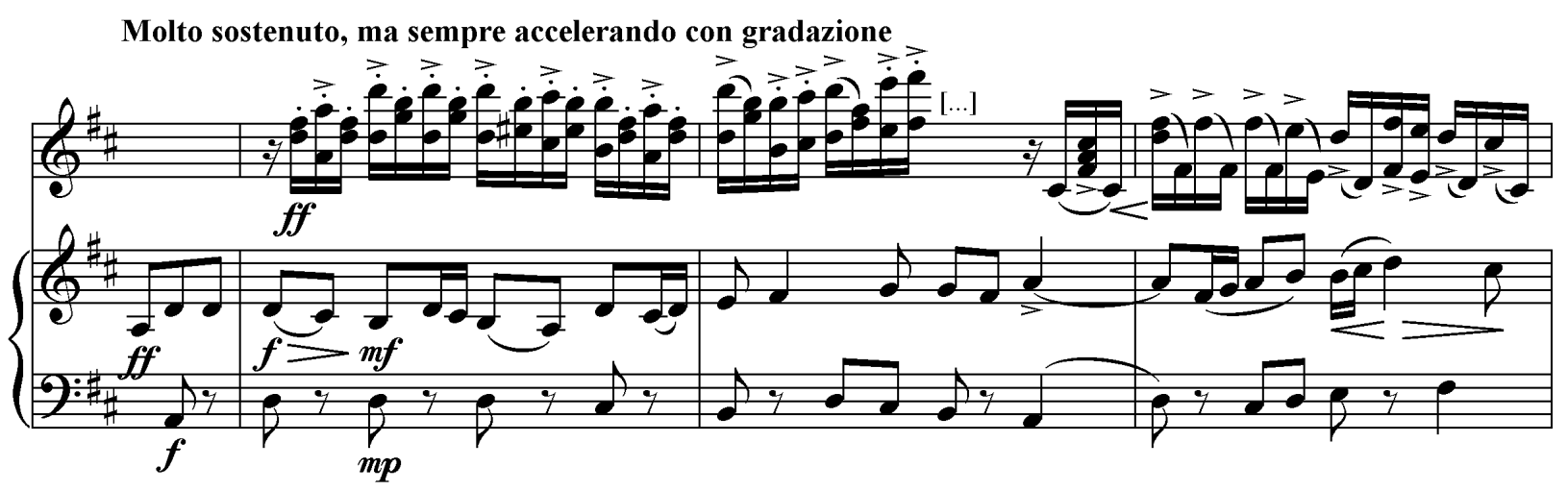

Example 2.3.1: Medtner, Piano Concerto, Op. 33, $1^{\text {st }}$ subdivision, mm. 157-159 (piano excerpt, violins, bass)

67 See Martyn 1995, p. 50: »The affinity of the two themes [from the A and B sections] encourages contrapuntal treatment, embarked on at length and with amazing ingenuity«. 


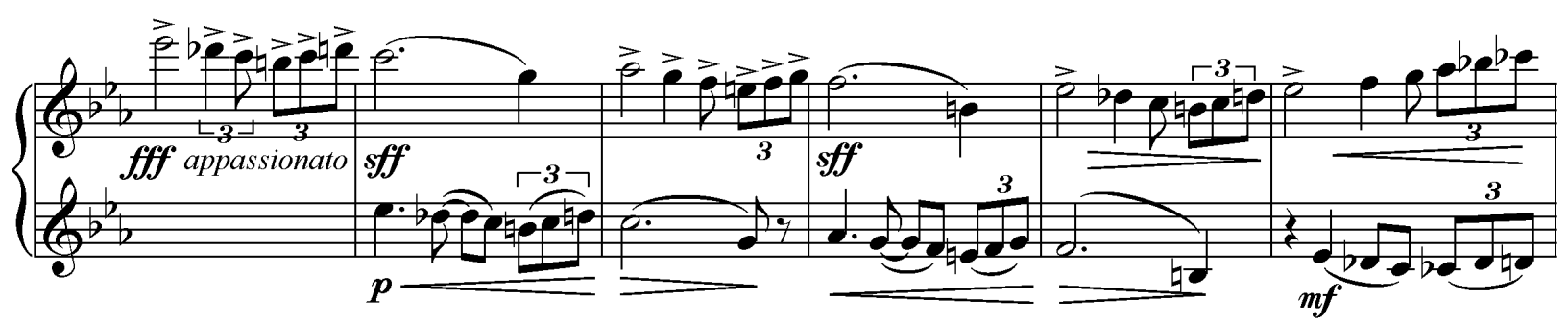

Example 2.3.2: Medtner, Piano Concerto, Op. 33, $3^{\text {rd }}$ subdivision, mm. 533-538 (piano top voice, $1^{\text {st }}$ violin)

Like hardly another work, the E minor Sonata, Op. 25 No. 2, further exemplifies the notion of Medtner as a skilful contrapuntist. In it, canon and fugato techniques play a crucial role both for the design of the pianistic texture and the overall dramaturgy of the work. While this aspect can be considered a general feature of Medtner's musical craftsmanship, imitative writing is employed here to an extent that it highlights and stabilises the formal outline of the sonata. Three passages may serve to illustrate this observation: First, the whole opening section of the sonata can be perceived as a fugue exposition with $d u x$ and comes entries of the introductory theme, the latter of which enters in a transposition to the upper fifth (mm. 2f. and 6f.; see example 3.5.4). Second, the introductory theme is inverted as soon as in $\mathrm{m} .14$ and, during the introduction to the $2^{\text {nd }}$ subdivision, reappears in a remarkable stretto passage with canons at the octave and fifth, and is also combined with its own inversion (m. 270ff.; see example 3.5.9 and the corresponding paragraph for a detailed discussion). Further contrapuntal processing of the introductory theme includes the juxtaposition with its own 2:1 diminution (m. 717ff.). Third, at the beginning of the $2^{\text {nd }}$ subdivision, the initial subject of that section $\left(\mathrm{S}_{\mathrm{III}}\right)$, itself derived from the introductory theme, enters in a four-part fugato at the octave $(\mathrm{m} .311 \mathrm{ff}$.; see example 2.3.3). ${ }^{68}$ This amount of polyphonic combinatoriality must be regarded as an extraordinary case even when measured by Medtner's own standards.

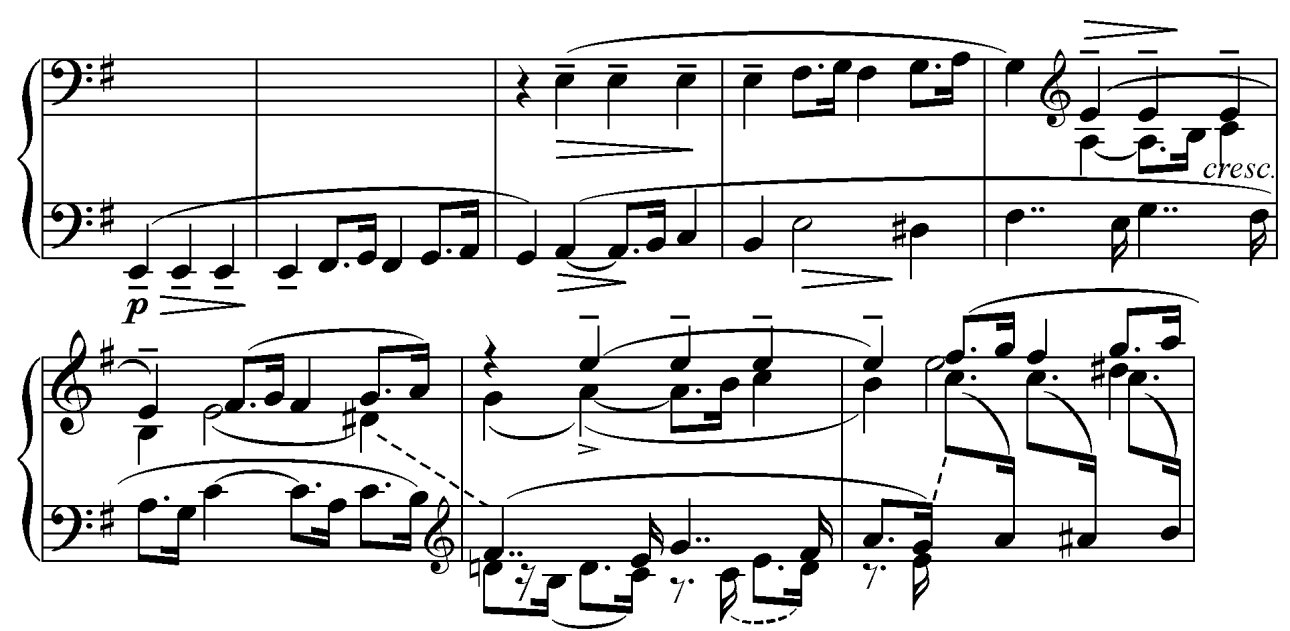

Example 2.3.3: Medtner, Sonata, Op. 25 No. 2, $2^{\text {nd }}$ subdivision, mm. 311-318

68 See also Flamm 1995, p. 231, pointing out the highly unusual formal position of this fugato: »Schon unmittelbar nach der 〉Exposition` des zweiten Hauptsatzes wird dieser als vierstimmiges Fugato verarbeitet $\ll$. 


\subsubsection{Fugues AND FugATI}

As Vladimir Protopopov notes, »fugal forms are of special interest in Medtner's works, exhibiting a heroic character, and being introduced in other larger forms such as the finales of [sonata] cycles. $\ll{ }^{69}$ Fugues are, as in the music of many other composers, employed as a means of culmination and increasing complexity — which does not necessarily mean that they are exclusively found at the endings of works, as frequently seen in the music of Medtner's contemporaries Max Reger and Karol Szymanowski. Instead, fugati or even multiple fugue expositions are mostly implemented in the development sections of the respective final movements, typically appearing as polyphonic transformations of these movements' primary themes. Medtner's employment of fugal writing thus responds to the topoi of craftsmanship and `learned style $<.{ }^{70}$ Yet he does not confine it to the conclusions of works as in the Baroque and Classical eras, but rather use it as a means of apotheotic re-enactment of the respective subjects, which are transformed to fugati after their preceding presentation in an homophonic environment. As such, Medtner's fugati mostly determine a dramaturgical climax before the music once again returns to the sphere of its beginning. A possible model for this tendency is the fugato from Liszt's B minor Sonata, but also earlier approaches to incorporate polyphonic passages in sonatas, chamber works, or symphonies (see chapter 1.1.4). In Medtner, sonata movements with fully elaborated fugal sections include:

- the final $4^{\text {th }}$ movement of the F minor Piano Sonata, Op. 5, where a three-part fugato over the contrasting idea of the movement's primary theme covers a large portion of the development section (m. $147 \mathrm{ff}$;; see example 3.1.11 from the corresponding analysis of Op. 5).

- the final $3^{\text {rd }}$ movement of the Sonata-Ballade in F $\#$ major, Op. 27, the development section of which elaborates on a subject first introduced as the initial theme of the sonata's $2^{\text {nd }}$ movement, here expanded to a lengthy four-part fugato. The theme is presented in three different harmonic guises and constellations of major and minor seconds, each comprised in a separate fugal exposition (mm. 130ff., 154ff., 172ff.; see example 3.6.10).

- the Grozovaya Sonata in F minor, Op. 53 No. 2; again, a developmental passage comprises a highly chromatic transformation of the monothematically devised initial subject, forming a three-part fugato commencing in the remote key of $\mathrm{F} \#$ minor (m. 210ff.; see example 2.3.4). The following theme entries modulate to $\mathrm{G}$ minor (comes in $\mathrm{m}$. 214ff.), then back to $\mathrm{F} \#$ minor ( $d u x$ in $\mathrm{m}$. 220ff.), and lead to a number of other unexpected tonalities in succession (m. 228ff.: $\mathrm{G} \#$ minor), as well as to a polytonal superposition of $\mathrm{E}$ minor and $\mathrm{B}$ minor, presenting the theme in a stretto at the upper fifth at one crotchet distance (m. 258ff.).

More instances of brief fugati, or allusions to fugue expositions, are found in a number of others of Medtner's mature works. In the middle section of the Sonata tragica in C minor, Op. 39 No. 5, the primary theme reappears as a powerful unaccompanied quasi-recitativo in the bass (m. 151ff.), answered by the upper voice an octave higher (m. 159ff.), but is not further elaborated as a fugato. In the development section of the Sonata-Vocalise in C major, Op. 41 No. 1, the primary theme enters four times in succession of the vocal

69 My translation of Protopopov 1987, p. 290: »Osobïy interes predstavlyayut fugirovannïe formï v sochineniyakh Metnera — oni nosyat geroicheskiy kharakter i vvodyatsya v drugie, bolee krupnïe formï-finali tsiklov«. The author also discusses the following examples from Op. 5, Op. 27, and Op. 53 No. 2.

70 Medtner must have been fully aware of the aspect of >learned style< when dealing with fugal technique, to an extent that he felt inclined to ironise this demand in composing a short Unfuge (1905), dedicated to Reger, in an attempt to mock this composer's chromaticism and obsession with polyphony. See Flamm 1995, p. 76f., for further thoughts and an excerpt from the piece. 
and piano parts (m. 134ff.), forming a fugato with imitation at the lower seventh. The $4^{\text {th }}$ movement of the Sonata epica in E minor, Op. 57, contains a developmental Tranquillo, ma sempre a tempo passage (m. 220ff.) where a derivation of the movement's primary theme is processed in a fugue-like manner-with two consecutive entries on $B$ and $F \#$, followed by two strettos at one measure distance with entries on $E$ / $B$ and $E$ / A. The piano duo work Knight Errant, Op. 58 No. 2 (1943-44), likewise incorporates a three-part fugato (m. 152ff.) Finally, the $1^{\text {st }}$ movement of the Piano Quintet in C major, Op. posth., makes use of a double canon on the movement's initial idea, first presented by the viola and cello, and answered an octave higher by the violins (m. 43ff.) before being transformed to a four-part imitation going downward through all the strings from the first violin to the cello part (m. 139ff., with theme entries on $A, F, C$, and $A$ ).

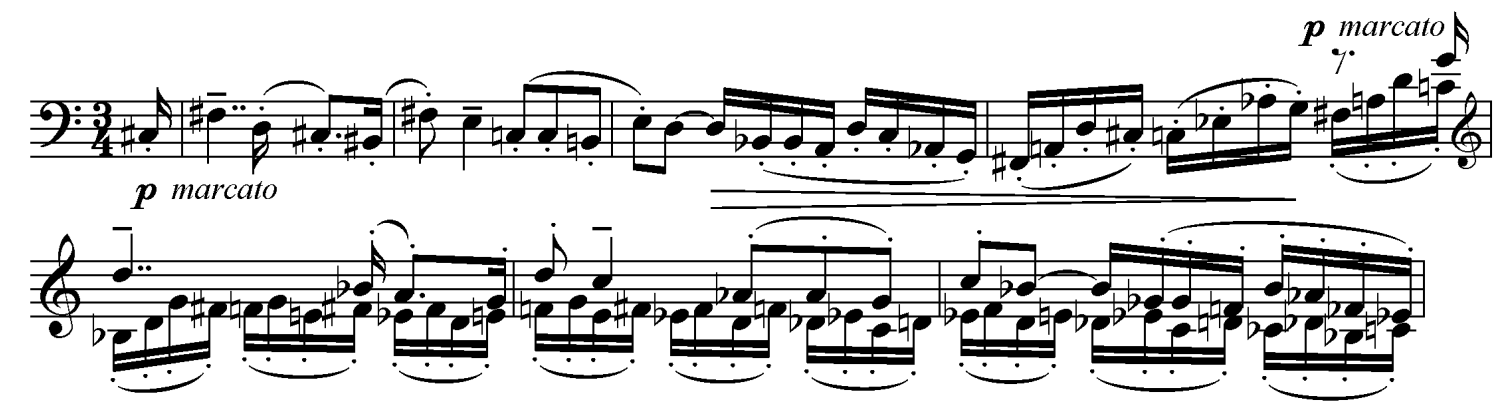

Example 2.3.4: Medtner, Grozovaya Sonata, Op. 53 No. 2, development, mm. 210-215

\subsubsection{INVERTIBLE COUNTERPOINT}

In addition to the variety of canons and fugal techniques discussed above, Medtner makes considerable use of invertible counterpoint, meaning that the upper and lower parts of a certain combination of voices can change their places. While this is a common strategy in fugue composition, Medtner resorts to this technique in otherwise homophonic contexts as well. A first remarkable instance of his application of double counterpoint at the octave is found in the concluding section of the E minor Skazka >March of the Paladin`, Op. 14 No. 2 (1904-07): the main themes of both the A and B sections of the work are combined, as already seen during its middle passage, in two successive phrases of two measures each (mm. 105f. and 107f.; see example 2.3.5). The B subject is heard in the top voice while A occupies the bass, and then vice versa.

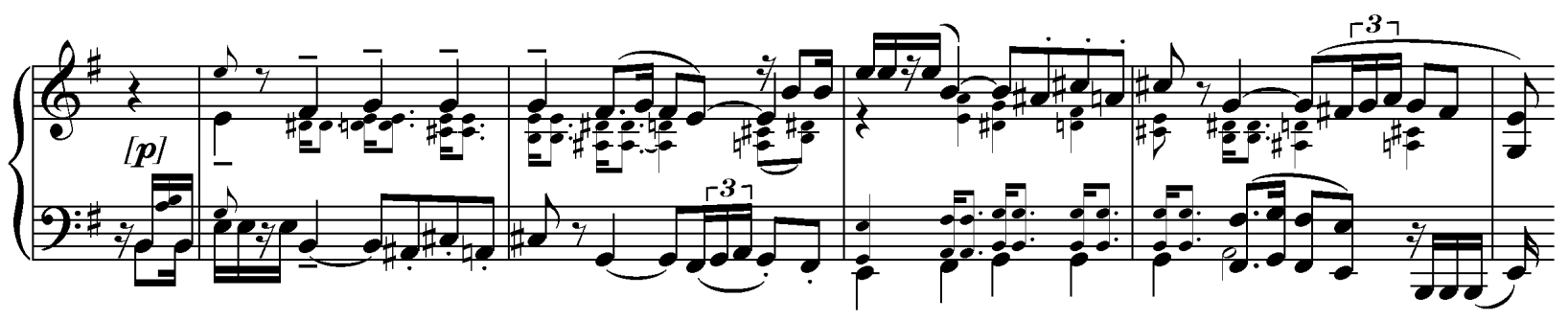

Example 2.3.5: Medtner, Skazka, Op. 14 No. 2, mm. 105-108 
More remarkable examples of invertible counterpoint are found in the two piano sonatas of Op. 25. The final $3^{\text {rd }}$ movement of the Sonata-Skazka, Op. 25 No. 1, introduces a two-part initial subject of four measures, with its voices being exchanged in immediate succession for another otherwise identical presentation of that theme (m. 5-8; see example 3.4.6). Also, in the E minor Sonata, Op. 25 No. 2, the primary theme of the $1^{\text {st }}$ subdivision and its accompaniment in quavers, presented as upper and lower voice in the exposition (m. 40ff.; see example 3.5.5), change their positions at the onset of the recapitulation section (m. 181ff.; see example 3.5.7), so as to have the primary theme, now in double octaves, sound in the bass. Similarly, the initial theme from the $2^{\text {nd }}$ subdivision of that sonata reappears with swapped voices at the moment of its recapitulation (m. 534ff.) as compared to the exposition (m. 285ff.; see example 3.5.10). ${ }^{71}$ In the light of the astonishing amount of canon and fugato writing in the E minor Sonata, we might claim that this work, as Medtner's longest and most complex composition for solo piano, can be singled out for making contrapuntal principles co-determine the pivotal inner borders of sonata form.

\subsection{FEATURES OF HARMONY}

Medtner's harmonic language is probably the least suitable factor to deduce distinctive observations on his spersonal style<. With regard to his harmony, which is variously described as conservative or even retrospective compared to many of his contemporaries, I will not overestimate Medtner's way of constructing chords, dissonances, and tonal sequences, given that his most remarkable achievements are rather found on the field of musical form. It is however possible to trace Medtner's rootedness in tradition, both in terms of his application of tonality and large-scale progression (in German scholarship referred to as >formbildende Harmonik $)$, to his harmonic language. In this context a number of observations can be made, even though some of these are not exclusive features of Medtner's music, but found in other late-Romantic and early- $20^{\text {th }}$ century composers as well. Thus, this chapter is not concerned with the idea to distinguish Medtner's harmonic style from other music, but rather meant to be a general survey of harmonic functions, progressions, cycles, and cadences in his compositions. Still, by means of the following conspectus, we will be able to address a number of peculiarities which might be considered typically Medtnerian.

\subsubsection{PARTICULAR HARMONIC FUNCTIONS}

\section{First Case: >Dorian< Chords}

From the predilection for the melodic-minor mode discussed in chapter 2.2.1, two attractive harmonic options arise. On the one hand, a minor-mode tonic can be enriched with a major sixth — a harmony which might be termed a >Dorian tonic $<$, as seen at the conclusion of the $1^{\text {st }}$ and beginning of the $2^{\text {nd }}$ movement of the Sonata-Ballade in F\# major, Op. 27 (see example 3.6.5), or in many places in the $1^{\text {st }}$ movement of the $3^{\text {rd }}$

71 Vasilyev 1962, p. 21f., hints to a parallel to the initial theme from the $3^{\text {rd }}$ movement of the Sonata-Skazka, Op. 25 No. 1: »Analogichnïy sluchay mï nakhodim vo vtorom sonatnom allegro sleduyushchey e-moll'noy sonatï iz ètogo opusa, gde pervaya tema izlozhena tozhe v dvoynom kontrapunkte i v reprize golosa perestavlenï«. 
Piano Concerto in E minor, Op. 60. On the other hand, subdominant harmonies derived from a melodicminor scale have a brighter sound, such as a minor-mode ii (instead of a diminished triad) and a major-mode IV. These phenomena occur with an increasing frequency from Medtner's middle period onwards — see, for instance, the primary theme of Medtner's most-performed work, the Sonata-Reminiscenza in A minor, Op. 38 No. 1 (example 2.2.2), which features B minor and D major as regular scalar triads. However, there are also earlier examples, such as the piano introduction to the Goethe song Meeresstille, Op. 15 No. 7 (190809 ), where a dominant-ninth chord above $B$ is employed as IV in F\# minor (see example 2.2.9).

\section{Second Case: Augmented Sixth Chords}

The three standard possibilities of chords comprising an augmented sixth above the bass are widely referred to as Italian sixth (triad in first inversion), German sixth (fifth-sixth chord with a perfect fifth), and French sixth (third-fourth chord with an augmented fourth), all of which are traditionally employed as predominant chords in cadences and regularly found in music from the mid- $18^{\text {th }}$-century onwards. I will further adhere to the accustomed terminology of the English-speaking world. From the perspective of German functional theory, however, these chords are conceived as double-dominant harmonies built upon a flattened fifth, referring to an imaginary root which is not included in the Italian (`verkürzter Dominantseptakkord $\iota$ ) and German sixth chords (>verkürzter Dominantseptnonakkord`, the enharmonic respelling of a secondary dominantseventh chord to the bII). In Medtner, a prolonged occurrence of the former is found in the measures preceding the final cadence of the Sonata-Vocalise, Op. 41 No. 1 (m. 261ff.: $D b-F-B$ alternating with C major); the latter one is prominently used in the $1^{\text {st }}$ movement of the Sonata in F minor, Op. 5 (m. 24, third beat). The material of the French sixth chord (>Dominantseptakkord mit tiefalterierter Quinte $<$ ) comprises four out of six notes of a whole-tone scale, making it particularly suitable for enharmonic modulation.

In Medtner, these harmonies are frequently encountered not only as secondary, but also as primary dominants, as seen at the beginning of the B minor Skazka >Campanella<, Op. 20 No. 2 (1908-09), where a French sixth chord figures as part of an ostinato figure (the very first chord, and the second beats in mm. 2, 4, 6 etc.; see example 2.4.1). In this context, the augmented sixth chords create a bassline of a descending minor seconds to the tonic (bII-I), making the respective chords appear as Phrygian (vii ${ }^{b 3} / \mathrm{V}^{7 / 65}$ ) dominants. In most other cases, the Phrygian second and leading-tone make up for a pair of voices resolving in contrary motion of minor seconds to their finalis (»parsimonious voice leading« as dubbed by the Neo-Riemannian theorist Richard Cohn). ${ }^{72}$ However, the leading-tone is missing in the abovementioned example from the Skazka, Op. 20 No. 2.

72 See Cohn 1998, 174f. 


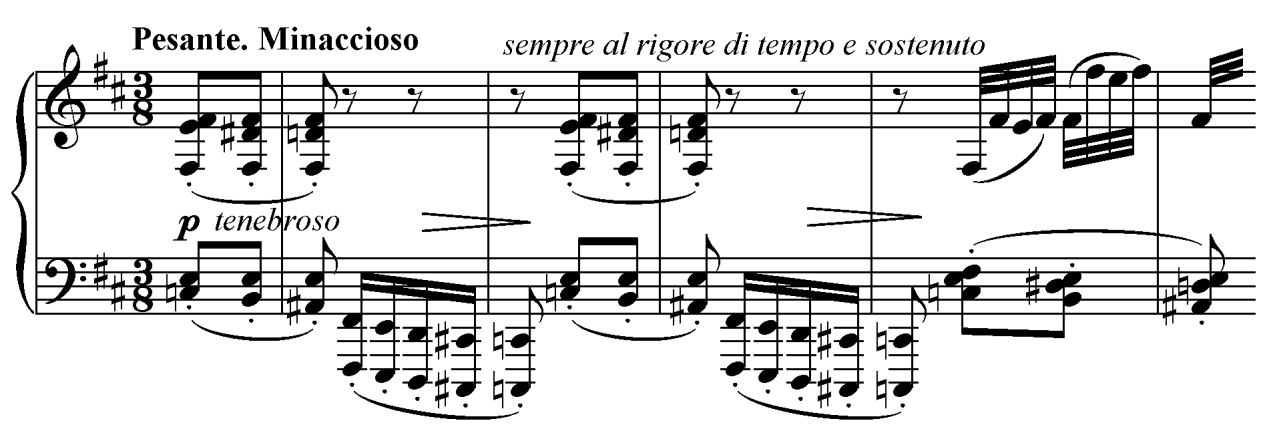

Example 2.4.1: Medtner, Skazka, Op. 20 No. 2, mm. 1-4

\section{Third Case: Multiple Leading-Tone Harmonies}

(a) Chromatically alternating chord (Wechselklang) with two parsimonious voices

A tetrad with flattened fifth, major thirteenth, and omitted seventh, sounding enharmonically equal to a half-diminished seventh chord, encounters as an alternating chord to the $\mathrm{Eb}$ major tonic in the $3^{\text {rd }}$ movement from Medtner's F minor Piano Sonata, Op. 5 (mm. 1-3 and 5-7, second beats; see example 2.4.2). Conceivable as a modified >Chopin dominant<, this harmony has two pitches ( $G$ and $B b)$ in common with the tonic triad, while the remaining notes proceed in contrary motion of minor seconds to $E b$. Initially, the chord appears ambivalent between scale degrees iii and $\mathrm{V}$ due to the flattened $F b$ in the bass; ${ }^{73}$ nevertheless, on its sixth occurrence, $F b$ is respelled as $E$, leading to a modulation to $\mathrm{F}$ minor (m. 7-8).

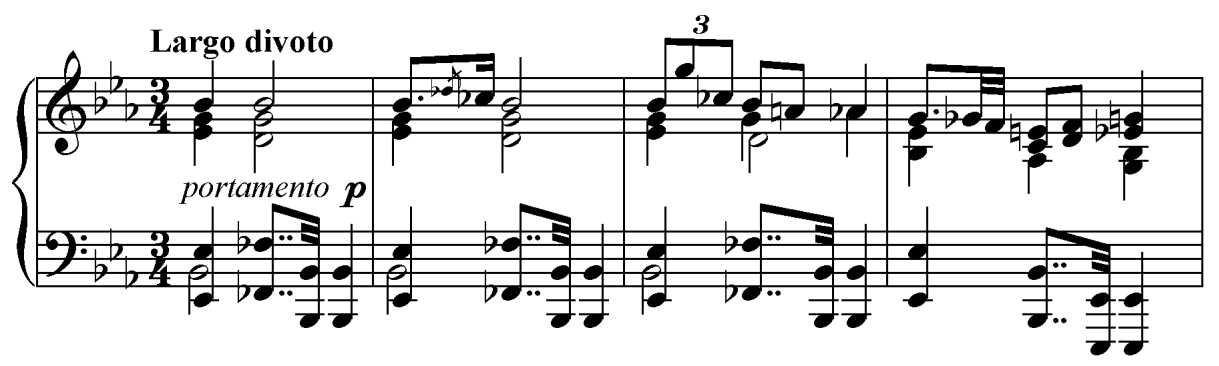

Example 2.4.2: Medtner, Sonata, Op. 5, $3^{\text {rd }} \mathrm{mvt}$, mm. 1-4

(b) Chromatically alternating chord with four parsimonious voices

A tetrad appearing even more harmonically ambivalent, with all four voices proceeding in half-tone motion, is found at the beginning of the Interludium from the G minor Sonata, Op. 22, occurring on the downbeat of every other measure from $\mathrm{m}$. 197ff. (see example 3.3.9 from the corresponding analysis of the sonata). As two of the four pitches seem ambivalent in their enharmonic notation, it is unclear if this chord should be conceived as a major sixte ajoutée, or as a $\mathrm{Gb}$ minor seventh chord in its third inversion $(F b-G b-B b b-D b)$. However, the bass note $E$ serves as a leading-tone, providing a strong argument for interpreting the chord as a triply-altered dominant harmony.

(c) Dominant seventh chord with flattened third ( $\$ 9)$

The abovementioned B minor Skazka >Campanella<, Op. 20 No. 2, one of Medtner's few ostinato compositions, includes another recurring chord which simultaneously comprises a leading-tone and a flattened $7^{\text {th }}$ scale degree ( $A \#$ versus $A$ : every other measure in $\mathrm{mm}$. $11-17$, first beats). As such, it is also conceivable as a polychord in superposition of the $\mathrm{V}^{7}$ and III: $(F \#)-A \#-D-E-A$. As the music proceeds, the chord is further enhanced by another $C$ (m. 19), thus comprising five or six out of eight pitches of an octatonic scale.

73 Malikova 1967 , p. 288, refers to that chord as an altered iii $^{7}$ with diminished seventh: »Mï nakhodim i svoeobraznïe obrashcheniya $\mathrm{III}_{7} \mathrm{~s}$ ponizhennoy septimoy.« 


\subsubsection{NON-FUnCTIONAL PROGRESSIONS}

Other types of chord progressions in Medtner belong to the field of non-functional harmony, which means that they cannot be identified as scalar triads or tetrads derived from a diatonic mode. Some of these result from chromaticised root progressions and alterations of scalar degrees; others are based upon equal division of the octave, involving symmetrical chords such as the augmented triad, the diminished seventh chord, and their derivations. These harmonies can be adequately analysed with the terminology of Neo-Riemannian Theory, or Albert Simon's Tonfeld Theory. According to the latter, scales and chords derived from equal division of the octave in minor thirds or tritones (Messiaen's mode 2) are referred to as `Funktionen<, while those based on divisions in major thirds (Messiaen's mode 3) are named \Konstrukte〈, pitch groups also known by the Neo-Riemannian term >hexatonic pole<.

While late-1 $19^{\text {th }}$-century and early- $20^{\text {th }}$-century harmony makes frequent use of these chords and progressions in general, we can identify some examples as distinct features of Medtner's pianistic writing. In the E minor Sonata, Op. 25 No. 2, there are several passages representative of non-functional harmony which qualify to demonstrate this aspect, such as the confrontation of $\mathrm{E}$ major and $\mathrm{F}$ minor triads (also respelled as $E \sharp-G \sharp C$ or $F-G \# C$ ) at the transitory passage between the $1^{\text {st }}$ and $2^{\text {nd }}$ subdivisions (m. $245 \mathrm{ff}$.; see example 3.5.8). ${ }^{74}$ A major-minor triad progression retaining its third while the other voices proceed by half-tone motion in parallel fifths, as seen here, is called a >slide relation « in Neo-Riemannian Theory-and this is one of its most prominent examples in Medtner's music, providing a harsh yet unbroken transition at a crucial point of this composition. Many years later, a similar harmonic relation is found in the Sonata epica for violin and piano, Op. 57, where the $\mathrm{F}$ minor of the $3^{\text {rd }}$ movement (Andante con moto) is reverted to the overall tonic $\mathrm{E}$ minor during the introductory measures to the final $4^{\text {th }}$ movement (Allegro molto).

In the C major Piano Quintet, Op. posth., we encounter a series of progressions of major triads with their roots shifting by minor thirds. Looking at the transitory passage connecting the $2^{\text {nd }}$ to the $3^{\text {rd }}$ movement, $\mathrm{Ab}$ major, F major, and B major appear in direct succession (m. 68ff.; see example 3.6.17), with their common tonal substance representing an octatonic scale (or a >Funktion $<$ in Tonfeld Theory), while only the pitch $D$ is absent. A complementary passage, combining a major and minor triad by root progression of a major third, is found in the $2^{\text {nd }}$ movement of the Sonata-Ballade in F\# major, Op. 27 (m. 44ff.; see example 3.6.7): $\mathrm{Eb}$ major and B minor (the latter triad is enhanced to a half-diminished seventh chord by adding $G \sharp$ ) are combined to a >hexatonic pole $<$, the modal representation of a symmetrical scale with alternating minor thirds and minor seconds $(E b-F \# G-[A b-] B b-B-D$, a subset of Messiaen's mode 3).

74 A similar effect is created by the confrontation of $\mathrm{B} b$ major and B minor in the Scherzo of Beethoven's $\mathrm{B} b$ major Sonata `Hammerklavier`, Op. 106, $2^{\text {nd }}$ movement, m. 159ff. As in other passages from this sonata, these two tonalities appear opposed to each other as two harmonic poles. 


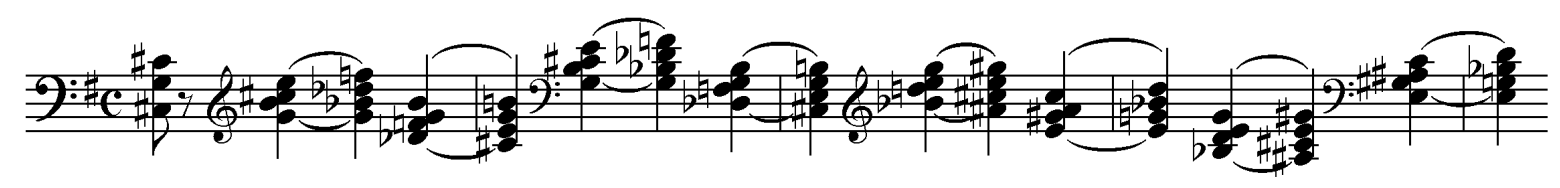

Example 2.4.3: Medtner, Sonata, Op. 25 No. 2, $2^{\text {nd }}$ subdivision, mm. 604-607 (left hand)

Medtner sometimes accumulates progressions of minor or major thirds to prolonged symmetrical sequences. Many of those cycles of non-scalar mediants are found in the E minor Sonata, Op. 25 No. 2 -in particular, a virtuosic developmental passage from its $2^{\text {nd }}$ subdivision calls for our attention (m. 604ff.; see example 2.4.3). Here, a pair of two tritone-related half-diminished seventh chords is arranged in a sequence ascending by minor thirds $\left(C \sharp^{\circ 7 / 65}-\mathrm{G}^{07 / 155} ; \mathrm{E}^{\mathrm{O} 7 / 65}-\mathrm{A} \sharp^{07 / 155}\right.$ etc. $)$, thus quickly modulating through relatively unrelated tonal regions, while preparing for the final culmination of the work. A very similar passage, with pairs of halfdiminished seventh chords ascending by major (instead of minor) thirds, is found at the beginning of the $3^{\text {rd }}$ Piano Concerto in E minor, Op. 60 (m. 36ff.: $\mathrm{G}^{07 / 15}-\mathrm{C} \sharp^{07 / 55} ; \mathrm{B}^{07 / 15}-\mathrm{F}^{07 / 55}$; $\mathrm{D} \sharp^{07 / 55}-\mathrm{A}^{07 / 55}$ ). Tritone progressions are of crucial relevance for this concerto's $1^{\text {st }}$ movement, appearing in many passages from its $1^{\text {st }}$ subdivision. On first instance, the gradual escalation preceding the abovementioned passage continuously alternates between $\mathrm{E}$ minor and $\mathrm{B} b$ minor chords, both enhanced with a >Dorian` major sixth (m. $28 \mathrm{ff}$.). Later, a variant of this progression arises in a sequence of pairs of dominant ninth chords, again in tritone relation, and shifting upwards by minor thirds (m. 170ff.: $\mathrm{E}^{9}-\mathrm{B} b^{9} ; \mathrm{G}^{9}-\mathrm{D} b^{9} ; \mathrm{B} b^{9}-\mathrm{E}^{9}$; see example 2.4.4).

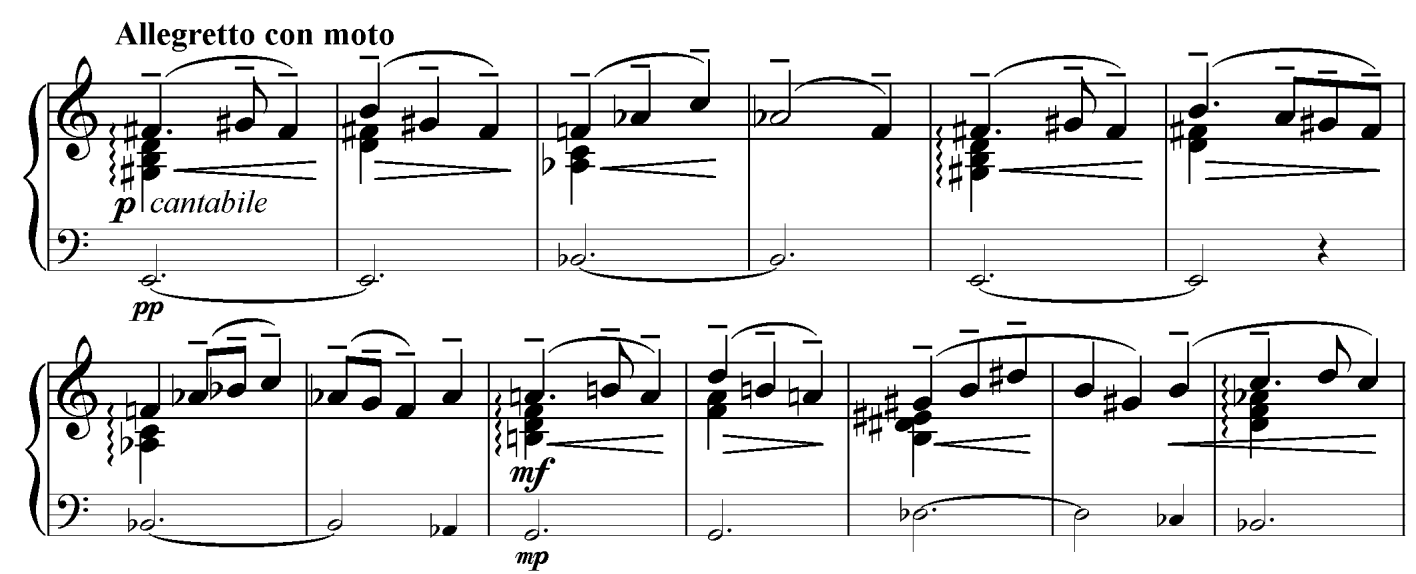

Example 2.4.4: Medtner, Piano Concerto, Op. 60, $1^{\text {st }}$ subdivision, mm. 170-182 (piano left hand and bass)

\subsubsection{HARMONIC CYCLES AND SCHEMATA}

Naturally, Medtner makes use of the standard models and patterns of tonal harmony, such as harmonic cycles and sequences of ascending and descending root progressions. The classification of these as >schemata (according to the Schema Theory developed in Robert Gjerdingen's Music in the Galant Style, ${ }^{75}$ or as topoi

75 For a definition see Gjerdingen 2007, p. 10f.; the individual schemata are explicated in the following chapters, such as the Romanesca (ibid., p. 25ff.), the >Fonte $<$ (p. 61ff.) and the $>$ Monte $<$ (p. 89ff.). 
of voice-leading and fundamental progressions (in the >Satzmodelle〈 discourse of German music theory) helps outline their historical origins, relevance, and, in some cases, semantic implications. In the light of Medtner's personal scepticism towards ıschemes`, the necessity of employing them for analysis may seem contentious. Yet, since the composer primarily referred to form and syntax, the sschematism deemed subject to obsolescence (as discussed in chapter 2.1), we might regard that statement as less significant with regard to harmony. In fact, Medtner at times makes use of well-known and long-established (and thus >schematic $<$ fundamental progressions, making the application of Schema Theory terminology to his music appear legitimate, even if they appear individualised in his personal manner.

The table below provides an overview of possible fundamental progressions of diatonic fifths, regardless of their significance in Medtner. The left column indicates the pattern which connects a pair of chords; the second to fifth columns specify the options of constructing sequences, generated from shifting the pair by ascending or descending seconds or thirds. More options can be generated when viewing other pairs of the same progressions, counted from the $2^{\text {nd }}, 4^{\text {th }}$, or $6^{\text {th }}$ chord. In general, the models found most frequently in music of the $18^{\text {th }}$ and $19^{\text {th }}$ centuries are: (1) the $>$ Fonte $<$ schema (descending cycle of fifths); (2) the Romanesca (also named >Pachelbel sequence $\prec$ or, in the Dahlhaus school, >major-minor parallelism $<$ ), and (3) the >Monte sequence (also referred to, though imprecisely, as >rising sequence of descending fifths or $>$ Rosaliar sequence). It is not my goal to locate instances of any of these eight possibilities in Medtner's music; I will rather highlight a number of characteristic examples and comment on their individual appearance.

\begin{tabular}{|c|c|c|c|c|}
\hline pattern of & $\begin{array}{c}\text { sequenced by } \\
\text { descending seconds }\end{array}$ & $\begin{array}{l}\text { sequenced by } \\
\text { ascending seconds }\end{array}$ & $\begin{array}{c}\text { sequenced by } \\
\text { descending thirds }\end{array}$ & $\begin{array}{l}\text { sequenced by } \\
\text { ascending thirds }\end{array}$ \\
\hline $\begin{array}{l}\text { descending } \\
\text { fifths }\end{array}$ & $\begin{array}{c}>\text { Fonte }<\text { (descending } \\
\text { cycle of fifths) } \\
\text { options: with sixth chords, } \\
\text { with } 7-6 \text { or } 2-3 \text { suspensions }\end{array}$ & $\begin{array}{l}>\text { Monte< sequence } \\
\text { option: chromatic bass }\end{array}$ & $\begin{array}{l}\text { descending } \\
\text { cycle of thirds } \\
\text { (very rare) }\end{array}$ & $\begin{array}{c}\text { reversed Romanesca } \\
\text { (minor-major } \\
\text { parallelism) }\end{array}$ \\
\hline $\begin{array}{l}\text { ascending } \\
\text { fifths }\end{array}$ & $\begin{array}{c}\text { reversed }>\text { Monte } \\
\text { option: chromatic bass }\end{array}$ & $\begin{array}{c}\text { ascending } \\
\text { cycle of fifths } \\
\text { option: } 4-3 \text { suspensions }\end{array}$ & $\begin{array}{l}\text { Romanesca } \\
\text { (major-minor parallelism) } \\
\text { options: with sixth chords, } \\
\text { with } 7-6 \text { or } 2-3 \text { suspensions }\end{array}$ & $\begin{array}{l}\text { ascending } \\
\text { cycle of thirds } \\
\text { (very rare) }\end{array}$ \\
\hline
\end{tabular}

Table 2: Classification of fundamental progressions of fifths

\section{Regular Schemata}

An astonishing conventional descending cycle of fifths, as it hardly ever occurs in Medtner, deserves attention just for its rarity: Near the end of the Pushkin song Zimniy vecher (Winter Evening), Op. 13 No. 1 (1904-06), a full cycle of seventh chords on all the diatonic scale degrees of $\mathrm{F}$ minor is encountered, each harmony lasting for half a measure (m. 51ff.: $\mathrm{Bbm}^{7}-\mathrm{Eb}^{7}-\mathrm{A}^{\mathrm{maj}}-\mathrm{D}^{\mathrm{maj}}-\mathrm{G}^{7}-\mathrm{C}^{7}-\mathrm{Fm}$ ). Almost as ordinary is a

$76>$ Fonte` and `Monteく are terms by Joseph Riepel, found in his treatise Anfangsgründe zur musicalischen Setzkunst, Vol. 2: Grundregeln zur Tonordnung insgemein, Regensburg [1755], p. 44. 
passage from the Elves' Skazka in G minor, Op. 48 No. 2 (1925), the B section of which commences with another purely diatonic cycle of fifths, descending measure by measure (m. $25 \mathrm{ff} .: \mathrm{Dm}-\mathrm{G}^{7}-\mathrm{C}^{7}-\mathrm{F}^{7}-\mathrm{B} b^{\mathrm{maj} 7}$ ). Similarly, the song-like simplicity of the initial theme from the A major Skazka, Op. 51 No. 3 (1928), is constructed from a $\mathrm{I}-\mathrm{vi}^{7}-\mathrm{ii}^{7}-\mathrm{V}^{7}$ cadence, also incorporating three descending perfect fifths. Another example from the B section of the $2^{\text {nd }}$ movement of the Sonata epica, Op. 57, echoing Brahms's $>$ Hungarian< tone, showcases an astonishingly plain variant of a descending cycle of fifths, proceeding every half of a measure (m. $21 \mathrm{ff}$.), then every crotchet from m. 23 (Em-Am-D-G-C-F\# $\left.{ }^{\circ}-\mathrm{B}^{7}-\mathrm{Em}\right)$. On the contrary, more individualised types of sequences and schemata are found in the following places:

- The exposition and recapitulation sections of the Sonata-Elegy in D minor, Op. 11 No. 2, feature a colourfully harmonised variant of the primary theme, employing seventh and ninth chords with multiple suspensions. Each harmony lasts for half a measure, while the harmonic rhythm unexpectedly slows down in the second measure by prolonging the third chord of the respective cycles of fifths $(\mathrm{m} .11 \mathrm{ff}$ : $\mathrm{Gm}^{7}-\mathrm{C}^{9}-\mathrm{F}^{9}-\mathrm{B} b^{9}-\mathrm{E}^{07 / b 5}-\mathrm{A}^{7} ; \mathrm{m}$. 60ff. starts with $\mathrm{Cm}^{7}$ correspondingly).

- The ardent beginning of the Fet song Ya potryasen, kogda krugom gudyat lesa (O'er thee I bend), Op. 24 No. 5 (1911), presents a descending cycle of fifths arranged in compelling asymmetry, with some chords being shortened and the $\mathrm{ii}^{7}$ prolonged (m. 3ff.: Am-Dm- $\mathrm{G}^{7}-\mathrm{C}-\mathrm{F}^{\mathrm{maj} 7}-\mathrm{B}^{\mathrm{o} 7 / \mathrm{b}}-\mathrm{E}$ ).

- In the $2^{\text {nd }}$ movement of the Sonata-Skazka in C minor, Op. 25 No. 2, we encounter a pattern of chord pairs, comprising a Neapolitan subdominant and a dominant seventh chord enharmonically respelled as German sixth $\left(\mathrm{bII}-\mathrm{V}^{7}\right)$. On a closer look, this turns out as a strongly altered sequence of diminished fifths, descending over a chromatic bassline, and somewhat reminiscent of Chopin's developmental harmony (m. 47ff.: $\mathrm{D} b-\mathrm{G}^{7}-\mathrm{B}-\mathrm{F}^{7}-\mathrm{A}$; see example 2.4.5).

- A beautiful instance of a reversed $>$ Monte< pattern, employed as a real sequence of minor-mode triads as frequently found in Schubert, occurs near the end of the B minor Skazka >Campanella<, Op. 20 No. 2 (1908-09), comprising the triad progressions of Bm-F\#m-Am-E-Gm-D-Fm (m. 127ff.)

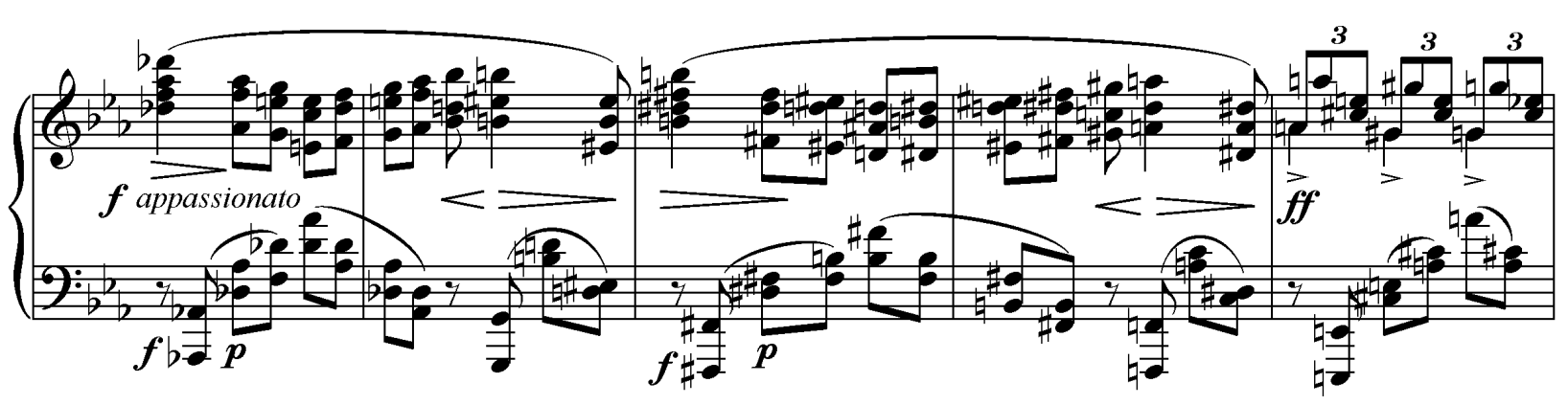

Example 2.4.5: Medtner, Sonata-Skazka, Op. 25 No. 1, $2^{\text {nd }}$ movement, mm. 47-51

\section{Sophisticated Sequences}

In many other places, the possible reference to traditional schemata is only effective in the background, especially where chordal progressions are idiosyncratically altered and enriched with optional notes to an extent that the underlying models are somewhat disguised. The coda to the $4^{\text {th }}$ movement of Medtner's F minor Piano Sonata, Op. 5, closes with two instances of a descending cycle of thirds in direct succession, the first one proceeding by minor thirds (m. $411 \mathrm{ff} .: \mathrm{E} b-\mathrm{C} ; \mathrm{C} b-\mathrm{A} b ; \mathrm{G}-\mathrm{G} b^{7}-\mathrm{F}$ ), the second by minor and diminished thirds (m. 415ff.: $E b-C ; C b-A ; A b-G^{7}-G b$ ). Another amazing real sequence of fifths shifting downward by 
major seconds, comprising dominant ninth and French sixth chords in alternation, figures near the end of the C major Skazka, Op. 9 No. 2 (1905). Scalar chords are arranged in an extended transposition pattern, giving a strong aroma of whole-tone harmony (m. 85ff; see example 2.4.6), while Medtner modulates along a full round of the circle-of-fifths: $\mathrm{A}^{7}-\mathrm{D}^{9 / 55}-\mathrm{G}^{7}-\mathrm{C}^{7 / 55}-\mathrm{F}^{7}\left[\right.$ German sixth] $-\mathrm{B} b^{9 / 55}-\mathrm{Eb}^{7}-\mathrm{A} b^{7 / 55}-\mathrm{D} b^{7}[\mathrm{German}$ sixth] $-\mathrm{G} b^{7}\left[\mathrm{~F} \sharp^{7}\right]-\mathrm{B}^{7}-\mathrm{E}^{7 / 55}-\mathrm{A}^{7}-\mathrm{D}^{7 / 55}$.

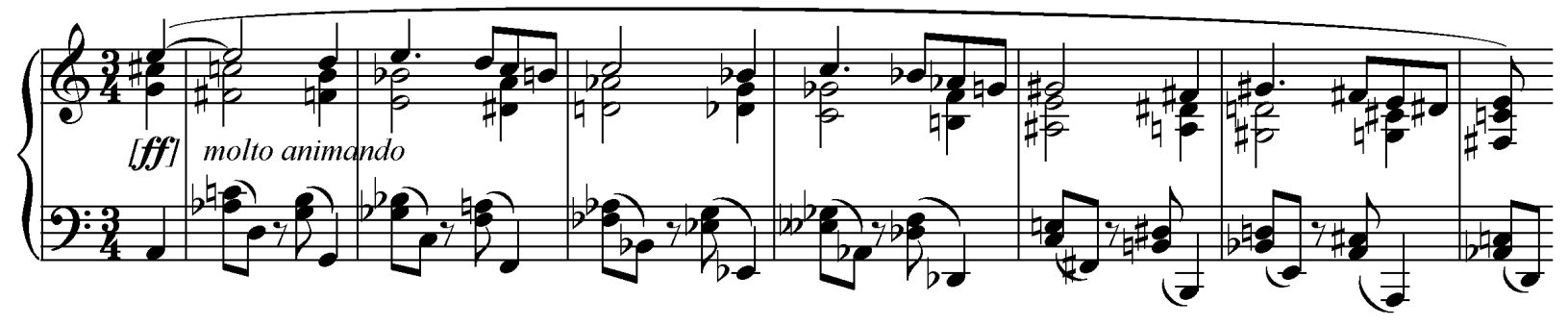

Example 2.4.6: Medtner, Skazka, Op. 9 No. 2, mm. 85-90

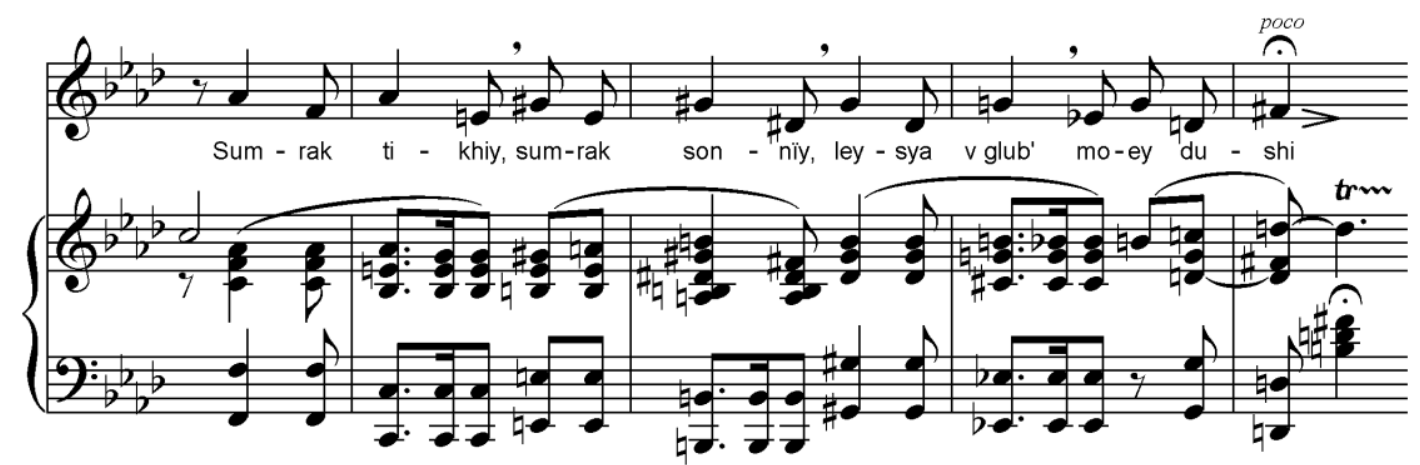

Example 2.4.7: Medtner, Eight Poems by Tyutchev and Fet: Sumerki, Op. 24 No. 4, mm. 29-33

As a last example I will now reference a passage of particularly intimate character, possibly in hermeneutic interpretation of the text, taken from the Tyutchev song Sumerki (Twilight), Op. 24 No. 4 (1911) - an intriguing piece right from the outset due to its continuously changing time signature, showing an alternating pattern of $4 / 8,5 / 8,6 / 8$, and $5 / 8$. In the middle section of the song, corresponding to the words $\gg$ sumrak tikhiy, sumrak sonnïy, leysya v glub’ moey dushi« (»deep and dreamy twilight, pour yourself deep into my soul«), we encounter several progressions of ascending fifths (m. 29ff; see example 2.4.7), every of which is first chromaticised in terms of a $>$ slide relation $<\left(F\right.$ minor $-C^{7}$; E major $\left.-B^{7}\right)$, and in turn sequenced by an ascending minor third (G\# minor $-\mathrm{D} \sharp^{7}\left[E b^{7}\right]$; G major $-\mathrm{D}$ major). This is one of the most appealing examples of music responding to the text within Medtner's songs, followed by a just as beautiful passage which transposes the song's beginning from $\mathrm{F}$ minor to a delicate B minor, with a trill of the pianist's right hand added. 


\subsubsection{Design of Final CADENCES}

The endings of Medtner's works and movements variously show compelling and inventive ways of approaching a final cadence, ${ }^{77}$ some of which will be appreciated by a closer look below. Opposed to the V-I progression of the traditional authentic cadence, Medtner preferably chooses plagal harmony (IV-I or even VI-I, as in the final three measures from the $1^{\text {st }}$ movement of the F minor Piano Sonata, Op. 5) for the conclusion of pieces; this observation matches a general tendency in late-Romantic music. Examples of perfect authentic cadences (PACs), or final progressions of several descending fifths are however encountered at the endings of the G minor Sonata, Op. 22 (with dominant minor ninth chords: $A^{7 / 69}-D^{7 / 69}-G m$ ), the E minor Sonata, Op. 25 No. 2 (with a flattened-fifth dominant: $\left.\mathrm{B}^{7 / 55}-\mathrm{Em}\right),{ }^{78}$ and the Ab major Sonata, Op. 11 No. 1 $\left(\mathrm{C}^{7}-\mathrm{Fm}-\mathrm{D} b-\mathrm{A} b-\mathrm{E} b^{\text {sus } 4}-\mathrm{A} b\right.$, the expansion of a very similar cadence found in Chopin's $3^{\text {rd }}$ Ballade, Op. 47, in the same key: $\mathrm{C}^{7}-\mathrm{Fm}-\mathrm{E} b^{7}-\mathrm{A} b$ ). However, cadences designed as simple as these are comparatively rare in Medtner, while he tends to »append harmonic complications at the endings of his compositions after a seemingly ultimate tonic has been already reached $\ll{ }^{79}$ Here follows a collection of more innovative cadential procedures.

- C major Sonata, Op. 11 No. 3 - a strongly altered, whole-tone harmony above $G$, functioning as a secondary dominant, precedes the penultimate chord Fm (with sixte ajoutée) which then resolves in a plagal progression to the tonic: $\mathrm{V}^{7 / 5513} / \mathrm{IV}-\mathrm{IV}^{\text {add6 }}-\mathrm{I}$ (see also the corresponding analysis in chapter 3.2 .3 ) ${ }^{80}$

- $\quad$ Goethe song Wandrers Nachtlied I, Op. 15 No. 1 (1907) - in one of Medtner's most delicate and colourful endings, a tritone substitution of the tonic precedes a flattened-fifth dominant, connected by the note $F \#$ respelled as $G$ b , before resolving to the tonic $\mathrm{F}$ major: $\sharp \mathrm{IV}-\mathrm{V}^{7 / 55}-\mathrm{I}$ (see example 2.4.8).

- G major Novelle >Daphnis et Chloë«, Op. 17 No. 1 (1908) - another exotic whole-tone chord, comparable to Op. 11 No. 3, is employed as the antepenultimate harmony: bVI ${ }^{9 / 45}-$ II $^{7}$ [German sixth] - I.

- D minor Skazka, WoO 3 (1915) - a half-diminished seventh chord on the \#iv (»an altered subdominant of the parallel major $\ll)^{81}$ proceeds to a diminished third-fourth chord of the \#vii, surprisingly resolving in a fundamental tritone progression to the tonic: $\# \mathrm{iv}^{07 / 55}-\# \mathrm{vii}^{07 / 45}-\mathrm{i}$.

- Delvig song Mogu l' zabït' to sladkoe mgnoven 'e (Waltz), Op. 32 No. 5 (1915) - a plagal Mixolydian cadence, moving from a $\mathrm{F}^{9}$ dominant ninth chord to the $\mathrm{G}$ major tonic, connected by the common pitch $G$ : bVII'-I.

- $\quad$ C $\sharp$ minor Skazka, Op. 35 No. 4 (1916-17) - during the last four measures, the tonic is approached by four different chords, every of which contains the pitch $C \#$ (referred to as a "progression of scattered chords « by Malikova) $:^{82} \# \mathrm{iv}^{07 / 65}-\mathrm{i}-\mathrm{iii}^{07 / 55}-\mathrm{i}-\mathrm{iii}^{6}-\mathrm{i}-\mathrm{ii}^{07 / 15}-\mathrm{i}$. This ending is slightly reminiscent of the final measures of Rachmaninov's C\# minor Prelude, Op. 3 No. 2 (1892).

77 Vasilyev 1962, p. 17, considers the frequent occurrence of extraordinary and resourceful closing cadences a peculiar feature of Medtner's music (my paraphrase of: „V takikh konechnïkh kadentsiyach Metner ochen' izobretatelen «). See also Loftis 1970, p. 168ff., for a general overview of cadence types in Medtner's piano sonatas.

78 Chernaya-Oh 2008, p. 17f., somewhat overstates the »dissonant altered chord« in this progression which appears rather unspectatular compared to Medtner's more sophisticated cadences.

79 My translation of Flamm 1995, p. 98: »Die [...] Ausweichung [...] entspricht einer generellen Tendenz bei Metner, nach der vermeintlich endgültigen Rückkehr zur Tonika gegen Ende der Stücke noch eine harmonische Verkomplizierung einzuschieben«.

80 The antepenultimate harmony is described by Malikova 1967, p. 290f., in neglection of the substantial b13, as a subordinate dominant third-forth chord to the subdominant (»pobochn[aya] dominant[a] $\left(\mathrm{V}_{43} \mathrm{k} \mathrm{S}\right) \ll$.

81 Ibid., p. 301: »V re-minornïy kadans neozhidanno vklyuchaetsya al'terirovannaya subdominanta odnoimennogo mazhora. Posleduyushchaya dominanta v vide $\mathrm{VII}_{43} \mathrm{~s}[\ldots]$ alteratsiey razreshaetsya [...] na uvelichennuyu kvartu«.

82 Ibid, p. 300: »posledovanie >razbrosannikh« akkordov«. The author does not analyse the individual chords, but gives a voice-leading scheme written on three staves to illustrate the chromatically descending lines of this concluding passage. 
- $\quad F \#$ minor Skazka, Op. 51 No. 5 (1928) - again, the most exciting harmony is the antepenultimate chord, a hexad with its six pitches matching Scriabin's >Prometheus chord five augmented, diminished, or perfect fourths $(C-F \#-B b-E-A-D){ }^{83}$ This $\gg$ sudden intrusion of a hexad is a singular event in Medtner's œuvre $\ll,{ }^{84}$ resulting in a secondary-dominant polychord constructed of a superposition of $\mathrm{C}^{7}$ and $\mathrm{D}$ major, and proceeding to a flattened-fifth dominant: $b \mathrm{~V}^{9 / 11 / 13}-\mathrm{V}^{7 / b 5}-\mathrm{I}$ (see example 2.4.9).

- C major Prelude from Romantic Sketches for the Youth, Op. 54 No. 7 (1931-32) - a progression employing two triads above the lowered scale degrees $B b$ and $A b$, sounding as if borrowed from the parallel minor: bVII-bvi-I. This sequence of chords seems to mock the so-called $>$ Disney cadence $<$ ( $b$ VI-b VII-I).

- $\quad$ Two Elegies, Op. 59 (1940-41) - both pieces show fascinating cadential variants (see example 2.4.10 for a comparison): The first Elegy in A minor, Op. 59 No. 1, concludes with a $b \mathrm{~V}^{\text {add }}-\mathrm{V}^{7}-\mathrm{I}$ progression, its upper voice from far resembling a Neapolitan cadence, and including an $\mathrm{E} b$ minor sixte ajoutée chord in foresight of the following piece's tonality. The second Elegy in Eb minor, Op. 59 No. 2, varies this cadential scheme to an even more idiosyncratic $b \mathrm{~V}-\mathrm{iv}^{7}-\mathrm{I}$, starting from the double-subdominant Neapolitan harmony of $\mathrm{B} b b$ major, ${ }^{85}$ and proceeding to an $\mathrm{Ab}$ minor seventh chord before resolving to $\mathrm{Eb}$ major in a plagal progression.

- Tyutchev song Polden' (Midday), Op. 61 No. 6 [Op. 59 $\left.{ }^{\text {bis }}\right]$ (1936) - this is the one of Medtner's compositions most reminiscent of Impressionist harmony. After the beginning had already avoided the $\mathrm{B} b \mathrm{mi}-$ nor tonic, discernible only at an half cadence in $\mathrm{m}$. 10, the song ambiguously closes with a prolonged $\mathrm{G} b$ major sixte ajoutée chord, offering two different conclusions: The music has, in the second half of the song, modulated to the Mixolydian VI (a reasonable notion as Gb major is stabilised already in a cadence at $\mathrm{m}$. 22f.); or the ending is considered atonical (which also seems plausible due to the unchanged key signature of five flats).

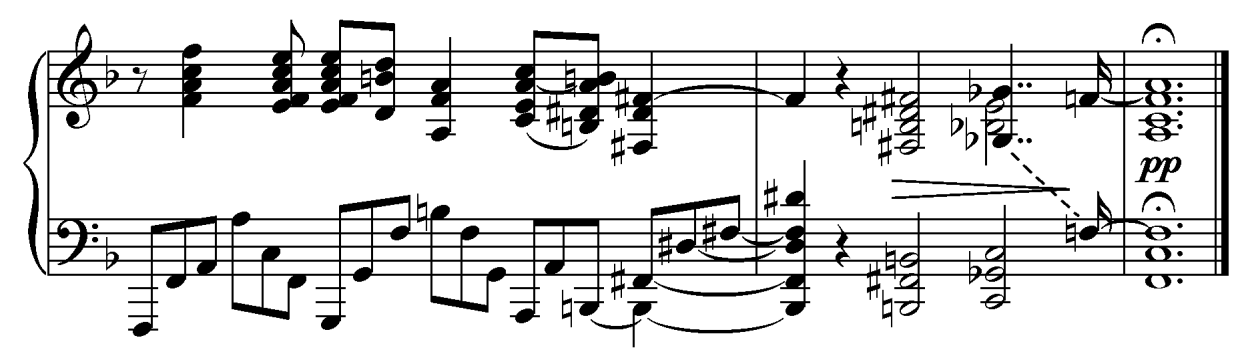

Example 2.4.8: Medtner, Twelve Songs by Goethe: Wandrers Nachtlied I, Op. 15 No. 1, mm. 17-19 (piano part)

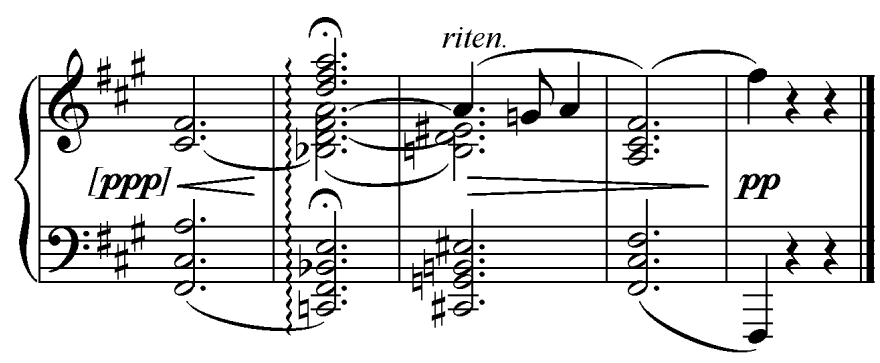

Example 2.4.9: Medtner, Skazka, Op. 51 No. 5, mm. 124-128

83 The alleged reference to Scriabin's >mystic chord ‘ is purported by Barban 1980, p. 17. However, Flamm 1995, p. 100 , argues that a direct adoption of that chord, as also suggested in Malikova 1967, p. 304f., may seem fallacious in view of Medtner's general rootedness in tonal harmony.

84 My translation of Flamm 1995, p. 100: »Dieser plötzliche, unvermittelte Einbruch eines Sechsklanges ist ein singuläres Ereignis in Medtners CEuvre.«

85 See ibid., p. 99: »Die erniedrigte V. Stufe [kann] diesmal als neapolitanischer Sextakkord zur Subdominante ausgelegt werden.« 

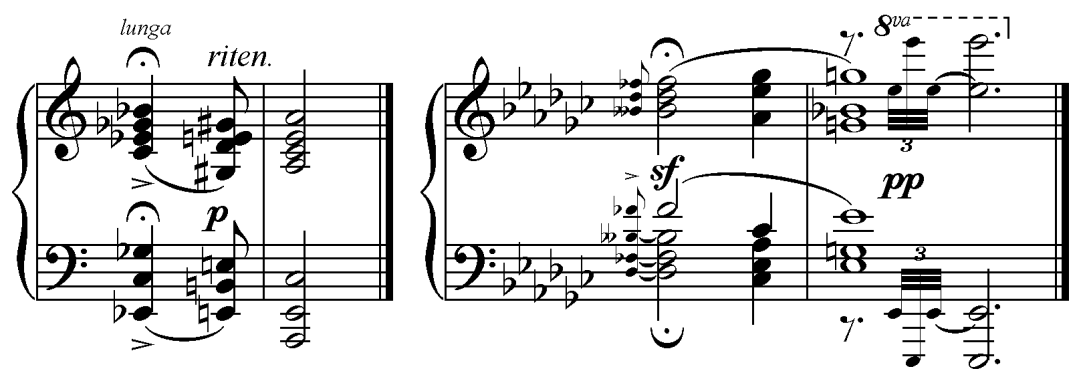

Example 2.4.10: Medtner, Elegy, Op. 59 No. 1, mm. 107-108 // Elegy, Op. 59 No. 2, mm. 107-108

A cadential pattern Medtner appears to have been particularly fond of is the progression of a tritone-related chord to the final tonic, preferably found at the end of harmonically exciting codas so as to produce an impressive concluding effect of utmost harmonic distance. Prominent examples are found in the final measures of the A minor Piano Sonata, Op. 30 (bV $\mathrm{V}^{7}$ [German sixth] - I), and the Grozovaya Sonata in F minor, Op. 53 No. $2\left(\sharp I V^{9}-I\right.$; see example 2.4.11). Both progressions feature a common pitch connecting the last two chords. In each case, the seventh of the remote penultimate harmony (Op. 30: $D$ b, enharmonically respelled as $C \#$, Op. 53 No. 2: $A$ ) is, upon resolution to the tonic, reframed as the major third above the root.
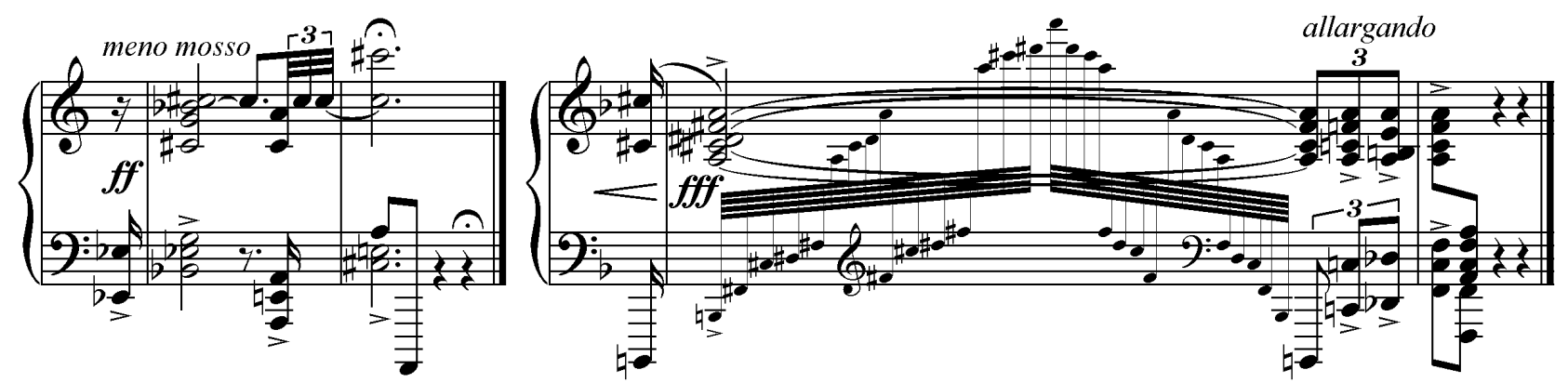

Example 2.4.11: Medtner, Sonata, Op. 30, mm. 609-610// Grozovaya Sonata, Op. 53 No. 2, mm. 446-447

\subsubsection{Key Semantics}

Medtner, as an artist with explicit affinity to Symbolism and spiritual metaphysics, has often employed tonality in semantic contexts which point beyond the music. This includes general feelings and affects associated with the character of different keys by tradition, as well as individual notions of particular harmonic environments which are semanticised according to his personal thoughts and convictions. Affective key characteristics in music history are exemplified by the writings of German scholars of the $18^{\text {th }}$ and $19^{\text {th }}$ centuries, such as Johann Mattheson, Georg Joseph Vogler, Christian Friedrich Daniel Schubart, Ernst Theodor Amadeus Hoffmann, and others. However, the notions of these authors were often diffusely expressed and appear inconsistent in direct comparison. It may seem doubtful anyway whether we can reasonably relate these historical approaches to Medtner's tonal semantics, given that he was primarily influenced by Andrei Bely, Aleksandr Blok, and other Symbolist thinkers and poets of his generation, rather than drawing 
inspiration from $18^{\text {th }}$-century German music scholarship. ${ }^{86}$ However, there are a number of obvious intercommunities which he shares with earlier semantic ascriptions to musical keys, ${ }^{87}$ some of which arise from the atmosphere or content of poems set by Medtner - and these most apparent cases are the subject of my elaborations in the following paragraphs. Even if he generally used every major and minor tonality, there is a certain tendency to prefer minor before major keys for his large-scale works, as in Scriabin and Rachmaninov, which partly predicates the observation that major keys with signatures of many flats (Ab major, $\mathrm{D} b$ major, $\mathrm{Gb}$ major) are slightly underrepresented in Medtner's music.

A first striking semanticisation concerns the use of the key of $\mathrm{C}$ major, which has a religious or at least spiritual connotation in many of Medtner's works. Still rather subliminally, the primary theme of the Piano Sonata, Op. 11 No. 3, conveys a serene and hymnic tone which is also found in a number of later compositions in the same key, most obvious in the Three Hymns in Praise of Toil, Op. 49 (1926-28), every of which is written in $\mathrm{C}$ major ${ }^{88}$ Other characteristic pieces include the Pushkin settings Angel (The Angel) and Arion from the Six Songs, Op. 36, Nos. 1 and 6 (1917-18), the latter of which escalates to a giant vocalise climax at its ending - and it is probably not by coincidence that the Sonata-Vocalise, Op. 41 No. 1, which features hymn-like melos throughout, was composed in the same key a few years later. The $\mathrm{C}$ major Prelude from the Romantic Sketches for the Youth, Op. 54 No. 7 (1931-32; see example 2.5.4) is subtitled >Hymn<; and most significantly, the $3^{\text {rd }}$ movement of the C major Piano Quintet, Op. posth., features a solemn theme marked Quasi Hymn (m. 346ff.; first appearance in m. 88ff., then in D major). Flamm points out that »all of Medtner's compositions titled $>$ Hymn $<[\ldots]$ are written in C major, [...] a symbol of utmost immaculacy and proximity to God ${ }^{89}$ and even notices echoes of the Grail’s bells from the finale of the $1^{\text {st }}$ act of Richard Wagner's Parsifal, also in C major, in Medtner's Hymn Before Work, Op. 49 No. 1 (m. 91ff.). Indeed, the pious, hymnic tone of the latter piece matches the atmosphere of $\mathrm{C}$ major not only in the music of Wagner, but also of Scriabin — see, for example, the solemn apotheoses from the $2^{\text {nd }}$ and $3^{\text {rd }}$ Symphonies, Opp. 29 and 43, and from the Poème de l'extase, Op. 54 - and Olivier Messiaen. Others of Medtner's compositions correspond to Schubart's conception of $\mathrm{C}$ major as a »completely pure and innocent « key. ${ }^{90}$

E minor, on the contrary, arises in Medtner as a key of epic breadth and highest expressivity, used for works of large dimensions in all of his favourite genres: the Skazka >March of the Paladin〈, Op. 14 No. 2 (1904-07); the Piano Sonata >Night Wind , Op. 25 No. 2, which bears an epigraph from the Tyutchev poem »O chëm tï voyesh, vetr nochnoy«; the Sonata epica for violin and piano, Op. 57, representing the longest of Medtner's compositions with a performance time of about 50 minutes; and the $3^{\text {rd }}$ Piano Concerto, Op. 60.

86 Due to the general philosophical orientation of the Russian Silver Age, and particularly through the influence of his brother Emil, Nikolai Medtner had been also familiar to the writings of the German philosophers Nietzsche and Schopenhauer.

87 For this reason the analyses of piano sonatas found in part 3 will incorporate short statements on the history of keys and modes, examining Medtner's choice of keys as compared to his predecessors' sonatas, as well as chamber and orchestral works, which share their respective tonality.

88 See Flamm 1995, p. 503.

89 Ibid., p. 95ff.; the quote is my paraphrase of p. 97.

90 Schubart 1806, p. 377: „C Dur ist ganz rein. Sein Charakter heißt: Unschuld, Einfalt, Naivetät, Kindersprache.« 
All of the mentioned works may, due to their inherent narrative or literary background, be regarded as >epic< music (for more details see chapter 3.5.4). However, other E minor characters also occur in Medtner, such as the flexible cantabile of the Canzona fluviala (Song of the River) from the $1^{\text {st }}$ cycle of Forgotten Melodies, Op. 38 No. 4 (1920). This piece might insinuate water nymphs, ${ }^{91}$ or more precisely Rusalka, a figure from Russian folk tales that, through Lermontov's poetic adaptation, figures as a narrative background.

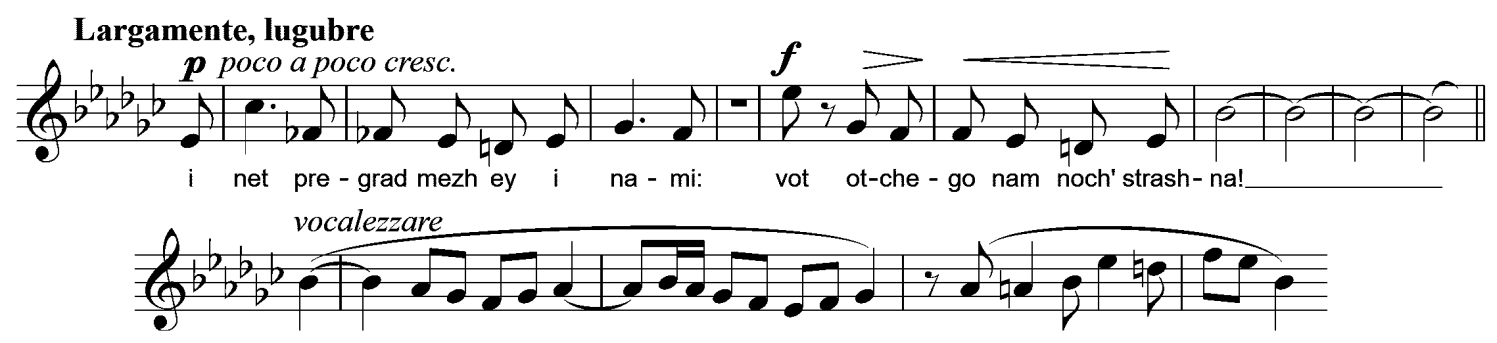

Example 2.4.12: Medtner, Den' i noch', Op. 24 No. 1, mm. 59-68 // Bessonnitsa, Op. 37 No. 1, mm. 61-64 (vocal parts)

The key of Eb minor, located at the lowest point of the circle-of-fifths' flat region, has variously been described as a >deathly< tonality, most strikingly exemplified by the grievous monody of the Eb minor Prelude from Bach's Well-tempered Clavier, Vol. I, or the death of Jesus in the St Matthew Passion. These and other examples might have prompted Schubart to claim that Eb minor transported »feelings of disquietude [...], of the darkest melancholia, of morbid constitution «. ${ }^{92}$ The key also frequently appears in Medtner's music with the connotation of night, grief, or death. An early example is the Stimmungsbild Op. 1 No. 3 (1897), picturesquely indicated Maestoso freddo, which possibly hints to a funeral procession with its steady, march-like rhythm. A distinct plaintive and mournful tone is also evident in the Goethe songs Im Vorübergehn, Op. 6 No. 4 (1903), ${ }^{93}$ Pesnya Min'onï (Mignon), and Das Veilchen, Op. 18 Nos. 4 and 5 (1909), all of which are in Eb minor. Also, the final section of the Tyutchev song Den' $i$ noch' (Day and Night), Op. 24 No. 1 (1911), programmatically darkens to the parallel minor key after having begun in a serene Eb major (m. 58: Largamente, lugubre; see example 2.4.12). More examples are found among others of Medtner's songs, most remarkably settings of Tyutchev's poems such as the elegiac Sizhu zadumchiv i odin (Absorbed and Alone), Op. 28 No. 6 (1913), and the dolefully tragic Bessonnitsa (Sleeplessness), Op. 37 No. 1 (1918)—after the last verse has been sung, this song closes with an extended vocalise stanza (m. 61ff.; see example 2.4.12). Two other pieces from the latter opus, Slëzï (Tears), also after Tyutchev, and Moego tot bezumstva zhelal (Impromptu) after Fet, Op. 37 Nos. 2-3, are written in Eb minor as well, suggesting a certain relationship between Medtner's fondness for sombre and elegiac poetry and the choice of key signatures with many flats. After all

91 Rizzi 2018, p. 15: »The wavy motion in E minor [...] well embodies the sinuous and bewitching song of a Rusalka«.

92 Schubart 1806, p. 378: »Empfindungen der Bangigkeit des aller tiefsten Seelendrangs; der hinbrütenden Verzweiflung; der schwärzesten Schwermuth, der düsteren Seelenverfassung. «

93 Flamm 1995, p. 169, suggests a semantic line connecting tragic or elegiac works in Medtner's œuvre, going from Op. 6 No. 4 to the Elegy, Op. 59 No. 2: »Tonal steht Im Vorübergehn in einer Reihe von es-Moll-Werken in tragischem oder elegischem Tonfall.« 
these examples, the grievous and even penitential character of the tonality is most apparent in the $\mathrm{Eb}$ minor Elegy, Op. 59 No. 2 (1940-41), a piece genetically connected to Bessonnitsa, and referred to by Medtner himself as `Ėlegiya pokayaniya (an >elegy of repentance $<$. ${ }^{94}$

On the opposite side of the spectrum, there is the bright key of $\mathrm{F} \#$ major, most significantly represented by the sparkling and buoyant $3^{\text {rd }}$ movement of the Sonata-Ballade, Op. 27. Likewise, it is found as early as in >Rusalka<, the first of the Three Fantastic Improvisations, Op. 2 No. 1 (1896), marked Veloce; and also in some of Medtner's songs, such as Glückliche Fahrt after Goethe, Op. 15 No. 8, (1908-09), and Ya prishël s privetom (Greeting) after Fet, Op. 24 No. 8 (1911), both of which share the brightness and vigour of the Sonata-Ballade's finale. As the key's enharmonic complement, the $\mathrm{G} b$ major setting of Fet's Babochka (The Butterfly), Op. 28 No. 3 (1913), also fits in this category. F\# major is even surpassed by the seven sharps of the unusual key of C\# major, found in the Tyutchev setting Pesn’ nochi (Night Song), Op. 45 No. 3 (1924)which, however, is a slow and elegiac song, indicated Largamente.

When it comes to considering the semantics of musical keys, some of Medtner's sonata cycles deserve a few additional thoughts. Two tonalities are used twice in the corpus of piano sonatas: F minor, in Op. 5 and the Grozovaya Sonata, Op. 53 No. 2; and C minor, in the Sonata-Skazka, Op. 25 No. 1 (see also the corresponding analysis in chapter 3.4) and the Sonata tragica, Op. 39 No. 5. In both cases, the earlier piece appears, in terms of harmony and musical form, as a rather conventional, multi-movement composition, while the latter realises a single-movement, monothematic structure, also exploring new dimensions of harmonic language. So it is obvious that, when Medtner chose a key for a sonata for the second time, he went for a formal conception as contrasting to the first instance as possible. This is remarkable also in the respect that he did not always adhere to the character of those keys found in the music of his spiritual ancestor Beethoven, whose symphonies, concertos, and sonatas in $\mathrm{C}$ minor and $\mathrm{F}$ minor mostly show a predominant character »of drama, pathos, gravity, and utmost seriousness « ${ }^{95}$ A similar observation as above, but in reverse order, applies to the $1^{\text {st }}$ and $2^{\text {nd }}$ Piano Concertos, Op. 33 (1914-18) and Op. 50 (1923-26), both of which are in $\mathrm{C}$ minor-but whereas the first piece employs a large and complex single-movement conception, the second very much resorts to the traditional three-movement outline.

\subsection{GENRES AND GENERIC HYBRIDS}

A distinctive feature of Medtner's music is the frequent occurrence of unusual genre titles. At the same time, the composer shows a predilection for the permeability of musical genres — or, in other words, the attribution of more than one generic category or title to the same work. The aesthetic and hermeneutic implications of Medtner's titles, labels, and their interrelations have not been examined in detail so far, and I will here propose a classification of hybrid musical genres in five categories: (1) >Genre sonatas` denominated with an

94 Ibid., pp. 127 and $524 f$.

95 Bertin 2018, p. 22. The autor further relates to the relevance of Beethoven's key characteristics for Medtner's works in $\mathrm{C}$ minor, $\mathrm{C}$ major, and a number of other tonalities. 
additional second genre; (2) >Symbolist sonatas` including descriptive attributes or adjectives in their titles; (3) approximations of sonatas and suites; (4) skazki and (5) other character pieces with hybrid titles, labels, or ascriptions. In addition, I will elaborate on the ambiguity of improvisation and variation form in Medtner.

Hybrid genre is certainly not a phenomenon which Medtner invented; instead, it roots back to developments in piano, chamber, and orchestral music of the early $19^{\text {th }}$ century (see also chapter 1.1.1). Descriptive subtitles were already common among instrumental works of Viennese Classicism, such as some of Haydn's and Mozart's symphonies and string quartets, as well as Beethoven's piano sonatas. Even if many of these epithets, be it the `Emperor Quartet, the >Jupiter Symphony, or the `Moonlight Sonata, were not originally conceived by the composers, but added by a publisher or impresario for commercial purposes, they coined a fixed characterisation and non-interchangeability of the respective work, making them easier for audiences to keep in mind. The $19^{\text {th }}$ century continues this tendency of giving epithets to the most famous works of the repertoire-when we think of Schubert's >Trout Quintet`, Mendelssohn's >Italian Symphony< or Chopin's >Raindrop Prelude<, the sound of the respective works spontaneously springs to mind. Medtner's goal in applying subtitles or attributes, however, was certainly not to enable his music to be triggered by some shibboleths or buzzwords, but to express a necessity of further specifying a work's denomination by subgenres or picturesque \Symbolist`attributes. This preference must be regarded in the context of permeable, or >fluid<, ascriptions of transdisciplinary genres as common among artists of the Russian Silver Age (see also chapter 0.2 .3 ).

\subsubsection{GenRe TitLes And SubTitLes}

Let us first have a general look on Medtner's way of naming his compositions and his affinity to special titles, subtitles, or combinations of titles, many of which are, if not unique, rarely found elsewhere. Already in his earliest publications, Medtner chose idiosyncratic captions for his solo piano cycles: Stimmungsbilder (Mood Pictures), Op. 1 (1896-1901); ${ }^{96}$ Fantastic Improvisations, Op. 2 (1896-98); Arabesques, Op. 7 (1901-04); Novelles, Op. 17 (1908); Forgotten Melodies, Opp. 38-40 (1919-20); or Romantic Sketches, Op. 54 (1931-32). Some titles refer back to antique literary forms, such as the Dithyrambs, Op. 10 (1898-1905), originally a genre of Greek choral poetry, or the Hymns in Praise of Toil, Op. 49 (1926-28). Also, individual pieces from Medtner's opuses often vary between genre titles and poetic attributes - we will rarely find Ball Reminiscences, Tragedy Fragments, or Lyric Fragments in other composers' music. At the same time, common genres of piano character pieces are comparatively rare in Medtner. There are very few examples of preludes, etudes, caprices, or moments musicaux, and after he had gathered one example of each in his Quatre Morceaux, Op. 4 (1897-1902) and wrote another random Etude of medium difficulty in C minor (c. 1912), he would hardly ever return to these genres.

96 Flamm 1995, p. 358, considers it possible that this title might have been inspired by Richard Strauss's publication of the same name, Op. 9 (1884). There is another three-part Stimmungsbilder cycle by Georgy Conus, Op. 19 (1903-05). 
Medtner's imaginative titles and subtitles often transcend the border of pure absolute music towards a narrative or poetic dimension - which does not mean that these works belong to the domain of program music. Instead, they might rather be considered descriptive pieces of art in a Symbolist manner, pointing to a subliminal atmosphere, topic, or super-musical content which is not further explicated. In his book Muza i moda, Medtner clearly rejected the notion of his compositions, and of other music in general, being recognised as >programmatic < just for their denominations:

\begin{abstract}
»Many are inclined to assign to the realm of program music just about every piece that has not a purely musical title (sonata, rondo, prelude), but one describing its character or mood (berceuse, reverie), or one which may even have been borrowed, for greater clarity, from some well-known literary work. In reality, however, program music is only music in which the form itself and contents are dictated and justified by a certain program or subject matter. Thus the very strict sonata form of Beethoven's Coriolanus [...] precludes any possibility of assigning this work to the category of program music. $\ll^{97}$
\end{abstract}

Among the typical sources of melodic inspiration for much of Medtner's instrumental music is the derivation from either chant or dance, as apparent in many of his titles and subtitles. Captions such as Canzona and Danza are frequently found in his character pieces and suite movements, sometimes with additional adjectives, as prominently encountered in the $1^{\text {st }}$ and $3^{\text {rd }}$ cycles of Forgotten Melodies, Opp. 38 and 40 (〉Tanzweisen $<$ ). These include a number of canzone (Canzona fluviala, Canzona serenata) and danze (Danza festiva, silvestra, sinfonica, ditirambica); and so do some of Medtner's chamber works such as the $1^{\text {st }}$ Violin Sonata, Op. 21, which likewise incorporates a Canzona and Danza, and the Canzonas with Dances for violin and piano, Op. 43 (1924-25). Numerous indirect allusions to dance genres complete this list, such as Quasi valse or Tempo di valse indications, found in the A major Stimmungsbild, Op. 1 No. 8 (c. 1902), the Ab major Lyric Fragment, Op. 23 No. 3 (1912), the F minor Skazka, Op. 26 No. 3 (c. 1912), and in the $3^{\text {rd }}$ variation from the Bb minor Improvisation, Op. 31 No. 1 (1914).

Many of Medtner's piano character pieces originated in collections of sketches, or soggetti as the composer named them, which he would notate on loose sheets of paper and keep in boxes or suitcases, »writing down melodic fragments and themes that occurred to him at moments of creative inspiration [...] from which he would later weave together the fabric of a musical work $\ll{ }^{98}$ This habit, developed already in his early years, allowed him to elaborate a considerable part of his piano and violin compositions of the 1910s and 1920s on the basis of reusing material developed years or even decades before- a technique relevant for works such as the Nachtgesänge for violin and piano, Op. 16; the Lyric Fragments, Op. 23; the Skazki, Opp. 26, 34, and 35; and the Forgotten Melodies, Opp. 38-40. ${ }^{99}$ However, the composer frequently seems to have faced difficulties with the application of a genre to a completed work. After he had renamed many of his earlier character pieces, the labeling of those works which can be traced back to soggetti was a process of

97 Medtner 1935, p. 130f., quoted after Swan's 1951 translation, p. 124. However, the $3^{\text {rd }}$ Piano Concerto, Op. 60, might indeed be considered a programmatic work due to the existence of explanatory notes, depicting its content, as recorded by Anna Medtner; see Flamm 1995, p. 249f.

98 Mitchell 2015, p. 104.

99 See Flamm 1995, pp. 425, 453, 462f., and 477f. 
particular ambivalence, resulting in continuous re-groupings and re-namings of pieces (skazki, canzone, danze, fragments) until they appeared under their ultimate title. This points to a general permeability and exchangeability of genre titles in Medtner, even before it comes to discussing their combination and superposition, which I will carry out with the typology presented in chapter 2.5.3.

\subsubsection{MusicAl StORYTELLING: THE SKAZKI}

Fairy tales, folk legends, epic poetry such as bilini, ${ }^{100}$ and other fantastic sujets enjoyed high popularity in late- $19^{\text {th }}$-century and early- $20^{\text {th }}$-century Russian music, as seen in compositions such as Nikolai RimskyKorsakov's symphonic poem Skazka in D minor, Op. 29 (1879-80), his operas on fairy-tale sujets, and the narratives of the early Ballets russes. The phenomenon of Medtner creating skazki, a genre of piano character pieces which he did not invent but developed to an extent no other composer had done before, ${ }^{101}$ corresponds to this trend, and lets these pieces appear as particularly characteristic of his creative thinking. In general, the skazki might be described as character pieces with a narrative tone, occasionally bearing descriptive subtitles, labels, or poetic mottos. As Boris Asafiev wrote, they »are not descriptive tales or tales relating to adventures of some kind. These are tales about personal experiences, about the conflicts of a man's inner life. « ${ }^{102}$ However, the tale-telling attitude of these compositions refers back to the musical tradition of the $19^{\text {th }}$ century. They may not seem particularly inspired by Felix Mendelssohn's Songs without Words, Opp. 19-102, or Edvard Grieg's Lyric Pieces, Opp. 12-71; rather, their generic predecessors might be seen in the ballades of Chopin and Brahms, with which they share a common approach and atmosphere. From that perspective, the most fascinating examples of skazki are those which include sub-genres or cross-references to others of Medtner's works - these will be discussed later on.

The evolution of the skazka genre in Medtner's euvre took shape around the year of 1904 when he started sketching two compositions which would emerge as the Two Skazki, Op. 8 (1904-06), both in the key of C minor (see chapter 2.1.2 for a more detailed discussion of the Skazka, Op. 8 No. 2, and chapter 2.1.5 for

100 The bilina is a traditional East Slavic type of narrative poem or song depicting the life of a heroic figure. Chernaya-Oh 2008, p. 12, relates to a mutual inspirational sphere of bilini and skazki in discussing the sources of Medtner's generic titles.

101 A number of $19^{\text {th }}$-century and early-20 $20^{\text {th }}$-century compositions may, yet only vaguely, qualify as predecessors of Medtner's skazki. One might first think of Robert Schumann's cycles Märchenbilder, Op. 113, for viola and piano (1851) and Märchenerzählungen, Op. 132, for clarinet, viola, and piano (1853), or Charles-Valentin Alkan's Petit conte for piano (1859). Some of Carl Reinecke's four-handed piano works, such as the Märchen-Vorspiele, Op. 99 (1868), and Ein Märchen ohne Worte, Op. 165 (1881) are inspired by German fairy tales. Medtner's contemporary Paul Juon composed a Märchen, Op. 8, for cello and piano (published 1904), and his piano trio cycle Six Silhouettes, Op. 9 (1899) contains a piece named Conte mystérieux. Sergei Taneyev also included a skazka as the $3^{\text {rd }}$ movement in his Suite for Violin and Orchestra, Op. 28 (1908-09). Leoš Janáček’s Pohádka, a three-movement composition for cello and piano (1910, rev. 1912 and 1924) is based on a tale by the Russian poet Vasily Zhukovsky. Other works by Russian composers in succession were Konstantin Eiges's Skazki, Op. 12 (1914), Sergei Prokofiev's Tales of the Old Grandmother, Op. 31 (1918) - though more distantly derived from Russian folkloristic narratives - and the symphonic tale Peter and the Wolf (Petya i volk), Op. 67 (1936), as well as the skazki from Dmitry Kabalevsky's Children's Pieces, Op. 27 Nos. 20 and 22 (1937-38).

102 Asafiev $1930^{\text {a }}$, p. 351, quoted here after Martyn 1995, p. 36. Bertin 2018, p. 44, even suggests an autobiographical relevance of the skazki: »Like Chopin's mazurkas, Medtner turned to the skazka most frequently to express his most personal and imaginative ideas." 
the diptych representing a bipartite cycle). The original German title Zwei Märchen was also considered at an early stage of composition; Medtner discussed this issue with his elder brother Emil who assured him in the choice of this title, noting the epic tone of the mutual initial phrases of the two pieces. ${ }^{103}$ During the following years, Medtner composed seven more skazki (Opp. 9, 14, and 20), followed by the Sonata-Skazka, Op. 25 No. 1, as a blend of his two most important genres, and another 29 skazki to be published in groups of two to six pieces until the year of 1932 (Op. 26, Op. 31 No. 3, Opp. 34, 35, 42, 48, 51; four pieces from the Romantic Sketches for the Youth, Op. 54; and a D minor piece without opus number). This corpus adds up to a total of thirty-eight pieces, prompting Isaak Zetel to dub Medtner »the outstanding tale-teller in Russian music «, ${ }^{104}$ a notion which sustains the occasionally-claimed indebtedness of the skazki to Slavic folklore. In fact, there is only one opus, the six Skazki Op. 51 (1928), which explicitly alludes to characters from Russian tales.

Due to the difficulties in translating the Russian term skazka, the applicability of commonly-used equivalents in other languages has variously been discussed. The English ( $>$ fairy tale $\triangleleft$ ) and French translations (`conte des fées $\measuredangle$ ) are frequently found, but imprecise as they mainly refer to works of literature, as opposed to the original meaning of skazka which more closely relates to the activity of narrating (>rasskazat' ). Moreover, fairies are a species unknown to Russian folkloristic literature, and it seems more satisfactory to employ the terms in their condensed forms (>tale $<,>$ conte $<$ ), which appear closer to the Russian noun >rasskaz` (>story<, >report`). Still, the most appropriate translation is the German >Märchen ${ }^{105}$

\subsubsection{ClassificAtion OF GENERIC HYBRIDS}

\section{Type 1: >Genre Sonatas` with Sub-Genres}

Probably the most characteristic example of Medtner's innovative way of naming his works are his piano sonatas and other sonata cycles bearing associative or imaginative attributes - a type of music named >genre

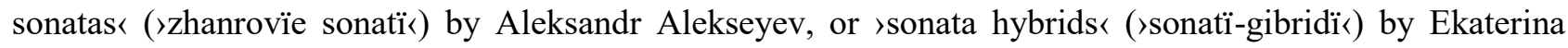
Podporinova. ${ }^{106}$ These are found in four of his fourteen piano sonatas, producing particular sub-genres that, in three of the four cases, have analogies in the titles of independent piano pieces: the Sonata-Elegy from the Sonata Triad, Op. 11 No. 2 (as opposed to the Two Elegies, Op. 59); the Sonata-Skazka, Op. 25 No. 1 (as opposed to the corpus of skazki); and the Sonata-Idyll, Op. 56 (as opposed to the Idyll from the Three Arabesques, Op. 7 No. 1; see example 2.5.2). The Sonata-Ballade, Op. 27, on the other hand, allows that work to

103 See Flamm 1995, p. 379f., quoting Nikolai’s letter to Emil of February 21, 1906.

104 Zetel 1981, p. 86. The author also quotes a line of Marietta Shaginyan (without giving the source): »The Tales are the actual and authentic realm of Medtner« (my translation).

105 Podporinova 2012, p. 248, points out that Medtner was fluent in both Russian and German, hence the terms skazka and Märchen can be considered equivalent in his œuvre. With regard to this specific genre, the author refers to the writings of Russian philologist Vladimir Propp.

106 Alekseyev 1969, p. 89, and Podporinova 2007, p. 75. See also Alekseyev 1982, p. 82: »Medtner's sonatas show poetic traits. A peculiar refraction is achieved by the saturation of some works with charakteristic elements of other genres, leading to the creation of unusual >hybrids« « (my translation of: »V sonatakh Metnera obnaruzhivayutsya chertï poèmnosti. Svoeobraznoe prelomlenie ikh—nasïshchenie nekotorikh sochinenii kharakteristicheskimi èlementami drugikh zhanrov, chto privodit k sozdaniyu neobïchnïkh >gibridov««). 
be regarded as a sonata cycle enclosing a single-movement ballade as its $1^{\text {st }}$ movement. Even though Medtner did not write independent ballades, this label reappears in the $3^{\text {rd }}$ Piano Concerto, Op. 60, a work also named Ballade. By means of the mentioned sub-genres, Medtner fuses the sonata, the genre with the highest formal and expressive demand within his œuvre, with the mood and texture of character pieces.

- $\quad$ Sonata-Elegy in D minor, Op. 11 No. 2: possibly inspired by the Elegie from Goethe's Trilogy of Passion ${ }^{107}$

- Sonata-Skazka in C minor, Op. 25 No. 1: two of three movements represent the tone and scope of skazki

- $\quad$ Sonata-Ballade in $\mathrm{F} \#$ major, Op. 27: the balladesque $1^{\text {st }}$ movement was first published separately

- $\quad$ Sonata-Idyll in G major, Op. 56: idyllic tone represented by its key and character of themes

- $\quad 3^{\text {rd }}$ Piano Concerto in E minor, Op. 60 (Ballade): with a narrative derived from Lermontov's Rusalka

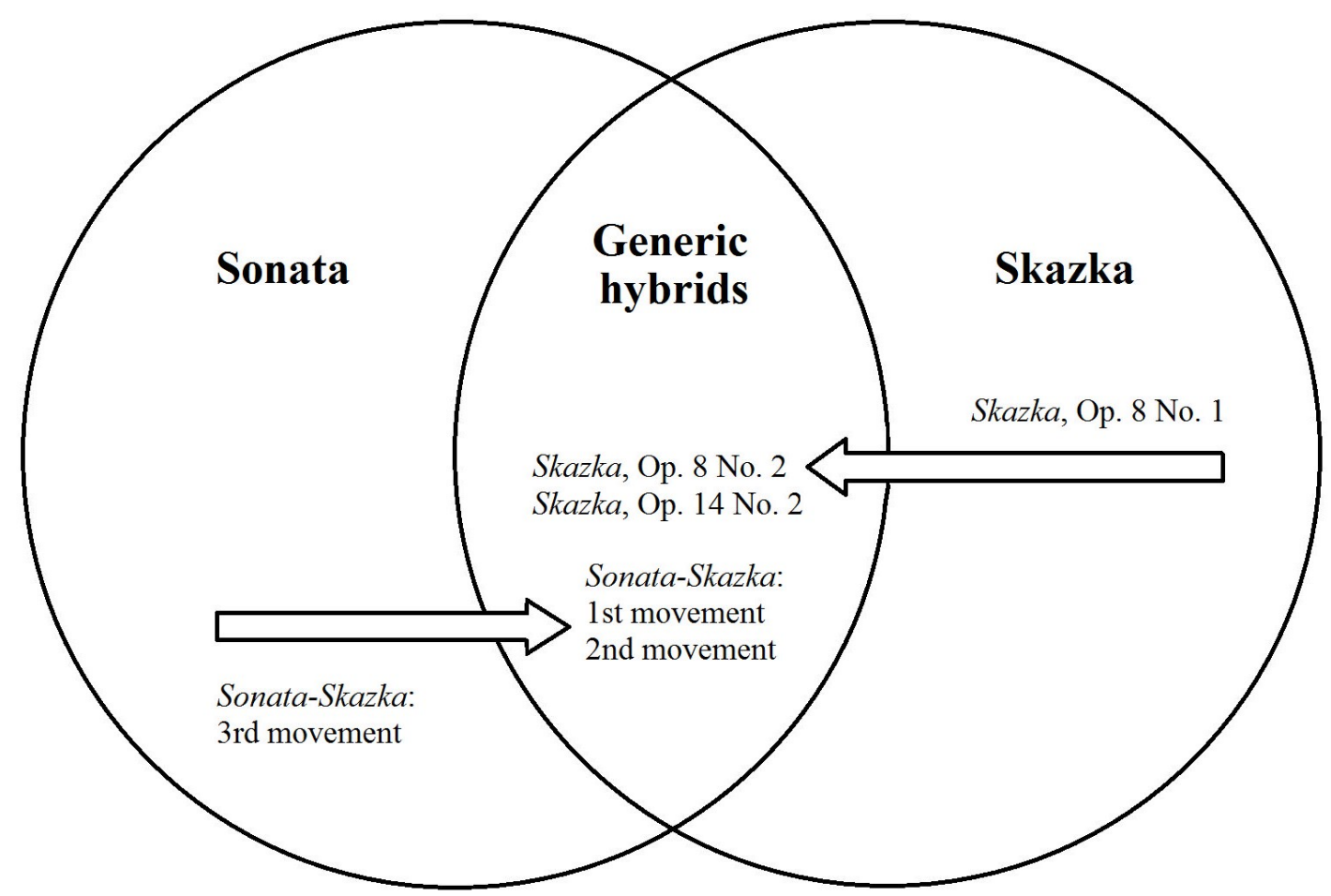

Figure 2.5.1: Intersections of the sonata and skazka genres in Medtner

The intersection between the sonata and skazka genres, as found in the Sonata-Skazka, Op. 25 No. 1, deserve a closer look because ambiguities apply in both directions. For instance, the C minor Skazka, Op. 8 No. 2 (1904-06), is a piece composed in sonata form, showing qualities of discourse and thematic dualism rather associated with sonatas. On the other hand, the Sonata-Skazka incorporates movements that could also function as independent character pieces, and thus figures as a unification of both of Medtner's most important musical genres. Its $1^{\text {st }}$ and $2^{\text {nd }}$ movements, like many of the skazki, exhibit narrative qualities in terms of their mood and structure (for details see the analysis in chapter 3.4.1). These relations can be illustrated in a diagram with two intersecting circles (see figure 2.5.1). Speaking of the general correlation of large-scale works and character pieces, as chiefly represented in Medtner by the corpuses of sonatas and skazki, their interrelation

107 Dolinskaya 2013, p. 35, asserts that that all three sonatas were closely modelled on the three poems, even though only the Sonata-Elegy retains the title of Goethe's Marienbader Elegie. 
suggests an aesthetic comparison to Aleksandr Scriabin's sonatas and poèmes. Even if a predilection for >Symbolist< ascriptions is not typical of Scriabin's sonatas, but rather of his character pieces—see, for instance, the Poème tragique, Op. 34 (1903); the Poème satanique, Op. 36 (1903); the Poème ailé, Op. 51 No. 3 (1906); or the Poème-Nocturne, Op. 61 (1911) - , he originally conceived his $5^{\text {th }}$ Piano Sonata, Op. 53 (1907), the first to attain single-movement form, as a Sonate-Poème. We might thus observe a certain intercommunity between the two composers as both of them tended to transcend their most significant genres by providing their sonatas and character pieces with cross-genre attributions.

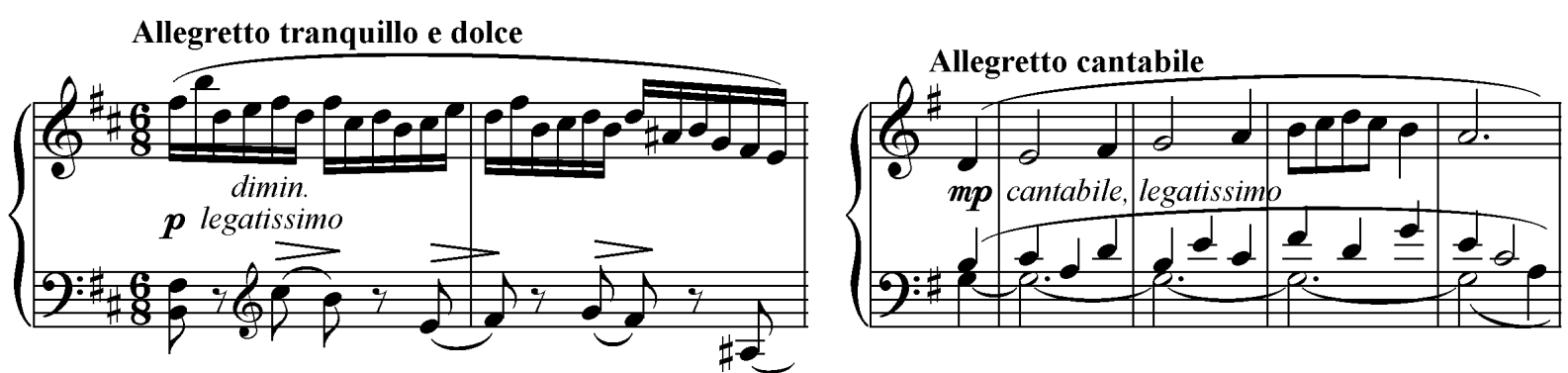

Example 2.5.2: Medtner, Idyll, Op. 7 No. 1, mm. 1-2 // Sonata-Idyll, Op. 56, $1^{\text {st }}$ movement, mm. 9-12

\section{Type 2: `Symbolist Sonatas` with Descriptive Attributes}

Another possibility, employed by Medtner for four more piano sonatas, is the use of descriptive adjectives in addition to the generic denomination of a sonata, as seen in the Sonata tragica, Op. 39 No. 5, Sonata romantica, Op. 53 No. 1, and Grozovaya Sonata, Op. 53 No. 2. I will here refer to this category as \Symbolist sonatas` as they feature a subliminal level of meaning which points towards a hermeneutic, yet unspecified, background - a similar tendency as with genre titles found in poetry and paintings of Russian Symbolism. In the case of the Sonata-Reminiscenza, Op. 38 No. 1, which is embedded in the $1^{\text {st }}$ cycle of Forgotten Melodies, Op. 38, the given attribute hints to a possible relation to Pushkin's poem of the same title (Vospominanie) ${ }^{108}$ as well as to its derivation from earlier-composed soggetti, as if >remembered < by the composer. The remaining six piano sonatas not mentioned here as types 1 or 2 do not belong to either category, as they lack a subtitle or descriptive attribute (Op. 5, Op. 11 Nos. 1 and 3, Op. 22, Op. 30). However, a special case is the E minor Sonata, Op. 25 No. 2, which features a poetic epigraph from Tyutchev, earning it the inofficial subtitle $>$ Night Wind Sonata — - a perspective allowing for further intertextual reference to literary works by Andrei Bely and Aleksandr Blok (see chapter 3.5.3).

- $\quad$ Sonata-Reminiscenza in A minor, Op. 38 No. 1: possibly inspired by Pushkin's Vospominanie

- $\quad$ Sonata tragica in C minor, Op. 39 No. 5: the most impressive instance of a Beethovenian sonata-drama in Medtner

- Sonata romantica in Bb minor, Op. 53 No. 1: nostalgically evoking the bygone era of Romanticism

- Grozovaya Sonata in F minor, Op. 53 No. 2: also named Sonate orageuse or Sonata minacciosa

- Sonata epica for violin and piano in E minor, Op. 57: Medtner's largest composition

108 The interrelation between the sonata and the Pushkin poem remains unclear, even though Alekseyev 1969, p. 272f., refers to its opening ritornello as a `theme of memories« (১tema vospominaniy`). Medtner also set Pushkin’s Vospominanie to music as his Op. 32 No. 2 (1915). 


\section{Type 3: Approximations of Sonatas and Suites}

Where the titles of sonata movements approach the names of character pieces, the genres of sonata and suite tend to converge. Such a structure is seen in Medtner's Sonata romantica, Op. 53 No. 1, which borrows the captions of three of its four movements from the domain of character pieces: Romanza, Scherzo, and Meditazione. ${ }^{109}$ All of these have equivalents in other works by Medtner, appearing as regular genre denominations; Meditazione and Romanza had previously figured as captions of the first two movements from the $2^{\text {nd }}$ cycle of Forgotten Melodies, Op. 39, Nos. 1 and 2 (see example 2.5.3 for a confrontation of both Romanze). The same applies to the $2^{\text {nd }}$ Piano Concerto, Op. 50, the movements of which are named Toccata, Romanza, and Divertimento; and likewise, the $1^{\text {st }}$ Violin Sonata, Op. 21, would make a proper suite with its movements titled Canzona, Danza, and Ditirambo - pointing to the fact that the work was not originally conceived as a sonata, but derived from Medtner's collections of soggetti. ${ }^{110}$ Cyclicity is, in Medtner, apparently not limited to a certain genre: just like a suite can include transformations of themes and even incorporate single-movement sonatas, a sonata cycle may approach the rather loose-knit scheme of a suite.

- $\quad 1^{\text {st }}$ Violin Sonata in B minor, Op. 21: comprises a Canzona, Danza, and Ditirambo

- $\quad$ Forgotten Melodies, $1^{\text {st }}$ cycle, Op. 38: comprises a single-movement sonata as well as Canzone and Danze

- $\quad$ Forgotten Melodies, $2^{\text {nd }}$ cycle, Op. 39: comprises a single-movement sonata

- $\quad 2^{\text {nd }}$ Piano Concerto in C minor, Op. 50: comprises a Toccata, Romanza, and Divertimento

- Sonata romantica in Bb minor, Op. 53 No. 1: comprises a Romanza, Scherzo, Meditazione, and Finale

- $\quad$ Sonata-Idyll in G major, Op. 56: comprises a Pastorale as its $1^{\text {st }}$ movement
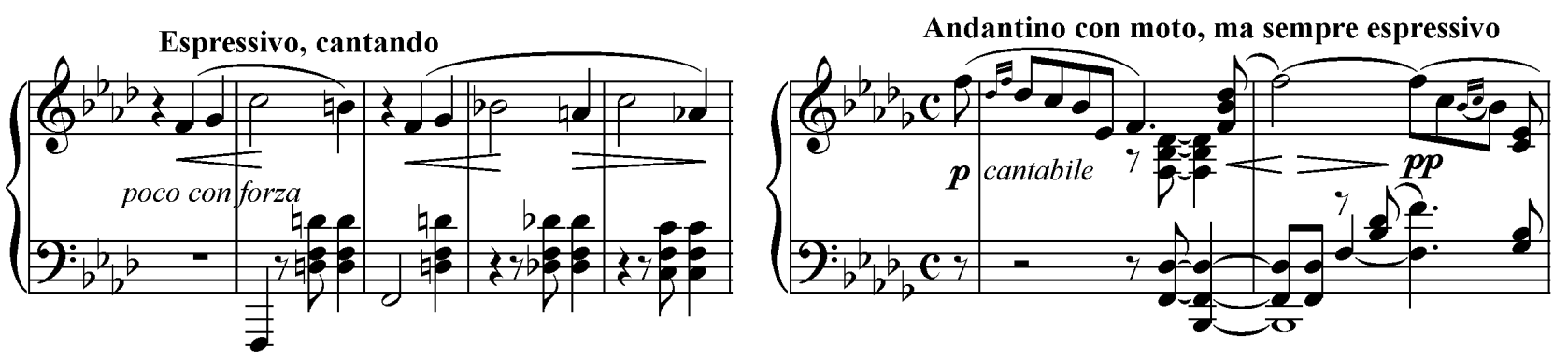

Example 2.5.3: Medtner, Romanza, Op. 39 No. 2, mm. 42-46 // Sonata romantica, Op. 53 No. 1, $1^{\text {st }}$ mvt: Romanza, mm. 1-2

\section{Type 4: Skazki with Hybrid Titles, Labels, or Ascriptions}

Many of Medtner's skazki also show a tendency to include additional references, such as hybrid titles and labels, poetic mottos, or ascriptions. Some of these were added only supplementarily in the Soviet Collected Edition, following Medtner's handwritten annotations in his personal copies. Just like the category of `Symbolist

109 See Dolinskaya 1966, p. 78: »Medtner employed programmatic genre titles also for individual parts of his sonata cycles. [...] This is due to his ambition to achieve brightness and concreteness in the musical image. « (»Zhanrovoprogrammnie zagolovki Metner daval i otdel'nïm chastyam sonatnogo tsikla. [...] Ėto svyazano so stremleniem k yarkosti i konkretnosti muzïkal'nïkh obrazov.«)

110 See Flamm 1995, p. 422. The Canzona figuring as the $1^{\text {st }}$ movement of the Sonata, Op. 21, with its indication canterellando ( $>$ warblingly $<$ ) and predominant siciliano rhythm, is particularly reminiscent of others of Medtner's song-like character pieces. 
sonatas, these do not coin a clear programmatic dimension, but merely an atmosphere enriching the listener's experience. Generic hybrids among the skazki include the C major Dance Skazka, Op. 48 No. 1 (1925) - see example 2.5.4, opposed to the $2^{\text {nd }}$ piece from the Canzonas with Dances for violin and piano, Op. 43 No. 2 , in the same key-, and an E minor composition from the Romantic Sketches for the Youth, Op. 54 No. 4 (193132), simultaneously named Skazka and Scherzo. In most other cases, the pieces from the following list feature picturesque labels, for instance `Song of Ophelia〈, `Campanella〈, or `The Magic Violin〈, or portray mythic or fabulous figures, such as in the skazki labelled `Wood Spirit‘, Elves' Tale, or Birds' Tale. As yet another option, the following list also includes skazki inscribed with short epigraphs from Tyutchev, Pushkin, or Shakespeare, coining a distinct literary background.

- C major, Op. 9 No. 2: >Serenade

- $\quad$ G major, Op. 9 No. 3: after Goethe’s Gleich und gleich

- $\quad$ F minor, Op. 14 No. 1: >Song of Opheliaく (১Pesnya Ofelii<)

- E minor, Op. 14 No. 2: >March of the Paladin〈 (১Shestvie rïtsarey<)

- B minor, Op. 20 No. 2: >Campanellar

- B minor, Op. 34 No. 1: >The Magic Violin〈 (`Bolshebnaya skripkaく)

- $\quad$ E minor, Op. 34 No. 2: after Tyutchev’s Uskopoenie

- A minor, Op. 34 No. 3: >Wood Spirit « (〉Leshchiyく)

- D minor, Op. 34 No. 4: after Pushkin’s »Poor Knight«

- $\quad$ C $\sharp$ minor, Op. 35 No. 4: after Shakespeare’s King Lear

- $\quad$ F minor, Op. 42 No. 1: Russian Skazka (Russkaya skazka)

- C major, Op. 48 No. 1: Dance Skazka (Tanets skazka)

- G minor, Op. 48 No. 2: Elves'Skazka (Skazka èl'fov)

- A minor, Op. 51 No. 2: inspired by Cinderella (Zolushka)

- G major, Op. 51 No. 6: inspired by Ivan the Fool (Ivanushka-Durachok)

- C minor, Op. 54 No. 2: Birds’ Tale (Skazka ptichek)

- $\quad$ E minor, Op. 54 No. 4: Scherzo (Skertso)

- D minor, Op. 54 No. 6: >The Organ Grinder (〉Sharmanshchik«)

- $\quad$ E minor, Op. 54 No. 8: >The Beggarく (`Nishchiy<), after Lermontov

\author{
drafted hybrid title ${ }^{111}$ \\ poetic inspiration $^{112}$ \\ label \\ supplementary label \\ supplementary label; ascription ${ }^{113}$ \\ label \\ supplementary poetic motto ${ }^{114}$ \\ supplementary label \\ supplementary poetic motto ${ }^{115}$ \\ supplementary poetic motto ${ }^{116}$ \\ label \\ hybrid title \\ label \\ dedication; supplementary ascription \\ dedication; supplementary ascription \\ label \\ hybrid title \\ label \\ label; possible poetic inspiration ${ }^{117}$
}

111 See ibid., p. 381; the piece had been sketched as \Ständchen` or `Serenadeく, which is echoed in its eventual tempo indication Allegro alla serenata, con alcuna licenza.

112 See ibid.; the Goethe poem had been set by Medtner as his Op. 15 No. 11 (1908-09).

113 Collected Edition, Vol. 2, p. 37: »Pesn' ili skazka kolokola, no ne o kolokole« (»Tale of the bell, but not about the bell«; the italics in the translation are mine).

114 Collected Edition, Vol. 3, p. 19: »Kogda chto zvali mï svoim, / Navek ot nas ushlo.« (»Once we have called a thing ours, it will leave us forever.«) A transcription of Nikolaus Lenau's poem Blick in den Strom, Tyutchev’s Uspokoenie was set by Medtner as one of hist last songs, Op. 61 No. 7; see Flamm 1995, p. 463.

115 Ibid., p. 32: »Zhil na svete rïtsar’ bednïy« (untitled poem: »There was a poor knight«).

116 Ibid., p. 56: »Duy, veter, zlis' / Poka ne lopnut shcheki« (King Lear, Act III, Scene II: »Blow, winds, and crack your cheeks! «). For a discussion of a possible narrative adaptation of Shakespearean content in Medtner's Skazki, Op. 14 No. 1 and Op. 35 No. 4, see Wodarski 2013, p. 14ff.

117 This piece might have been inspired by Lermontov's poem of the same name, set by Medtner as Op. 3 No. 1 (1903). 

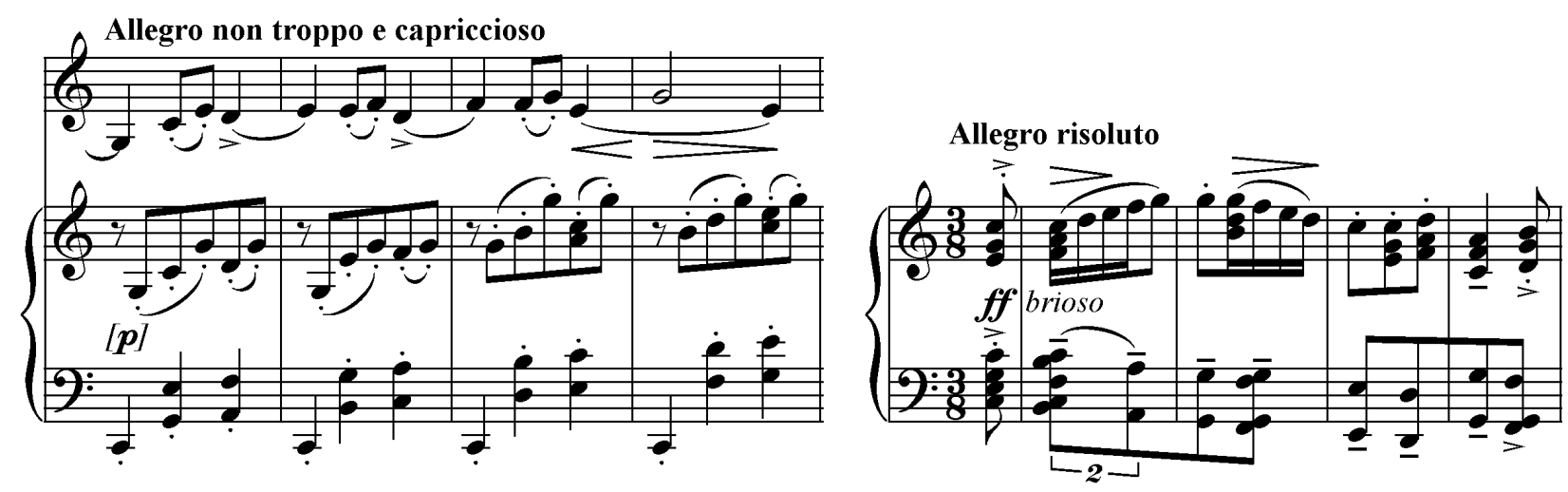

Example 2.5.4: Medtner, Canzonas with Dances, Op. 43 No. 2, mm. 5-8 // Dance Skazka, Op. 48 No. 1, mm. 1-4

\section{Type 5: Other Character Pieces with Hybrid Titles, Labels, or Ascriptions}

Moreover, there is another group of piano character pieces with additions to their titles similar to those seen in the aforementioned skazki. A very special case is found in the Three Arabesques, Op. 7 (1901-04), the first piece of which is a generic hybrid, marked Idyll, whereas the $2^{\text {nd }}$ and $3^{\text {rd }}$ pieces are subtitled Tragedy Fragment, a peculiar Medtnerian term in distant reference to Goethe. Other interesting captions are found within the Romantic Sketches for the Youth, Op. 54 (1931-32), a set of eight pieces comprising four skazki and four preludes. Some of the latter are provided with additional labels or subtitles, such as Pastorale or Hymn (see also example 2.5.5, opposed to the Hymn in Praise of Toil, Op. 49 No. 1), resulting in generic hybrids with a triple denomination: Romantic Sketch, prelude, and the respective subtitle.

- $\quad \mathrm{F} \#$ major Improvisation, Op. 2 No. 1: $>$ Rusalka<, after Lermontov

- G minor Improvisation, Op. 2 No. 2: >Reminiscence of a Ball

- F minor Improvisation, Op. 2 No. 3: Scherzo infernale

- C minor Moment musical, Op. 4 No. 3: >Gnome’s Lament< (`Zhalova gnoma $)$

- $\quad$ B minor Arabesque, Op. 7 No. 1: Idyll

- $\quad$ Arabesques, Op. 7 Nos. 2 and 3: Tragedy Fragments, after Goethe

- G major Novelle, Op. 17 No. 1: >Daphnis et Chloeく

- $\quad$ Suite-Vocalise in F minor, Op. 41 No. 2, after Goethe

- $\quad \mathrm{Ab}$ major Prelude, Op. 54 No. 1: Pastorale

- $\quad$ B major Prelude, Op. 54 No. 3: Tempo di Sarabanda

- A major Prelude, Op. 54 No. 5: >Tender Reproach` (>Nezhnïy uprëk $८$ )

- C major Prelude, Op. 54 No. 7: Hymn (Gimn)

- E major Chorovod (Russian Round Dance), Op. 58 No. 1: >Skazkar label; possible poetic inspiration label hybrid subtitle supplementary label hybrid subtitle hybrid subtitles; ascription ${ }^{118}$ supplementary label ${ }^{119}$ movements with subtitles hybrid subtitle tempo indication / label label hybrid subtitle hybrid subtitle

118 Martyn 1995, p. 32, asserts that the hybrid titles of Op. 7 Nos. 2 and 3 (Tragoedie-Fragment) were »taken from Goethe«. In the Collected Edition, Vol. 1, p. 153, the third piece bears the supplementary ascription »Presentiment of the [1905] Revolution« (»Predchuvstvie revolyutsii«), possibly reflecting the influence of the political situation during the time of its genesis.

119 According to Flamm 1995, p. 409, the label alludes to antique bucolic literature and to the pastoral character exemplified in others of Medtner's G major compositions. 

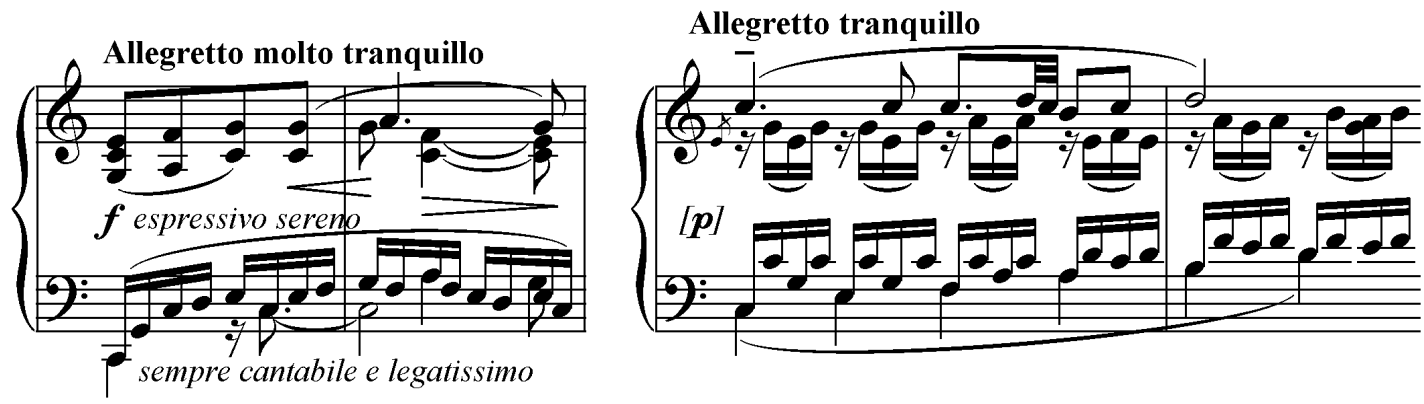

Example 2.5.5: Medtner, Hymn Before Work, Op. 49 No. 1, mm. 5-6 // Prelude (Hymn), Op. 54 No. 7, mm. 5-6

\section{Ambiguity of Improvisation and Variation Form}

Finally, as yet another phenomenon characteristic of Medtner's way of treating genre titles, the common attitude of improvisation and variation form in his œuvre deserves some consideration. In succession of the early Fantastic Improvisations, Op. 2 (1896-98), the composer would use that title for two more works: the $1^{\text {st }}$ Improvisation in B $b$ minor, published as part of the Trois pièces, Op. 31 No. 1 (1914), and the $2^{\text {nd }}$ Improvisation in $\mathrm{F} \#$ minor, Op. 47 (1925). Both are conceived as sets of variations, indicating that the element of spontaneous invention was, in the composer's imagination, somehow connected with the ambition to instantly produce variants and developments of an initial idea. Furthermore, variation forms beyond the context of hybrid genres are found in the $2^{\text {nd }}$ movement of the $2^{\text {nd }}$ Violin Sonata in G major, Op. 44, framed by two large cadenzas, and in the Theme and Variations in $\mathrm{C} \#$ minor, published on its own as Op. 55 (1933).

The $2^{\text {nd }}$ Improvisation, Op. 47, with a performance duration of roughly 30 minutes, is the longest of Medtner's piano solo works apart from the sonatas, ${ }^{120}$ dedicated to his friend Marcel Dupré. It commences with the enigmatic Pesn' rusalki (Song of the Water-Nymph; see example 2.5.6) which serves as a subject for the following cycle of fourteen variations, and refers to the legend of Rusalka, a prominent character in Russian literature and folklore throughout the $19^{\text {th }}$ century. ${ }^{121}$ Medtner absorbed that legend through the poetic rendering of Lermontov, which also provided inspiration for his early piano piece of the same title, Op. 2 No. 1

120 Dolinskaya 2013, p. 95, misconceives the $2^{\text {nd }}$ Improvisation as a work originally composed for violin and piano (»Vtor[aya] improvizatsi[ya] dlya skripki i fortepiano op. 47 (avtor ispolnyal svoyu versiyu dlya odnogo royalya)«). Such a version does not exist. However, there are still things to discover, as revealed by the findings of pianist Michael Brown who located three previously unpublished variations among Medtner's sketches preserved in the National Library of Canada, Ottawa, and recorded two of them in 2018.

121 The reception of the Rusalka legend was, in $19^{\text {th }}$-century Russia, primarily shaped through the literary adaptations of Aleksandr Pushkin (an unfinished epic poem of 1819) and Mikhail Lermontov (a poem of 1832). The poetic rusalki are closely related to tales on mermaids (or sirens) from Western Europe, such as Friedrich de la Motte-Fouqué's Undine (1811); Heinrich Heine's Loreley (1823); and Hans Christian Andersen's The Little Mermaid (1836). Besides popular adaptations of the Undine legend, such as Ernst Theodor Amadeus Hoffmann's Undine opera (181314); Carl Reinecke's Sonata for flute and piano `Undine〈, Op. 167 (1882); and Antonín Dvořák’s Rusalka opera, Op. 114 (1900), the figure has inspired a number of Russian composers before Medtner, mainly through the poetic sources provided by Pushkin and Lermontov. Examples are Aleksandr Alyabiev's incidental music to Rusalka (1838); Aleksandr Dargomïzhsky's Rusalka opera (1858); Pëtr Tchaikovsky's Undine opera (1869, destroyed by the composer); and many settings of the Lermontov poem by Anton Rubinstein, Aleksandr Borodin, Mily Balakirev, Mikhail Ippolitov-Ivanov, Anton Arensky, and others. All this information is taken from Naroditskaya 2006, p. 217ff. For the Rusalka legend as a source of inspiration for some of Medtner's compositions, possibly depicting earthly temptation as conveyed in a note of Anna Medtner, see Swan 1969, p. 109, and Flamm 1995, p. $528 f$. 
(see also example 2.5.6) and the $1^{\text {st }}$ subdivision of his $3^{\text {rd }}$ Piano Concerto, Op. $60 .{ }^{122}$ Like many others of Medtner's cycles and shorter works, the $2^{\text {nd }}$ Improvisation also includes generic hybrids as the individual variations approach the scope of independent character pieces. We encounter various types of sub-genres, such as Meditation (Var. I), Caprice (Var. II), and Humoresque (Var. V), alongside with other variations portraying mythical scenes and figures, many of which originate, like the water-nymph, from nature and forest—such as Gnomes (Var. XI), Elves (Var. X), and Wood Spirit (Var. IX). The latter pair allows for cross-references to the skazki >Wood Spirit‘, Op. 34 No. 3, and Elves'Skazka, Op. 48 No. 2, where the same characters are introduced, suggesting that these creatures played an enigmatic yet significant role in Medtner's inspiration.
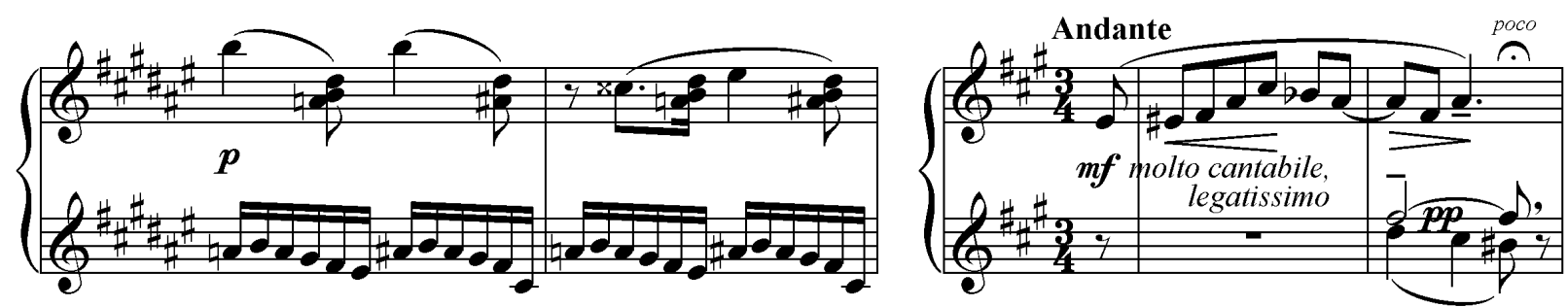

Example 2.5.6: Medtner, Rusalka, Op. 2 No. 1, mm. 13-14 // Improvisation, Op. 47, theme: Pesn' rusalki, mm. 1-2

As has been already shown in chapter 0.2.2, Medtner's aesthetic position should be regarded in the context of general developments of his time and geographical sphere, the most influential of which were Russian Symbolism and philosophy and literature of the >Silver Age<. Just like generic borders appeared permeable in other artistic disciplines such as literature, visual arts, and dance, musical genre titles could also be stretched and transcended, as seen in the music of Scriabin, Čiurlionis, and some of their contemporaries. The same applies to Medtner, whose affinity to musical narratives, intertexts, and restrained semanticisation reflects a general hallmark of this aesthetic environment. In Medtner scholarship, these aspects are widely recognised as a central element of the composer's style, reflecting his indebtedness to his familial and social environment, and to the Symbolist movement in general.

122 See Flamm 1995, pp. 362 and 527ff. The Song of the Nymphs from the Suite-Vocalise, Op. 41 No. 2, does however not refer to Lermontov but rather to Goethe's Geweihter Platz, the first two lines of which read »Wenn zu den Reihen der Nymphen, versammelt in heiliger Mondnacht, / Sich die Grazien heimlich herab vom Olympus gesellen«. 


\section{Medtner's Early Piano Sonatas}

This part finally turns to the analysis of individual works. It includes detailed examinations of roughly the first half of Nikolai Medtner's output in the genre of the piano sonata, comprising a group of eight works composed between approx. 1901-14, and published between 1904-14. The works covered by this period are Medtner's Op. 5, Op. 11, Op. 22, Op. 25 Nos. 1-2, and Op. 27. After some introductory remarks on analytic methodology and terminology, the successive six chapters will be dedicated to the individual analyses chronologically arranged by their opus numbers. The three works from the Sonata Triad, Op. 11, are combined in one chapter, whereas the two works from Op. 25 will be discussed separately. Explicit hints to the preceding parts and chapters of the study are included where they appear convenient or necessary. If particular melodic or harmonic phenomena have already been subject to the observations of the second part, I will include cross-references to avoid doublings and redundancies.

\subsection{Methodology AND TeRminOlogy}

Before starting to examine the musical scores in detail, I will approach every sonata as a subject of musichistorical discussion. Besides outlining the genesis of the works and relating to biographical aspects and possible connections to contemporary history, political incidents, or other external factors insofar as these appear relevant, I will also include accounts of their history of edition, performance, and recording. In many cases, contemporary reviews and assessments of the sonatas will be taken into consideration so as to give an impression of how the music appealed to audiences, critics, and the composer's friends in comparison to later evaluations. The musical analyses themselves will be supplemented, or even permeated, by the elucidation of hermeneutic dimensions where these are inherent to the music. Such a superordinate view of the music may require to shed light on literary, philosophical, or spiritual contexts - and the narrative aspects which arise from these are likely to reflect an interdisciplinary dimension related to the artistic principles of the Russian Symbolist movement. In some places, these intertexts lead to general thoughts on the nature of Medtner's music, or to discussions whether the respective composition can be considered an example of absolute, descriptive, or program music. 


\subsubsection{MusicAl Form AND SynTAX}

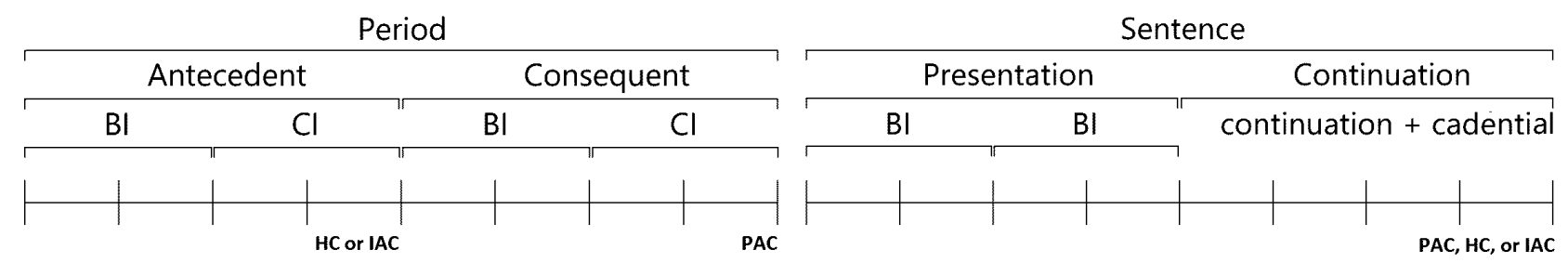

Figure 3.0.1: Schematic graphs of the period and sentence theme structure (conceived as ideal types) ${ }^{1}$

Sonata form is basically understood in accordance with the writings of James Hepokoski and Warren Darcy, referring to the exposition and recapitulation section as >rotations < comprised of an invariable succession of a primary theme zone, a transition (often delimited by a medial caesura), a secondary theme zone, and possibly a closing zone. This terminology is preferred to William Caplin's main-theme group, subordinate-theme group, and closing section. As for the syntactical structure of themes, the concepts of period and sentence, originally conceived by Arnold Schoenberg and Erwin Ratz, are applied as used in Caplin and maintained by Hepokoski and Darcy, along with their respective subdivisions (see figure 3.0.1). A period is comprised of an opening antecedent - typically closing with a half cadence (HC) or imperfect authentic cadence (IAC) and a concluding consequent, often closing with a perfect authentic cadence (PAC); an option to avoid a PAC is the deceptive cadence (DC), substituting the I / i for the vi / VI. On the contrary, a sentence consists of a presentation phrase and a continuation phrase, with the latter developing the motives of the former. Both antecedents and presentation phrases can be further subdivided into a basic idea (BI) and a contrasting idea (CI). Mixtures of the period and sentence constructions can be achieved by combining an antecedent and continuation phrase, or a presentation phrase and consequent (hybrid theme), or by interlacing a large period with two sentences figuring as its halves (compound theme). Extended thematic structures are, according to Caplin, typically conceived as a small ternary (A-B-A), comprising a loose-knit contrasting middle (B) as opposed to the exposition and recapitulation of a rather tight-knit exterior section (A).

Sonata form itself is, if not indicated otherwise, conceived throughout my analyses as the standard case of tripartite, bi-rotational layout, defined as a >Type 3 Sonata according to Hepokoski's and Darcy's Sonata Theory (see figure 3.0.2), and consisting of an exposition, development, and recapitulation section by default. Options for the extension of this outline include a slow introduction or coda.

1 As described in Caplin 1998, p. 9-12; diagrams taken from the website OpenMusicTheory, reproduced here via a CreativeCommons BY-SA 4.0 license. 


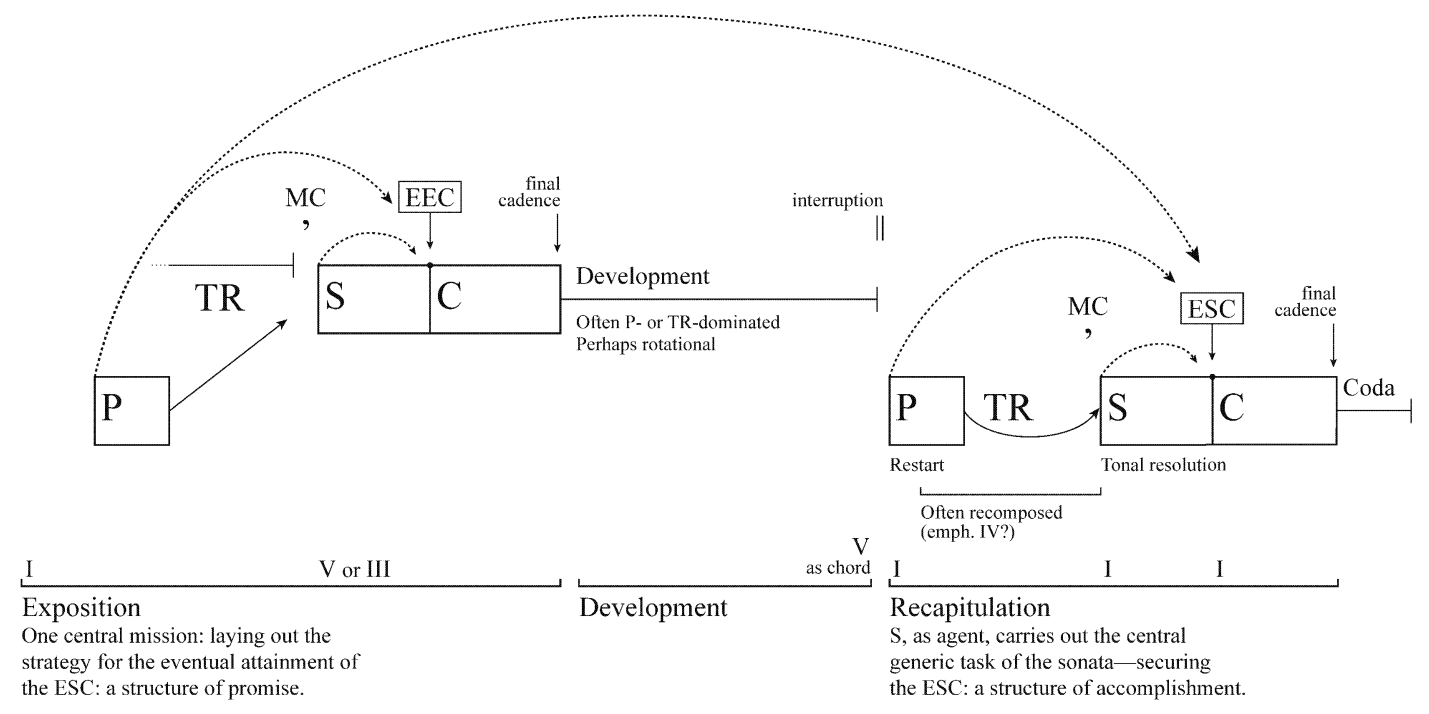

Figure 3.0.2: Hepokoski and Darcy, generic layout of sonata form (»The Essential Sonata Trajectory« $)^{2}$

\subsubsection{OTHER FIELDS OF ANALYSIS}

Harmonic analyses are carried out using Roman numerals, as familiar in English-speaking music theory. Alternatively, terminology from German functional theory is used, unless a passage has appeared in need of a more detailed explanation before - in that case a reference to part 2 is given. Other analytical methods for describing tonality or harmonic progression are, where appropriate, incorporated into the analyses. The NeoRiemannian Theory (primarily as conceived by Richard Cohn) and Tonfeld Theory (after Albert Simon), both capable of grasping phenomena derived from the equidistant division of the octave, are occasionally employed for the description of harmonic progressions the abovementioned systems cannot adequately grasp. At times, terminology from reductive analysis (inspired by Heinrich Schenker) contributes to illuminate certain aspects of the middleground which might be overshadowed by other analytic approaches. However, I will not resort to Schenkerian graphs on a regular basis, as these tend to neglect the elaborate motivic structure characteristic of most of Medtner's textures. Neither is the Pitch-Class Set Theory, designed as a means to tackle the diastematic structures of non-tonal and post-tonal music, considered an adequate instrument to capture Medtner's fundamentally tonal language.

The applied methods of analysis are not collectively determined in advance, but chosen according to the demands of the music taken into consideration - this means that the respective approaches comply with the peculiarities of the individual pieces, as distinguished by parameters such as melody, rhythm, harmony, and musical form. However, an aspect common to the analyses is that I will attempt to employ multiple perspectives of examination in order to oppose different terminological options, where appropriate, or to compare two divergent structural plans for movements or sections deviating from the ideal types of musical form.

2 Hepokoski and Darcy 2006, p. 17, reproduced here by kind permission of James Hepokoski. The abbreviations read as follows: $\mathrm{P}=$ primary theme zone, $\mathrm{TR}=$ transition, $\mathrm{S}=$ secondary theme zone, $\mathrm{C}=$ closing zone; $\mathrm{MC}=$ medial caesura, $\mathrm{EEC}=$ essential expositional closure, $\mathrm{ESC}=$ essential structural closure. 


\subsection{PIANO SONATA IN F MINOR, OP. 5}

Title page: Sonate (fa) pour Piano // Sonate [1904]; Sonate / Piano solo [1955]

Composed: 1895-96 ( $\left.2^{\text {nd }} \mathrm{mvt}\right), 1901-03$; premiered: December 13, 1903, Moscow, by the composer

Dedication: none ${ }^{1}$

Editions: Belyayev 1904; Belyayev 1955 (rev. by the composer), reprinted Peters 1955; Muzgiz Collected Edition 1959 (Vol. 1, pp. 98-142), reprinted Dover 1998; Muzïka c. 1975

Recordings: Fellegi 1988; Milne 1989; Hamelin 1997; Tozer 1998; Neller 2009; Stewart 2011; Russo 2012; Debargue 2016

\section{A Spiritual Organism in Music ${ }^{2}$}

Nikolai Medtner's first piano sonata, completed in 1903, can be considered what one might call a >first big strokeく. After having published a couple of smaller piano works, the 23-year-old composer-pianist addressed the public with a full-scale work in which he referred back to his predecessors in many respects, but already displayed his individual style. According to Sergei Rachmaninov, Medtner had »from the beginning published works that it would be hard for him to equal in later life «. ${ }^{3}$ A statement like Robert Schumann's appraisal of the young Johannes Brahms, comparing his early maturity to the armored Minerva springing from Zeus's head, could also apply to Medtner. ${ }^{4}$ With this piece he boldly positioned himself as a composer of sonatas in the succession of Beethoven and Brahms, ${ }^{5}$ and might have caused his mentor Sergei Taneyev to state that Medtner »was born with sonata form «. ${ }^{6}$ The composition may well be mentioned along with these two ancestors' »high-riding first strokes « because of its »mastery that outpaces most of the traditional models from the second half of the $19^{\text {th }}$ century . $^{7}$ It challenges the listener with its length, elaborate structure, and motivic and contrapuntal complexity, realised in a demanding virtuoso writing, and thus giving an outstanding sample of the composer's juvenile inventiveness.

1 Swan 1967, p. 70, reports that the composer's brother Emil Medtner was considered as a dedicatee on first hand, and Ljunggren 1994, p. 22, erroneously assumes that he indeed received the dedication. Even if this did not turn out, the hermeneutic context of the sonata was certainly influenced by Emil (see chapter 3.1.3). After all, Medtner's last composition in the sonata genre, the Sonata epica for violin and piano in E minor, Op. 57 (1936-38), was published in Emil's memory shortly after his death.

2 Paraphrased from Ivan Ilyin's attribution in Holt 1955, p. 183 f.

3 Reported by Swan 1944 , p. 8 . Dubal 1989 , p. 544 , characterises the sonata as »already entirely mature, though less chromatic than what would come later«. Similar notions are expressed in Tozer 1998, p. xii: »While few composers produce early works that exhibit unmistakable signs of mature thought and craftsmanship, Medtner was among those notable exceptions «; in Tozer 1999, p. 10: »His mastery of musical grammar is evident [...] in his earliest published compositions - an old head on young shoulders «; and in Morrison 2010, p. 6: »[Medtner was] a composer who found his truest voice so early and who staunchly maintained his integrity throughout his entire creative life«.

4 Robert Schumann, »Neue Bahnen«, in: Neue Zeitschrift für Musik, Vol. 39, No. 18, October 28, 1853, p. 1: »Es würde und müsse [...] Einer erscheinen, [...] der uns die Meisterschaft nicht in stufenweiser Entfaltung brächte, sondern, wie Minerva, gleich vollkommen gepanzert aus dem Haupte des Kronion spränge.«

5 On the preconditions of Medtner's use of sonata forms, see chapter 1.1, as well as Flamm 1995, p. 212f.

6 The attribution of this quote to Taneyev is supported by a number of authors; see chapter 2.1.1. As excerpts from Taneyev's diaries prove, his lessons with Medtner concentrated on sonata form during the years 1901-02. See also Flamm 1995, p. $5 \mathrm{ff}$.

7 My translation of Flamm 1995, p. 218: »In dieser Hinsicht gleicht Metners Sonate den ähnlich >überfliegenden〈 Erstlingswerken von Beethoven [...]«; »Meisterschaft [...], die das Gros der traditionellen Vorbilder aus der zweiten Hälfte des 19. Jahrhunderts im kompositorischen Anspruch hinter sich lässt«. 
A most obvious parallel to some earlier composers' sonatas is conveyed in the choice of key. After having sketched part of the first movement in $\mathrm{G}$ minor and $\mathrm{C}$ minor, Medtner soon turned to F minor, a key anticipated in a number of piano sonatas of profound importance in the history of the genre - such as Beethoven's $1^{\text {st }}$ Sonata, Op. 2 No. 1 (finished in 1795); Jan Ladislav Dussek's Piano Sonata, Op. 77 >L'invocation< (1812), the textures of which are, as Francis Pott has suggested, curiously similar to those of Medtner's $1^{\text {st }}$ movement; as well as Brahms's $3^{\text {rd }}$ Sonata, Op. 5 (1853), with which Medtner's work shares its opus number. ${ }^{8}$ All of these are large-scale works, bringing the development of sonata composition in their authors' œuvres to an early climax, just like Schumann's $3^{\text {rd }}$ Sonata in F minor, Op. 14 (1836) and Aleksandr Scriabin's $1^{\text {st }}$ Sonata, Op. 6, in the same key (1893), the latter of which being a direct predecessor of Medtner's work. ${ }^{9}$ Both Scriabin and Medtner composers might in turn have influenced the young Prokofiev, who also chose the key of F minor for his $1^{\text {st }}$ Piano Sonata, Op. 1 (1909), and possibly even Dmitry Shostakovich, whose $1^{\text {st }}$ Symphony in F minor, Op. 10 (1924-25) was composed as his graduation work at the Leningrad Conservatory. While, during the Baroque era, F minor had figured as the utmost possible mode in the circleof-fifths' flat region, the usage of this key considerably increased in Beethoven's and his successors' music. ${ }^{10}$ When Medtner's sonata was published, two close friends of his had just finished compositions in $\mathrm{F}$ minor as well: Georgy Catoire's Piano Trio, Op. 14 (1900), and Aleksandr Goedicke's $1^{\text {st }}$ Symphony, Op. 15 (1903), ${ }^{11}$ a coincidence which would deserve to attract more detailed research. Given that the decision for the eventual key was only made in the course of composing the $1^{\text {st }}$ movement, we may well assume that Medtner's choice of F minor was shaped by his predecessors and direct contemporaries. However, when looking at the mentioned historical background of that tonality, Christoph Flamm argues that »in the key of F minor everything has already been said on the piano «, ${ }^{12}$ trying to explain why Medtner did not resort, like Brahms and Scriabin, to a gripping opening gesture involving the whole keyboard, but chose to begin his sonata in a somewhat modest atmosphere.

The conventional construction of a grande sonate with four separate movements is, leaving aside the Sonata romantica, Op. 53 No. 1, with its attacca transitions, not encountered anymore in Medtner's piano œuvre. Anyway, the movements are not to be seen as fully independent as they are closely connected to each

8 See Montagu-Nathan 1918, p. 309; Loftis 1970, p. 35; Sacre 1998, p. 1813; and Flamm 2006, p. 8.

9 Dolinskaya 2013, p. 31, also observes these coincidences, but without commenting on a certain tradition of tonality: »Napisannaya $\mathrm{v}$ fa minore-kharakternoy tonal'nosti, v kotoroy sozdavali svoy pervïy opus i Betkhoven, i sovremenniki Metnera-Skryabin i Prokof'ev, sonata op. 5 eshche ne vpolne samostoyatel'naya po stilyu. « A possible influence of a piano sonata fragment by Tchaikovsky (1863), an Allegro movement in the key of F minor, on Medtner's work is unclear; its strong ascending gestures seem to rather prefigure the $1^{\text {st }}$ movement of Scriabin's F minor Sonata, Op. 6.

10 Examples are the F minor Sonata >Appassionata<, Op. 57 (1804-05), a piece highly appreciated by Medtner and frequently performed in his recitals; and, to name but a few others, the Egmont Overture, Op. 84 (1809-10), and the >Serioso< String Quartet, Op. 95 (1810-11). Looking at the following decades, a number of other F minor compositions may have, in terms of mood or dramatic content, additionally served as a model for Medtner's sonata: Chopin's Piano Concerto, Op. 21 (1830) and Fantaisie, Op. 49 (1841); the piano quintets of Brahms (Op. 34, 1864) and Franck (1879); Tchaikovsky's $4^{\text {th }}$ Symphony, Op. 36 (1878); and Arensky's Piano Concerto, Op. 2 (1882).

11 This work was premiered in Saint Petersburg on November 15, 1903, in Medtner's presence. See Martyn 1995 , p. 28.

12 My translation of Flamm 1995, p. 215: »In f-Moll ist auf dem Klavier in dieser Richtung nahezu alles gesagt«. 
other through a network of motivic cross-references. This interdependence of material refers back to a standard model of $19^{\text {th }}$-century music throughout Europe, showing a certain affinity to transformation of themes, and to the synthesis of material in the last movements of cyclic sonata compositions (for more details see chapter 1.1.3). These features are also evident in the aforementioned F minor sonatas by Schumann (Op. 14) and Scriabin (Op. 6); the latter work looks as if it might have modelled Medtner's approach through its elaborate motivic transformation, involving the primary themes of the $1^{\text {st }}, 3^{\text {rd }}$, and $4^{\text {th }}$ movements (see example 1.5), as well as the secondary theme of the $2^{\text {nd }}$ movement. ${ }^{13}$ But even though transformational techniques in a Lisztian manner are not employed in Medtner's Op. 5, the work, when regarded in the tradition of cyclic multi-movement composition, can be considered a prime example of thematicism and self-referentiality in music, presenting its motivic relationships more consistently than found in most other piano sonatas of that period. In this context, the succession of tonalities of the four movements (F minor $-\mathrm{C}$ minor $-\mathrm{E} b$ major $-\mathrm{F}$ minor / major) serves as another cyclic aspect, symmetrically contrasting a relative minor / major relation in the exterior movements with a parallel minor / major pair in the interior ones. ${ }^{14}$

\subsubsection{Genesis, RECEPTION, AND PERFORMANCE}

The F minor Sonata had not been Medtner's first attempt to write a piano sonata. In addition to two fragments of sonata movements in F\# minor (1897) and C minor (1901), eventually breaking off at the beginnings of their development sections, there are a complete sonata movement in B minor (1897) and a two-movement Sonatina in G minor (1898), which precede the Sonata, Op. 5. The earliest part of the work is the Intermezzo, composed in 1895-96 and originally titled Moment musical before finally appearing as the sonata's $2^{\text {nd }}$ movement. ${ }^{15}$ A first draft of the initial Allegro movement, still in G minor, dates of 1901 and differs from the final version in introducing the secondary theme much earlier. ${ }^{16}$ According to recent research, sketches of the finale also verify Medtner's intention to reuse that subject in the $4^{\text {th }}$ movement already at an early stage of the composition. This manuscript appears more complicated than the movement's final appearance; Francis Pott describes its development section as »overloaded with elaboration, threatening to collapse under its own weight «. ${ }^{17}$ While working on the other movements, Medtner already performed the Allegro on various occasions, sought advice from Taneyev, and discussed his music with pianist Józef Hofmann. ${ }^{18}$ By January 1903 he completed the finale, but

13 Hull 1916, p. 492f., comments in greater detail on the motivic cross-references in Scriabin's Sonata, Op. 6. See also Mauser 2004, p. 84f., and Protopopov 2010, p. 319f. Flamm 1995, p. 216, remarks that >Substanzgemeinschaft is limited here to the reuse of a double ascending second, with the notes $F-G-A b$ being subject to rhythmic variation and augmentation.

14 See Podporinova 2009, p. 30: »V pervoy sonate [...] obrazuyushcheysya mezhdu odnomennïm f-moll i f-moll / FDur kraynikh chastey kompozitor ispol'zuet parallel'noe sootnoshenie tonal'nostey v seredinnikh chastyakh (cmoll—Es-Dur), chto vosprinimaetsya voploshcheniem idei zerkal'nosti.«

15 See Flamm 1995, pp. 213ff. and 368ff.

16 It was not Francis Pott, as stated by Stewart 2012, p. 7, but Christoph Flamm who first noticed the different key signature in the manuscripts. Flamm 1995, p. 670f., also gives a facsimile of a sketch of the Allegro, breaking off after m. 21.

17 Pott as quoted in Stewart 2012, p. 7.

18 Hinson 1989, p. 544, suggests that he also played it to Rachmaninov in 1902, which seems unlikely as the two composers' friendship did not develop significantly before 1912-13. 
continuously struggled with the Largo movement, the themes of which turned out to be difficult to handle, until finally finishing the sonata in August. ${ }^{19}$ Medtner himself gave the premiere of his sonata in December as part of a recital at Georgy Catoire's house, which also included performances by Taneyev and Arensky, and also performed it in two consecutive concerts in Moscow and Berlin during November and December $1904 .{ }^{20}$ After he had successfully applied to the renowned publisher Mitrofan Belyayev in Saint Petersburg, as recommended by Taneyev, ${ }^{21}$ the first edition of the sonata was printed in Belyayev's Leipzig edition during the spring of 1904 (see also figure 0.1). This can be considered a somewhat prestigious improvement since Medtner's earlier compositions, Opp. 1-4, were published by Yurgenson in Moscow from 1903 on, and likewise were the successive piano works. A revised edition of the sonata, done by the composer shortly before his death, was published posthumously (Belyayev 1955, Bonn), with slight discrepancies to the first edition. ${ }^{22}$ The Soviet Collected Edition maintains these differences as well as the later Muzika edition of c. 1975, which was newly engraved but appears nearly identical in every detail of the score. As with most other's of Medtner's compositions, no critical edition of the sonata has been released so far.

After its premiere, which was excitedly evaluated, the sonata seems to have soon disappeared from concert programmes. Józef Hofmann, with whom Medtner established a durable friendship after their first meeting in November 1902, was alleged to have played part of the sonata's $1^{\text {st }}$ movement, which he described as »a perfect whole «, from memory after having heard it a couple of times; ${ }^{23}$ he apparently considered the sonata to be one of the most important contemporary piano pieces. ${ }^{24}$ Hofmann reported to Medtner in October 1903 that he had introduced the work in Berlin and London with good response, but he does not seem to have ever played it in public as a whole. ${ }^{25}$ Barrie Martyn claims that the work was conserved on a pianola roll before it remained in vain, hardly ever performed, ${ }^{26}$ until the first commercial recording done by Ádám Fellegi in 1988 - it was the latest of all Medtner's piano sonatas to appear on record, and became known to a wider public only through the performance of French pianist Lucas Debargue at the 2015 Tchaikovsky Competition in Moscow.

19 Martyn 1995, p. 25, quoting letters of Karl Karlovich Medtner to Emil Medtner of August 10 and 17, 1903: »He said that somehow this form came to him with difficulty, and it was only the other day that he at last managed to achieve a result that satisfied him «.

20 See Flamm 1995, p. 576 f.

21 Pinsonneault 1956, p. 23, reports that the evaluating members of the publisher's jury, consisting of Rimsky-Korsakov, Balakirev, Glazunov, Lyadov, and Cui, »deviennent de grands admirateurs de sa musique [de Medtner] «. See also Covatta 1965, p. 7; abd Mussky 2003, p. 224, quoting part of Taneyev's letter to Belyayev of November 12, 1903.

22 Chris Crocker assumes that the revision be made in 1951, but there are no definitive sources. Stewart 2012, p. 8, describes the changes between the 1904 and 1955 editions as »harmonically altering several passages, adding or removing nuances and other indications, and refining the texture«. More details are given by Keller 1971, p. 26.

23 See Martyn 1995, pp. 15 and 26, as well as Flamm 1995, p. 368.

24 Martyn 1995, p. 15, quoting a letter of Karl Medtner to Emil Medtner of November 28, 1902: »When he [Hofmann] learned that Kolya had not studied the whole of the theory of composition he said, >That is good; if you had, you perhaps might not have written this sonata<.«

25 See Martyn 2002, p. 22.

26 Ibid., p. 26. The author gives the numbers of pianola rolls Nos. 23325-328, but doesn't name the performer and circumstances of this recording. Zetel 1981, p. 240, also mentions performances by Soviet pianist Yakov Zak, but doesn't give dates. 
Since the work was first published in Leipzig, it was available to contemporary German reviewers who, however, did not appear particularly enthusiastic. When Walter Niemann referred to the sonata in a critique in Neue Zeitschrift für Musik, he appreciated it as »a proficient work, proving its author's remarkable skills in counterpoint and compositional technique«, while stating »a decreasing power of invention, proceeding toward dryness and tedious labour « in the last two movements. ${ }^{27}$ According to Eugen Segnitz, the work didn't leave a convincing impression at all, with its finale being only of a certain technical interest. ${ }^{28}$ Ernest Newman contemptuously stated »a good deal of mere academism« in this »cubbish work«, but found »undeniable suggestions of strength $«$ in the $2^{\text {nd }}$ movement. ${ }^{29}$ Nikolai Myaskovsky, though defending Medtner against contemporary criticism, called the sonata a $»$ green work « $;^{30}$ and Teichmüller and Herrmann claimed that $»$ the first theme's idiosyncratic power doesn't dare to develop and is soon forgotten in the magic of Neo-German formalism «. ${ }^{31}$ Other, more positive observations include, alongside with feelings of stylistic kinship to Brahms or Glazunov, an »enlarged scope of emotion and architectonic power«, and »youthful passion and talkativeness «. In any case, none of these early reviewers appreciated the sonata's extraordinary qualities in terms of motivic relationship and development.

When Russian music theorist Yuri Tyulin discussed his music with Medtner, he remarked that the Sonata, Op. 5, showed a tendency to overdevelop its themes, also reporting Medtner's reply: »Certainly, how did you notice that? I don't compose in this way anymore. $\aleph^{32}$ Later, Geoffrey Tozer would observe the very same themes to be $»$ minutely, obsessively examined, varied and extended through a movement ${ }^{33}$. One of the first scholars to review the work in greater detail was Medtner's friend, the philosopher Ivan Ilyin, who appreciated the sonata within his 1955 essay titled Sonata Form in Medtner. Although Ilyin does not actually analyse the score, he provides a picturesque and programmatic summary of each movement's atmosphere, pointing out some significant musical features such as the »contrapuntal interweaving « of the $1^{\text {st }}$ movement's main subjects. ${ }^{34}$ First thorough analyses of the sonata, though not fully convincing ones, were provided by some American authors, such as the dissertations of Lona Ruth Ginsburg and Charles William Keller. ${ }^{35}$ Isaak Zetel feels, like many other recipients, the influence of Schumann and praises the cyclic connection of the movements as well as the richness in melody, with the first measures of the Allegro being »just as if

27 My translation of Niemann 1905, p. 544: »Ein tüchtiges, von bemerkenswerter kontrapunktischer und satztechnischer Gewandtheit zeugendes Werk«; »ein bis zur Trockenheit und mühsamen Arbeit gehendes Nachlassen der Erfindungs- und Entwicklungskraft $\ll$.

28 See Segnitz 1906, p. 64, misspelling the composer's name as »N. Mendtner«.

29 Newman 1915, p. 10.

30 Myaskovsky 1913 as translated in Campbell 2003, p. 189; the term directly corresponds to the Russian >zelënaya ('green $)$.

31 My translation of Teichmüller 1934, p. 43: »Die eigenwillige Kraft des 1. Themas wagt sich nicht zu entfalten und wird rasch vergessen im Zauber des neudeutschen Formalismus«.

32 My translation of Zetel 1981, p. 116: »Gewiss, [...] wie haben Sie das bemerkt? Heute schreibe ich so nicht.«

33 Tozer 1998, p. xii.

34 Ilyin 1955, p. 186ff. More detailed comment on Ilyin's idea of >spiritual analysis «s, referring to Op. 5, found in Kinley 1970, p. 18ff., but without including any independent analytical results.

35 Ginsburg 1961, pp. 11-27; Keller 1971, pp. 26-57. 
aspirated by Russian breath «. ${ }^{36}$ More recently, scholars have fully acknowledged Medtner's impressive early command of the form while pointing out some of the work's deficiencies. Barrie Martyn refers to the sonata as a transitional composition of Medtner's at the border to maturity, with his true qualities and stylistic individualities still to come; ${ }^{37}$ Christoph Flamm notes an outstandingly dense correlation of themes and movements, while sthe sophisticated contrapuntal voice-leading still exhibits scholastic traits, and the problem of motivic integration is not always solved in an organic manner «. ${ }^{38}$ Vladimir Protopopov also remarks that the sonata, despite its traditional outline, proves the composer's individual originality to much extent, particularly when looking at the motivic processing during the $1^{\text {st }}$ movement's development section. ${ }^{39}$

\subsubsection{ANALYSIS OF THE SCORE}

First movement: Allegro

\section{F minor, 4/4, $\downarrow=100,246$ measures on 17 pages $^{40}$}

\begin{tabular}{|c|c|c|c|c|}
\hline \multirow{5}{*}{$\begin{array}{l}\text { SECTION } \\
\text { exposition }\end{array}$} & THEMES AND SUBJECTS & Position & INDICATIONS & KEY \\
\hline & primary theme $(\mathrm{P})$ & mm. 1-24 & Allegro; f tranquillo & F minor \\
\hline & transitional idea (Tr) & mm. 25-34 & addolcito, poco dolente & $\mathrm{C}$ minor $(\mathrm{V})$ \\
\hline & secondary theme $(\mathrm{S})$ & mm. 35-52 & $\mathrm{mp}$ cantabile & $\mathrm{C}$ minor \\
\hline & closing zone $(\mathrm{C})$ & mm. 53-64 ${ }^{\mathrm{a}}$ & $\mathrm{pp}$ molto tranquillo & $\mathrm{C}$ minor \\
\hline \multirow[t]{3}{*}{ development } & primary and secondary themes & mm. $61^{\mathrm{b}}-84$ & a tempo (Allegro) & $\mathrm{B}^{7}, \mathrm{C} \sharp^{7}$ \\
\hline & secondary theme, primary theme & mm. 85-105 & Maestoso, ma a tempo; $\mathrm{f}$ & $\mathrm{F} \#$ minor \\
\hline & retransition: secondary, primary & mm. 106-123 & ff & F minor (IV) \\
\hline \multirow[t]{4}{*}{ recapitulation } & primary theme $(\mathrm{P})$ & mm. 124-147 & ff sostenuto & F minor \\
\hline & transitional idea $(\mathrm{Tr})$ & mm. 148-157 & addolcito & $\mathrm{F}$ minor $(\mathrm{V})$ \\
\hline & secondary theme $(\mathrm{S})$ & mm. 158-179 & pp sempre piano e dolce & F minor \\
\hline & closing zone $(\mathrm{C})$ & mm. 180-198 & più tranquillo e dolce & F minor \\
\hline coda & primary theme, secondary theme & mm. 199-246 & Alla breve & F minor \\
\hline
\end{tabular}

A large-scale sonata movement, repeating its exposition, stands at the outset of Medtner's first published piano sonata. With regard to the dense network of motives developed throughout the work, unifying all of its parts on a technical level, a chronological approach of analysis seems most appropriate. I will thus examine the movements in the order of being played, focusing on their numerous interrelations, and introduce a numbering of motives giving a Roman numeral for the movement and a lowercase letter for the respective motives (see example 3.1.1). The first five of these appear successively in the course of the Allegro's exposition, relevant for the construction of the movement's main themes. Motif Ia, the very beginning of the sonata, spans an ascending five-note scale from $F$ to $C$, twice reaching the fifth scale degree in semiquavers (anacrusis

36 My translation of Zetel 1981, p. 86: »Gleichsam durchweht von russischem Atem ist die Erste Sonate op. 5 in fMoll«. See also Tyulin 1972 in Apetyan 1981, p. 115f.

37 Martyn 1995, p. 26.

38 My translation of Flamm 2006, p. 4: »Die anspruchsvolle kontrapunktische Stimmführung [trägt] noch akademische Züge [...] und das Problem der motivisch-thematischen Integration [ist] nicht immer organisch gelöst «.

39 My paraphrase of Protopopov 2010, p. 342: »Allegro sonatï f-moll sokhranyaet klassicheskuyu strukturu [...]. Odnako za ètim skrïvaetsya bol'shoe svoeobrazie v konkretnom voploshchenii i tematizma, i putey tonal'nogo dvizheniya, osobenno v razrabotke.«

40 Here, and in every following instance, the page count is given according to the Soviet Collected Edition (1959-60). 
to $\mathrm{m} .1$ ) and later being subject to superposition and augmentation. ${ }^{41}$ Motif $\mathrm{Ib}$, in direct succession, freely recombines these notes in longer values, also reaching $C$ (anacrusis to $\mathrm{mm}$. 2 and 3). Motif Ic and Id are combined to the movement's secondary theme: the former, a diatonic line enclosing a syncope, covers a descending sixth $C-E b$ (m. 35f., anticipated in m. 32), while the latter, directly following and closely related to motif Ib, augments that syncopation and makes up most of the secondary theme zone's motivic development. The descending tetrachord $C-B b-A b-G$, found again later in the $4^{\text {th }}$ movement's motif IVc, forms the common substance of motif Ic and the combination of motives $\mathrm{Ia}$ and $\mathrm{Ib}$ - a relation which serves to connect the individual themes and movements to a cyclic whole, referred to by most authors analysing this sonata, ${ }^{42}$ and qualifies, in terms of Schenkerian analysis, as a >linear progression « of a descending fourth. Finally, motif Ie, an ascending triad with flexible upbeat and thus being a variant of motif Ia, is used for the construction of the closing zone (anacrusis to m. 53).

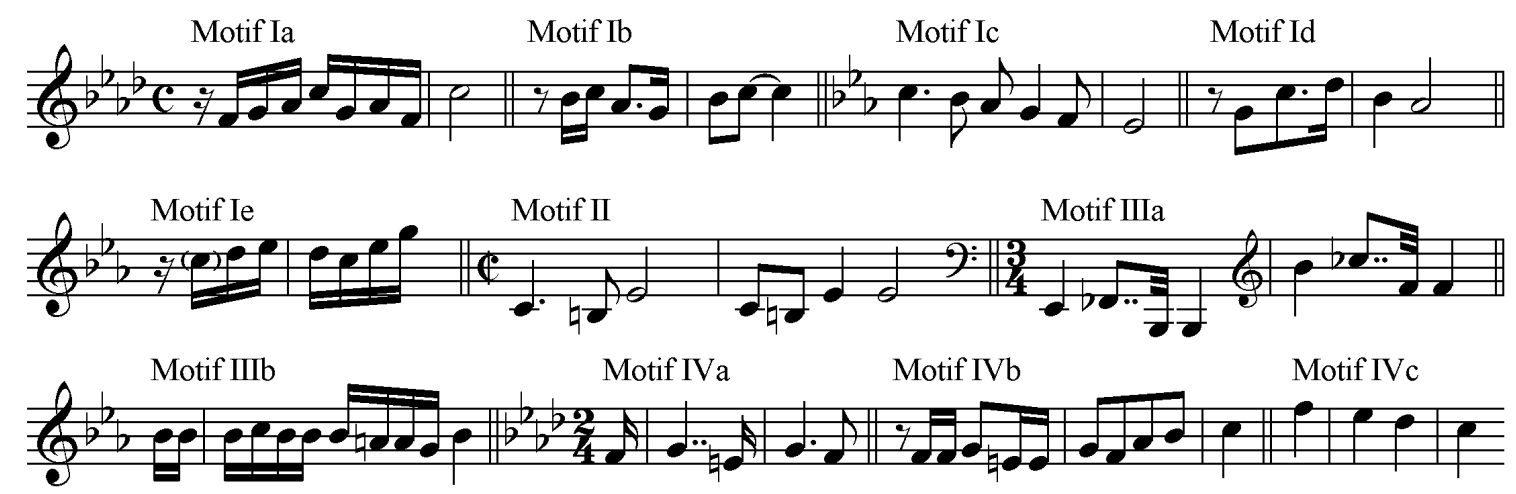

Example 3.1.1: Medtner, Sonata, Op. 5, table of motives (my numbers)

The exposition of the Allegro starts with its primary theme in two manifestations, both shaped as a period and representing a lyric and somewhat folkloristic mood, ${ }^{43}$ its character being variously described as a »mournful lament [that] soon reaches despair« or »thème de désespérance ${ }^{44}{ }^{44}$ In the initial tranquillo character, an unison of both hands is employed as a common gesture of opening, with motif Ia, motif Ib, and a variant of the latter being combined to a four-measure antecedent, contrasting with an Eb minor transposition in

41 One might be struck by the similarity of this motif to the opening soggetto of Johann Sebastian Bach's C major Invention, BWV 772, to which Tobias Fasshauer and Lucas Debargue drew my attention. However, such an observation might apply to many other themes from Baroque and Classical music as well, since motif Ia is constructed from a simple permutation of the ascending minor-mode scale and does not exhibit a very distinct outline. The ostinato figure at the beginning of Shostakovich's Trumpet and Piano Concerto in C minor, Op. 35, might, due to the same argumentation, be regarded as a reflection of Medtner's theme. Diastematic resemblances of this kind do not necessarily establish a connection between different pieces of music.

42 See Ginsburg 1961, p. 13f.; Kinley 1970, p. 25; Loftis 1970, p. 53f.; Keller 1971, pp. 34f. and 51f.; and Flamm 1995, p. $215 \mathrm{ff}$.

43 See Tyulin 1972, p. 115, who observes traits of Russian folk song in both the primary and secondary themes: »Tipichnie >metnerovskie intonatsii nesut $\mathrm{v}$ sebe i podlinnie cherti russkoy narodnoy pesni; mimo nee ne proshel ètot chutkiy khudozhnik.«

44 Ilyin 1955, p. 186f.; Sacre 1998, p. 1813. According to Vasilyev 1962, p. 12, the primary theme sounds like a signal call, grasping the listener's attention. 
its consequent, before modulating back to F minor (m. 5ff.). ${ }^{45}$ Secondly, the primary theme's $>$ touched-on repetition ${ }^{46}$ is presented in an agitato version, also alternating between motives Ia and $\mathrm{Ib}$, but additionally using motif Ia as an answering bass line, lowered by two octaves (m. 9ff.). ${ }^{47}$ The theme now displays a sequencing scheme with a four-measure antecedent, rising the melodic top note from $C$ to $D$, and includes a continuation (m. 13ff.) comprising a transitional idea — the quadruple repetition of a quaver followed by a descending chromatic scale. This motif, appearing first in the anacrusis of $\mathrm{m}$. 15, dominates the following transitional section. ${ }^{48}$ Tension gradually increases while motif $\mathrm{Ib}$ and the transitional idea are recombined in a crescendo, leading to a first full cadence (m. 21: fortissimo), and twice opposing a Neapolitan Gb major chord to the cadential tonic. A modulatory process starts here, with $G b$ being altered enharmonically to $F \#$, serving as a leading-note to the chord of $\mathrm{G}$ major. Multiple recurrences of a diatonic variant of the transitional idea (m. 25ff.), suggesting a mirrored variant of motif Ia, make up a dominant region of $\mathrm{C}$ minor. ${ }^{49}$ The key of the secondary theme zone is finally reached in $\mathrm{m}$. 33f., with its introductory measures seemingly resembling a passage at the beginning of Rachmaninov's $2^{\text {nd }}$ Piano Concerto in C minor, Op. 18 (finished in 1901). ${ }^{50}$

Here Medtner annexes the cantabile melody of the secondary theme which his older brother Emil, his mentor and significant aesthetic authority, was supposed to associate with Anna Bratenshi, ${ }^{51}$ Nikolai's future wife, who was engaged to Emil at the time of composition. >Anna's theme is a widespread cantilena of outstanding grace and melancholy which seems, by purpose or not, related in shape and tonal organization to an Andantino by Clara Wieck, used by Robert Schumann as a variation theme in his $3^{\text {rd }}$ Sonata in F minor >Concert sans orchestre〈, Op. 14 (1836). This sonata poses another possible influence to Medtner, looking at the final choice of key and the derivation of all its main subjects from a unifying motivic cell, as modelled in the first notes $[C]-C-B b-A b-G-F$ of Clara's Andantino. ${ }^{52}$ This descending five-note scale encapsulates not only Medtner's motif Ic, but also mirrors the ascending frame of motif Ia—and, from a Schenkerian perspective, we can observe that the linear progression of a descending fourth, as comprised in motif Ic, is elaborated here to a fifth or sixth progression in either direction of the scale. When looking at the beginning of Schumann's $1^{\text {st }}$ movement where Clara's subject is transformed to a syncopated line, now descending from

45 A passage at the beginning of the first rondo episode (m. 65ff.) from the finale of Chopin's Piano Concerto, Op. 21 (1829-30), shows a very similar harmonic outline, modulating from F minor to Eb minor and back again. Moreover, the transposition i-vii recalls some of Beethoven's expositions, such as that of the Coriolan Overture, Op. 62 (1807), or the $1^{\text {st }}$ movement of the >Waldstein< Sonata in C major, Op. 53 (1803-04), the primary theme of which appears in two different harmonic guises (I-bVII). The same progression is also found in Brahms, for instance, in the $1^{\text {st }}$ movement of the $\mathrm{C}$ minor Piano Trio, Op. 60 (1875).

46 My translation of a characteristic term from Ratz 1951, p. 36: >angegangene Wiederholung ‘.

47 For a summary of the various transformations of motives Ia and Ib, see Loftis 1970, p. 116.

48 Lyle 1931, p. 264, feels this »bridge passage« to be »pure Beethoven«, whatever may be meant by that.

49 See Keller 1971, p. 33.

50 In the $1^{\text {st }}$ movement of the Concerto (m. 9f.), directly preceding the entrance of the primary theme in the strings.

51 See Swan 1967, p. 69f.; Pinsonneault 1959, p. 24, marks the movement's main subjects as »masculin et féminin«.

52 Stewart 2012, p. 7, doesn't mention Schumann's sonata, but feels an emotional relationship of >Anna's theme< to the descending three-note figure $C-B-A$, symbolising the name CHiAra, which was used by Schumann in a number of works »that symbolised estrangement and yearning for his beloved Clara 
the second scale degree, the similarity to >Anna's theme grows even further. ${ }^{53}$ More distantly, Medtner's theme also resembles the initial subject of Schumann's $2^{\text {nd }}$ Sonata in G minor, Op. $22(1830-38),{ }^{54}$ and the third theme from the Prestissimo finale of Beethoven's F minor Sonata, Op. 2 No. 1 (see example 3.1.2 for all these relationships). What is more, Lucas Debargue has noticed echoes of the final lament of Tchaikovsky's $6^{\text {th }}$ Symphony >Pathétique in B minor, Op. 74 (1893), ${ }^{55}$ adding up to an impressive total of possible intertexts connecting this subject to various preceding points in music history.

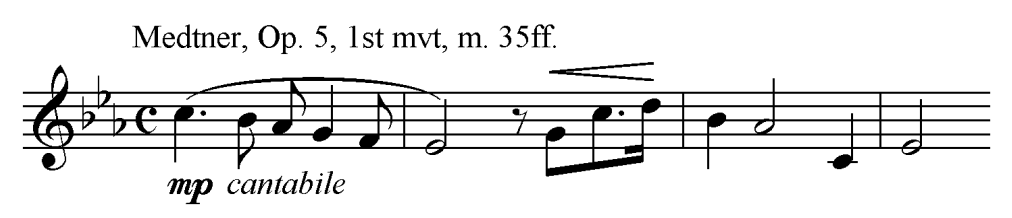

Wieck / Schumann, Op. 14, 3rd mvt, m. 1ff.

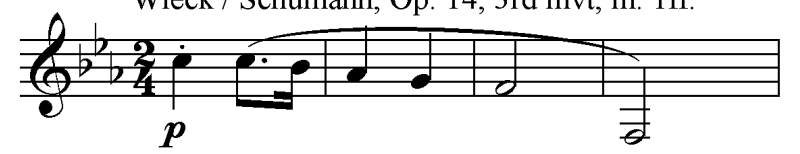

Schumann, Op. 14, 1st mvt, m. 1f. // m. 8ff.
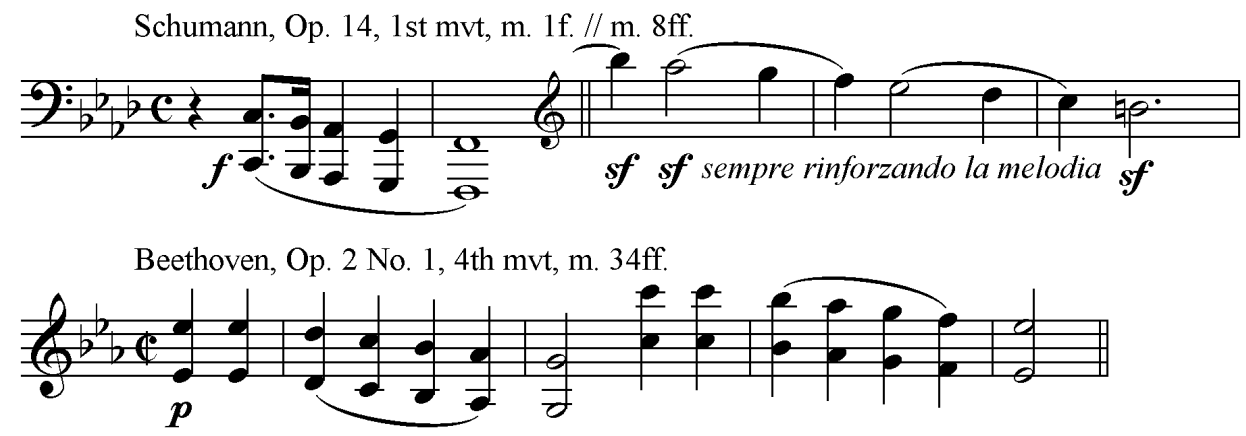

Schumann, Op. 22, 1st mvt, m. 4ff.

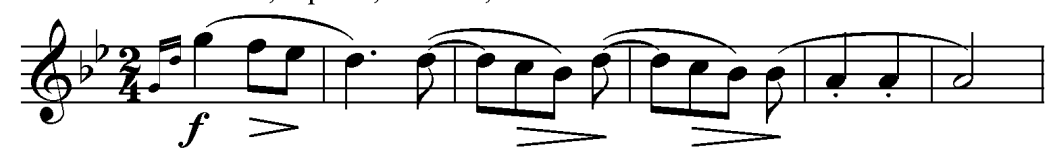

Example 3.1.2: Medtner, Sonata, Op. 5, $1^{\text {st }} \mathrm{mvt}$, mm. 35-38 (top voice), confronted with themes by Clara Wieck, Robert Schumann, and Ludwig van Beethoven

Early assumptions of some sort of biographical content are, accompanying the genesis of the sonata, found in the memories of Symbolist poet Andrei Bely, a close friend of the Medtner brothers, who recalled a dialogue between Emil and Nikolai in which a certain >Clara Wieck themeく was directly opposed to themes from Medtner's F minor sonata. ${ }^{56}$ It seems likely, but still remains uncertain whether Emil's notion referred to

53 This is particularly expressed in Podporinova 2007, p. 94 (again in Podporinova 2009, p. 31f.): »Tema glavnoy partii pervoy sonatï op. 14 R. Shumana, v osnove kotoroy lezhit pyatizvuchnïy motiv, prinadlezhashchiy peru Klarï Vik. Vpervïe oboznachennaya leyttema [...] voznikaet v Pervoy fortepiannoy sonatï Metnera op. 5: v pobochnoy partii pervoy chasti, zatem [...] v pobochnoy partii finala. Ee vizitnoy kartochkoy stanovitsya niskhodyashchiy postupennïy khod s kharakternïm sinkopirovannïm risunkom.«

54 See Drozdov 1927 in Flamm 1995, p. 346. A connection to Schumann is also drawn in a contemporary critique by Niemann 1905, p. 544, who marks the theme as »warm schumannisch dahinströmend «.

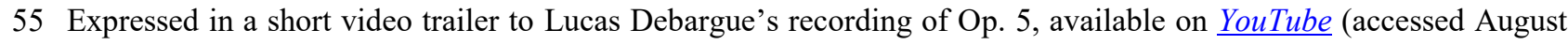
29, 2018).

56 Bely reports Emil Medtner using the rhythmic syllables >tata-ti-tatá when prompting his brother to »give him Clara Wieck« (»Tï, Kolya, day >Klara Vik««); quoted after Bely 1933, p. 97f. Flamm 1995, p. 46 gives a German translation 
Clara's Andantino or not-at least the fact that, when composing their F minor piano sonatas, both Schumann and Medtner suffered of remoteness from their beloved ones, establishes a biographical link between the two works. Also in analogy to Schumann, Ekaterina Podporinova even claims >Anna's theme< to be a sort of >Leitthema< in Medtner's œuvre, connecting the first sonata to the Sonata-Reminiscenza, Op. 38 No. 1 (1919-20), the secondary theme zone of which features a very similar descending contour, and to a number of derivative occurrences in other sonatas. ${ }^{57}$

The theme in question forms a small ternary with repetition of its first clause (A-A-B-A), constructed from an alternation of the two-measure motives Ic and Id, condensing the latter to a middle passage harmonised in a cycle of fifths, and quoting the former at its closure, transposed a fifth upward. Thus, motif Ic appears both in a tonic (m. 35f.) and a ii-V half-cadential harmonization (m. 41f.) which enables Medtner to instantly repeat the whole theme with interlaced quotations and transformations of motif $\mathrm{Ib}$ (m. $47 \mathrm{ff}$.). ${ }^{58}$ These are superposed in a stretto before the closing zone starts (m. 53), a sparkling polyrhythmic episode in semiquavers and triplets, with motif Ie, derived from motif Ia, figuring as an upper voice. This passage is composed in a strict sequential order: the first measure, consisting of three ascending chords on the notes $C-D$ $\mathrm{Eb}\left(\mathrm{C}\right.$ minor, $\mathrm{G}^{7}$ third-fourth chord, $\left.\mathrm{Eb}^{7}\right)$, is transposed downward by major seconds. This results in a sequence of $\mathrm{C}$ minor, $\mathrm{B} b$ minor, and $\mathrm{A} b$ minor, ${ }^{59}$ before the fourth measure modulates back to the original key. This four-measure scheme is repeated in the lower octave, leading back to the exposition's repetition with the initial three notes of motif Ia returning in a middle-voice figuration. ${ }^{60}$ In the seconda volta, Medtner uses the sequential scheme's third measure to prepare for the development section - $\mathrm{A} b$ minor is enharmonically altered to $\mathrm{G} \#$ minor, and the dominant harmony of $\mathrm{B}^{7}$, reached in $\mathrm{m} .59^{\mathrm{b}}$, is stretched over the following twelve measures, leaving behind the exposition's tonality. ${ }^{61}$

The composer does not begin the development section with the movement's primary theme, but chooses to organically evolve it out of the closing zone, employing two pedal points to achieve harmonic uniformity. First, the prolonged chord of $\mathrm{B}^{7}$ (mm. 60-72) serves as a basis for a series of variants and superpositions of motif $\mathrm{Ib}$. The descending line of motif Ic gradually starts to creep in, truncated at first (m. 71) and leading the harmony to a $\mathrm{C}^{7}$ tableau which further extends the dense processing of motives $\mathrm{Ib}$, Ic, and the transitional

of Bely's account. Even though these syllables seem easily applicable to Clara's F minor Andantino, also matching the initial notes of Schumann's Sonata, Op. 14, Flamm 2009, p. 45f., pleads for a similarity to Chiarina from Schumann's Carnaval, Op. 9, misled by the key of that piece which is in C minor, not F minor. See also Podporinova 2007, p. 100f.

57 See ibid., p. 106 (again in Podporinova 2009, p. 31f.), referring to the technique of thematicism, evident in the transformation of 〉Anna's theme〈, as a »centre of gravity« and, in the sense of art nouveau, as an »iconographic motif «.

58 This repetition is marked forte and pieno voce in Medtner's revised edition of 1955 (p. 4), but not in the first edition.

59 This relation of chords enhances the harmonic design of the primary theme. The harmonic progression i-vii-vi is, as a minor-mode real sequence, modelled in the initial unison of Mozart's C minor Fantasy, K. 475.

60 Ginsburg 1961, p. 11: »In this early stage of Medtner's compositional technique, he adheres to the use of the double bar, repeat sign, and first and second endings [...].« With the exceptions of the C major Sonata, Op. 11 No. 3, and the $4^{\text {th }}$ movement of the Sonata romantica, Op. 53 No. 1, repeated expositions are not encountered any more in Medtner's piano sonatas.

61 Keller 1971, p. 28 , notes that the $1^{\text {st }}$ movement of Beethoven's Op. 57 similarly employs a B ${ }^{7}$ dominant to an E minor tonic at the beginning of its development. In Medtner's case, though, this harmony is subject to further modulation. 
idea (mm. 73-84), preparing for a dramatic eruption in F\# minor (m. 85ff.: Maestoso). ${ }^{62}$ This distinctive contrapuntal passage basically consists of a two-part stretto, showing wan intricacy and austerity peculiarly Medtner's own «: ${ }^{63}$ While the bass starts from $F \#$ with a complete quotation of the secondary theme, the top voice answers, delayed by half a measure, with motif Ic, beginning on the third scale degree $A$ (see example 3.1.3). The following passage ( $\mathrm{mm} .92-103$ ), mysteriously reiterating motif $\mathrm{Ia}$ in the lower region of the keyboard, modulates from $\mathrm{F} \#$ minor upward to $\mathrm{G}$ minor, $\mathrm{G} \sharp$ minor, $\mathrm{A}$ minor, and $\mathrm{B} b$ minor, making permanent use of motives Ib and Ic, and employing motif Ia as an ostinato bass. The original key signature is restored in $\mathrm{m}$. 106; further quotations of motif Ic, alternating between the bass and descant voices, culminate in the retransition which gradually slips from the subdominant back to the tonic region. The movement's initial idea occasionally reappears in $\mathrm{B} b$ minor in augmented and original note values (m. 113f.), then combined with reiterations of motif $\mathrm{Ib}$ in the descant voice. Then, raising its first note from $B b$ to $B$, the procession of motif Ia results in a $\sharp \mathrm{IV}^{\mathrm{b} 2}$ seventh chord (double-dominant with flattened fifth) harmonisation in mm. 120123 , increasing tension, and eventually merging to the strong unison of the primary theme (m. 124).

In this manner the composer develops the start of the recapitulation section out of the retransition's tonic-subdominant conflict, with a simultaneous return of motivic and tonal features of the movement's beginning. Tension is quickly reduced by returning to a gentle piano mood within three measures; this applies to the antecedent as well as the consequent, the latter starting once more in a fortissimo sostenuto ( $\mathrm{m} .127)$. The agitato version of the primary theme and its direct succession are literally quoted (compare mm. 9-20 and 132-143), and it is not before $m .145$ that the recapitulation section distinguishes itself from the exposition. Here, the $\mathrm{G} b$ major strokes are continued to a $\mathrm{D} b^{7}$ chord (m. 146), the note $C b$ of which is altered enharmonically to $B$ in order to modulate back to a pedal point on $C^{7}$; this process corresponds to the exposition's transitional section and subsides to a medial caesura on a single $C$ (m. 155). The secondary theme zone enters, also in direct quotation, with a F minor restatement of >Anna's theme (m. 158). The transitional passage to the closing zone differs from the exposition as it introduces a polyphonic combination of motives Ia, $\mathrm{Ib}$, and the transitional idea (m. 173ff.); this is, after a ritenuto, followed by the corresponding polyrhythmic episode, slightly altered in its harmonisation as it now employs a descending cycle of fifths instead of uprising scales in the bass, but matches the exposition in its syntactic design.

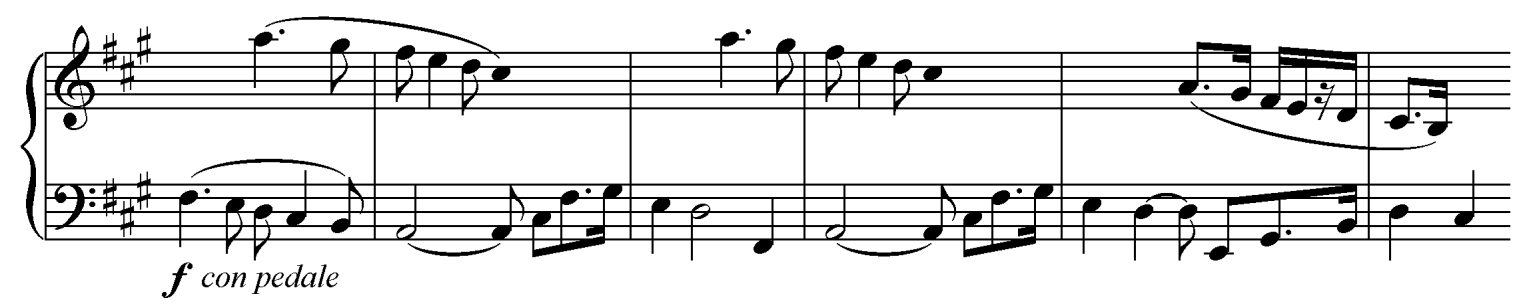

Example 3.1.3: Medtner, Sonata, Op. 5, $1^{\text {st }}$ mvt, development, mm. 85-90 (motivic reduction)

62 The keys of $\mathrm{E}$ minor and $\mathrm{F} \sharp$ minor, both significant for the development's modulatory plan, thus establish a symmetrical half-note proximity to the tonic key. See also Protopopov 2010, p. 343.

63 Morrison 2010, p. 6. 


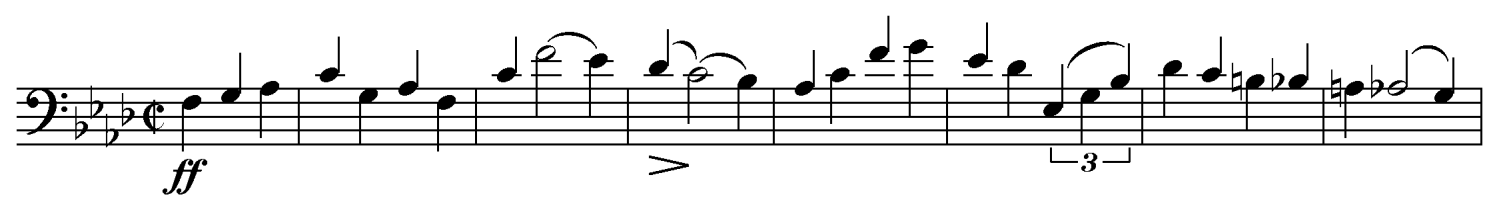

Example 3.1.4: Medtner, Sonata, Op. 5, $1^{\text {st }} \mathrm{mvt}$, coda, mm. 199-206 (motivic reduction)

An abrupt single-line cadenza is appended (m. 191ff.) at the same position in which the development had emerged out of the exposition's closing zone earlier. The following alla breve coda (starting in m. 199) functions as a fourth part of the quaternary sonata form, similar to many of Beethoven's $1^{\text {st }}$ movements, and brings the material to a final synthesis. An augmented version of motif Ia, no longer in semiquavers but in crotchets, alternates note-by-note between the left and right hand, embellished with sparkling broken triads, and merges with the secondary theme which is attached in the same manner. ${ }^{64}$ Thus, Medtner newly combines motives Ia and Ic to an eight-measure theme (see example 3.1.4), repeated in the upper octave. In m. 215ff., the syncopated figure of motif Ic is extended to a modulation which deserves special attention-harmonies follow each other in a dramatically ascending sequence, each measure forming a fourth-sixth suspension to the chords of $F$ minor, $\mathrm{Gb}$ minor, $\mathrm{A} b$ minor, $\mathrm{Cb}$ minor, and finally reaching Ebb major (mm. 215-220) as the utmost point of chromatic modulation within this movement. Ultimately, two quotations of motif Id (m. 224ff.) lead to the concluding fortissimo culmination. Motif Ia appears in diminution again with a series of vast martellato chords ( $\mathrm{m}$. 240f.), and the movement closes with an unusual VI-i cadence, avoiding the dominant.

\section{Second movement: Intermezzo (Allegro) \\ $\mathrm{C}$ minor, 2/2, 135 measures on 5 pages}

$\begin{array}{lllll}\text { SECTION } & \text { THEMES AND SUBJECTS } & \text { POSITION } & \text { INDICATIONS } & \text { KEY } \\ \text { first refrain } & \text { initial theme } & \mathrm{mm} .1-20^{\mathrm{a}} & \text { Allegro; } \mathrm{p} \text { marcato, legatissimo } & \mathrm{C} \text { minor } \\ \text { first episode } & \text { secondary theme } & \mathrm{mm} .19^{\mathrm{b}}-38 & \text { without indication }[\mathrm{f}] & \mathrm{E} b \text { major } \\ \text { second refrain } & \text { initial theme } & \mathrm{mm} .39-46 & \mathrm{pp} & \mathrm{B} b \text { major } \\ \text { first episode } & \text { secondary theme } & \mathrm{mm} .47-76 & {[\mathrm{f}]} & \mathrm{D} b \text { major } \\ \text { third refrain } & \text { variant of initial theme } & \mathrm{mm} .77-96 & \mathrm{pp} \text { legatissimo } & \mathrm{C} \text { minor } \\ \text { fourth refrain } & \text { initial theme } & \mathrm{mm} .97-123 & \text { Tempo primo; } \mathrm{ff} & \mathrm{C} \text { minor } \\ \text { interlude } & \text { initial theme } & \mathrm{mm} .124-135 & \text { Moderato-Andante; } \mathrm{p} & \mathrm{C} \text { minor }\end{array}$

The movement was, in an earlier version named Moment musical, already completed in 1896 and later implemented into the sonata. In renaming the piece as an Intermezzo, Medtner, be it deliberately or not, refers back to Brahms who had used that title for the introductory section ( $>$ Rückblick $\iota$ ) preceding the finale of his $3^{\text {rd }}$ Sonata, Op. 5 (1853), where the beginning of its $2^{\text {nd }}$ Andante espressivo movement is recollected. ${ }^{65}$

64 Vasilyev 1962, p. 12f., observes the fusion of the two main themes to a single subject during the coda. Protopopov 2010 , p. 343 , similarly notices that both of the themes, one following the other, are here being transformed into one single line (»Obe temï vïtyagivayutsya v edinuyu liniyu, odna za drugoy«). Martyn 1995, p. 24, identifies the primary and secondary themes to be »complementary facets of the same material«, brought to a synthesis within the coda.

65 See Keller 1971, p. 27. For the history of Intermezzi within piano sonatas, particularly in Schumann and Brahms, see Podporinova 2007, p. 95f. 
Occasionally characterised as a kind of march, ${ }^{66}$ and with its textures somewhat similar to the $2^{\text {nd }}$ movement of Anton Rubinstein's $3^{\text {rd }}$ Piano Sonata, Op. 41 (1855), Medtner's movement is composed in a free rondo form with four refrains. One of these transposes to the minor vii key, alternating with two episodes in major mode, and is followed by an attached interlude functioning as the sonata's internal connector which aligns the movements to each other. ${ }^{67}$ The Intermezzo's initial idea-derived from the $1^{\text {st }}$ movement's motives Ia and Ie, and referred to as motif II in this analysis - is the three-note group $C-B-E b$, a falling minor second followed by a rising diminished fourth. Due to its resemblance to the interrogative phrase Der schwer gefaßte Entschluß (»Muss es sein?«) from the finale of Beethoven's F major String Quartet, Op. 135 (1826), Christoph Flamm names it a >question motif (Fragemotiv). ${ }^{68}$ It serves as a monothematic nucleus for most of the Intermezzo's development, and later also proves constitutive for the connecting interludes at the end of the $2^{\text {nd }}$ and $3^{\text {rd }}$ movements. In long-term backview, the motif's diastematic contour also resembles the crosswise soggetto of Bach's C\# minor Fugue (Well-tempered Clavier, Vol. 1), an affective melodic shape echoed in a number of $19^{\text {th }}$-century compositions, such as Schubert's Doppelgänger, D. 957 No. 13 (1828), the >SchicksalskundeMotiv< from Wagner's Ring of the Nibelung, the first motif of Liszt's symphonic poem Les Préludes (184854), and, most obviously, the $1^{\text {st }}$ movement from César Franck's D minor Symphony (1886-88). ${ }^{69}$

The parallel to the latter is most obvious as both pieces employ motif II in the same rhythmical design; but while Franck goes on with an ascending sequence, Medtner restates the notes $C-B-E b$, condensing their note values and repeating the last note once, then twice ( $\mathrm{mm} .2$ and 3). Thus, the Intermezzo's initial theme is formed out of a triple recurrence of motif II and its distinctive diminished fourth, being set in regular fourpart harmony which states the $\mathrm{i}, \mathrm{iv}^{7}$, and $\mathrm{V}$ chords in every measure within a close chain of crotchets. The scheme of the first four measures is repeated, but alters the harmonic scheme to an ascending sequence of thirds, while motif II is modified to $E b-D-G, G-F \# B b$, and $B b-A-D$, now incorporating a perfect fourth instead of a diminished (mm. 5-8; see example 3.1.5). These transformations correspond to the underlying chords of $\mathrm{E} b$ major, $\mathrm{G}$ minor and $\mathrm{B} b$ major. The following two measures modulate back to $\mathrm{C}$ minor, preparing for a modified repetition of the beginning. The continuation (m. 15ff.) transfers the >question motif to

66 Ilyin 1955, p. 187: »A gloomy, detached, and yet defiant and questioning march«; Pinsonneault 1959, p. 25: »Une marche, tel un chevalier intrépide dans l'infini d'une steppe«.

67 The formal function of these passages is not clear to some authors. Loftis 1970, p. 91f., and Martyn 1995, p. 24, misperceive them as >codas`, while Keller 1971, p. 42f., marks them as `transitions`. Elmore 1972, p. 82f., suggests that the »interlocking of movements«, occurring in some of Medtner's multi-movement sonatas, might indicate that the composer considered the single-movement design as an ultimate achievement of musical form.

68 See Flamm 1995, p. 216, and Flamm 2006, p. 8. Another similarity arises from the comparison to the Allegro con brio ed appassionato theme from the $1^{\text {st }}$ movement of Beethoven's C minor Sonata, Op. 111 (1821-22). Both pieces, Op. 135 and Op. 111, prefigure the diminished fourth of Medtner's motif, the former $G-E-A b$ also coinciding in its dotted rhythm, while the latter $C-E b-B$ also matches the key of $C$ minor. Moreover, the primary theme of the $1^{\text {st }}$ movement from Anton Rubinstein's $4^{\text {th }}$ Piano Concerto in D minor, Op. 70 (1864), seems to refer to Beethoven's Op. 111 even more directly as it quotes and transposes the initial three notes, sounding $D-F-C \#$. An inversion of the motif is employed as a central idea for the $2^{\text {nd }}$ movement of Scriabin's $2^{\text {nd }}$ Symphony in C minor, Op. 29 (1901), here sounding $E b-D-G b(-F)$. After Medtner, the motif is further used at the very beginning of Anton Webern's $1^{\text {st }}$ String Quartet (1905).

69 This fact was first observed by Ginsburg 1961, p. 16. However, Flamm 2006, p. 8, states that Medtner was not familiar to Franck's symphony at the time of composition. 
the tenor voice, now as an anacrusis of quavers, and repeats it twice in a descending cycle of seconds $\left(\mathrm{F}^{7}-\right.$ $\left.E b^{7}-\mathrm{D} b^{7}\right)$. The first refrain thus essentially consists of the initial idea and its processing and sequentiation, following the outline of a period with a ten-measure antecedent and consequent. It is repeated as a whole, with its seconda volta appending the chord of $\mathrm{Bb}^{7}\left(\mathrm{~m} .18^{\mathrm{b}}\right)$ so as to prepare for the secondary theme.

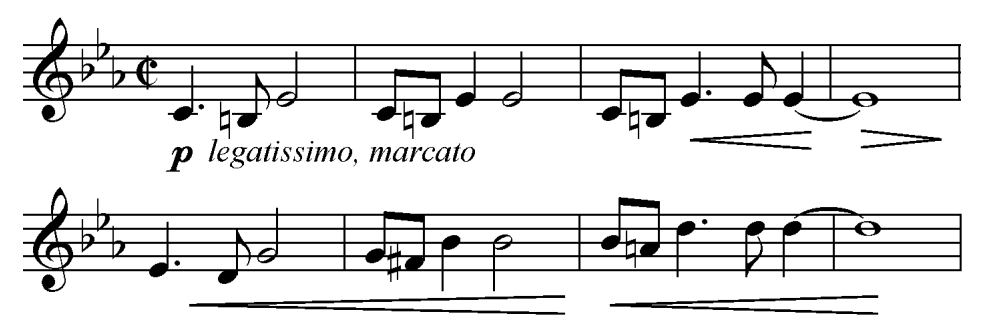

Example 3.1.5: Medtner, Sonata, Op. 5, $2^{\text {nd }}$ mvt, beginning, mm. 1-8 (top voice)

The first episode is closely related to the refrain as it presents an upbeat, diatonic transformation of motif II (m. $19^{\mathrm{b}}$ ff.), again spanning four measures, and ascending through the Eb major triad from $E b$ to $G$, now reaching forte (m. 22). The secondary theme is followed by a contrasting idea seemingly derived from the repeated notes of the beginning, now combining a five-time repeated $G$ with a descending chromatic middle voice (mm. 27-28). ${ }^{70}$ This phrase is also affected by the piece's highly sequential character-its consecutive appearances modulate from $\mathrm{C}$ minor to $\mathrm{B} b$ minor (m. 30), F minor (m. 32), Eb minor (m. 36) and once more to $\mathrm{B} b$ minor, marking the beginning of the short second refrain (m. 39). What follows is an exact transposition of mm. 11-17, the initial theme's consequent, with its original key lowered by a major second. The cycle of seconds (m. 43ff.) now comprises the dominant-seventh chords $\mathrm{E} b^{7}, \mathrm{D}^{7}$, and $\mathrm{Cb}^{7}$, ending up in $\mathrm{A} b^{7}$, a dominant harmony to the successive second episode. This division modulates to $\mathrm{D} b$ major, lowering the secondary theme by a major second as well (mm. 19 -34 are equal to $\mathrm{mm}$. 47-62), and results in a prolonged sequential passage, proceeding from $\mathrm{B} b$ minor to $\mathrm{Ab}$ minor (m. 58), $\mathrm{Eb}$ minor (m. 60), and further descending chromaticism in F minor. A retransitional passage in $\mathrm{G}$ major is reached (m. 68ff.), suggestively reiterating the descending tetrachord $C-B b-A b-G$ in the bass voice, and thus resembling the $1^{\text {st }}$ movement's motif Ic before returning to $\mathrm{C}$ minor (m. 77$){ }^{71}$

Medtner does not employ an exact recapitulation of the movement's beginning for the third refrain, but resorts to another variant of the initial idea, transforming it to an eight-measure theme which resembles a fugato-but rather in its gesture than in its compositional structure. A continuously descending chromatic scale, starting from $A b$, is used as a contrapuntal accompaniment, and the whole theme is repeated an octave higher, increasing in dynamics (mm. 85-92), before an eruptive chordal manifestation of the >question motif< bursts out. The notes $C-B-E b$ are now harmonised with $\mathrm{Fm}^{7}$ and $\mathrm{Fm}^{7 / b 5}$ chords, breaking off on a fermata 
(m. 95; see example 3.1.6). ${ }^{72}$ The movement lacks another episode which might have been expected here; Medtner instead proceeds with a regular recapitulation of the initial theme as the fourth refrain. This passage is a restatement of mm. 1-20 a slightly altered at its ending (m. 116ff.), and leads to a PAC in C minor (m. 120).

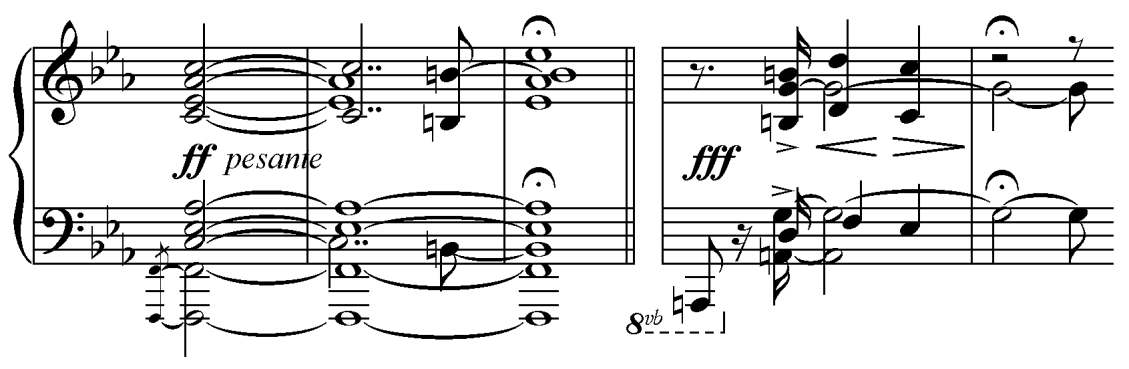

Example 3.1.6: Medtner, Sonata, Op. 5, $2^{\text {nd }} \mathrm{mvt}$, mm. 95-97 // mm. 128-129

The movement could have ended here, but a single $G$ is left over from the concluding staccato chord, enabling the composer to attach an enigmatic, twelve-measure Moderato interlude in 3/2 time. Here, motif II is sequenced twice in ascending major seconds and applied as the subject of a canon at the upper fifth (m. 124f.), resulting in a progression of augmented triads, dramatically ascending over two octaves. While steadily increasing the tempo, Medtner continues with a downward alternation of $\mathrm{C}$ minor and $\mathrm{G}$ augmented major triads (m. 126f.: irato). With the massive disruption of the keyboard's lowest $A$ (m. 128), the music suddenly halts, forte-fortissimo, and is shadowed by the thrice-repeated phrase $B-D-C$, a permutated inversion of the >question motif ( see example 3.1.6). This threatening gesture prompted Ivan Ilyin to express the association of $»$ a blind alley, hopelessness, darkness $«{ }^{73}$ picturesquely characterising the movement's striking climax, which breaks off without a regular cadence and leaves the listener in confusion about its tonality. ${ }^{74}$ Again, the sound vanishing into silence is a half-diminished seventh chord, now on the fundament of $A$; and its sole remaining element, the seventh $G$, links the final harmony of the interlude to $\mathrm{E} b$ major, the key of the subsequent Largo movement. Later, the sonata's internal dramaturgy is further enforced by the recurrence of this interlude between the $3^{\text {rd }}$ and $4^{\text {th }}$ movements. ${ }^{75}$

72 This chord is ambivalent between dominant and subdominant functions. Its half-diminished structure, comprising the notes $F$ and $A b$, seems to qualify it as the latter; but since it also contains a leading-tone to the tonic, Malikova 1967 , p. 290, dubs it a dominant with missing root and added sixth (»dominantï s sekstoy«), referring to Yury Tyulin’s terminology of interchanged side-notes (»zamennïmi pobochnïmi tonami«). Keller 1971, p. 42, alternatively analyses its as »a subdominant chord with added seventh and raised eleventh «.

73 Ilyin 1955, p. 187.

74 Loftis 1970 , p. 170, discusses the cadential implication of this ending, but fails to explain its special effect- the succession of the Intermezzo's last and the Largo's first chord might indeed be regarded as a kind of incomplete cadence, lacking a dominant between the harmonies of $\mathrm{ii}^{7 / 55}$ and $\mathrm{I}$.

75 See Flamm 2006, p. 8. 
Third movement: Largo divoto $^{76}$

Eb major, $3 / 4, \downarrow=42,89$ measures on 6 pages

\begin{tabular}{|c|c|c|c|c|}
\hline \multirow{4}{*}{$\begin{array}{l}\text { SECTION } \\
\text { exposition }\end{array}$} & THEMES AND SUBJECTS & Position & INDICATIONS & KEY \\
\hline & primary theme $(\mathrm{P})$ & mm. $1-20$ & Largo $; \mathrm{p}$ portamento & Eb major \\
\hline & transition $(\mathrm{Tr})$ : secondary th & mm. $21-30$ & meno mosso; pp tranquillo assai & $\mathrm{G}$ minor $(\mathrm{V})$ \\
\hline & secondary theme $(\mathrm{S})$ & mm. 31-35 & $\mathrm{mf}$ pietoso & $\mathrm{B} b$ major \\
\hline development & primary and secondary th & mm. 36-51 & a tempo; $\mathrm{pp}$ & Eb minor \\
\hline recapitulation & primary theme $(\mathrm{P})$ & mm. 52-59 & Maestoso; fff / p & $\mathrm{Eb}$ major \\
\hline & transition (Tr): secondary th & mm. $60-70$ & & $\mathrm{C}$ minor $(\mathrm{V})$ \\
\hline & secondary theme $(\mathrm{S})$ & mm. 71-77 & fff plenissimo, con entusiasmo & Eb major \\
\hline interlude & initial theme of $2^{\text {nd }} \mathrm{mvt}$ & mm. 78-89 & Moderato-Andante; $\mathrm{p}$ & $\mathrm{B} b$ minor \\
\hline
\end{tabular}

Like the sonata's $1^{\text {st }}$ movement and finale, the Largo is composed in sonata form. It is an expressive piece of dense motivic construction, forming the emotional core of the sonata, in which numerous authors have observed an atmosphere of spirituality and prayer. Its most meaningful melodic phrases are motif IIIa with its descending diminished fifth, appearing as the primary theme's bass voice and as a transitional subject, and motif IIIb, source of the movement's secondary theme in two different manifestations. In the exposition, the regular eight-measure period of the primary theme alludes to sarabande rhythm, ${ }^{77}$ leading to an authentic cadence in its antecedent and modulating to F minor in the consequent (m. 8). The rather unsuspicious melodic motion of the beginning $B b-C b-B b$, a minimal shift upwards and downwards from the fifth scale degree, then rises to $G$ (m. 3) and to the expressive leap of an ascending ninth (m. 7); more significant is the lowest voice, an ostinato of motif IIIa, starting from $E b$ and repeated throughout the first eight measures. This double-dotted rhythmic figure might have been derived from the $2^{\text {nd }}$ movement's concluding interlude, as Ginsburg has pointed out, ${ }^{78}$ and proves constitutive for most of the Largo's thematic development. Certain attention should be paid to the second chord in each of the measures 1-3 and 5-7, confronting the Eb major tonic with an altered >Chopin dominant $<$ above $F$, incorporating a flattened fifth and thirteenth (discussed in more detail in chapter 2.4.1; see also example 2.4.2).

A second melodic shape follows, superposing a descending diatonic figure in a canon of three voices (m. 9ff.), which produces a descending cycle of fifths and leads to a HC in Bb major (m. 12). Motif IIIa returns in the passage poco a poco agitato e più mosso passage, now complemented with a more flexible melody in the top voice, starting with $B$ b. A continuous crescendo extends over eight measures, the second half of which, adding an upper third, being a more intense version of the first half. In m. 20, forte is reached in the unexpected succession of an F augmented major and a D major triad. Medtner here appends a gracefully enraptured episode in a high and fragile register, representing the formal function of a transition, and introducing motif IIIb as a chromatic anticipation of the secondary theme (m. $21 \mathrm{ff}$. : pianissimo) - the

76 The attribute divoto appears in the first edition and the revision of 1955, but is absent in the 1959 Collected Edition.

77 According to Dolinskaya 2013, p. 31, the theme resembles a ballad, infused with subtle poetry (»Napominaet balladu, proniknutuyu tonkoy poėziey«). In contrast, Stewart 2012, p. 8, feels reminded of Russian Orthodox chant.

78 See Ginsburg 1961, p. 19 f. 
small-interval contour $(D-D-D-E b-D-D)$ and Phrygian-dominant harmonisation of this melody might remind the listener of similar passages in Rachmaninov. ${ }^{79}$ Its continuation displays Medtner's predilection for polyrhythm and harmonic complexity, incorporating an ascending cycle of minor thirds as a sequence of motif IIIb (m. 24f.: Bb major - Db major - E major - G major; see example 3.1.7). These progressions, while arranged in phrases of two crotchets contrasting to the movement's $3 / 4$ time, appear in permanent superpositions of duplet against triplet semiquavers. As if this were not enough, the middle voice continuously alludes to motif Ic. ${ }^{80}$ As part of a prolonged process of intensification, m. 27ff. introduces a variant of motif IIIa, in contrary motion of the outer voices and combined with several quotations of the three-note group $F \sharp A-G$ - a phrase derived from the inversion of motif II as encountered during the preceding interlude. Finally having reached $\mathrm{B} b$ major again (m. 30), the secondary theme is now presented in a harmonious and purely diatonic environment (see example 3.1.8). bringing the exposition to a consoling closure. Its middle phrase, lingering on a Phrygian half cadence for a short moment, is imperceptibly lengthened from three to four crotchets (m. 33).

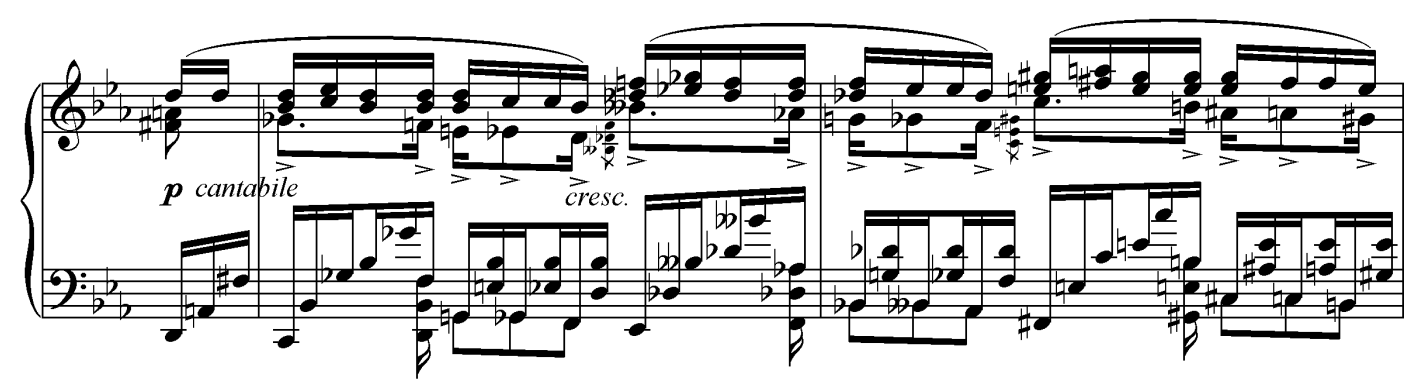

Example 3.1.7: Medtner, Sonata, Op. 5, $3^{\text {rd }}$ mvt, exposition, mm. 24-25

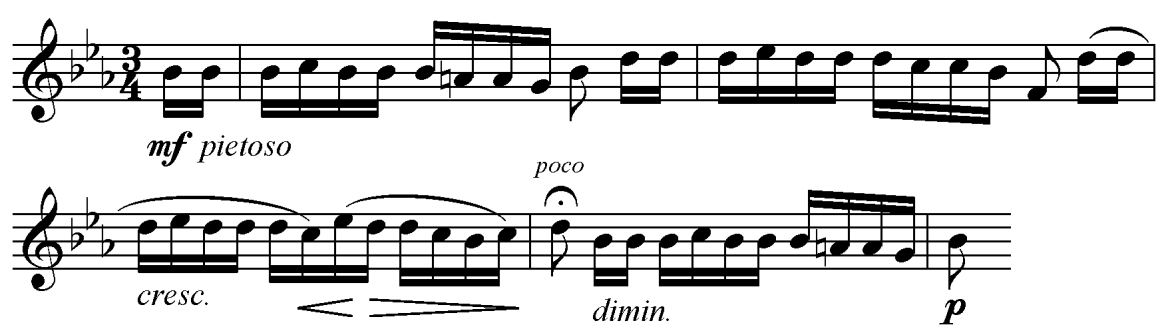

Example 3.1.8: Medtner, Sonata, Op. 5, $3^{\text {rd }}$ mvt, exposition, mm. 30-33 (motivic reduction)

The short development section first recalls, with the notes $G-B b-A b$ and $D-F-E b$, more reminiscences of the interlude's transformation of the >question motif $\iota$, before quoting the imitative passage of mm. 9-12, now in the key of $\mathrm{Eb}$ minor (m. 38ff.). An ascending cycle of seconds (m. 42ff.) alludes to mm. 13-20, modulating from $\mathrm{A} b$ major to $\mathrm{B} b$ major, $\mathrm{C}$ major, and, quite surprisingly, $\mathrm{E}$ major (m. 45: irresoluto). In this key, Medtner refers

79 See, for instance, the middle section of Rachmaninov's G minor Prelude, Op. 23 No. 5 (1903). Ilyin 1955, p. 187, refers to that first appearance of motif IIIb as »choirs of angels«; Gerstlé 1924, p. 504, also notes the »delicious harmonic colouring « of this episode.

80 See Flamm 1995, p. 217. 
back to the secondary theme's fragile and chromatic first appearance, enharmonically altered to $\mathrm{Fb}$ major $-\mathrm{a}$ Neapolitan subdominant to the tonic key of $\mathrm{Eb}$ major, the return of which is prepared during the following measures. ${ }^{81}$ Inversions of motif II are reiterated in a sharply dotted rhythm (m. 50), arising over a strong dominant pedal which leads to a sonorous restatement of the primary theme, entering in m. 52 (maestoso, fff).

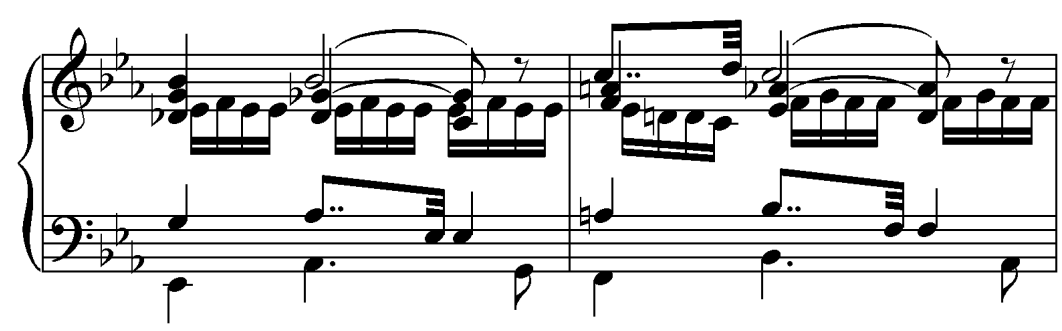

Example 3.1.9: Medtner, Sonata, Op. 5, $3^{\text {rd }}$ mvt, recapitulation, mm. 56-57

The recapitulation adds a persistent countersubject to the primary theme, replenishing its middle voices; the alternating notes $B b$ and $C$ are obviously derived from motif IIIb and thus from the secondary theme. Motivic synthesis is continued when motif IIIa, now encompassing a perfect fourth and starting from $G$, returns in combination with the primary theme's consequent (m. 56ff.; see example 3.1.9), and with constant reiterations of the abovementioned countersubject. In this manner, all significant motives of the Largo are juxtaposed here, modulating to the dominant area of $\mathrm{C}$ minor $(\mathrm{m} .59)$. The canonic passage of $\mathrm{m}$. 9f. is omitted during the recapitulation; what follows here is an exact recollection of the exposition's transitional section, quoting mm. 21-30 a fifth lower, and resulting in a broad fff cadenza which launches the final appearance of the secondary theme (m. 70). The latter is now presented as a hymnic climax in Eb major (plenissimo, con entusiasmo), ${ }^{82}$ with its closing unexpectedly modulating away from the tonic (m. 76f.) and reaching a $\mathrm{HC}$ in $\mathrm{B} b$ minor. The Moderato interlude from the $2^{\text {nd }}$ movement's ending is attached here without changes, except that it is transposed to $\mathrm{B} b$ minor, and therefore breaks off on a $\mathrm{Gm}^{7 / 55}$ chord, leaving behind a single $F$ which prepares for the entrance of the finale.

81 Loftis 1970 , p. 68 , notes an »almost constant shifting of tonal centers in this movement « and observes »the use of foreign chords and enharmonic common chords « in $\mathrm{m}$. 47, without identifying E major as the enharmonic variant of the Neapolitan chord $\mathrm{Fb}$ major, leading back to the tonic.

82 Martyn $1998^{\mathrm{b}}$, p. 4, describes the secondary theme's change of character as follows: »A kind of prayerful meditation, a spiritual struggle from uncertainty to hope in prayer (a passage marked pietoso), through further uncertainty to a fervent climax in further prayer (con entusiasmo)«. Pullman 2001 describes the theme as a »broad, serious, passionate yearning $\ll$. 


\section{Fourth movement: Finale (Allegro risoluto - Presto) $F$ minor $-F$ major, 2/4, $\bullet=126,431$ measures on 17 pages}

\begin{tabular}{|c|c|c|c|c|}
\hline \multirow{6}{*}{$\begin{array}{l}\text { SECTION } \\
\text { exposition }\end{array}$} & THEMES AND SUBJECTS & POSITION & INDICATIONS & KEY \\
\hline & primary theme $(\mathrm{P})$ & mm. $1-48$ & Allegro risoluto; $\mathrm{p}$ & F minor \\
\hline & transitional idea (Tr) & mm. 49-57 & dolce & $\mathrm{A} b$ major $(\mathrm{V})$ \\
\hline & secondary theme of $1^{\text {st }}$ mvt $(\mathrm{S})$ & mm. 58-73 & $\mathrm{p}$ simplice & Ab major \\
\hline & transitional idea & mm. 74-117 & [p] tranquillo e dolce & Ab major \\
\hline & closing zone $(\mathrm{C})$ : primary & mm. 118-146 & $\mathrm{ff}$ & Ab major \\
\hline \multirow[t]{3}{*}{ development } & fugato: primary theme & mm. 147-190 & pp sempre sotto voce & $\mathrm{B} b$ minor \\
\hline & transitional idea & mm. 191-203 & dolce & $\mathrm{Eb}$ minor \\
\hline & retransition: primary theme & mm. 204-266 & $\mathrm{p}$ & $\mathrm{Eb} / \mathrm{F}(\mathrm{V})$ \\
\hline \multirow[t]{5}{*}{ recapitulation } & primary theme $(\mathrm{P})$ & mm. 267-315 & Teтро рrimo; [p] & F minor \\
\hline & quotation from $3^{\text {rd }} \mathrm{mvt}$ & mm. 316-322 & Tempo di Largo; $\mathrm{mf}$ & modulating \\
\hline & variant of primary theme & mm. 323-350 & Allegro; ppp & F major \\
\hline & secondary theme $(\mathrm{S})$ & mm. 351-365 & Maestoso; fff & F major \\
\hline & transitional idea $(\mathrm{Tr})$ & mm. 366-402 & $\mathrm{mf}$ dolce, poco a poco agitato & F major \\
\hline coda & secondary theme & mm. 403-431 & Presto; fff & F major \\
\hline
\end{tabular}

The beginning of the finale yet again refers back to music history as it features a restless semiquaver motion in 2/4 meter, in a manner reminiscent of the $3^{\text {rd }}$ movement of Beethoven's F minor Sonata >Appassionata<, Op. 57 (1804-05). ${ }^{83}$ Notwithstanding this coincidence, the movement's construction is by no means traditional. A number of individual divergences from the formal model, incorporating a fugato passage, a recollection from the Largo, and an extended coda overlapping the recapitulation section, make this finale a somewhat confusing but impressive example of Medtner's early command of sonata form, continuously disguising the traditional succession of themes in its progress. These structural ambiguities have caused Elena Dolinskaya to speak of a »rhapsodic and mosaic-like« texture, somewhat suffering from its extreme length and elaborateness. ${ }^{84}$ However, the finale's motivic layout appears as stringent as in the preceding movements - three separate motives can be identified as constitutive, all of which rely on previously developed material. Motif IVa, a sharply dotted upbeat figure introduced at the movement's beginning, is derived from the inversion of motif II at the $2^{\text {nd }}$ movement's climax, encircling the tonic $F$; motif IVb, the contrasting idea directly following, is a variant of motif IVa with diminished note values and its anacrusis doubled; and motif IVc, comprising the subsequent four notes, forms a descending tetrachord which establishes a link to motif Ic, recurring in the movement's secondary theme. ${ }^{85}$ The combination of these three motives make up the finale's primary subject, revealing its origin from the $1^{\text {st }}$ movement's motif Ia, the ascending diatonic contour of which appears in a rhythmically altered shape here, maintaining the framing interval $F-C$.

83 For a discussion of further similarities between those two finales see Keller 1971, p. 28.

84 Paraphrased after Dolinskaya 2013, p. 31: »Monumental'nï final, naibolee slozhnïy po kompozitsii, bïl zaduman kak obobshchayushchaya sinteticheskaya chast' v rapsodicheski-mozaichnom sklade.«

85 Martyn 1995, p. 25, characterises this relationship as »sharing an insistent tonic to dominant descending scale figure «. 


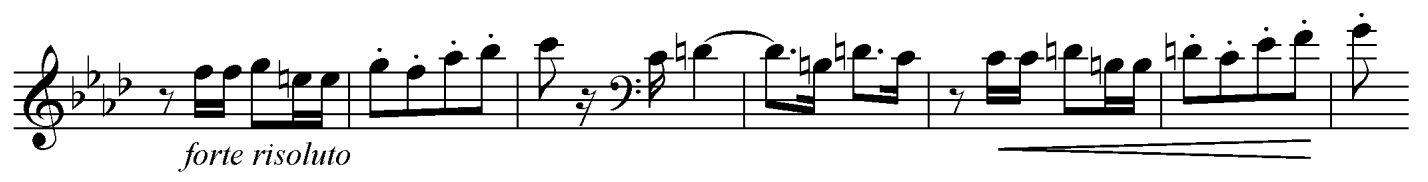

Example 3.1.10: Medtner, Sonata, Op. 5, $4^{\text {th }}$ mvt, exposition, mm. 33-40 (top voice)

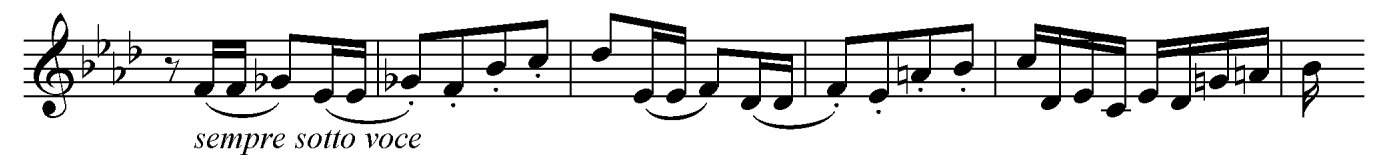

Example 3.1.11: Medtner, Sonata, Op. 5, $4^{\text {th }}$ mvt, development: fugato, mm. 149-154

Continuous semiquaver motion is characteristic of most of the exposition's material, as seen in the lower voice accompanying the primary theme in downward scales. The theme itself is organised in periodic syntax again, composed of an antecedent and consequent of eight measures each, but with an asymmetric phrase structure - the former consists of motif IVa, entering not on the tonic but on a subdominant sixte ajoutée chord, emphasising the second scale degree $G$ in two measures. The successive phrase, at a length of six measures, starts with motif IVb, quickly reaching the upper octave $F$ to descend again in diatonic scales, first in crotchet motion, and then in diminution to semiquavers (m. 6f). The same structure is repeated in the consequent—but instead of seizing an authentic cadence (m. 8: F minor), the period denies a stable closure, going back to the subdominant $\mathrm{B} b$ minor with the top voice descending from $B b$ to $F$ (m. 16). Both the antecedent and consequent show the internal syntax of a sentence, making the whole sixteen measures appear as a compound theme. ${ }^{86}$ Medtner subsequently extends it by further diminutions of its initial phrase, applied to a descending chromatic middle voice which again fills the distance between $F$ and $C$ (mm. 17ff., 21ff., 25ff.), then being gradually condensed and shortened (m. 29f.) before joining in a ritenuto half cadence. This expansive process makes the primary theme grow to double size from 16 to 32 measures, giving an accurate example of Schoenberg's concept of $>$ developing variation $<{ }^{87}$ The primary theme seems to start again as a $>$ touched-on repetition $<$ (m. 33), but omits motif IVc and, above the ascending bass $C-D-E b$, transposes to $\mathrm{C}$ minor in another pair of four-measure phrases (mm. 33-41; see example 3.1.10). After that, the descending line of motif IVc occurs multiple times in crotchets and quavers (m. 42ff.), already preparing for the entrance of the secondary theme, which is actually a minor-major transformation of that of the $1^{\text {st }}$ movement $\longrightarrow$ Anna's theme here changes its character to a tender chorale, including motif Ic as an interlaced stretto in the left hand (m. 58ff.).

The transformation of >Anna's theme<, contributing to the impression of the whole sonata as a coherent cycle, thus covers both the keys traditionally employed for the secondary theme in minor-mode sonata forms, the $\mathrm{v}$ and III. Hartmut Hein remarks that the theme »returns, converted per aspera ad astra to the tonic major, in the finale and, in its ultimate apotheosis, prevails as the poetic core of the whole work. ${ }^{88}$ Before the

86 See Caplin 1998, p. $63 \mathrm{ff}$.

87 See Schoenberg 1950, p. 39ff.

88 My translation of Hein 2006, p. 501f.: »Es kehrt auch - per aspera ad astra nach Dur gewandt - im Schlußsatz wieder und setzt sich in der Schluß-Apotheose endgültig durch als das poetische Zentrum des ganzen Werkes«. The 
theme sounds in its definite key of Ab major, a dominant pedal on $\mathrm{Eb}$ is initiated by motif Ic (m. 47f.: fortissimo), representing a short transitional section. Medtner here employs a significant melodic outline as a transitional idea in dotted rhythm, from far resembling Tchaikovskian melos even though derived from motives IVa and IVb, and gaining more importance as the secondary theme zone proceeds. After a complete statement of the secondary theme, the composer returns to his transitional material, appending another eightmeasure phrase unfolding above a chromatically descending bassline (m. 73ff.), and realised as alternating pairs of martellato semiquavers. Further intense processing of the transitional idea leads to a descending cycle of seconds (m. 94ff.: Eb major - Db major - Cb major - A major), continuously resorting to the martellato figures. The latter harmony leads to the temporary tonic of D major (m. 102), a tonality at the greatest possible distance from the tonic key (bV). At this point, another series of quotations of motif Ic occurs, quickly modulating back to $\mathrm{Ab}$ major, with the closing zone (m. 118ff.) representing a major-mode variant of the primary theme. All motives are polyphonically combined when heading for the exposition's effective conclusion, with the primary theme being sequenced downwards, starting with the notes $E b, C$, and $A b$, and eventually fading away with multiple quotations of motif IVc in the right hand (m. 134f.).

After the exposition's EEC (»essential expositional closure« after Hepokoski and Darcy; see figure 3.0.2), the primary theme's recurrence prepares for a three-part fugato, marking the beginning of the development section. ${ }^{89}$ The contrasting idea of motif IVb, its descending sequence, and a continuation phrase in semiquavers are combined to a fugal subject of eight measures, sounding in Bb minor (m. 149; see example 3.1.11). Whereas motif IVb had originally enclosed the first scale degree and its upper neighbour, $F$ and $G$, it now encircles the fifth scale degree, alternating between $F$ and $G$ b. A countersubject is skillfully constructed from the diminution of motives Ic and Id, accompanying the fugal subject's comes variant (m. 157ff.) as well as the subsequent $d u x$ (m. 165ff.). As the third voice fills in traces of motif IVa, Medtner succeeds in creating a polyphonic structure which bears thematic content in every single voice. The fugal subject reappears in the bass only once more, now in $\mathrm{Eb}$ minor (m. 173ff.), before a sequence of the countersubject leads to a number of further quotations of motif IVc. The transitional idea is processed in a passage resembling the closing zone (m. 191ff.), still in the key of Eb minor, before motif IVa starts to creep in again, now starting from the seventh scale degree (m. 204), and launches an extensive retransition, alternating with motif Ic in both its manifestations (as the secondary theme and the fugato's countersubject). This whole passage is repeated, with mm. 204-222 being equivalent to $\mathrm{mm}$. 224-242, now bringing about a prolonged dominant area in $\mathrm{F}$ minor. As a culmination of this process, motif Ic appears in a broadly augmented version (m. $247 \mathrm{ff}$.), calming down the restless semiquaver motion to steady minims. This passage surprisingly drops back to an exotic cadence, enharmonically connecting B bb major, $\mathrm{D} b$ minor, and a French sixth chord above $D b$, to $\mathrm{F}$ minor, taking place above a bassline chromatically ascending from $B$ bb to $C$ (m. 252ff.: poco ritenuto).

author again refers to the per aspera ad astra idea in order to describe the various transformations of the secondary theme. Flamm 2006, p. 8, considers the Latin term in a closer context to the recurrences of the >question motif<.

89 Sacre 1998, p. 1813, sees that fugato in the role of a catharsis in the course of the movement. 


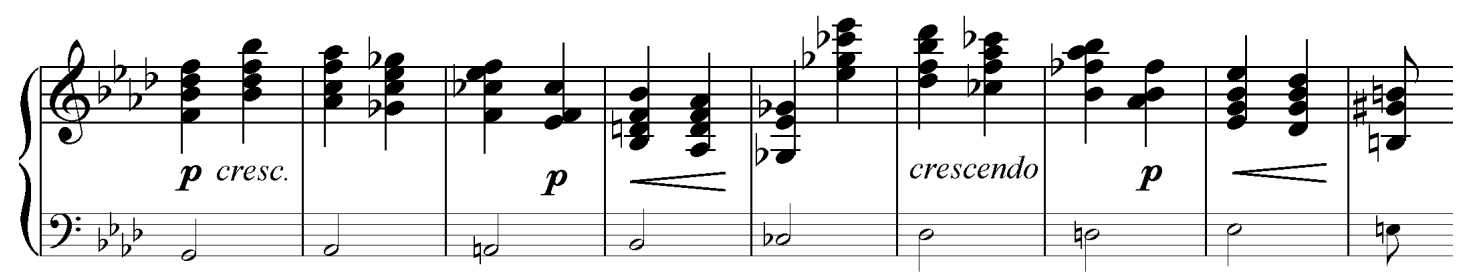

Example 3.1.12: Medtner, Sonata, Op. 5, $4^{\text {th }}$ mvt, recapitulation, mm. 279-287 (harmonic progressions)

Further fragmentation of motif IVa directly leads to the recapitulation, entering with the primary theme in its original shape (m. 267). Here, Medtner seems to aim at a solid recovery of the tonic at first, but turns out to quote only twelve measures from the movement's beginning and then modulate away, breaking off the primary theme's continuation phrase. This fascinating passage comprises another ascending sequence of motif IVc, and features a chain of deceptive cadential progressions (example 3.1.12), undergoing continuous modulation as if still located in the development section. From m. 287, Medtner juxtaposes four-measure clauses of contrasting moods, one of which diminishes motif IVc in a light E major, while the other alludes to motif IVa in figuration of the notes $E, F$, and $G$, based on an obscure Phrygian harmony. At this point, the juvenile composer already displays an inclination to harmonic ambiguity which would prove characteristic of many of his later works. The music continues to destabilise its tonic by quoting the eruptive Andante formula from the preceding interludes (m. 314f.), with the notes $C \#-E-D$ unmistakably demonstrating the common diastematic origin of motif II (inversed) and motif IVa. The following measures, marked Tempo di Largo, recall the initial measures of the $3^{\text {rd }}$ movement, recurring to motif IIIa and its succession in chromatic contrary motion (as seen in the Largo's m. 27ff.). Once again, a moment of rapture is inserted in the finale's permanent semiquaver flow, establishing a radical contrast to its general agitato character.

Out of this dreamlike episode, the primary theme evolves again above a chromaticised bassline in semiquavers (m. 327ff.: Allegro), ${ }^{90}$ transferred to F major and, just like the fugato from the development section, encircling the fifth scale degree $C$; the latter is used as an axial basis for motif IVa. This time, the primary theme is not allowed to fully evolve, with its consequent phrase being truncated, and leads directly to further quotations of motif IVc and the transitional idea. The formal position of this passage remains ambivalenteven if most authors locate the onset of the recapitulation in $\mathrm{m}$. 267, this would be the focal point to continue with the remaining part of the development section after having detected a »broken-off recapitulation «. ${ }^{91}$ But even though this interpretation seems plausible, we must admit that there are at least two other options of structuring the whole movement. In deviation from the subdivisions given in the table above, we might consider the following possibilities:

90 This texture occurred very displeasing to Montagu-Nathan 1917, p. 247: »The excessively low chromatic scalefigures produce a tonal muddiness «. However, the succession of each measure's initial note $C$ produces a dominant pedal lasting for 28 measures, reminding Ginsburg 1961, p. 171, of a similar pedal point at the beginning of the recapitulation in the $1^{\text {st }}$ movement of Beethoven's Op. 57: »The influence of Beethoven, too, is apparent in Medtner's use of long dominant pedals, particularly at the end [that is: m. 327ff.] of the last movement of Op. $5 \ll$.

91 Flamm 1995, p. 217: »Diese Stelle dient zur Überwindung der abgebrochenen Reprise«. 
- m. 327 can be identified as the recapitulation's beginning, which would cause the development section to extend significantly and contain a feigned recapitulation in $\mathrm{m} .267$.

- $\quad \mathrm{m} .327$ can be identified as the onset of a large coda, encompassing most of the secondary theme zone's material, and with the regular recapitulation covering only the primary theme zone.

Whatsoever, the secondary theme apparently returns in continuation of this passage (m. 351ff.: Maestoso), giving a triumphant restatement of >Anna's theme < with an alternative bassline in contrary motion. ${ }^{92}$ In staging this subject as an apotheosis of the sonata's formal dramaturgy, Medtner pays his tribute to the piano concertos of his predecessors Tchaikovsky and Rachmaninov, both of which tend to transform the recapitulations of their secondary theme zones to a hymnic culmination..$^{93}$ The transitional idea follows in further analogy (m. 366ff.), with its melody passing to the middle voice, and again modulating to the bV, the exotic key of $\mathrm{Cb}$ major (m. 395). Instead of a regular closing zone, Medtner attaches a Presto coda (m. 403ff.) which refers back to motif Id in its first eight measures, a figure which had remained unused since the $1^{\text {st }}$ movement's coda. The following measures employ two different types of chromaticised cycles of thirds, opposing the tonic to the mediant chords $\mathrm{C}$ major and $\mathrm{Ab}$ major (m. 411ff.) and A major and $\mathrm{Gb}$ major respectively (m. 415f.). The rhythmic contour of the secondary theme, here condensed to a semiquaver figure as seen in the fugato's countersubject, culminates in a polymetric conclusion: The top voice fills the descending fourth $F-$ $C$ with a chromatic scale, in derivation of motives Ic and IVc, while the left hand adds chords in syncopated rhythm. These shifting accents eventually merge to a final passage in perceived $3 / 8$ meter, interfering with the written 2/4 time (m. 427f.), and with the semiquaver anacrusis of motif IVa once more being employed as an emphatic upbeat to the final $\mathrm{F}$ major chord.

\subsubsection{HERMENEUTIC IMPLICATIONS}

Unlike many others of Medtner's sonatas, this work does not obviously draw inspiration from literature or other extramusical content, as evident in works such as the E minor Sonata, Op. 25 No. 2, the SonataBallade, Op. 27, or the $3^{\text {rd }}$ Piano Concerto, Op. 60. When talking about these pieces, hermeneutic approaches, pointing beyond the score, are naturally suggesting themselves. Given the popularity of semantic and autobiographical contexts taken into consideration for analyses of some of Medtner's sonatas, these mightto some extent—also apply to the Sonata, Op. 5, as the composer's personal relationships have evidently influenced the genesis of the work.

It was Medtner's friend Alfred Swan who first referred to the $1^{\text {st }}$ and $4^{\text {th }}$ movements' secondary subjects as >Anna's theme〈, relying on Emil Medtner's remark to Anna Bratenshi: »In the piece he is working on,

92 Ilyin 1955, p. 187, interprets this passage as follows: »The second theme has won, and the consolation it bestows is manly and authoritative«, while Pinsonneault 1959, p. 25, remarks that »le thème féminin du début deviendra un hymne grandiose et vainqueur de toutes attaches terrestres «.

93 See the finales of Tchaikovsky's $1^{\text {st }}$ Piano Concerto in Bb minor, Op. 23 (1874), as well as Rachmaninov's $2^{\text {nd }}$ and $3^{\text {rd }}$ Piano Concertos in C minor, Op. 18 (1900-01), and D minor, Op. 30 (1909). 
Kolya makes use of a theme that is somehow connected to you«. ${ }^{94}$ This attribution indicates an emotional or even lovelorn origin of that cantilena, and many authors in Swan's succession have maintained his assertion. Unfortunately, the connection of that passage to Anna is not proven by any statement of Medtner himself, and one might therefore argue that it doesn't seem to reveal anything of importance; and moreover, authors employing such terminology might face the allegation of working on a speculative level. However, the least we can conclude from this attribution is that the sonata genre in Medtner, with regard to its significance as the highest possible embodiment of his piano music, apparently coincides with real-life experience. In this sense, the F minor Sonata, although clearly no programmatic and not even a descriptive work, may be conceived as music charged with individual symbolism, representative of the biographical entanglements during the time of his genesis (see chapter 0.1). Of such quality is the alleged analogy to Robert and Clara Schumann, embedding in the music the enciphered thought of a beloved woman which was out of reach during the time of composition. We might consider this whole interrelation as merely >literary<, arising under the influence of Andrei Bely's writings and ideas-particularly of his Second >Dramatic Symphony (Simfoniya 2-ya, dramaticheskaya) of 1902 (see also figure 0.2). This work, aiming to transfer the principles of musical form to a literary genre, prompted Emil to draw parallels between figures from Bely's prose and certain subjects from Nikolai's sonata. ${ }^{95}$ Astonishingly, the final sentence of the Symphony reads: »The dew was falling on a grey stone shrine engraved with the words: ^Peace be with you, Anna, my wife! « ${ }^{96}$ At last, the idea of absolute music somehow decreases in value when considering such coincidences hidden behind the score.

Nevertheless, the determining object of analysis remains the musical score which should be used as its basis. This does not preclude the use of picturesque labels such as »choirs of angels« as attributed by Ivan Ilyin to the $3^{\text {rd }}$ movement's secondary theme and its hymnic culmination. ${ }^{97}$ Even if this notion originates from pure speculation, and again lacks compulsory evidence from Medtner himself, it may appear more justified than the imprudent application of the term >Anna's theme - - that is, in suggesting an atmosphere of spirituality, and in illustrating the character of the music and its possible stimuli in a manner that appeals to the recipient. However, the present analytic approach towards the F minor Sonata has mainly focused on aspects which appear on its surface as distinct stylistic devices, such as features of musical form, development of themes and motives, and cross-movement cyclic relationship. In this respect, the young composer's skills already show an astonishing level of proficiency, leading to the conclusion that we are facing an exemplary work with regard to the aforementioned techniques of composition.

94 My translation of Swan 1967, p. 69f.: »»Kolja arbeitet an seinem Stücke mit einem Thema, das irgendwie mit Ihnen verbunden ist<, pflegte Emil zu sagen, Anna besuchend.«

95 See Ljunggren 1994, p. 17f., Flamm 1995, p. 50f., and Flamm 2009, p. 46.

96 Bely 1902, p. 150. Roger Keys's translation corresponds to the following original line: »Rosa pala na chasovnyu serogo kamnya; tam bïli vïsechenï slova: `Mir tebe, Anna, supruga moya!««

97 See Ilyin in Holt 1955, p. 187, and Flamm 2006, p. 8. 


\subsection{SONATA TRIAD, Op. 11}

Title page: Triade de Sonates pour Piano [1906]; Sonaten-Triade für Klavier [1907, 1908]; Sonaten-Triade / Sonata Triad / Piano solo [1925]

Composed: 1904-08, premiered: November 20, 1906, and February 9, 1909, Moscow, by the composer

Dedication: in memory of Andrei Mikhailovich Bratenshi

Editions of all three sonatas: Benjamin c. 1925 (rev. Martin Frey), reprinted Simrock 1925; Moscow 1958; Muzgiz Collected Edition 1959 (Vol. 1, pp. 216-250), reprinted Dover 1998; Muzika c. 1975. First editions: see separate entries Recordings: see separate entries

\section{A Poetic Triptych}

Medtner's Sonata Triad (Sonaten-Triade), Op. 11, is a set of three single-movement works assembled in one opus number, but without an obvious interconnection to each other. The triptych must thus be regarded an acyclic work, and as such doesn't have any formal model in music history. Only one year after the completion of the traditionally-shaped, four-movement $1^{\text {st }}$ Sonata, Op. 5, the young composer came up with a conception hitherto unknown in the sonata genre, already departing from the established generic archetype, and demonstrating a strong motivation to explore new designs in sonata form. But even if so, we have to bear in mind that the publication of groups of three, or six, works of the same genre had been quite common throughout the $18^{\text {th }}$ century - and this editorial tradition still affected Mendelssohn, Schumann, Reger, and others when publishing their multi-movement sonatas or chamber works. At times, orchestral or stage works have also appeared in groups of three, such as Antonín Dvořák's triptych of concert overtures Nature, Life and Love, Opp. 91-93 (1891-92), Ottorino Respighi’s >Roman Trilogy< of symphonic poems (1916-28), or Giacomo Puccini's one-act opera cycle Il trittico (premiered 1918). Nevertheless, a triptych of singlemovement piano sonatas remains an extraordinary conception. ${ }^{1}$

Like many of Medtner's earlier works, the Sonata Triad emerged from a long and intricate period of genesis. First drafts are found in sketchbooks of 1901, including an »exercise in sonata form « as a preliminary stage of what would later form the Sonata-Elegy, Op. 11 No. $2,{ }^{2}$ but the actual elaboration of the three works did not start before 1904. Given that Medtner did not realise his original idea to compose a second moment for the Ab major Sonata, Op. 11 No. 1, and instead published the three works separately in the successive years of 1906-08, it is not quite clear when exactly he came up with the trilogy idea; anyway, the three works were collectively referred to as a triad already from the first edition of Op. 11 No. 1 (1906). However, the connection of the sonatas appears weaker than in the cases of, say, Beethoven's three piano sonatas, Op. 31, or Schumann's three string quartets, Op. 41. Medtner himself used to perform them separately, never programming the Sonata Triad as a whole, nor did he require this should be done. ${ }^{3}$ Apart from

1 Kholopov 1990, p. 286, refers to Prokofiev's three >War Sonatas`, opp. 82-84, as a Sonata Triad as well.

2 Flamm 1995, p. 383: »Die Elegie entsteht Anfang des Jahrhunderts als eine `Übung in Sonatenform८, namentlich als Allegretto pastorale in der Paralleltonart F-Dur, das motivisch den Sonatenbeginn vorausnimmt «.

3 With regard to the tempo indications of the three pieces, Flamm (ibid., p. 218) discusses the hypothetical possibility of conceiving the Triad as a fast-slow-fast sonata cycle, and argues that, with the exception of the A minor Sonata, Op. 30, Medtner has never published a regular single-movement sonata form in one exclusive opus number. 
recordings, where the three sonatas are naturally grouped together, they are rarely heard in succession of each other, ${ }^{4}$ if ever performed in the same concert. Other than the Sonata-Elegy, which has gained a certain popularity, the first and third sonata range among Medtner's lesser known works.

Aussöhnung [dritte Strophe]

Und so das Herz[,] erleichtert[,] merkt behende,

Dass es noch lebt und schlägt und möchte schlagen,

Zum reinsten Dank der überreichen Spende

Sich selbst[,] erwiedernd[,] willig darzutragen.

Da fühlte sich - o dass es ewig bliebe! -

Das Doppel-Glück der Töne wie der Liebe.

Johann Wolfgang von Goethe (1823)
Atonement [third stanza]

And so the lightened heart soon learns to see That it still lives, and beats, and ought to beat, Offering itself with joy and willingly, In grateful payment for a gift so sweet. And then was felt,- - oh, may it constant prove!The twofold bliss of music and of love. Translation by Edgar Alfred Bowring $(1853)^{5}$

Although the three pieces appear basically disparate in material and atmosphere, there is an element beyond the music which endows the Triad with a certain interconnection and hermeneutic coherence- the reference to Johann Wolfgang von Goethe's poetry. After having visited Germany from November 1905 to January 1906, Medtner showed a strong affinity to the Classicist poet who, through familial influence, had already been one of the aesthetic landmarks of his early artistic development. Shortly before, the young composer had resorted to a number of Goethe poems for his Nine Songs, Op. 6 (1904-05), and even modelled his Skazka in G major, Op. 9 No. 3 (1905), on the structure of Goethe's Gleich und gleich; and when still working on the C major Sonata, Op. 11 No. 3, he would employ the poem Nachtgesang as a preamble to his three Nachtgesänge for violin and piano, Op. 16 (1907-1908). The Sonata Triad, though, bears an epigraph from the Trilogie der Leidenschaft (Trilogy of Passion), an extended tripartite poem which was published by Goethe in 1827, composed of three poems dating from 1823-24. These are titled An Werther (To Werther), Elegie, and Aussöhnung (Atonement); the second poem is also known as the >Marienbader Elegieく, which Goethe is said to have written after finally splitting up with his late love Ulrike von Levetzow. The six lines used by Medtner as an inscription — and thus as a sort of motto - make up the third and last stanza of the Trilo$g y$ 's third and last section. The question of whether the music makes subtle reference to the poetry or not has been subject to many speculations; ${ }^{6}$ I will get back to the issue of inner coherence in chapter 3.2.4.

In the first editions of Op. 11 Nos. 1 and 3, printed by Pëtr Yurgenson in Moscow, the epigraph appears in Russian and German languages on an extra page between the frontispiece and the first page of the score, and was also printed in the premiere programmes. Curiously, it is absent in the first edition of Op. 11 No. 2 , and likewise in the revised edition of the Sonata Triad as published by Anton J. Benjamin in 1925, which has the German and Russian verses inscribed on top of the first score pages of Nos. 1 and 3. The Benjamin

4 The first performances of Op. 11 Nos. 1 and 2 took place in the same recital in 1906, though not consecutively, while Op. 11 No. 3 was premiered only in 1909.

5 Nathan Haskell Dole (ed.), Poems of Goethe, Vol. 9, London and Boston, n.d. (1853), p. 253.

6 For instance, Alekseyev 1969, p. 278, suggests a proximity of music and text according to the fact that Medtner seems to have composed the Sonata Triad under the impression of Goethe's lyrics, and asserts a particular interrelation between the Trilogy of Passion and the Sonata-Elegy, Op. 11 No. 2. 
edition also omits the Sonata Triad's dedication to the memory of Andrei Bratenshi, the brother of Medtner's love Anna, who had committed suicide earlier in the year of $1906^{7}$ - and so do all of the following editions printed in Soviet Russia, no longer including the epigraph nor the dedication, as if to eliminate all supermusical reference from the music.

\subsubsection{DigRESSION: ASPECTS OF TONAL SYMMETRY}

The idea of symmetry origins from geometry where it is applied to two-dimensional planes and threedimensional spheres. Even if temporal process is not included in traditional comprehensions of symmetry, time may be introduced as an additional dimension. This can be relevant for musical compositions as a means of balance in architecture and horizontal structure-different sections of a piece may correspond in length or in note durations. Moreover, symmetry can be interpreted vertically with regard to pitches or tonal >regions $<$ I will refer to the latter case, defining the tonal plan of a composition in relation to its tonic key as a central axis, as >tonal symmetry<.

In traditional sonata form, especially when looking at compositions of the Viennese Classical era, tonal symmetry is not necessarily an essential aspect and can be largely neglected as a category of analysis. As for the tonal relationship of secondary theme zones, the ssonata principle< demands for a contrasting key to be reached during the exposition (usually $\mathrm{I}-\mathrm{V}$ in major mode, and $\mathrm{i}-\mathrm{V}$ or, more commonly, $\mathrm{i}-\mathrm{III}$ in minor mode), in order to >rise< the secondary theme by a third or fifth as compared to the tonic. The exposition is supposed to close in that contrasting key, producing an EEC (»essential expositional closure«; see figure 3.0.2). During the recapitulation, the tonal contrast is abandoned, resulting in a uniform tonality of the primary and secondary theme zones (I-I, i-i, or i-I), and leading to an ESC (»essential structural closure «). While this standard model is predominant in most sonata forms of the $18^{\text {th }}$ and $19^{\text {th }}$ centuries, there are however some deviations. Occasionally, a symmetry of secondary theme keys is realised in comparison of the exposition and recapitulation sections, which means that the latter one turns toward the subdominant or submediant region. In this case, the recapitulation section displays a incoherent sequence of keys, turning away from the sonata principle<, and inevitably requires to modulate back to the tonic in the course of its secondary theme zone. ${ }^{8}$

Such an irregular tonal plan is, although exemplified in a number of sonata movements of the $19^{\text {th }}$ century, rarely reflected in theories of musical form. One of the first authors to mention tonal symmetry is the English theorist Ebenezer Prout, ${ }^{9}$ whose writings, through their Russian translations, have presumably had some influence on the Russian composer and theorist Georgy Catoire, a friend of Medtner. Catoire briefly

7 The first editions had the words »To the memory of Andrei Bratenshi« (»Pamyati Andreya Bratenshi«) printed on the very top of their title pages. Martyn 1995, p. 42, asserts that the dedication might have established a hidden reference to Werther, also a suicidal person, even if the epigraph does not refer to the first poem of Goethe's Trilogy.

8 Riemann 1902, p. 438f., remarks that if the onset of the recapitulation does not allow the secondary theme to enter in the tonic key, it is supposed to be restored during the further progression of the recapitulation section.

9 Prout 1895, p. 185, elaborates on several special cases in the sequence of keys in sonata movements of the $18^{\text {th }}$ and $19^{\text {th }}$ centuries, arguing as follows: $» I n[\ldots]$ movements in which Beethoven has put his second subject in the mediant $[\ldots]$, the second subject in the recapitulation is first given in the key of the submediant major, and then repeated in the key of the tonic." 
refers to the possibility of beginning a secondary theme's recapitulation in the VI in the second volume of his 1936 textbook Muzikal'naya forma (see chapter 1.3.2). Both authors only discuss symmetry of scalar thirds (confronting the supermediant and submediant in the secondary theme zones), a layout occurring more frequently than symmetry of fifths, which doesn't seem to take place at all during the $18^{\text {th }}$ and $19^{\text {th }}$ centuries. In general, three scenarios are possible, differentiated by the overall major or minor mode of the piece:
(1) major-mode tonic
exposition: $\mathrm{I}-\mathrm{V}$
recapitulation: I - IV - I
(2) minor-mode tonic
exposition: $\mathrm{i}-\mathrm{V}$
recapitulation: $\mathrm{i}-\mathrm{iv}-\mathrm{i} / \mathrm{I}$
(3) minor-mode tonic
exposition: $\mathrm{i}-\mathrm{III}$
recapitulation: $\mathrm{i}-\mathrm{VI}-\mathrm{i} / \mathrm{I}$

In Beethoven, irregularities mainly appear with respect to the key of secondary themes in expositions, ${ }^{10}$ but very rarely in recapitulation sections - apart from the occasional occurrence of feigned entries of the secondary theme, which mostly modulate back to the tonic after a few measures and do not establish an actual tonal symmetry. ${ }^{11}$ After all, the secondary theme zones of Beethoven's recapitulations almost invariably display tonal unity with the movement's tonic. With regard to Beethoven, Prout, as well as the German theorist Richard Stöhr, implies that secondary themes introduced in a remote key area to be more likely to avoid the tonic during the recapitulation. ${ }^{12}$ The most prominent test case is the sonata-movement section of the Egmont Overture in F minor, Op. 84 (1809-10), the secondary theme of which is first heard in Ab major and recapitulated in $\mathrm{D} b$ major, establishing symmetry of thirds on either side of the tonic. More notable examples include the $1^{\text {st }}$ movements of the G major Piano Sonata, Op. 31 No. 1 (1801-02), the C major Piano Sonata >Waldstein<, Op. 53 (1803-04), and the Bb major String Quartet, Op. 130 (1826). ${ }^{13}$ While most authors focus on Beethoven when discussing secondary theme recapitulations in keys other than the tonic, other composers of the Classical era are somewhat neglected. Markus Neuwirth points out that there are notable examples for tonal symmetry of thirds in minor-mode sonatas by Muzio Clementi, and refers to i-VI-i recapitulations as the $»$ Clementian< strategy «. ${ }^{14}$

10 In the major mode, this might be a major mediant or submediant, as seen in the Bb major Sonata >Hammerklavier<, Op. 106 (exposition: secondary theme in G major). In the minor mode, a preferable choice in Beethoven is the major submediant, as, for instance, in the $1^{\text {st }}$ movements of the C minor Sonata, Op. 111 (Ab major), and the $9^{\text {th }}$ Symphony in D minor, Op. 125 (Bb major).

11 See, for example, the $1^{\text {st }}$ movements of the C minor Sonata, Op. 10 No. 1 (the secondary theme's recapitulation begins in $\mathrm{F}$ major, with $\mathrm{C}$ minor being restored only a few measures later), and the $\mathrm{C}$ minor Sonata $>$ Pathétique $<$, Op. 13 (onset in F minor). At times, secondary themes appear in even another key during other formal sections-such as in the $1^{\text {st }}$ movement of the F minor Sonata >Appassionata<, Op. 57, the secondary theme of which is encountered in no less than four tonalities: Ab major (exposition), D b major (development), F major (recapitulation), and F minor (coda).

12 Prout 1895, p. 184; Stöhr 1911, p. 243, both referring to the $1^{\text {st }}$ movement of Beethoven's C major Sonata, Op. 53.

13 The $1^{\text {st }}$ movement of Op. 53 features an E major secondary theme zone within the exposition and a short A major episode at the onset of its recapitulation, modulating to A minor and back to $\mathrm{C}$ major very soon; tonal symmetry is thus realised only marginally. The $1^{\text {st }}$ movement of Op. 130 comprises a full symmetry of major thirds, employing the mediant and submediant of the parallel major as secondary theme keys (exposition: $\mathrm{G} b$ major, recapitulation: $\mathrm{D} b$ major). I am grateful to Oliver Korte for making me aware of these examples.

14 Neuwirth 2016 elaborates on the recapitulations of the $1^{\text {st }}$ movements of Clementi's Piano Sonatas in $G$ minor, Op. 7 No. 3 (1783), G minor, Op. 34 No. 2 (1795), and B minor, Op. 40 No. 2 (1802). 
When looking at other composers' sonatas during the early $19^{\text {th }}$ century, similar third relations to a minor tonic are applied in Ignaz Moscheles’s Sonate mélancolique in F\# minor, Op. 49 (1814, rev. 1822) and in Schumann's Allegro in B minor, Op. 8 (1831), both of which feature a supermediant exposition and submediant recapitulation of their secondary themes. In orchestral music of the $19^{\text {th }}$ century, some more interesting instances of tonal symmetry can be found. First, there is the $1^{\text {st }}$ movement of Schubert's B minor Symphony >Unfinished<, D. 759 (1822), employing G major for the secondary theme of its exposition, while the recapitulation modulates to D major, reversing the key relation of secondary theme zones to an ascending fifth. Then, there is the $1^{\text {st }}$ movement of Tchaikovsky's $4^{\text {th }}$ Symphony in F minor, Op. 36 (1878) which, in the course of a full cycle of minor thirds, employs Ab minor and D minor for the keys of its secondary theme. ${ }^{15}$ And third, Brahms chose a similar approach for the $1^{\text {st }}$ movement of his $3^{\text {rd }}$ Symphony in F major, Op. 90 (1883), with its secondary themes symmetrically encircling a major tonic — while the exposition modulates to A major, then A minor, the recapitulation section goes from $\mathrm{D}$ major and $\mathrm{D}$ minor back to $\mathrm{F}$ major.

In order to examine large-scale harmonic progression (`formbildende Harmonikı) and the sequence of tonal regions within sonata movements, an applicable tool is found in James Hepokoski's and Warren Darcy's Sonata Theory which provides a »generic layout of sonata form « (see figure 3.0.2). ${ }^{16}$ In their diagrams, the authors illustrate the tonal plan of an exposition or a movement as a whole, with the secondary theme region (a fifth or third above the main key) appearing at a higher vertical position. In my following analyses, I will maintain Hepokoski's and Darcy's abbreviations for the formal sections of sonata form, and apply them to diagrams of tonal regions used for the analysis of Medtner's Sonata Triad. In doing so, the vertical axis will be expanded in order to include a greater number of scale degrees arranged in thirds and fifths (see figures 3.2.1, 3.2.2, and 3.2.3, as well as figure 3.3.2 in the discussion of Medtner's G minor Sonata, Op. 22). Tonal symmetry can thus be made visible in the shape of a curve. Sergei Taneyev has evidently used similar graphs in his classes of musical form, applied to the analysis of some of Beethoven's piano sonatas (see also chapter 1.3.2); ${ }^{17}$ however, these diagrams depicted tonal progression in exposition and development sections, while recapitulations - and thus the essential passages for the establishment of tonal symmetry-were omitted.

In Hepokoski and Darcy, the crucial cadential moment of sonata form is the ESC (»essential sonata closure «), located just ahead of the closing zone of a recapitulation section. The overall dramaturgical arch of the movement, the »essential sonata trajectory «, is directed towards this point; and if tonal symmetry is applied, it is also supposed to finally restore the tonic key. Since Sonata Theory chiefly refers to the Viennese Classical style, every digression from the formal or tonal standards is dubbed a >deformation< or >deviation from the norm — - an approach which might cloud the view from of the individual or even spectacular features in sonata movements. Subdominant recapitulations of secondary themes are hardly even touched on,

15 Tchaikovsky's three-key exposition modulates from $\mathrm{F}$ minor to Ab minor and B major, while the recapitulation, only vaguely touching the primary theme, features D minor and F major. See Cinnamon 2013, p. 48ff. (diagram: p. 59).

16 Hepokoski and Darcy 2006, p. 17.

17 See Arzamanov 1963, p. 84f. 
since these can be considered exotic in late- $18^{\text {th }}$-century music. ${ }^{18}$ However, the submediant recapitulation of the secondary theme in Beethoven's Egmont Overture is mentioned as an example of special tonal balancedespite the unusualness of its tonal plan, the respective subject in a way sticks to the common scheme as it enters a fifth below its exposition, just as expected ( $\mathrm{A} b$ major- $\mathrm{D} b$ major). Yet this passage is dubbed an irregular $»$ nonresolution ${ }^{19}{ }^{2}$ as well.

When we now look at music written one century later in pre-revolutionary Russia, those >deformations seem to have become an attractive option for a composer like Medtner, who applies tonal symmetry of secondary theme zones in two of the Triad sonatas, Op. 11 Nos. 1 and 3. Most remarkably, he employs the upper and lower fifth of the tonic keys of $\mathrm{Ab}$ major and $\mathrm{C}$ major - a tonal layout which had, to my knowledge, never been applied to a major-mode sonata movement before. Neither has this feature yet been identified by Medtner scholarship as an idiosyncratic trait of his early sonatas, ${ }^{20}$ with the exception of Ekaterina Podporinova's writings, pointing out symmetry on different levels of sonata movements. ${ }^{21}$ Similar tonal layouts are also found in piano sonatas by some of Medtner's Russian contemporaries: Prokofiev, in his $1^{\text {st }}$ Sonata in F minor, Op. 1 (1909); Myaskovsky, in his $2^{\text {nd }}$ Sonata in F\# minor, Op. 13 (1912); and Aleksandrov, in his $2^{\text {nd }}$ Sonata in D minor, Op. 12 (1918) do use tonal symmetry in their respective single-movement sonatas-but only resorting to the minor mode, encircling the tonic key with its respective mediant and submediant, and hence adopting the scheme of the Egmont Overture. ${ }^{22}$ In introducing tonal symmetry, Medtner himself would go even further in his G minor Sonata, Op. 22 (1910) - a work which draws on the achievements of the Sonata Triad and deserves further recognition for its architectural balance, realising a mirrored sequence of theme entries in its recapitulation section (see chapter 3.3.2).

18 According to Hepokoski and Darcy 2006, p. 237f., the abovementioned example from Beethoven's Op. 10, No. 1, features a »wrong-key start of the $\mathrm{S}$ « which needs to be followed by another instance of the secondary theme, now in the >correct< key.

19 Ibid., p. 245ff.; see also Prout 1895, p. 185. Boris Asafiev names the three stages of a sonata form (exposition, development, and recapitulation section) a striad and refers to the Egmont Overture as a paradigm of overcoming the tripartite structure, establishing a quaternary design which includes an independent coda. See Asafiev $1930^{\mathrm{b}}$, p. $150 \mathrm{ff}$.

20 The phenomenon is identified as simply »unusual« in Ginsburg 1961, pp. 28 and 38f., and as a »mirrored tonal plan « in Keller 1971, p. 77. Korobov 1991, p. 119, notes the originality of tonal progression in the recapitulation of Op. 11 No. 1, while Protopopov 2010, pp. 344 and 346, refers to the subdominant recapitulation of Nos. 1 and 3 as a »peculiarity« (»osobennost'«). However, neither of these authors appreciates the significance of tonal symmetry for Medtner's early single-movement sonatas.

21 See Podporinova 2007, p. 107 (again in Podporinova 2009, p. 27). The author first contextualises the subdominant recapitulations of secondary theme zones in Op. 11 Nos. 1 and 3, determining the relevance of tonal symmetry for the inner balance of each piece as well as for the overarching structure of the Sonata Triad. In doing so, she exemplifies the principle of >concordances in the unity< ( >soglasovaniya v edinstvo $<$ ) as termed by Medtner in his book Muza i moda. See Medtner 1935, p. 15.

22 The $1^{\text {st }}$ movement of Scriabin’s $2^{\text {nd }}$ Piano Sonata in G\# minor, Op. 19 (1897), also sets out for third symmetry of its secondary theme zones (exposition: B major, recapitulation: E major), but curiously refuses to modulate back to the tonic key, closing in $\mathrm{E}$ major, and leaving the restoration of $\mathrm{G} \sharp$ major to the $2^{\text {nd }}$ (and final) movement. 


\subsubsection{Piano Sonata IN A-FLAT MAJOR, OP. 11 No. 1}

Title page: Sonate (As-dur) [1906] // Sonaten-Triade / Triade de Sonates / Sonatnaya Triada / No. 1 [1925]

Composed: 1904-06, premiered: November 20, 1906, Moscow, by the composer

First edition: Yurgenson 1906; Muzgiz Collected Edition 1959 (Vol. 1, pp. 216-230); other editions: see main entry

Recordings: Yudina 1958; Milne 1977; Fellegi 1988; Tozer 1992; Korobov 1996; Hamelin 1997; Hanselmann 1999;

Mejoueva 1999; Bekhterev 2004; Kawakami 2004; Derzhavina 2006; Shishkina 2009; Mejoueva 2011; Bekhterev 2014; Stewart 2016

In his first single-movement sonata, Medtner created an ample, fully developed tripartite outline of roughly 10 minutes. It was first intended to commence a multi-movement sonata, but the composer soon abandoned the idea to add a second movement in variation form, starting in the parallel minor key; ${ }^{23}$ this conception, if realised, would have put the work in direct relation to Beethoven's last sonata, Op. 111. Even in its singlemovement design, it remains the longest and most comprehensive of the Triad sonatas, and as such was apparently hard to grasp for the contemporaries. Early evaluations of the work appeared rather sceptical or failed to capture its peculiarity, as seen in some reviews following the first edition. ${ }^{24}$ Medtner's choice of key seemingly ties in with the F minor Sonata, Op. 5, the inner movements of which omit the relative key in favour of $\mathrm{C}$ minor and $\mathrm{Eb}$ major; yet in being used as the tonic of Op. 11 No. 1, Ab major now completes the four-b signature's tonal environment. As a key of cyclic multi-movement compositions, it came to full popularity only during the $19^{\text {th }}$ century. ${ }^{25}$ But even if there is no sonata or chamber work of a Russian composer prior to the Sonata Triad from which Medtner could have drawn inspiration, ${ }^{26}$ we may well assume that the character of his $\mathrm{A} b$ major Sonata relates to Romantic piano sonatas and character pieces in the same key, many of which are written in a serene and placid tone. Medtner's composition appears similarly moderate in tempo and expression, with the majority of its subjects being marked cantabile or cantando.

23 The $2^{\text {nd }}$ movement was never sketched, but Medtner’s notes reveal that he imagined a piece starting with a G\# minor or Ab minor theme, and closing with a final variation in Ab major. See Flamm 1995, pp. 383 and 385.

24 Thiessen 1909, p. 896f., has characterised Op. 11 No. 1 as a »Sturm und Drang work «, misinterpreting the singlemovement form as indebted to Scriabin. Montagu-Nathan 1917, p. 240, found »interesting evidences of his [Medtner's] approach to the Brahmsian manner « in the Sonata Triad, while Prokofiev 1913 in Flamm 1995, p. 302, stated a combination of »concentrated Germanic power« and »Slavic softness«, particularly in the Sonata-Elegy (»Sosredotochennaya sila, svoystvennaya germanskoy rase [...], i slavyanskaya myagkost' ' ).

25 This being said, we must admit that Ab major had not been an unusual key for Haydn (Hob. XVI:43 and XVI:46) and Beethoven (Opp. 26 and 110), both of who published two piano sonatas in that key. Many of their successors, such as Carl Czerny, Louis Spohr, Ferdinand Hiller, Carl Maria von Weber, and Franz Schubert, also wrote piano sonatas in $\mathrm{Ab}$ major.

26 Georgy Catoire's Piano Concerto, Op. 21, is in Ab major, but only dates from 1909. 
Single movement: Allegro non troppo A $b$ major, $4 / 4, \downarrow=108,221$ measures on 15 pages

\begin{tabular}{|c|c|c|c|c|}
\hline \multirow{7}{*}{$\begin{array}{l}\text { SECTION } \\
\text { exposition }\end{array}$} & THEMES AND SUBJECTS & Position & INDICATIONS & KEY \\
\hline & primary theme $(\mathrm{P})$ & mm. $1-22$ & Allegro non troppo; $\mathrm{mf}$ & $\mathrm{Ab}$ major \\
\hline & transition: primary theme $(\mathrm{Tr})$ & mm. $23-36$ & Con moto; ff risoluto & $\mathrm{G}$ minor $(\mathrm{V})$ \\
\hline & secondary theme zone $\left(\mathrm{S}_{\mathrm{I}}\right)$ & mm. 37-47 & $\mathrm{mp}$ cantando & Eb major \\
\hline & secondary theme zone $\left(\mathrm{S}_{\mathrm{II}}\right)$ & mm. $48-63$ & p sempre; $\mathrm{p}$ leggiero & G minor \\
\hline & secondary theme zone $\left(\mathrm{S}_{\mathrm{I}}\right)$ & mm. 64-75 & giocondamente, cantando & Eb major \\
\hline & closing zone: primary $(\mathrm{C})$ & mm. 76-94 & $\mathrm{p}$ portamento, sostenuto & Eb major \\
\hline \multirow[t]{3}{*}{ development } & primary theme $(\mathrm{P})$ & mm. 95-106 & $\mathrm{p}$ a tempo & $\mathrm{G}$ minor $(\mathrm{V})$ \\
\hline & variant of $\mathrm{S}_{\mathrm{II}}$ & mm. 107-122 & Sognando ${ }^{27} \mathrm{p}$ cantabile & B minor \\
\hline & retransition: $\mathrm{S}_{\mathrm{I}}(\mathrm{Rt})$ & mm. 123-138 & $\mathrm{p}$ legatissimo & modulating \\
\hline \multirow[t]{6}{*}{ recapitulation } & primary theme $(\mathrm{P})$ & mm. 139-149 & Teтро primo; ff risoluto & $\mathrm{A} b$ major \\
\hline & transition: primary theme $(\mathrm{Tr})$ & mm. 150-159 & piano, marcato il basso & F minor $(\mathrm{V})$ \\
\hline & secondary theme zone $\left(\mathrm{S}_{\mathrm{I}}\right)$ & mm. 160-170 & f sempre diminuendo & $\mathrm{D} b$ major \\
\hline & secondary theme zone $\left(\mathrm{S}_{\mathrm{II}}\right)$ & mm. 171-186 & $\mathrm{p}$ legato $; \mathrm{p}$ leggiero & F minor \\
\hline & secondary theme zone $\left(\mathrm{S}_{\mathrm{I}}\right)$ & mm. 187-198 & giocondamente, cantando & $\mathrm{Ab}$ major \\
\hline & closing zone: primary $(\mathrm{C})$ & mm. 199-221 & $\mathrm{mp}$ portamento, sostenuto & Ab major \\
\hline
\end{tabular}

The primary theme (see example 3.2.11) starts with the third $C-A b$, a constructive interval which permeates nearly every section of the sonata, followed by a figure in seconds, encircling $C$, in the alto voice. ${ }^{28}$ Yuliya Moskalets names the initial anacrusis of a descending third an »invocation motif«, being a characteristic feature of main themes of some of Medtner's later sonatas as well. Its continuation also shows a structure of parallel thirds in the quavers of the middle voices, ${ }^{29}$ and unfolding to a nine-measure period, the consequent of which lets the note values gradually accelerate. After the subject has been presented, m. 9 is appended subito pianissimo, interrupting the continuous semiquaver movement of the preceding measures, and leading to an authentic cadence in $\mathrm{Eb}$ major. The latter might just as well be interpreted as a $\mathrm{HC}$, judging from the previous harmonic progressions establishing $E b$ as an extended dominant pedal (a Schenkerian >elaboration of the $\mathrm{V} \iota)$. The pedal point is maintained while the dynamics increase, and the primary theme is further developed and sequenced in metric condensation ( $\mathrm{mm}$. 19-20 are temporarily in 3/4 time), culminating in a first climax in $\mathrm{m}$. 23. The dominant pedal ends here, suddenly shifting to a $\mathrm{D}^{7}$ chord (fortissimo risoluto) this striking harmony represents a crucial moment which determines the exposition's further tonal evolution, as it serves as a dominant to the later $\mathrm{S}_{\mathrm{II}}$ subject in $\mathrm{G}$ minor, and also triggers a series of inventive modulations as part of a transitional passage (Tr), leaving the tonic key behind and preparing for the secondary theme zone. In the recapitulation section, the corresponding passage (m. 150) features a $\mathrm{C}^{7}$ chord, prefiguring $\mathrm{S}_{\mathrm{II}}$ being reiterated in $\mathrm{F}$ minor. Another noteworthy harmony within the exposition is an altered $\mathrm{Eb}^{7}$ with flattened fifth $B b b$, enharmonically changed to the $\sharp 11$ (m. 75: con fermezza), curiously opening out to a general pause in the following measure. The latter chord, consisting of four out of six pitches from a whole-tone

27 The Muzika edition of c. 1975 reads Sognaremento (p. 54).

28 Moskalets $2004^{\mathrm{a}}$, p. 120f. I accept >invocation « as the most appropriate translation of the terms >prizïv < and >zov<.

29 The circulatio figure (m. 2) makes Stewart 2016, p. 6, feel reminded of the hymn-like middle section of Sibelius's Finlandia, Op. 26, which, however, certainly is an unconscious coincidence. 
scale, initiates the exposition's closing zone which is also pervaded by the primary theme's descending thirds, before leading to an affirmative EEC. The same observations apply to the corresponding passage within the recapitulation (m. 198: $\mathrm{A} \mathrm{b}^{7 / \# 11}$ ).

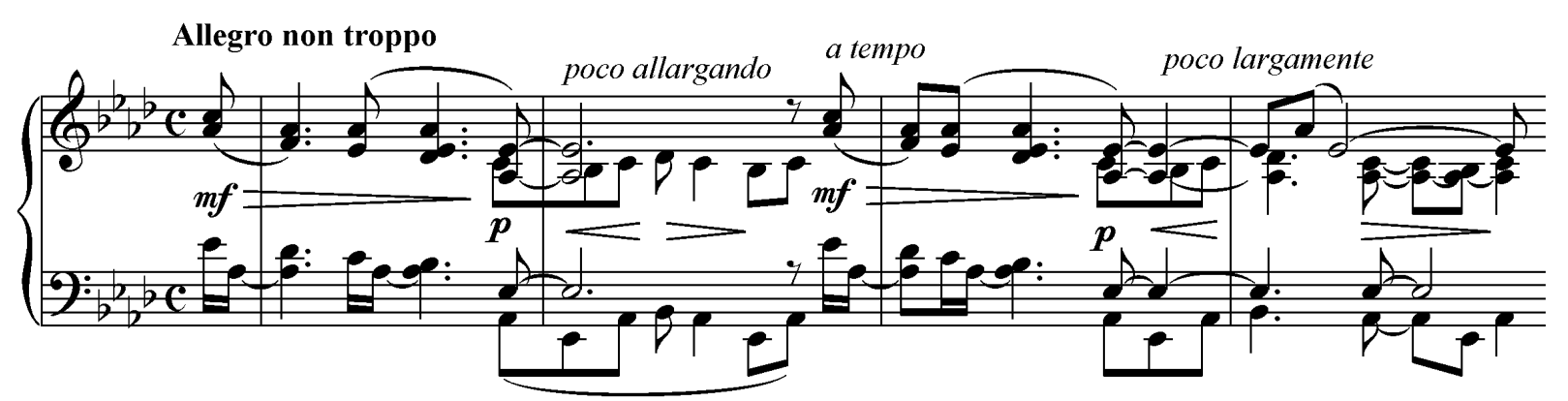

Example 3.2.11: Medtner, Sonata, Op. 11 No. 1, exposition: P, mm. 1-4

The secondary theme zone is designed as a large ternary structure. During the exposition, there are the following subdivisions: a first appearance of the $\mathrm{S}_{\mathrm{I}}$ cantilena in $\mathrm{Eb}$ major, shaped as a large sentence $(\mathrm{m}$. 37ff.; see example 3.2.12); then, a passage shifting to $G$ minor for the $S_{I I}$ theme (m. 48ff.; see example 3.2.14), being itself subdivided into a calm, hesitant poco dolente melody and a more distinctive, descending poco capriccioso theme (m. 56ff.); and the eventual return of $\mathrm{S}_{\mathrm{I}}$, again in Eb major, and now cunningly set in a canon at the upper fifth and at a distance of two crotchets (m. 64ff.; see example 3.2.13 for the analogous passage from the recapitulation). ${ }^{30}$ The whole section can be regarded in analogy to what Felix Salzer named a »three-key exposition «. ${ }^{31}$ During the recapitulation section, the tonal relations within the secondary theme zone are transposed as follows: $\mathrm{S}_{\mathrm{I}}$ appears in $\mathrm{D} b$ major, now forte (m. 160ff.; see example 3.2.13), and $\mathrm{S}_{\mathrm{II}}$ correspondingly moves to F minor (m. 171ff.); yet, upon the return of $\mathrm{S}_{\mathrm{I}}$, Medtner finally modulates back to $\mathrm{Ab}$ major (m. 187ff.). In this manner, both the exposition and recapitulation sections comprise three different tonal areas; but while the exposition (I-V-vii-V), after two modulations, results in an ESC in the expected key of $\mathrm{Eb}$ major (m. 89), the recapitulation section (I-IV-vi-I) comprises three separate tonal regions even within its secondary theme zone. Thus, the tonal coherence of the primary and secondary theme zones, after being denied for the most part of the recapitulation, is achieved only during the work's very last section. With its innovative modulatory plan, Medtner's recapitulation contradicts that section's traditional need for harmonic stability, and instead produces a continuous curve of successive roots, moving up and down in the tonal layout diagram (see figure 3.2.1).

30 Yagodkina 1959, p. 69, analyses this passage with the help of the terminology of vertically-shifting counterpoint as introduced in Sergei Taneyev's treatise Podviznoy kontrapunkt strogogo pis'ma (1909).

31 After the phenomenon was first described by Carl Czerny, the term >three-key exposition< was introduced by Salzer 1928, p. 86, as >Dreitonarten-System der Exposition<, gaining considerable popularity in scholarship on sonata form from the late 1970s on. For an overview of more recent usage, see Longyear and Covington 1988, p. 448ff. In Medtner, however, the starting point of these three keys ascending by scalar thirds is the IV (Db major) rather than the tonic. 


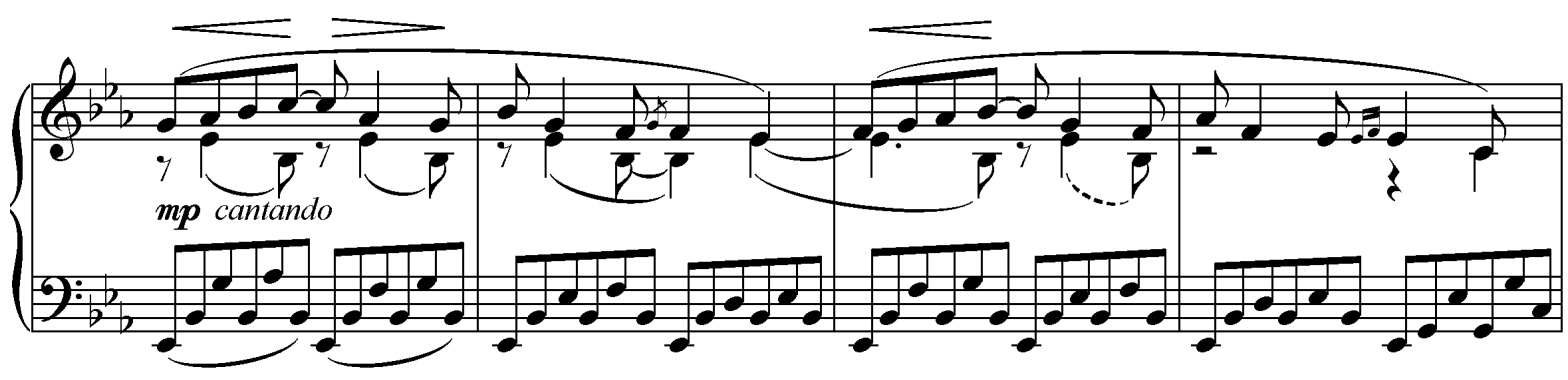

Example 3.2.12: Medtner, Sonata, Op. 11 No. 1, exposition: $\mathrm{S}_{\mathrm{I}}, \mathrm{mm} .37-40$

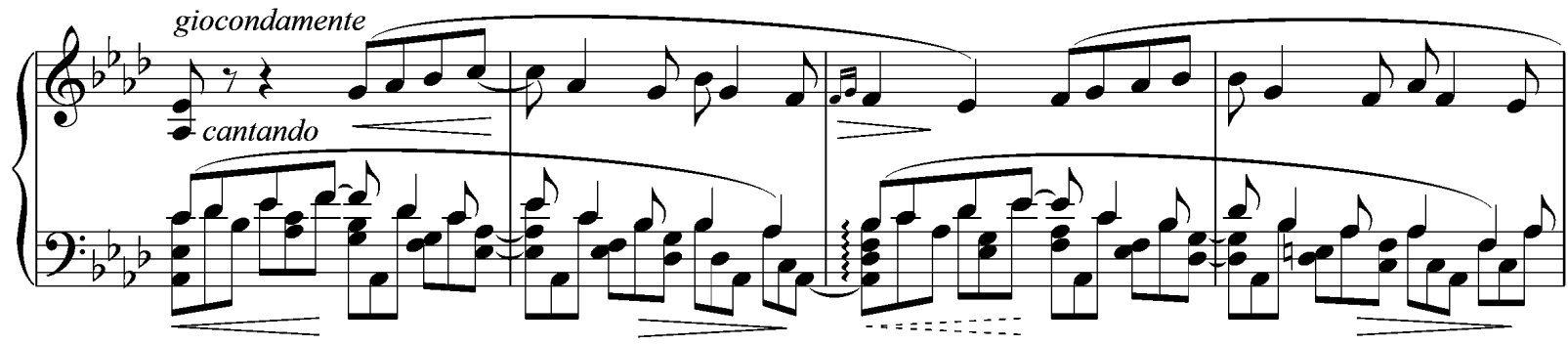

Example 3.2.13: Medtner, Sonata, Op. 11 No. 1, recapitulation: $\mathrm{S}_{\mathrm{I}}$ in canon, mm. 187-190

The development section, starting in G minor and touching on other keys in its vicinity, is in itself remarkable for establishing a temporarily stable region in B minor, a rather remote key which might be considered the sarithmetical mean of the two otherwise unused scale degrees (ii: $\mathrm{B} b$ minor, iii: $\mathrm{C}$ minor). In this delicate episode, marked Sognando (m. 107ff.; see example 3.2.14), Medtner adopts a transformation of the $\mathrm{S}_{\mathrm{II}}$ theme in the bassline, combined with murmuring, dreamlike triplet figures in the right hand.
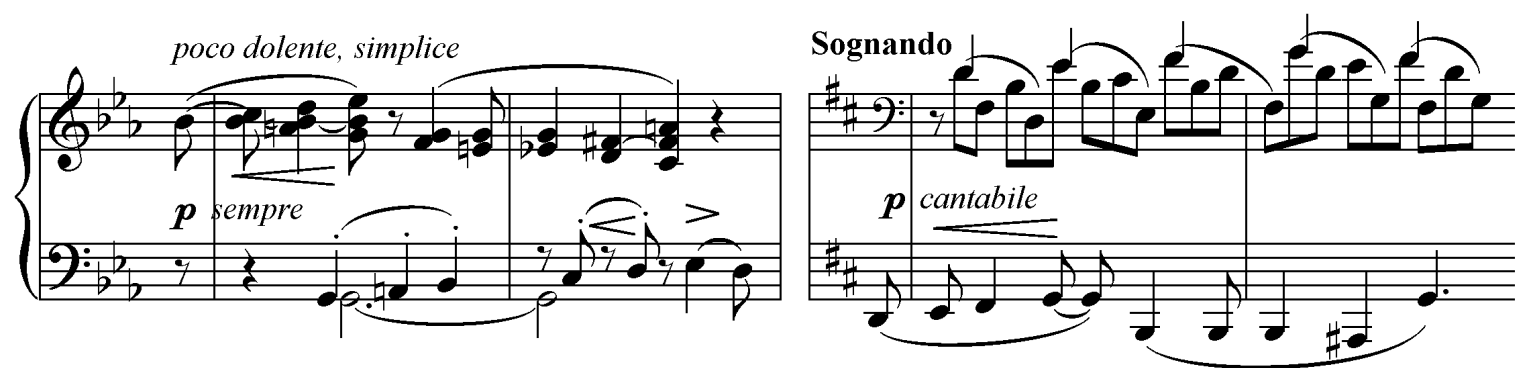

Example 3.2.14: Medtner, Sonata, Op. 11 No. 1, exposition: $\mathrm{S}_{\mathrm{II}}, \mathrm{mm} .48-49$ // development: $\mathrm{S}_{\mathrm{II}}, \mathrm{mm} .107-108$

Summing up the previous observations, it becomes apparent that one of the most important qualities of the >sonata principle < - the unification of tonality within the recapitulation section - is replaced here by tonal symmetry of fifths. Throughout the piece, five out of seven scale degrees are employed as stable harmonic centres, with the keys of the $\mathrm{S}_{\mathrm{I}}$ theme's first appearances (the dominant and subdominant) framing the $\mathrm{Ab}$ major tonic. A model for such a tonal scheme does not seem to exist in any previously composed major-mode sonata movement for solo piano. Yet Medtner himself would again, and even more extensively, make use of this outline in the $\mathrm{C}$ major Sonata, Op. 11 No. 3; and in even greater consequence, the tonal plan of the G minor Sonata, Op. 22, is indebted to the formal and harmonic experiments conducted within the Sonata Triad. 


\begin{tabular}{|c|c|c|c|c|c|c|c|c|c|c|c|}
\hline & \multicolumn{2}{|c|}{ Exposition } & \multicolumn{2}{|l|}{ MC } & EEC & $\begin{array}{l}\text { Development } \\
\begin{array}{l}\mathrm{P}, \mathrm{S}_{\mathrm{II}}, \mathrm{Rt} \\
\begin{array}{l}G m, B m \\
\mathrm{~m} .95\end{array}\end{array}\end{array}$ & \multicolumn{4}{|c|}{ Recapitulation MC } & \multirow[t]{2}{*}{ ESC } \\
\hline vii & & $\underset{\mathrm{Tr}}{\mathrm{Tr}} 23$ & & $\begin{array}{l}\mathrm{S}_{\mathrm{II} G m} \mathrm{~mm} \\
\mathrm{~m} .56\end{array}$ & & \multirow{3}{*}{$\underset{\substack{G m, B m \\
\text { m. } 95}}{\mathrm{P}, \mathrm{S}_{\mathrm{II}}, \mathrm{Rt}}$} & & & & & \\
\hline V & & & $\begin{array}{l}\mathrm{S}_{\mathrm{I} E b} \\
\mathrm{~m} .37\end{array}$ & & $\mathrm{~S}_{\mathrm{I}}, \mathrm{C}_{E b}$ & & & & & & \\
\hline & & & & & & & & & & & \\
\hline I & $\begin{array}{l}\mathrm{P}_{A b} \\
\text { m. } 1\end{array}$ & & & & & & $\begin{array}{l}P_{A b} \\
\text { m. } 139\end{array}$ & & & & $\begin{array}{c}\mathrm{S}_{\mathrm{I}}, \mathrm{C}_{A b} \\
\mathrm{~mm} .187,199\end{array}$ \\
\hline vi & & & & & & & & $\begin{array}{l}\operatorname{Tr} \\
\text { m. } 150\end{array}$ & & $\begin{array}{l}\mathrm{S}_{\mathrm{II} F m} \\
\text { m. } 179\end{array}$ & \\
\hline IV & & & & & & & & & $\begin{array}{l}\mathrm{S}_{\mathrm{I} D b} \\
\text { m. } 160\end{array}$ & & \\
\hline
\end{tabular}

Figure 3.2.1: Medtner, Sonata, Op. 11 No. 1, layout of tonal regions ${ }^{32}$

\begin{tabular}{|c|c|c|c|c|c|c|c|c|c|}
\hline & Exposition & & $\mathrm{MC}$ & EEC & Development & Recapitulati & & ESC & Coda \\
\hline $\mathbf{v}$ & & & & & $\underset{\substack{\mathrm{I} \\
\text { m. } 39}}{\mathrm{P}_{\mathrm{S}} \mathrm{S}, \mathrm{C}_{A m}}$ & & & & \\
\hline III & & $\begin{array}{l}\mathrm{Tr} \\
\mathrm{m} .21\end{array}$ & $\begin{array}{l}\mathrm{S}_{F} \\
\mathrm{~m} .25\end{array}$ & $\begin{array}{l}\mathrm{C}_{F} \\
\text { m. } 35\end{array}$ & & & & & \\
\hline $\mathbf{i} \mid \mathbf{I}$ & $\begin{array}{l}\mathrm{P}_{\mathrm{I}}, \mathrm{P}_{\mathrm{II}} D m \\
\text { m. } 1\end{array}$ & & & & & $\begin{array}{l}\mathrm{P}_{\mathrm{I} .51}+\mathrm{S}_{D m} \\
\end{array}$ & \multirow[b]{2}{*}{$\begin{array}{l}\mathrm{P}_{\mathrm{II}} G m, D m \\
\text { m. } 60\end{array}$} & $\begin{array}{l}C_{\mathrm{m} .71}^{\prime} D m \\
\end{array}$ & $\begin{array}{l}S^{\prime} D \\
\text { m. } 79\end{array}$ \\
\hline iv & & & & & & & & & \\
\hline
\end{tabular}

Figure 3.2.2: Medtner, Sonata-Elegy, Op. 11 No. 2, layout of tonal regions

\begin{tabular}{|c|c|c|c|c|c|c|c|c|c|c|}
\hline \multirow[b]{2}{*}{$\mathbf{V}$} & \multicolumn{2}{|c|}{ Exposition } & \multicolumn{2}{|r|}{ EEC } & \multicolumn{2}{|c|}{ Development } & \multicolumn{2}{|c|}{ Recapitulation } & \multirow[t]{2}{*}{ MC ESC } & \multirow[t]{2}{*}{ Coda } \\
\hline & & & $\begin{array}{l}\mathrm{S}_{G} \\
\text { m. } 32\end{array}$ & $\begin{array}{l}\mathrm{C} \sim \mathrm{P} \\
\text { m. } 56\end{array}$ & $\begin{array}{l}\mathrm{P}_{G m} \\
\text { m. } 68\end{array}$ & & & & & \\
\hline iii & & $\underset{\mathrm{m} .17}{\mathrm{Tr}}$ & & & & & & & & \\
\hline I & $\begin{array}{l}\mathrm{P} C \\
\text { m. } 1\end{array}$ & & & & & \multirow[t]{2}{*}{$\begin{array}{l}\mathrm{T}, \mathrm{Rt} \\
\text { Am, Cm } \\
\text { m. } 91\end{array}$} & $\begin{array}{l}P_{C} \\
\text { m. } 136\end{array}$ & & & \multirow{2}{*}{$\begin{array}{l}\mathrm{Tr}, \mathrm{T}, \mathrm{P} \\
\text { Am,C } \\
\mathrm{m} .194\end{array}$} \\
\hline vi & & & & & & & & & & \\
\hline IV & & & & & & & & & $\begin{array}{l}S_{F} \\
\text { m. } 158\end{array}$ & \\
\hline ii & & & & & & & & $\begin{array}{c}\mathrm{Tr} \\
\text { m. } 150\end{array}$ & & \\
\hline
\end{tabular}

Figure 3.2.3: Medtner, Sonata, Op. 11 No. 3, layout of tonal regions

32 In accordance with Hepokoski and Darcy 2006, p. xxv ff., the abbreviations read as follows: $\mathrm{P}=$ primary theme zone, $\mathrm{Tr}=$ transition, $\mathrm{S}=$ secondary theme zone, $\mathrm{C}=$ closing zone, $\mathrm{MC}=$ medial caesura, $\mathrm{EEC}=$ essential expositional closure, $\mathrm{ESC}=$ essential structural closure. I am using the following symbols in addition: $\mathrm{T}=$ tertiary theme, $\mathrm{Rt}=$ retransition, ${ }^{\prime}=$ variant of a subject or theme zone, $\sim=$ similarity to another subject or theme zone. 


\subsubsection{SONATA-ELEGY IN D MINOR, OP. 11 No. 2}

Title page: Sonate (d-moll) / Elegie [1907] // Sonaten-Triade / Triade de Sonates / Sonatnaya Triada / No. 2 (Élégie) [1925] Composed: c. 1905-06, premiered: November 20, 1906, Moscow, by the composer

First edition: Yurgenson 1907; Muzgiz Collected Edition 1959 (Vol. 1, pp. 231-239); other editions: see main entry Recordings: Yudina 1958; Milne 1977; Svetlanov 1983; Fellegi 1988; Demidenko 1992; Tozer 1992; Korobov 1996; Hamelin 1997; Hanselmann 1999; Mejoueva 2000; Konsistorum 2001; Bekhterev 2004; Kawakami 2004; Derzhavina 2006; Shishkina 2009; Krutogolovy 2009; Bekhterev 2014; Stewart 2016

The Sonata-Elegy, located at the middle of the Sonata Triad, is one of the comparatively rare cases of a sonata movement bearing a slow tempo indication (Andante molto espressivo). ${ }^{33}$ Its denomination preserves the title of the second poem (Elegie) from Goethe's Trilogie der Leidenschaft. In doing so, it is the first of a series of >genre sonatas« or >sonata hybrids« most characteristic of Medtner's treatment of the sonata as a generic archetype, often endowed with a narrative quality through subtitles or poetic references. ${ }^{34}$ Considering the choice of key, many earlier D minor works from $19^{\text {th }}$-century piano and chamber music spring to mind; ${ }^{35}$ but even more frequently, the key has been used for symphonies and piano and violin concertos. D minor, which evolved from the modal system's Dorian scale, is by tradition viewed as a key of severity or even gravity, or at least frequently related to a solemn or austere mood-descriptions which also apply to Medtner's composition.

With a duration of barely seven minutes, and a score comprising only nine pages, the Sonata-Elegy is the shortest and, in terms of musical form, the most compact of Medtner's piano sonatas. The composer allows little space for the introduction and processing of themes, and the development section appears as brief as possible. It is partly due to its limited dimensions that the piece succeeds in realising a close convergence and even combination of its main themes - a technique which, compared to what is generally expected from sonata movements, may be described as a kind of transformation in place of the regular thematic dualism. ${ }^{36}$ By this means the traditional thematic contrast within the exposition is overshadowed by the common substance of the main subjects. Both the primary and secondary theme, the material of which can be traced back to Medtner's sketchbooks of 1901, are constructed from the interval of a diatonic second, ascending and descending (or vice versa), and encircling the first, fifth, or various other scale degrees of the respective

33 Some authors have asserted that this fact particularly entitles the piece to occupy the middle position, just as if it were included in a three-movement sonata cycle. See Sokolov 1968 in Kuhn 2008, p. 173, and Flamm 1995, p. 218.

34 The term >genre sonata ( >zhanrovaya sonata ) was introduced by Alekseyev 1969, p. 89, whereas >sonata hybrids $<$ (>sonati-gibridï) is derived from Podporinova 2007, p. 75. Other works matching this description are the SonataSkazka, Op. 25 No. 1, Sonata-Ballade, Op. 27, and Sonata-Idyll, Op. 56.

35 In the succession of Beethoven's D minor Sonata >Tempest<, Op. 31 No. 2 (1801-02), a number of consecutive works should at least be mentioned as possible stimuli of Medtner's sonata, most of them corresponding to the aforementioned character or atmosphere: Schubert's String Quartet 〉Death and the Maiden〈, D. 810 (1824); Mendelssohn's $1^{\text {st }}$ Piano Trio, Op. 49 (completed in 1839); Liszt's Fantasia quasi Sonata >Après une lecture de Dante< (completed in 1849); Brahms's $3^{\text {rd }}$ Violin Sonata, Op. 108 (1886-88); Rachmaninov's D minor Piano Trio, Op. 9 (1893); and also Arensky's $1^{\text {st }}$ Piano Trio (Op. 32, 1894). A work composed at the same time as Medtner's Sonata Triad is Myaskovsky's stern $1^{\text {st }}$ Piano Sonata in D minor, Op. 6 (1907).

36 Even if Alekseyev 1969, p. 279, presumes a thesis and antithesis contained in the exposition, resulting in a synthesis in the recapitulation, the close relationship of both subjects is rather indicative of a transformation than of an antagonism. 
scale. Initially, the half-tone figure $A-B b-A$ forms the essence of the sonata's opening, immediately transposes to the whole-tone variant $D-E-D(\mathrm{~m} .2)$ and, in continuation, to $E-F-E(\mathrm{~m}$. 5). Later, the secondary theme commences with an inverted version of that figure, $F-E-F$ (m. 25). ${ }^{37}$ This idea, in original shape or inversion, figures as the basis of the sonata's entire motivic development, unfolding to a dense network of cross-references and recombinations.

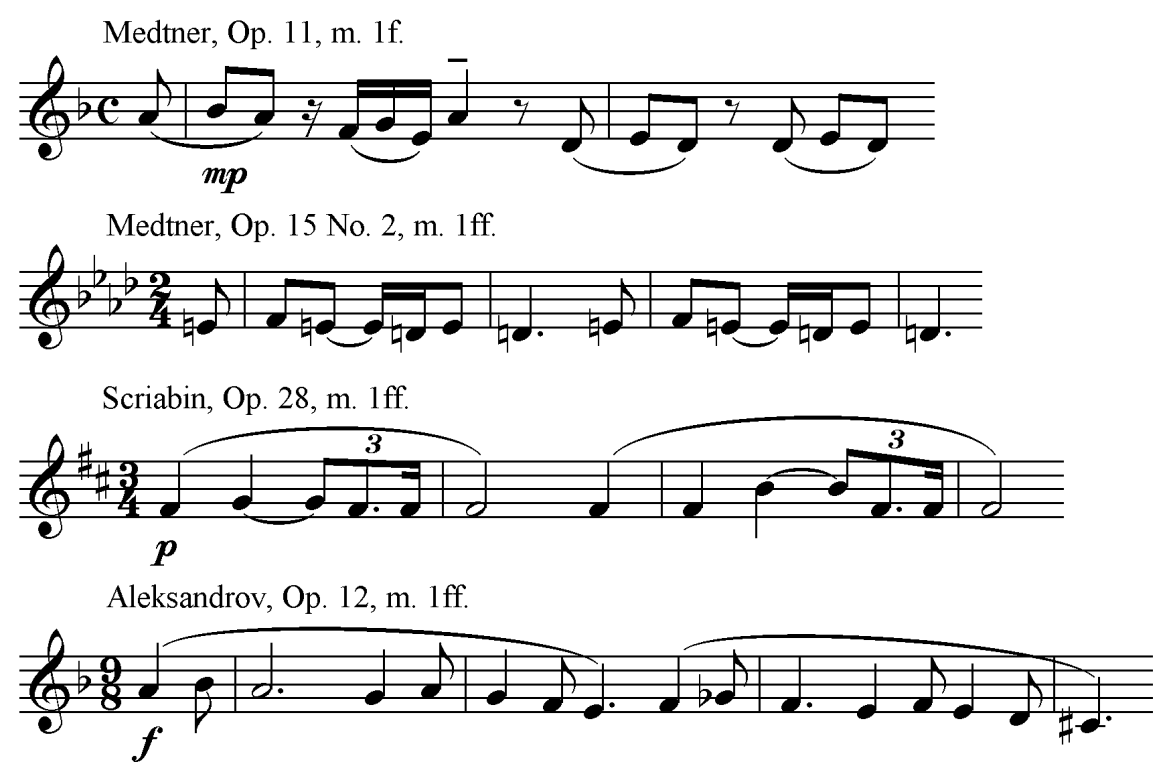

Example 3.2.20: Medtner, Sonata-Elegy, Op. 11 No. 2, exposition, mm. 1-2, confronted with other works: Medtner, An die Türen will ich schleichen, Op. 15 No. 2, mm. 1-3// Scriabin, Fantasy, Op. 28, mm. 1-4// Aleksandrov, Piano Sonata, Op. 12, mm. 1-4 (thematic reductions)

Regarding this motivic >nucleus $\measuredangle$, as I am going to call it henceforth, there is a striking similarity to a number of other pieces by Russian composers of the same period which also substantially employ ascending and descending minor seconds. Aleksandr Scriabin's B minor Fantasy, Op. 28 (1900; see also chapter 1.2.2) commences with the three pitches $F \#-G-F \#$, encircling the fifth scale degree of its tonic key, but entering on the downbeat and in a syncopated dotted rhythm. The piano introduction of Medtner's own Goethe song $A n$ die Türen will ich schleichen, Op. 15 No. 2 (1908-09), starts with the notes $E-F-E$, here in a leading-tone context of $\mathrm{F}$ minor, and is followed by a passage of motivic processing very similar to the beginning of the Sonata-Elegy. Finally, Anatoly Aleksandrov's single-movement $2^{\text {nd }}$ Piano Sonata in D minor, Op. 12 (1918) shares its key and initial notes $(A-B b-A)$ with Medtner's Sonata-Elegy, showing an obvious indebtedness to that work not only regarding the mutuality of key and motivic substance, but also with respect to form and tonal layout). See example 3.2.20 for a comparison of all these relationships.

37 See Podporinova 2007, p. 111: »The initial phrases of the main and subordinate themes appear as >inversions each other « (»Nachal'nie intonatsii tem glavnoy partii i pobochnoy partii predstayut >otrazheniem drug druga «). Stewart 2016, p. 7, notes the secondary theme, continued as $F-E-F-D-E-(F)$, giving a subtle reminiscence of the Gregorian Dies irae motif, with possible reference to the death of the dedicatee Andrei Bratenshi. 


\section{Single movement: Andante molto espressivo $D$ minor $-D$ major, $4 / 4, \_=40-50,114$ measures on 9 pages}

\begin{tabular}{|c|c|c|c|c|}
\hline \multirow{6}{*}{$\begin{array}{l}\text { SECTION } \\
\text { exposition }\end{array}$} & THEMES AND SUBJECTS & POSITION & INDICATIONS & KEY \\
\hline & primary theme $\left(\mathrm{P}_{\mathrm{I}}\right)$ & mm. $1-22$ & Andante molto espressivo; $\mathrm{mp}$ & D minor \\
\hline & primary theme $\left(\mathrm{P}_{\mathrm{II}}\right)$ & mm. $11-20$ & mp a tempo & D minor \\
\hline & transition: secondary theme $(\mathrm{Tr})$ & mm. 21-24 & ff a tempo, mobile & F maj $(V)$ \\
\hline & secondary theme $(\mathrm{S})$ & mm. 25-34 & $\mathrm{p}$ tranquillo, cantabile & F major \\
\hline & closing zone $(\mathrm{C})$ & mm. 35-38 & $\mathrm{p}$ molto cantabile & F major \\
\hline \multirow[t]{2}{*}{ development } & primary $\left(\mathrm{P}_{\mathrm{I}}\right)$ and secondary $(\mathrm{S})$ & mm. 39-47 & ... Tranquillo cantabile (solo) & A minor \\
\hline & closing zone $(\mathrm{C})$ & mm. 48-50 & tranquillo, piano subito & D minor \\
\hline \multirow[t]{3}{*}{ recapitulation } & primary $\left(\mathrm{P}_{\mathrm{I}}\right)+$ secondary $(\mathrm{S})$ & mm. 51-59 & without indication $[\mathrm{p}]$ & D minor \\
\hline & primary theme $\left(\mathrm{P}_{\mathrm{II}}\right)$ & mm. $60-70$ & espressivo - f marcato il tema & $\mathrm{G} / \mathrm{D} \min$ \\
\hline & variant of closing zone (C') & mm. 71-78 & ff molto appassionato & D minor \\
\hline coda & variant of secondary theme (S') & mm. 79-114 & $\begin{array}{l}\text { Allegro molto; Vivace, leggiero, } \\
\text { tutti; } \mathrm{mp} \text { articolando }\end{array}$ & D major \\
\hline
\end{tabular}

The primary theme $\mathrm{P}_{\mathrm{I}}$ (see example 3.2.21) is a melody of beautiful simplicity, consisting of four short phrases based on the nucleus motif and its transpositions; its first statement closes with a light plagal cadence (m. 4). ${ }^{38}$ In continuation, a steady accumulation unfolds during eight measures, charging the melodic development with imitative variants of the nucleus $(A-) A-B b-A$. While tension and dynamics gradually increase, a Phrygian half cadence is prolonged through repetitions of the notes $B b-A$ in the bass, finally discharging into the lowest note of the keyboard (m. 8: A), before reaching a broken A major chord (m. 10). This cadential event shows an astonishing resemblance to the $1^{\text {st }}$ movement of Beethoven's D minor Sonata 〉Tempest<, Op. 31 No. 2, the quasi-improvised Largo introduction of which enters with a very similar A major arpeggio. Medtner's opening passage is further characterised through the continuous use of the French sixth chord $B b$ $D-E-G \#$, opening the harmonic space to an extended chromatic environment of $\mathrm{D}$ minor, and preparing for another entrance of the primary theme. Because of its introductory character, the listener might be inclined to consider these first ten measures a mere preparation of what comes afterwards, as Elena Dolinskaya has claimed. ${ }^{39}$ However, when observing the motivic content of this opening, it is apparent that the passage forms a constitutive part of the exposition.

38 Konsistorum 2004, p. 74, describes the theme as »almost banal, were it not for its original and masterly invention, which is unmistakably Medtnerian« (my translation of »Man könnte es fast als banal bezeichnen, wenn es nicht auf so originelle, meisterhafte Art gestaltet wäre - eben auf Medtners unverwechselbare Art «).

39 See Dolinskaya 1966, p. 25 (again in Dolinskaya 2013, p. 36): »The sonata opens with a short introduction which prepares for the entrance of the main theme« (»Sonate predposillaetsya nebol'shoe improvizatsionnoe vstuplenie, kotoroe gotovit poyavlenie osnovnoy temï «). This view might well have influenced a number of later analyses, also assuming the sonata to commence with an introduction. 


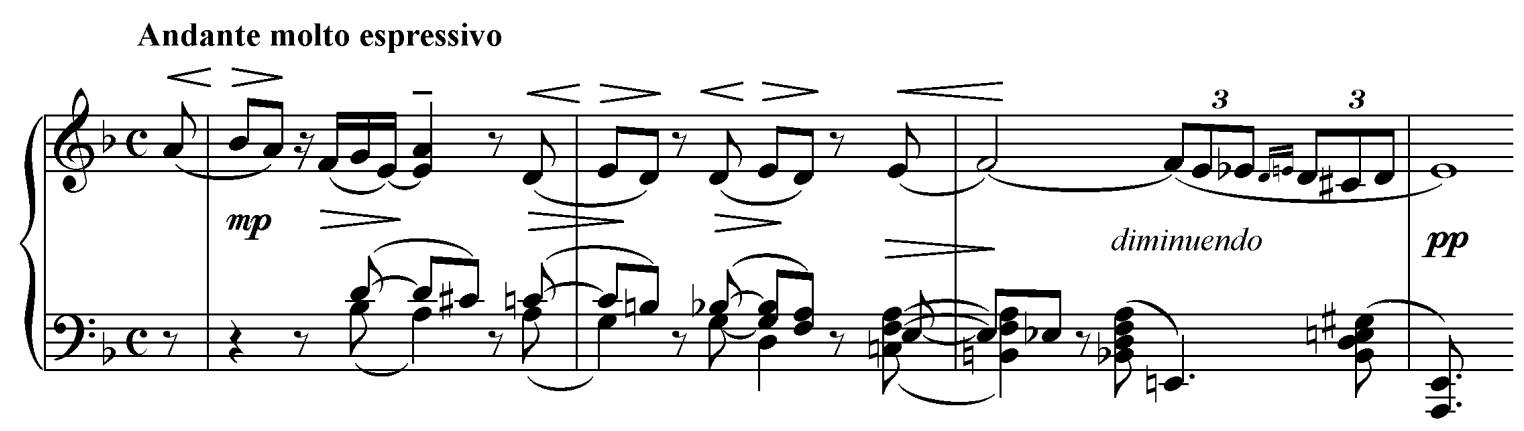

Example 3.2.21: Medtner, Sonata-Elegy, Op. 11 No. 2, exposition: $\mathrm{P}_{\mathrm{I}}, \mathrm{mm} .1-4$

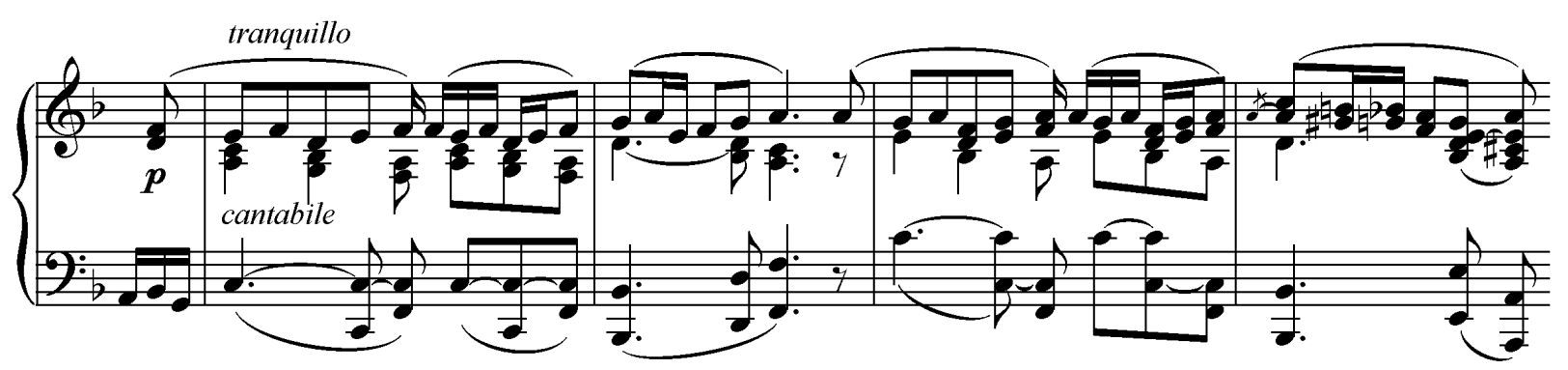

Example 3.2.22: Medtner, Sonata-Elegy, Op. 11 No. 2, exposition: S, mm. 25-28

The harmonic frame of the primary theme's second occurrence $\mathrm{P}_{\mathrm{II}}$ ( $\mathrm{m}$. 11ff. as a >touched-on repetition $<$ is configured as a cycle of fifths with seventh chords, starting with the subdominant $\mathrm{Gm}^{7}$ and, as another intensification confronted with a contrapuntal middle voice in descending seconds ( $\mathrm{m}$. 15ff.). The third chord in this sequence, based on $F$, is extended to a whole measure in order to have the two following chords (m. 17f.: $\mathrm{Bb}^{79}-\mathrm{E}^{7 / 55}$ ) alternate within one measure. Tension increases again towards the entrance of a short transitional subject (m. 21ff.; the Yurgenson edition adds a simplified ossia stave here), and with a dominant pedal on $C$ leading to a medial caesura (m. 24). The secondary theme, in F major, enters in $\mathrm{m}$. 25 (see example 3.2.22). Its calm and repetitive melody oscillates between the dominant and tonic chords, being transposed a third upward after two measures; Charles Keller points out the remarkable sequence of dominant ninth chords in its continuation phrase (m. 28f.). ${ }^{40}$ A brief closing zone follows, concluding the exposition (m. 35ff.), with its bass melody passing downward through the scale of F major. At a sudden shift to A minor (m. 39: placabile), the beginning of the development section can be localised by a varied statement of the primary theme appearing in the bass voice. Only two measures later, the secondary theme drops in again (m. 41: Tranquillo cantabile; see example 3.2.25), set in parallel thirds and with appealing syncopation, somewhat disguising the $4 / 4$ meter. $^{41}$ The development of both subjects continues with amazing density and rhythmic complexity, employing sequences of continuously syncopated semiquavers.

40 See Keller 1971, p. $75 f$.

41 This passage does not bear any indication in the first prints, but is marked tranquillo cantabile (solo) in the 1959 Collected Edition (Vol. 1, p. 234). Read on for more considerations on the solo marking. 


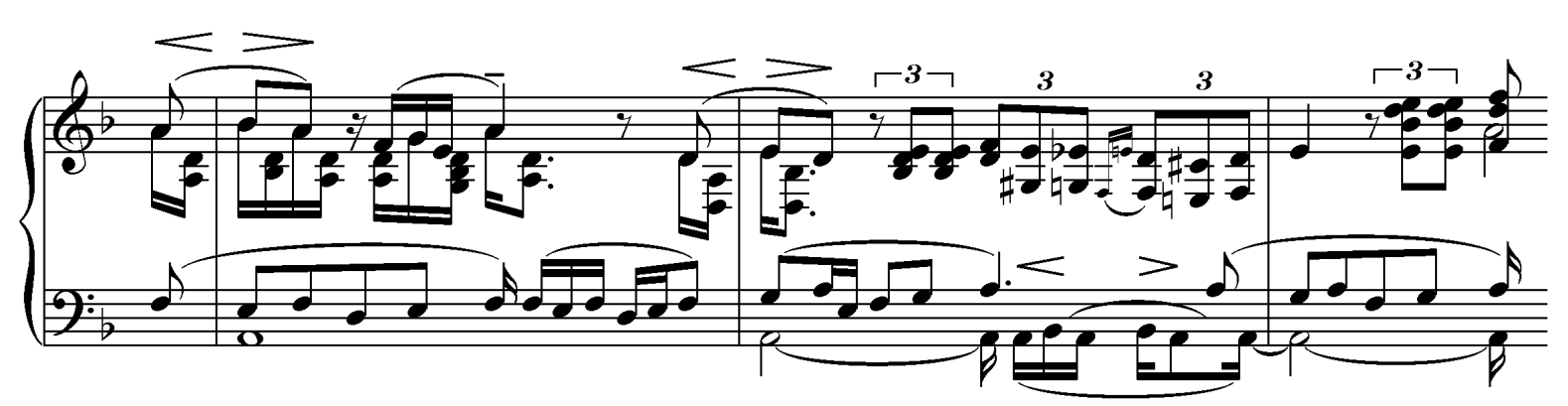

Example 3.2.23: Medtner, Sonata-Elegy, Op. 11 No. 2, recapitulation: $\mathrm{P}_{\mathrm{I}}+\mathrm{S}, \mathrm{mm}$. 51-53

In view of such intensity of texture, the development section appears extremely short. After a reminiscence to the closing zone (m. 48ff.), already back in D minor, the primary theme re-enters in the upper voice of $\mathrm{m}$. 51 - but, most remarkably, in contrapuntal juxtaposition with the secondary theme, sounding in complementary rhythm in the tenor voice of the left hand, now starting on the third scale degree $F$ (see example 3.2.23). ${ }^{42}$ Both subjects, closely interrelated to each other on motivic level by their initial motion in minor seconds, thus appear as each other's dialectical opposite, as two sides of one coin, merging together at the beginning of the recapitulation section - a notion metaphorically expressed by Veniamin Korobov as an »exhaustive brooding, a collision which does not find reconciliation « ${ }^{43}$ After Medtner had already experimented with combinations of the primary and secondary theme of a sonata movement in the exposition of his C minor Skazka, Op. 8 No. 2, and would later recur to a similar technique in the D minor Skazka, Op. 34 No. 4, he here withholds the thematic synthesis up to the recapitulation, the onset of which is marked by a double barline and the change of key signature, returning to D minor. All of these features make this formal border appear as an unmistakable event; a number of authors, however, have not acknowledged this structural subdivision. ${ }^{44}$ Regardless of the secondary theme's previous tonality, F major, both subjects here fuse to the sonata's tonic key, with the nucleus motif simultaneously encircling the third and fifth scale degrees. However, as Christoph Flamm

42 In his G minor Sonata, Op. 22, Medtner again makes use of this device in beginning the recapitulation section with both instances of its primary theme simultaneously.

43 My translation of Korobov 1991, p. 123: »Obrazuyutsya dve linii, kak bï napryazhennoe razdum'e, kolliziya, ne nakhodyashchaya svoego razresheniya.« After Medtner, we find a related strategy of integration of themes in Prokofiev's $3^{\text {rd }}$ Piano Sonata in A minor, Op. 28 (1917); see chapter 1.2.2 and example 1.10.

44 Vasilyev 1962, p. 16, is mislead by the combination of the two themes, designed as each other's melodic and rhythmic complement, to localise that passage still within the development section, and to take the $G$ minor episode sounding a few measures later (m. 60ff.) for the primary theme's subdominant recapitulation. This view is only consistent when considering mm. 1-10 as a mere introduction, so that both starts of the $\mathrm{P}_{\mathrm{II}}$ subject (mm. $11 \mathrm{ff}$. and $60 \mathrm{ff}$.) can be perceived as formal borders. Sokolov 1968 in Kuhn 2008 a , p. 174f., adopts this erroneous view in dubbing the passage a feigned recapitulation. Martyn 1995, p. 43, also mislocates the section, claiming that the recapitulation doesn't make use of the primary theme; and even Grigory Semykin, in his broad study of Russian single-movement piano sonatas, fails to recognise the role of the secondary theme within the recapitulation (»Repriza yavlyaetsya sokrashchënnoy, ved' v ney prisutstvuet tol'ko glavnaya partiya«; Semykin 2017, p. 122). These misconceptions appear particularly weird when considering that already Alekseyev 1969, p. 279, had quoted an handwritten annotation in Medtner's autograph, proving the purposeful synthesis of both subjects, and omitting an independent recapitulation of the secondary theme: $\gg \mathrm{V}$ reprize pobochnaya partiya idet odnovremenno s glavnoy $\mathrm{i}$ poètomu kak partiya vïpuskaetsya; tak chto posle otvetnogo predlozheniya glavnoy temï nastupaet pryamo zaklyuchitel'naya «. Thus, the composer clearly indicates the onset of the recapitulation section in m. 51, even if there remains some formal ambiguity. See also Flamm 1995, p. 221, stating that the listener still considers himself within the development section (»Der Hörer wähnt sich noch in der Durchführung«). 
remarks, the tonic is never explicitly confirmed in a PAC, ${ }^{45}$ neither at the onset of the recapitulation-where D minor sounds over a dominant pedal point_- nor anywhere else throughout the sonata.

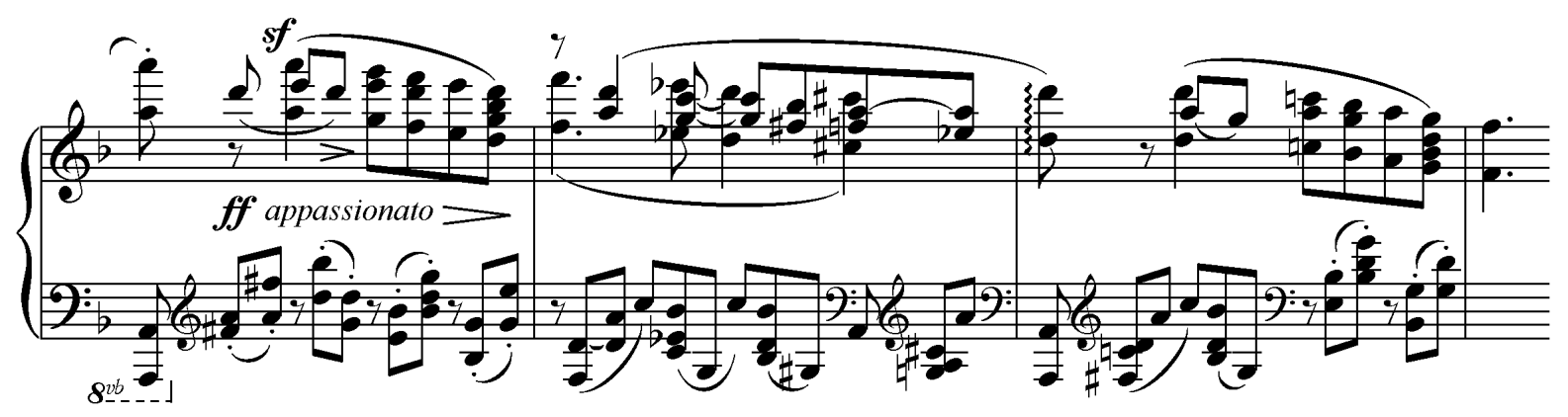

Example 3.2.24: Medtner, Sonata-Elegy, Op. 11 No. 2, recapitulation, mm. 71-74

The recapitulation twice halts at half cadences with fermatas on dominant seventh chords (mm. 57 and 59: $\mathrm{C}^{7}$ and $\mathrm{D}^{7}$ ), before the primary theme $\left(\mathrm{P}_{\mathrm{II}}\right)$ starts over again. As in the exposition, it is harmonised with a cycle of fifths progression (m. 60ff.), now starting with $\mathrm{Cm}^{7}$ and temporarily establishing the subdominant region of G minor. Soon after, the climax of the sonata's internal dramaturgy is reached (m. 71: fortissimo molto appassionato). At that point, a melodic katabasis of outstanding passion and anguish, remotely related to the theme of the closing zone, is presented (see example 3.2.24). The music halts again, resting on a Neapolitan sixth chord on the flattened second scale degree Eb (m. 78: poco allargando), and a large D major coda is attached, doubling the preceding tempo to Allegro molto. ${ }^{46}$ This affirmative final section is based throughout on the secondary theme's material. The texture of its first measures directly corresponds to an episode at the development's beginning (m. 41ff.), a transformed variant of the secondary theme, the semiquaver figurations of which predetermine the coda's continuous movement in quavers (see example 3.2.25 for a comparison). In Medtner's own copy of the sonata, the interrelation of these passages is further clarified by a handwritten indication found at $\mathrm{m} .41, » \mathrm{~V}$ protivopolozhnost' Kode« (»In antagonism to the coda«), opposing the character of the developmental episode (marked solo) to the coda as its major-mode counterpart (tutti). These remarks, taken over into the Soviet Collected Edition, also qualify the latter passage as the quasi-orchestral apotheosis of the former, transforming its tendency to syncopated rhythm to a metrically complex, triumphant epilogue; and through their mutual thematic substance, the correlation of the development and coda section constitutes an overall quaternary form of the whole movement. The sonata's secondary theme is thus treated with special emphasis as it superimposes the primary theme at its recurrence, and eventually dominates the whole coda (see figure 3.2.2 for a tonal layout diagram illustrating these cross-references).

45 See ibid., p. 220; the coda is in fact the only portion of the sonata to unfold an unchallenged tonic. Protopopov 2010 , p. $345 \mathrm{f}$, gives some other examples of recapitulations starting with a dominant pedal, such as the $1^{\text {st }}$ movements of Tchaikovsky's $4^{\text {th }}$ Symphony in F minor, Op. 36 (1878), and Rachmaninov's $2^{\text {nd }}$ Symphony in E minor, Op. 27 (1906-07).

46 The music critic Rostislav Genika, though highly appreciative of the sonata in general, felt that the coda did not go well with the preceding parts: »Ona prekasna, no pod"em nastroeniya ne udalsya, a zaklyuchenie ne vyazhetsya s glavnoy chastyu.« Genika 1909 in Flamm 1995, p. 274. 

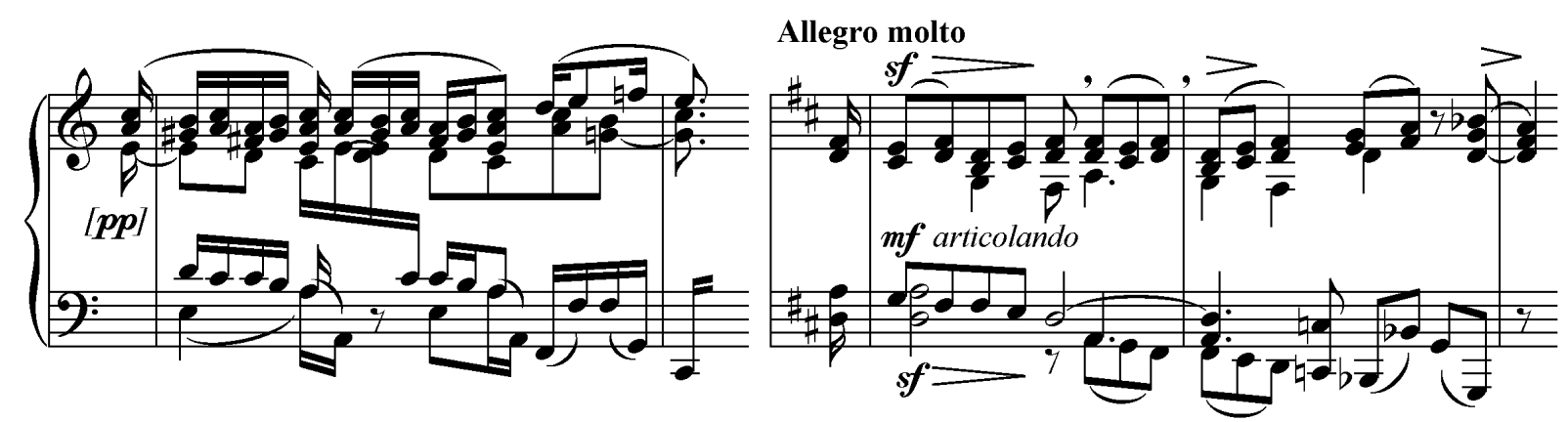

Example 3.2.25: Medtner, Sonata-Elegy, Op. 11 No. 2, development: S, m. 41 // coda: S, mm. 79-80

In its whole, the Sonata-Elegy must be considered a very special variant of sonata form, significantly diverging from the traditional order and formal function of its main subjects. ${ }^{47}$ Through the simultaneous recurrence of the primary and secondary themes, the recapitulation section deviates from the norm of establishing a formal analogy to the exposition. While the second rotation omits an independent restatement of the secondary theme zone, the juxtaposed synthesis of both subjects stands for both theme zones and both keys, before the coda makes up for a transformation of the secondary theme. To my knowledge, the Sonata-Elegy appears to be the first composition in sonata history to realise a structural ambiguity of this kind, occurring in direct succession of the Ab major Sonata, Op. 11 No. 1, which had pioneered in terms of its innovative progression of keys and tonal symmetry.

Moreover, the work contributes to the overall tendency in Medtner to transcend traditional genres of piano music in bearing a twofold title, belonging to the species of sonata and elegy at the same time (see also chapter 2.5.1).$^{48}$ Considering the elegiac component of its title, the Sonata-Elegy functions as a sort of continuation of earlier developments in Russian music, where the latter genre often corresponded to an atmosphere of lament or grief—such as in Rachmaninov's Eb minor Elegy, Op. 3 No. 1 (1892), and the G minor Elegy, Op. 36 No. 16, from Arensky’s Morceaux caractéristiques (1894). In addition, elegies were often assigned a memorial character when composed under the impression of somebody's death —as seen in the epitaph-like Trios élégiaques by Tchaikovsky, Op. 50 (1881-82) and Rachmaninov, Op. 9 (1893), as well as Arensky's $2^{\text {nd }}$ String Quartet (Op. 35; (see also chapter 1.2.3). In this respect, the Sonata-Elegy, as a posthumous monument for its dedicatee Andrei Bratenshi, adheres to a peculiar generic tradition of elegies in Russian music. ${ }^{49}$ What is more, it points forward to Medtner's future use of that genre: no less than three Pushkin songs bear the same title, ${ }^{50}$ and so do the Two Elegies for solo piano, Op. 59 (1940-41).

47 Flamm 2009, p. 49: »The evanescence of common sonata structures first occurs in the Sonata-Elegy, where the traditional Beethovenian functions of the formal divisions are disguised or totally redefined « (my translation of: »Razlozhenie obïchnoy sonatnoy strukturï proizoshlo v pervï raz v Sonate-èlegii op. 11 No. 2, gde po-betkhovenski funktsii traditsionnïkh razdelov zavualirovanï ili sovsem izmenlilis' «).

48 In music, the elegy has been denominated as a vocal genre since Henry Purcell's and John Blow's Elegies for Queen Mary (1695) and was also employed by Beethoven and Reichardt as a song with piano accompaniment. Elegies regularly figure as a genre of piano character pieces throughout the $19^{\text {th }}$ century, often representing a sombre or melancholic character.

49 For more thoughts on the specific tone and features of Russian elegies, see Smith 2003, p. 156ff.

50 Ya perezhil svoi zhelaniya (Gone are my Heart's Desires), Op. 29 No. 5 (1913); Lyublyu vash sumrak neizvestnïy (I Love thy Obscure Twilight), Op. 45 No. 1 (1924), which represents the most extensive song in Medtner's œuvre, 


\subsubsection{Piano SONATA IN C MAJOR, OP. 11 No. 3}

Title page: Sonate (C-dur) [1908] // Sonaten-Triade / Triade de Sonates / Sonatnaya Triada / No. 3 [1925]

Composed: 1904-08; premiered: February 9, 1909, Moscow, by the composer

First edition: Yurgenson 1908; Muzgiz Collected Edition 1959 (Vol. 1, pp. 240-250); other editions: see main entry

Recordings: Sofronitsky 1956; Yudina 1958; Milne 1977; Fellegi 1988; Tozer 1992; Hanselmann 1993; Korobov 1996; Hamelin 1997; Bekhterev 2004; Kawakami 2004; Derzhavina 2006; Solomina 2009; Bekhterev 2014; Stewart 2016

A considerable number of compositions of Viennese Classicism have been written in $\mathrm{C}$ major. When looking, for instance, at Mozart's œuvre, C major is the third-most-popular in a selection of only seven major keys which account for over $90 \%$ of individual movements of his instrumental works. ${ }^{51}$ By tradition, the key is associated with clarity, purity, innocence, and childlike simplicity, while more pathetic attributions can also be found - such as victory, religious authority, and even divinity. C major is far less frequently used during the Romantic era, while other keys, namely those with many accidentals, rise in significance. However, there are a number of famous $\mathrm{C}$ major piano sonatas and orchestral works from the $19^{\text {th }}$ century, ${ }^{52}$ all of which might have served as potential stimuli for Medtner, who used C major more often than any other major key. He seems to have drawn direct inspiration for the textures and structure of the Sonata, Op. 11 No. 3 , from Schumann's Toccata in C major, Op. 7 (1829-30, rev. 1834), a work also written in sonata form. ${ }^{53}$ With regard to the work's general indication con passione innocente, endowing it with »a predominant mood of serene luminescence «, ${ }^{54}$ Medtner clearly refers back to the traditional semantics mentioned above. In his later œuvre, C major reappears in the Sonata-Vocalise, Op. 41 No. 1 (which is also closely connected to the poetry of Goethe), in the Three Hymns in Praise of Toil, Op. 49 (1926-28), and, most substantially, in the Piano Quintet, Op. posth.; all of these compositions feature an overall atmosphere of clarity, serenity, and prayer. ${ }^{55}$ One could go so far and consider C major Medtner's >key of hymnic devotion` (see also chapter 2.4.5) —an attitude possibly influenced by the worldview of his brother Emil as well as by Russian Symbolism.

exceeding the Sonata-Elegy (as his shortest sonata) in length; and also Bezumnïh let ugassheye vesel'e (The Futile Years' Extinguished Cheerfulness), Op. 52 No. 3 (1929).

51 See Rom 2006, p. 19.

52 A list of works with possible influence starts with Beethoven's C major Sonata >Waldstein<, Op. 53 (1803-04), which Medtner frequently performed in his recitals; Schubert's Wanderer Fantasy, D. 760 (1822), and C major Symphony >Great<, D. 944 (1825-26); Schumann's $2^{\text {nd }}$ Symphony, Op. 61 (1845-46); as well as Brahms's $1^{\text {st }}$ Piano Sonata, Op. 1 (1852-53).

53 This at least is asserted by Aleksandrov 1979 in Apetyan 1981, p. 103, referring to Medtner's love for that piece: »Ya slïshal takzhe, kak on [Metner] proigrïval Tokkatu Shumana. Ya znayu, chto on lyubil èto sochinenie. Ono, pomoemu, okazalo nekotoroe vliyanie na ego Sonatu C-dur iz op. 11«. Tozer 1999, p. 11, also states that Op. 11 No. 3 »is closely modelled on Schumann's Toccata«.

54 Nelson $1989^{\mathrm{a}}$, p. 6.

55 Flamm 1995, p. 97f.: »The key of C major is particular significant in Medtner as a symbol of utmost immaculacy and proximity to God« (my translation of: »Die Tonart C-Dur [...] hat innerhalb Metners Euvre als Symbol größter Reinheit und Gottesnähe einen besonderen Stellenwert«). See also Bertin 2018, p. $22 \mathrm{f}$. 


\section{Single movement: Allegro moderato, con passione innocente C major, $2 / 4, \downarrow=100,241$ measures on 11 pages}

\begin{tabular}{|c|c|c|c|c|}
\hline SECTION & THEMES AND SUBJECTS & POSITION & INDICATIONS & KEY \\
\hline exposition & primary theme $(\mathrm{P})$ & mm. $1-16$ & Allegro moderato; $\mathrm{mf}$ & $\mathrm{C}$ major \\
\hline \multirow[t]{3}{*}{ (repeated) } & transitional theme $\left(\operatorname{Tr}_{\mathrm{I}}, \operatorname{Tr}_{\mathrm{II}}\right)$ & mm. 17-31 & $\mathrm{p}$ & $\mathrm{C}$ maj / E min \\
\hline & secondary theme $(\mathrm{S})$ & mm. 32-57 & mp cantabile & G major \\
\hline & closing zone: primary $(\mathrm{C})$ & mm. 58-68 & $\mathrm{p}$ marcato & G major \\
\hline \multirow[t]{3}{*}{ development } & primary theme $(\mathrm{P})$ & mm. $68^{\mathrm{b}}-90$ & $\mathrm{mf}$ tranquillo & G minor \\
\hline & new tertiary theme $(\mathrm{T})$ & mm. 91-115 & $\mathrm{mp}$ pieghevole & $\mathrm{A} / \mathrm{C}$ minor \\
\hline & retransition: primary $(\mathrm{Rt})$ & mm. 116-135 & Poco rubato, tenebroso; $\mathrm{pp}$ & modulating \\
\hline \multirow[t]{4}{*}{ recapitulation } & primary theme $(\mathrm{P})$ & mm. 136-149 & Tempo primo; ff cantando & C major \\
\hline & transitional theme $\left(\operatorname{Tr}_{\mathrm{I}}, \operatorname{Tr}_{\mathrm{II}}\right)$ & mm. $150-157$ & $\mathrm{p} / \mathrm{mf}$ & $\mathrm{C}$ maj / D min \\
\hline & secondary theme $(\mathrm{S})$ & mm. $158-173$ & pp cantabile simplice & F major \\
\hline & culmination: $\operatorname{Tr}_{\mathrm{I}}$ & mm. 174-193 & p poco а росо più mosso & modulating \\
\hline \multirow[t]{2}{*}{ coda } & transitional theme & mm. 194-203 & Animato, più mosso; mp & $\mathrm{C}$ major \\
\hline & tertiary $(\mathrm{T})+$ primary $(\mathrm{P})$ & mm. 204-241 & p subito & $\mathrm{A}$ min / C maj \\
\hline
\end{tabular}

The overall tonal plan of the sonata appears very similar to that of the Ab major Sonata, Op. 11 No. 1, with the keys of the secondary theme zones, G major (exposition) and F major (recapitulation), symmetrically encircling the tonic. An additional tonal axis is constituted when, in the development section, a tertiary subject emerges in A minor, which is restated and transformed within the coda (again in A minor, modulating to $\mathrm{C}$ major). In this manner, the traditional dualism of the primary and secondary theme zones, appearing in two rotations, is enhanced to a trinity, even if the tertiary theme is not comprised in the exposition and recapitulation sections. Yet its tonicised return during the coda produces a comparable effect to the recurrence of a subject within the recapitulation section-a concept rooting in the quaternary sonata form of some of Beethoven's symphonic movements, termed »double sonata form « by the Russian musicologist Oleg Sokolov. ${ }^{56}$ Whereas the sonata's tonal plan includes only four scale degrees (I-V-vi-I-IV-I), two additional regions of minor significance are established during the transitory passages preceding the secondary theme zones, each located a third below the target of the modulation to follow. By this means, the keys of E minor and D minor, employed as transitory tonalities leading to $\mathrm{G}$ major and F major, are included in the overall progression of keys. The corresponding layout diagram (see figure 3.2.3) appears somewhat torn compared to the curve of Op. 11 No. 1, but illustrates the stringent tonal symmetry anyway.

56 Sokolov 1968 in Kuhn $2008^{\text {a }}$, p. 176f., also refers to the piece as »sonata form with secondary features of the sonata principle« (»Sonatenhauptsatzform mit Sekundärmerkmalen des Sonatenprinzips«). See also Loftis 1970, p. 55, who identifies the $1^{\text {st }}$ movement of Beethoven's $3^{\text {rd }}$ Symphony >Eroica< in Eb major, Op. 55, as a historical reference point for this kind of extension. Beethoven here introduces a new E minor subject within the development section. However, the return of that subject within the coda leads to F minor and thus refuses tonal unification, which is an important feature in Sokolov's view. 


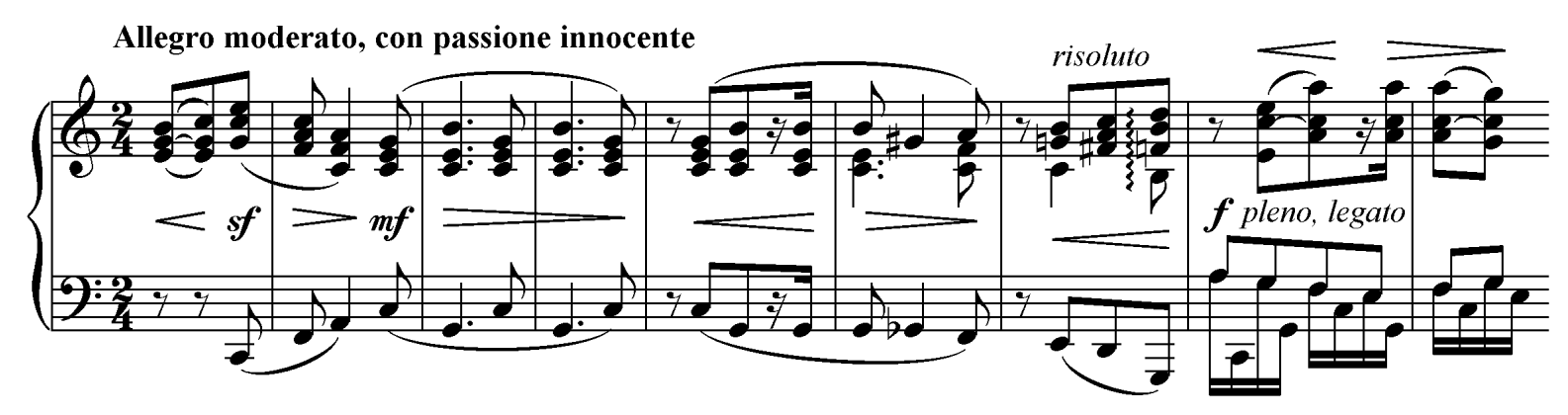

Example 3.2.31: Medtner, Sonata, Op. 11 No. 3, exposition: P, mm. 1-8

The serene primary theme (see example 3.2.31) is composed in four-part harmony, although not quite resembling a chorale. The indecisive motion of its presentation phrase twice rests on a $\mathrm{C}^{\text {maj7 }}$ (m. 3) and appends a shorter motif, ${ }^{57}$ again pausing on a $\mathrm{F}$ major chord preceded by a secondary dominant whole-tone tetrad (m. 5: $G b-C-E-G \#$, comprising two contending alterations of $G$ ), ${ }^{58}$ before proceeding with a wholly diatonic continuation phrase (m. 7ff). During dense motivic processing, the melodic lines and harmonies are soon chromaticised again. A short transitional section introduces two new motives, both unfolding over a dominant pedal. The first proceeds in semiquavers of ascending diatonic seconds with every other note being repeated $\left(\operatorname{Tr}_{\mathrm{I}}\right.$ : m. 17ff.), ${ }^{59}$ while the second - in the shape of a dotted left-hand figure, and leading to a series of half cadences in E minor ( $\operatorname{Tr}_{I I}$ : $\mathrm{m}$. 24ff.) — is freely combined with chromatic inversions of $\operatorname{Tr}_{I}$ 's semiquavers, now directed downwards. The secondary theme in $G$ major occupies the middle voice in a fascinating texture of broken chords over three octaves (m. 32ff.: cantabile; see example 3.2.32). For listeners unfamiliar with Medtner's music, this purely diatonic subject might appear as a shallow or even cheesy tune; ${ }^{60}$ other than the primary theme, it is most regularly shaped as a 16-measure sentence, modulating to D major. The $\operatorname{Tr}_{\mathrm{I}}$ figures are dropping in again (m. 48ff.), joined by the primary theme a few measures later, reassuring the key of $\mathrm{G}$ major. With a short fortissimo burst, a brief closing zone commences in $\mathrm{m}$. 58, introducing another derivation of the primary theme, before the exposition, lasting no longer than one and a half minutes, is repeated. This is one of the rare instances where Medtner makes use of that traditional feature.

57 Benjamin Bertin has made me aware of the similarity of this figure $G-B-B-B-G \#-A$ to a motif present in the $2^{\text {nd }}$ movement of Scriabin's $4^{\text {th }}$ Piano Sonata in F\# major, Op. 30 (1904), m. 5 ( $G \# G \# G \# E \# E \# F \#$, also $\mathrm{mm} .13$ and 17). Even if we might well assume that Medtner knew Scriabin's sonata at the time of composing Op. 11 No. 3, this is most probably a coincidence.

58 Malikova 1967, p. 288f., articulates a special interest in this type of disaltered chord (»with double alteration «), here »with a >split< fifth in a dominant triad « (»Osobïy interes predstavlyayut akkordï s dvoynoy al’teratsiey—s >rasshcheplennoy< kvintoy v trezvuchii V stupeni «).

$59 \operatorname{The} \mathrm{Tr}_{\mathrm{I}}$ figure seems to resemble a motif from Chopin's $2^{\text {nd }}$ Ballade in F major, Op. 38 (1836-39). See Flamm 1995, p. 102, quoting a statement by Anatoly Aleksandrov, and Sacre 1998, p. 1814.

60 In contrast, Alekseyev 1969, p. 257, refers to that subject as »one of the composer's most inspiring lyric creations « (»odno iz vdokhnovenneyshikh liricheskikh sozdaniy kompozitora«), emphasising the cunning polyphonic texture of the middle voices. Martyn 1995, p. 43, feels it to be »in the composer's most heart-easing vein «, while Morrison 2010, p. 3, metaphorically describes the theme as »startlingly beautiful and arresting«, an »epiphany which [...] quietly illuminate[s] [its] entire context«. 


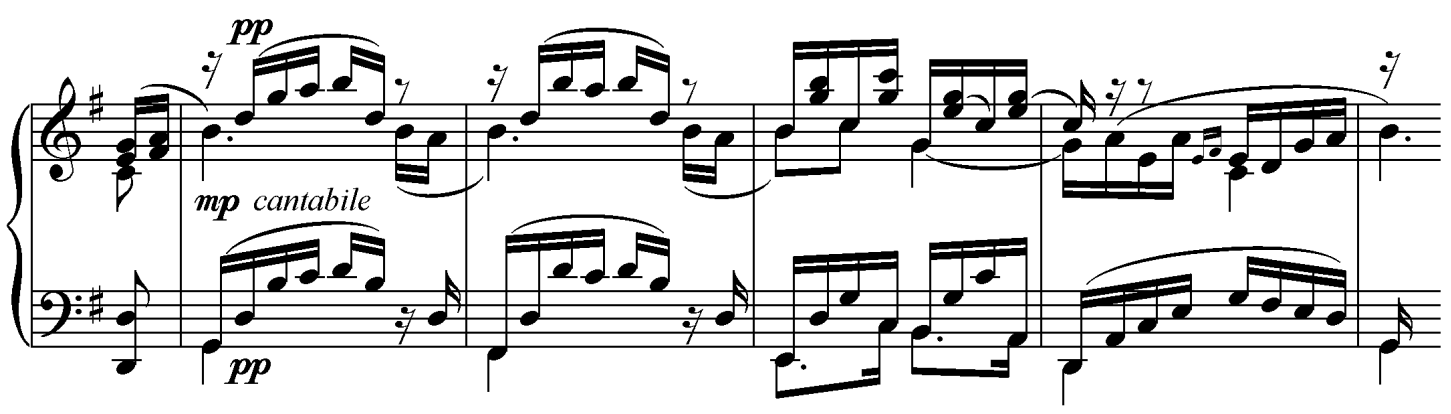

Example 3.2.32: Medtner, Sonata, Op. 11 No. 3, exposition: S, mm. 32-36

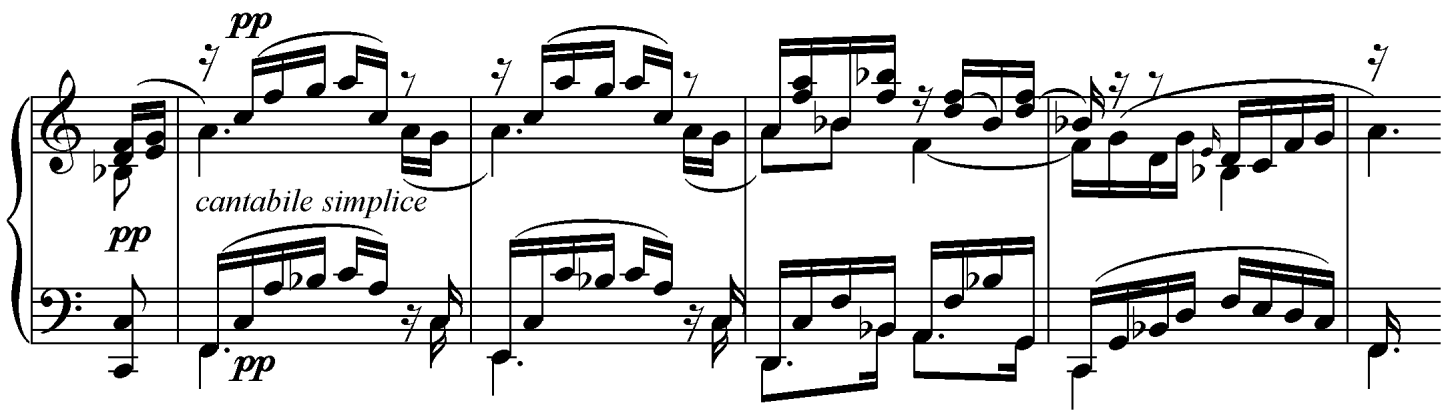

Example 3.2.33: Medtner, Sonata, Op. 11 No. 3, recapitulation: S, mm. 158-162

The development section starts with a primary theme variant in the parallel key of G minor, including a sequence of the four-measure opening phrase which is repeated a fifth below. The subsequent modulatory process is temporarily stabilised by the entry of the tertiary theme in A minor (m. 91: pieghevole; see example 3.2.34). Its onset, thrice repeating $E$, is the earliest in a series of emblematic Medtner themes starting with multiple note repetitions (see chapter 2.2.1 for details). ${ }^{61}$ While the tertiary theme and its $\mathrm{C}$ minor variant, arranged in imitational overlap, dominate the development section (m. 103ff.), Medtner does not resort to the secondary theme, probably due to its customary syntax and lack of potential for further processing. After some more diminutions, a retransitional passage (m. 116ff.: tenebroso), quickly increasing in range and dynamics, prepares for the recapitulation which enters with the initial theme (m. 136) - now in full fortissimo, yet still cantabile. The section is built in close analogy to the exposition, except that the $\operatorname{Tr}_{I}$ motif is left out. $\operatorname{Tr}_{\mathrm{II}}$, in D minor, leads over to the secondary theme in F major (m. 158; see example 3.2.33). The need of the tonal-symmetrical layout, requiring a modulation back to the tonic key, is achieved in a different way as in Op. 11 No. 1, where Ab major had to be reached within the recapitulation section. Here, thanks to the existence of a coda, the recapitulation's closing zone is omitted and replaced by a large dynamic climax (m. 174ff.), functioning as a transition to the coda. This passage, referring to the ascending semiquaver figures of $\operatorname{Tr}_{\mathrm{I}}$, reaches the top of its escalation with the primary theme's augmentation in the left hand (m. 190ff.: $C$ $D b-F-D b-B)$, combined with an accompaniment of sparkling sextuples in the descant.

61 In his early appreciation of Op. 11 No. 3, Swan 1922, p. 617, identifies this subject as an example of »original accented figures, so typical of the later Medtner«. 


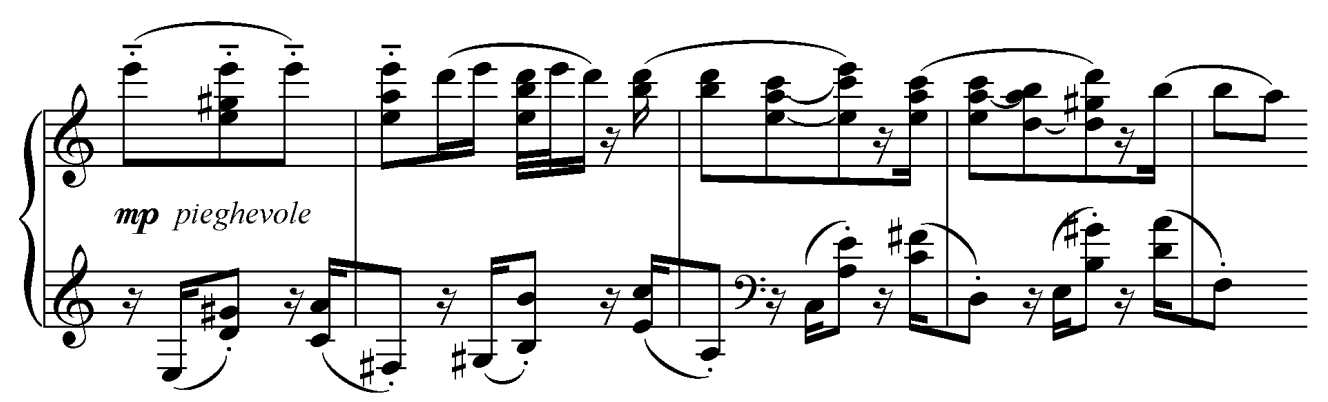

Example 3.2.34: Medtner, Sonata, Op. 11 No. 3, development: T, mm. 91-95

The formal function of the coda serves to reinstall the tonic und thus compensates for the recapitulation's lack of a closing zone. Yet with regard to its motivic content, it is far more than a substitute; the highly chromatic lines of its initial measures hint to the transitional passages of both the exposition and recapitulation sections. Mikhail Gnesin considers the coda a concluding section re-narrating the whole sonata in condensed form, quoting it as an example in his Beginner's Course of Practical Composition (1941). ${ }^{62}$ It also serves, as mentioned earlier, as a means of recapitulation and culmination for the tertiary theme. In analogy to the development section where that subject was initially established, the coda functions as a fourth formal subdivision - and it does so in even greater consequence than the coda of the Sonata-Elegy. Moreover, a derivative quotation of >Anna's theme (from Medtner's F minor Sonata, Op. 5, is introduced (m. 218f.), ${ }^{63}$ almost hidden between the tertiary theme's note repetitions, and with its original range of a descending sixth compressed to a fifth, but not to be mistaken in the distinctive gesture of its upper voice. Barrie Martyn gives an account of the difficulties Medtner must have encountered in completing this last section of the sonata, which was delayed until the beginning of the year $1908 .{ }^{64}$ In the light of its previous peculiarities, the work coherently closes with a remarkable cadence: Following an expressive white-key glissando, ${ }^{65}$ the fourth to last measure presents an exciting whole-tone harmony — an altered dominant chord preceding the subdominant $\left(G b-A b-B b-C-E\right.$, or $\left.C^{7 \text { add } b 5 / 1313}\right)$. This pentad seems to refer back to the whole-tone tetrad of $\mathrm{m}$. 5, sounding enharmonically equal except for the additional $B$ b. Finally, the last two measures consist of a lapidary plagal progression, reaching the tonic via a sixte ajoutée subdominant minor chord.

\subsubsection{ON CONSISTENCY AND CYCLICITY}

The foregoing analysis features some highly individual and selective points of view, and in addressing some irregularities and >deviations « from the norm, I might have neglected other aspects which are also worth discussing. However, tonal symmetry seems to be the most significant aspect of Medtner's variety of sonata forms during the considered period, distinguishing his approaches from those of his predecessors as well as

62 Gnesin 1941, p. 82f. The author ignores the fact that the secondary theme is not restated in the coda.

63 This hint I owe to Chris Crocker's encyclopedic knowledge of Medtner's music.

64 See Martyn 1995, p. 43.

65 The glissando hits the top note of the keyboard at its upper end, in analogy to m. 8 of the Sonata-Elegy reaching the lowest key. 
from his Russian contemporaries. This hints to the fact that the foremost peculiarities of Medtner's style are discernible not so much in the detail of his scores, but in his overall conceptions of formal architecture.

Authors have occasionally raised the question whether there is a mutuality of motivic material among the Triad sonatas. At first glance one would say there isn't — but, if we compare the diastematic substance of the main subjects in detail, some interrelations might indeed arise. According to Hiroaki Takenouchi, these are noticeable when acknowledging that each of the sonatas' initial motives consists of only a few notes, and the main subjects tend to be constructed of similar figures and interval constellations. ${ }^{66}$ In particular, it is the ascending and descending diatonic second and its inversion which seem particularly significant of the primary and secondary themes. Ekaterina Podporinova proposes a derivation of the primary theme of Op. 11 No. 3 from those of Op. 11, Nos. 1 and 2, observing that the former subject combines the constructive intervals from the latter ones, bringing them to a diastematic synthesis. ${ }^{67}$ Earlier than these two authors, Charles Keller has detected an analogous interval contour in the secondary theme of the first and the primary theme of the third sonata, ${ }^{68}$ concluding they must have been generated from a mutual source. However, such and similar findings are likely to be produced through confirmation bias. Analysing music with the ambition to discover conjunctive features may well result in the detection of these, and if one only tries hard enough, one will probably find similarities in motives of any kind and origin. The mentioned authors' observations may appear rather negligible when compared to the far-more-obvious motivic interrelations which Medtner's F minor Sonata, Op. 5, is based on.

There is also no overall consent in Medtner scholarship regarding the question of cyclicity and inner coherence of the Sonata Triad. Several misconceptions are to be found, such as Eric Blom's belief that the three works »have originally been planned as a sonata in three movements « ${ }^{69}$ the bizarre assertion of Bernard Pinsonneault who takes the whole triptych for something related to a Lisztian >two-dimensional sonata form $<{ }^{70}$ or occasional notions of the triad as a suite. ${ }^{71}$ As for the role of the Goethe epigraph, one might assume that the Trilogy of Passion did not only serve as a creative trigger, but also as a structural model for the composition, implying that the three sonatas match the three poems in mood or psychological content. Some authors have taken this for granted-Dolinskaya refers to the work as a cycle and asserts that »its whole structure corresponds to the tripartite outline of Goethe's Trilogy«, with the three pieces being unified through their mutual lyric atmosphere. ${ }^{72}$ Vladimir Konnov even considers the work's alleged cyclicity as

66 See Takenouchi 2004, p. $12 \mathrm{ff}$.

67 See Podporinova 2007, p. 107 (again in Podporinova 2009, p. 27f.).

68 See Keller 1971, p. 87f. The analogy applies to the descending thirds that both subjects have in common, although related to different scale degrees.

69 Blom 1954, p. 650. A similar notion is expressed in Newman 1969, p. 722.

70 Pinsonneault 1956, p. 30, incorrectly refers to Op. 11 as a »sonata of three movements with each being a sonata in itself« (»Cet op. $11[\ldots]$ est une sonate composée de trois mouvements et chaque mouvement est une sonate par elle-même«).

71 See Martens 1919, p. 361, and Wolf 1957, p. 178.

72 Dolinskaya 1966, p. 24 (again in Dolinskaya 2013, p. 35): »Each poem bears a name [...], and after the composer retained the poetic title only for the second sonata [...], he still linked the other two entirely to the poems' descriptive layer« (my translation of: »Obshchaya struktura tsikla sonat polnost'yu otvechaet trekhchastnomu stroeniyu poèticheskoy >trilogiiく. Kazhdoe stikhotvorenie Gëte imeet nazvanie [...]. Sokhraniv poèticheskoe nazvanie lish’ vo 
derived from the per aspera ad astra dramaturgy of the poetic model. ${ }^{73}$ In fact, we do not clearly know about Medtner's motivation for choosing the lyrics, only that he seems to have followed Emil's suggestion at the time of composition, whereas he may even have dismissed the Goethe reference later on. ${ }^{74}$ So there is no evidence at all of the music being structured in accordance to the text, apart from the title Elegy taken over as an attribute for Op. 11 No. 2. Nevertheless, the tripartite design offers possibilities to draw connections to the dialectic model of thesis and antithesis, resolving to a final synthesis. Such a strategy pursues Podporinova when transferring Hegelian ideas to the Sonata Triad — while the secondary theme seems to prevail in the first sonata and the primary in the second, the third sonata can be characterised through a balance of its thematic and tonal architecture. ${ }^{75}$ On a superordinate level as well, the $\mathrm{C}$ major Sonata combines the tonal plan of the $\mathrm{A} b$ major Sonata with the formal outline of the Sonata-Elegy, converting a tripartite to a quaternary sonata form, and applying tonal symmetry of the respective secondary theme zones.

Despite the aforementioned contentions, the Sonata Triad must still be considered an acyclic work. Its overall significance appears to be independent of any diastematic connection and hermeneutic superstructure, and its distinctive qualities mainly arise in other fields of analysis. Rather than an alleged intercommunity of material, aspects of musical form, progression of harmonic regions, and tonal symmetry will more probably attract the attention of future researchers.

vtoroy sonate tsikla (`Ėlegiya), kompozitor dve drugie sonatï polnost'yu svyazïvaet s obraznïm stroem stikhotvoreniy«). See also Tozer 1998, p. xiii. For further elaboration on the relationship of poetry and music, see Flamm 1995, pp. 176, 218, and 383f., as well as Martyn 1995, p. 41 f.

73 See Konnov 2001, p. 251 f.

74 Swan 1967, p. 72, quotes Anna Medtner's statement that Nikolai later regretted the idea to incorporate the Goethe epigraph.

75 My paraphrase of Podporinova 2007, p. 106: »Takim obrazom, gegelevskaya triada masterski realizuetsya khudozhnikom na ladotonal'nom urovne sochineniya. Triadnïy printsip ıtezis - antitezis - sintez« voploshchaetsya $v$ tsikle i cherez sootnoshenie glavnïkh i pobochnïkh partiy. Esli v pervoy sonate prevaliruet pobochnaya partiya, a vo vtoroy—glavnaya, to $\mathrm{v}$ tret'ey—glavnaya i pobochnaya uravnoveshivayut drug druga $\mathrm{v}$ dramaturgicheskom i strukturnom planakh.« 


\subsection{Piano SONATA IN G MINOR, Op. 22}

Title page: Sonate (G-moll) pour piano // Sonata / Sonate

Composed: c. 1901-10; premiered April 13, 1910, Moscow, by the composer

Dedication: Georgy Lvovich Catoire [Katuar]

Editions: Édition Russe de Musique 1910, reprinted Recital Publications 1998; Muzgiz 1929; Muzgiz Collected Edition 1959 (Vol. 2, pp. 46-74), ${ }^{1}$ reprinted Dover 1984 (ed. Dmitry Feofanov) and Dover 1998; Muzïka c. 1975

Recordings: Moiseiwitsch 1943; Grinberg 1948; Gilels 1954; Ponti 1974; Iles 1978; Zhukov 1980; Milne 1988; Fellegi 1989; Madge 1991; Tozer 1991; Istomin 1993; Margolina 1996; Hamelin 1998; Hanselmann 1998; Mejoueva 2002; Margulis 2003; Golka 2007; Ilinskaya 2007 and 2009; Mikitsky 2009; Kusunoki 2010; Paley 2015

\section{Maximum Symmetry and Balance}

The G minor Sonata, Op. 22, marks a preliminary climax in Medtner's use of the sonata form as an compact, single-movement conception. It was composed in part simultaneously to the Sonata Triad, Op. 11, and represents an organic continuation of the triptych as it transcends each of the three pieces in length and structural complexity. With a duration of roughly 17 minutes, the work's formal outline shows some ambivalences, and sonata form is enlarged to the edge of perceptibility: »Medtner [...] extended the one-movement plan to extreme limits, beyond which it is difficult to imagine it as a serviceable vehicle for any known musical impression $\ll^{2}$ Passages with contrasting tempo indications follow each other, and successive sections are connected through motivic interrelation — a structure which was occasionally referred to as a »sonata-poem «. ${ }^{3}$ The work's most remarkable formal features are an introduction of crucial importance and an Interludium, a slow middle section integrated into the movement's development, which it does not replace, but enhance. ${ }^{4}$ Nonetheless the sonata qualifies as a large single-movement work, with its sections not being equivalent to separate movements as they were sometimes mistaken for. ${ }^{5}$ It thus does not, in the succession of Franz Liszt's B minor Sonata, refer to a >two-dimensional sonata form ‘, even if a number of authors have claimed such a structure. ${ }^{6}$ This would typically require transformation of themes as a main feature of development,

1 For Chris Crocker's variorum of the first edition (1910) and the Collected Edition (1959), see medtner.org.uk (accessed June 24, 2018).

2 Boyd 1952, p. 262.

3 Tumanina 1960, p. 300: »Sonata sol' minor [...] priblizhayushchayasya k tipu sonatï-poèmï«. See also Sokolov 1968 in Kuhn $2008^{\text {a }}$, p. 172, and Protopopov 2010, p. 340. While the poem genre signifies a departure from traditional formal archetypes towards a >fantastic style, most prominently in Scriabin who had considered naming his $5^{\text {th }}$ Sonata, Op. 53, a >sonata-poem<, there are also attributions of the subtitle >poem< to other single-movement sonatas. Notable examples by Russian composers include Georgy Catoire's $2^{\text {nd }}$ Violin Sonata in A major, Op. 20 (1910), as well as the piano sonatas of Medtner's fellow student in Taneyev's counterpoint class, Konstantin Eiges, in A major, Op. 15 (1915) and C minor, Op. 28 (1930).

4 The interpolation of an independent contemplative section within a single-movement structure is considered the sonata's singular achievement by Truscott 1961, p. 114. In this respect, the author relates it to Brahms's Tragic Overture in D minor, Op. 81 (1880), which contains a Molto più moderato middle section with a fugal development of its primary theme.

5 This misconception is frequently found in liner notes, such as Ramey 1977, Craats 2001, p. 6, and Morrison 2010, p. 4, who speaks of »four movements virtually compressed into one«.

6 While Dubal 1989, p. 544, only vaguely speaks of a »Lisztian affinity in Medtner dress«, Alekseyev 1969, p. 283, and Rueger 1979, p. 465, incorrectly assert that the Interludium occupies a similar formal position as the slow inner section of the B minor Sonata. Tozer 1998, p. xiii, is also misguided when he states that the work is »clearly modelled on the form of Liszt's [...] Sonata, with its elements of a multi-movement work contained within a single 
while »Medtner's way of dynamisation of musical form shares virtually nothing with Lisztian transformational technique « on a formal level. ${ }^{7}$ For the purpose of analysis, however, it seems convenient to assume three subdivisions, taking the Interludium's beginning and ending for the most significant formal borders. These provide a useful segmentation even if they do not exactly correspond to the overall sonata scheme.

The key of G minor has a long history, and its usage was in many occasions connected to certain musical semantics. Originating from the transposed Dorian mode which was frequently used throughout the $16^{\text {th }}$ and $17^{\text {th }}$ centuries, $\mathrm{G}$ minor was conceived as a grave, severe and profound key during the Baroque era, often chosen for music of fervent or pathetic character-and this is exactly how Daniel Zhitomirsky characterises Medtner's sonata: »In its energy lies a spiritual ardour, pathos, but also ruthlessness «, and »the predominant tone of the work is harsh «. ${ }^{8}$ This corresponds to Elena Dolinskaya's notion of the work being a »pathetic sonata «. ${ }^{9}$ In Viennese Classical music, G minor encounters less often, but still remains one of the most popular minor-mode keys, ${ }^{10}$ before rising in importance again throughout the $19^{\text {th }}$ century.

\subsubsection{GENESIS AND RECEPTION}

Early drafts of Medtner's Op. 22 already appeared in sketchbooks of the 1890s, including the subject that later figures as the most significant subject of the sonata's secondary theme zone, then penned in the shape of an E minor Allegretto. ${ }^{11}$ A set of sketches preserved in the Moscow Glinka museum show that Medtner had originally planned to compose a violin sonata from these ideas, initially in E minor, then switching to G minor. Elena Dolinskaya gives a reproduction of one of these drafts, ${ }^{12}$ probably originating from 1901, which are elaborated to such extent that the main themes of the later Op. 22 are clearly discernible. The sketches also reveal plans for a multi-movement work, including the initial theme of a final rondo never to be elaborated, and fragments of a Prestissimo finale in G major for solo piano. In addition, one of the piano drafts is titled `Conzert-Sonate<, already indicating that it would finally turn out to be an effective and impressive

span«. See also Rimm 1999, p. 44; Skvorak 2003, p. 33; Margulis 2003, p. 5; Hackbridge Johnson 2011, p. 3; Dolinskaya 2013, p. 117; Hartnett 2014, p. 13f.; Vasyutinskaya 2014, p. 83f.; and Semykin 2017, p. $125 \mathrm{ff}$.

7 My translation of Flamm 1995, p. 228: »Metners Art der Dynamisierung der Form [hat] praktisch nichts mit Liszts Thementransformation gemein «.

8 My translation of Zhitomirsky 1981, p. 306: »V ee ènergii est' dushevnaya pïlkost', patetichnost', no i zhestkost' «; »obshchiy gospodstvuyushchiy ton proizvedeniya surovïy

9 Dolinskaya 2013, p. 110: »Syuda zhe primïkayut takie znachitel'nïe dostizheniya Metnera, kak Pateticheskaya sonata op. $22[\ldots]$. The author also marks the sonata as an `excited « work, without further elaborating on these attributions.

10 Some of Haydn's and Mozart's finest symphonies, string quartets and quintets are written in G minor, as well as no less than four piano sonatas by Muzio Clementi. After Beethoven who, after the early Cello Sonata, Op. 5 No. 2 (1796), and Piano Sonata, Op. 49 No. 2 (1795-96), largely omits the key, most of the leading composers of the $19^{\text {th }}$ century have composed sonata cycles in G minor. Examples are Mendelssohn's $1^{\text {st }}$ Piano Concerto, Op. 25 (183031); Chopin's Cello Sonata, Op. 65 (1846); Brahms's $1^{\text {st }}$ Piano Quartet, Op. 25 (1861); 10 Tchaikovsky's $1^{\text {st }}$ Symphony, Op. 13 (1866); 10 Max Bruch's $1^{\text {st }}$ Violin Concerto, Op. 26 (1866-68); Dvořák’s Piano Concerto, Op. 33 (1876); Grieg's $1^{\text {st }}$ String Quartet, Op. 27 (1877-78); Medtner's cousin Aleksandr Goedicke's Piano Trio, Op. 14 (1900); and Rachmaninov's Cello Sonata, Op. 19 (1901). Curiously, this list features hardly any solo piano sonatas in G minor, with the only notable examples being the twelve-year-old Mendelssohn's Op. 105 (1821), Schumann's $2^{\text {nd }}$ Sonata, Op. 22 (1833-35), with which Medtner's shares its opus number, and Smetana's Sonata (1846).

11 All information on Medtner's sketches is given according to Flamm 1995, p. 424.

12 Dolinskaya 1966, p. 89f. (again in Dolinskaya 2013, p. 111f.) 
piece for performance. ${ }^{13}$ The sources of the Interludium, which is based on a separate piano piece, seem to originate even earlier, but the date of its composition is obscure. All we know is that there must have been a pre-existent Prelude in F minor, the original shape of which is not preserved. After abandoning an Eb major section that was also considered for the G minor Sonata's middle portion, ${ }^{14}$ Medtner implemented the Prelude into the work. In order to adapt the composition to the motivic environment of the sonata, some alterations were applied, the effectiveness of which cannot be assessed without looking at the original Prelude. This is revealed by a comment in Medtner's sketches: »Incorporate into the development as a separate part (as an interlude) the F minor Prelude. Tie its unrelated parts into the Sonata by inserting these elements into the secondary [theme zone] material ${ }^{15}{ }^{15}$ The final completion of the sonata must have taken place in late 1909 or early 1910.

There is an interesting connection between the G minor Sonata and an earlier character piece by Medtner, the Tragödie-Fragment in the same key (1904), published as the concluding piece of the Three Arabesques, Op. 7. Anna Medtner reports that this agitated piece was annotated as a »Predchuvstvie revolyutsii« (»Presentiment of the [1905] Revolution«) in Medtner's own printed copy, which was taken over as a subtitle into the Soviet Collected Edition. In addition, a footnote in that edition implies that the piece could »possibly serve as a finale to the G minor Sonata, Op. $22 \ll .{ }^{16}$ Even if it is unclear whether Anna referred to a verbal statement of her husband or to another handwritten annotation, the imagination of employing an earlier piece as a sort of >tragic< epilogue to the sonata sheds additional light on the work's genesis.

Shortly after Medtner had accepted an invitation of Mikhail Ippolitov-Ivanov, the current director of the Moscow Conservatory, to join the faculty as a piano professor, he played the premiere of the G minor Sonata on April 13, 1910, in a concert at Moscow Rossiyskoe Blagorodnoe Sobranie hall which also saw the first performance of his $1^{\text {st }}$ Violin Sonata, Op. 21. In the same year the first edition was published in Serge Kusevitsky's Édition Russe de Musique where Medtner now belonged to the board of editors. First reviews of the sonata were mostly positive. After music critic Yuli Engel had attended a concert at the same venue in March 1911, listening to Medtner performing the sonata again, he wrote in his review for Russkie vedomosti that the work was »rich in profound beauty «. ${ }^{17}$ Two years later the famous critic Vyacheslav Karatygin, who usually was dismissive towards Medtner's compositions, admitted that the G minor Sonata convinced him more than the E minor, Op. 25 No. 2, and stated that »the themes of either work are, although not quite successful and lacking character, very suitable for being developed polyphonically«. In particular he appreciated

13 See Yagodkina 1959, p. 8, Alekseyev 1969, p. 288, and Rueger 1979, p. 466: »Die geradezu sinfonischen Dimensionen der Konfliktaustragung ließen Medtner vorübergehend erwägen, das Werk 〉Sonate-Konzert< [sic!] zu nennen.«

14 A musical example is reproduced in Dolinskaya, opp. cit., p. 91 / p. 113, as well as in Martyn 1995, p. 73.

15 Translation by Martyn 1995, p. 73, of »Vzyat' $v$ razrabotku kak otdel'nuyu chast' (kak interlyudiyu) f-moll'nuyu prelyudiyu. Svyazat' ee neskhodnie mesta s sonatoy putem vneseniya ikh ėlementov v pobochnuyu partiyu«. I am quoting the Russian original paragraph after Flamm 1995, p. 424; see also ibid., p. 227, for thoughts on Medtner's handwritten comments. Martyn's translation of >chast'< to >movement is somewhat inappropriate as the sonata is clearly written in a single movement.

16 My translation of »Mozhet bït' kak final k g-moll'noy sonate op. 22« (Collected Edition, Vol. 1, p. 153). The »Predchuvstvie revolyutsii« inscription is documented by Anna Medtner's account in Apetyan 1981, p. 45. See also Flamm 1995, p. 378, and Zetel 1981, p. 112, who implies that it was Medtner's own thought to employ the Tragödie-Fragment as a finale to the $\mathrm{G}$ minor Sonata.

17 Engel 1911 in Flamm 1995, p. 299: »Bogataya glubokimi krasotami fortepiannaya [sonata] op. 22«. 
the $»$ interesting rhythm of the last pages, where ternary and quaternary figures are combined ${ }^{18}$ —a remarkable statement in view of Karatygin's otherwise negative opinion of Medtner. The composer Nikolai Myaskovsky felt that Medtner's works were generally »distinguished not only by the wholeness of their general conception [...], but also by an amazing naturalness and necessity in the way all their constituent movements are combined «. However, in playing and listening to the G minor Sonata, he was troubled by »the unexpected bustle in the bridge passage between the first and second subjects « which struck him »as a kind of disruption or something far-fetched «. ${ }^{19}$

Other reviewers appreciated »the curious way in which the melodic contour, the harmonic flavour, and the rhythmic gait all combine to give a clear and unusual physiognomy to the second subject of the $\mathrm{G}$ minor Sonata $\ll^{20}$ or characterised the work as a $»$ fine, close-knit conception, quite an individual and characteristic expression of its composer's genius «. ${ }^{21}$ Boris Asafiev, in describing the music as »saturated with Romantic pathos «, ${ }^{22}$ emphasised the sonata's retrospective tendencies rather than its modern aspects. Likewise did Richard Holt when he designated the piece as »picturesque [and] ardently romantic « ${ }^{23}$ Some authors have drawn a parallel to Scriabin's music, a notion that seems to stem from certain features of harmony: »Doubly augmented and diminished chords — an echo of Scriabin — are also to be found in climaxes of the greatest intensity «. ${ }^{24}$ This and similar comparisons tend to be a bit vague, neglecting the fact that Medtner's versatile design of themes and phrases contrasts significantly to Scriabin's mostly binary, regularly-shaped thematic contour.

After a number of performances in the years following its premiere, the G minor Sonata seems to have disappeared from the programmes, as indicated by Kaikhosru Sorabji's regretful statement. ${ }^{25}$ It nearly fell into oblivion like most of Medtner's œuvre did during the 1930s and 1940 — this applies both to the West, where the composer himself remained the only notable performer of his works, and to Stalinist Russia, from where his music was banned for ideological reasons. However, from the 1950s on, the sonata emerged as one of Medtner's most frequently performed pieces. Barrie Martyn has an eloquent explanation why this is the case: »This is the Medtner sonata which has so far achieved the most currency, and deservedly so, for not only does its powerful drama strongly appeal to the emotions but its coherence as a perfect organic whole on

18 Karatygin 1913 in Flamm 1995, p. 306: »I tam i zdes’ maloudachnï i beskharakternï temï, kotorïe, vprochem, chrezvïchayno podatlivï $\mathrm{k}$ polifonicheskomu razvitiyu. [...] $\mathrm{V}$ g-moll'noy sonate $\mathrm{v}$ osobennosti interesna ritmika poslednikh stranits, gde soedinenï trekh- i chetïrekhdol'nïe razmerï $\ll$.

19 Both quotes reproduced after Myaskovsky 1913 in Campbell 2003, p. 189f. The author does not specify the exact source of the passage; the Russian term translated as >bustle $<$ is >begotnya

20 Newman 1915, p. 10.

21 Sorabji 1932, p. 61.

22 Asafiev $1930^{\mathrm{a}}$, p. 351, paraphrased after the German translation by Ernst Kuhn (»die von romantischem Pathos durchdrungene g-Moll-Sonate $\ll$ ).

23 Holt $1948^{\text {a }}$, p. 20. See also Pinsonneault 1956, p. 34: »C'est une œuvre de grand romantisme.«

24 Swan $1927^{\mathrm{a}}$, p. 49. See also Wier 1940, p. 225: »A one-movement sonata somewhat influenced by Scriabin«; Lockwood 1940, p. 137: »As with Scriabin, rhythm plays a vital part in [Medtner's] music, but the rhythmic life is less nervous, though at times altogether as complicated«; and Teichmüller 1927, p. 97: »Hat manches mit den ersten Skrjabin-Sonaten (Op. 19, Op. 23) gemeinsam, weist aber [...] mehr Linien- als Farbentemperament auf«.

25 Sorabji 1955, p. 129: »The G minor Sonata [...] is a masterly and powerful conception, and its total disappearance from the programmes of recital pianists during the past fifteen years or so is puzzling, seeing that at one time it enjoyed a mild vogue.« 
a large scale is also profoundly satisfying to the intellect. ${ }^{26}{ }^{2}$ It enjoyed acknowledgement by Sergei Prokofiev and Vladimir Horowitz, whose words »Why nobody plays Medtner? He is wonderful composer. Piano composer - in some ways deeper than Rachmaninov« are repeatedly quoted. ${ }^{27}$ The sonata was also among the earliest of Medtner's compositions on record, featuring the mono recordings of Benno Moiseiwitsch, Mariya Grinberg, and Emil Gilels (1943-54) as initial landmarks of the Medtner discography. Gilels, who saw the composer as a successor in line with Beethoven, Schumann, and Tchaikovsky, ${ }^{28}$ popularised the sonata through his playing and writings. He thus significantly contributed to the growing interest in Medtner in the Soviet Union during the 1950s, undertaking strong efforts in favour of the composer after his death. ${ }^{29}$ In a short essay in Sovetskaya muzika, Gilels valued the work as follows: »Recently I have come across Medtner's G minor Sonata, Op. 22. What remarkable music it is! It's a pity we've heard it seldomly lately. I think our music lovers would appreciate its performance in the current concert season $\ll{ }^{30}$ Some years later, Gilels's teacher Heinrich Neuhaus praised »the sonata's trajectory [being] felt from the first to the last note as one uninterrupted line« and felt that the work was »admirable not only for the courageous drama of its content, but also for its of contrasting moments, be it tenderness, timidity, or profound contemplation - there are both elegiac mood and inexhaustible energy «. ${ }^{31}$ Another Soviet pianist to champion the sonata was Tatyana Nikolayeva. ${ }^{32}$

If any of Medtner's sonatas entered the canon of piano music during his lifetime, it certainly was his Op. 22-a fact that was also reflected in music scholarship. After Igor Sposobin had referred to the sonata's incipit in his textbook Muzikal'naya forma (1947), the sonata was subject to first analyses (Yagodkina 1959, Tumanina 1960, Ginsburg 1961, Dolinskaya 1966), most of them agreeing that it was a piano work which

26 Martyn $1998^{\text {b }}$, p. 5.

27 See Istomin 1998, p. ix, claiming that Horowitz never turned out to play the sonata in public. Other authors contradict this statement, such as pianist Julius Isserlis, who had been a fellow student of Horowitz in Feliks Blumenfeld's piano class, recalls a performance in Kiev; see Isserlis 1955, p. 157, and Zetel 1981, p. 242. Rimm 1999, p. 44, likewise asserts that »Horowitz popularized it in Kiev and Leningrad«; Martyn 1995, p. 76, quotes a Chicago Tribune review of a 1943 Horowitz recital. As for Prokofiev, the exact amount of his occupation with the music is even more obscure; although Martyn 1998a , p. 12, and Rattalino 2012, p. 340, claim that he performed the sonata, it is unclear when, where, and whether this happened on an occasion with public audience.

28 See also Feofanov 1981, p. ix: »The sonata [...] is an outstanding example of Medtner's masterly treatment of thematic development and form and of his demanding piano style. These features, derived from the German Romantic tradition, prove him to be a direct musical descendant of Beethoven and Brahms.«

29 Flamm $2004^{\mathrm{a}}$, p. 185 , sheds light on the impact of Gilels's advocacy of Medtner, encouraging many other Soviet pianists to perform and record his music.

30 Paraphrase of Gilels 1953, p. 55, in Paperno 1998, p. 80: »Nedavno ya nachal razuchivat' sol' -minornuyu sonatu N. Metnera (soch. 22). S pervikh zhe taktov muzïka uvlekla menya soderzhatel'nost'yu i krasotoy obrazov, iskrennost'yu chuvstva, bogatoy i interesnoy fortepiannoy fakturoy. V svoey sonate Metner predstaet kak talantlivnïy prodolzhatel' klassicheskikh traditsii Betkhovena, Shumana i osobenno Chaykovskogo. Vmeste s tem èto khudozhnik yarkoy i samobïtnoy tvorcheskoy individual'nosti.« For a detailed characterisation of Gilels's rendering see Zetel 1969, p. 335 (again in Zetel 1981, p. 236f.).

31 Translation of Neuhaus 1961, p. 74, in Martyn $1998^{\text {b }}$, p. 5: ») Traektoriya< sonatï ot pervoy do posledney notï oshchushchaetsya kak odna neprerïvnaya liniya!« The second quote is my translation of Neuhaus, ibid.: »Ona [sonata] voskhishchaet ne tol'ko muzhestvennoy dramatichnost'yu soderzhaniya, no i obiliem kontrastiruyushchikh momentov-tut i nezhnost', i robost', i glubokoe razdum'e, i èlegicheskie nastroeniya, i neissyakaemaya ènergiya «.

32 See Zetel 1981, p. 240ff. 
appeared remarkable in balance and formal refinement. Harold Truscott, in his 1961 study of the sonata, deemed it »one of the outstandingly original large-scale twentieth-century achievements in music. $\aleph^{33}$

\subsubsection{Digression: Tonal Symmetry AND ARCHITECTURAL BALANCE}

As mentioned above, the structure of the G minor Sonata, Op. 22, can be seen as a result of the achievements of the Sonata Triad, Op. 11. Looking at the relations of its successive tonal regions, it once more shows an explicit tonal symmetry, now encircling a minor-mode tonic. After Tchaikovsky and Brahms had pioneered in applying equidistant cycles of minor or major thirds for the $1^{\text {st }}$ movements of their $4^{\text {th }}$ and $3^{\text {rd }}$ Symphonies (see chapter 3.2.0), Medtner seems to have been the first to employ a full round of ascending diatonic thirds for a sonata movement's main thematic zones: »The sonata's daring tonal scheme [...] is further evidence of Medtner's originality in his use of traditional musical language and design «. ${ }^{34}$ This chain of thirds includes each of the seven scale degrees of $\mathrm{G}$ minor, and tonal regions of equal distance to the tonic key are assigned to corresponding themes in the exposition and recapitulation sections (see example 3.3.1 for a visualisation of tonal symmetry and the background succession of tonal regions in shape of a Schenkerian bass-line graph). Thus, three interlaced pairs of keys are established: symmetry of fifths (D minor $-\mathrm{C}$ minor) as relevant for the secondary theme $\mathrm{S}_{\mathrm{I}}$; symmetry of seconds ( $\mathrm{F}$ minor - A minor) at the transition from the Interludium to the recapitulation; and, less distinctly, symmetry of thirds ( $\mathrm{B} b$ major- $\mathrm{E} b$ major), as seen in the trimodular block of the exposition's intermediate theme $\left(\mathrm{TM}_{\mathrm{I}}, \mathrm{TM}_{\mathrm{II}}\right)^{35}$ compared to an episode at the belated recapitulation of the primary theme $\mathrm{P}_{\mathrm{I}}$, serving as a coda-rhetoric interpolation (CRI) in the terminology of Sonata Theory. ${ }^{36}$ In further comparison to the Sonata Triad, where tonal symmetry of the secondary themes was introduced in a major-mode context (Op. 11, Nos. 1 and 3), the G minor Sonata constitutes a minormode symmetry of fifths for the first time in Medtner's œuvre, if not at all in the history of sonata form.

The key of $\mathrm{G}$ minor frames the whole sonata through the tonal correspondence of the introduction and coda, while neither the development nor the recapitulation significantly touch on the tonic key-a fact made visible by the frequent change of key signatures. Within the development section, the F minor Interludium

33 Truscott 1961, p. 122.

34 Martyn $1998^{\text {b }}$, p. 5. A similar characterisation is found in Truscott 1956, p. 5f.: »The G minor Sonata, Op. 22, with its extraordinary balancing of six different fully-established keys in the total work [...] and fully half [...] of the total expressive force of the sonata comes from this extraordinary but [...] completely natural tonal arrangement.« See also Rueger 1979, p. 466: »Bezeichnend für die konstruktive Disziplin des Komponisten ist [...] die durchdachte Symmetrie im Harmonieplan sowie der allgemeinen Dramaturgie. [...] Die Tonarten der einzelnen Formteile und Abschnitte beziehen sich auf Grundtöne, die von Einleitung und Hauptthema $(g)$ über das Interludium $(f)$ bis zur Reprise des Hauptthemas (wiederum $g$ ) eine aufsteigende Terzenkette bilden.«

35 Other than I have asserted in Bitzan 2016 a , p. 457, the notion of a secondary and tertiary theme is abandoned here in favour of the mentioned trimodular block (TMB), which is a terminological option offered by Sonata Theory for analysing theme zones with multiple subjects, bordered by a dual medial caesura. See Hepokoski and Darcy 2006, p. Xxvii f. I am numbering the modules as $\mathrm{TM}_{\mathrm{I}}, \mathrm{TM}_{\mathrm{II}}$, and $\mathrm{TM}_{\mathrm{III}}$ rather than $\mathrm{TM}^{1}, \mathrm{TM}^{2}$, and $\mathrm{TM}^{3}$ in order to comply with my subdivisions of the $\mathrm{P}$ and $\mathrm{S}$ zones, and to avoid confusion with footnote numbering. When compared to the analysis of the $1^{\text {st }}$ movement of Tchaikovsky's $4^{\text {th }}$ Symphony in Cinnamon 2013, pp. 48-69, the Ab minor episode of which shows a somewhat similar design as Medtner's intermediate theme, the notion of a TMB might seem justifiable despite the lack of clear medial caesurae.

36 See Hepokoski and Darcy 2006, p. $288 f$. 
reaches the greatest distance from the tonic, along with the subsequent recapitulation of the primary theme which irregularly transposes to A minor, establishing the $\mathrm{ii}^{\natural}$ as a stable tonal region (for an overview of the large-scale harmonic progressions in the sonata, see figure 3.3.2). The only deviation from a modulatory plan of impressive coherence occurs in the use of the VI: While Eb major might have been expected at the recapitulation of the intermediate theme's $\mathrm{TM}_{\mathrm{I}}$ (m. 290ff.), this key is omitted in the latter passage and saved for its appropriate position in the ascending cycle of thirds. It shows up rather inconspicuously in an episode following the recapitulation of the secondary theme $\mathrm{S}_{\mathrm{I}}$, processing the primary theme before turning back to G minor (m. 370ff.). Although less obvious in its appearance, Eb major is needed to round out a complete chain of thirds, a feature often considered by Medtner scholarship as the sonata's central achievement. This proves true even though most scholars have disagreed with an untarnished symmetry of the tonal plan. ${ }^{37}$

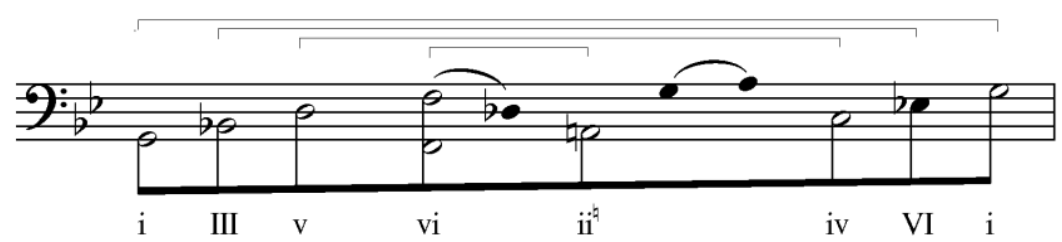

Example 3.3.1: Medtner, Sonata, Op. 22, bass-line graph and tonal symmetries

\begin{tabular}{|c|c|c|c|c|c|c|c|c|c|c|c|c|c|}
\hline & \multicolumn{3}{|c|}{ Exposition } & \multirow[t]{2}{*}{ MC } & \multirow[t]{2}{*}{ EEC } & \multicolumn{3}{|c|}{ Development } & \multicolumn{2}{|c|}{ Recapitulation } & \multirow[t]{2}{*}{ MC } & \multirow[t]{2}{*}{ ESC } & \multirow[t]{2}{*}{ Coda } \\
\hline vii & & & & & & & \begin{tabular}{|l} 
I' \\
$F m$ \\
m. 189 \\
\end{tabular} & \begin{tabular}{|l} 
Interludium \\
$F m$ \\
m. 197
\end{tabular} & & & & & \\
\hline $\mathbf{v}$ & & & & $\begin{array}{l}\mathrm{S}_{\mathrm{I}} \sim \mathrm{I}, \mathrm{S}_{\mathrm{II}}, \mathrm{S}_{\mathrm{I}} \\
\begin{array}{l}\mathrm{m} \\
\mathrm{m} .95\end{array}\end{array}$ & $\begin{array}{l}\mathrm{C} \sim \mathrm{P}_{\text {II }} \\
D m \\
\text { m. } 131\end{array}$ & & & & & & & & \\
\hline III & & & $\begin{array}{l}\mathrm{TM}_{\mathrm{I}, \text { II, III }} \\
B b \\
\text { m. } 60\end{array}$ & & & & & & & \multirow[t]{2}{*}{$\begin{array}{l}\text { TMB } \\
G, B b, A \\
\text { m. } 290\end{array}$} & & & \\
\hline $\mathbf{i}$ & $\begin{array}{l}\mathrm{I}, \mathrm{P}_{\mathrm{I}} \\
G m \\
\mathrm{~m} .1 \\
\end{array}$ & $\begin{array}{l}\mathrm{P}_{\mathrm{II}} \\
G m \\
\mathrm{~m} .36 \\
\end{array}$ & & & & \multirow[t]{2}{*}{$\begin{array}{l}\mathrm{TM}_{\mathrm{I}}, \mathrm{P} \\
E^{b^{\prime}, G} \\
\text { m. } 147\end{array}$} & & & & & & \multirow[t]{2}{*}{$\begin{array}{l}\text { CRI P } \\
G m, E b \\
\text { m. } 370\end{array}$} & $\begin{array}{l}C^{\prime}, I^{\prime} \\
G m \\
\text { m. } 393 \\
\end{array}$ \\
\hline vI & & & & & & & & & & & & & \\
\hline iv & & & & & & & & & & & $\begin{array}{l}\mathrm{S}_{\mathrm{I}} \sim \mathrm{I}, \mathrm{S}_{\mathrm{II}}, \mathrm{S}_{\mathrm{I}} \\
\mathrm{Cm} \\
\mathrm{m} .324\end{array}$ & & \\
\hline ii & & & & & & & & & $\begin{array}{l}\mathrm{P}_{\mathrm{I}}+\mathrm{P}_{\mathrm{II}} \\
\mathrm{Am} \\
\text { m.261 }\end{array}$ & & & & \\
\hline
\end{tabular}

Figure 3.3.2: Medtner, Sonata, Op. 22, layout of tonal regions ${ }^{38}$

37 Yagodkina 1959, p. 47, introduces a diagram of ascending thirds (with an erroneously omitted accidental at the sixth scale degree) and dubs the VI the »omitted link of the tonal chain« (»vypushchennoe zveno v tonal'noy tsepi«). Dolinskaya 1966, p. 98 (again in Dolinskaya 2013, p. 118) maintains this view, reuses Yagodkina's diagram without reference, and inaccurately gives no accidentals at all. The misconception of the allegedly missing $E$ (instead of $E$ b) is still preserved in Flamm 1995, p. 224. While claiming that the submediant is absent as a stable tonal centre, Truscott 1961, p. 121, admits that there is a »full-throated statement « of the $\mathrm{P}_{\mathrm{I}}$ episode, without noticing that its tonality fits into the overall chain of thirds. The only author to approve of an autonomous region in $\mathrm{E} b$ major is Voroshilova 2004, p. 79, assuming $\mathrm{P}_{\mathrm{I}}$ to be recapitulated entirely in that key, while neglecting the temporary return to $\mathrm{G}$ minor in $\mathrm{m} .374 \mathrm{ff}$.

38 In accordance with Hepokoski and Darcy 2006, p. xxv ff., the abbreviations read as follows: $\mathrm{P}=$ primary theme zone, $\mathrm{TMB}=$ trimodular block, $\mathrm{S}=$ secondary theme zone, $\mathrm{C}=$ closing zone, $\mathrm{CRI}=$ coda-rhetoric interpolation; $\mathrm{MC}=$ medial caesura, EEC = essential expositional closure, ESC = essential structural closure. I am using the following 
Furthermore, the sonata shows another type of formal balance, referring to the succession of themes and of corresponding passages in the exposition and recapitulation sections. In music as a time-based art form, symmetry of temporal structures always remains an analytic construction, a mere borrowing of a term derived from the visual arts. In analogy to geometry, it is yet possible to define a temporal (bilateral) axis of symmetry, presumably at a work's or movement's centre - which is, in the case of sonata form, located at the core of the development section. A mirrored progression of formal sections implies their return in reverse order compared to their first statements. I will refer to these and similar ideas as >architectural balanceく (the term is used in disambiguation from a strict retrograde structure, which is not what I am referring to as the sections themselves obviously do not run backwards). This means that the order of a sonata exposition (P-S) is reversed in the recapitulation section (S-P), a conception occasionally termed >mirror recapitulation (in Russian ızerkalnaya repriza<, in German `Spiegelreprise ). In the course of such a formal plan, the primary theme's traditional role as an inaugurating, tight-knit element, typically generating a process of motivic growth, gradually loses significance. The same applies to the secondary theme's function, which departs from being a mainly lyrical, rather loosely-knit episode, directed toward an EEC or ESC. By the application of architectural balance in sonata form, the different formal functions of the theme zones tend to converge. Moreover, the moment of recapitulation is significantly weakened as the re-entrance of the primary theme is postponed towards the end of the movement. Even if the secondary theme's recapitulation returns to the tonic as usual, the listener might misconceive it as a passage still within the development section, possibly resulting in a misbalance of the whole movement.

Sonata forms of Viennese Classicism do not show much inclination for architectural balance. The general expectation of a recapitulation to enter affirmatively with the primary theme, followed by the secondary theme zone, is fulfilled in the vast majority of cases. Variants deviating from this norm tend to be conceived as unstable and irregular, and there are very few examples for $>$ mirror recapitulations $<$ in $18^{\text {th }}$-century music. At least there is a historical test case: The recapitulation of the $1^{\text {st }}$ movement of Mozart's D major Piano Sonata, K. 311 (1777), actually commences with the secondary theme, getting back to the primary theme only shortly before the ending. ${ }^{39}$ The initial unison functioning as a primary theme thus frames the movement's outer edges. Some four decades later, Franz Schubert uses a similar design in his Quartet Movement in C minor, D. 702 (1820), where the recapitulation enters with the secondary theme (surprisingly in Bb major), postponing the return of the primary theme until the very end. Fryderyk Chopin also omits recapitulations of primary themes in the $1^{\text {st }}$ movements of both his $2^{\text {nd }}$ and $3^{\text {rd }}$ piano sonatas (Op. 35 in $\mathrm{B} b$ minor, $1837-39 ;^{40}$ Op. 58 in B minor, 1844), whereas the $1^{\text {st }}$ Ballade in G minor, Op. 23 (1831-35), also features an idea of mirror symmetry, applied to the general structure of the work, even if its primary theme is briefly quoted in A minor (m. 94ff.) before the secondary theme is further developed. Richard Wagner's single-movement

symbols in addition: $\mathrm{I}=$ introductory theme, ' = variant of a subject or theme zone, $\sim=$ similarity to another subject or theme zone.

39 The authors of Sonata Theory refuse to acknowledge the reverse order of themes here, rather identifying the movement as a >Type 2 Sonata without a developmental space. See Hepokoski and Darcy 2006, p. 292.

40 However, an allusion to the primary theme is heard in the bass region near the ending of the $1^{\text {st }}$ movement of Op. 35. 
$\mathrm{A} b$ major Piano Sonata (1853), written for Mathilde Wesendonck's album, also reverses the order of primary and secondary themes within its recapitulation section, yet in a most unusual progression of keys, and using a generally idiosyncratic plan of modulation. ${ }^{41}$

In $20^{\text {th }}$-century music, inverted sequences of formal sections become more frequent and apparent, leading towards fully established applications of temporal mirror symmetry. After Medtner had also avoided a recapitulation of the primary theme in his sonata-like C minor Skazka, Op. 8 No. 2 (1904-06), the symmetries seen in his G minor Sonata represent a rather independent phenomenon, seemingly without consequences for Russian and West-European music. In contrast, the music of Béla Bartók or the Schoenberg circle ends up in constructive experiments going far beyond architectural balance; see, for example, the palindrome construction in the $2^{\text {nd }}$ movement of Alban Berg's Kammerkonzert (1923-25); or the multiple instances of the so-called >arch form $<$ in Bartók, as seen in the $4^{\text {th }}$ and $5^{\text {th }}$ string quartets $(1928,1934)$. Mirror symmetry is now frequently employed within single movements or as an overall principle in multimovement works, a tendency with long-term impact even on serial composition after World War II. Medtner himself would go no further than in the $1^{\text {st }}$ movement of his Sonata-Ballade, Op. 27 (1912), where architectural balance of successive sections is evident on a subordinate level, realised through the reversed entrance of themes during the development section compared to the exposition or recapitulation (see chapter 3.6.1).

Let us get back to the architectural balance observed in the G minor Sonata, a phenomenon to be »conceived as an arch« or »as a chiastic design « ${ }^{42}$ According to Medtner's annotations in the sketches, he had considered a distinct mirror structure in the course of the sonata's genesis, planning to begin the recapitulation with the secondary theme zone prior to the primary ${ }^{43}$ - a conception he did not fully realise, eventually preferring a combination of both primary subjects for that crucial point, and further recapitulating the subjects in irregular, if not exactly reversed, order. An independent restatement of the initial subject only appears within the affirmative pre-coda passage (CRI), preceded by elaboration on the intermediate and $\mathrm{S}_{\mathrm{I}}$ subjects - the order of which, however, remains unchanged. Regardless of these deflections, the whole structure has been inaccurately termed a >mirror recapitulation` in some places. ${ }^{44}$

The Tenebroso introduction gains crucial importance for the sonata's overall structure. Its motivic onset, an ascending and descending fourth, reappears in many places throughout the score, and, as Panteleymon Vasilyev remarks, »permeates the sonata's whole narrative«. It most prominently initiates the $\mathrm{S}_{\mathrm{I}}$ theme,

41 Other examples of >mirror recapitulations` include Liszt's symphonic poem Les Préludes (1848-54), the $1^{\text {st }}$ movements of Shostakovich's $1^{\text {st }}$ Symphony in F minor, Op. 10 (1924-25), of the Cello Sonata in D minor, Op. 40 (1934), and of the $2^{\text {nd }}$ Piano Trio in E minor, Op. 67 (1944), as well as the $1^{\text {st }}$ movement of the third and final version of Rachmaninov's $4^{\text {th }}$ Piano Concerto in G minor, Op. 40 (1941), which is dedicated to Medtner.

42 Keller 1971, pp. 91 and 106. See Yagodkina 1959, p. 48, and Moskalets 2004ª , p. 119 (also in Moskalets 2004 , p. 110) for schematic diagrams of the sonata's symmetric outline. The latter author proposes the overall shape of an arch with its peak in the middle (»duga s vershinoy v tsentre«).

43 See Flamm 1995, pp. 226 and 424.

44 Dolinskaya 2013, p. 111, determines a »non-tonal mirror recapitulation« (»On stroit ee [sonatu] v vide mnogotemnogo razvernutogo Allegro [...] i daet netonal'nuyu zerkal'nuyu reprizu«); see also ibid., p. 117f. Sokolov 1968 in Kuhn $2008^{\text {a }}$, p. 173 , also employs this term, but wrongly identifies the entrance of the recapitulation at the recurrence of the secondary theme in G major (m. 290ff.). Semykin 2017, p. 129, suggests the term >concentric form< ( $>$ kontsentricheskaya forma $<$ ) as an alternate model to traditional sonata form. 
»repeatedly intruding its melody like a call or invocation«, and also dominates the whole culmination of the coda. ${ }^{45}$ I will henceforth refer to this initial motif as a $>$ nucleus $<$ idea, ${ }^{46}$ in accordance with other authors having noticed its unifying importance; Geoffrey Tozer speaks of a >cell or $>$ kernel ${ }^{47}$ in a similar manner as Vincent d'Indy has described the construction of a sonate cyclique and its motivic and thematic transformation. ${ }^{48}$ The nucleus idea initially sets the music in motion with its alternating fifth and first scale degrees (see example 3.3.3) and later prepares for the entrance of the Interludium in an turbulent episode located at the end of the work's first subdivision (m. 189ff.). Eventually it is the nucleus again, with harmonic progressions quoted from the introduction, that concludes the whole piece (m. 405ff.). These features do not, however, qualify the sonata as a monothematic work, as Nadezhda Tumanina suggests when determining a »governing principle of monothematism, despite the polymorphic character of its sections and the great richness of thematic material «. ${ }^{49}$

\subsubsection{ANALYSIS OF THE SCORE}

\begin{tabular}{|c|c|c|c|c|}
\hline \multirow{11}{*}{$\begin{array}{l}\text { SECTION } \\
\text { exposition }\end{array}$} & THEMES AND SUBJECTS & Position & INDICATIONS & KEY \\
\hline & introductory theme (I) & mm. $1-8$ & Tenebroso, sempre affrettando; pp & G minor \\
\hline & primary with episode $\left(\mathrm{P}_{\mathrm{I}}\right)$ & mm. 9-36 & Allegro assai; $\mathrm{mp}$ & G minor \\
\hline & primary theme $\left(\mathrm{P}_{\mathrm{II}}\right)$ & mm. 37-59 & ff precipitato & G minor \\
\hline & intermediate theme $\left(\mathrm{TM}_{\mathrm{I}}\right)$ & mm. 60-74 & $\mathrm{p}$ armonioso & $\mathrm{B} b$ major \\
\hline & intermediate theme $\left(\mathrm{TM}_{\mathrm{II}}\right)$ & mm. $75-80$ & $\mathrm{p}$ poco a poco svegliando & $\mathrm{B} b$ major \\
\hline & intermediate: $\mathrm{P}_{\mathrm{I}}\left(\mathrm{TM}_{\mathrm{III}}\right)$ & mm. 81-94 & ff risoluto & D minor (ii) \\
\hline & secondary theme zone: I $\left(\mathrm{S}_{\mathrm{I}}\right)$ & mm. 95-104 & $\mathrm{p}$ dolce cantabile, con timidezza & D minor \\
\hline & secondary: episode of $\mathrm{P}_{\mathrm{I}}\left(\mathrm{S}_{\mathrm{II}}\right)$ & mm. 105-120 & $\mathrm{mf}$ & F maj / A min \\
\hline & secondary: variant of $\mathrm{S}_{\mathrm{I}}$ & mm. $121-130$ & f risoluto, a tempo & D minor \\
\hline & closing zone: I with $\mathrm{P}_{\mathrm{II}}(\mathrm{C})$ & mm. 131-146 & $\mathrm{p}$ a tempo & D minor \\
\hline \multirow[t]{7}{*}{ development } & $\mathrm{TM}_{\mathrm{I}}$, primary theme $\left(\mathrm{P}_{\mathrm{I}}\right)$ & mm. 147-164 & [p dolente] & $\mathrm{E}^{7}, \mathrm{G}$ minor \\
\hline & episode of $\mathrm{P}_{\mathrm{I}}$ & mm. $165-188$ & $\mathrm{p}$ cantando, ma a tempo & $\mathrm{G}^{7}$, modulating \\
\hline & variant of introductory (I') & mm. 189-196 & Tempo accelerando; $\mathrm{mf}$ & F minor \\
\hline & Interludium: $1^{\text {st }}$ section & mm. 197-221 & Andante lugubre; pp & F minor \\
\hline & Interludium: $2^{\text {nd }}$ section & mm. 222-233 & Maestoso ma a tempo; frisonante & $\mathrm{D} b$ major \\
\hline & Interludium: var of $1^{\text {st }}$ section & mm. 234-255 & Andante tranquillo & A / F minor \\
\hline & Interludium: var of $2^{\text {nd }}$ section & mm. 256-263 & f sempre accelerando & F phrygian \\
\hline
\end{tabular}

45 Both quotes are my translations of Vasilyev 1962, p. 18: »Pod znakom etogo vozglasa razvertïvaetsya vse deystvie sonatnoy formï [...] On zvuchit v moment kul'minatsii razrabotki. On vvodit vo vtoruyu pobochnuyu temu i neskol'ko raz, kak klich ili prizï, vonzaetsya v ee melodiku. « The term >vozglas` (>call«, sinvocation`) first appears in Tumanina 1960 , p. 300 . Alekseyev 1969, p. 284, similarly speaks of an sinvocatory motif^ (’prizïvnï motiv ). Kalendarev 2005 , p. 25 , describes that motif as a »laconic phrase with [...] interrogative nature, ringing out as if in response to the second element, that of interrupted and imperious chords."

46 Martyn 1995, p. 74f, suggests that the introduction was the last composed part of the sonata, added only when the rest of the score had already grown to its definitive shape. This would imply that Medtner had derived the nucleus idea from the beginning of the earlier-sketched $S_{I}$ theme in order to constantly have it in mind while proceeding with the composition.

47 Tozer 1999, p. 11f.: »A unifying kernel [...], a melodic and rhythmic cell [which] frequently occurs, often cunningly disguised. It is used by Medtner as a means of giving unity to his large structure, [...] always clearly present at the beginning of >paragraphs « «.

48 See Indy 1909, p. 378ff., introducing the terms élément cyclique and cellule.

49 My translation of Tumanina 1960, pp. 300 and 304: »Tematicheskiy material sonatï otlichaetsya bol'shim bogatstvom, kazhdiy razdel formi mnogotemen, v to zhe vremya proizvedenie nosit monotematicheskiy kharakter«; »Printsip monotematisma, kotorïy gospodstvuet v sonate«. Some other authors in Tumanina's succession also assumed a monothematic approach; see Mochalova 1962, p. 31, and Zetel 1981, p. 119. 


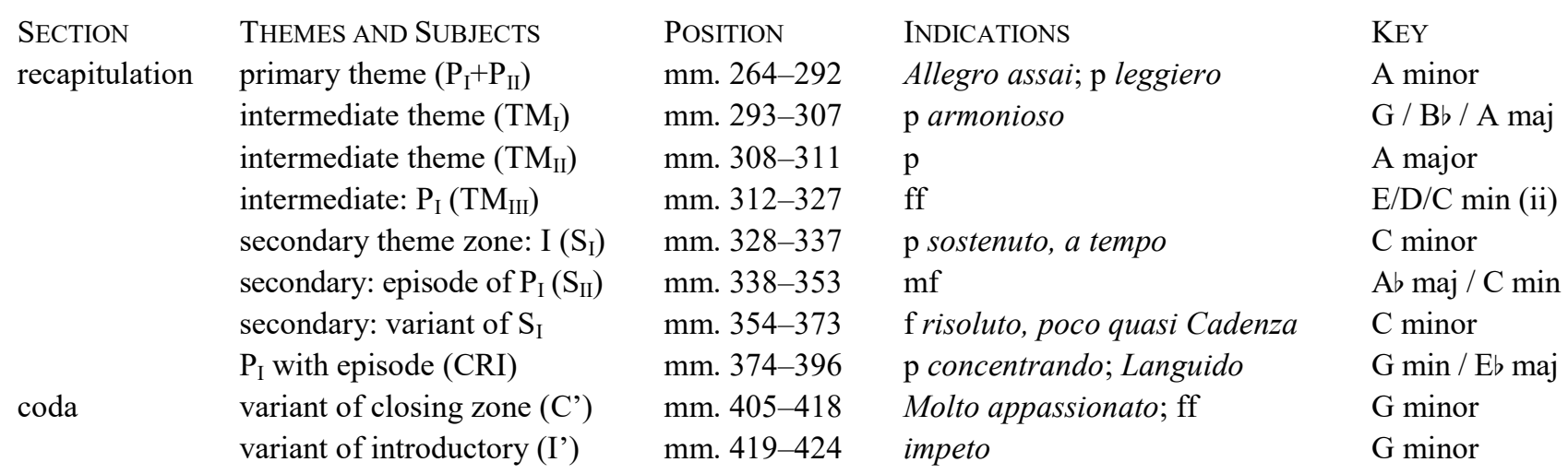

First subdivision: Tenebroso, sempre affrettando-Allegro assai G minor - D minor $-F$ minor, 4/4, $d=72,196$ measures on 13 pages

The sonata commences with its nucleus idea in the bass region, a rising and falling fourth $D-G-D$ immediately expanding to a fifth $C-G-C$ (mm. 1-2; see example 3.3.3). This motivic variation is a technique modelled a few years earlier in the $1^{\text {st }}$ movement of Scriabin's $3^{\text {rd }}$ Piano Sonata in F $\#$ minor, Op. 23 (1898). ${ }^{50}$ The notes of the nucleus are then harmonised using the iambic figure of a repeated chord with a semiquaver upbeat— - here, a $\mathrm{G}$ minor triad with added minor sixth, followed by a $\mathrm{C}$ dominant ninth chord. The combination of these two basic figures might remind the listener of the beginning of Rachmaninov's $1^{\text {st }}$ Piano Sonata in D minor, Op. 28 (1908), which similarly confronts a rocking fifth with an iambic chordal figure. ${ }^{51}$ In the following two measures, both elements are transposed a third higher, reaching the chords $\mathrm{B} b$ minor $-\mathrm{Eb}^{7 / 9}$ accordingly, and resulting in a gradually ascending top voice including the pitches $E b-E-F-G$. The sequence's third chain link, rising another minor third to $\mathrm{D} b$ minor, ${ }^{52}$ is signified in $\mathrm{m} .5$, but evades through chromatic voice-leading to $\mathrm{Ab}$ minor, $\mathrm{C}$ minor sixte ajoutée, and $\mathrm{G} b$ major, to eventually culminate in an altered $\mathrm{A}^{7 / 9 / 13}$ double-dominant chord (m. 6). With another expansion of the nucleus idea, now spanning a minor sixth (m. 7), the music dramatically opens for the diatonic primary theme $\mathrm{P}_{\mathrm{I}}$ (m. 9ff.). This moment reveals the introductory character of the preceding Tenebroso passage (a $\mathrm{P}^{0}$ module in Sonata Theory terminology), played significantly slower than the following Allegro assai section, the beginning of which »should have a sostenuto quality (within the limits of the general tempo) $\ll .{ }^{53}$ Most recordings, however, accelerate only slightly after presenting the eight-measure introduction in a quasi-improvised tempo rubato, reaching a tempo giusto only from m. 37 on. $^{54}$

50 With regard to expansion of intervals, Medtner's motivic development is applied in a similar way as in Scriabinthe initial ascending fourth is transformed into a seventh $(\mathrm{mm} .3-4)$, fifth (m. 5), and sixth (m. 6). Vasyutinskaya 2014 , p. 84 , hints to this fact by confronting examples of both works' opening measures, but without elaborating on the obvious similarity.

51 See Martyn 1995, p. 74. Moskalets $2004^{\text {a }}$, p. 120f., regards iambic rhythm as a »landmark of the epoch « (»primeta èpokhi«) in the Russian Silver Age, also referring to works of Medtner's contemporaries, and quotes a statement by Aleksandr Blok implying a sociological-semantic use of the iamb.

52 Yagodkina 1959, p. 13, provides a diagram depicting the sequential ascension of the opening motives in mm. 1-8.

53 See footnote in the Collected Edition, Vol. 2, p. 46, translated by Robert Rimm in the 1998 Dover edition (p. 78).

54 Smith 2003, p. 176f., proposes possible stages of acceleration for mm. 1-37, giving metronome markings of his own performance ranging between 40 (introduction) and $176 \mathrm{bpm}(\mathrm{m} .18)$. This amplitude of different tempos might seem a bit extreme. 


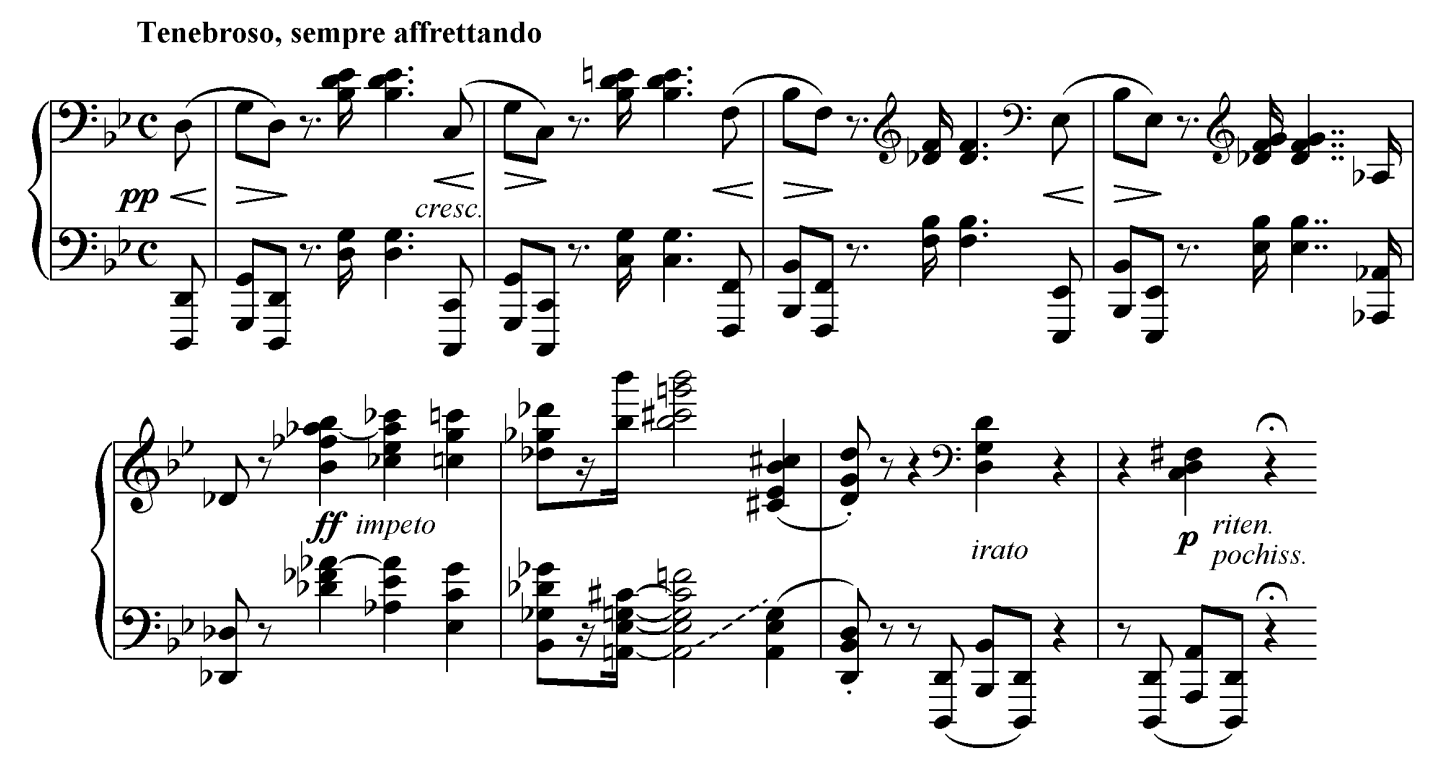

Example 3.3.3: Medtner, Sonata, Op. 22, exposition: I, mm. 1-8

The primary theme zone includes two embodiments of different character. Its first subject $\mathrm{P}_{\mathrm{I}}$ contains in itself three contrasting modules, the first of which is built of a chordal progression characterised through its erratic staccato, stepwise downward movement, and plagal harmony. ${ }^{55}$ Iosif Yasser feels reminded here of the Russian folk tune Dumal Vanyushka krepkuyu dumushku (Ivan Thought a Strong Thought). ${ }^{56}$ What relates this module to the introductory theme is the iambic chordal figure at the middle of measures, with a semiquaver anacrusis repeated on the beat, which frequently returns in the accompaniment throughout the primary theme zone. $\mathrm{P}_{\mathrm{I}}$ then unfolds in calm legato crotchets, with a contrasting second module formed in $3 / 2$ phrases, superposed to the 4/4 meter (m. 13ff.: addolcito, cantabile; see example 3.3.4). In repetitions of double-dotted notes, a third module follows (m. 18ff.) which must be regarded as an independent episode as it will be quoted later in the course of $\mathrm{S}_{\mathrm{II}}$. This development leads, increasing in intensity, to the return of the first module of $\mathrm{P}_{\mathrm{I}}$ in the subdominant (m. 26ff.: risoluto) and, as first noticed by Christoph Flamm, to an inversion of the second module (m. 30ff.: fortissimo espressivo; see end of example 3.3.4). ${ }^{57}$ Thus, the $\mathrm{P}_{\mathrm{I}}$ subject is in itself shaped as a small ternary, with the episode functioning as a central module, and finally resulting in the sonata's first authentic cadence and a drastic acceleration in movement.

55 With regard to the omission of dominant chords, Malikova 1967, p. 283, compares this subject to the main theme of the $1^{\text {st }}$ movement of Tchaikovsky's $5^{\text {th }}$ Symphony in E minor, Op. 64: 》Glavn[aya] tem[a] iz sonati op. 22, v kotoroy nastoychivaya povtornost' plagal'nïkh oborotov napominaet nachalo glavnoy temï I chasti 5-ï simfonii Chaykovskogo«. Zetel 1981, p. 134, quotes this association without reference to Malikova.

56 Yasser in Holt 1955, p. 61f. (again in Apetyan 1981, p. 206) quotes the melody from Elsa Mahler's volume Altrussische Lieder aus dem Pečoryland, Basel 1951 (No. 118). While it is unlikely that Medtner explicitly alluded to the tune, this observation hints to the composer's predilection for evoking folkloristic melos in his thematic invention (see also chapter 0.2.2). However, Kinley 1970, p. 28, argues that Medtner might have been acquainted with the song before it was first recorded in Mahler's collection.

57 After a not very successful approach in Keller 1971, p. 95ff., to analyse the motivic derivations in the primary theme zone, Flamm 1995, p. 224f., gives a detailed overview of motivic interrelations in the course of the whole sonata (see also Flamm 2006, p. 9f.). The author designates the interior structure of $\mathrm{P}_{\mathrm{I}}$, consisting of five portions in the order A-B-C-A'-B', as a miniature sonata form, while Skvorak 2003, p. 34, dubs the succession of the three elements a »miniature exposition«. Vasyutinskaya 2014, p. 86f., distinguishes four separate elements within the primary theme group, but without noticing the inversed relationship between $\mathrm{mm}$. $18 \mathrm{ff}$. and $30 \mathrm{ff}$. 


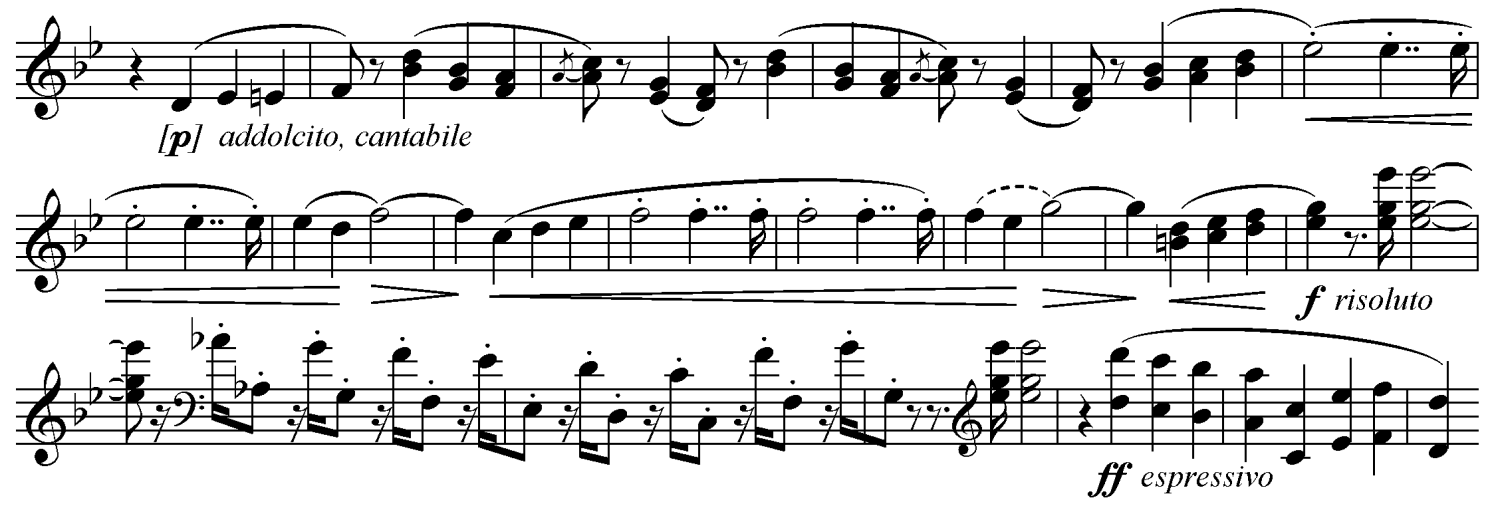

Example 3.3.4: Medtner, Sonata, Op. 22, exposition: $\mathrm{P}_{\mathrm{I}}$, second and third module, mm. 13-31 (motivic reduction)

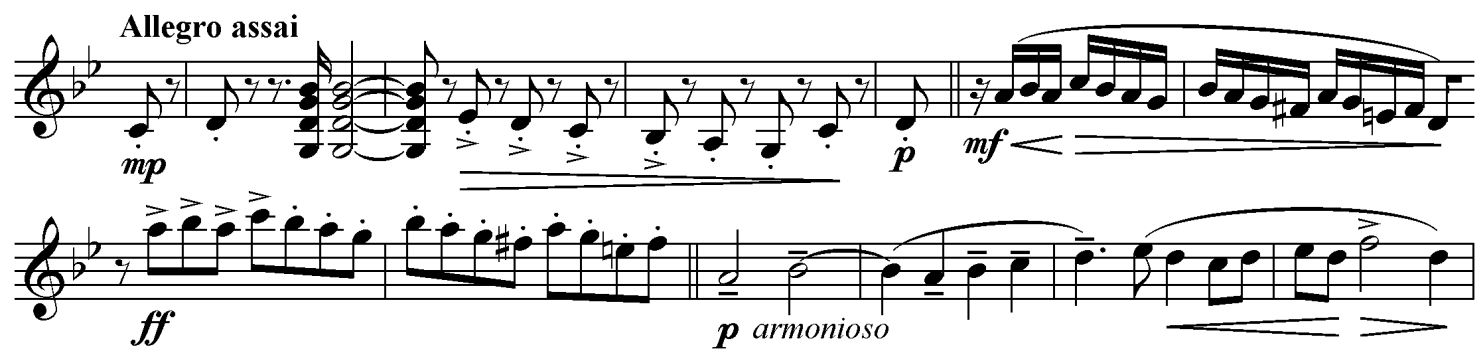

Example 3.3.5: Medtner, Sonata, Op. 22, exposition: $\mathrm{P}_{\mathrm{I}}$, mm. 9-11// $\mathrm{P}_{\mathrm{II}}, \mathrm{mm} .37-38,46-47 / / \mathrm{TM}_{\mathrm{I}}$, mm. 60-63 (top voice)

The following passage with its semiquaver figuration actually marks the beginning of the primary theme's second embodiment $\mathrm{P}_{\mathrm{II}}$ (m. 37ff.: precipitato), still in $\mathrm{G}$ minor. One may actually regard the $\mathrm{P}_{\mathrm{II}}$ figuration as a diminutive refinement of $\mathrm{P}_{\mathrm{I}}$, ${ }^{58}$ enhanced with accentuated chords in the lower voices (see example 3.3.5). Yet, in its general acceleration of note values, it qualifies as the beginning of something formally and thematically independent, later serving as a countersubject to $P_{I}$; and this aspect justifies it as a $P_{\text {II }}$ module, even though it simultaneously serves as a transitional passage giving way to modulation. After augmentations of the initial notes of $\mathrm{P}_{\mathrm{II}}$ in crotchets (m. 46f.) and a quote of the first module of $\mathrm{P}_{\mathrm{I}}$ interpolated into the continuous semiquaver movement (m. 52f.), a three-key exposition ${ }^{59}$ of enormous dimensions unfolds on the following pages, comprising the tonal regions of $\mathrm{G}$ minor, $\mathrm{B} b$ major (intermediate theme) and $\mathrm{D}$ minor (secondary theme and closing zone). ${ }^{60}$

58 Tumanina 1960 , p. 301, refers to $\mathrm{P}_{\mathrm{II}}$ as a mere conjunctive passage (»svyazuyushchaya partiya «). Likewise does Dolinskaya 1966, p. 94, speaking of a passage of etude-like nature (»osnovn[aya] >etyudn[aya]< tem[a]«), and thus rejecting the interpretation of Vasilyev 1962, p. 19, who recognized it as the »second but still a main theme« (»vtoraya, glavnaya zhe tema «). Truscott 1961, p. 115, and Ginsburg 1961, p. 47, similarly designate $\mathrm{P}_{\text {II }}$ as a transitional passage or further development of $\mathrm{P}_{\mathrm{I}}$. These notions somewhat blur the significance of $\mathrm{P}_{\mathrm{II}}$ not only for its recapitulation in combination with $\mathrm{P}_{\mathrm{I}}$, but also for its elaboration in the closing zone. Flamm 1995, p. 224, maintains this perspective, possibly influenced by the earlier writings, but at the same time captures the justified impression of a >genuine< sonata movement starting at that point (»Erst die anschließende Überleitungspassage [...] vermittelt den Eindruck eines >echten< Sonatenallegros«).

59 Harold Truscott preferred the term >three-tier exposition for his writings on Medtner's Op. 22.

60 Truscott 1956, p. 5 (again in Truscott 1961, p. 123) points to the fact that exactly the same tonal design (i-III-v) was pre-established in the exposition of the finale of Clementi's G minor Sonata, Op. 34 No. 2 (published 1795). The recapitulation of this movement, however, restates all three themes in the tonic key. Even earlier, the $1^{\text {st }}$ 
Upon arrival at the intermediate theme $\mathrm{TM}_{\mathrm{I}}$, sounding as a graceful left-hand cantilena in the high middle register (m. 60ff.: armonioso), the $\mathrm{G}$ minor tonic loses its significance, while the semiquaver motion is maintained in the accompanying figures. Sonata Theory helps structure the intermediate theme and its continuations: The ascending contour of $\mathrm{TM}_{\mathrm{I}}$, the first of three modules of a trimodular block and thus easily mistaken for a secondary theme, is derived from a free inversion of both the $\mathrm{P}_{\mathrm{I}}$ and $\mathrm{P}_{\mathrm{II}}$ subjects (see example 3.3.5). In his sketches Medtner already referred to this $\mathrm{B} b$ major melody as a spromezhutochnaya temar (with the meaning of an intermediate theme, in German `Zwischensatz $).{ }^{61}$ This view seems justifiable despite the fact that $\mathrm{B} b$ major (the intermediate key) is reached without a medial caesura and endures only for some 15 measures (the recapitulation of $\mathrm{TM}_{\mathrm{I}}$ will prove even more unstable in tonality). In the exposition it soon gives way to the $\mathrm{TM}_{\mathrm{II}}$ module, a passage further elaborating on the nucleus idea (m. 75ff:: poco a poco svegliando), setting the ascending fourth in a dense canon at a crotchet's distance (m. 79f.), and followed by the more dramatic module $\mathrm{TM}_{\mathrm{III}}$ which gradually modulates to D minor, the exposition's third tonal centre (m. 81ff.).

Most scholars have paid more attention to the $S_{I}$ theme following in $\mathrm{m}$. 95ff., triggered by a medial caesura at an half-diminished ninth chord on $A$ (m. 94). ${ }^{62}$ Whereas the exposition of Medtner's Ab major Sonata, Op. 11 No. 1, had returned to the V after displaying an additional subject in a contrasting key, the exposition of the $G$ minor Sonata shows a fully established third key, unfolding the $\mathrm{S}_{\mathrm{I}}$ and $\mathrm{S}_{\mathrm{II}}$ modules as well as the closing zone. As a regular ten-measure sentence structure, the $\mathrm{S}_{\mathrm{I}}$ subject finally establishes the key of $\mathrm{D}$ minor, as expected in a traditional sonata exposition, at a fifth above $\mathrm{G}$ minor. The theme further resorts to the nucleus idea through the leaps of fourths at its onset, the first notes $A-D-A$ being stretched to a sixth $A-F-A$ two measures later, and thus builds a cyclic link to the material of the introduction (see examples 3.3.6 and 3.3.7). Moreover, its texture with a predominance of parallel thirds is reminiscent of the secondary theme of the Sonata-Elegy, Op. 11 No. $2 .^{63}$ The subject was picturesquely characterised as a $\gg$ submissively hesitant and plaintive melody «, ${ }^{64}$ while Daniel Zhitomirsky describes it as »a theme convincingly introduced with such a

movement of Haydn’s >Farewell Symphony in F $\sharp$ minor, Hob. I:45 (1772), seems to be the first instance of a minor-mode three-key exposition; this hint I owe to Markus Neuwirth. Also, the expositions of Beethoven's Coriolan Overture in C minor, Op. 62 (1807), and of the $1^{\text {st }}$ movement of Mendelssohn's C minor Piano Trio, Op. 66 (1845) present a similar modulatory plan. In Medtner, another remarkable instance of an exposition with even four keys is found in his Sonata-Vocalise in C major, Op. 41 No. 1 (1922), the themes of which appear in the succession of C major, A minor, E minor, and $\mathrm{G}$ major (I-vi-iii-V) and are recapitulated as $\mathrm{C}$ major, $\mathrm{B} b$ minor, $\mathrm{F}$ minor, and $\mathrm{F}$ major (I-b vii-iv-IV). See Uhl 2017, p. 24f.

61 The term was adopted by Dolinskaya 1966, p. 94 (again in Dolinskaya 2013, p. 115), and translated (>Zwischensatz $\iota$ ) by Flamm 1995, p. 223. Yagodkina 1959, p. 21, reports that Medtner referred to the secondary theme as $\gg$ major subordinate theme (»mazhornaya pobochnaya tema«) in his autograph, an attribution that indicates a formal connection with $\mathrm{S}_{\mathrm{I}}$ rather than the primary theme. Tumanina 1960, p. 301f., Truscott 1961, p. 116, and Vasilyev 1962 , p. 19, support this view when referring to »the first theme of the second group« or »pervïy razdel pobochnoy partii« respectively; Zetel 1981, p. 118, likewise speaks of an exposition with two main and two subordinate themes. Other authors refer to a first, second, and third theme of equal significance, such as Keller 1971, p. 91ff., and Elmore 1972, p. 78.

62 This HC recalls a very similar moment before the entrance of the coda of the Sonata-Elegy, Op. 11 No. 2.

63 Podporinova 2007, p. 146, draws a parallel to the primary theme of Op. 11 No. 2, without specifying the similarity in detail.

64 Martyn 1995, p. 74. 
simple and intimate lyricism, and with such concentrated expressivity like none of his contemporaries was capable to create $\ll .{ }^{65}$ As such it functions as an effective counterpole to the primary theme zone.

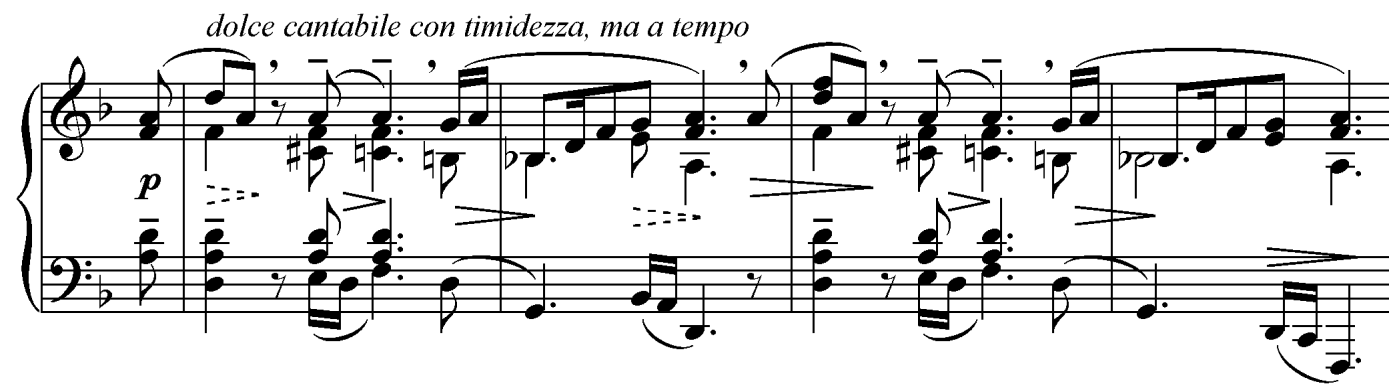

Example 3.3.6: Medtner, Sonata, Op. 22, exposition: $\mathrm{S}_{\mathrm{I}}$, mm. 95-98

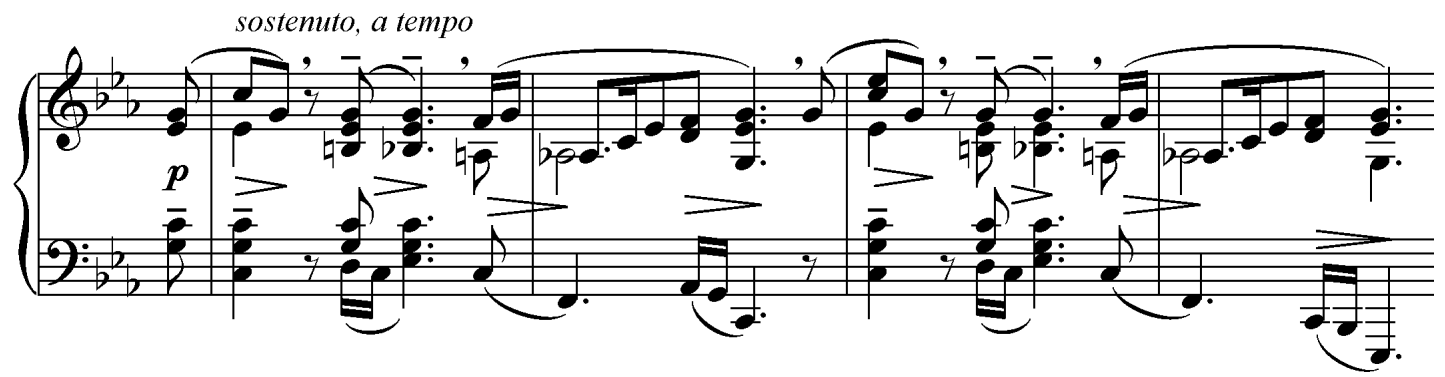

Example 3.3.7: Medtner, Sonata, Op. 22, recapitulation: $\mathrm{S}_{\mathrm{I}}$, mm. 328-331

The secondary theme zone appears, just like the primary, as a small ternary. Its middle passage $\mathrm{S}_{\text {II }}$ borrows the episode from $\mathrm{P}_{\mathrm{I}}$, arising in diminished note values (m. 105ff.), and leading to a puzzling modulatory sequence of altered seventh chords (m. 117ff.). After that, $\mathrm{S}_{\mathrm{I}}$ returns for further elaboration (m. 121ff.) ${ }^{66}$ resulting in a imitative treatment of its contrasting phrase, an ascending figure in dotted rhythm. After another medial caesura, the following passage (m. 131ff.) again operates with the nucleus idea $A-D-A$, transferred to the bass register. It is arranged in a descending sequence of seconds $(G-C-G ; F-B b-B)$, and blended with further semiquaver movement derived from $\mathrm{P}_{\mathrm{II}}$ (see example 3.3.8). It thus serves as a closing zone, giving additional tonal stability to the second half of this massive expositional trajectory.

65 My translation of Zhitomirsky 1981, p. 306f.: »Ya ne znayu, komu iz sovremennikov Metnera posil'no bïlo bï sochinit' i ubeditel'no prepodnesti temu stol' liricheski prostuyu, intimnuyu i pritom stol' kontsentrirovanno vïrazitel'nuyu, kak >pobochnaya< v toy zhe sonate.«

66 Semykin 2017, p. 126, identifies the varied restatement of the $\mathrm{S}_{\mathrm{I}}$ theme as an internal recapitulation (»Obshchee stroenie pobochnoy partii-trekhchastnoe repriznoe. V pervom razdele tema izlagaetsya, $\mathrm{v}$ srednem-poyavlyaetsya novoe tematicheskoe obrazovanie, [...] tak i s tret'im motivom glavnoy partii, repriza—dinamicheskaya, pridayushchaya teme novïy kharakter zvuchaniya — volevoy i reshitel'nïy«). 


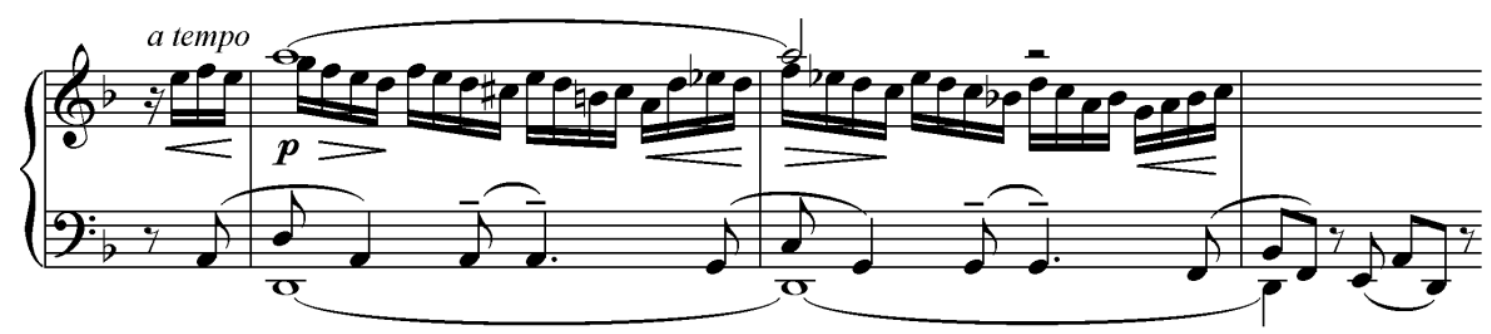

Example 3.3.8: Medtner, Sonata, Op. 22, exposition: C, mm. 131-133

With a quotation of $\mathrm{TM}_{\mathrm{I}}$, sounding in a choral-like homophony of unclear tonality, combined with its own inversion in the tenor voice (m. 147ff.), the closing zone seamlessly blends into the beginning of the development section. In continuation, numerous versatile allusions to the $\mathrm{P}_{\mathrm{I}}$ theme occur, most of them in vague harmonic guises, and along with another restatement of the $\mathrm{P}_{\mathrm{I}}$ episode (m. 165ff.). Owen Hartnett notices the similarity of that passage to a subject from the secondary theme zone of Liszt's B minor Sonata (m. 153ff.: cantando espressivo) - an observation which recalls the Lisztian indebtedness of some aspects of Medtner's music, but does not necessarily establish an intercommunity of the two works on formal level. ${ }^{67}$ The music then temporarily reaches a dominant plateau on a $\mathrm{G}^{7}$ chord before it advances into subtle regions of quasiimpressionist flavour, gradually decreasing in volume, while the motivic substance of this harmonically indecisive passage (m. 173ff.) echoes the $\mathrm{S}_{\mathrm{I}}$ theme. This delicate process little by little leads over to a crescendo and accelerando, finally resulting in a diminished version of the introductory chords and nucleus ( $\mathrm{m}$. 189ff.: Tempo accelerando). In reaching the developmental climax in m. 194, similar to the transition of the introduction to the primary theme zone, the entrance of the recapitulation might have been prepared. But instead of returning to the tonic, the modulation leads to F minor, another third above the D minor of the $S_{I}$ and $\mathrm{C}$ themes, in order to have the Interludium attached in that key. Medtner approaches a $\mathrm{HC}$, halting on a dominant seventh chord with flattened fifth, and the nucleus idea being adapted to this interval. Then, the music suddenly falls mute on a general pause marked silenzia (m. 196).

\section{Second subdivision: Interludium (Andante lugubre) ${ }^{68}$ $\mathrm{F}$ minor, 3/4, $\_=52,67$ measures on 5 pages}

A homophonic insular region woven into the dense meshwork of the development section, the Interludium is a sombre and contemplative episode, in its static flow contrasting significantly to the compelling force of the sonata exposition. This subdivision, described by Bernard Pinsonneault as a »veritable abyss «, ${ }^{69}$ leaves the

67 See Hartnett 2014, p. 13f.: »Op. 22 is clearly inspired by the Liszt sonata. Both are very large single movement works that are comprised of smaller sub-movements without break. Medtner uses a repeating theme throughout all of these movements, and its contour is very similar to the cyclic theme of Liszt's Sonata in B minor." The validity of this conclusion is not ensured by the given argument, as Liszt's subject, appearing in various guises throughout the B minor Sonata after being first introduced in $\mathrm{m}$. 14, is subject to extensive transformation, whereas Medtner's $\mathrm{P}_{\mathrm{I}}$ episode basically sticks to its initial shape.

68 The $\mathrm{B} b$ minor Interludio comprising the middle section of Anatoly Aleksandrov’s $3^{\text {rd }}$ Piano Sonata in F $\sharp$ minor, Op. 18 (1920), showing a characteristic Medtnerian melos, is probably modelled on the G minor Sonata. See Flamm $2004^{\mathrm{a}}$, p. 192.

69 Pinsonneault 1956, p. 34: »L’Interlude est un véritable abîme.« 
overall constructive progress of the movement in prolonged suspension before starting again in the following recapitulation. ${ }^{70}$ The Interludium invites for two contrasting formal conceptions. It has been unterstood as a middle movement within a three-fold, yet uninterrupted cycle of movements—or, alternatively, as the inner subdivision of a stwo-dimensional sonata form $<$. In fact, it is neither of these. The formal analogy and symmetry of the outer subdivisions is too obvious to speak of separate movements; and at the same time, the Interludium appears disparate in mood, with only inconspicuous motivic intercommunities to the rest of the sonata, which would have been compulsory in order to claim a `two-dimensional design for the whole piece.

Despite the impression of independency, the Interludium has a number of elements in common with the sonata's exposition - first, the interval of a descending fourth derived from the nucleus idea (mm. 198, 200); and second, the repeated chords in the middle register, falling on the second beat of the interlude's first measure as well as in many other places (mm. 197, 199, 201f.). This rhythmic structure builds a link to the introduction and $\mathrm{P}_{\mathrm{I}}$ theme, ${ }^{71}$ and also contributes to the predominant iambic design characteristic of most of the sonata's significant themes. ${ }^{72}$ The Interludium's theme starts with a fascinating harmonic moment right away, confronting the F minor tonic on the upbeat with an unexpected chord on the downbeat which is connected through half-tone voice leading in every of the four parts (see example 3.3.9). This tetrad, sounding like the enharmonic equivalent of an $\mathrm{F} \#$ minor seventh chord, is in fact written as an $\mathrm{Gb}$ minor fifth-sixth with the augmented sixth $E$ in the bass (for more thoughts see chapter 2.4.2) - a harmony very similar to a German sixth chord in the context of $\mathrm{B} b$ minor, ${ }^{73}$ and paralleled by the somewhat similar atmosphere of the opening of Medtner's $1^{\text {st }}$ Piano Concerto in C minor, Op. 33 (1914-18), where $D b$ and $C$ are repeatedly confronted. Through its ambivalent Phrygian-dominant and Neapolitan-subdominant quality the chord involves an enormous potential for modulation. However, the centrifugal tendency remains unused during the first pair of measures and its repetition, unfolding only on its third occurrence (m. 201f). In building an eight-measure sentence, the theme comes to a regular closure with a $\mathrm{HC}$ in $\mathrm{m}$. 204. It subsequently starts over again and leads to a derivative phrase marked Poco a poco più sereno e con moto (m. 209ff.), echoing the $\mathrm{P}_{\mathrm{I}}$ episode in its note repetitions - but it might also be borrowed from an earlier piece of Medtner's, the F minor Skazka, Op. 14 No. 1 >Song of Ophelia (190507), where a very similar phrase is heard in $\mathrm{m} .15 \mathrm{ff} .{ }^{74}$ This element is extended with a phrase in continuous crotchets, stepwise ascending and descending in the range of a sixth, and thus distantly derived from $\mathrm{P}_{\mathrm{I}}$. It develops to a two-part canon (m. 218ff.; see example 3.3.12) to conclude the Interludium's first section.

70 See Vasilyev 1959, p. 12: »Andante, vnezapno priostanovivshee techenie sonatnogo allegro, posle kotorogo sleduet repriza ètogo allegro.«

71 However, the similarity goes not as far as suggested by Truscott 1961, p. 120, claiming that the $\mathrm{P}_{\mathrm{I}}$ theme $/ r$ receives magical power and new meaning « at the opening of the Interludium. Equally inaccurate is an assertion in Tumanina 1960 , p. 303, implying that the Interludium »is based on entirely new thematic material« (»osnovan na novom tematicheskom materiale «).

72 See Ginsburg 1961, p. 43: »The interval of the fourth and the dotted rhythms [...] serve as unifying factors in the whole work.«

73 Malikova 1967 , p. 288 , conceives this chord as the derivation of a vii ${ }^{07}$ diminished seventh chord with two flattened notes, emphasising its dominant quality through the leading note $E$ in the bass.

74 Vasyutinskaya 2014, p. 100, draws a parallel from the delicate polyphony of this passage to the contemplative Moderato section of Prokofiev's $3^{\text {rd }}$ Piano Sonata in A minor, Op. 28 (1917). 


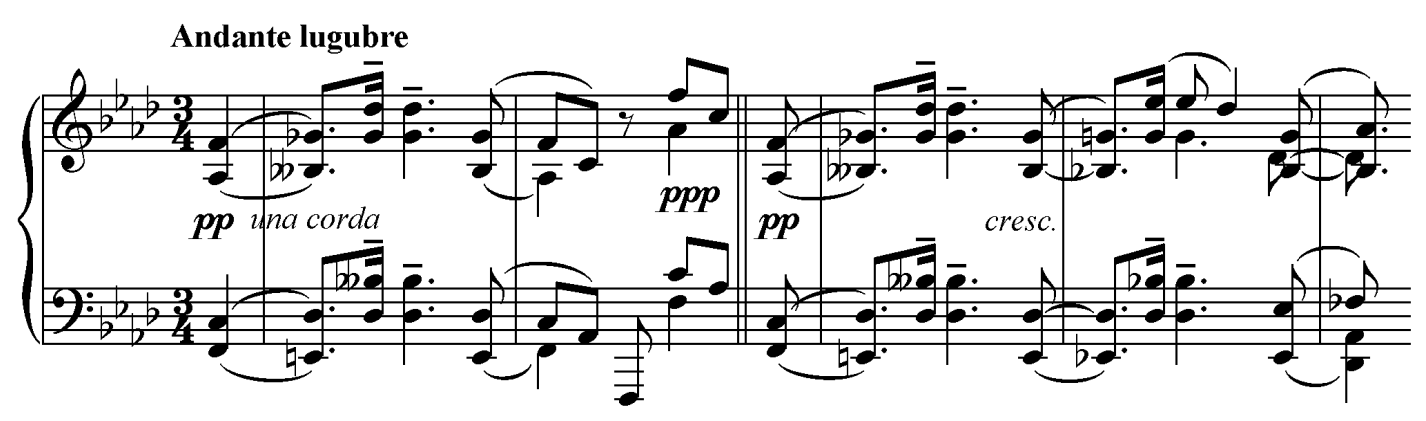

Example 3.3.9: Medtner, Sonata, Op. 22, Interludium, mm. 197-198 // mm. 201-202

The whole Interludium comprises four sections in A-B-A'-B' form, a quaternary design possibly qualifying as a smaller sonata form within the overall structure. ${ }^{75}$ The first section and its varied restatement (m. 234ff.) frame a contrasting middle episode in $\mathrm{D} b$ major (m. 222ff.: Maestoso ma a tempo), marking the centre of the whole sonata. Written on four staves, the texture of this passage is reminiscent of the final section of Rachmaninov’s celebrated C\# minor Prelude, Op. 3 No. 2 (1892), and even more so as it also evokes the sound of orthodox church bells. ${ }^{76}$ Medtner here introduces another motif derived from the iambic chordal element, set in contrary movement of the outer voices, while varying the dotted rhythms of the first section to tripledotted crotchets. Expressive whole-tone harmony and an ascending cycle of minor thirds are employed to modulate to far-remote tonal regions, eventually reaching E major - the dominant key of the passage to follow. A feigned recapitulation in A minor (m. 234f.), quickly modulating back to F minor, precedes a shortened variant of the Interludium's first section. Here the sixth-ranged phrase from m. 218ff. is heard again (m. 245ff.), now extended to an imitative passage of no less than ten measures, and eventually brightening toward F major. The middle episode is also briefly restated (m. 256ff.), and its sombre closure is staged in a quasi-Phrygian environment, while the ambivalent initial tetrad is transformed into a doubly altered dominant chord by replacing $D b$ with $C$ (m. 260f.). The flattened dominant seventh $B b b$ is enharmonically equivalent to the tonic third $A$ - and this very note, ingredient of four different chords in succession (mm. 262-64), is optionally allowed to be sustained through the following general pause (m. 263), establishing a link to the following section. Moreover, the bass progression $F-E$ can be conceived as a Phrygian half cadence with fourth-sixth suspension, initiating a sudden throwback to A minor, the key of the entrance of the recapitulation section (see example 3.3.10).

75 Alekseyev 1969, p. 284, speaks of a »small >sonata within a sonata « (»nebolsh[aya] >sonat[a] v sonate««). See also Dolinskaya 2013, p. 117: »Medtner connects the Interludium with the sonata [...] also by means of its structure: its general formal contour appears analogous to the overall sonata form « (my translation of: »Metner svyazïvaet Interlyud s sonatoy [...] strukturno: obshchie konturï formï èpizoda sootvetstvuyut planu sonatnoy formï v tselom.«) This notion is echoed in Semykin 2017, p. 128: »In the Interludium there appears a sonata within a sonata« (»V interlyudii poyavlyaetsya priyom $>$ sonati v sonate $($ ).«

76 See Moskalets $2004^{\mathrm{a}}$, p. 122f., for a discussion of the semantics inherent in the musical imitation of church bells (২kolokol'nost'`). The author conceives the Maestoso passage as »the dramatic climax of the piece« (»kolokol'nïy épizod $[\ldots]$ dramaturgicheskaya vershina proizvedeniya «). 
Third subdivision: Allegro assai - Languido - Molto appassionato A minor - $C$ minor - $G$ minor, 4/4, $d=72,161$ measures on 11 pages

The recapitulation is most obviously remarkable for starting in a >wrong key different from the tonic- - a feature with has a number of parallels in music history, and also attracted the attention of most scholars concerned with the sonata. ${ }^{77}$ But even more, this passage qualifies as extraordinary for its deviation from the order of formal sections as experienced in the exposition. By contrapuntally combining the $\mathrm{P}_{\mathrm{I}}$ and $\mathrm{P}_{\mathrm{II}}$ themes (see example 3.3.10), ${ }^{78}$ Medtner attains an outstanding synthesis of the exposition's material. The deliberate choice of A minor for that passage is proven through a line from the composer's hand: »Achieve the conjunction of the intermediate and main theme in A minor rather than G minor «. ${ }^{79}$ Even if G minor does not yet return, the passage cannot be mistaken as a part of the development section. This impression is supported by the suddenness of the event, as the curious joint between the subdivisions lacks an organic transition. Without preparation, the instantaneous return of $\mathrm{P}_{\mathrm{II}}$ 's semiquaver figures throws the listener right into a new developmental process, dispensing with the $\mathrm{P}_{\mathrm{I}}$ theme in its original chordal appearance, which will later undergo a more independent recapitulation (m. 370ff.).

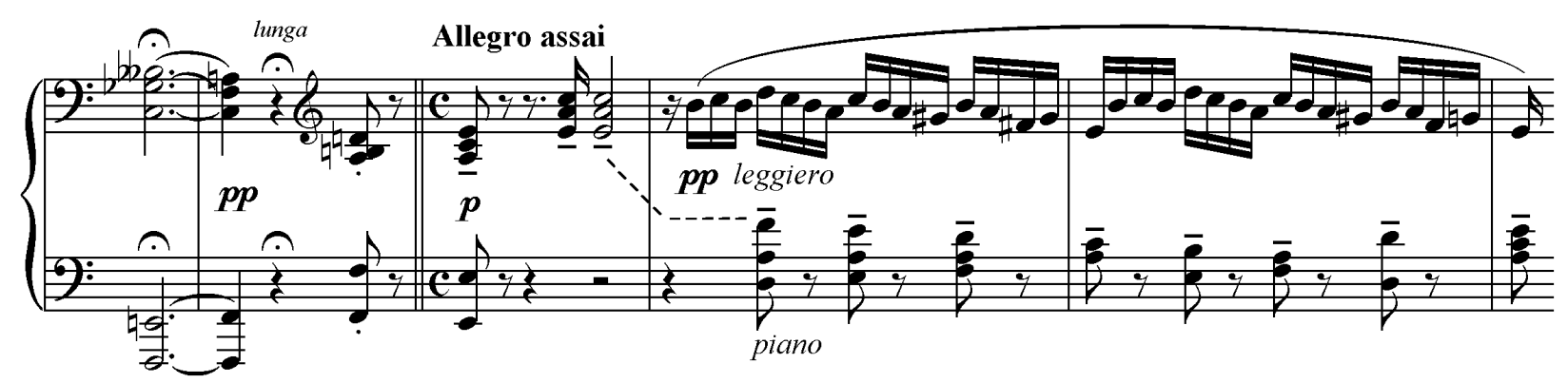

Example 3.3.10: Medtner, Sonata, Op. 22, recapitulation: $\mathrm{P}_{\mathrm{I}}+\mathrm{P}_{\mathrm{II}}, \mathrm{mm} .262-266$

The secondary theme zone starts in G major (m. 293ff.), but instead of employing a stable tonal region, the armonioso $\mathrm{TM}_{\mathrm{I}}$ theme is centered in three different keys, advancing successively to $\mathrm{B} b$ major (m. 300) and A major (m. 304). Even less predictably, $\mathrm{S}_{\mathrm{I}}$ is recapitulated in C minor (m. 328ff.; see example 3.3.7), ${ }^{80}$ producing a tonal symmetry of fifths compared to the exposition. The following passage is attached in compliance with the exposition section, restating the episode from $\mathrm{P}_{\mathrm{I}}\left(\mathrm{m}\right.$. 338ff.) as well as the imitative treatment of $\mathrm{S}_{\mathrm{I}}$

77 Atonical onsets of recapitulation sections are most prominently found in the $1^{\text {st }}$ movements of Mozart's C major Sonata, K. 545 (1788), as well as Schubert's $4^{\text {th }}$ Symphony in C minor, D. 417, and $5^{\text {th }}$ Symphony in Bb major, D. 485 (both of 1816).

78 This feature was first described by Vasilyev 1962, p. 19f.: »Repriza nachinaetsya [...] v nachale obe temï glavnoy partii danï odnovremenno, v kontrapunkticheskom soedinenii«. See also Rueger 1979, p. 466: »Die leidenschaftliche Reprise vereint dann stellenweise die beiden Themen der Exposition. « Skvorak 2003, p. 38, localises the first combination of $\mathrm{P}_{\mathrm{I}}$ and $\mathrm{P}_{\mathrm{II}}$ as early as in $\mathrm{m}$. 47, foreshadowing the beginning of the recapitulation.

79 My translation of Dolinskaya 2013, p. 118: »Soedinenie promezhutochnoy temï i glavnoy luchshe ne v g-moll, a v a-moll«. The author unfortunately does not specify the origin of the quote, which is probably part of Medtner's annotations to his sketches for the sonata.

80 Vasyutinskaya 2014, p. 103, localises the beginning of the recapitulation section at the restatement of the $S_{\text {I }}$ theme. This results in an absurdly misbalanced structural diagram of the whole sonata, signifying the Interludium as an >introduktsiyar enclosed by two stages of development; see ibid., p. 106. 
(m. 354ff.), now with an altered chromatic bassline. Due to the modified order of subjects, the closing zone is missing here, and in its place follows a recapitulation of the primary theme zone in a pure but harmonically altered variant; this passage can be conceived as a coda-rhetoric interpolation (CRI). Instead of unambiguously returning to $\mathrm{G}$ minor, the $\mathrm{P}_{\mathrm{I}}$ subject exchanges the tonic for a half-diminished seventh chord on $E(\mathrm{~m}$. 374). In succession, the otherwise missing sixth scale degree gains importance when the $\mathrm{P}_{\mathrm{I}}$ episode returns in $\mathrm{Eb}$ major (m. 379ff.), staged in a similar way as it was first heard in m. 18ff. Its continuation could be mistaken for the beginning of the coda as it finally reinstates G minor (m. 397ff.: Languido. Poco a poco appassionato), ${ }^{81}$ but in fact corresponds to the inversion of $\mathrm{P}_{\mathrm{I}}$ 's second module (m. 30ff.) which here appears in a rhythmically enhanced version, broadened to crotchet sextuples in the right hand.

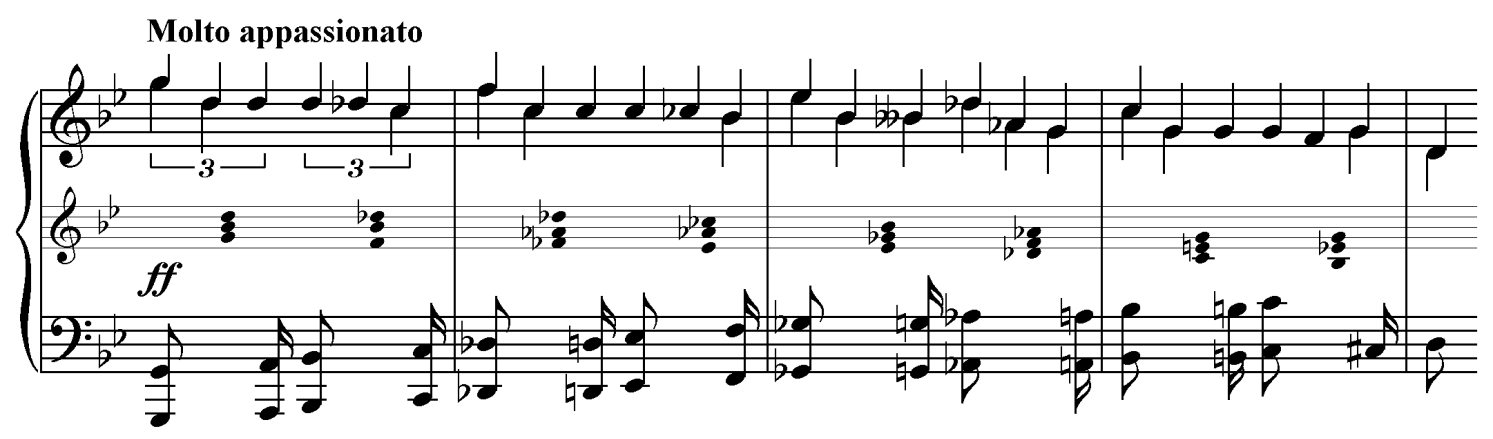

Example 3.3.11: Medtner, Sonata, Op. 22, coda, mm. 405-408 (exterior voices and harmonic progressions)

The Molto appassionato coda (m. 405ff.) is appended at the same structural position where $\mathrm{P}_{\text {II }}$ was introduced in the exposition, again making use of a precipitato impetus to accelerate the movement after a moment of allargando. Besides bringing the symmetrical tonal plan to a final closure, the coda also gives way for the nucleus idea to return, framing the whole work with rocking fourths and their sequenced expansions, and leading to an ultimate accumulation of the sonata's motivic and harmonic content. Most remarkable in this respect is a real sequence of the nucleus in descending seconds, in response to the diatonic sequence heard in the exposition's closing zone, which is now replaced by the coda: $D-G-D ; C-F-C ; B b-E b-B b ;(B b b-) D b-A b$; $G-C-G$ (see example 3.3.11). The sequential process is counterpointed by a newly developed bassline, stepwise ascending in an irregular scale of half-tones and whole-tones. With its exuberant textures reminiscent of the final section of Chopin's G minor Ballade, Op. $23,{ }^{82}$ the coda further draws on the polyrhythmic structure that preceded its entrance. Many authors have appreciated the cunning juxtaposition of ternary and quaternary figures, eventually leading to interlaced triplets in a nine-versus-four division. ${ }^{83}$ In doing so, Medtner merges elements from the introduction, from the primary theme zone, and also a melodic phrase from the Interludium (m. 403f./ m. 411f.: risoluto; see example 3.3.12) »to a continuous movement of crotchets [...]

81 So do Truscott 1961, p. 122, and Ginsburg 1961, p. 55. Skvorak 2003, p. 47f., localises the coda as early as in m. 374.

82 Sacre 1998, p. 1815: »Une admirable coda [...] conclut l'œuvre dans l'effervescence d'une ballade.«

83 Zetel 1981, p. 150, points to the fact that Medtner, by means of alternative ossia staves, included facilitated versions in order to practise the polyrhythmic structure. A footnote remark for this passage (Collected Edition, Vol. 2, p. 74; translated by Robert Rimm in the 1998 Dover edition, p. 106) reads: »To master the rhythm in a slow tempo, it is necessary to resort to the compromise specified on the previous page $\ll$. 
while the left-hand accompaniment fills in the dotted anacrusis of the $\mathrm{P}_{\mathrm{I}}$ theme in a polyrhythmically most complex manner ${ }^{84}$ (see also example 2.2.8). As »the concluding part of the sonata, synthesizing its whole thematic content, forms the work's culmination $\ll,{ }^{85}$ the motivic interconnection of its three subdivisions is reinforced. When all is said and done, the sonata closes as it had begun - with a concentrated variant of the introduction in the very last measures (mm. 419ff.), framing the whole work.

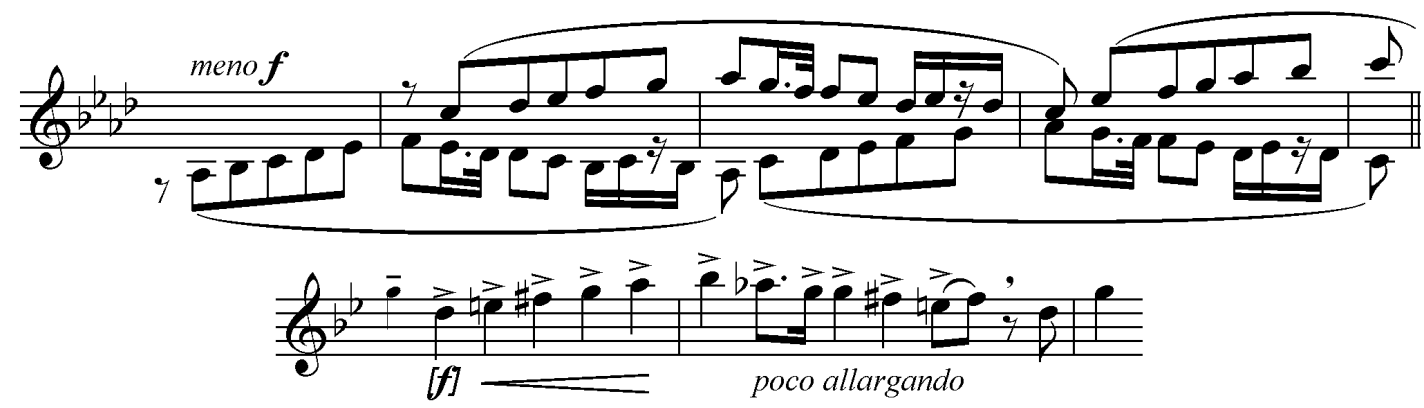

Example 3.3.12: Medtner, Sonata, Op. 22, Interludium, mm. 245-248 // coda, mm. 403-404 (motivic reduction)

\subsubsection{CONCLUDING REMARKS}

The G minor Sonata's dedicatee is the Russian composer, pianist and music theorist Georgy Catoire. As a composer, he was fundamentally inspired by Wagner and Franck, and had to struggle with various adverse judgments of his music until he was appointed professor at the Moscow Conservatory in 1917. The dedication is a mutual one, as Catoire had already dedicated his $1^{\text {st }}$ Violin Sonata in B minor, Op. 15 (1904), to Medtner. ${ }^{86}$ Their families cultivated a friendship, and Medtner and his brother Aleksandr, who taught Catoire's son Pëtr on the violin, were frequent guests in Catoire's house- but apart from a number of appreciative statements, ${ }^{87}$ the relationship of the two composers remains somewhat obscure. After Catoire's death Medtner praised him as a "genuine artist, one of a very rare kind« in a letter to Aleksandr Goedicke, ${ }^{88}$ but never wrote anything directly to Catoire, and only occasionally mentioned him in otherwise his correspondence. Catoire's writings, including the harmony treatise Teoreticheskïy kurs garmonii (1924) and a posthumously published textbook on musical form, Muzikal'naya forma (1936-37), were particularly influential in the early Soviet Union. In the latter book, Catoire briefly dealt with >mirror recapitulations` (>zerkalnaya repriza $<$ ) in sonata form and non-tonic recapitulations of secondary themes (see also chapters 1.3.2 and 3.2.0), but it is not sure whether Medtner had been familiar to Catoire's conceptions before his emigrationthis seems at least likely, given the close, if not intimate, relationship of the two composers.

84 My translation of Flamm 2006, p. 10: »In der [...] Coda verschmelzen Elemente aus Schlussgruppe [...] und Hauptsatz mit Tonfiguren aus der Durchführung bzw. aus dem Interludium zu einer durchlaufenden Viertelbewegung, während die Begleitfiguren der linken Hand in polyrhythmisch überaus komplexer Weise die punktierte Auftaktigkeit des Hauptsatzbeginns konsequent dagegensetzen.«

85 My translation of Alekseyev 1969, p. 286: „Zaklyuchitel'nïy razdel sonatï, sinteziruyushchiy ee tematicheskiy material,-_kul'minatsiya sochineniya.«

86 Medtner's own $1^{\text {st }}$ Violin Sonata, Op. 21 (1909), is written in the same key.

87 See Pëtr Catoire in Zassimova 2011, p. 39, suggesting that Medtner was held in high esteem by Catoire.

88 Letter to Goedicke of March 13, 1926, published in Apetyan 1973, p. 318ff. See also Zassimova 2011 , p. 229. 


\begin{tabular}{|c|c|c|c|c|c|c|c|c|c|c|c|c|c|c|c|c|c|c|c|c|c|c|c|c|c|c|c|c|c|c|c|c|c|c|c|c|c|c|c|c|c|c|c|c|c|c|c|}
\hline \multicolumn{48}{|c|}{ First subdivision: 196} \\
\hline & \multicolumn{36}{|c|}{ Exposition: 146} & \multicolumn{11}{|c|}{ Development: 50} \\
\hline & \multirow{2}{*}{\multicolumn{6}{|c|}{$\mathbf{P}_{\mathrm{I}}: 28$}} & \multirow{2}{*}{\multicolumn{5}{|c|}{$\mathbf{P}_{\mathrm{II}}: 23$}} & \multicolumn{11}{|c|}{ TMB: 35} & \multicolumn{9}{|c|}{$S_{\mathrm{I}}, S_{\mathrm{I}}, S_{\mathrm{I}}: 36$} & \multirow{2}{*}{\multicolumn{5}{|c|}{ C: 16}} & \multicolumn{9}{|c|}{ TM, P: 42} & \multirow{2}{*}{\multicolumn{2}{|c|}{ I }} \\
\hline $\mathbf{I}$ & & & & & & & & & & & & & & 15 & & & 6 & & & 14 & & & & 10 & & & 10 & & & 10 & & & & & & & & 18 & & & & & 2 & & & & \\
\hline 8 & 4 & 5 & 8 & 4 & 5 & 2 & 7 & 4 & 4 & 2 & 6 & 4 & 3 & 4 & 2 & 2 & 4 & 2 & 2 & 2 & 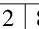 & 8 & 4 & 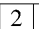 & 4 & 4 & 4 & 4 & 4 & 5 & 5 & 4 & 4 & 2 & 2 & 4 & 4 & 6 & 2 & 6 & 4 & 4 & 4 & 2 & 8 & 2 & 8 \\
\hline
\end{tabular}

\begin{tabular}{|l|l|l|l|l|l|l|l|l|l|l|l|l|l|l|l|l|}
\hline \multicolumn{8}{|c|}{ Second subdivision = Interludium: 67} \\
\hline \multicolumn{8}{|c|}{ A: 25} & \multicolumn{3}{|c|}{ B: 12} & \multicolumn{7}{|c|}{ A': 22} & \multicolumn{3}{|c|}{ B': 8} \\
\hline 8 & 4 & 4 & 5 & 4 & 4 & 2 & 2 & 4 & 2 & 4 & 3 & 2 & 8 & 3 & 2 & 6 \\
\hline
\end{tabular}

\begin{tabular}{|c|c|c|c|c|c|c|c|c|c|c|c|c|c|c|c|c|c|c|c|c|c|c|c|c|c|c|c|c|c|c|c|c|c|c|c|c|c|c|c|}
\hline \multicolumn{40}{|c|}{ Third subdivision: 161} \\
\hline \multicolumn{35}{|c|}{ Recapitulation: 141} & \multicolumn{5}{|c|}{ Coda: 20} \\
\hline & \multirow{2}{*}{\multicolumn{6}{|c|}{$\mathbf{P}_{\mathrm{I}}+\mathbf{P}_{\mathrm{II}}: 29$}} & \multicolumn{10}{|c|}{ TMB: 35} & \multicolumn{12}{|c|}{$\mathbf{S}_{\mathrm{I}}, \mathbf{S}_{\mathrm{II}}, \mathbf{S}_{\mathrm{I}}: 46$} & \multirow{2}{*}{\multicolumn{6}{|c|}{ CRI: 31}} & \multirow{2}{*}{\multicolumn{4}{|c|}{ C': 14}} & \multirow{2}{*}{ I' } \\
\hline & & & & & & & \multicolumn{4}{|c|}{15} & 6 & & \multicolumn{4}{|c|}{14} & \multicolumn{3}{|c|}{10} & \multicolumn{4}{|c|}{16} & \multicolumn{5}{|c|}{20} & & & & & & & & & & & \\
\hline 5 & 4 & 4 & 2 & 6 & 2 & 6 & 4 & 3 & 4 & 4 & 4 & 2 & 2 & 2 & 2 & 8 & 4 & 2 & 4 & 4 & \begin{tabular}{|l|}
4 \\
\end{tabular} & 4 & 4 & 3 & 6 & \begin{tabular}{|l|}
3 \\
\end{tabular} & \begin{tabular}{l|l|}
6 \\
\end{tabular} & 2 & 4 & 5 & 8 & 4 & 2 & 8 & 4 & \begin{tabular}{|l|}
4 \\
\end{tabular} & & 2 & 6 \\
\hline
\end{tabular}

Figure 3.3.13: Medtner, Sonata, Op. 22, numeric metrotechtonic graph

A number of authors have also related to a suitability of Georgy Conus's metrotechtonic analysis for the examination of Medtner's music. Conus had taught Medtner at the Moscow Conservatory for a brief period, ${ }^{89}$ presumably in 1899 , but there is no evidence of his teaching being particularly influential on the young composer. The relationship seems to have been rather on a familial level, as Medtner was close friends with Georgy's younger brother Lev Ėduardovich (1871-1944), the dedicatee of his Sonata-Idyll, Op. 56, and of two other works. Conus's theory of metrotechtonism developed to a leading paradigm of musical analysis in Soviet Russia during the 1920s and 1930s; however, as Medtner had still emigrated by this time, it cannot be verified if he was attracted by Conus's conceptions when they evolved prior to gaining overall significance. The fascination with symmetry, as characteristic of metrotechtonic analyses (see chapter 1.3.2), does not necessarily suggest the applicability of Conus's theory to Medtner's compositions, and if carried out, this procedure might still seem a bit arbitrary. ${ }^{90}$ However, the G minor Sonata, with its multi-dimensional symmetry and balance, particularly seems to call for a graphic visualisation that depicts its formal qualities. So, to conclude my analysis, I am additionally providing a metrotechtonic approach to the sonata (see figure 3.3.13), based on the initially proposed subdivisions of $196+67+161$ measures in length. ${ }^{91}$ The numeric graph is derived from the grouping of measures and phrases - and even if it does not form a perfectly symmetrical arch, like most of Conus's analyses do, it shows the sonata as a coherent whole which, in terms of its architecture and overall roundedness, »brings technical and musical demand to a genuine synthesis «. ${ }^{92}$ Even if Truscott's claim that »the work is without forerunners or successors « may seem a bit bold, ${ }^{93}$ we may anyhow state that, at the time of its genesis, it appeared without a match in the history of piano sonata composition.

89 Konsistorum 2004, p. 27, states that Medtner studied harmony with Conus in addition to Taneyev's counterpoint classes, which he attended only infrequently. See also Golovinsky 1956, p. 51, and Sarest 2014, p. 45.

90 Aleksandra Sarest has provided metrotechtonic analyses of the F minor Skazka, Op. 26 No. 3, and of the $1^{\text {st }}$ Piano Concerto in C minor, Op. 33. A possible legitimation for applying Conus's theory to Medtner's music is rendered ibid., p. $55 \mathrm{ff}$.

91 The structural diagram provided in Voroshilova 2004, p. 79, includes a very similar segmentation.

92 My translation of Flamm 2006, p. 9: »Zu einer genuinen Synthese von technischem und musikalischem Anspruch fand Metner wohl erst mit der Sonate g-moll op. 22."

93 Truscott 1956, p. 6. 


\subsection{SONATA-SKAZKA IN C MINOR, OP. 25 NO. 1}

Title page: Sonate-Conte / Märchen-Sonate (C-moll) / pour piano

Composed: 1910-11; premiered March 20, 1911, Moscow, by the composer

Dedication: Aleksandr Fëdorovich Goedicke [Gedike]

Editions: Édition Russe de Musique 1911, reprinted Boosey \& Hawkes before 1959; Muzgiz Collected Edition 1959 (Vol. 2, pp. 101-120), reprinted Dover 1998; Muzïka c. 1975

Recordings: Akselrod 1964; Iles 1975; Binns 1981; Svetlanov 1983; Fellegi 1989; Hanselmann 1989; Berman 1995; Tozer 1997; Hamelin 1998; Mejoueva 1998; Sama 1999; Milne 2000; Konsistorum 2001; Bekhterev 2004; Hadland 2004; Hominick 2007; Zhuravleva 2009; Avdeyeva 2015; Stewart 2016

\section{Narrative Tone, Ambiguous Structure}

The Sonata-Skazka (original German title of the first edition: Märchen-Sonate) is Medtner's sixth sonata in chronological order, and the first one to employ a three-movement form. The work has a duration of about 13 minutes and is dedicated to Medtner's cousin Aleksandr Goedicke. ${ }^{1}$ It was originally conceived as a sonatina, ${ }^{2}$ a denomination which is reflected in its comparatively moderate difficulty, while $\gg$ the calm, epicnarrative tone of the music which suggests a sense of recollection justifies the label of sonata. $\ll^{3}$ In its structural compactness and clarity, the work contrasts significantly to the preceding sonatas as well as to its massive companion published in the same opus, the E minor Sonata, Op. 25 No. 2. After the Sonata-Elegy, Op. 11 No. 2, the work is the second instance of Medtner fusing the sonata genre with the mood and texture of a piano character piece; the forms originating from this predilection were termed >genre sonatas ( zhanrovie sonatǐ) by Aleksandr Alekseyev and `sonata hybrids` (>sonatï-gibridï $<$ by Ekaterina Podporinova. ${ }^{4}$ In derivation from its ambiguous title, my examination of the Sonata-Skazka will depart from a central feature of this work, its narrativity, while later discussing the aspects of hybridity and formal cyclicity, apparent through the finale's unifying restatements of the earlier movements' main themes.

The composition of the sonata mainly falls into the year of 1910. Some sketches to the work are found aside drafts of the Eight Songs, Op. 24, and the E minor Sonata, Op. 25 No. 2, presumably dating from winter $1910-11 .^{5}$ After Medtner had intermittently planned to publish the work alongside with the G minor Sonata, Op. 22, he later resolved to pair it with the monumental E minor Sonata, maintaining his notion that the Sonata-Skazka did not >deserve< a proprietary opus number. ${ }^{6}$ After Medtner had premiered it in a concert at Rossiyskoe Blagorodnoe Sobranie in March 1911, the first edition was published in Édition Russe de Musique during the second half of the year. During the following years and decades, the Sonata-Skazka had

1 Goedicke later received the dedication of Medtner's $2^{\text {nd }}$ Violin Sonata in G major, Op. 44, as well. Nothing is reported of a re-dedication, and it is unclear if he ever performed Medtner's compositions as a pianist.

2 See Flamm 1995, p. 432. The author adds that it was Medtner's original intention to publish the Sonata-Skazka as Op. 22 No. 2, along with the G minor Sonata.

3 Kalendarev 2005, p. 31. See also Alekseyev 1969, p. 20: »The narrative character of the initial theme somehow explains the label `Sonata-Skazka«" (»Povestvovatel'nïy kharakter nachal'noy temï Allegro abbandonamente kak bï ob"yasnyaet i samo nazvanie >Sonata-Skazka/«).

4 Alekseyev 1969, p. 89; Podporinova 2007, p. 75.

5 Information given according to Flamm 1995, p. 432f.

6 This decision has caused some confusion among researchers. See ibid., as well as the hermeneutical remarks in the following chapter on the E minor Sonata, Op. 25 No. 2, for further details. 
considerable impact on some of his successors. Anatoly Aleksandrov, a composer who was strongly influenced by Medtner in his early creative period, published a Sonata-Skazka in F\# minor as his Op. 4 (1914), later revised and published as his $13^{\text {th }}$ Sonata (Op. 90, 1964). ${ }^{7}$ Some other works by Russian and Soviet composers also adopted the title, such as Issay Dobrowen's (1891-1953) Sonata-Skazka in Eb minor, Op. 5a (1913), Sergei Evseyev's (1894-1956) Sonata-Skazka for violin and piano, Op. 15 (1928), Nikolai Peyko's (1916-1995) one-movement Sonatina-Skazka in D minor (1943), and Dmitry Blagoy's (1930-1986) Sonata-Skazka (1958).

\subsubsection{ON NARRATIVITY}

In general, narrativity exists in Medtner's music as a perspective of reception and of analysis; this may apply even where no specific super-musical reference is given. Medtner's skazki, as his second most important genre of piano music, comprising a body of thirty-eight pieces, are especially likely to represent narrative or descriptive aspects, even if not all of them automatically imply such traits. In particular, a verbal suggestion of narrativity, the Italian term narrante, is found as a general indication in some skazki (such as Op. 26 No. 3, Op. 35 No. 3, Op. 42 No. 3, and Op. 54 No. 8). Several other pieces bear additional attributions, subtitles, labels, or poetic mottos, reinforcing a descriptive character as described in detail in chapter 2.5.3; and in this way, a significant portion of the skazki tends to evoke different kinds of imagery through verbal indications, suggesting a certain narrative quality which provides »musical signification«, as Byron Almén puts it. ${ }^{8}$ The same is true for Medtner's >genre sonatas«: attributes from other musical genres are likely to result in a subliminal narrative. Even if the works themselves do not tell a story - and must not be mistaken for programme music as they do not depict a comprehensible content—, ${ }^{9}$ they still represent the process of narration.

In this context, the expansion of a skazka to a multi-movement work (see also figure 2.5.1) is a process of significant consequence because it presupposes the hybrid combinations of the sonata and other types of character pieces appearing later in Medtner's œuvre. The possible transfer of topical phrases such as »Once upon a time«, the first line of a fairy tale, into music, might characterise the >storytelling many of Medtner's skazki. This also applies to the Sonata-Skazka, and particularly to the music of the opening sections of the first and second movements; Podporinova even observes an analogy between the narrative patterns unfolding in a fairy tale plot and the principles of development in sonata form, ${ }^{10}$ while David Nelson's proposal to refer to the Sonata-Skazka as a >legend deserves consideration as well. ${ }^{11}$

7 Scholars widely agree that Aleksandrov's $1^{\text {st }}$ Sonata is closely modelled on Medtner, who himself asserted that the work was indebted to Mussorgsky and Scriabin. See Pevzner 2013, p. 85ff. A more detailed comparison and narrative analysis of Medtner's and Aleksandrov's Sonati-Skazki is provided in Podporinova 2012.

8 See Almén 2008, p. 12. For more general thoughts on sonata form as a narrative, see chapter 1.3.3.

9 Anna Medtner is quoted in Ginsburg 1961, p. 56, that the term skazka »does not imply any particular story in connection with the music«, which »is left to the imagination of the listener«.

10 Podporinova 2012, p. 246: »Zakonomernosti razvërtïvaniya skazochnogo syuzheta okazïvayutsya podobnïmi printsipam razvitiya sonatnoy formï.«

11 Nelson 1991, p. 8: »'Legend might be a closer rendering and one that characterizes this sonata's dreamy opening and vaguely folkish, march-like finale.« 
Another aspect of this work's inherent narrative is the choice of key which arguably contributes to a certain semantic environment. Piano sonatas in $\mathrm{C}$ minor are frequently found during the $18^{\text {th }}$ and $19^{\text {th }}$ centuries, often conveying an idiomatic atmosphere associated with many of Beethoven's works in that key to exemplify a dramatic or pathetic character. ${ }^{12}$ But, as Medtner's Sonata-Skazka explicitly does not respond to such affirmative gestures, a possible predecessor may be seen in Joseph Haydn's C minor Sonata, Hob. XVI:20 (1771), a three-movement work with decent thematic subjects of a declamatory tone, appearing in restrained virtuosity and moderate tempo. ${ }^{13}$ We might thus state that, in Medtner, there are two possible instances of $\mathrm{C}$ minor: the boastful, pathetic, Beethovenian character, as found in the Sonata tragica, Op. 39 No. 5, and the $1^{\text {st }}$ Piano Concerto, Op. 33 - and the more lyrical and sometimes melancholic mood, rather typical of the skazki (Op. 8 No. 1; Op. 42 No. 2) and others of Medtner's character pieces (Moment musical, Op. 4 No. 3; Lyric Fragment, Op. 23 No. 1).

\subsubsection{ANALYSIS OF THE SCORE}

First movement: Allegro abbandonamente ${ }^{14}$ C minor - C major, $4 / 4, \downarrow=108,114$ measures on 10 pages

\begin{tabular}{|c|c|c|c|c|}
\hline \multirow{7}{*}{$\begin{array}{l}\text { SECTION } \\
1^{\text {st }} \text { exposition }\end{array}$} & THEMES AND SUBJECTS & POSITION & INDICATIONS & KEY \\
\hline & primary theme $\left(\mathrm{P}_{\mathrm{I}}\right)$ & mm. $1-4$ & $\mathrm{mf}$ & $\mathrm{C}$ minor \\
\hline & primary theme $\left(\mathrm{P}_{\mathrm{II}}\right)$ & mm. 5-14 & p carezzando & $\mathrm{C}$ minor \\
\hline & transitional idea: variant of $\mathrm{P}_{\mathrm{II}}$ & mm. 15-25 & f cantando & $\mathrm{C}$ minor \\
\hline & secondary theme $(\mathrm{S})$ & mm. 26-35 & p tranquillo (quasi V-cello) & G minor \\
\hline & transitional idea & mm. 36-44 & $\mathrm{p}$ stentato & $\mathrm{F} \sharp / \mathrm{G}$ minor \\
\hline & epilogue: $\mathrm{P}_{\mathrm{II}}$ in canon & mm. 45-58 & p carezzando & G minor \\
\hline \multirow[t]{5}{*}{$2^{\text {nd }}$ exposition } & primary theme $\left(\mathrm{P}_{\mathrm{I}}\right)$ & mm. 59-64 & [f] con forza & C minor \\
\hline & primary theme $\left(\mathrm{P}_{\mathrm{II}}\right)$ & mm. 65-68 & $\mathrm{p}$ dolce & $\mathrm{F} \#$ minor \\
\hline & transitional idea & mm. 69-78 & carezzando & $\mathrm{F} \#$ minor \\
\hline & secondary theme $(\mathrm{S})$ & mm. 79-88 & $\mathrm{p}$ tranquillo & A minor \\
\hline & epilogue: $\mathrm{P}_{\mathrm{II}}$ in canon & mm. 89-100 & $\mathrm{p}$ non legato & $\mathrm{C}$ minor \\
\hline conclusion & secondary theme, $\mathrm{P}_{\mathrm{I}}$ & mm. 101-114 & f espressivo ma a tempo & $\mathrm{C}$ major \\
\hline
\end{tabular}

12 See, for instance, Beethoven's Piano Sonatas, Opp. 10 No. 1, 13, and 101, and the $5^{\text {th }}$ Symphony, Op. 67. Medtner himself performed Beethoven's $3^{\text {rd }}$ Piano Concerto, Op. 37, and Grieg's $3^{\text {rd }}$ Violin Sonata, Op. 45, both C minor compositions in a largely pathetic tone. The key repeatedly occurs in the orchestral repertoire, particularly often in Russian symphonies, such as in Tchaikovsky's $2^{\text {nd }}$, Op. 17 (1872); Glazunov's $6^{\text {th }}$, Op. 58 (1896); Taneyev's Op. 12 (1898); Scriabin's $2^{\text {nd }}$ and $3^{\text {rd }}$, Op. 29 (1901) and Op. 43 (1902-04); and Myaskovsky's $1^{\text {st }}$ Symphony, Op. 3 (1908). C minor is also frequently found in Myaskovsky's piano works, such as the $3^{\text {rd }}$ and $4^{\text {th }}$ Piano Sonatas, Op. 19 (1920) and Op. 27 (1924-25). See also chapter 2.4.5.

13 Bertin 2018, p. 45, hints to a similarity in tone and voice-leading, comparing the three-part harmony of the initial themes of the $1^{\text {st }}$ movements of Haydn's C minor Sonata and Medtner's Sonata-Skazka.

14 This adjective doesn't actually exist in Italian; a more proper suggestion might be abbandonatamente (>abandoned >isolated ). See Robert Rimm in the foreword to the Dover edition, referenced in Tozer 1998, p. vi. 
The structure of the $1^{\text {st }}$ movement, »alluring through its formal compactness, the delicately balanced interaction of themes and their dense and forward-pushing development $\ll,{ }^{15}$ is ambiguous and, unlike Barrie Martyn asserts, nothing but a »regular sonata form $\ll .{ }^{16}$ Instead, transitory passages are permeating the two outer sections as well, and the high amount of motivic variation contained in the primary and secondary theme zones compensates the lack of a developmental middle section. The movement thus allows for different opposing interpretations of musical form, the first of which being a truncated sonata form with an omitted (or only unclearly defined) development section, as claimed by a number of authors - a concept termed by Sonata Theory as a >Type 1 Sonata $<.{ }^{17}$ However, the passage appearing to the listener as a varied restatement of the primary theme (m. 59ff.), a standard model of starting a development section, might also be recognised as the onset of a recapitulation section. Compared to the rather inconspicuous primary theme, the secondary theme zone gradually gains greater importance. The movement's formal ambiguity is particularly evident in the last part of the exposition section and its later restatement (serving as an epilogue in the place of a closing zone), where the primary theme appears in a cunning augmentation canon. ${ }^{18}$

Analyses have also highlighted internal symmetries in the movement's architecture, as does Podporinova in showing that the halves of the bipartite form are of nearly equal length, with the same observation applying to the primary theme zones and epilogues which frame both sections as a balanced »structural arch «. ${ }^{19}$ Another approach has viewed the piece as a »movement with secondary features of the sonata principle«, as termed by Oleg Sokolov, ${ }^{20}$ regarding the epilogue parts as instances of developmental sections attached to the exposition and recapitulation. In my analysis I propose a third possible outline, featuring a double exposition, each rotation of which forms a small ternary (A-B-A') with their respective primary and secondary theme zones, and concluded by the aforementioned epilogue. In assuming that there is no convincing development nor recapitulation section, I will refer to each of these subdivisions as an expositional space, with the latter one appearing as a variant of the former. The movement is finally concluded by a brief conclusion that restates the secondary theme in a final apotheosis.

The $1^{\text {st }}$ rotation of the exposition starts with an eight-measure primary subject $\left(\mathrm{P}_{\mathrm{I}}\right)$ in three-part harmony, characterised as »a theme breezed with tale atmosphere and filled with warm lyricism $\ll^{21}$ and $»$ narrative

15 My translation of Konsistorum 2004, p. 73: »Der erste Satz fasziniert durch seine formale Kompaktheit, das fein abgestimmte Zusammenspiel der Themen, ihre dichte und drängende Entwicklung.«

16 Martyn 1995, p. 84.

17 Hepokoski and Darcy 2006, p. 343ff. See also Protopopov 2010, p. 346f., who claims a bipartite form with two sections of almost equal length (exposition: 58 measures, recapitulation and conclusion: 56 measures) and also relates the recurrences of the secondary theme, as a sort of additional formal layer, to rondo form: »Pobochnaya tema poyavlyaetsya trizhdï [...], blagodarya chemu na vtorom plane formï obrazuetsya nechto rondoobraznoe« (ibid., p. 347).

18 In unconvincing attempts to identify a development section, some authors have located beginning of such a passage at m. 46ff. (Ginsburg 1961, p. 59f.; Skvorak 2003, p. 27) or m. 36ff. (Loftis 1970, p. 56). This shows that even if such a section is assumed, it is unclear where it is supposed to start.

19 See Podporinova 2007, p. 138: »Dopolnitel'naya strukturnaya arka skreplyaet èkspozitsiyu: g[lavnaya p[artiya] (14 t.) i z[aklyuchitel'naya] p[artiya] (14 t.) odnovremenno na razlichnïk urovnyakh nakhodit otrazhenie metnerovskaya ideya ravnovesiya (v chastnosti, vse sonatnïe partii otlichayutsya ravnovelikost'yu).«

20 Sokolov 1968 in Kuhn $2008^{\mathrm{a}}$, p. $180 \mathrm{ff}$.

21 Zetel 1981, p. 95. 
refraction of the composer's personal worldview «. ${ }^{22}$ It is subdivided in two elements: a first one, representing a chiastic $\mathrm{i}-\mathrm{V}-\mathrm{V}-\mathrm{i}$ scheme on the tonic and dominant chord, with the top voice repeatedly alternating between $G$ and $A b, 23$ and a second element (m. 3f.), setting the three voices in a fauxbourdon-style parallel downward motion (see example 3.4.1). The succession of both elements allows for an interpretation of intertwined period and sentence structures. The dominating rhythm of the Allegro abbandonamente is the combination of a quaver and two semiquavers, being heard throughout the whole primary theme zone. A third element appears in the continuation phrase ( $\mathrm{m}$. $5 \mathrm{f}$.: carezzando), here marked as the primary theme's second instance $\left(\mathrm{P}_{\mathrm{II}}\right)$, and employed as the basis for extensive motivic development from $\mathrm{m}$. 9 onwards. Its complementary rhythm reverberates in one of Medtner’s later compositions, Vögleins Märchen (»Birds’ Tale«), No. 2 from the Romantic Sketches for the Youth, Op. 54 (1931-32), also in C minor. There is a puzzling similarity in texture, rhythm, and sound - as if the earlier passage is echoed in the later (see example 3.4.2), ${ }^{24}$ and it might seem justified from a narrative perspective to interpret both passages as musical renderings of birdsong. To complete the primary theme zone, a motif derived from the second element perpetuates the complementary rhythm of semiquavers, now in a line of parallel sixths (m. 15ff.: cantando), and providing a transitional idea, departing from $\mathrm{C}$ minor to the contrasting key of $\mathrm{G}$ minor.

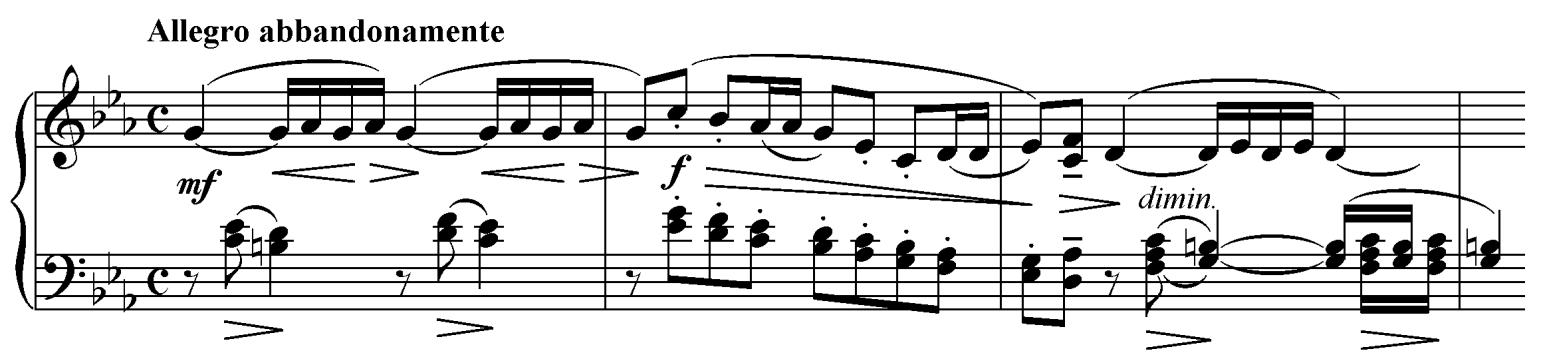

Example 3.4.1: Medtner, Sonata-Skazka, Op. 25 No. $1,1^{\text {st }}$ mvt, $1^{\text {st }}$ exposition, mm. 1-4

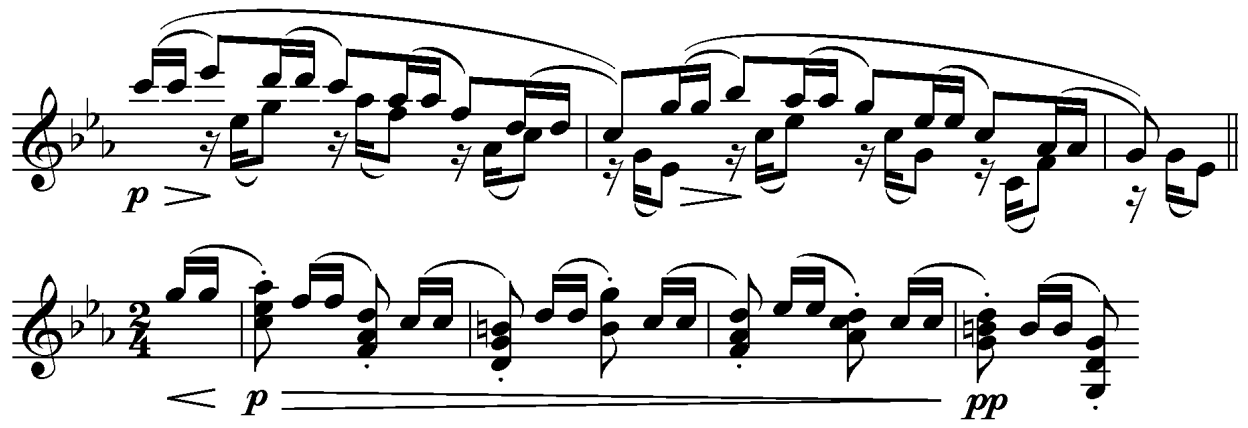

Example 3.4.2: Medtner, Sonata-Skazka, Op. 25 No. $1,1^{\text {st }}$ mvt, $1^{\text {st }}$ exposition, mm. 9-11// Medtner, Vögleins Märchen, Op. 54 No. 2, mm. 1-4

22 My translation of Tumanina 1960, p. 305: »Povestvovatel'noe nachalo, yasno oshchushchaemoe v pervonachal'noy teme, prelomleno v ney skvoz' lichnoe mirooshchushchenie kompozitora.«

23 The semiquaver figure is seemingly echoed in the $1^{\text {st }}$ movement of Prokofiev's $4^{\text {th }}$ Piano Sonata in C minor, Op. 29 (1917), mm. 21f. and 27f. I do not regard these passages as obvious quotations as they are derived from an inversion of the bass figuration from the movement's very beginning.

24 Zetel 1981, p. 106, refers to the beginning of Vögleins Märchen as »onomatopoetic« (»klangmalend«). 
The secondary theme zone is reached in $\mathrm{m}$. 26 with a tenor cantilena (tranquillo e molto cantando, quasi Violoncello), ${ }^{25}$ starting on the dominant of $\mathrm{G}$ minor. The theme is inventively structured as a four-measure sentence, comprising a sequenced presentation phrase of five crotchets, and a one-and-a-half-measure continuation. Two varied restatements of this subject are appended, compressed to three measures, and brightening to $\mathrm{B} b$ major as the melody is played in the descant (m. 33ff.). A short digression to $\mathrm{F} \#$ minor follows, referring back to the transitional idea (m. 36ff.: stentato), quickly modulating back to $\mathrm{G}$ minor. The aforementioned epilogue is then appended after a full cadence with a flattened-fifth dominant (m. 44). Here Medtner combines the descending scale of the primary theme's second element (left hand) with its augmented variant in crotchets, filled with repetitions of notes in accelerated motion of semiquaver triplets (m. 45ff.; see example 3.4.3). Thus, a refined augmentation canon is employed for a duration of four measures, transferring the contrapuntal features expected of a development section to the exposition. What is more, the secondary theme's continuation phrase also joins in $\mathrm{m}$. 49 , juxtaposed to reiterations of the primary theme.

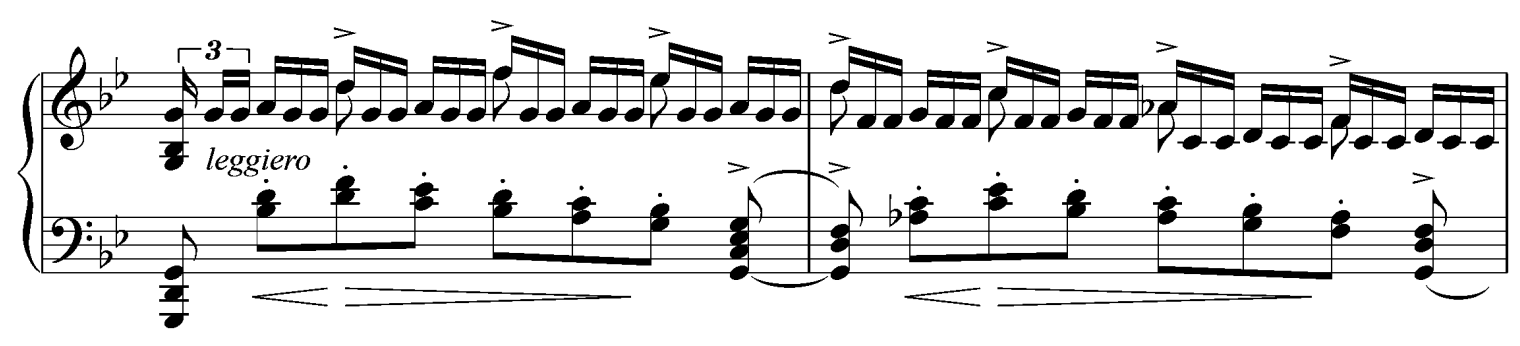

Example 3.4.3: Medtner, Sonata-Skazka, Op. 25 No. $1,1^{\text {st }}$ mvt, $1^{\text {st }}$ exposition, mm. $45-46$

As early as in m. 59 the primary theme enters again, con forza and above a dominant pedal, but without showing any affirmative qualities of recapitulation. ${ }^{26}$ In backview, this moment can be recognised as the beginning of the $2^{\text {nd }}$ expositional rotation. Medtner very soon modulates again to the remote region of $\mathrm{F} \#$ minor (m. 65ff.) for further intense processing of the primary theme's third element, referring back to the transitional idea of the $1^{\text {st }}$ exposition (m. 69ff.). The secondary theme's tenor cantilena is heard again in $\mathrm{m}$. 79, now in A minor, and in the same three-part sequential structure as heard before. Surprisingly, the modulation leading from A minor to $\mathrm{G} \#$ minor (completed in $\mathrm{m}$. 88) does not have further consequences here. Instead of restating the transitional idea like in the $1^{\text {st }}$ exposition, Medtner directly proceeds with a variant of the imitative epilogue, back again in $\mathrm{C}$ minor (m. 89: Tempo accelerando). This leads to a dramatic climax in semiquaver chords alternating between both hands (m. 96ff.), preparing for the final conclusion.

25 Bertin 2018, p. 46, notes that the theme, »written in the rich baritone range of the instrument«, is »not far away from the mood of Rachmaninov's Cello Sonata [op. 19] in the same key«.

26 However, this moment is recognised as the onset of a recapitulation section by most scholars, while some of them note the formal and harmonic irregularities of this section. See, for instance, Skvorak 2003, p. 28: »One twist of this >recapitulation<, though, is the fact that the thematic material is not yet all in the tonic key. [...] And even in arriving at the tonic, Medtner lessens its effect by going past it to G-sharp minor before stopping and suddenly bringing us back into $\mathrm{C}$ again for the coda.« 
When viewing the $1^{\text {st }}$ and $2^{\text {nd }}$ expositional rotations as a whole, they both appear as ternary structures with their respective secondary theme zones as a middle section, framed by two sections developing the primary theme. As such, these sections show qualities of formal roundedness rather than indicating recapitulation in the framework of a sonata trajectory. Since the $2^{\text {nd }}$ exposition is slightly shorter than the $1^{\text {st }}$, it requires a short concluding section, named coda by a number of authors, which provides the third and final statement of the secondary theme, transposed to $\mathrm{C}$ major (m. 101ff.). In this affirmative transformation, the conclusion functions as the movement's climax, with the primary subject's continuation phrase, ascending in range and dynamics, leading towards a fortissimo quote of the movement's opening measures (m. 111: risoluto) as a concluding back reference.

\section{Second movement: Andantino con moto Eb major, $3 / 4, \_=60-72,83$ measures on 4 pages}

$\begin{array}{lllll}\text { SECTION } & \text { THEMES AND SUBJECTS } & \text { POSITION } & \text { INDICATIONS } & \text { KEY } \\ \text { single section } & \text { main theme } & \mathrm{mm} .1-16 & \mathrm{p} \text { semplice } & \text { Eb major } \\ & \text { transitional idea } & \mathrm{mm} .17-20 & \mathrm{f} & \text { modulating } \\ & \text { antecedent of main theme } & \mathrm{mm} .21-34 & \mathrm{p} & \mathrm{B} b \text { major } \\ & \text { main theme } & \mathrm{mm} .35-50 & \mathrm{f} \text { pleno } & \text { Eb major } \\ & \text { transitional idea } & \mathrm{mm} .51-60 & \mathrm{ff} & \text { modulating } \\ & \text { retransition (quasi Cadenza) } & \mathrm{mm} .61-62 & \text { Lento, poco a poco accelerando } & \text { Eb major } \\ & \text { main theme + figuration } & \mathrm{mm} .63-70 & \mathrm{f} \text { leggiero } & \text { Eb major } \\ \text { transition to } 3^{\mathrm{rd}} \mathrm{mvt} & \text { continuation of main theme } & \mathrm{mm} .71-83 & \text { pp molto tranquillo }- \text { Allegro } & \text { modulating }\end{array}$

The outset of the sonata's $2^{\text {nd }}$ movement features a cantilena of remarkable beauty and simplicity, coining a »sphere of love lyricism «, ${ }^{27}$ a type of melody rarely found elsewhere in Medtner. Early reviewers described it as a »dithyrambic Andantino« with a »Chopinistic lyrical vein [...] coming to the surface ${ }^{28}{ }^{28}$ while Medtner's pupil Panteleymon Vasilyev observed a »lyrical state of mind, quiescence and romanticism «, ${ }^{29}$ later resembled by the Romanza from his $2^{\text {nd }}$ Piano Concerto, Op. 50 (1923-26). This Eb major theme also brings to mind the famous $18^{\text {th }}$ variation in $\mathrm{D} b$ major (Andante cantabile) from Rachmaninov's Rhapsody on a Theme of Paganini, Op. 43 (1934), a piece predated by Medtner's sonata by more than two decades. The melodies share their first five notes and then proceed differently; while Medtner starts with $B b-G-A b-B b-E b$, the Rachmaninov reads $A b-F-G b-A b-D b$ (see example 3.4.4). In general, detecting a similarity of that kind may prompt the researcher to classify the later composition as one of three cases: (a) an obvious and conscious quote; (b) an unconscious quote, or relevant coincidence, which might be hard to distinguish; or (c) an irrelevant coincidence. A direct adoption seems unlikely here, considering that Rachmaninov derived his melodic contour from the inversion of the theme of Paganini's $24^{\text {th }}$ Caprice. However, he might indeed have

27 Podporinova 2012, p. 250: »Ėto sfera lyubovnoy liriki.«

28 Engel 1911 in Flamm 1995, p. 299; Montagu-Nathan 1917, p. 240.

29 Vasilyev 1962, p. 21: »Liricheskaya nastroennost', pokoy i romantika ètogo Andantino prekrasno vïrazhenï shirokoy melodiey«. See also Flamm 2015a, p. 127, for more thoughts on the role of cantability in Medtner's piano textures. 
been inspired by Medtner's Sonata-Skazka, a piece he repeatedly performed in his recitals, ${ }^{30}$ and Barrie Martyn argues that, because of this fact, the similarity is more than pure coincidence. ${ }^{31}$ In any case, Rachmaninov's melody gains a specific narrative since it forms the only lyrical episode in a virtuoso composition with predominantly fast motion - a romance within a piano concerto. The same applies to Medtner: in its possible perception as a separate character piece, the movement might have been labelled a skazka just as convincingly.

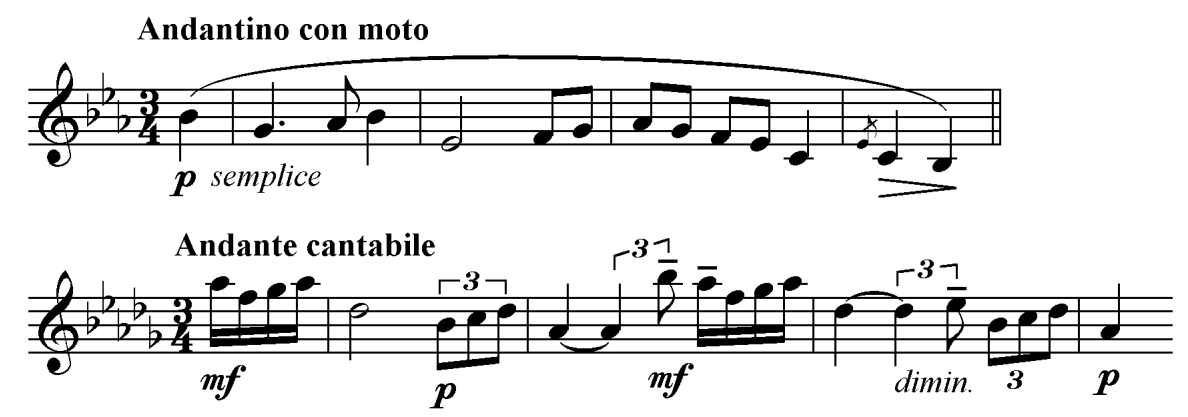

Example 3.4.4: Medtner, Sonata-Skazka, Op. 25 No. 1, $2^{\text {nd }} \mathrm{mvt}, \mathrm{mm} .1-4 / /$ Rachmaninov, Paganini Rhapsody, Op. 43, $18^{\text {th }}$ variation, mm. 3-6 (motivic reduction)

The whole movement is based on the abovementioned $\mathrm{Eb}$ major cantilena and its derivations, building up a rather diffuse formal model which might be identified as a type of theme and variations. ${ }^{32}$ In its first appearance as a main theme, it comprises eight measures with static harmonies unfolding over a tonic pedal. While the antecedent (mm. 1-4) is predominantly linear in motion, the consequent (mm. 5-8) includes a sequence of upward leaps of sixths and sevenths, still maintaining the initial semplice character. The following passage develops to a higher range and slightly increases in dynamics, with an evaded modulation to G minor in two instances, and leading to a chromatic passage (m. 17ff.) which serves as a transitional idea, modulating towards the next presentation of the main theme in $\mathrm{B} b$ major (m. 21ff.). The cantilena now appears in parallel thirds and shows an instable tonality, touching on $\mathrm{D}$ minor and being sequenced to $\mathrm{Ab}$ major and $\mathrm{C}$ minor, while omitting the theme's consequence phrase. Lawrance Collingwood described those modulatory progressions as »crushes of harmony «. ${ }^{33}$

These transformations eventually result in a full tutti restatement of the cantilena, back in Eb major (m. 35ff.: pleno). At the movement's climax, a charming sequence arises over a chromatically descending bassline $A b-G-F \#-F-E$. In the doubled pairing of a Neapolitan subdominant with a dominant seventh chord, the latter is reinterpreted as an augmented fifth-sixth chord resolving to the consecutive fourth-sixth triad.

30 Martyn 1995, p. 84, assumes that Rachmaninov chose this sonata because of its »compactness and melodic appeal«. Similarly, Morrison 2010, p. 14, notes »its appealing simplicity [which] makes it readily accessible on first hearing «. Another pianist who included the sonata in her repertoire was Tatyana Nikolayeva; see Zetel 1981, p. 241.

31 See Martyn 1995, p. 84, and also Martyn $1998^{\text {a }, ~ p . ~ 12: ~ » T h e ~ S o n a t a-S k a z k a, ~ w h o s e ~ m i d d l e ~ m o v e m e n t ' s ~ s t r i k i n g l y ~}$ beautiful theme anticipates by 23 years the famous $18^{\text {th }}$ variation of Rachmaninov's Paganini Rhapsody«. Be that as it may, there is another passage much more reminiscent of Rachmaninov- the secondary theme from the $1^{\text {st }}$ movement of Medtner's $2^{\text {nd }}$ Piano Concerto, Op. 50 (1923-26), echoing his delicate lyricism in conjunct melodic motion.

32 See Ginsburg 1961, p. 62.

33 Collingwood in Holt 1955, p. 144: »The beautiful middle movement [...] incidentally displays [Medtner's] employment of what I call, for lack of a better name, >crushes« of harmony.« 
Medtner thus realises a chromaticised variant of a cycle of fifths (m. $47 \mathrm{ff} .: \mathrm{D} b-\mathrm{G}^{7} ; \mathrm{B}-\mathrm{F}^{7}$; A). The chromatic bassline is then transferred to the top voice to restate the transitional idea from $\mathrm{m}$. $17 \mathrm{ff}$. While the quaver movement gradually accelerates to semiquaver triplets and demisemiquavers, a Lento quasi Cadenza episode is reached which serves as a retransition (m. 61f)., leading over to the last statement of the main theme. The melody's antecedent here shifts to the left hand, with the top voice sticking to the demisemiquaver figurations, while the consequent returns to its original design, featuring a tonic pedal with bell-like diatonic pentads on the even beats. The continuation from m. $9 \mathrm{ff}$. is now converted into a transitional passage connecting the $2^{\text {nd }}$ and $3^{\text {rd }}$ movements, rising again in tension and dynamics. Bursting trill figures (m. 78f.) and a scale descending over three octaves, representing a Phrygian dominant through the use of a flattened fifth $D$, prepare for the entrance of the finale. The katabasis arrives on a low $D$, followed by an open general pause, after which the energetic $3^{\text {rd }}$ movement is appended in attacca continuation.

Third movement: Allegro con spirito

C minor, $5 / 2-3 / 4-4 / 4, \downarrow=88,74$ measures on 6 pages

$\begin{array}{lllll}\text { SECTION } & \text { THEMES AND SUBJECTS } & \text { POSITION } & \text { INDICATIONS } & \text { KEY } \\ \text { first refrain } & \text { initial theme } & \mathrm{mm} .1-8 & \text { f portamento } & \mathrm{C} \text { minor } \\ & \text { subordinate idea } & \mathrm{mm} .9-16 & \mathrm{p} \text { leggiero } & \mathrm{G} / \mathrm{C} \text { minor } \\ \text { second refrain } & \text { variant of initial theme } & \mathrm{mm} .17-20 & \mathrm{p} \text { cantabile, legatissimo } & \mathrm{C} \text { minor } \\ & \text { reminiscence of subordinate idea } & \mathrm{mm} .21-24 & \mathrm{f} \text { risoluto } & \mathrm{C} \text { minor } \\ \text { backview section } & \text { main }\left(2^{\text {nd }} \mathrm{mvt}\right)+\text { transitional }\left(1^{\text {st }}\right) & \mathrm{mm} .25-43 & \text { Andantino } \text { p tranquillo } & \mathrm{Eb} \text { maj / F min } \\ & \text { subordinate idea }+ \text { secondary }\left(1^{\text {st }}\right) & \mathrm{mm} .44-49 & \text { Allegro con spirito } \text { p leggiero } & \mathrm{C} \text { minor } \\ & \text { primary (I, II) from } 1^{\text {st }} \mathrm{mvt} & \mathrm{mm} .50-74 & \mathrm{f} & \mathrm{C} \text { minor }\end{array}$

The finale's character has been variously described as a type of march, but a corrupted or deficient one.$^{34}$ Its initial theme of four measures is composed in an unusual 5/2 meter and in double counterpoint at the octave, ${ }^{35}$ being immediately repeated with swapped right and left hand voices (mm. 1-4 and 5-8; see example 3.4.5). Both voices equally contribute to the thematic quality of the beginning, establishing complementary rhythm, and it is hard to tell which one should be considered the leading part. The firm and compact texture of chords in parallel sixths, reminiscent of the final movement of Rachmaninov's $3^{\text {rd }}$ Piano Concerto in D minor, Op. 30 (1909), seems to serve as an affirmative conclusion to the sonata - but curiously, the theme is hardly developed any further in the course of the movement. After the four-measure presentations at the outset, both of which modulate to G minor, the following passage (m. 9ff.) once more returns to C minor, introducing a subordinate idea which only insignificantly contrasts to the main theme, ${ }^{36}$ and temporarily switches to $3 / 2$ meter. It is characterised through its stomping note repetitions in quavers, borrowing the dotted rhythm from the initial theme's counterpoint (m. 2).

34 Martyn 1995, p. 84: »a stern and imperious march«; Tozer 1999, p. 12: »Perhaps Medtner thought that if Tchaikovsky could succeed in writing the waltz from the Pathétique Symphony in 5/4 then he could achieve a march in a similarly $>$ wrong $<$ metre.«

35 See Vasilyev 1962, p. 21.

36 Due to the repetitions of pitches in the subordinate idea's melodic contour, Keller 1971, p. 125, observes a possible derivation from the $1^{\text {st }}$ movement's secondary theme. 


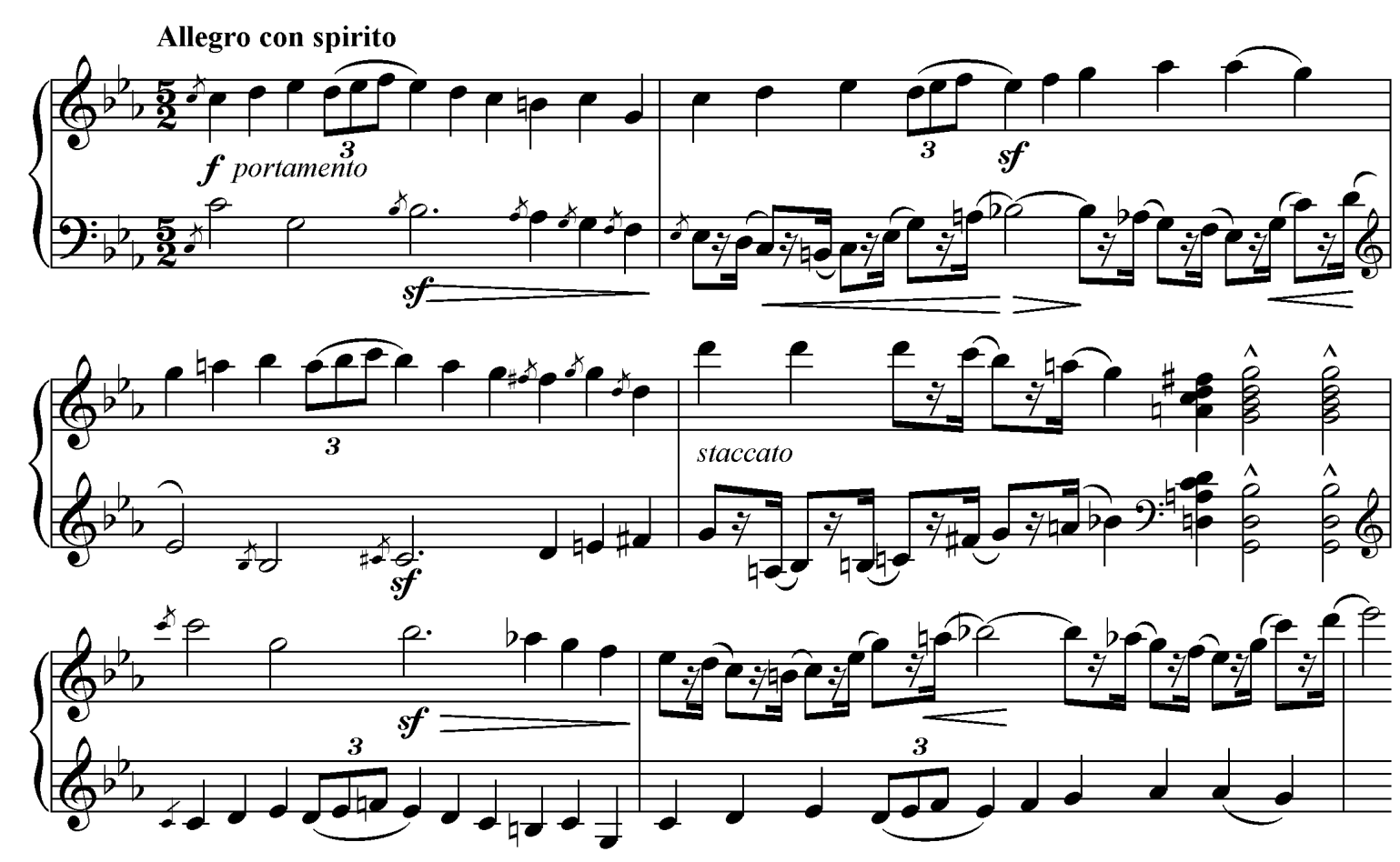

Example 3.4.5: Medtner, Sonata-Skazka, Op. 25 No. 1, $3^{\text {rd }}$ mvt, mm. 1-6 (motivic reduction)

Instead of establishing a firm thematic dualism, Medtner produces a strange hybrid of rondo and variation form, twice confronting the main theme with the subordinate idea as a type of rondo episode. A cantabile, legatissimo variant of the main theme's first four-measure element follows in $\mathrm{m}$. 17, in the same contrapuntal design as introduced at the movement's beginning, but with a continuous figuration of quaver triplets in the middle voice. The passage of $\mathrm{mm}$. 9-20, comprising the subordinate idea (as a first quasi-episode) and the second refrain, is then heard again - this is one of the rare occasions that Medtner makes use of repetition marks. The seconda volta of $\mathrm{m}$. 20 unexpectedly breaks off with a $\mathrm{HC}$ on the $3^{\text {rd }}$ beat of the $5 / 2$, followed by a mere fragment of the subordinate idea that, in risoluto character, only recurs for three measures before disappearing again, curiously abbreviated by two chords forming a lapidary PAC (m. 23f).

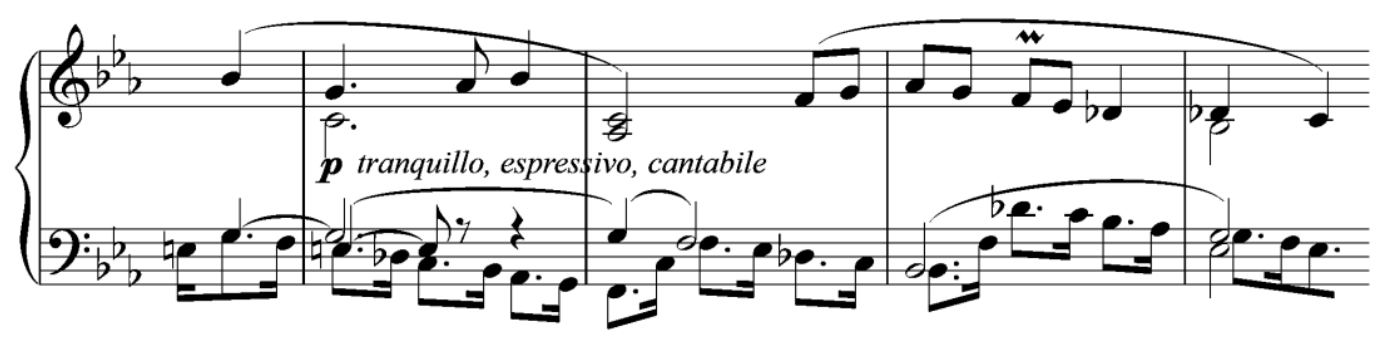

Example 3.4.6: Medtner, Sonata-Skazka, Op. 25 No. $1,3^{\text {rd }} \mathrm{mvt}$, mm. $25-28$

At this point Medtner is virtually done with the finale's material, arriving at a general pause totally unusual at this early stage of musical development. It would seem nearly ironic that the previous movements, not at all convincing in their respective sonata-like qualities, have to rely on such a stub of a finale. But, as a matter of fact, the sonata could not have ended here. What follows as the movement's second half is another section 
of nearly equal length, almost exclusively dedicated to backview to the $1^{\text {st }}$ and $2^{\text {nd }}$ movements, and appearing oddly separated to the finale's beginning. By this means the finale does not fail to provide a certain roundedness and cyclicity for the sonata as a whole, unifying it through a »masterful synthesis of the preceding movements, in apparent reference to the Russian epic tradition « ${ }^{37}$ In a freely designed, potpourri-style structure, denying any significant features of a first-movement form, Medtner starts over with a newly varied restatement of the $2^{\text {nd }}$ movement's Andantino cantilena (m. 25ff.; see example 3.4.6), maintaining the dotted rhythms of the finale's opening in the left hand. ${ }^{38}$ Natasha Konsistorum suggests that $\gg$ it is not by accident that, in the balladesque-chivalric $3^{\text {rd }}$ movement, Medtner returns to the $2^{\text {nd }}$ movement's main theme. After a tense rigor, the beginning of the $1^{\text {st }}$ movement tentatively reappears, sounding as from afar «. ${ }^{39}$ This $»$ pungent cross-relationship ${ }^{40}$ results, after modulating around $\mathrm{F}$ minor, in a cadential event (m. 42f.) recalling those of mm. 4 and 8 . Echoes of the $1^{\text {st }}$ movement's primary (mm. 50f., 52f.) and secondary theme $(\mathrm{mm} .46 \mathrm{f}$. and 56ff.; see example 3.4.7) follow, each of them combined with elements introduced during the first half of the finale - such as the dotted figures from the main theme, which also permeate the passage recalling the $2^{\text {nd }}$ movement, and approach the similar rhythmic design of the $1^{\text {st }}$ movement's transitional theme.

The quasi Violoncello secondary theme from the $1^{\text {st }}$ movement returns as well, interweaved with material from the finale's subordinate idea and various echoes of the sonata's narrative opening theme, while maintaining the $3 / 2$ meter throughout (m. 46ff.; see example 3.4.7). The last page of the score presents further elements derived from material of the $1^{\text {st }}$ movement, again accelerating to figures of quintuplets that explore the whole keyboard in upward and downward direction (m. 66ff.). This whole concluding passage is invariably centered in the tonic key of $\mathrm{C}$ minor, with no further tonal development being intended, and leaving the listener with a static, circulating impression of harmony. Similarly puzzling are the last few measures that barely deserve being referred to as a cadence - $\mathrm{a}$ few appoggiatura chords, each of them leaping down to $C$, proceed from $\mathrm{Ab}$ major and an enharmonically altered $\mathrm{Eb}$ minor (m. 71: with $F \#$ instead of $G$ b) back to $\mathrm{C}$ minor. Producing an aesthetic and compositional understatement of fascinating nature, this series of short and fragmentary events, all encircling the tonic in various guises, terminates a three-movement sonata layout which appears irregular in a considerable number of aspects.

37 Alekseyev 1969, p. 279f.: »V finale, primechatel'nom masterskim sintezom tematicheskogo materiala predshestvuyushchikh chastey, zametnï svyazi s russkoy épicheskoy traditsiey.« See also Skvorak 2003, p. 23, who states that the »relatively short movements are unified by recurrent thematic repetition and transformation that occurs throughout«, with the finale »becom[ing] a true showcase of thematic unification and compositional ingenuity« (ibid., p. 31).

38 The assertion in Bertin 2018, p. 57, of this passage acting like a Lisztian thematic transformation does not seem fully convincing as it lacks distinct changes in meter, tonality, or character.

39 My translation of Konsistorum 2004, p. 73: »Nicht zufällig kehrt er zu[m Hauptthema des zweiten Satzes] im balladenartig-chevaleresken dritten Satz zurück.«

40 Newman 1969, p. 726: »[Medtner] does apply his harmony in newly sensitive and fresh ways (as in [...] the diagonal relationships, passing dissonances, and pungent cross-relationships of Op. 25 / 1 [...]).« 


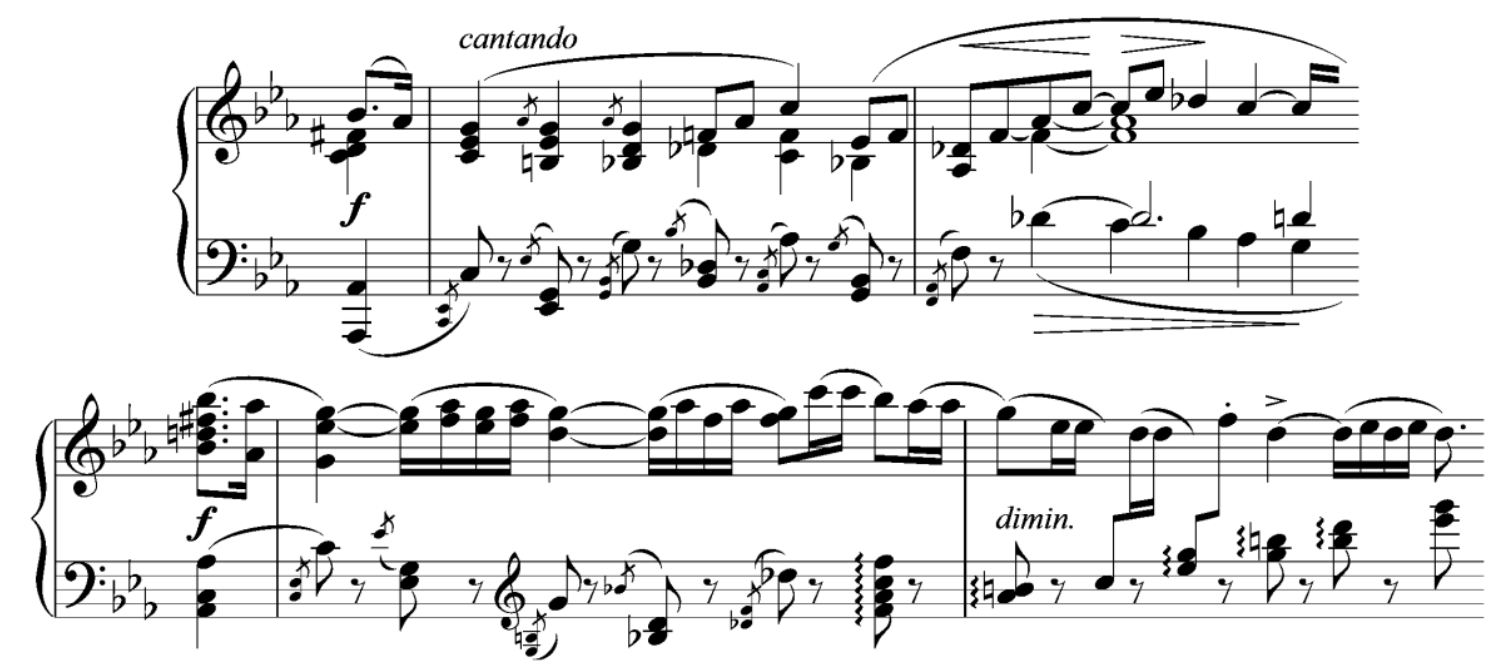

Example 3.4.7: Medtner, Sonata-Skazka, Op. 25 No. 1, $3^{\text {rd }}$ mvt, backview section, mm. 46-47 // mm. 50-51

\subsubsection{ON HYBRIDITY AND CYCLICITY}

In Medtner, borders of musical genres are frequently stretched, and appear permeable in many cases. For the sonata and skazka, this applies in both directions. When looking at the C minor Skazka, Op. 8 No. 2, or the E minor Skazka >March of the Paladin<, Op. 14 No. 2, we encounter character pieces composed in sonata form; these examples are hardly more convincing as character pieces than the first movement of Op. 25 No. 1. On the other hand, the Sonata-Skazka incorporates two movements that could also function as independent skazki beyond the scope of a sonata-both the Allegro abbandonamente and Andantino con moto exhibit narrative qualities through their mood and structure. Thus the Sonata-Skazka functions as a combination of Medtner's two most frequently used musical genres, which suggests two differing interpretations. It can be conceived as a sonata enriched with the narrative content associated with the skazka genre; or, alternatively, as a set of skazka-like movements compiled into the cyclic whole of a sonata. In Geoffrey Tozer's words, the work forms a »delightful three-part >storybook«« which »may be heard either as an elaborate three-part Fairy Tale or a Sonata even more vivid and programmatic than usual. Clearly the sonata is going to tell a story « ${ }^{41}$ Both genres' features are merged into a Symbolist cross-adaptation, the narrative of which is only subconsciously developing beneath the surface-Amanda Marsrow states that »Medtner's elusive blend of Symbolism and structure is nowhere more evident $\ll$ than here. ${ }^{42}$ Hybridity also determines the structural outline of the music: It is probably due to the opposed preconditions and aesthetic requirements of both genres that Medtner refrains from using formal archetypes at all. Neither of the three movements is composed in sonata form, nor adheres to any other traditional scheme. Instead, principles of free variation emerge in the second and third movements, prompting Isaak Zetel to refer to the sonata as a »decentralised cycle of variations « ${ }^{43}$

41 Tozer 1998, p. xiii, and Tozer 1999, p. 12.

42 Marsrow 2008, p. 91.

43 My translation of Zetel 1981, p. 122: »Die Sonate op. 25/1 bildet gleichsam einen dezentralisierten Variationszyklus. Hier basieren der erste und der dritte Satz auf dem Prinzip der Veränderung«. 
In considering the sonata an archetypical species of multi-movement cyclic form, the finale is the portion of the work that most likely entitles it to be classified as a sonata. As for the superposition of genres, this $3^{\text {rd }}$ movement is no less of a hybrid; but even if it does not resort to sonata or rondo form, its stern and affirmative initial theme gives the work a strong sense of directedness towards its ending. ${ }^{44}$ This teleology is questioned again at the finale's closure, dwindling away in perdendosi fragments instead of boasting a strong cadence. The incorporation of quotes from the other movements' main themes within the last section of the movement also makes it the most sonata-like part of the composition: Were it not for this movement, providing a cyclic link by restating the main themes from the preceding movements, the interconnection of the tripartite structure would be too weak to establish a cyclic whole. In this respect, the finale functions as an adhesive agent - a feature also found two decades later in the Sonata romantica in Bb minor, Op. 53 No. 1.

As a cyclic work, the Sonata-Skazka invites for some additional considerations. Charles Keller proposes to consider the $1^{\text {st }}$ movement a mere stub of sonata form, containing an exposition and development section, and to understand it as part of a >two-dimensional sonata form $<$ distributed over the three movements, with the recapitulation being saved for the finale. ${ }^{45}$ Another aspect is architectural symmetry, most convincingly unfolded in Medtner's G minor Sonata, Op. 22, but also evident in the Sonata-Skazka: Yuliya Moskalets introduces a scheme showing that, after the subordinate idea of the $3^{\text {rd }}$ movement functioning as the central axis of symmetry, the initial idea theme and the recurrences of themes from the previous movements are appended in reverse order (see figure 3.4.8). This structure represents a mirrored scheme of thematic entries within the overall trajectory of the sonata, even if it does not adhere to its real proportions or numbers of measures.

\begin{tabular}{|c|c|c|c|c|c|c|c|c|}
\hline A & $\mathrm{B}$ & $\mathrm{C}$ & $\mathrm{D}$ & E (central axis) & $\mathrm{D}$ & $\mathrm{C}$ & $\mathrm{B}$ & A \\
\hline $\begin{array}{c}1^{\text {st }} \text { mvt: } P \\
\text { (m. 1ff.) }\end{array}$ & $\begin{array}{l}1^{\text {st }} \text { mvt: } \mathrm{S} \\
\text { (m. 26ff.) }\end{array}$ & $\begin{array}{l}2^{\text {nd }} \text { mvt: } \\
\text { main theme } \\
\text { (m. 1ff.) }\end{array}$ & $\begin{array}{l}3^{\text {rd }} \text { mvt: } \\
\text { initial theme } \\
\text { (m. 1ff.) }\end{array}$ & $\begin{array}{c}3^{\text {rd }} \text { mvt: } \\
\text { subordinate idea } \\
\text { (m. 9ff.) }\end{array}$ & $\begin{array}{l}3^{\text {rd }} \text { mvt: } \\
\text { initial theme } \\
\text { (m. 16ff.) }\end{array}$ & $\begin{array}{c}3^{\text {rd }} \text { mvt: } \\
\text { th of } 2^{\text {nd }} \mathrm{mvt} \\
\text { (m. 26ff.) }\end{array}$ & $\begin{array}{l}3^{\text {rd }} \mathrm{mvt}: \\
\mathrm{S} \text { of } 1^{\text {st }} \mathrm{mvt} \\
\text { (m. 46ff.) }\end{array}$ & $\begin{array}{l}3^{\text {rd }} \mathrm{mvt}: \\
\text { P of } 1^{\text {st }} \mathrm{mvt} \\
\text { (m. } 50 \mathrm{ff} \text { ) }\end{array}$ \\
\hline
\end{tabular}

Figure 3.4.8: Medtner, Sonata-Skazka, Op. 25 No. 1, mirror scheme of theme entries after Moskalets $2004^{\mathrm{a}}$, p. 132

To sum up the foregoing considerations, Medtner's Sonata-Skazka remains highly ambiguous in form and musical content. The composition cannot, due to its title, be defined as pure absolute music; yet it is not assigned a definitive meaning, and thus the interpretation of its semantics is left to the recipient. An impalpable narrative, a fairy tale for instance, might be invented and filled in individually — or the work may be purposefully regarded as a polyvalent, or Symbolist, piece of art.

44 See Vasilyev 1962, p. 21.

45 See Keller 1971, p. 108f. Even if this unifying approach is a somewhat creative approach to the work, it neglects the fact that within the second half of the $1^{\text {st }}$ movement the tonic is stabilised again, which is a highly unusual process for a development section. Also, the finale's recollections of themes from the $1^{\text {st }}$ and $2^{\text {nd }}$ movements are not substantial enough to establish a »tonal recapitulation for the complete sonata (ibid., p. 122). 


\subsection{PiANO SONATA IN E MINOR, OP. 25 No. 2}

Title page: Sonate (E-moll) pour Piano // Sonata / Sonate / Motto by Tyutchev: »O chëm tï voyesh, vetr nochnoy« Composed: 1910-12; premiered February 27, 1912, Moscow, by the composer

Dedication: Sergei Vasilyevich Rachmaninov

Editions: Édition Russe de Musique 1912; Muzgiz Collected Edition 1959 (Vol. 2, pp. 121-181), with performance instruction »Vsya p'esa v ėpicheskom dukhe«, reprinted Dover 1998; Muzika c. 1975

Recordings: Milne 1977; Fellegi 1989; Lidsky 1995; Hamelin 1996; Tozer 1997; Stewart 1997; Mejoueva 2003; Preiser 2005; Eckardstein 2007 and 2012; Favorin 2009; Mejoueva 2009; Kholodenko 2013

\section{The Summit of Sonata Form}

The E minor Sonata is Medtner's longest and most complex composition for solo piano. Its textures are quasi-symphonic, and its dimensions are massive in every respect-the large single-movement form of approx. 35 minutes comprises 723 measures on 61 pages of score. ${ }^{1}$ Paired in one opus with a work representing its polar opposite in length and artistic pretension, the Sonata-Skazka, Op. 25 No. 1, the E minor Sonata is one of two of Medtner's compositions dedicated to Sergei Rachmaninov, ${ }^{2}$ the other being the $2^{\text {nd }}$ Piano Concerto in C minor, Op. 50 (1923-26). However, Rachmaninov would never perform the sonata in public, and it seems almost ironic in this context that the only Medtner sonata he programmed in his recitals was the Sonata-Skazka. Preceded by a verse motto by Fëdor Tyutchev and accordingly often referred to as the $>$ Night Wind Sonata<, and provided with a performance instruction suggesting an sepic< scope and content, the E minor Sonata allows for a rich network of intertextual and hermeneutic readings.

For so extended and elaborated a work, not many facts are known about the process of the manuscript's genesis. According to Christoph Flamm, early sketches to the material of the sonata's $2^{\text {nd }}$ subdivision, notated in the style of an study-like perpetuum mobile, date back to $1901{ }^{3}$ From the composer's annotations, Elena Dolinskaya concludes that he originally planned a second movement in rondo form - an intention he abandoned in favour of the eventual design of the $2^{\text {nd }}$ subdivision, the themes of which were derived »from the material of the $1^{\text {st }}$ subdivision «. ${ }^{4}$ The main period of elaboration seems to have started by autumn 1910 ,

1 Even if there are recordings of the F minor Sonata, Op. 5, of nearly equal length, most renderings of that work last for about 30-31 minutes. In contrast to the notions of Sorabji 1932, p. 60, who claims a playing time of »roughly forty-five minutes « for the E minor Sonata, and Flamm 2015a, p. 133, who states a similar length for the composer's own performance, Ilyin 1932, p. 306f., gives an account of Medtner performing the work in a non-public concert in Moscow, lasting 35 minutes without a break (»dlitsya bez pererïva 35 minut«). Most of today’s recordings have the sonata performed in 32-34 minutes.

2 Shaginyan 1957 in Wehrmeyer 2003, p. 205f., hints to a possible humiliation of Medtner who, after dedicating his sonata to Rachmaninov, might have expected something similar in return. Yet Rachmaninov, after receiving harsh criticism from Emil Medtner during the spring of 1914, decided to dedicate his choral symphony The Bells, Op. 35, to the conductor Willem Mengelberg - an artist with whom Medtner had sour memories from a called-off concert in 1910; see Martyn 1995, p. 78f.. A decade later, though, Rachmaninov dedicated his $4^{\text {th }}$ Piano Concerto in G minor, Op. 40 (completed in 1926) to Medtner, who would react with the re-dedication of his $2^{\text {nd }}$ Concerto which he was working on during this time. See also Clarke 2013.

3 All information on the sonata's genesis is given according to Flamm 1995, p. $433 \mathrm{f}$.

4 Dolinskaya 1996, p. 32: „Voznik variant resheniya formï sonatï v tselom: sonatnoe allegro i final-rondo. Pod pervïmi nabroskami osnovnoy temï vtorogo Allegro kompozitor pomechaet: `Finale e-moll podumat' o rondor. No dal'neyshiy protsess rabotï podskazal inoe: Metner sozdaet vtoroe Allegro kak bï `po materialam pervoy chasti<, no v bolee svobodnoy, tekuchey forme.« 
at a stage Medtner was simultaneously working on the Sonata-Skazka, Op. 25 No. 1, and on the Eight Songs, Op. 24, on poems by Tyutchev and Fet; this circumstance might have influenced the choice of a lyric motto for the E minor Sonata. The most part of the work was composed during summer and autumn 1911 in the Medtners' summer residence in Khlebnikogo, where the manuscript was completed and signed on January 3, 1912. After the premiere performance, given by Medtner in Rossiyskoe Blagorodnoe Sobranie in February 2012, the sonata was published later that year in Kusevitsky's Édition Russe de Musique. The work earned Medtner the Glinka Prize of the year 1916, alongside the Sonata-Ballade, Op. 27.

\subsubsection{RECEPTION AND PERFORMANCE}

Following the premiere, there were largely positive descriptions of the work in the Russian press and public life. According to David Dubal, Rachmaninov »was overwhelmed by the score«, and he »applauded and demanded for encores until the lights were put out «. ${ }^{5}$ Oskar von Riesemann wrote an euphoric review of the premiere, stating that »the E minor Sonata maybe represents the point of culmination of all his work «, ${ }^{6}$ and Ivan Ilyin was very impressed by a private performance given by Medtner the same year, which he described as »the pristine chaos and awakening storms of Medtner's powerful playing«, evoking »spells, orders, and laws, imperative towards the sound as well as the listener «. ${ }^{7}$ The following year, Nikolai Myaskovsky literally burst with fascination of the work, admitting that »no composition has given me greater satisfaction than the remarkable, I would even say inspired, E minor Sonata«, and naming it »one of the most substantial and outstanding compositions of the present time «. ${ }^{8}$ Music critic Grigory Prokofiev was similarly thrilled, stating that »from the point of view of wholeness of the design, this sonata is a real masterpiece, and in the craftsmanship of its execution it is really exceptional «. ${ }^{9}$ Vyacheslav Karatygin, on the contrary, attended Medtner's St Petersburg recital in January 1913 and gave a generally dismissive evaluation, only highlighting some technical aspects: »Interesting features of the E minor Sonata are [...] the sequences of tenths and ninths [...], and also the extended use of five-part meter (in the first section) and the many syncopations. The whole piece [...] not only reveals the influence of German classicism, but also that of Chopin on Medtner,

5 Dubal 1989, p. 545. The author asserts that Rachmaninov attended the premiere performance, which seems doubtful as this is not mentioned anywhere else. He might have confused this with Medtner's Moscow recital on March 24, 1916 - this concert was recalled by Anna Medtner as reported by Swan 1967, p. 84; translation quoted after Martyn 1995, p. 89.

6 Riesemann 1912, p. 16: »Iz novïkh veshchey Metner sïgral dve sonati, iz kotorïh vtoraya (e-moll), predstavlyaet iz sebya, mozhet bït', kul'minatsionnuyu tochku vsego ego tvorchestva.«

7 My translation of Ilyin 1932, p. 306f.: »[Sonata] [...] nesomaya edinïm dvukhtemnïm dïkhanniem >rodimogo khaosa i sprobudivshikhsya bur'‘... Metner igraet vlastno: èto zaklyatiya, prikazï, zakonï, povelitel'nïe i zvuku, i slushatelyu.«

8 Myaskovsky 1913 in Dolinskaya 1966, p. 35 (»Ni odno proizvedenie ne udovletvoryalo menya bolee, nezheli zamechatel'naya, ya dumayu, dazhe genial'naya e-moll'naya sonata «), translation quoted after Campbell 2003, p. 190; Myaskovsky in a letter to Sergei Prokofiev on January 26, 1913 (»Ego poslednyaya sonata [:] odno iz naibolee soderzhatel'nïkh i vïdayushchikhsya sochinenii sovremennosti«), translation quoted after Martyn 1995, p. 89.

9 Prokofiev 1913, p. 70: »S tochki zreniya tsel'nosti zamïsla èta sonata-pryamo shedevr, i po masterstvu fakturï ona yavlyaetsya pryamo isklyuchitel'noy«, translation from Martyn, ibid. Some authors, such as Orlova 1982, p. 174, and Rimm 1999, p. 41, have apparently mistaken the critic Grigory Prokofiev for the composer Sergei Prokofiev who did not comment on the work. 
and is wholly monotonous and lengthy. $\ll^{10}$ Leonid Sabaneyev, however, positively related to these influences as he felt a special kinship to Beethoven. ${ }^{11}$ The most appreciative advocate of the work was Kaikhosru Sorabji, who repeatedly considered it a summit of piano composition, acknowledging it as an epic work-an attribution I will later elaborate on in more detail.

»This splendid specimen [...] is indubitably the greatest piano work that has come from contemporary Russia. [...] Mr Ernest Newman, I believe, wrote an article on the composer and his work [...], in the course of which [he] observed that Medtner's was the temperament that would one day give us an epic in music. [NB: Sorabji refers to Newman 1915, an article from The Musical Times, which he misremembers with regard to the repic in music<, a phrase not mentioned in it.] He has most certainly done so in the great E minor Sonata; and I seem to recollect wondering why Mr Newman did not mention this work in his article. [NB: This is exactly what Newman did]. [...] Very darkly and sombrely coloured, it is charged from first to last with the intense, infinite, and inhuman sadness of vast, cold, lonely expanses - a true elegiac nature poem. It is, one feels sure, much more truly and essentially Russian [...]; but it has an intellectual power and grip in which much Russian art, particularly music, seems deficient, and this is doubtless owing to Medtner's German ancestry. ${ }^{12}$

»I am inclined to give primacy of place, among the works for piano solo, to the great E minor Sonata [...]. I question whether any other work in the same genre $[\ldots]$ retains its impressive power, its assertion of itself as one of the major pianistic masterpieces of modern times. Of immense difficulty and intricacy and of great length, it is in one continuous musical stream. $\ll^{13}$

After two more performances in Moscow, given by Medtner himself in 1913 and 1916, the E minor Sonata seems hardly ever to have been programmed. ${ }^{14}$ Other pianists to champion the sonata were Samuil Feinberg, whose repertoire also included the Sonata-Ballade, Op. 27, and Georgy Edelman, a student of Feliks Blumenfeld at the Moscow Conservatory, who worked on the sonata with Medtner in $1927,{ }^{15}$ but there are no accounts of their performances. The Maharadjah of Mysore, Medtner's patron of his late years, had urged the composer to record it himself in 1948; yet this turned out impossible due to Medtner's bad health. ${ }^{16}$ So the first professional recording of the work was done by Hamish Milne only in 1977, which made it the next to last of Medtner's sonatas on record, except only for the F minor Sonata, Op. 5; this might illustrate the challenge that the work poses to performers until today. Notable recordings of the recent time include those of Marc-André Hamelin and Geoffrey Tozer, as well as two renderings by Severin von Eckardstein of 2007 and 2012.

10 My translation of Karatygin in Flamm 1995, p. 306: »V e-Moll'noy sonate lyubopïtnï, mezhdu prochim, sekventsionnïe khodï detsim $\mathrm{i}$ non, chereduyushchikhsya s tertsiyami (v nachale), interesno obshirnoe primenenie 5dol'nogo ritma ( v 1 chasti), svoeobraznï mnogie sinkopicheskie obrazovaniya. Vse sochinenie izlozheno v slitnïkh formakh (sonata kak bï v odnoy chasti), oblichaet vliyanie na Metnera ne tol'ko nemetskikh klassikov, no i Shopena, i v obshchem odnoobrazno i rastyanuto.«

11 Sabaneyev 1928, p. 210: »Beethoven's spirit, the spirit of the last Quartets, reigns over Medtner's Sonatas, over his monumental Sonata in E minor.«

12 Sorabji 1932, p. 60f., with my annotations.

13 Sorabji in Holt 1955, p. 127f.

14 Martens 1919, p. 361: »Owing to its great length and complexity, it is seldom played in public, even by the composer.«

15 See Zetel 1981, p. 243, giving a short account of Edelman's memories.

16 Ibid., p. 79. 


\subsubsection{STRUCTURAL PROBLEMS}

The sonata is cast in one large movement; yet it has hardly anything in common with Medtner's earlier approaches to single-movement form. Due to the concurrence of opposed formal concepts such as sonata form, rondo form, and fugue, the work features an ambivalent outline, and the overall structure resulting from these ambiguities makes it appear unparalleled in the history of sonata composition. Most authors have insisted that the work contains two movements in sonata form, or respectively »an introduction and two massive sonata-allegros, connected through thematic unity «, ${ }^{17}$ while others have claimed the second half to resemble a »fantasy « or »free improvisation ${ }^{18}$ — but the structure is in fact more complicated. While it is true that the sonata shows an extreme coherence of intonation and thematic work with regard to its larger and smaller sections $«,{ }^{19}$ there are two clearly discernible main subdivisions (a term more appropriate than $>$ movements $<$ ) framed by an Introduzione, and interconnected through their motivic material — as Geoffrey Tozer aptly puts it, »two monumental Allegro movements prefaced, joined, and finally crowned in a grand peroration by a grand Introduzione rich in thematic possibilities « ${ }^{20}$ Yet there are a number of further aspects contributing to the work's structural morphogenesis. First, we can observe an alternation between firmly-knit regions of clear syntactical organisation and more loosely-knit (or rhapsodic) episodes that tend to destabilise the overall form; and second, the unusually frequent recurrences of the Introduzione's material create an impression of rondo, or more adequately, ritornello form. These aspects may be considered atypical in this context as they contradict the traditional teleology and dynamic processuality of form which is in many cases inherent to the sonata genre. Moreover, the work may appear as a curiously diverse and capricious, fantasy-style, and even potpourresque whole, especially with regard to the barely graspable internal structure of its $2^{\text {nd }}$ subdivision.

However, there are also evident features typical of sonata form, such as the enormous Allegro in 15/8 time which forms the $1^{\text {st }}$ subdivision, as well as increasing motivic density and synthesis of themes throughout the work. Through its targetedness towards the final section, Medtner's approach proves to be significantly indebted to Beethoven's sonata philosophy. The idea of Liszt's B minor Sonata, on the contrary, does not serve as an apparent model-Medtner's work cannot be conceived as a work in `two-dimensional ( double-function) form, as it does not show features of a sonata movement and sonata cycle at the same time. Instead, it oscillates between a single and double movement conception, thus opposing an integrative entity to a bipolar formal contrast. By this means the work exhibits a synthesising aspect (with regard to the traditionally-shaped $1^{\text {st }}$ subdivision and the Introduzione as a framing agent) and, simultaneously, a dissociative force (with regard to the improvisational $2^{\text {nd }}$ subdivision).

17 My translation of Dolinskaya 1966, p. 32: »Forma sonatï neobïchna: introduktsiya i dva ogromnïkh sonatnïkh allegro, svyazannïkh tematicheskim edinstvom.« See also Alekseev 1969, p. 289; Keller 1971, p. 128; and many other places.

18 Martyn 1995, p. 86f. See also Tozer 1999, p. 13, and Eckardstein 2007, p. 16.

19 My translation of Chernova 2007, p. 78f.: »Sonata [...] demonstriruet chrezvïchaynuyu intonatsionno-tematicheskuyu spayannost' svoikh krupnïkh i melkikh chastey«.

20 Tozer 1999, p. 13, emphasising the rhetoric qualities of the introduction and its recurrences. 
One possible approach to the sonata in its entirety is to use graphical analogies such as Marie-Agnes Dittrich proposes in her publication Musikalische Formen. ${ }^{21}$ The teleological dramaturgy of sonata movements and expositions is visualised using the elements of arch and arrow - these may be applied to the $1^{\text {st }}$ subdivision of Medtner's work. The circle, in contrast, symbolises less directional forms; I am altering this element into an ellipse with a waved double-arrow so as to depict the flexible network of interrelations and motivic transformations in the $2^{\text {nd }}$ subdivision (see figure 3.5.1). Thus, an unidirectional, rather traditional sonata form is paired here with a counterpart of equal weight and dimension, but in a less teleological, potpourri-like trajectory, combining features of fantasy, sonata, and rondo form with fugal characteristics in a spectacular manner.

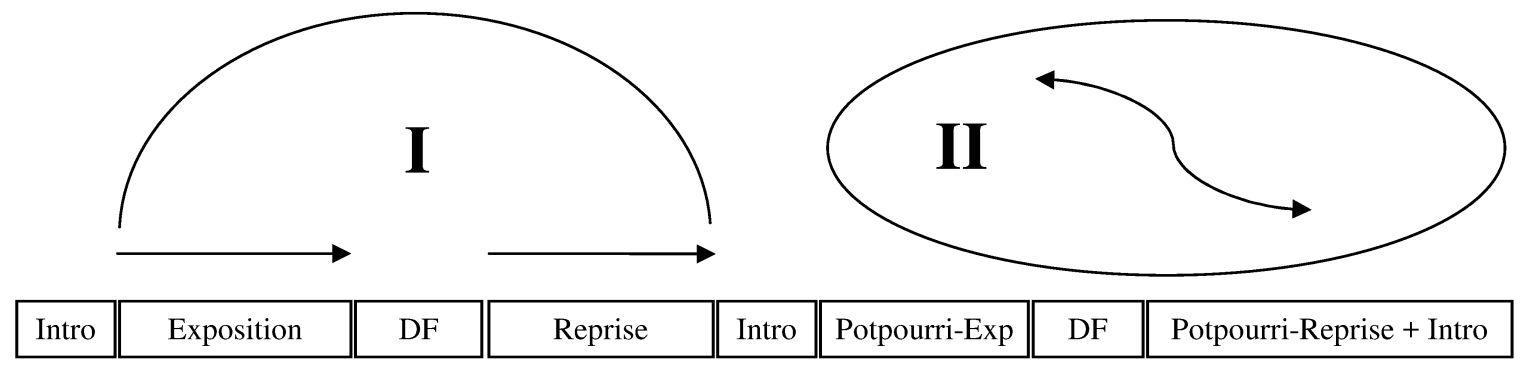

Figure 3.5.1: Medtner, Sonata, Op. 25 No. 2, structural graph with arch-like and elliptic shapes

The Introduzione borders the sonata's two main subdivisions, with its calmly evolving introductory theme frequently returning in the course of the sonata, determining the crucial points of the overall form, and providing an adhesive means in a massive structure which might be likely to diverge during performance. ${ }^{22}$ On first instance, it is stated as a large tranquillo prologue (m. 2ff.). It then returns, increasing in intensity, at the middle of the work, preceding the $2^{\text {nd }}$ subdivision (m. 250ff.). After that, it reappears more and more frequently: at the onset of the $2^{\text {nd }}$ subdivision's development section (m. 442ff.); in several other places during the continuation of that passage, interweaved with other themes from the $2^{\text {nd }}$ subdivision, and tending to gain power with every reiteration (mm. 362ff., 577ff., 595ff., 616ff., 697ff.); and it also marks the beginning of the sonata's majestic final culmination (m. 631ff.). The introductory theme thus pervades the whole last third of the work and, as a cyclic agent, is brought to several consecutive climaxes to eventually conclude the sonata. Moreover, as Yuliya Moskalets notes, »it takes effect as a means of (vertical and architectural) mirror symmetry [...]. The introduction, in original shape and inversion, is repeated at the end of the $1^{\text {st }}$ movement; the recapitulation mirrors the exposition, the development stands at the centre ${ }^{23}$ Even if this view misinterprets the middle passage as belonging to the $1^{\text {st }}$ subdivision, it emphasises the introduction's framing function.

21 Dittrich 2011, p. 7, develops a series of analogies between archetypes of musical form and their graphical representations. While the small ternary, sonata form, and rondo forms are associated with the model of an arch, the arrow type is found in introductions, bar forms, and expositions (also as part of sonata form), and the circle appears as a model for ostinato forms or musical plateaus (»Klangfläche«).

22 This aspect lets the work appear somewhat indebted to the $1^{\text {st }}$ movement of Beethoven's C minor Sonata $>$ Pathétique Op. 13, the slow introduction of which also recurs at crucial points throughout the piece. See Bertin 2018, p. 105.

23 My translation of Moskalets 2004a , p. 131: »Deystvie printsipa zerkal'noy simmetrii nablyudaetsya i v kompozitsii vsey pervoy chasti [...]. Introduktsiya s normativnïm i obrashchennïm zvuchaniem temï povtoryaetsya v kontse I chasti; èkspozitsii sootvetstvuet repriza, tsentr—razrabotka«. Similar notions are found in Podporinova 2007, p. 149. 
Due to the abovementioned features, the main challenge of the sonata's dramaturgy lies in the mere existence of the $2^{\text {nd }}$ subdivision. Even if it also shows traits of sonata form, it is introduced only after a full-scale section of that type has already been heard, with its themes being derived from those of the $1^{\text {st }}$ subdivision. This fact demands for a special legitimation. The sonata's overall balance is not primarily achieved by cyclicity or by the hierarchical order of its sections, but rather through the dialectic role of the $2^{\text {nd }}$ subdivision - it simultaneously functions as an antithesis to the $1^{\text {st }}$ subdivision and, at the same time, as a synthesis of both parts with the introduction. This aspect represents, in my opinion, the work's most distinctive peculiarity, and makes it transcend the sonata conceptions of the Liszt school as well as those of Medtner's contemporaries. We do not find similar approaches in the music of Scriabin, Prokofiev, or Myaskovsky, nor do the singlemovement sonatas of composers such as Eugène Ysaÿe, Karol Szymanowski, or Arnold Bax show tendencies of this kind.

\subsubsection{HERMENEUTICS: THE LYRIC ELEMENT}

О чем ты воешь, ветр ночной?

О чем так сетуешь безумно?..

Что значит странный голос твой,

То глухо жалобный, то шумно?

Понятным сердцу языком

Твердишь о непонятной муке -

И роешь и взрываешь в нем

Порой неистовые звуки! ...

O, страшных песен сих не пой Про древний хаос, про родимый!

Как жадно мир души ночной Внимает повести любимой!

Из смертной рвется он груди, Он с беспредельным жаждет слиться!

O, бурь заснувших не буди -

Под ними хаос шевелится! ...

Fëdor Ivanovich Tyutchev (1836)
Why do you howl, night wind?

Why do you complain insanely?

Your voice is strange. What does it mean?

First muffled, pitiful, then loud?

My heart understands your tongue,

your tale of madness it can't,

and at times you uproot and plough up

frenzied noises in your words!

Don't sing these songs, these fearsome songs of ancient Chaos, kindred Chaos!

How avidly the inner soul of night hears the beloved tale!

It wants to burst from the breast,

it wants to merge with the boundless.

Oh, do not wake the sleeping storms -

Chaos writhes beneath them!

Translation by Frank Jude (2000) ${ }^{24}$

\author{
What do you howl about, night wind? \\ What do you lament so wildly? \\ What does your strange voice mean, \\ Now mutely, now noisily complaining? \\ In a language comprehensible to the heart \\ You reiterate incomprehensible torment - \\ And you burrow and arouse in the heart \\ Sounds that are at times furious!... \\ $\mathrm{O}$, do not sing these fearsome songs \\ About ancient, native chaos! \\ How greedily in the world of the night soul \\ Drinks in its favourite tale! \\ It tears itself from the mortal breast, \\ It strives to fuse with the infinite ... \\ $\mathrm{O}$, do not rouse storms that have fallen asleep - \\ Beneath them chaos stirs! ... \\ Translation by Michael Wachtel $(2018)^{25}$
}

We will now turn to some narrative approaches which might, in addition to its structural features, help understand the music in a more imaginative, or metaphysical, way. The most obvious element to go beyond the objectivity of the score is the initial motto which is taken from an 1836 poem by Fëdor Ivanovich Tyutchev: »O chëm tï voyesh, vetr nochnoy« (»What do you howl about, wind of the night?«), to quote only the first line. ${ }^{26}$ Martyn asserts that Tyutchev's poem be captioned Silentium — which is incorrect as the latter title was

24 Published online at Russkiy Pereplet (accessed January 16, 2018).

25 Published in the liner notes of Caspar Vos's recording of the Op. 25 sonatas, Seven Mountain Records 2018 , $7 \mathrm{MNTN}-011$.

26 Flamm 2009, p. 50, points out that Emil Medtner had related to this very poem to describe Beethoven's $5^{\text {th }}$ Symphony at the time his brother composed the E minor Sonata. 
given to an earlier poem of 1830 , while $» \mathrm{O}$ chëm tï voyesh « is untitled. ${ }^{27}$ The first edition includes the poem in full text, and so do the subsequent prints, mostly arranged in two columns quoting two eight-lined stanzas side by side, located between the title and the top stave of the music. The poem's first line also provides an inofficial subtitle for the sonata, and it has become common over time among pianists to refer to the work as the >Night Wind Sonata . By this means, it appears in a similar context as a number of Medtner's other sonatas with descriptive attributes, such as Sonata tragica or Sonata romantica - but, in contrast to these, the reference to wind as a poetic character gives this ascription a more distinct personality and, as common in Symbolist art, a superordinate narrative easily applicable to the music.

In piano sonatas, inspirations through poetry or drama do have a certain tradition. A first reference point for this phenomenon is, although not a sonata by title, Robert Schumann's C major Fantasy, Op. 17 (183638), to which the composer attached an epigraph by Friedrich Schlegel. ${ }^{28}$ This tendency is further exemplified by Liszt's B minor Sonata (1849-53) and Rachmaninov's $1^{\text {st }}$ Sonata in D minor, Op. 28 (1908), both pointing towards the dramatis personae of Goethe's Faust, as well as by Brahms's $3^{\text {rd }}$ Sonata in F minor, Op. 5 (1853), the $2^{\text {nd }}$ movement of which quotes three verses of Sternau's poem Junge Liebe. ${ }^{29}$ In a different way, Scriabin's $5^{\text {th }}$ Sonata, Op. 53 (1907) is also inspired by literature as it bears a motto of Scriabin's own hand, taken from his extensive epic verse Le poème de l'extase, ${ }^{30}$ which was written alongside the composition of the sonata and the symphonic poem of the same title, Op. 54 (see also chapter 1.2.2). However, Scriabin does not seem to have influenced Medtner in relating his compositions to literature, and his own first approach towards incorporating a lyric epigraph (from Goethe's Trilogy of Passion) in the Sonata Triad, Op. 11 , is of a totally different nature, creating a rather distant relation between words and music.

Interpreting the $>$ Night Wind Sonata allows for a closer correlation of the composition and the preceding epigraph. The sonata seems to respond to the poem in two different ways: with regard to its expressiona highly agitated tone, corresponding with a sombre atmosphere and extreme gestures, can be found in the poetry as well as in the music — and maybe also concerning musical form. Even if Medtner himself never hinted to this issue, it seems well imaginable that he shaped the sonata's two subdivisions to match the poem's two stanzas. Dolinskaya acknowledges the work as a »tyutchevskaya sonata«, interpreting its »bipartite form in response to the structure of the poem «. ${ }^{31}$ When, in the second stanza, Tyutchev relates to the Night Wind's affinity to transcendence and chaos, lingering within the »sleeping storms «, the vocabulary tends to find an equivalent in the seemingly chaotic construction of the sonata's $2^{\text {nd }}$ subdivision. In

27 See Martyn 1995, p. 85. A number of other authors follow his assumption.

28 The motto verses put in front of the score, taken from the poem Die Gebüsche out of Schlegel's Abendröte cycle, read as follows: »Durch alle Töne tönet / Im bunten Erdentraum / Ein leiser Ton gezogen / Für den der heimlich lauschet $\ll$.

29 C. O. Sternau was the pen name of Otto Julius Inkermann. The lines used by Brahms read »Der Abend dämmert, das Mondlicht scheint / da sind zwei Herzen in Liebe vereint / und halten sich selig umfangen.«.

30 Scriabin includes the following verses, translated to French from the Russian original text: »Je vous appelle à la vie, ô forces mystérieuses! / Noyées dans les obscures profondeurs / De l'esprit créateur, craintives / Ébauches de vie, à vous j'apporte l'audace. « See also Scriabin's programme notes to his $3^{\text {rd }}$ Piano Sonata in F\# minor, Op. 23, as quoted in Delson 1961, p. 21.

31 Dolinskaya 1966, p. 169; ibid., p. 32: »Dvukhchastnaya forma sonatï sootvetsvuet strukture dvukh strof tyutchevskogo stikhotvoreniya.« 
Panteleymon Vasilyev's words, »the first sonata movement proved not suitable for Medtner to measure up to this primordial chaos [...], and he needed to begin another, even more terrific, movement [...] which appears as if the composer struggled to sufficiently use the sounds to express the imagination of >sleeping storms « « ${ }^{32}$ This being said, we might claim that the musical logic seems to be derived from the poetic logic: the composition in a way continues the narrative of the poem, and Medtner literally wakes the storms that were left sleeping by Tyutchev - and while the first stanza tells of the wind as a real natural phenomenon, the second metaphorically refers to the interior`storms within the human soul. ${ }^{33}$ However, this hermeneutic approach is only one of several possible interpretations at hand.

Another hermeneutic context is provided by the three-note initial motif $G-E-E$ which, with its quadruple echo, functions as a fanfare-like outset for the work, and, much like a Berliozian idée fixe, »returns throughout as a structural marker «. ${ }^{34}$ In Medtner's manuscript, the first three groups of quaver triplets are underlain with the words »Slu-shay-te, slu-shay-te, slu-shay-te!« (»Listen, listen, listen!«). ${ }^{35}$ A number of scholars have elaborated upon this fact by semanticising the motif with different vocabulary. Dolinskaya refers to the dactylic signal as a `klich` (>calk), while Aleksandr Alekseyev names it a >prizïv $(>a p p e a l<)$ in response to the metaphorical cry of the poet's soul; ${ }^{36}$ Moskalets also speaks of a >prizïv< or >zov< (>mystic invocation $<$ ) and Martyn of a $>$ call for attention $<.{ }^{37}$ This terminological complex relates to the semantic environment of evocation and incantation, impersonating the Night Wind and its »strange voice« (»strannïy golos «) as a principal character right at the outset of the sonata - a context of meaning which I will pertain here in referring to the >Slushayte` phrase as an invocation motif.

The similarity of two passages from earlier Russian piano music might shed further light on that phrase, too obvious not to mention in this context, even if their relationship to Medtner is unclear. There are the last notes of Samuel Goldenberg and Schmuyle from Mussorgsky's Pictures at an Exhibition (1874); and the ending of the final Funebre movement from Scriabin's $1^{\text {st }}$ Piano Sonata in F minor, Op. 6 (1893). Regardless of the fact that these two examples are concluding phrases, and not opening formulas as in Medtner, they resemble each other by their common rhythmic conciseness, their massive, motto-like unison, and their

32 Vasilyev 1962, p. 25, translated in Kuhn $2008^{\text {a }}$, p. 136. See also Tumanina 1960, p. 304f.: »The idea of the struggle between the human soul and the primordial chaos is being psychologically refracted in the sonata « (»Ideya bor'bï chelovecheskogo dukha s pervobïtnïm khaosom prelomlena v sonate [...] v strogo psikhologicheskom plane«).

33 Flamm 1995, p. 232, proposes an interpretation of the $1^{\text {st }}$ subdivision's triumphant E major ending in contrast to the final conclusion, dying away in E minor, symbolising a »preliminary harmonious balance of the antagonistic forces « as opposed to the »awakening of profound chaos, leading to a spooky dissolution in nothingness « (»der vorläufige, harmonisierende Ausgleich der widerstreitenden Kräfte«; »das abgründige Chaos [wird] erweckt [...] und führt [...] letztlich nur zu einer spukhaften Auflösung ins Nichts«).

34 Hamilton 2017, p. 32.

35 See Vasilyev 1962, p. 23. Dolinskaya 1966, p. 33, states the conjunction of the words and the motif and recognises its heralding function for the main thematic zones within the $1^{\text {st }}$ subdivision, but doesn't deduce any further implications from this fact. Martyn 1995, p. 86, also underestimates its semantic potential when he states that it is »only a marker indicating the movement's structural divisions «.

36 Dolinskaya 1966, p. 33; Alekseyev 1969, p. 22f: »Svoey grandioznoy zvukovoy kartinoy [sonata] otklikaetsya na krik dushi poèta«; »Ėtot motiv [...] imeet znachenie prizïva«. This sounds very similar to what Alekseyev wrote on the initial phrases of the sonatas Op. 5 and Op. 22.

37 Martyn 1995, p. 88; Moskalets $2004^{\mathrm{a}}$, p. 121 , also noting a similarity of the motif's contour to the beginning of Medtner's Ab major Sonata, Op. 11 No. 1, which commences with a descending third to the $1^{\text {st }}$ scale degree as well. 
melodic contour of a descending minor third to the root (see example 3.5.2 for a comparison of the abovementioned passages). In all three examples, a group of three or four notes appears separated from its respective environment in dynamics and articulation. What is more, the beginning of Anatoly Aleksandrov's Sonata-Skazka in $\mathrm{F} \#$ minor, Op. 4 (1914), also features this motif $(A-F \#-F \#)$ as a substantial element of its thematic invention - a work much indebted to Medtner's compositions, most obviously through its title, but also in its reference to a narrative tone exemplified in many of his skazki. In particular, a comparison of the Aleksandrov to Medtner's C minor Skazka, Op. 8 No. 2 (1906), suggests itself (see example 3.5.3). Additionally, Dolinskaya notes a certain similarity between the opening of the latter work and the primary Moderato con moto theme of Myaskovsky's $3^{\text {rd }}$ Piano Sonata in C minor, Op. 19 (1920). ${ }^{38}$
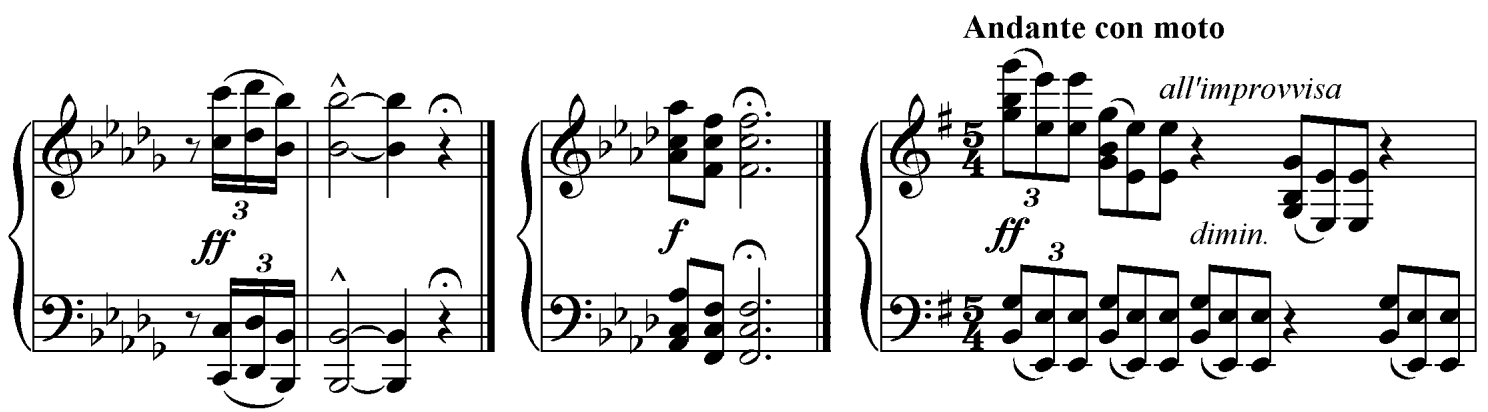

Example 3.5.2: Mussorgsky, Pictures at an Exhibition: Samuel Goldenberg and Schmuyle, mm. 28-29 // Scriabin, Sonata, Op. 6, $4^{\text {th }}$ mvt, m. $71 / /$ Medtner, Sonata, Op. 25 No. 2, $1^{\text {st }}$ subdivision, introduction, m. 1
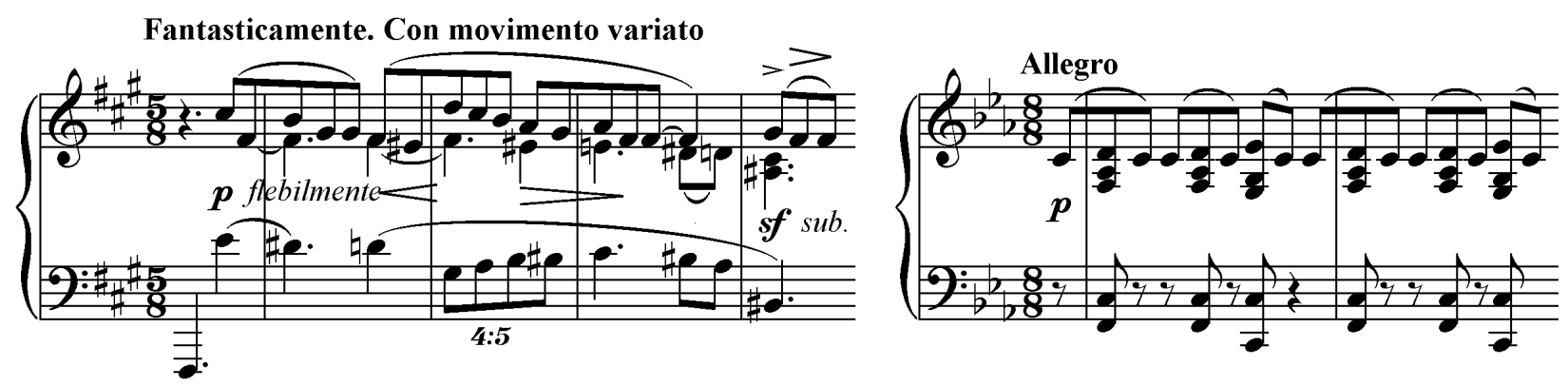

Example 3.5.3: Aleksandrov, Sonata-Skazka, Op. 4, mm. 1-5 // Medtner, Skazka, Op. 8 No. 2, mm. 5-8

Besides this emblematic relationship of music and lyrics, the >Slushayte tion of another literary intertext. In 1918 the Symbolist poet Aleksandr Blok published an essay named Intelligentsiya $i$ revolyutsiya (Intelligence and Revolution), prominently featuring the line »Rossiya-burya« (»Russia is a tempest«), and introducing multiple flections of the verbs >slushat'〈 and >slïshat'〈 (to hear, to listen) as well as >slushat'sya< and >slïshat'sya< (to obey, to sound) as a versatile leitmotif, recurring throughout the text, and closing with the lines »But the spirit is music. Once the Demon commanded Socrates to obey the spirit of music. Listen to the Revolution—with your whole body, heart, and consciousness «. ${ }^{39}$

38 See Dolinskaya 1981, p. 76.

39 Blok 1918, p. 20: »A dukh est' muzïka. Demon nekogda povelel Sokratu slushat'sya dukha muzïki. / Vsem telom, vsem serdtsem, vsem soznaniem — slushayte Revolyutsiyu. « In building an analogy between the country and a tempest, Blok relates to the writings of Thomas Carlyle. 
Blok's œuvre was considered one of the foremost artistic expressions of the Russian Revolution, and this essay in particular puts creativity, namely music, in a political context, regarded as a force capable of destruction of society-just like revolution. Intelligentsiya $i$ revolyutsiya had not been written at the time Medtner composed his E minor sonata, but his acquaintance to Blok's ideas of that time is possible, or even likely, through the intermediation of Andrei Bely, another key figure of Russian Symbolism, who highly appreciated Blok and his most famous work, the twelve-part poem Dvenadtsat' (The Twelve, also of 1918). While already Tyutchev's »O chëm tï voyesh, vetr nochnoy« may be interpreted as an allegory of agitation and overthrow, Blok supported this imagery in referring to revolution as a »thunderous hurricane« or »snowstorm $\ll{ }^{40}$ Natural phenomena were by tradition seen as metaphorical embodiments of social or political cataclysms, and, according to Isaak Zetel, the metaphor of blizzard essentially belonged to the familiar political imagery of these chaotic times. Zetel provides more insights to this field of influences in looking upon Medtner's music in direct relation to Blok's and Bely's writings, referring particularly to Bely's Fourth Symphony Kubok meteley (Goblet of Blizzards, 1908) as a poem emblematic of the artists' situation between the two Russian revolutions. ${ }^{41}$

Furthermore, some passages from Blok's Dvenadtsat' seem to resemble the Russian folkloristic genre of chastushka, a type of burlesque or ironic peasant song, which was frequently adapted as a literary or musical art form in the cultural sphere of the revolution, and certain echoes of which might be heard in the ritornello-like motif of marching Bolshevik soldiers. This element and its variants (»the Twelve are walking«) appears at the beginning of the $2^{\text {nd }}, 7^{\text {th }}$, and $11^{\text {th }}$ parts of the poem. ${ }^{42}$ Pianist Vasily Gvozdetsky goes as far as to claim a presentiment of Blok's idiomatic style in Medtner's E minor Sonata, with special regard to two passages: (1) the initial subject of the $2^{\text {nd }}$ subdivision in its second appearance $\left(\mathrm{P}_{\text {III }}\right)$, as well as in its fugato transformation (mm. 285ff. and 311ff.) convey an implicit march character through their dotted quavers; and (2) an idea introduced as a type of ritornello (>cadenza idea, first in m. 325ff., more explicitly in m. $392 \mathrm{ff}$., and culminating in $\mathrm{m}$. 561ff.), the contour of which, in its blunt profanity or even vulgarism, poses a contrast to the noble and epic tone of the introductory theme and main subjects of each subdivision. ${ }^{43}$ From a

40 Ibid., p. 12: »The revolution as a thunderous hurricane, as a snowstorm, always brings the new and unexpected; [...] this roar at any rate indicates its magnitude« (my translation of: »Revolyutsiya, kak grozovoy vikhr', kak snezhnïy buran, vsegda neset novoe i neozhidannoe; [...] gul ètot vse ravno vsegda—o velikom «).

41 See Zetel 1981, p. 112f.: »Nach der misslungenen Revolution des Jahres 1905 spiegelten sich die Wirren vor dem >Weltchaos` häufig in Bildern des Schneetreibens, Schneegestöbers und Schneesturms wieder. Das >Thema des Sturms« war Künstlern der verschiedensten Richtungen damals nicht fremd, und die Art, wie sie es behandelten, sagt viel über ihre ästhetischen Positionen aus. Belyj zeichnete [...] im Kubok metelej eine mystische, mit dem >Totenhemd des Schneesturms bedeckteWelt. Stetig dunkler wurde die wirbelnde Finsternis dieses Sturms, immer mehr steigerte sich der $>$ wilde Tanz des Schneegestöbers und Schneetreibens $`$. [...] Beeindruckend setzte sich Aleksandr Blok mit dem >Thema des Sturms« auseinander. [...] Insbesondere wird dies in einem Poem wie Dvenadcat' manifest, auf Grund dessen Bloks Platz auf Seiten der Revolution definiert wurde.« See also Ljunggren 1994, p. 29. Further thoughts on chaos and cataclysm as metaphoric elements of Symbolist art are found in Podporinova 2007, p. 147, and Hamilton 2017, p. 9.

42 »Gulyaet veter, porkhaet sneg. / Idut dvenadtsat' chelovek« (part 2, lines 1-2); »I opyat' idut dvenadtsat', / Za plechami-ruzh'etsa« (part 7, lines 1-2); »I idut bez imeni svyatogo / Vse dsenadtsat'—vdal' « (part 11, lines 1-2).

43 Gvozdetsky wrote in an email on November 19, 2017: »Am erstaunlichsten finde ich, dass auch hier [in Dvenadtsat'] wie im Finalsatz der Wind als rondoartiges Motiv wiederkommt, in verschiedenen Tonarten, entsprechend dem Thema der Einleitung. Dazu muss man wissen, dass das Gedicht im Tschastuschka-Gestus geschrieben ist [...]. 
Symbolist point of view, Medtner's sonata might likely be embedded in a broader context of Russian Silver Age aesthetics, reflecting the spirit of the pre-revolutionary years when it was written, as well as an »atmosphere of anxiety [...] when the Russian people were anticipating political convulsions « ${ }^{44}$-its tempestuous narrative may thus be interpreted as indicative of developments yet to come. ${ }^{45}$ In the same sense as Blok's writings can be perceived as an echo of (or rather: an attentive >listening to) the revolution, Medtner's composition might, according to Gvozdetsky, be seen as a pre-echo.

Looking at Medtner's œuvre as a whole, it becomes apparent that a group of compositions, including songs and instrumental works based on or preceded by Tyutchev's lyrics, stand for the sombre, pathetic, dramatic, and agitated side of his musical expression. The perhaps most grievous of Medtner's works, a setting of Tyutchev's Bessonnitsa (Sleeplessness), Op. 37 No. 1, belongs to this category; but other compositions, some of which refer to a >windy< or >stormy< atmosphere, are particularly characteristic of this group. From the composer's earliest period, there are works such as the $\mathrm{B} b$ minor Stimmungsbild, Op. 1 No. 5 (1901), including a motto by Lermontov: »The blizzard rages, and snow falls« (»Metel' sumit, i sneg valit«), and from far resembling Liszt's Étude d'exécution transcendante No. 12 (Chasse-neige) with which it shares its key; and also the G\# minor Étude, Op. 4 No. 1 (1897), associated by Zetel with the metaphor »Storm of the nightly soul« (»Burya dushi nochnoy«). ${ }^{46}$ Later there follows the E minor Skazka, Op. 34 No. 2 (1916), related to the $>$ Night Wind Sonata through its key and another Tyutchev motto »Once we have called a thing ours, it will leave us forever« (»Kogda chto zvali mï svoim, navek ot nas ushlo«), and in its passionate lefthand figures directly referring to Rachmaninov's famous Moment musical in E minor, Op. 16 No. 4 (1896); ${ }^{47}$ and, similar in atmosphere, the C\# minor Skazka, Op. 35 No. 4 (1916), which includes a motto from Shakespeare's King Lear: »Blow, winds, and crack your cheeks!«. Yet another considerable fact is that, a few years after the E minor Sonata, Medtner again chose Tyutchev's >Night Wind poem as basis for a song: $O$ chëm tï voyesh, Op. 37 No. 5 (1917-18), is written in a tempestoso mood well reminiscent of the sonata's stormy passages, and belongs to the same group like the abovementioned Bessonnits $a$ - as well as another

Wenn man das deklamiert, wie es auf spontanen >Revolutionsräten $<$ auf der Straße üblich war, solche $>$ Klassenkampfgedichte zu deklamieren, hat man sich durch den Rhythmus und die Lautstärke gesteigert, um den Kampfmut zu steigern. Ich stelle bei Medtner fest, [wie sich] der simple Rhythmus in der Sonate immer weiter in ein solches Toben schaukelt - die Plattheit, die in blinde Wut übergeht, auf fast biologischem Niveau. [Man] kann [...] erkennen, wie ähnlich die Atmosphäre, der vulgare Erzählstil sich reimt mit dem Finalsatz. Zum Beispiel erscheint das Marschieren bei Blok mehrmals, und bei Medtner auch, [wo es] auf symbolistischer Ebene mit Blok resoniert; solche Fetzen von Märschen, Volksmusik und Wind-Leitmotiv.«

44 Kalendarev 2005, p. 27.

45 In a broader sense, this notion resonates with Truscott 1956, p. 9, who asserts that »this sonata [could] fitly bear the name $>$ Russia — - only it is not the evocative interpretation of a country but of a whole people «.

46 See Zetel 1981, p. 114, who hints to most of the other examples and contexts mentioned here, and also Flamm 1995 , p. 64.

47 These are the first two lines of Tyutchev's 1858 poem Uspokoenie (Conciliation) after Nikolaus Lenau, set to music by Medtner as one of his last songs, Op. 61 No. 7. As in many other cases, this motto was not included in the first edition, but found in Medtner's personal copy of the Skazka and amended ex post in the Collected Edition, Vol. 3, p. 19. The similarity to Rachmaninov's Op. 16 No. 4 is discussed in Alekseyev 1969, p. 258f.; see also Alekseyev 1982 , p. 85. 
Tyutchev song, Slëzï, Op. 37 No. 2, both of which are written in the grave key of Eb minor. The whole opus is dedicated to the memory of Nikolai's brother Karl who was killed in World War I.

The manifold implications which can be found in the artistic and philosophical background of the E minor Sonata may, as a result, lead to two possible epithets. The work might appropriately be named a >tempest sonata,${ }^{48}$ in succession of Beethoven's D minor Sonata, Op. 31 No. 2, and in further analogy to another peak of formal innovation in sonata form realised by the mature Medtner, the Grozovaya (〉Thunderous $\triangleleft$ ) Sonata in F minor, Op. 53 No. 2. With equal justification, Op. 25 No. 2 might be called a >sonata of revolution<, interpreting tempest as an emblem of political turmoil as indicated by the abovementioned literary works - and also establishing a parallel to an earlier work which, though maybe arbitrarily, bears this ascription: Chopin's Revolutionary Etude in C minor, Op. 10 No. 12.

\subsubsection{HERMENEUTICS: THE EPIC ELEMENT}

There is another narrative approach suggested by a performance instruction which was not included in the first edition, but amended in the Collected Edition on the basis of Medtner's autograph. At the head of the score, right beneath the title but above the Tyutchev verses, there is a remark saying »The entire piece [is] in an epic spirit« (»Vsya p'esa v èpicheskom dukhe«). This description once more allows for a classification of the work as a >literary< piece of music. Authors have occasionally referred to the sonata's >epic $<$ as related to Russian novels, such as Hamish Milne and Bryce Morrison who named it as »a positively Dostoyevskian struggle of will $\ll$ or »a Dostoyevskian epic in sound $«{ }^{49}$ If we interpret the alleged >epic as a narrative element inherent in various types of literature as well as in some musical genres, for instance in Medtner's skazki (conceivable as tales in music), the transfer of a specific denotation becomes more concrete- the sonata may then be understood as an epic flow of action inspired by Tyutchev's poem, quite similar to a stream of consciousness as exemplified in works such as James Joyce's Ulysses and Virginia Woolf's novels. ${ }^{50}$ This notion even gains plausibility if we take into consideration that an interdisciplinary superposition of genres also takes place in the œuvre of Medtner's friend Andrei Bely who, transferring traditional principles of musical form to literature, wrote four works titled `symphony«. Bely's first publication, the experimental Second

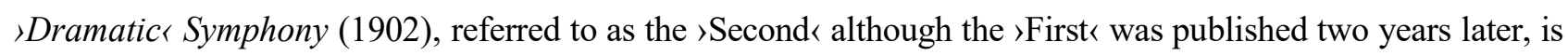
in fact non-dramatic literature with an epic character, virtually a work of $>$ symphonic prose $\prec$. Even if Medtner did not seem to have fully approved of those genre-crossing tendencies in Bely, he considered them an innovative achievement, ${ }^{51}$ and the mutual influence of both artists may also have presupposed and shaped Medtner's own understanding of a certain permeability of art forms and their respective genres (see chapter 2.5).

48 See Georgii 1976, p. 486: »[...] dem phantastischen, etwas zu weit ausgesponnenen Werk 25,2, das man nach dem dichterischen Motto als Sturm-Sonate bezeichnen könnte [...]«.

49 Milne 1980, p. 23; Morrison 2010, p. 3.

50 A character of sunconsciousness< particularly applies to the $2^{\text {nd }}$ subdivision and its rather improvisational passages, following each other in seemingly free and associative order. Flamm 1995z, p. 18 (again in Flamm 2015a, p. 133) also refers to a stream of consciousness with regard to the E minor Sonata. Bertin 2018, p. 65, characterises the $2^{\text {nd }}$ subdivision as »the ideas flow[ing] wildly from one to the next, in a sort of frenzied stream of consciousness «.

51 See Flamm 1995, pp. 49f. and 67f. 
If we keep on tracing the >epic in Medtner's later œuvre, we soon arrive at the longest of all his compositions, the $3^{\text {rd }}$ Violin Sonata, Op. 57 (1936-38), titled Sonata epica. This four-movement work is, just like the >Night Wind < Sonata, composed in E minor - and so are a number of others of Medtner's major pieces, such as the $3^{\text {rd }}$ Piano Concerto, Op. 60 (1941-42), named Ballade in response to a Lermontov poem, as well as the Skazka, Op. 14 No. 2 >March of the Paladin` (1904-07). Hence it is possible to claim that, in every of the genres most important for Medtner, a composition in E minor, featuring an obscure or more obvious narrative, figures as a sort of generic pinnacle (see also chapter 2.4.5). ${ }^{52}$ Musical epic and large-scale narrativity seem, in Medtner, to correspond to the key of E minor, a not-so-popular key for sonatas throughout the $18^{\text {th }}$ and $19^{\text {th }}$ centuries, and exemplified rather in symphonic literature than in the piano repertoire. ${ }^{53}$ Considering the mentioned compositions, the >epic< moment applies, on the one hand, to works of great length or ponderosity in dimension - and, on the other hand, with regard to the possible indication or reference to antique or archaic imagery, as seen in the violin sonata and the March of the Paladin. At any rate, the respective works are supplied with a quasi-Symbolist background which points beyond the music, but only in allusion, and impossible to be precisely determined as some sort of programme or definitive sujet. ${ }^{54}$

The epic context may also have provided a possible motivation for Medtner to publish the massive E minor Sonata in the same opus alongside the rather lightweight, sonatina-style Sonata-Skazka, Op. 25 No. 1. The composer would never give an explanation why he did this, neither orally nor in written form, and so his decision remains an editorial curiosity scholars have long been puzzled about. ${ }^{55}$ Some researchers imply that Medtner's coupling was intended to produce an intentional contrast ${ }^{56}$ others vaguely argue that this might have happened out of an editorial dilemma as the Sonata-Skazka was originally meant to be paired with the

52 This might be compared with a similar notion in Rachmaninov's œuvre where, in every significant genre, a D minor work of large dimensions is present, such as the $2^{\text {nd }}$ Piano Trio, Op. 9; the $1^{\text {st }}$ Symphony, Op. 13; the $1^{\text {st }}$ Piano Sonata, Op. 28; and the $3^{\text {rd }}$ Piano Concerto, Op. 30.

53 There are many examples in Carl Philipp Emanuel Bach and Haydn, for instance the latter's Symphony No. 44 $>$ Trauersymphonie< (1772); Mozart's Violin Sonata, K. 304 (1778); Beethoven's String Quartet, Op. 59 Nr. 2 (1806); Chopin's Piano Concerto, Op. 11 (1830), performed by Medtner twice in his adolescent years; Mendelssohn's Violin Concerto, Op. 64 (completed 1844); Brahms's $1^{\text {st }}$ Cello Sonata, Op. 38 (1862-65) and $4^{\text {th }}$ Symphony, Op. 98 (1884-85); the second version of Rimsky-Korsakov's $1^{\text {st }}$ Symphony, Op. 1 (1884, after the $1^{\text {st }}$ version of 1861-65 had been composed in the more unusual key of Eb minor); Tchaikovsky's $5^{\text {th }}$ Symphony, Op. 64 (1888); Dvořák's Dumky Piano Trio, Op. 90 (1891) and $9^{\text {th }}$ Symphony, Op. $95>$ From the New World $(1892-95)$; Sibelius's $1^{\text {st }}$ Symphony, Op. 39 (1899); Rachmaninov's $2^{\text {nd }}$ Symphony, Op. 27 (1906-07); and Elgar's Cello Concerto, Op. 85 (1919). Piano sonatas in E minor are comparatively rare, apart from Haydn's E minor sonatas (Hob. XVI:34 and XVI:47) and Beethoven's Op. 90 (1814), which Medtner himself performed several times. Further notable contributions to the genre are Grieg's (Op. 7, 1865) and d'Indy's sonatas (Op. 63, 1907), as well as Glazunov's $2^{\text {nd }}$ Sonata, Op. 75 (1901), a work that, due to its conservative three-movement form, less readily serves as a predecessor of Medtner's work.

54 Zetel 1981, 114, indeed accepts the Tyutchev context as a programme, but at the same time warns to take it for a move to the supernatural or obscure.

55 It seems absurd in this context to assert, like Morrison 2010, p. 14, that »banal commercial considerations brought together these two extremes of Medtner's art.«

56 See, for example, Martyn 1995, p. 85: »Its pairing with the Sonata-Tale [...], far from reflecting any similarity in form or content, merely emphasizes their stark differences«; and Tozer 1999, p. 12: »These two sonatas reveal a view of the world that is very Medtnerian: a pairing of something childlike with an abyss.« 
G minor Sonata, Op. $22,{ }^{57}$ which would have enabled Medtner to assign the opus number 25 exclusively to the E minor Sonata. However, despite the apparent dichotomy of the two works' artistic claim and formal dimension, a connecting element is at least provided by the narrative atmosphere of both pieces - the derivation from the skazka genre, establishing a folkloristic narrative in the background, is interdependently paired with an epic poem of imaginative tone, content, and structure.

\subsubsection{ANALYSIS OF THE SCORE}

First subdivision: Introduzione (Andante con moto) - Allegro E minor - E major, 4/4-15/8, .. = 92-100, 249 measures on 33 pages

\begin{tabular}{|c|c|c|c|c|}
\hline \multirow{4}{*}{$\begin{array}{l}\text { SECTION } \\
\text { introduction }\end{array}$} & THEMES AND SUBJECTS & Position & INDICATIONS & KEY \\
\hline & invocation, introductory th (I) & mm. $1-13$ & ff all' improvvisa; $\mathrm{p}$ tranquillo & E minor \\
\hline & inversion of introductory theme & mm. 14-21 & cantabile dolce & E minor \\
\hline & introductory theme & mm. $22-37$ & $\mathrm{ff} ; \mathrm{mp}$ cantabile & E minor \\
\hline \multirow[t]{7}{*}{ exposition } & invocation, primary theme $\left(\mathrm{P}_{\mathrm{I}}\right)$ & mm. 38-65 & Allegro; pesante ma non forte & E minor \\
\hline & transitional idea $(\operatorname{Tr})+P_{I}$ & mm. 66-79 & [f] espressivo & modulating \\
\hline & secondary theme $\left(\mathrm{S}_{\mathrm{I}}\right)$ & mm. 80-95 & Tranquillo; pp & D major \\
\hline & secondary theme $\left(\mathrm{S}_{\mathrm{II}}\right)$ & mm. 96-107 & Giocondamente; $\mathrm{p}$ leggiero & A major \\
\hline & secondary theme $\left(\mathrm{S}_{\mathrm{I}}\right)$ in the bass & mm. 108-117 & Stentato; $\mathrm{pp}$ & D major \\
\hline & secondary theme $\left(\mathrm{S}_{\mathrm{II}}\right)$ & mm. 118-124 & Giocondamente; ff risoluto & D major \\
\hline & ne $(\mathrm{C})$ & mm. 125-134 & ff; ppp dolce & D major \\
\hline \multirow[t]{4}{*}{ development } & invocation, $\mathrm{S}_{\mathrm{I}}, \mathrm{S}_{\mathrm{II}}$ & mm. 135-143 & Largamente; sf all' improvvisa & B major \\
\hline & primary theme & mm. 144-159 & Più mosso; p senza pedale & $\mathrm{D} / \mathrm{F} \# / \mathrm{Eb} \min$ \\
\hline & transitional idea & mm. 160-168 & Allegro; $\mathrm{p}$ poco scherzando & modulating \\
\hline & retransition: $\mathrm{S}_{\mathrm{II}}+\mathrm{P}_{\mathrm{I}}$ & mm. 169-178 & ff risonante & A maj / $B^{7}$ \\
\hline \multirow[t]{5}{*}{ recapitulation } & primary theme $\left(\mathrm{P}_{\mathrm{I}}\right)$ & mm. 179-201 & Tempo I, ff; molto pesante & E minor \\
\hline & secondary theme $\left(\mathrm{S}_{\mathrm{I}}\right)$ & mm. 202-209 & mp; Tranquillo & G major \\
\hline & secondary theme $\left(\mathrm{S}_{\mathrm{II}}\right)$ & mm. 210-221 & mp leggiero, giocondamente & $\mathrm{B}$ major \\
\hline & secondary theme $\left(\mathrm{S}_{\mathrm{I}}\right)$ in the bass & mm. 222-233 & pp stentato & $\mathrm{Eb} / \mathrm{E}$ major \\
\hline & closing zone $(\mathrm{C})$ & mm. 234-240 & giocondamente; ffp & E major \\
\hline codetta & variant of $S_{I}, P_{I}$ & mm. 241-248 & Molto giocondamente & E maj / F min \\
\hline
\end{tabular}

As the Introduzione commences, the three-note invocation motif is heard five times in the first measure, all'improvvisa heralding the entrance of the elegiac cantilena of the introductory theme (m. 2ff.), a type of melody reminiscent of Russian Orthodox chant. ${ }^{58}$ When it broadly unfolds, the invocation motif is transformed into an accompanying figure, maintaining the material from the first measure. While the introductory theme itself shows an ascending contour, it is complemented with a bass voice in contrary motion, and with off-beat quaver triplets forming a descending diatonic scale (see example 3.5.4). Ekaterina Podporinova regards the melodic anabasis and katabasis of the exterior voices, both covering an octave, as rhetoric figures

57 See Flamm 1995, p. 432, suggesting that the coupling of two sonatas in one opus does not really interfere with the rank of the E minor Sonata, but rather indicates a compromise with regard to the Sonata-Skazka which might have appeared too unsubstantial for being assigned a proprietary opus number.

58 While some authors have asserted a similarity in tone to Rachmaninov (the sonata's dedicatee), Bertin 2018, p. 95, refers to it as $/$ a prime example of liturgical chant influence, with its quasi-melismatic, step-wise motion and plaintive - even penitential — rising fourths. « Nelson 1991, p. 8, also feels a Slavic inflection, the theme being »pregnant with all manner of developmental possibilities«. 
in analogy to the metaphorical terminology of light and dark, good and evil, or, as in Tyutchev, day and night. ${ }^{59}$ The whole introductory theme is shaped as a sentence, with an eight-measure presentation clause and a chromatically descending, four-measure continuation (m. 10ff.). After a first light closure on a German augmented sixth chord with added major ninth (m. 5; see also m. 571ff.), the second phrase of the presentation transposes the melody to the $\mathrm{V}$, as if to resemble the comes of a fugue exposition; however, the music still remains in $\mathrm{E}$ minor, with the theme now starting from the $5^{\text {th }}$ instead of the $1^{\text {st }}$ scale degree. As early as in $\mathrm{m}$. 13, Medtner reaches the relatively distant harmony of $\mathrm{F}$ minor, a half-tone above the tonic - this relation will later prove important for the sonata's overall harmonic outline. ${ }^{60}$

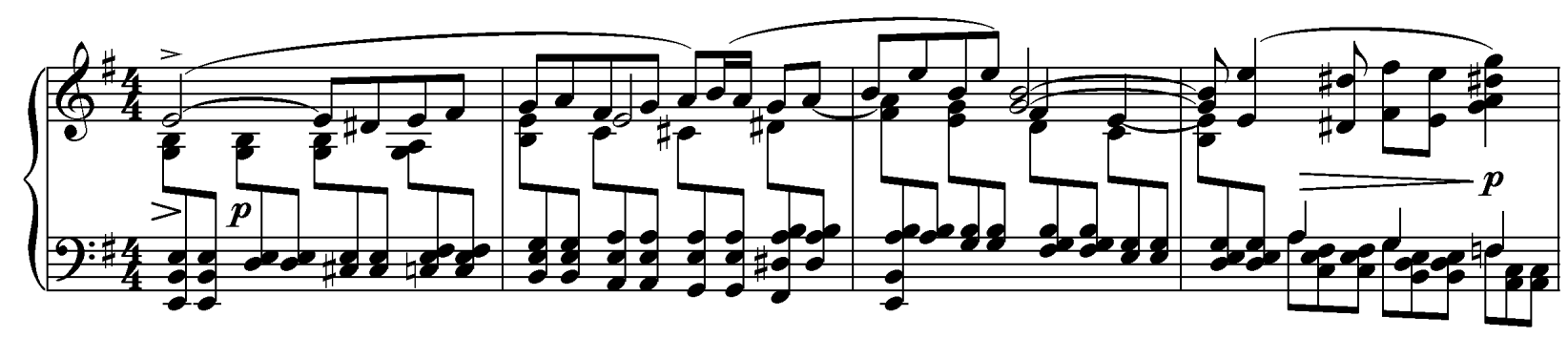

Example 3.5.4: Medtner, Sonata, Op. 25 No. $2,1^{\text {st }}$ subdivision: I, mm. $2-5$

If we stick to fugal terminology in analysing the further structure of the Introduzione, another $d u x$ is presented in m. 14ff., now as an inverted version of the introductory theme, starting from $B$; this predominant rectus and inversus structure has been described as a vertically-palindromic feature by James Pitts. ${ }^{61}$ As tension and dynamics gradually rise, the following entrances of the theme are both duces presented fortissimo (m. $22 \mathrm{ff}$. in original shape, m. 32f. as a truncated inversion). From the deceptive cadence in m. 34, a short transitional passage is appended, preparing for the beginning of the main sonata movement while accelerating the Andante con moto to Allegro, and prolonging the plagal harmonies of A minor and C major. Having reached the faster tempo, the invocation motif, repeated four times, also initiates the $1^{\text {st }}$ subdivision's primary theme. This subject is presented in an 8-plus-9-measure compound period structure, combining two sentence-like clauses with an one-measure basic idea and quaver counterpoint in the tenor voice $(\mathrm{m}$. 40ff.: pesante ma non forte; see example 3.5.5). While it exposes the unusual time signature of $15 / 8,{ }^{62}$ the theme makes use of the rather traditional material of diatonic scales and triads, and thus opposes the chromatically enhanced introductory material by which it is preceded. With reiterations and sequences of the basic idea,

59 My paraphrase of Podporinova 2007, p. 100: »Introduktsi[ya] Sonatï op. 25 No. 2, >fokusiruyushch[aya]< ritoricheskie figurï anabasis i katabasis, vïstupayushchie, v sootvetstvii s predposlannïm ėpigrafom (iz Tyutcheva), simvolami >nochnogo $\mathrm{i}$ >dnevnogo< v dushe, t'mï i sveta, dobra i zla.«

60 It is hardly understandable what led Loftis 1970, p. 158, to the absurd conclusion that »in Op. 25 No. 2 the harmonic progressions are basically simple, with much use of the I and IV chords $\ll$.

61 See Pitts 1999, p. 18: »The fact that the inversion begins on the $5^{\text {th }}$ degree [...] and reaches down to center around the tonic, while the original starts from the tonic [...] and climbs up to dwell about the $5^{\text {th }}$ degree, gives this passage a monumental quasi-palindromic wave contour. The rectus and inversus volleying of the rocking fourth motive further intensifies the architectural symmetry.«

62 Figuring as an equivalent to the triplet division of 5/4 time, the 15/8 time signature appears not as exotic as some authors have suggested, as quintuple meters are comparatively common in Russian folk music. See Eberle 2001, p. 68. 
a chromaticised transitional idea is introduced, preparing for modulation ( $\mathrm{m}$. 66ff.). The music reaches a preliminary climax at a strong series of altered fff chords (m. 76: con fermezza), ascending over a chromatic bassline towards a $\mathrm{F} \#$ minor fourth-sixth triad. This chord functions as a leading-tone harmony to the following secondary theme in the rather unexpected key of D major (m. 80ff.: Tranquillo), again heralded by the invocation motif marking the formal border between the primary and secondary theme zones.

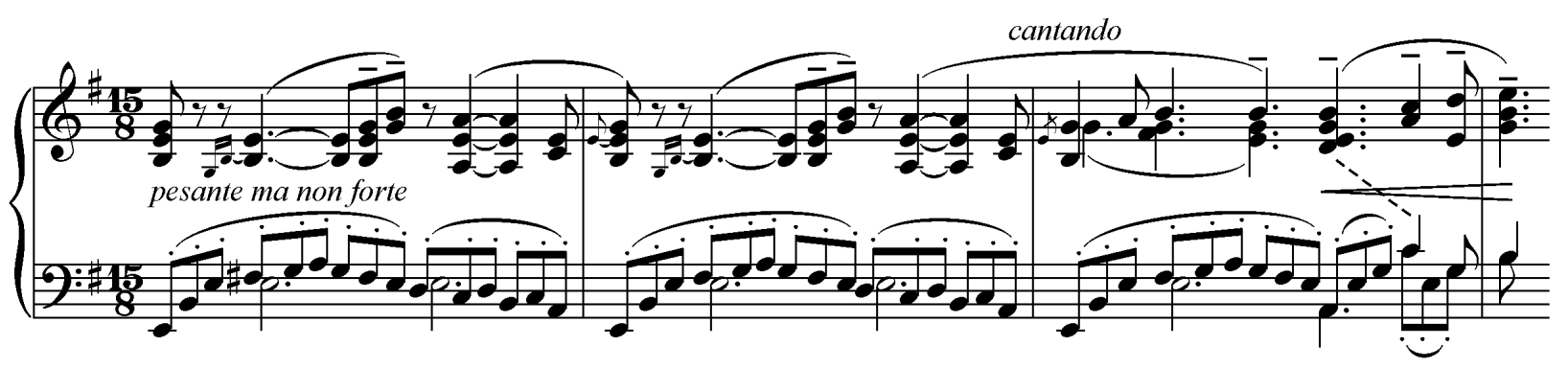

Example 3.5.5: Medtner, Sonata, Op. 25 No. $2,1^{\text {st }}$ subdivision, exposition: $\mathrm{P}_{\mathrm{I}}, \mathrm{mm} .40-42$

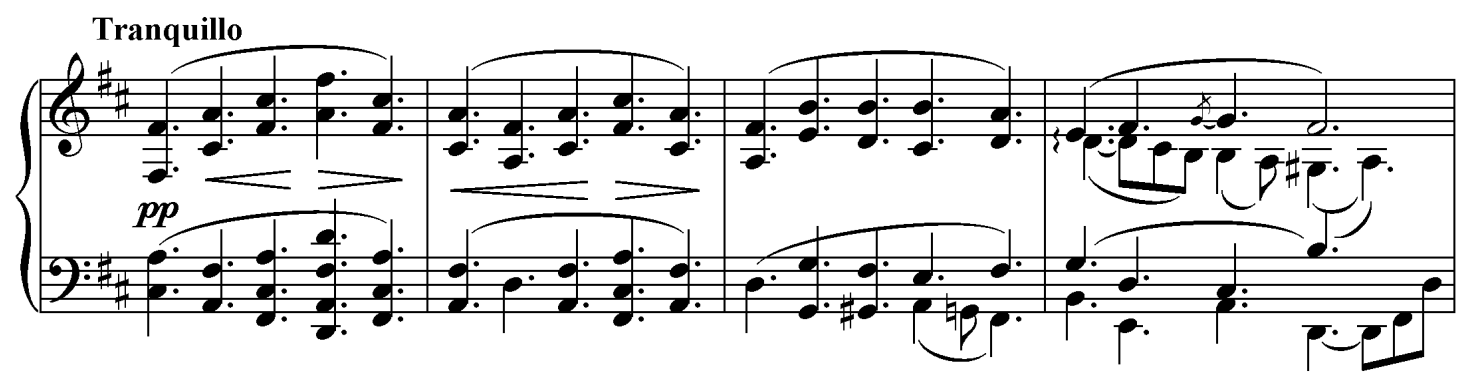

Example 3.5.6: Medtner, Sonata, Op. 25 No. $2,1^{\text {st }}$ subdivision, exposition: $\mathrm{S}_{\mathrm{I}}, \mathrm{mm} .80-84$

The chorale-like first secondary theme $\left(\mathrm{S}_{\mathrm{I}}\right)$, sounding »like an illuminated lyrical chorus « in contrary motion of both hands, shows vertical and horizontal symmetry of voices within each measure (see example 3.5.6) ${ }^{63}$ It appears in period syntax again, split into an antecedent and consequent of eight measures each; the first clause is divided in 5+3 measures, the latter of which introduces a contrasting idea in dotted rhythm. Another period-shaped subject in A major, named $\mathrm{S}_{\mathrm{II}}$ here, is introduced in $\mathrm{m} .96$ (giocondamente), the contrasting idea of which is presented in a charming $3+3+2+2+2+2+1$ division of the $15 / 8$ meter, making use of a real sequence of descending major seconds above the bass progressions $A-E-G-D-F-C$ (m. 100). The $\mathrm{S}_{\mathrm{II}}$ theme is transformed to a sudden outburst in $\mathrm{Ab}$ major (m. 106), a brief episode which immediately returns to the previous D major for another rotation of both secondary themes. $\mathrm{S}_{\mathrm{I}}$ is reiterated in the bass, now in a variant with continuous arpeggios (m. 108ff.), while $\mathrm{S}_{\mathrm{II}}$ returns for a fortissimo conclusion of the secondary theme zone (m. 118: risoluto), ${ }^{64}$ destabilising the tonic with a half-diminished seventh chord on $A(\mathrm{~m} .120)$. In the closing zone, D major is finally confirmed by another dynamic climax, presenting an idea derived from $\mathrm{S}_{\text {II }}$ in parallel tenths (m. 125), and followed by a calmly murmuring episode, ebbing away over a tonic pedal point.

63 My translation of Moskalets 2004a , p. 130: »Zvuchit kak prosvetlennïy liricheskiy khoral [...]. Printsip zerkal'noy simmetrii deystvuet po vertikali i po gorizontali«. See also Podporinova 2007, p. 89.

64 Podporinova 2007, p. 149, refers to the secondary theme zone as a complex binary form (»ab + a'b' «), representing the two subjects $S_{I}$ and $S_{I I}$ and their respective variants (»slozhn[aya] dvukhchastn[aya] form[a]«). 
The comparatively short development section, as most other constitutive parts of the movement before, commences with the invocation motif alternating between B major and D major, and quotes from the $\mathrm{S}_{\mathrm{I}}$ and $\mathrm{S}_{\mathrm{II}}$ themes in dense succession. A significant passage elaborating on the primary theme resorts to $\mathrm{E} b$ minor as a temporary tonic for a number of measures (m. 153ff.) before the exposition's transitional idea is heard again in the bass region (m. 161ff.). A retransition in continuous semiquaver motion begins in $\mathrm{m}$. 169, increasingly chromaticising the $\mathrm{S}_{\mathrm{II}}$ material and gaining even more polymetric complexity before triumphantly arriving at the primary theme's recapitulation.

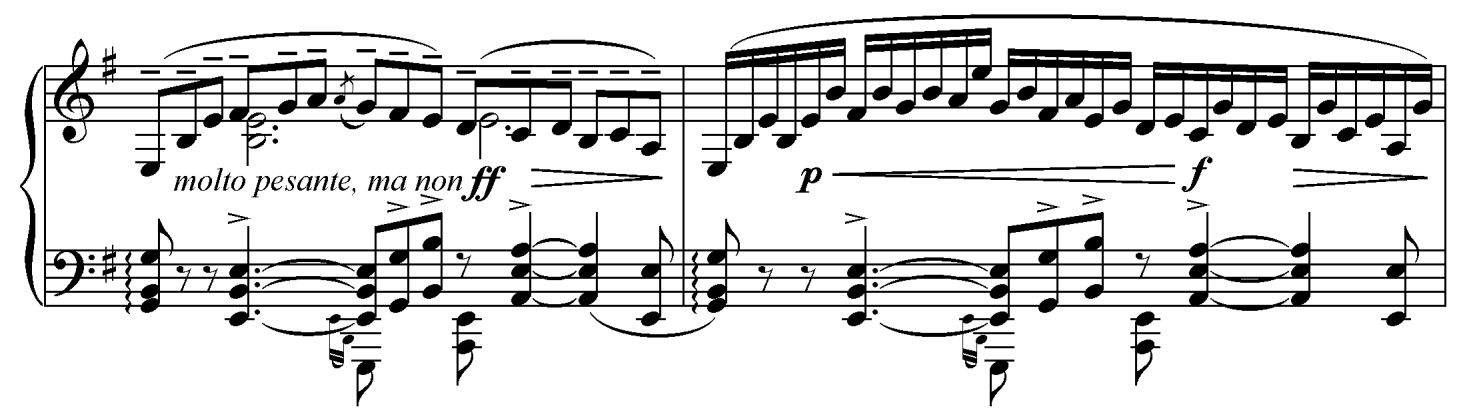

Example 3.5.7: Medtner, Sonata, Op. 25 No. $2,1^{\text {st }}$ subdivision, recapitulation: $\mathrm{P}_{\mathrm{I}}, \mathrm{mm}$. 181-182

Making use of a contrapuntal device in possible derivation from Mendelssohn and Schumann, Medtner here transfers the main melodic contour of the primary theme to the left hand, while the accompanying line in quavers now sounds in the top stave, made possible by double counterpoint at the octave (m. 181ff.; see example 3.5.7). During the following measures, $\mathrm{P}_{\mathrm{I}}$ is heard again in flexible keys such as $\mathrm{A}$ minor and $\mathrm{B} b$ major, and an impressionist-flavoured episode, condensing the passage that earlier functioned as a transitional space earlier, quickly leads to the secondary theme zone. The entrance of $S_{I}$, however, is masked by the semiquaver figuration of the preceding passage which overlaps the tranquillo dotted-crotched values, now in G major (m. 202f.), while the original choral-style harmonisation is restored only in its third measure. The more obvious formal border, perceivable by the change of character and rapidity of note values, is thus retarded by two measures, even if the first chord in m. 204 is a half-diminished seventh chord to scale degree ii. $\mathrm{S}_{\mathrm{I}}$ is also shortened in favour of $\mathrm{S}_{\mathrm{II}}$ to arrive as early as in $\mathrm{m}$. 210 , now in B major - a harmony that was not used before, now changing the tonal relation between $S_{I}$ and $S_{I I}$ from a fifth to a major third. In analogy to $\mathrm{m}$. 106, B major is flattened to $\mathrm{B} b$ major (m. 220), but with different consequences as compared to the exposition: the following reiteration of $\mathrm{S}_{\mathrm{I}}$ in the bass now commences in $\mathrm{E} b$ major, keeping in the flattened key region for two more measures before, even more surprisingly, shifting a half-tone to E major. Now that the tonic's relative major is reached, Medtner sticks to it for the rest of the $1^{\text {st }}$ subdivision. Brief reminiscences of the closing zone's contrasting elements form a culmination and an impressive ESC (m. 237), leading over to a codetta section that combines material from the $S_{I}$ and $P_{I}$ themes, and adds a chromatically descending lower voice reminiscent of the introduction's katabasis. In this final passage, the polymetric potential of the $15 / 8$ time is exploited to the maximum. 


\section{Second subdivision: Tempo dell'introduzione - Allegro molto sfrenatamente, presto - Largamente F minor $-E$ minor, $4 / 4, \delta=84,475$ measures on 29 pages}

\begin{tabular}{|c|c|c|c|c|}
\hline \multirow{5}{*}{$\begin{array}{l}\text { SECTION } \\
\text { introduction }\end{array}$} & THEMES AND SUBJECTS & Position & INDICATIONS & KEY \\
\hline & invocation, introductory theme (I) & mm. 249-261 & [ff] Tempo dell'introduzione & $\mathrm{F} / \mathrm{A} b$ minor \\
\hline & introductory theme (inverted) & mm. 262-269 & $\mathrm{p}$ teneramente & E minor \\
\hline & introductory theme: stretto & mm. 270-276 & $\mathrm{ff} ; \mathrm{mp}$ cantando & E minor \\
\hline & introductory + initial theme $\left(\mathrm{P}_{\mathrm{II}}\right)$ & mm. 277-284 & a tempo; irresoluto & modulating \\
\hline \multirow[t]{8}{*}{ potpourri exp } & initial theme $\left(\mathrm{P}_{\mathrm{II}}, \mathrm{P}_{\mathrm{III}}\right)+$ intro & mm. $285-310$ & Allegro molto sfrenatamente & E minor \\
\hline & fugato: initial theme $\left(\mathrm{P}_{\mathrm{III}}\right)$ & mm. 311-325 & $\mathrm{p}$ & E minor \\
\hline & transition: cadenza idea, $\mathrm{P}_{\mathrm{II}}$ & mm. 326-335 & pesante & G major (V) \\
\hline & transition: inversion of $\mathrm{P}_{\mathrm{III}}$ & mm. 336-361 & pp susurrando & G major \\
\hline & transition: introductory $+\mathrm{P}_{\mathrm{VI}}$ & mm. 362-371 & [p] cantando & $\mathrm{B}$ minor $(\mathrm{V})$ \\
\hline & secondary theme $\left(\mathrm{S}_{\mathrm{III}}\right)$ & mm. 372-391 & Tenebroso tranquillo; $\mathrm{p}$ & B minor \\
\hline & secondary theme $\left(\mathrm{S}_{\mathrm{III}}\right), \mathrm{P}_{\mathrm{II}}$ & mm. 392-411 & Meno mosso; pp una corda & E minor \\
\hline & secondary $\left(\mathrm{S}_{\mathrm{IV}}, \mathrm{S}_{\mathrm{III}}\right)$, cadenza idea & mm. 412-441 & $\mathrm{mf}$ espressivo, dolente & B minor \\
\hline \multirow[t]{5}{*}{ development } & introductory theme (I) & mm. 442-461 & Meno mosso, con meditazione & $\mathrm{B} / \mathrm{C}$ minor \\
\hline & initial theme $\left(\mathrm{P}_{\mathrm{II}}, \mathrm{P}_{\mathrm{III}}\right)$ & mm. 462-479 & a tempo; $\mathrm{p}$ & $\mathrm{F} \sharp / \mathrm{D}$ minor \\
\hline & intermediate th (variant of $\mathrm{S}_{\mathrm{IV}}$ ) & mm. 480-495 & ff diminuendo & $\mathrm{G} \sharp$ minor \\
\hline & intermediate theme & mm. 496-521 & $\mathrm{p}$ leggiero, vertiginoso & A minor \\
\hline & retransition: $\mathrm{P}_{\mathrm{II}}, \mathrm{P}_{\mathrm{III}}$, intermediate & mm. 522-533 & $\mathrm{p}$ molto vertiginoso & E minor $(V)$ \\
\hline \multirow[t]{5}{*}{ potpourri recap } & initial theme $\left(\mathrm{P}_{\mathrm{II}}, \mathrm{P}_{\mathrm{III}}\right)+\mathrm{I}$ & mm. 534-560 & [ff] Tempo I; molto marcato & E minor \\
\hline & transition: cadenza + introductory & mm. 561-576 & fff Quasi cadenza, fermato & $\mathrm{B} b$ major $(\mathrm{V})$ \\
\hline & transition: introductory $+\mathrm{P}_{\mathrm{III}}$ & mm. 577-594 & Concentrando; pp susurrando & $\mathrm{Cm} / \mathrm{Ab}(\mathrm{V})$ \\
\hline & transition: introductory $+\mathrm{P}_{\mathrm{III}}$ & mm. 595-615 & [mp] poco a poco più agitato & $\mathrm{Gm} / \mathrm{C} \sharp \mathrm{m} / \mathrm{Em}$ \\
\hline & transition: introductory + cadenza & mm. 616-628 & meno mosso & E min / Dorian \\
\hline \multirow{5}{*}{$\begin{array}{l}\text { [introduction } \\
\text { interweaved] }\end{array}$} & invocation + introductory $+\mathrm{S}_{\mathrm{III}}$ & mm. 629-646 & Largamente; f plenissimo & E minor \\
\hline & $\mathrm{S}_{\mathrm{III}}$, variant of $\mathrm{P}_{\mathrm{II}}$ & mm. 647-672 & Tenebroso; $\mathrm{p}$ & A / E minor \\
\hline & var of $\mathrm{S}_{\mathrm{IV}}+$ intermediate theme & mm. 673-684 & $\mathrm{p}$ dolente & $\mathrm{C}$ maj / E min \\
\hline & conclusion: introductory, $\mathrm{P}_{\mathrm{III}}$ & mm. 685-716 & {$[\mathrm{pp}]$} & E minor \\
\hline & conclusion: canon of introductory & mm. 717-723 & pp tenebroso legatissimo & E minor \\
\hline
\end{tabular}

My proposal for structuring the $2^{\text {nd }}$ subdivision — which clearly does not adhere to a single traditional model such as sonata form, rondo form, or variation form, but incorporates various aspects of every of these schemes - aims, however, to deduce the progression of formal sections in loose derivation from sonata form. This structure is further detailed in the table above, and the following analysis also resorts to sonata terminology —all being told with the awareness that there may exist several differing, yet just as reasonable, approaches. ${ }^{65}$ The potpourri-style exposition is interspersed with several transitional ideas, while the recapitulatory second rotation appears partly truncated and deviant from the exposition in its sequence of sections. In addition, the introductory theme permeates the whole remainder of the sonata, prompting Jane Ginsburg to conclude that the $2^{\text {nd }}$ subdivision $»$ is mainly a development of this introductory theme in diminution «, ${ }^{66}$ while Martyn, more appropriately, stating that it is »is a fantasy based on the material of the Sonata's

65 Flamm 1995, p. 231, gives a number of arguments in contradiction to sonata form: (1) the various restatements of the introductory theme clearly do not correspond to the formal borders of a first-movement form; (2) the moment of recapitulation appears blurred due to a complete quote of the initial theme in the preceding measures; (3) themes and motives are so related to each other, with developmental elements permeating every part of the $2^{\text {nd }}$ subdivision, that the delimitation of sections is hindered.

66 Ginsburg 1961, p. 82. 
Introduction «. ${ }^{67}$ Apart from being contrapuntally processed and fragmented in a number of ways, the introductory theme also appears to have a strong moment of recapitulation on its own (mm. 629ff.), which is independent from the alleged sonata form's initial theme being recapitulated much earlier from m. 534 .

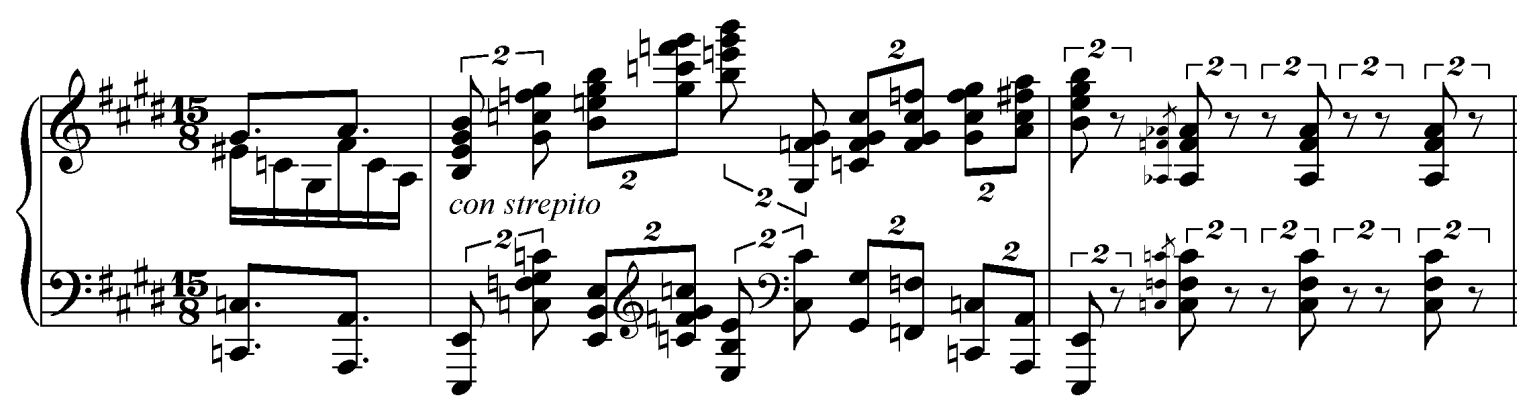

Example 3.5.8: Medtner, Sonata, Op. 25 No. 2, $1^{\text {st }}$ subdivision: codetta, mm. 241-242

The transitional measures repeating the final chords of the $1^{\text {st }}$ subdivision (m. 245-247; see example 3.5.8), ${ }^{68}$ connecting it to the return of the Introduzione and thus to the $2^{\text {nd }}$ subdivision, gradually slide from E major to F minor (see also chapter 2.4.2 for the harmonic implications of this chord progression). The latter key is tonicised for a short passage of five measures, launching the invocation motif and the first of several new presentations of the introductory theme (m. 250ff.), which is then sequenced a whole-tone below for the consecutive continuation phrase (m. 254ff.). Tonality remains ambivalent here as it is unclear whether $E b$ is root in $\mathrm{Eb}$ minor or fifth in $\mathrm{Ab}$ minor, which is also plausible. However, both conceptions seem justifiable if we concede the analogy of the initial Introduzione's theme entries to a fugue exposition - this observation likewise applies to its second rotation, where the $\mathrm{F}$ minor $d u x$ is complemented by another $d u x$, lowered by a major second, instead of a comes. The following theme entries directly correspond to the sonata's beginning, with an inverted dux back in E minor, in m. 262ff. (according to m. 14ff.) and an original version in $\mathrm{m}$. 270ff. (as in m. 22ff.). As dynamics and polyphonic density gradually increase, the latter initiates a remarkable stretto passage which includes the following theme entrances and imitative variants, all unfolding over a diatonically descending bass (see example 3.5.9): ${ }^{69}$

- $\quad$ m. 270ff.: introductory theme in the alto voice ( $d u x$ in E minor) combined with itself in the upper octave at one measure distance

- m. 272f.: truncated introductory theme in the alto voice (quasi-comes in A major) combined with an inversion in the soprano voice ( $d u x$ in E minor) at the distance of half a measure

- $\quad$ m. 273f.: another entrance of the introductory theme, lacking its first note (quasi-dux in D major) in the tenor voice, half a measure later

67 Martyn 1995, p. 87. See also Keller 1971, p. 128: »the second section based upon the first and recapitulating the first section's most important material.«

68 Sacre 1998, p. 1816: »In the moment of the final chord, the composer changes his mind, and through an unprecedented gesture, a mixture of pride and nonchalance, he brings back his introduction « (my translation of: »Au moment de poser l'accord conclusif, le compositeur change d'avis, et par une geste sans précédent, mélange d'orgeuil, de désinvolture, de démence, ramène son introduction«).

69 Flamm 2006, p. 11, further comments on the role of this dense polyphonic meshwork as a quality of Medtner's mature style. 


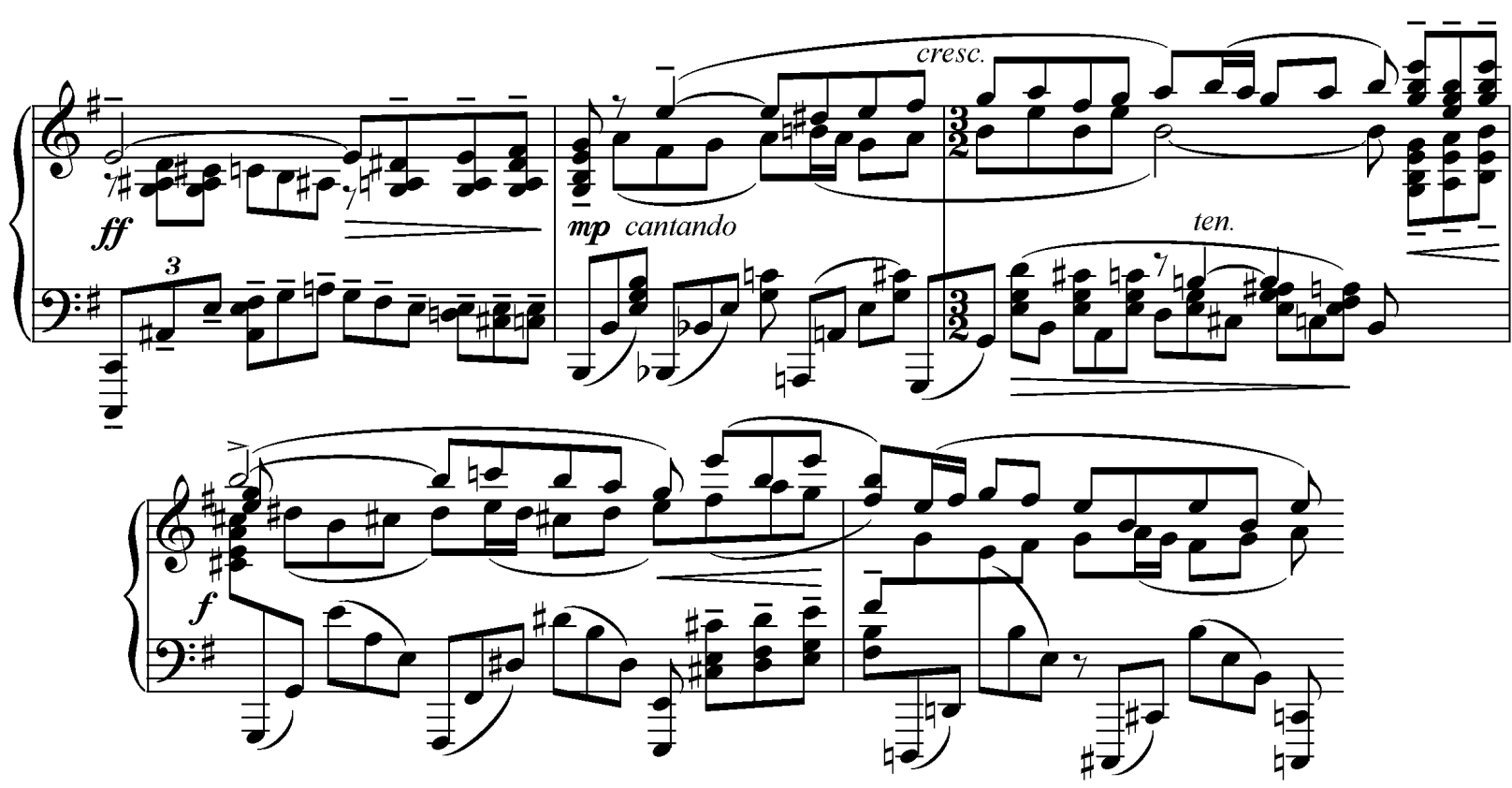

Example 3.5.9: Medtner, Sonata, Op. 25 No. 2, introduction to $2^{\text {nd }}$ subdivision, mm. 270-274

This passage directly leads into some transitional measures preceding the $2^{\text {nd }}$ subdivision's potpourri exposition, the beginning of which is prefigured through three cascades of ascending semiquaver figurations ( $\mathrm{m}$. 277ff.) that are in fact diminutions of the introductory theme. Now, in analogy to the pair of voices defining the Introduzione's outline through their contrary motion, an initial theme to the $2^{\text {nd }}$ subdivision (here referred to as $\mathrm{P}_{\mathrm{II}}$ ) marks the beginning of the sunrestrained Allegro molto sfrenatamente, conceived by Nadezhda Tumanina as »an episode resembling the $>$ Night Wind's dreadful song of the primordial chaos $\ll{ }^{70}$ It is designed as a two-part combination of the abovementioned diminutive derivation of the introductory theme in the right hand and a series of descending chords in crotchets in the left hand (m. 285ff.). What is more, the contour of the left hand's top voice $B-B-B-B-A-G-F \#-E$, framed by a fifth above the root $E$, is amplified by its inverted counterpart in ascending direction and with inserted dotted rhythms, first appearing in $\mathrm{m}$. 289f. to form another instance of the initial theme $\left(\mathrm{P}_{\mathrm{III}}\right): E-E-E-E-F \#[G-F \#] G-[A-G-] A-[B-C-] B$. Just like the introductory theme's $d u x$ and comes being complementary variants of each other, both traversing an ascending or descending fifth, these two instances also form a dialectic pair representative of the $2^{\text {nd }}$ subdivision's initial theme - connected through their onset with three repetitions of their first notes, ${ }^{71}$ and shaping their multiple appearances throughout the second half of the sonata (see example 3.5.10 for an overview of all these motivic correlations). In succession, I will refer to the descending contour of the initial theme as $\mathrm{P}_{\mathrm{II}}$ and to the ascending contour derived from its inversion as $\mathrm{P}_{\mathrm{III}}$.

70 My translation of Tumanina 1960, p. 305: »V nachale vtoroy chasti sonatï est' épizod, napominayushchiy >strashnuyu pesn' nochnogo vetra< o pervobïtnom khaose «.

71 In this respect the contour appears very similar to that of the tertiary theme from Medtner's C major Sonata, Op. 11 No. 3, and a number of other characteristic subjects commencing with repetitions of the same note. Lockwood 1940 , p. 138, also feels a kinship to the second subject of the C\# minor Fugue from Bach’s Well-tempered Clavier, Vol. 1: »This rhythm seems to haunt Medtner, as it is found in his first sonata, and also in the [1 $\left.{ }^{\text {st }}\right]$ Concerto. It is what one may call his Bach mood.« 


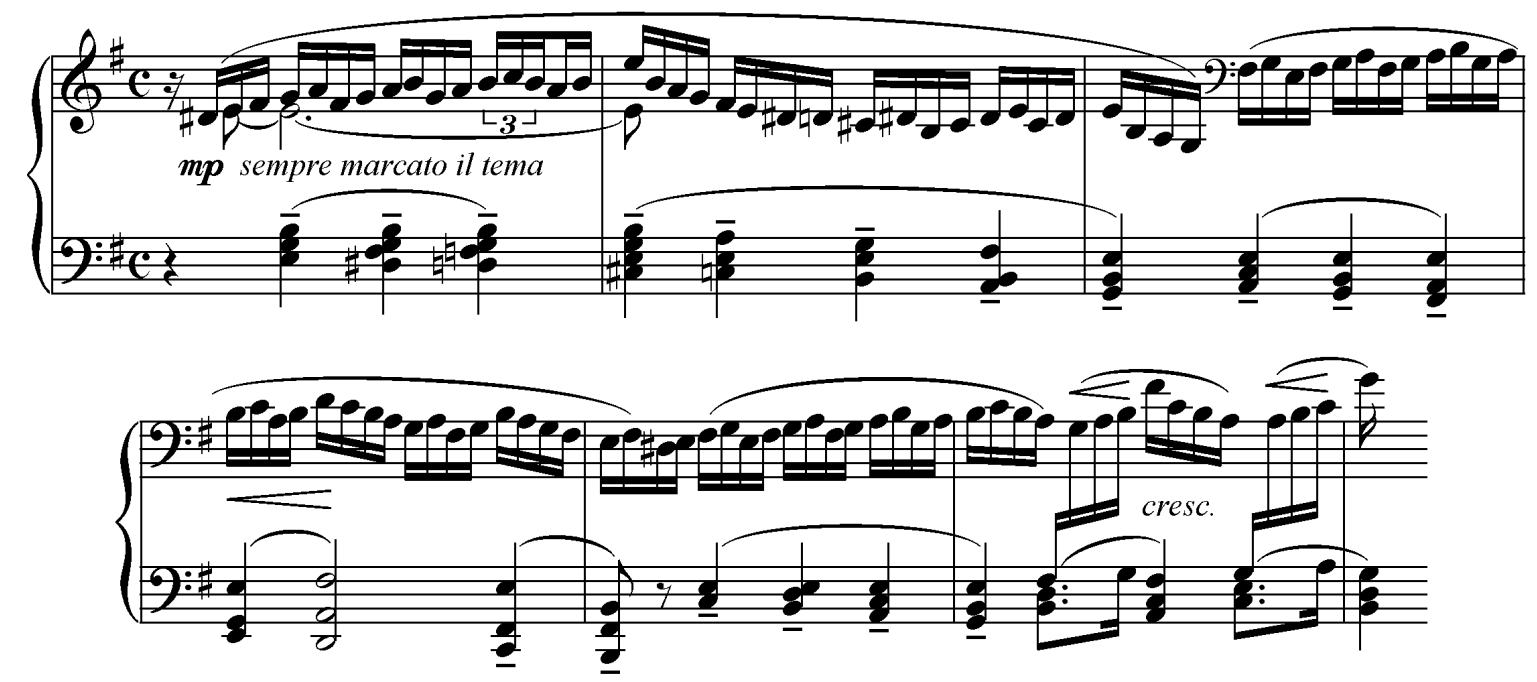

Example 3.5.10: Medtner, Sonata, Op. 25 No. 2, $2^{\text {nd }}$ subdivision, exposition: $\mathrm{P}_{\mathrm{II}}$ and $\mathrm{P}_{\mathrm{III}}, \mathrm{mm} .285-290$

The dotted-note variant $\mathrm{P}_{\mathrm{III}}$ gains additional weight through being developed in a four-part fugato section (m. 311ff.: see example 2.3.3 from chapter 2.3.1), just as if the $2^{\text {nd }}$ subdivision's exposition was to be restarted again from here. The fugato does not have consequences for the architecture of the whole section and remains a mere episode, however a significant one in order to show the initial theme's enormous polyphonic potential. What follows next is an extended transition (m. 325f.), modulating to G major and eventually B minor, and introducing an element which I will refer to as the >cadenza idea<, named after its most prominent occurrence later on. Basically this is a derivation of the initial theme's four-note repetition which now develops a discrete character through its reiterations and variants (see example 3.5.11). Furthermore, in the light of the elaborations on revolutionary semantics above, we might conceive it as reminiscent of the tone of Russian chastushki and their bouncy, abandoned vivacity. On the following pages, material from both instances of the initial theme (m. 336ff.: $\mathrm{P}_{\mathrm{III}}$ ), the >cadenza idea (mm. 332f., 354f.) and the introductory theme (m. 362ff.: in a dominant $\mathrm{F} \#$ major episode, something of a surprise), is confronted with two new subjects introduced in $\mathrm{m} .372$ (a Tenebroso tenor cantilena in ascending triads in B minor, named $\mathrm{S}_{\mathrm{III}}$ here, showing a similar melodic contour as the first secondary theme $S_{I}$ from the $1^{\text {st }}$ subdivision) ${ }^{72}$ and $\mathrm{m} .412$ (a chromatic melody also in B minor, which I will refer to as $\mathrm{S}_{\mathrm{IV}}$ ). Even if these themes appear too episodic to be regularly developed or later recapitulated, it is at least their tonality that defines the potpourri exposition's dominant region and thus a secondary theme zone.

72 Chernova 2007, p. 78, considers this Tenebroso theme (which she takes for a closing zone) as derived of the $1^{\text {st }}$ subdivision's secondary theme: »Iz rel'efnogo materiala nachal'noy chasti zaimstvuetsya pervaya tema pobochnoy, zvuchashchaya zatem [...] v razdele zaklyuchitel'noy partii finala.« 


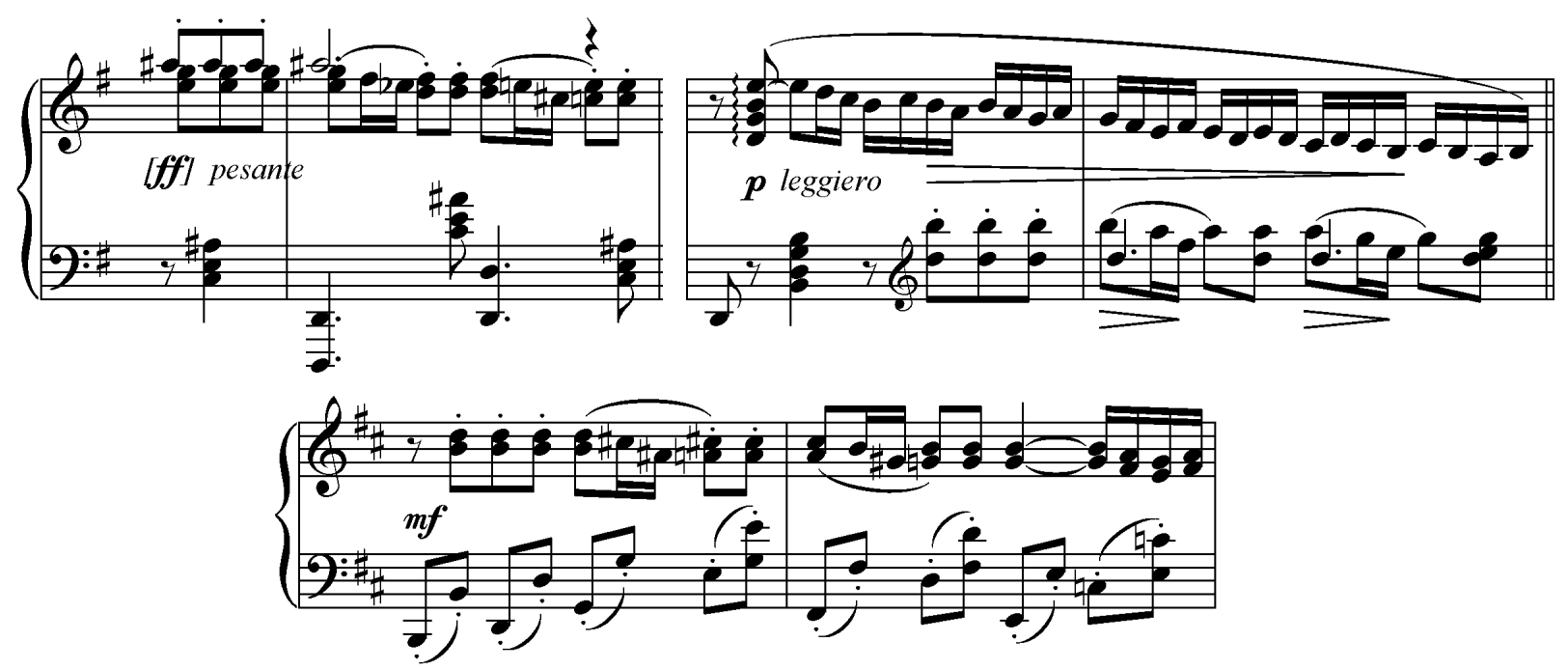

Example 3.5.11: Medtner, Sonata, Op. 25 No. $2,2^{\text {nd }}$ subdivision, mm. 325-326 // mm. 332-333// mm. 434-435

Whereas the modulatory scheme of the $1^{\text {st }}$ subdivision's exposition (the main tonal zones confronting E minor and D major, being recapitulated as a traditional pair of relative keys, E minor and E major), has an analogy in the $1^{\text {st }}$ movement of Tchaikovsky's $5^{\text {th }}$ Symphony, Op. 64 (1888), the secondary theme zones of the $2^{\text {nd }}$ subdivision establish contrasting keys at the distance of fifths to the tonic — such as B minor (exposition) and A minor (recapitulation). Through this relation Medtner produces a derivative form of tonal symmetry, yet not as explicitly as in the Triad Sonatas, Op. 11 Nos. 1 and 3 (see the respective analyses). In terms of large-scale harmonic progression, the unexpected recurrence of E minor within the secondary theme zone (m. 392ff.: Meno mosso) particularly calls for attention, as it returns just shortly after the $\mathrm{S}_{\mathrm{III}}$ theme had been introduced in a seemingly stable $B$ minor. The respective passage presents $S_{\text {III }}$ again, now in a variant with curious off-beat figures. Through its rhythm and tonality, it appears alien to its environment, rather suggesting a hierarchical likeness to the initial theme, as if it was the second (and varied) instance of a recurring ritornello. Yet $\mathrm{E}$ minor is left behind only a few measures later, returning to B minor again for the introduction of $\mathrm{S}_{\mathrm{IV}}$, and leaving the previous episode without further consequences. Thus, looking at the potpourri exposition in its whole, we can neither discern a stable tonal region in a contrasting key, nor are the borders of the secondary theme zone clearly discernible - if not by simply defining the end of a fifty-measure transition at the entrance of $\mathrm{S}_{\mathrm{III}}$. This polyvalence is the main and eponymous feature of the potpourri exposition which continuously shifts between the formal functions of theme zones and transitional spaces, and finally comes to an end at another extended passage processing the introductory theme (m. 442ff.).

This marks the beginning of the development section. It sheds fascinating new light on the introductory theme which is restated in B minor (with two recurrences in mm. 442 and 444) and C minor (m. 450), each with a newly developed counterpoint in minims. Further polyphonic processing of both instances of the initial theme follows during a $\mathrm{F} \#$ minor episode (m. 462ff.; $\mathrm{D}$ minor from m. 470), commencing as if to start another fugato, and intertwined with fanfare-like triplets. The minim accompaniment of the preceding passage is maintained here while tempo and dynamics increase towards the development's core, presenting a tightly-knit 
intermediate theme in $\mathrm{G} \#$ minor (m. 480ff.) which, in its chromatically descending outline, appears to be a free derivation of $\mathrm{S}_{\mathrm{IV}}$ and the >cadenza idea . This virtuosic episode soon changes its character again, arriving at a leggiero passage in A minor (m. 496ff.) which also sounds the intermediate theme in the top voice. Further progressions lead to an energetic augmentation canon of a motif first seen in $\mathrm{m}$. 485 as the intermediate theme's contrasting idea, here transformed to an ascending acoustic scale on $C$ (m. 512ff.; see also chapter 2.2.2).

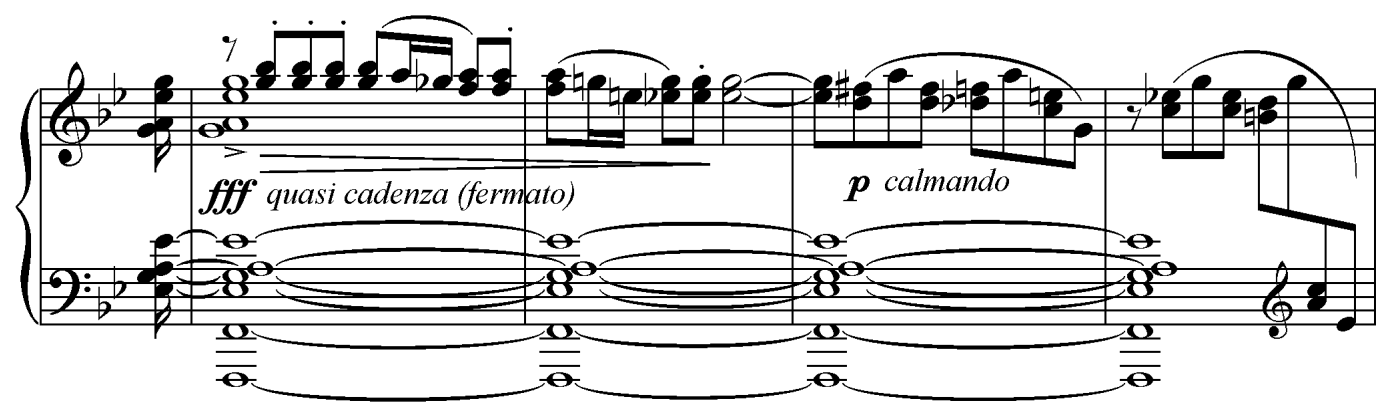

Example 3.5.12: Medtner, Sonata, Op. 25 No. 2, $2^{\text {nd }}$ subdivision, mm. 561-564

Unexpectedly back in $\mathrm{E}$ minor, we encounter a cunning variant of both $\mathrm{P}_{\mathrm{II}}$ and $\mathrm{P}_{\mathrm{III}}$ (m. 522ff.: leggiero), its descending contour presented in a canon of the exterior voices, and combined with the intermediate themea passage that could easily be mistaken for the onset of the recapitulation, or at least another ritornello resorting to the main tonic. Yet the actual recapitulation of the initial theme must be located no earlier than in $\mathrm{m}$. 534, presenting the subject in its original two-part shape, along with its semiquaver accompaniment ${ }^{73}$ - but with swapped upper and lower voices as compared to the exposition, thus purporting another impressive example of Medtner's application of double counterpoint. It also becomes apparent that the previous passage has been a mere retransition, and $\mathrm{m}$. 522 was only a feigned recapitulation with comparatively little dramaturgical weight. The passage develops, in analogy to the exposition, in continuous semiquaver motion, but without resorting to a fugato again. In its place, the culmination of the >cadenza idea< suddenly breaks in, boasting an impressive deceptive chord progression in tritone relation to the tonic $\left(\mathrm{m} .560 \mathrm{f} .: \mathrm{B}^{7}-\mathrm{F}^{7 / 9}\right)$, marked Quasi cadenza. At the same position we find an annotation in Medtner's manuscript: »From here there is a distant prospect $\ll,{ }^{74}$ and the following episode is a surreal moment of rapture and outbreak, alien to the previously established harmonic environment — while the right pedal is held down for five measures, the dominant-ninth chord on $F$ is ornamented in the highest register (see example 3.5.12). This pivotal harmony also refers back to $\mathrm{m}$. 5 at the very beginning of the sonata where it had appeared as a phrase ending; further elaboration on $\mathrm{P}_{\mathrm{III}}$ is appended in the same tonality from m. 571ff., establishing an independent German-sixth

73 In observing a »double purpose of (1) recapitulation for Section II and (2) a coda for the whole sonata «, Keller 1971 , p. 128ff. and p. 153, delineates a central feature of the work's concluding portion. However, his view of the whole remainder of the work as a $>$ coda $<$ is implausible.

74 The full annotation reads: »Otsyuda dalekaya perspektiva i poètomu nachat' i vsju sleduyushchuyu stranitsu prodolzhat' igrat' bez vsyakogo napryazheniya « (»From here there is a distant prospect, and therefore begin and continue to play without any tension the whole following page «). Vasilyev 1962, p. 25, quotes only the first three words; the translation is found in Martyn 1995, p. 88, and in Rimm's appendix to the 1998 Dover edition. 
region as opposed to the E minor tonic. Notwithstanding its eruptive detachedness, the passage does not fail to represent the formal function of a transition within the potpourri recapitulation. ${ }^{75}$

The continuous reappearances of the introductory theme, growing more frequent towards the end of the sonata, reach an exceptional stage as that subject, emerging from the near-impressionist sphere of the previous passage, is applied in contrapuntal combination with $\mathrm{P}_{\mathrm{III}}$ (see example 3.5.13). This juxtaposition is realised three times, first in $\mathrm{C}$ minor (m. 577ff.), then harmonised with a dominant-second $\mathrm{Eb}^{7}$ chord (m. 583ff.), and finally in G minor (m. 593ff.). An exciting sequence of tritone-related half-diminished chords emerges in m. 604ff. (see also chapter 2.4.2), ${ }^{76}$ arriving at an E minor sixte ajoutée triad which constitutes a Dorian tonic. In this tonality, the next truncated restatement of the introductory theme is appended (m. 616ff.), in alternation with the scadenza idea<, and leading to a Largamente variant of the invocation motif (m. 629f.). At this point the key signature of $\mathrm{E}$ minor is finally restored, and we are reaching the final culmination point, represented by an independent recapitulation of the introductory theme in sonorous parallel sixths - and juxtaposed with the $\mathrm{S}_{\mathrm{III}}$ theme, sounding in the bass voice (see example 3.5.14).

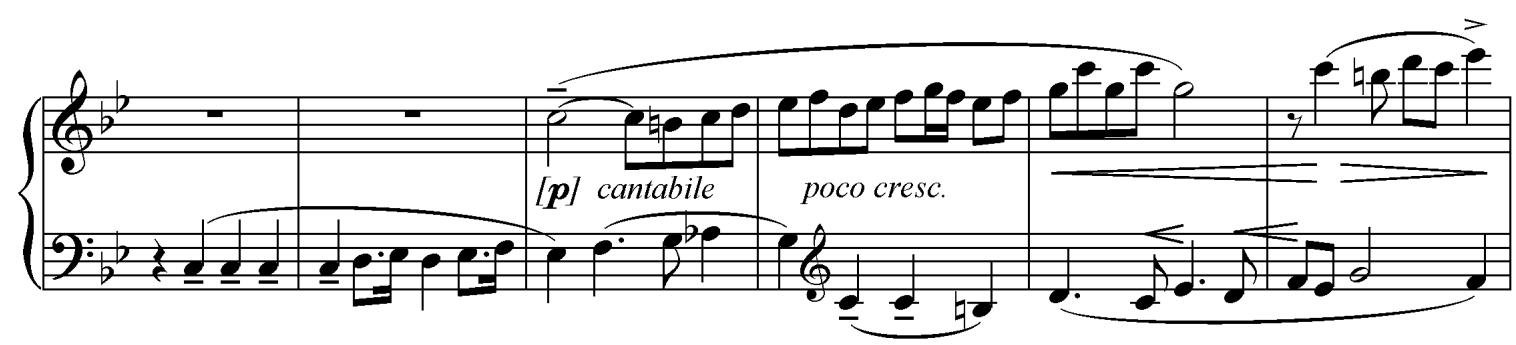

Example 3.5.13: Medtner, Sonata, Op. 25 No. 2, $2^{\text {nd }}$ subdivision: $\mathrm{P}_{\mathrm{III}}+\mathrm{I}, \mathrm{mm}$. 577-582 (motivic reduction)

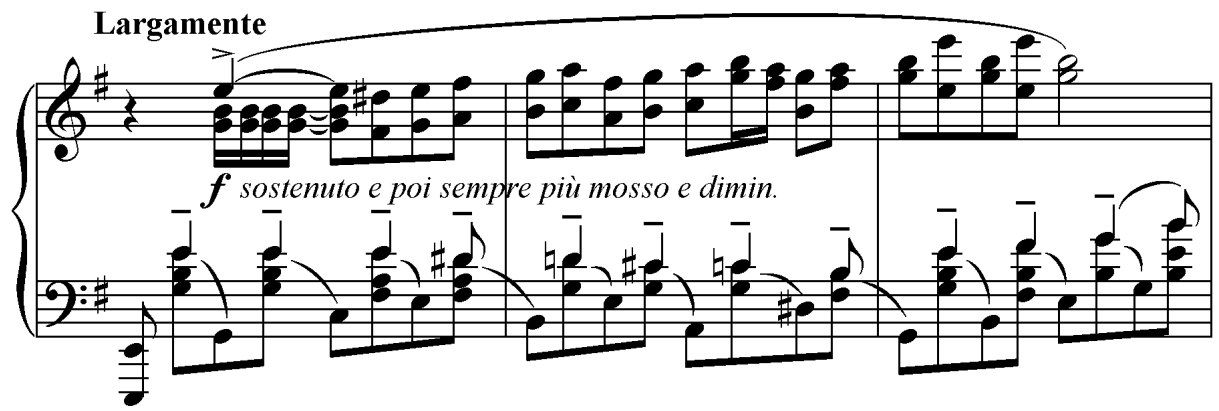

Example 3.5.14: Medtner, Sonata, Op. 25 No. 2, $2^{\text {nd }}$ subdivision: $\mathrm{I}+\mathrm{S}_{\mathrm{III}}, \mathrm{mm} .631-633$

After that, the subjects from the secondary theme zone are also briefly restated so as to complete the discontinued recapitulation section. The tenebroso $\mathrm{S}_{\mathrm{III}}$ is heard in its original appearance but transposed to A minor, a key so far unused (m. 647ff.), and $\mathrm{S}_{\mathrm{IV}}$ returns in a transformed variant with triplet accompaniment, oscillating between $\mathrm{C}$ major and $\mathrm{E}$ minor, also echoing the intermediate theme from the development section

75 Takenouchi 2004 , p. 19 , inappropriately considers that passage as part of the $2^{\text {nd }}$ subdivision's development section. Equally improper is the notion of Pitts 1999, p. 7, of the passage representing »a second development section which increasingly concentrates on the cyclic theme«, as the development section had just ended some thirty measures before.

76 See Pitts1999, p. 32: »Medtner often pivots in this fashion between two chords a tritone apart.« 
(m. 673ff.). Instead of being recapitulated in full, these themes simply pass by, being mere episodes in the sonata's stretto-like final section which dwindles away in a steadily accelerating and softening conclusion (m. 685ff.). ${ }^{77}$ Here, most of the significant themes are being recollected and merged in dense succession; namely, the invocation motif reappears in an off-beat variant (m. 693), interweaved with the beginnings of the introductory and initial themes. The ultimate closure is accomplished by a superposition of the introductory theme with its own rhythmic diminution (m. 717ff.) before the last two arpeggios resolve a $B^{7 / 13}$ flattened-fifth Phrygian dominant to the tonic, referring back to the measures directly preceding the onset of the potpourri exposition. Thus, Medtner's most majestic and colossal piano composition dissolves in a breeze of pianissimo.

\subsubsection{CONCLUDING REMARKS}

Besides Boris Asafiev's statement that, with regard to the E minor Sonata, »Medtner is, like Scriabin, a symphonist at the piano «, ${ }^{78}$ many other authors have highlighted the monumental character and symphonic dimensions of this work. Alekseyev noted that »we can feel in the sonata a concerto-style, [...] a type of symphonic concerto for solo piano «, ${ }^{79}$ and according to Dolinskaya, Myaskovsky named it »a peculiar symphony for piano $\ll{ }^{80}$ Anna Medtner recalls that the composer himself believed that the work demanded for an orchestral realisation, just like the Sonata epica, Op. 57, which he also ranked among his most >symphonic< compositions. ${ }^{81}$ However, he never attempted to orchestrate the sonata, and it thus remains an outstanding product of early-20 $20^{\text {th }}$-century keyboard music. After the first euphoric descriptions of Myaskovsky, Sabaneyev, and Sorabji, the work is constantly mentioned throughout the following decades whenever special technical challenges or intellectual and emotional demands in Medtner need to be exemplified. Even in brief accounts of Medtner's œuvre, the work is often recognised as a `climax^ or `summit« within the composer's sonata output. ${ }^{82}$ As Flamm puts it, the tragic Tyutchevian worldview »demands for the greatest conceivable

77 Takenouchi 2004, p. 18, refers to this passage as Alla Passacaglia.

78 Asafiev $1930^{\mathrm{a}}$, p. 351. The quote goes on as follows, in my translation: »The grand Sonata in E minor [is] a terrific work, but not without an obsessive pianistic elocution. Maybe this is because of its volitional spontaneity? «

79 My translation of Alekseyev 1969, p. 288: »Chertï kontsertnosti [...] oshchutimï v Sonate e-moll op. 25 No. 2, [...] svoego roda simfoni[i]-kontsert[e] dlya fortepiano solo.«

80 Dolinskaya 1966, p. 31: NVtoraya sonata iz op. 25 mi minor, o kotoroy pishet Myaskovskiy,—svoeobraznaya $>$ simfoniya dlya fortepiano/ $\ll$. The author does not give the source of this quote.

81 Ibid., p. 34, reporting Anna's words: »Zakonchiv rabotu nad sonatoy [...], Metner sam pochuvstvoval, chto ètomu sochineniyu tesno $\mathrm{v}$ ramkakh fortepiannogo izlozheniya i predpolagal sdelat' ee orkestrovïy variant. Ob etom rasskazïvala avtoru broshyurï A. M. Metner.« Accordingly, Anna Medtner in Apetyan 1981, p. 40, states: »Nekotorie ego proizvedeniya trebovali, kak on sam govoril, orkestrovogo vopoloshcheniya, naprimer, Sonata e-Moll, op. 25 ili Sonata-èpika op. 57, kotorie schital simfonichnïmi.« These quotes suggest that Medtner saw a symphonic potential in the mentioned pieces, but do not hint to a particular intention to orchestrate it - which, however, is taken for granted by Vasilyev 1962, p. 27 (»So slov vdovï kompozitora A. M. Metner izvestno, chto avtor zhelal orkestrovat' ee«), and Martyn 1995, p. 88 (»In fact the composer prepared to make an orchestral version of the work «). Both authors thus tend to over-interpret Anna's statement; and, given Medtner's difficulties in symphonic writing, becoming most apparent during the genesis of his $1^{\text {st }}$ Piano Concerto, Op. 33, it is hardly surprising that he did not undertake the attempt to orchestrate any of his earlier works.

82 See, as a representative example, Morrison 2010, p. 4: »The E minor Sonata forms a sort of summa and alpine climax to Medtner's achievement.« 
expansion — and receives it: through its temporal dimension [...], its breadth and depth of thought, and its sheer multitude of musical ideas and their development ${ }^{83}{ }^{83}$

One needs not necessarily agree with Truscott's flamboyant notion of the sonata being "possibly the greatest piano work of this century « ${ }^{84}$ or with Boyd's statement that $»$ Medtner explored and extended the one-movement plan to extreme limits, beyond which it is difficult to imagine it as a serviceable vehicle for any known musical expression ${ }^{85}$. But without any doubt, we can finally state that the sonata holds a unique position within the music of the Russian Silver Age, and marks a general point of culmination in the history of piano sonata composition. This applies to Russia as well as to Western Europe, where composers already tend to turn away from the genre during the 1910s. Medtner's predecessors and contemporaries have hardly achieved such a concentration of multifacetedness and contrapuntal density in the framework of a traditional genre. At best, Medtner himself had prefigured certain strategies of motivic work in his earlier works (such as the F minor and G minor Sonatas, Opp. 5 and 22) that he could draw on and even surpass in Op. 25 No. 2. If we take into account the multiple layers of extra-musical significance, most notably the lyric and epic implications discussed above, it does not seem too exorbitant to define the sonata as a »monumental and encyclopedic opus summum«, the most substantial achievement of which is »to fulfil the demands of both genre history and individual philosophy «. ${ }^{86}$ In this context I feel justified to acknowledge the work, echoing the headline of this chapter, as an integrative, symphonic, single-movement summit of sonata form.

83 My translation of Flamm 2015a, p. 133: »Dieses zutiefst tragische Weltbild verlangt nach der denkbar größten Expansion und bekommt sie auch: in den zeitlichen Dimensionen [...], in der Breite und Tiefe der Gedanken, in der schieren Vielfalt der Ideen und ihrer Entwicklung«.

84 Truscott 1956, p. 9.

85 Boyd 1951, p. 262.

86 My translation of Flamm 1995, p. 232: „Gattungsgeschichtlicher und individuell-philosophischer Anspruch sind hier gemeinsam eingelöst worden in einem monumentalen und gewissermaßen enzyklopädischen $\gg$ summum opus ««. 


\subsection{SONATA-BALLADE IN F-SHARP MAJOR, OP. 27}

Title page: Sonate-Ballade pour Piano [1913]; Sonate-Ballade avec Jntroduction et Finale pour Piano [1914] Composed: $1912\left(1^{\text {st }} \mathrm{mvt}\right)$, 1913-14; premiered February 22, 1913 and March 18, 1914, Moscow, by the composer Dedication: none

Editions: Édition Russe de Musique 1913 ( $\left.1^{\text {st }} \mathrm{mvt}\right), 1914$; Muzgiz 1927; Muzgiz Collected Edition 1959 (Vol. 2, pp. 202-243), reprinted Dover 1998; Muzika c. 1975

Recordings: Medtner 1947; Iles 1958; Brumberg c. 1970; Pleshakov 1970; Binns 1976; Clegg 1976; Fellegi 1990; Tozer 1991; Milne 1994; Hamelin 1996; Mejoueva 2000; Kawakami 2001; Lifshitz 2002; Rymko 2009; Iwai 2016; Karpeyev 2018

\section{A Milestone of Symbolist Music}

The Sonata-Ballade in F\# major, Op. 27, holds a central position within Medtner's sonata output. This applies in context of the chronological order of works as well as to its relevance. The composition outmatches every of the composer's preceding sonatas in terms of cyclic architecture and super-musical semantics, and therefore also contrasts significantly to the following works to come. For the first time in his sonata œuvre, Medtner realises a bipartite formal outline, subdivided in three movements, the second and third of which being connected through an attacca crossover (Introduzione e Finale) - a concept similar to that of Beethoven's >Waldstein $<$ Sonata, Op. 53 (1803-04). There are two other works whose formal design may have served as a model: Beethoven's Piano Sonata, Op. 78 (1809), which pairs a rather lyrical first movement (Allegro ma non troppo) with a lively and sparkling finale (Allegro vivace); and Scriabin's $4^{\text {th }}$ Piano Sonata, Op. 30 (1904), a direct predecessor of Medtner's work, which, with its Andante and Prestissimo volando sections, shares Beethoven’s two-movement design. Both works are written in the key of F\# major as well. ${ }^{1}$

When speaking about the Sonata-Ballade and its possible references, we must admit that the cyclic character of the work was evidently not planned at first hand. As the sketches reveal, the composer had thought of a piece named \Sonate-Variazionen〈, after discarding plans for a piano concerto and a set of character pieces at an early stage of the work's genesis. ${ }^{2}$ The first movement was eventually finished in 1912 , soon after Medtner, together with his brother Emil and his wife Anna, had moved out of Moscow to a country estate in rural Khlebnikovo, where he could dedicate himself almost exclusively to composing. In the following year he performed and published the first movement separately, already bearing the subtitle Sonate-Ballade. The sonata as a whole, with its sections being connected through attacca transitions and quotes of previously established motives, was subsequently completed to a three-movement work in 191314. Medtner premiered the whole composition in March 1914, and it was published by Édition Russe de Musique later that year. Interestingly enough, the front matter of this edition (»Sonate-Ballade avec Jntroduction et Finale pour Piano op. 27. Nouvelle édition«) retains the subtitle for the first movement only, so that the Allegretto may still be considered a single-movement sonata on its own, despite the completion to

1 Other sonatas in Medtner with a bipartite outline, incorporating an introductory first section or movement, are the Sonata-Vocalise in C major, Op. 41 No. 1, and the Sonata-Idyll in G major, Op. 56.

2 See Flamm 1995, p. 436ff., and Martyn 1995, p. 95f. 
a three-movement work. The Introduzione and Finale are only separated by a double barline instead of a music end, discarding the usual line break between the successive movements.

The attribute of a ballade, referring in particular to the $1^{\text {st }}$ movement, allows the work to be regarded as sort of a generic hybrid - it is a cyclic three-movement sonata which encloses a single-movement ballade. In this respect, the initial Allegretto hints to other composers' ballades and one-movement works of descriptive or narrative character. When, prompted by the term >ballade`, looking at the rich corpus of works in music history, another fact is noteworthy: In Medtner's œuvre, this subtitle reappears in the Concerto-Ballade in E minor, Op. 60 (completed in 1942), a work with certain structural and semantic parallels to the SonataBallade, Op. 27. Likewise to the sonata, the concerto features a short introductory movement in the middle of a tripartite structure, named Interludium. Its subtitle Ballade is taken from Mikhail Lermontov's poem Rusalka, assigning to the first movement a narrative directly derived from poetry, while the subsequent movements draw on the poem's atmosphere and main dramatis personae as well. ${ }^{3}$ The concerto relates to literature in a stronger way than most of Medtner's other instrumental compositions do, and thus features a more obvious programmatic dimension than in the case in the sonata.

Contemporary critics were widely appreciative of the Sonata-Ballade, praising its formal and aesthetic mastery, which earned its composer the Glinka Prize (together with the E minor Sonata, Op. 25 No. 2) in 1916. Kaikhosru Sorabji most enthusiastically dubbed the sonata »in every sense a first-class work», its polyphonic textures being »astonishingly attractive and seductive«, and notes »an easy, gracious spontaneity and freedom of movement «. ${ }^{4}$ For Medtner himself, the Sonata-Ballade was clearly a work of great personal importance. He frequently performed it in his recitals, more often than any of his other sonatas, and recorded it in 1947 for His Master's Voice, along with a number of other piano works of his. Given the many autobiographical and supermusical implications which are connected to its genesis, the sonata is literally bursting with meaning and semantics, making the work an impressive example of Medtner's musical symbolism. In order to make this rich associative network accessible to the recipient, we need to distinguish at least three semantic layers:

(a) A number of motivic cross-references, establishing direct connections to at least two other compositions by Medtner: The Muse, a Pushkin song from Op. 29; the Piano Quintet in C major, Op. posth.; and, more distantly, the $2^{\text {nd }}$ Violin Sonata in G major, Op. 44.

(b) Possible references to $19^{\text {th }}$-century piano compositions of balladesque or narrative character. Works which spring to the mind are the ballades of Chopin, Brahms, Fauré, Grieg, Lyadov, and many others. ${ }^{5}$ Medtner's own skazki also belong to the category of musical >storytellings` (see chapter 2.5.2).

3 Flamm 1995, p. 249f. quotes from Medtner's programmatic notes to the $3^{\text {rd }}$ Piano Concerto, with its $2^{\text {nd }}$ movement (Interludium) being »just an introduction to the finale « (»nur eine Einleitung zum Finale «).

4 Sorabji 1932, p. 61f.

5 Gabriel Fauré wrote a large-scale Ballade in $\mathrm{F} \#$ major, Op. 19 (composed for solo piano in 1877-79, and arranged for piano and orchestra in 1881). Anatoly Lyadov's somewhat shorter Barcarolle, Op. 44 (1898), is also written in the key of $\mathrm{F} \#$ major. The subtitle Ballade appears in a number of other sonata compositions, such as Eugène Ysaÿe's D minor Sonata \Ballade〈 for solo violin in D minor, Op. 27 No. 3 (1923), which could, however, hardly have been influenced by Medtner. Possible relations to other works of Russian composers which are not examined here include Mikhail Gnesin's Sonate-Ballade for cello and piano in C\# minor, Op. 7 (1910), Vissarion Shebalin's Piano Sonata (1921), Boris Lyatoshinsky's $2^{\text {nd }}$ Sonata, Op. 18 (1925), Aleksandr Glazunov's Concerto ballata for violoncello and orchestra in C major, Op. 108 (1931), and Nikolai Myaskovsky's (22 ${ }^{\text {nd }}$ ) Symphony-Ballad, Op. 54 (1941). For the semantic context of $\mathrm{F} \sharp$ major in Medtner, see also chapter 2.4.5. 
(c) A religious background, conveyed through Afanasy Fet's poem Kogda bozhestvennïy bezhal, which is connected to the genesis of the sonata. The poem's content serves as a subliminal annotation to the music, and is enriched by another metaphorical annotation (»Erdenfrühling «) by Medtner's biographer Alfred Swan.

These intertextual narratives need to be examined in greater detail, as they establish a link between several compositions by Medtner of different genres, written over a period of more than 40 years. However, in this analysis of the Sonata-Ballade I first assume that only the score itself existed, examine it as it appears, and consider the mentioned semantic implications in a later stage of the analysis.

\subsubsection{THE SCORE ON ITS OWN}

First movement: Allegretto - Allegro molto agitato $F \#$ major $-F \#$ minor, 6/8, 297 measures on 19 pages

\begin{tabular}{|c|c|c|c|c|}
\hline \multirow{6}{*}{$\begin{array}{l}\text { SECTION } \\
\text { exposition }\end{array}$} & THEMES AND SUBJECTS & POSITION & INDICATIONS & KEY \\
\hline & primary $>$ ballade $<$ theme $(\mathrm{P})$ & mm. 1-9 & mp cantando; molto commodo & $\mathrm{F} \#$ major \\
\hline & transitional theme $(\mathrm{Tr})$ & mm. 10-34 & poco a poco svegliando; appassionato & $\mathrm{F} \sharp$ major \\
\hline & secondary theme $\left(\mathrm{S}_{\mathrm{I}}\right)$ & mm. 35-60 & $\mathrm{p}$ dolce & $\mathrm{D} \# / \mathrm{A} \#$ minor \\
\hline & intermediate idea $\left(\mathrm{S}_{\mathrm{II}}\right)$ & mm. 61-66 & pp carezzando & $\mathrm{C} \#$ major \\
\hline & variant of primary theme & mm. 67-80 & pp cantando & $\mathrm{F} \sharp$ major \\
\hline \multirow[t]{5}{*}{ development } & primary theme $(\mathrm{P})$ & mm. 81-90 & $\mathrm{p}$ dolce, a piacere & modulating \\
\hline & intermediate idea $\left(\mathrm{S}_{\mathrm{II}}\right)$ & mm. 91-100 & [p] росо а росо а tетро & modulating \\
\hline & secondary theme $\left(\mathrm{S}_{\mathrm{I}}\right)$ & mm. 101-116 & Risoluto & $\mathrm{F} / \mathrm{C}$ minor \\
\hline & transitional theme $(\mathrm{Tr})$ & mm. 117-134 & concentrando; pp cantabile & $\mathrm{C} \sharp$ minor \\
\hline & retransition: primary theme & mm. 135-149 & $\mathrm{ff}$ & $\mathrm{F} \# \operatorname{minor}(\mathrm{V})$ \\
\hline \multirow[t]{5}{*}{ recapitulation } & primary theme $(\mathrm{P})$ & mm. 150-159 & pp sereno; molto commodo & A major \\
\hline & transitional theme $(\mathrm{Tr})$ & mm. 160-182 & appassionato & $\mathrm{F} \#$ minor \\
\hline & secondary theme $\left(\mathrm{S}_{\mathrm{I}}\right)$ & mm. 183-208 & $\mathrm{p}$ dolce, cantabile & $\mathrm{B} / \mathrm{F} \#$ minor \\
\hline & intermediate idea $\left(\mathrm{S}_{\mathrm{II}}\right)$ & mm. 209-214 & p carezzando & $\mathrm{F} \sharp$ major \\
\hline & variant of primary theme & mm. 215-230 & pp cantando & B major \\
\hline \multirow[t]{2}{*}{ coda } & Tr, intermediate $\left(\mathrm{S}_{\mathrm{II}}\right), \mathrm{P}, \mathrm{S}_{\mathrm{I}}$ & mm. 231-277 & Allegro molto agitato; ff & $\mathrm{F} \sharp$ minor \\
\hline & culmination: derived from $\mathrm{Tr}$ & mm. 278-297 & ff a tempo & $\mathrm{F} \sharp$ minor \\
\hline
\end{tabular}

The movement commences with a serene, slowly rocking primary theme in 6/8 meter (molto commodo, cantabile), characterised by Swan as »one of Medtner's rare smiles «, ${ }^{6}$ and reminiscent of the descriptive tone of Chopin's large one-movement works, particularly his four ballades. ${ }^{7}$ In particular, it points to the F\# major Barcarolle, Op. 60 (1845-46), which Medtner's Allegretto seems to resemble not only in key and in its narrative atmosphere, but also in its persistent ternary rhythm. ${ }^{8}$ In addition to the barcarolle topic, the music also

6 Swan 1922, p. 618.

7 Martens 1919, p. 361, adequately describes the tone of the Allegretto as »an epic pastoral style«. See also Sacre 1998, p. 1817, and Flamm 2015a, p. 127, claiming that the opening with a grand cantilena is rather atypical of Medtner, yet indebted to the model of Chopin's ballades.

8 Further influence of barcarolle rhythm is evident in Medtner's Sonate-Vocalise in C major, Op. 41 No. 1. As Emerson $2016^{\mathrm{a}}$, p. 41f., remarks, there might be another point of reference to Chopin in the contour of the first five notes in Medtner's $>$ ballade theme $<$ which resemble the first melodic ascension at the beginning of the $2^{\text {nd }}$ Ballade in $\mathrm{F}$ major, Op. 38 (mm. 2-3). 
alludes to siciliano rhythm as a very related metrical archetype; anyway, I will further refer to this $\mathrm{P}$ subject as the >ballade themer. Its compound theme structure, closing with perfect cadences in mm. 4 and 9 in a nearly predictable manner, defines the subject as a self-contained entity, seemingly lacking an organic connection to the movement's further progress - an atypical approach for the construction of a first-movement form with its need for developable, open-ended material. It is not until the appearance of a figure in quavers, employing a cycle of fifths sequence (m. 10ff.) that the music shows real potential for development. Naturally, it is this transitional theme ( $\mathrm{Tr})$ and its continuation, an appassionato cantilena descending from $F \#(\mathrm{~m}$. 19, with an allusion of canon in the following measure; see example 3.6.1), of which much of the material of the development and coda sections will be constructed. More transitional material is appended after another perfect cadence in $\mathrm{m}$. 23f., finally leaving the tonic key behind. As the movement continues, a secondary theme $\left(S_{I}\right)$ enters in the relative key of $D \#$ minor (m. 35), later modulating to $A \#$ minor (m. 44; see example 3.6.2). This subject, in its imitative dotted polyrhythm of both hands, curiously disguises the $6 / 8$ meter, making use of »most infinitesimal syncopations «. ${ }^{9}$ Its onset with the intervals of a descending fifth and ascending third seems reminiscent of the sixth (D minor) variation of Tchaikovsky's Rococo Variations for cello and orchestra, Op. $33 .{ }^{10}$ The theme remains fragile in character and unstable in tonality, and, just like the $>$ ballade theme $\triangleleft$, rather stays in the background of the overall motivic development.

\begin{tabular}{|c|c|c|c|c|c|c|c|c|c|c|c|c|c|c|c|}
\hline \multicolumn{5}{|c|}{ Exposition } & \multicolumn{5}{|c|}{ development } & \multicolumn{5}{|c|}{ recapitulation } & coda \\
\hline $\mathrm{P}$ & $\operatorname{Tr}$ & $\mathrm{S}_{\mathrm{I}}$ & $\mathrm{S}_{\text {II }}$ & $\mathrm{P}$ & $\mathrm{P}$ & $\mathrm{S}_{\mathrm{II}}$ & $\mathrm{S}_{\mathrm{I}}$ & $\operatorname{Tr}$ & $\mathrm{P}$ & $\mathrm{P}$ & $\operatorname{Tr}$ & $\mathrm{S}_{\mathrm{I}}$ & $\mathrm{S}_{\mathrm{II}}$ & $\mathrm{P}$ & $\operatorname{Tr}, \mathrm{S}_{\mathrm{I}}, \mathrm{S}_{\mathrm{II}}, \mathrm{P}$ \\
\hline m. 1 & m. 10 & m. 35 & m. 61 & m. 67 & m. 81 & m. 91 & m.101 & $\mathrm{m} .117$ & m.135 & m.150 & m.160 & m.183 & m.209 & $\mathrm{m} .215$ & mm. 231-297 \\
\hline \multicolumn{5}{|c|}{$\operatorname{arch} \rightarrow$} & \multicolumn{5}{|c|}{$\leftarrow \operatorname{arch}$} & \multicolumn{5}{|c|}{$\operatorname{arch} \rightarrow$} & $\begin{array}{c}\text { analogy } \\
\text { to development }\end{array}$ \\
\hline
\end{tabular}

Figure 3.6.0: Medtner, Sonata-Ballade, Op. 27, $1^{\text {st }}$ mvt, mirror scheme of theme entries after Podporinova 2007, p. 140

When, at the end of the exposition section, a closing zone might have been expected, there appears a brief intermediate idea in dotted rhythm (m. 61ff.). While it might seem arbitrary to dub this passage a substantial thematic subject $\left(\mathrm{S}_{\text {II }}\right.$ of the secondary theme zone), this view is later justified in the coda section where it is extensively developed. After that, the >ballade theme< enters again (m. 67, cantando) — but, curiously, in the `wrongく key of $F \sharp$ major which the exposition was supposed to leave behind. Medtner plays the same trick in the recapitulation section, where the `ballade theme`, starting again in B major, builds a thematic link to the coda. The unusual manner of unalteredly restating a sonata movement's primary theme has already been noticed by Aleksandr Alekseyev, who therefore observed elements of rondo form find their way into the Allegretto. ${ }^{11}$ Ekaterina Podporinova points out that, through the reiterations of the >ballade theme<, each of

9 Truscott 1956, p. 4f., further stating that Medtner »frequently combines two subtle rhythms of this type in cunning overlaps «.

10 I owe this hint to Alexander Karpeyev. See also Emerson $2016^{\text {a }}$, p. 52.

11 See Alekseyev 1969, p. 281: „Neobïchno chastaya dlya sonatnogo allegro povtornost' glavnoy temï privnosit v nego èlementï rondo.« The continuous changes of mood, expressed in the alternation between the bright >ballade theme $<$ and the gloomy contrasting subjects, are described as a process of >emotional rocking or $>$ swinging (ibid.: 
the three sections of the movement forms a figure of an arch, establishing »crystal symmetry « mirrored by axes of reflection located at the borders of each section. What is more, the development section employs the subjects in the exactly reverse order of the exposition, which makes the thematic material »subordinate itself to an idea of mirroring « (see figure 3.6.0). ${ }^{12}$ Leaving aside the coda, we might even consider the exposition, development and recapitulation sections as equivalent to >stanzas in narrative poetry, referring back to the tripartite structure of medieval French ballads. ${ }^{13}$ From the perspective of Sonata Theory, though, the whole section would qualify as a >failed exposition< as its tonal trajectory returns to $\mathrm{F} \#$ major instead of establishing a firm EEC in the secondary key of $\mathrm{C} \#$ major. ${ }^{14}$

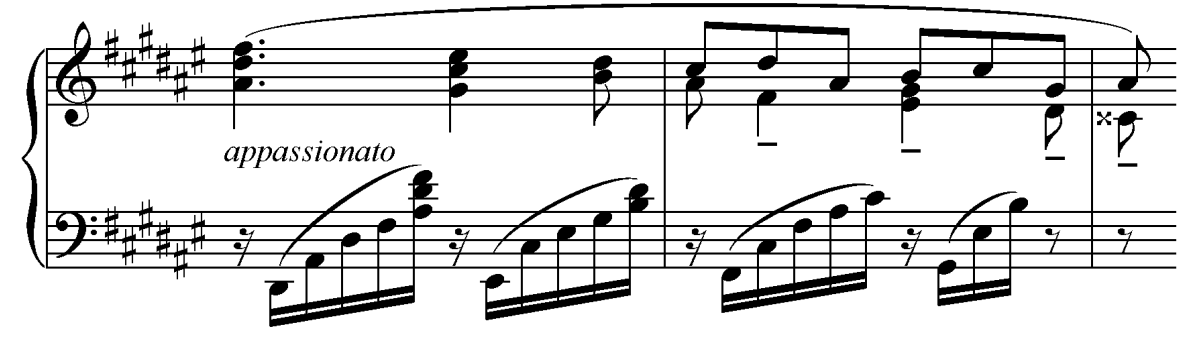

Example 3.6.1: Medtner, Sonata-Ballade, Op. 27, $1^{\text {st }}$ mvt, exposition, mm. 19-20
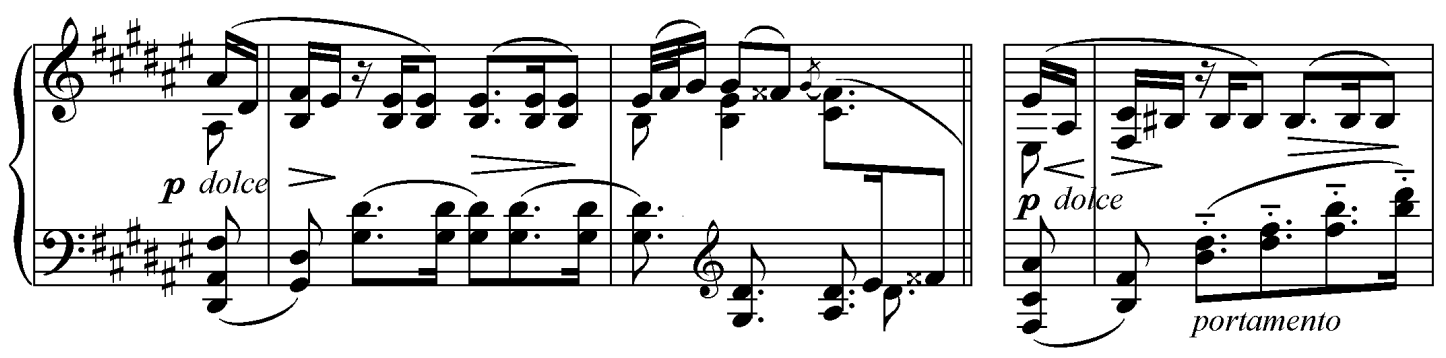

Example 3.6.2: Medtner, Sonata-Ballade, Op. 27, $1^{\text {st }}$ mvt, exposition, mm. 35-36 // m. 44

The development section, although processing every of the main themes in equal intensity, features a remarkable passage based on the transitional theme which advances to an almost impressionist harmonic aura, extending the regional tonic of $\mathrm{C} \#$ minor to an acoustic scale on $\mathrm{D}$ (m. 124ff.; see example 2.2.5). While the whole Allegretto is held together by only slightly altered appearances of the >ballade theme<, the movement lacks an affirmative relaunch of its primary subject at the beginning of the recapitulation section. Instead,

»ėmotsional'naya raskachka«), producing a dialectic struggle between light and dark forces. The similarity of the Russian verbs raskachat' (to start swinging) and rasskazat' (to narrate) may be more than just a coincidence in this context.

12 The diagram appears in translation of Podporinova 2007, p. 140. Both quotes ibid., p. 139f. (again in Podporinova 2009, p. 30): »Mnogourovnevaya >kristallicheskaya simmetriya< sostavlyaet [...] organizatsiyu pervoy chasti SonatïBalladi, op. 27. Zdes' [...] kompozitor vïstraivaet arochnïe svodï èkspozitsii, razrabotki i reprizi. [...] Na kazhdom etape ikh poyavlenie podchinyaetsya idee zerkal'nosti.« The author inapplicably marks the intermediate idea (m. $61 \mathrm{ff}$.), preceding the restatement of the $>$ ballade theme $<$ in the exposition and recapitulation, a closing $\mathrm{Zone}(>\mathrm{ZP}<$ for >zaklyuchitel'naya partiyar).

13 See ibid., p. $173 \mathrm{f}$.

14 This >deformation< particularly applies when conceiving the half cadence on C\# major (m. 76) as an »EEC substitute in the wrong key«. See Hepokoski and Darcy 2006, p. 177f. 
there appears a tender and distant reiteration of the >ballade theme`, sounding in the unexpected key of A major (m. 150; see example 3.6.3), after an extended dominant pedal could have easily made it possible to proceed with the regular $\mathrm{F} \#$ major - and after some cunning imitative processing of the subject at the distance of only one quaver (mm. 137f. and 148f.). Thus, after the highly unusual tonal plan of the exposition, the movement's recapitulation also shows a >nonresolution<, as Hepokoski and Darcy dubbed it, ${ }^{15}$ and drastically neglects the traditional sonata trajectory.

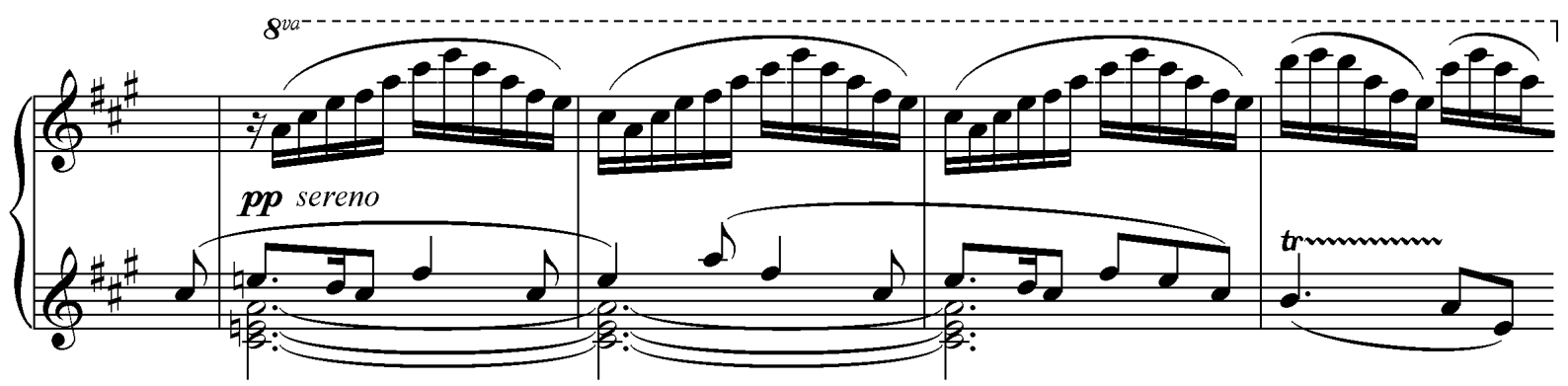

Example 3.6.3: Medtner, Sonata-Ballade, Op. 27, $1^{\text {st }}$ mvt, recapitulation, mm. 150-153
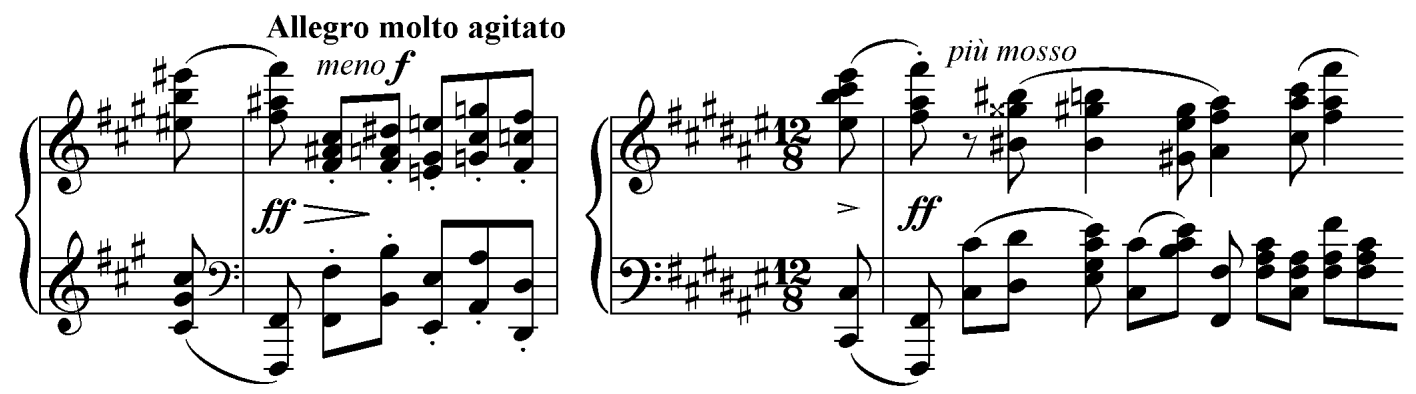

Example 3.6.4: Medtner, Sonata-Ballade, Op. 27, $1^{\text {st }}$ mvt, m. $231 / /$ Chopin, Barcarolle, Op. 60, m. 93

As the movement goes on, the >ballade theme`seems to gradually move to the background, although it frames the thematic space of both the exposition and recapitulation. The $\mathrm{F} \#$ minor coda once again presents the transitional theme's cycle of fifths, preceded by a climactic sequence of ascending chords, a caesura, and a cadential progression reminiscent of a very similar moment at the climax of Chopin's Barcarolle, which appears at a corresponding position in the course of the movement (m. 231; see example 3.6.4). ${ }^{16}$ Medtner's coda allows every of the movement's themes to reappear and synthesise, with the transitional theme and intermediate idea gaining special attention, and ending "tragically and abruptly« in the very same key of the tonic minor. ${ }^{17}$ This feature is rarely found in major-mode first-movement forms, and of special interest since as the Allegretto was first published separately as a single movement. One might regard this aspect as a tonal inconsistency, and a number of scholars looked upon the movement as incomplete, its minor-mode ending

15 Ibid., p. 245.

16 Plaistow 1976 perceives these chords as an allusion to Chopin. I would go even further and call them a quotation, for it is only the higher octave of the anacrusis that discriminates Medtner's cadence from m. 93 of Chopin's Barcarolle, Op. 60. See also Martyn 1995, p. 96, and Emerson 2016 a , p. 65ff.

17 Laberge 1955, p. 149. The author characterises this conclusion with the idiosyncratic expression »This is nothingness«. 
demanding for continuation — but, bearing in mind that the movement's exposition appears just as imbalanced as the recapitulation and coda sections, this argument cannot satisfactorily explain why Medtner decided to append two more movements. ${ }^{18}$ The eventual bipartite structure, conceiving the Allegretto and Introduzione e Finale as two poles complementary in form and mood, owes more to a concept of integrative balance than to a strive for tonal resolution or, as Siegfried Mauser suggests, to a reverse development of tempo. ${ }^{19}$

However, in the multi-movement context of the final version, the Allegro molto agitato coda is harmonically connected to the onset of the $2^{\text {nd }}$ movement. The $F \#$ minor triad is occasionally enriched with the Dorian major sixth $D \#$ (mm. 285 and 287), as if to prepare for the attacca transition to the Introduzione, which starts with that very sixte ajoutée chord (see example 3.6.5). During the last measures of the coda (m. 288ff.), the tonic minor chord $F \# A-C \#(-D \#)$ is repeatedly confronted with its tritone transposition $C-E b-G$ $(-A)$, a progression commonly referred to by Russian music theory as a $>$ tritonant ${ }^{20}{ }^{20}$ These two sixte ajoutée tetrads have two mutual pitches in common, and their combination covers six pitches out of an octatonic scale, while the differing notes of the latter, $C$ and $G$, are applied in half-tone voice leading to the tonic triad of $\mathrm{F} \#$ minor - with $C$ being enharmonically equivalent to $B \#$. The $C$-based chord, although lacking a clear harmonic function, thus gains a slight dominant quality. The harmonic situation gets further complicated with the movement's third-but-last and second-but-last chords, a G major triad (Neapolitan sixth in F\# minor) and $\mathrm{Eb}^{7}$ fifth-sixth chord. Where a regular antepenultimate and penultimate cadential progression is expected, Medtner again employs a chord comprising $E b$ instead of the leading-tone $E \#{ }^{21}$ and with the Phrygian clausula $G-F \#$ replacing a clear $\mathrm{V}-\mathrm{I}$ cadence (see example 3.6.5).

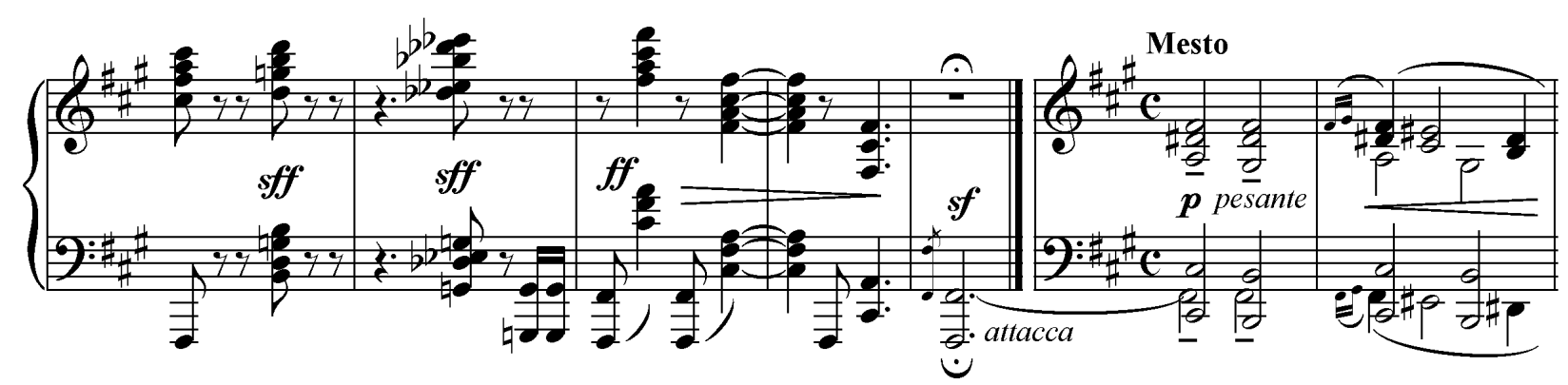

Example 3.6.5: Medtner, Sonata-Ballade, Op. 27, $1^{\text {st }} \mathrm{mvt}, \mathrm{mm} .293-297 / / 2^{\text {nd }} \mathrm{mvt}, \mathrm{mm} .1-2$

18 Kalendarev 2005 , p. 32, considers the coda an unsatisfactory ending with a need for continuation in order to $»$ prolong the broken line of the development and bring the piece to a stable conclusion«. See also Plaistow 1976.

19 It remains unclear in what way Mauser 2004, p. 91, sees a process of deceleration during the finale (»das [...] in Umkehrung zum ersten Satz [...] einen fortlaufenden Verlangsamungsprozess abbildet «).

20 Recent theory of harmony in Russia was shaped through the writings of Boleslav Yavorsky, Lev Mazel, Yuri Kholopov, and others. The terminology for functional analysis was, on the basis of extensive reception of German music theory, widely borrowed from Hugo Riemann. However, the term >Tritonante<, denoting a tritone relation of the roots of successive triads, is derived from Sigfrid Karg-Elert's Polaristische Klang- und Tonalitätslehre (1930).

21 For Malikova 1967, p. 302, the $\mathrm{Eb}^{7}$ is an altered subdominant chord of the preceding Neapolitan harmony -an interpretation that fails to illuminate the progression to the final $\mathrm{F} \#$ major (»Chuzhdïy fis-moll'yu >vvodyashchiy< akkord >prishel< iz tonal'nosti predidushchey >neapolitanskoy< garmonii $\mathrm{v}$ kachestve prinadlezhashchey ey al'terirovannoy subdominanti $\ll$ ). Loftis 1970 , p. 173, is totally misled in stating the $\mathrm{Eb}^{7}$ to be a »doubly lowered bbVII« and »extremely foreign progression«. 


\section{Second movement: Introduzione (Mesto) $\mathrm{F} \#$ minor, $4 / 4, \downarrow=84,68$ measures on 4 pages}

\begin{tabular}{|c|c|c|c|c|}
\hline \multirow{4}{*}{$\begin{array}{l}\text { SECTION } \\
\text { exposition }\end{array}$} & THEMES AND SUBJECTS & POSITION & INDICATIONS & KEY \\
\hline & initial theme & mm. $1-8$ & mp pesante & $\mathrm{F} \#$ minor \\
\hline & middle episode & mm. 9-16 & $\mathrm{p}$ & $\mathrm{C} \#$ minor \\
\hline & initial theme & mm. 17-24 & $\mathrm{mp}$ subito & $\mathrm{F} \#$ minor \\
\hline \multirow[t]{2}{*}{ central } & secondary theme & mm. $25-36$ & $\mathrm{p}$ tenebroso & $\mathrm{C} \sharp$ minor \\
\hline & introduction of $>$ Muza $<$ motif & mm. 37-48 & f espressivo, ma a tempo & $\mathrm{G} \sharp \operatorname{minor}(\mathrm{V})$ \\
\hline \multirow[t]{3}{*}{ recapitulation } & initial theme & mm. 49-56 & Maestoso; ff & $\mathrm{F} \#$ major \\
\hline & secondary theme, $>$ Muza $<$ motif & mm. 57-64 & ritenuto accelerando & $\mathrm{F} \#$ minor \\
\hline & initial theme & mm. 65-68 & p tenebroso & $\mathrm{D} \#$ minor \\
\hline
\end{tabular}

According to Medtner's pupil Nikolai Shtember, this movement marked a certain change in Medtner's creative work, enabling the composer to reach a new stage of facility and excellence of composing. ${ }^{22}$ The short Introduzione in $\mathrm{F} \#$ minor, written in a quasi improvvisando mood, is less tightly constructed than the first movement; its function in the overall trajectory of the sonata is to introduce material which will be further processed in the finale. The gloomy initial subject, marked pesante, uses a harmonic minor scale with sharpened sixth and seventh degrees which the composer was evidently fond of. Barrie Martyn notices a similarity to another pesante passage from the ending of Medtner's early Scherzo infernale, Op. 2 No. $3{ }^{23}$ while Vladimir Protopopov feels reminded by the mood of Borodin's Song of the Dark Forest (also written in the key of F\# minor) ${ }^{24}$ Bradley Emerson, on the contrary, identifies the subject as a funeral march. ${ }^{25}$ Medtner's subject features a tripartite syntax, with a $\mathrm{C} \#$ minor episode in dotted rhythm as its middle part (mm. 9-16). ${ }^{26}$ The central section of the movement starts with a steady tenebroso melody (m. 25) as the secondary theme, now stabilising the key of $\mathrm{C} \sharp$ minor. According to Yuliya Moskalets, this second theme resembles the Gregorian Dies irae sequence, making the passage function as »an instance of the evil and demonic in Medtner’s music «. ${ }^{27}$ In the following measures, Medtner introduces a phrase of crucial importance, the so-called `Muzaく motif. After being introduced as a restrained left-hand subject in $\mathrm{m} .37$, entering in a middle voice within figurations (see example 3.6.6), this motif unfolds to a network of intertextual references and self-quotes, which will be subject to the second part of this analysis. As a sort of a recapitulation, the initial theme returns in a brighter $\mathrm{F} \#$ major version

22 Shtember in Apetyan 1981, p. 88, quoting the composer: »From the $2^{\text {nd }}$ movement of the Sonata-Ballade on, I started composing with much greater ease than in anything I wrote before « (my translation of »Nachinaya so vtoroy chasti Sonatï-Balladï op. 27 ya stal pisat' znachitel'no legche, chem vse, ran'she do togo sochinennoe«).

23 See Martyn 1995, p. 97. The similarity rather applies to the repeated chords in minims than to the subject's general character.

24 See Protopopov 1987, p. 291.

25 This might seem a rather vague notion as dotted rhythms, a common feature of any march type, do not appear. Emerson $2016^{\mathrm{a}}$, p. 75f., argues that the double grace note anacrusis of mm. 2 and 6 resembles a drum pattern, and compares the later variant of the initial theme (m. 17ff.) to the beginning of Medtner's Funeral March in B minor, Op. 31 No. 2, which appears very similar in texture.

26 In the dotted rhythm of this episode, Emerson $2016^{\mathrm{a}}$, p. 113 , notices a presentiment of the $3^{\text {rd }}$ movement's opening.

27 My translation of Moskalets 2004 a , p. 126 (again in Moskalets 2004 ${ }^{\mathrm{b}}$, p. 116): »Obraz zlogo, demonicheskogo v muzïke Metnera simvoliziruetsya posredstvom temï, intonatsionno svyazannoy s sekventsiey Dies irae. « The similarity only applies when omitting the first note of the Dies irae (in both the right and left hands), and without considering Medtner's repeated notes (in the right hand). 
(m. 49), before it is restated again at the ending of the Introduzione, now in a sombre unison and in the key of $\mathrm{D} \#$ minor (m. 65). It finally halts at a fermata on the note $B$, thus preparing for the entry of the $3^{\text {rd }}$ movement, and anticipating the subject of the fugato implemented into the finale's development section.

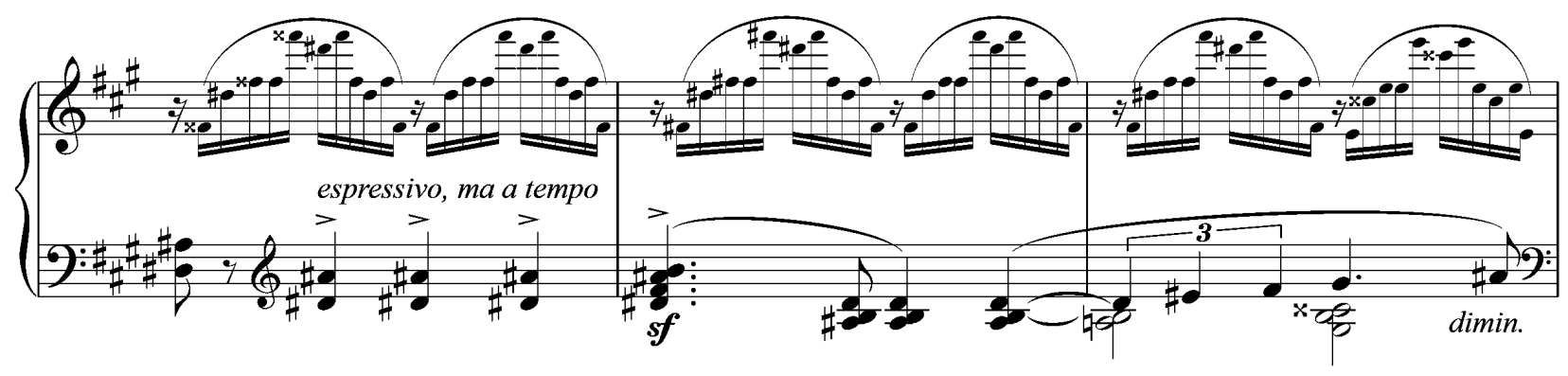

Example 3.6.6: Medtner, Sonata-Ballade, Op. 27, $2^{\text {nd }}$ mvt, central section, m. 37-38

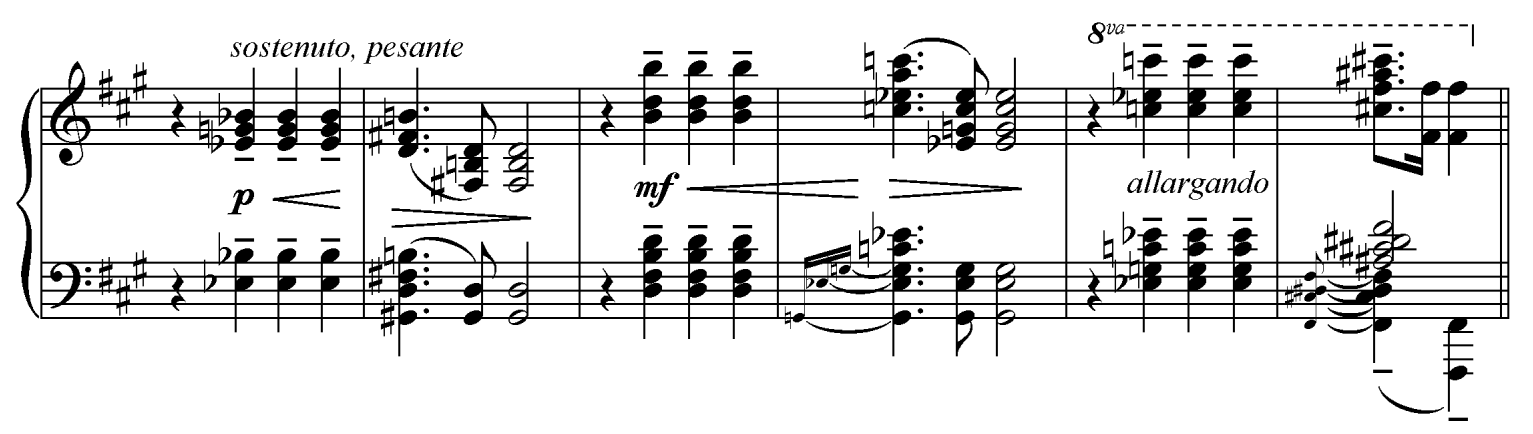

Example 3.6.7: Medtner, Sonata-Ballade, Op. 27, $2^{\text {nd }}$ mvt, central section, mm. $44-49$

\section{Third movement: Finale (Allegro) $)^{28}$ \\ $\mathrm{F} \#$ major, 2/4, 373 measures on 19 pages}

\begin{tabular}{|c|c|c|c|c|}
\hline \multirow{5}{*}{$\begin{array}{l}\text { SECTION } \\
\text { exposition }\end{array}$} & THEMES AND SUBJECTS & POSITION & INDICATIONS & KEY \\
\hline & primary theme $(\mathrm{P})$ & mm. $1-16$ & $\mathrm{p}$ leggierissimo & $\mathrm{F} \#$ major \\
\hline & transitional idea ( $\mathrm{Tr})$ & mm. $17-48$ & f cantando & $\mathrm{F} \# \mathrm{maj} / \mathrm{D} \sharp \min$ \\
\hline & secondary theme $>$ Muza $<(S)$ & mm. 49-66 & [p] dolce pacatamente & Eb major \\
\hline & initial theme of $2^{\text {nd }} \mathrm{mvt}$ & mm. $67-78$ & $\mathrm{p}$ & $\mathrm{C} / \mathrm{F} / \mathrm{Eb}$ minor \\
\hline \multirow[t]{5}{*}{ development } & primary theme (as if repeated) & mm. 79-94 & $\mathrm{p}$ a tempo & $\mathrm{F} \#$ major \\
\hline & transitional idea & mm. 95-129 & $\mathrm{f}$ & $\mathrm{F} \# / \mathrm{D} b$ major \\
\hline & fugato: initial theme of $2^{\text {nd }} \mathrm{mvt}$ & mm. 130-171 & $\mathrm{p}$ espressivo, stentato & $\mathrm{Bb} / \mathrm{G}$ minor \\
\hline & fugato: continuation & mm. 172-235 & Risoluto; $\mathrm{f}$ & $\mathrm{Eb}$ minor \\
\hline & secondary theme of $2^{\text {nd }} \mathrm{mvt}$ & mm. 236-273 & affanato; $\mathrm{p}$ sordamente & $\mathrm{E}^{7} / \mathrm{F}^{7} / \mathrm{C} \sharp^{7}$ \\
\hline \multirow[t]{4}{*}{ recapitulation } & primary theme $(\mathrm{P})$ & mm. 274-289 & Teтро I; p leggierissimo & $\mathrm{F} \#$ major \\
\hline & transitional idea (Tr) & mm. 290-313 & {$[\mathrm{f}]$} & $\mathrm{F} \#$ major \\
\hline & secondary theme $>$ Muza $<(S)$ & mm. 314-333 & pp molto tranquillo & $\mathrm{F} \#$ major \\
\hline & transitional theme of $1^{\mathrm{st}} \mathrm{mvt}$ & mm. 334-348 & molto espressivo; f pleno & $\mathrm{F} \sharp$ major \\
\hline codetta & primary theme of $1^{\text {st }} \mathrm{mvt}$ & mm. 349-373 & Maestoso, gaudioso; ff & $\mathrm{F} \#$ major \\
\hline
\end{tabular}

28 The first edition of 1914 only reads Allegro (p. 22). In the printed copy owned by Medtner's English student Edna Iles, the handwritten line »Sempre al rigore di tempo« is added. This amendment was taken over into the Collected Edition, Vol. 2, p. 225, probably through Anna Medtner's influence, and omitted again in the Muzika edition of c. 1975 for whatever reason. 
The finale's beginning is of a seemingly indecisive character, twice halting on a subdominant chord as if unsure how to proceed (mm. 4 and 8 ). The primary theme, whose Schumannian mood has been noticed by a number of authors, ${ }^{29}$ displays an idiosyncratic upbeat figure in dotted semiquavers, resembling a texture of horn fifths in its outer voices, and once more falls short of the expectations raised by a sonata's final movement. Anything but affirmative, it feels its way forward to a sentence-like, hybrid thematic structure of sixteen measures, the continuation phrase itself forming an eight-measure sentence. In $\mathrm{m} .48$, the secondary theme establishes a cross-movement connection as it refers to the >Muzar motif from the Introduzione's central section, now shaped as a dolce pacatamente cantilena in $\mathrm{Eb}$ major (m. 48ff.; see example 3.6.8). Later, this theme will be transformed to a two-part canon in $\mathrm{F} \#$ major as it reappears within the recapitulation section (m. 314ff.; see example 3.6.9). The exposition restarts as if it was to be repeated from $\mathrm{m} .79$ on and quotes the primary theme unalteredly, but then modulates to $\mathrm{D} b$ major before reaching the secondary theme zone, revealing that the development section has in fact already begun. Oleg Sokolov refers to this formal ambiguity, which is something peculiar in some of Medtner's sonatas and not found earlier, as a »sonata form with double exposition « ${ }^{30}$ Another interpretation of the movement's overall form is that of a sonata-rondo, ${ }^{31}$ which seems justified with regard to the recurrences of the principal theme and the tonal adjustment of the recapitulation's secondary theme zone to the tonic key. However, the massive development section appears so totally different in profoundness and formal weight that I feel reluctant to call it a mere rondo episode. Also, the ending lacks a final reiteration of the principal theme, which is replaced by a codetta borrowing the >ballade theme from the $1^{\text {st }}$ movement.

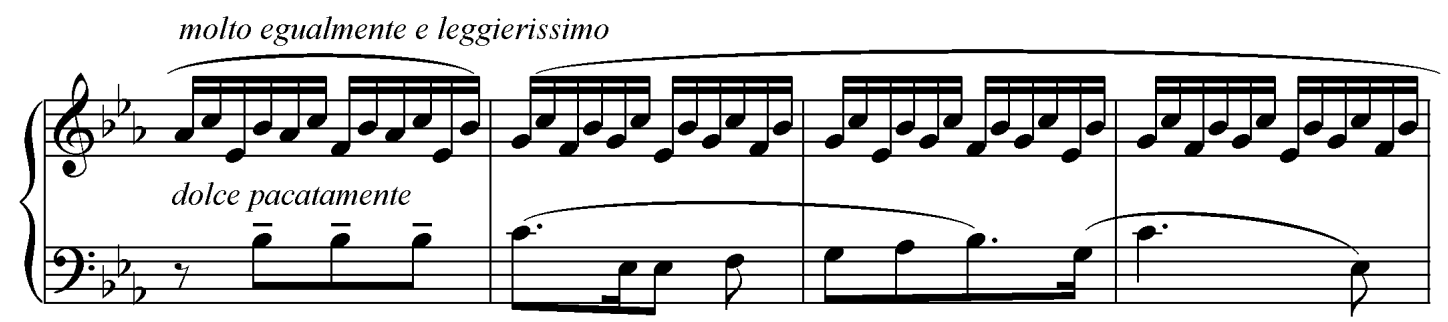

Example 3.6.8: Medtner, Sonata-Ballade, Op. 27, $3^{\text {rd }}$ mvt, exposition, mm. 48-51

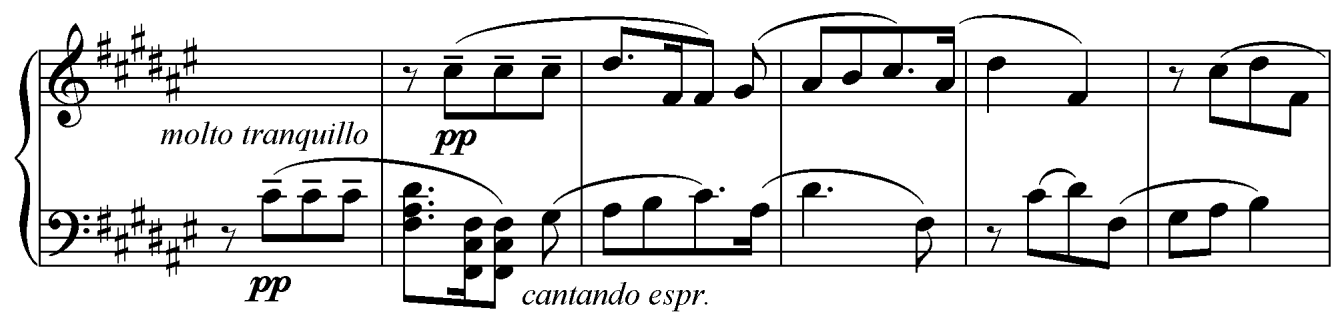

Example 3.6.9: Medtner, Sonata-Ballade, Op. 27, $3^{\text {rd }}$ mvt, recapitulation, mm. 314-318 (motivic reduction)

29 The alternating tonic and subdominant chords in dotted rhythm particularly suggest an intertextual relation to the Préambule from Schumann's Carnaval, Op. 9. See Elmore 1972, p. 119, and Emerson 2016 , p. $114 \mathrm{f}$.

30 See Sokolov 1968 in Kuhn $2008^{\text {a }}$, p. 191f. The author admits that, in this interpretation, the second exposition appears somewhat shortened. His approach does not seem fully convincing as the secondary theme zone is omitted in the exposition's second manifestation, and the beginning of the development section is hardly discernible. Another example of a »sonata form with double exposition« is found in the Sonata-Reminiscenza, Op. 38 No. 1.

31 As found in Emerson 2016 a , p. 98, and termed a >Type 4 Sonata in Sonata Theory. 
In the middle episode of the development section, Medtner challenges the listener and performer with an extensive fugato, its subject taken from the Introduzione's initial theme (m. 130ff.; see examples 3.6.10 and 3.6.5). First, a regular four-part exposition in $\mathrm{B} b$ minor is realised with entries of the theme starting with $B b$ and $F$. The fugato then deviates from the standard in a più risoluto passage in $\mathrm{G}$ minor, starting anew with entries on $B b, D$ and $A$ (m. 154). Eventually modulating to $\mathrm{E} b$ minor, Medtner proceeds with another fourpart entry scheme at the development section's core (m. 172), ${ }^{32}$ making it possible for multiple allusions to the finale's primary theme to appear in the lower voices. The fugal subject's initial note $B b$ remains constant, successively functioning as the root, the third, and the fifth scale degree of the respective keys, with the following notes altered accordingly. The music steadily rises in density and dynamics during a cunning stretto passage, presenting the fugal subject in various voices (m. 202ff.), until reaching $f f$ at the development's core (m. 214ff.). After that, the fugato gradually vanishes, leading to an extended passage without a clear tonal centre. All of the $2^{\text {nd }}$ movement's subjects are quoted and varied here in juxtaposition, most remarkably the Introduzione's secondary theme (m. 236ff.), and with occasional allusions to the finale's primary theme. The dense developmental process culminates at another quote of the $>$ Muza motif, resting at a fermata on the polychord $\mathrm{C}$ major $/ \mathrm{F}^{7}(\mathrm{~m} .270) .{ }^{33}$ At this climactic point, the music breaks off before the recapitulation section is attached.

In the last portion of the movement, the transitional theme from the $1^{\text {st }}$ movement is recalled, twice descending from $F \#(\mathrm{~m}$. 334: molto espressivo; m. 338: pleno), and replenishes the canonical treatment of the secondary theme. ${ }^{34}$ The Maestoso codetta then functions as a polymetric combination of the sonata's most important subjects, blending a diminution of the $>$ Muza< motif with a bell-like restatement of the $1^{\text {st }}$ movement's $>$ ballade theme $<$ (m. 353ff.; see example 3.6.11). Thus, the whole sonata is eventually legitimated as a hybrid formal entity, comprising a single-movement ballade and a cyclic multi-movement structure at the same time-in a similar way as the Sonata-Skazka, Op. 25 No. 1, had incorporated two skazka-like movements into a tripartite structure. These contrasting concepts are realised independently from each other, and Medtner achieves their synthesis through the overarching quote of the >ballade theme $<$ at its ending. This dithyrambic apotheosis, $\gg$ standing for the victory of illuminated forces $«,{ }^{35}$ gives an impressive close to a composition of emotional and spiritual importance to its creator, the intertextual dimension of which has not yet been considered within this analysis.

32 The unusual plan of modulation was, just like the curious restarts of the entry scheme, already noticed by Vasilyev 1959 , p. 13. For further elaboration on these three different fugato initiations and a possible connection to episodebased variation form (»kupletno-variatsionnaya forma«), see Protopopov 1987, p. 291.

33 Emerson $2016^{\text {a }}$, pp. 129 and 138ff., proposes the Passion of Christ as an overall narrative of the $3^{\text {rd }}$ movement, in accordance with its semantic potential as indicated by Swan, Pinsonneault, and Medtner himself. In this interpretation, the fugato invocates the crucifixion scene, with its climax in m. 270 indicating »Christ's last breath« (ibid., p. $151)$, and the final reiteration of the $>$ ballade theme being emblematic of resurrection.

34 Boyd $1980^{\text {a }}$, p. 24 , speaks of an »almost forgotten phrase from [...] the first movement«, allowing the music »to proceed naturally to a transformed version of the first (`Erdenfrühling $`$ ) theme of the sonata«.

35 Alekseyev 1982, p. 83: »Likuyushchaya koda znamenuet pobedu svetlikh sil«. 


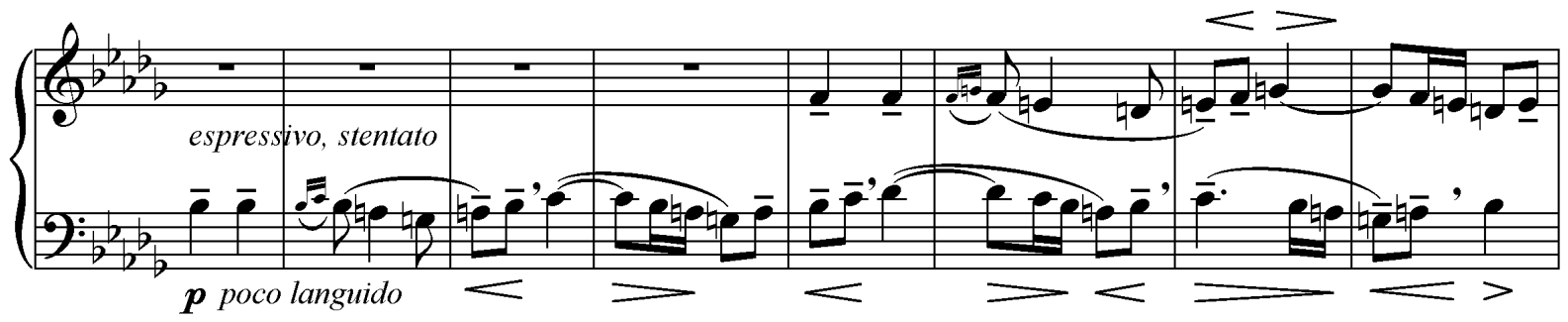

Example 3.6.10: Medtner, Sonata-Ballade, Op. 27, $3^{\text {rd }}$ mvt, development, mm. 130-137

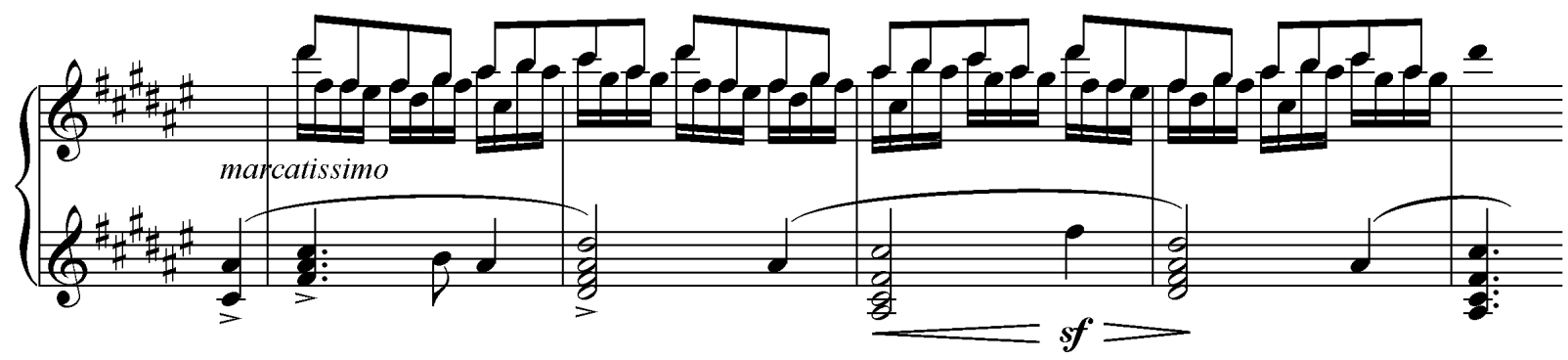

Example 3.6.11: Medtner, Sonata-Ballade, Op. 27, $3^{\text {rd }}$ mvt, codetta, mm. 353-356 (upper two of three staves)

\subsubsection{A Multitude of Hermeneutics}

As has been shown, it is possible to analyse and appreciate the Sonata-Ballade as a three-movement cyclic composition, comparable to such works as César Franck's F minor Piano Quintet (1879) or Scriabin's Piano Concerto, Op. 20 (1896). But, in addition, the work is part of a musical-semantic network, established by several hints to Christian theology, to the literary concept of the >muse as described by Medtner as an essential element of his artistic inspiration, ${ }^{36}$ and to the poetry of Russian lyricist Afanasy Fet (1820-92). Moreover, Medtner introduces a certain autobiographical context through self-quotation. This is evident in the recurrences of a certain phrase named the $>$ Muza motif by a number of scholars, according to its first considerable appearance in the Pushkin song Muza (The Muse), Op. 29 No. $1 .^{37}$ This phrase is subject to a series of intertextual quotations, valid for a certain group of compositions, most of them key works in Medtner's œuvre. It is important to emphasise that these implications apply to the $2^{\text {nd }}$ and $3^{\text {rd }}$ movements only, whereas the balladesque Allegretto stands for itself, not quoting the >Muza motif, and allegorically expressing the $»$ joy of Spring but without religious feeling $\ll^{38}{ }^{38}$ The metaphorical context of springtime, pastoral scene, and buoyancy, applying in particular to the >ballade theme «, is predominant in an assessment of one of Medtner's students, Bernard Pinsonneault, and, more precisely, in Alfred Swan's description, suggesting that the three

36 See Emerson $2016^{\text {a }}$, p. 2 f.

37 Vasilyev 1962, p. 139, was the earliest author to notice this derivation in his brief study of Medtner's piano sonatas, even if he only stated the motif to have accompanied the composer through all his œuvre. Plaistow 1976, in his liner notes to Malcolm Binns's recording of the Sonata-Ballade, called it the >Pushkin themeく. Boyd 1980, p. 23ff., has first examined the intertextual and motivic relationship between Op. 27, Op. 29 No. 1, and the Piano Quintet, Op. posth., but without illustrating the spiritual and poetic background in detail, and neglecting the two different sources and melodic guises of the motif. However, Boyd's terminology (the >muse authors to follow, and eventually became a topical phrase in Medtner scholarship.

38 Holt $1948^{\text {a }}$, p. 19 f. 
movements be characterised as a »beautiful spring on earth«, »temptation in the desert«, and »the same spring again, but aspiring to heaven, and with bell-ringing « ${ }^{39}$ Pinsonneault's and Swan's associations are based on oral transmission and the composer's notebooks, but in any case they remain somewhat speculative. By no means do they provide a programme necessary for the reception of the music, ${ }^{40}$ and could more appropriately be considered a spiritual narrative, effective in the background.

Myза

В младенчестве моем оне меня любила И семиствольную цевницу мне вручила. Она внимала мне с улыбкой - и слегка, По звонким скважинам пустого тростника, Уже наигрывал я слабыми перстами И гимни важные, внушенные богами, И песни мирные фригийских пастухов. С утра до вечера в немой тени дубов Прилежно я внимал урокам девы тайной, И, радуя меня наградною случайной, Откинув локоны от милого чела, Сама из рук моих свирель она брала. Тростник был оживлен божественным дыханьем И сердце наполнял святым очарованьем.

Aleksandr Sergeyevich Pushkin (1821)
The Muse

In my youth's years, she loved me, I am sure. The flute of seven pipes she gave in my tenure And harked to me with smile-without speed, Along the ringing holes of the reed, I got to play with my non-artful fingers The peaceful songs of Phrygian village singers, And the important hymns, that gods to mortals bade. From morn till night in oaks' silent shade I diligently harked to the mysterious virgin; Rewarding me, by chance, for any good decision, And taking locks aside of the enchanting face, She sometimes took from me the flute, such commonplace. The reed became alive in consecrated breathing And filled the heart with holiness unceasing.

Translation by Evgeny Bonver (1999) $)^{41}$

When tracing back the origins of the $>$ Muza motif, we find that it has two sources, distinguishable from each other in a slightly altered melodic outline. First, the motif is developed as a homophonic sketch, underlain with a line from Fet, and in linear melodic motion with rising and falling seconds (see example 3.6.12). Fet's poem is untitled, starting with the very verse referenced by Medtner »Kogda bozhestvennïy bezhal lyudskikh rechey« (»When the God-like fled human speech«). In a free account of the Gospel of Matthew, it depicts the temptation of Christ in the wilderness and his assertion against the devil through overcoming the temptation. The sketch is undated, but origins from a very early stage of Medtner's creative life, probably during the first years of the $20^{\text {th }}$ century. Christoph Flamm found it among a number of drafts for the C major Piano Quintet, a work not to be completed until four decades later. Although Medtner did not elaborate these three measures to a complete song, they are nonetheless important for the instrumental works to follow.

39 My translation of Swan 1967, p. 79f.: »Ein herrlicher Erdenfrühling«, »Versuchung in der Wüste«, and »Derselbe Erdenfrühling, aber schon gen Himmel strebend und mit Glockengeläute«. See also Pinsonneault 1959, p. 38: »Au premier [mouvement], c'est le thème du Printemps, avec ses joies, ses chants, mais sans croyance en un Créateur.«

40 Dolinskaya 2013, p. 119: »Sonata - sochinenie neprogrammnoe« (»The sonata is not a programmatic work«). Unlike Scriabin, who penned very precise programmatic notes to some of his sonatas, and a work such as Rachmaninov's $1^{\text {st }}$ Sonata in D minor, Op. 28, the three movements of which represent the main characters of Goethe's Faust, Medtner's sonatas do not show such a distinctive programmatic dimension.

41 Published online at Poetry Lovers Page (accessed April 5, 2016). Another translation by Edna Iles was used in Elisabeth Schwarzkopf's and Medtner's 1950 recording of Muza, Op. 29 No. 1. 
Когда божественний бежал людских речей

И празднословной их гордыни,

И голод забывал и жажду многих дней,

Внимая голосу пустыни,

Его, взалкавшего, на темя серых скал

Князь мира вынес величавый.

»Вот здесь, у ног твоих, все царства, - он сказал, -

$\mathrm{C}$ их обаянием и славой.

Признай лишь явное, пади к моим ногам,

Сдержи на миг порыв духовный -

И эту всю красу, всю власть тебе отдам

И покорюсь в борьбе неровной.«

Но он ответствовал: »Писанию внемли:

Пред Богом Господом лишь преклоняй колени!«

И сатана исчез - и ангелы пришли

В пустыне ждать его велений.

Afanasy Afanasievich Fet (1876)
When the God-like fled human speech

and forgot about their vain pride

and about his hunger and thirst of many days,

listening to the voice of the desert,

the prince of the world carried him, the thirsting,

onto the crest of grey rocks.

»Here at your feet I lay all the kingdoms - he spoke, with their magic and glory.

Just recognize the apparent, fall to my feet, restrain your mental reflection for a moment and all these beauty and power I shall give you and submit myself to you in uneven fight.«

But he replied: »Behold the scripture,

Before God alone bow your knees! «

And Satan disappeared - and angels came

To receive his orders in the desert.

My translation $(2016)^{42}$

Subsequently, the motif appears in a more distinctive contour within the mentioned song Muza (The Muse), the first piece from a set of seven Pushkin songs, Op. 29, written in 1912 or $1913 .{ }^{43}$ Here it comprises a significantly descending major sixth (see example 3.6.13). What both versions have in common is their melodic anacrusis and a three-note repetition, a characteristic feature of Medtner's melodic invention, before rising a major second on the downbeat. In the song, the corresponding passage (m. 11ff.) bears the text $\gg$ gimni vazhnie, vnushennïe bogami« (»and of great hymns, inspired by the Gods«). This line maintains the religious context of Fet's poem, but with the plural form »bogami« now pointing towards polytheism. After the $1^{\text {st }}$ movement of the Sonata-Ballade Op. 27 had already been finished, the Pushkin song might have directly preceded the composition of the $2^{\text {nd }}$ and $3^{\text {rd }}$ movements. ${ }^{44}$ It seems likely that Medtner's idea to elaborate on the >Muza motif within the sonata is associated with the Pushkin setting, since he uses the motif in exactly the same appearance as in the song - and, interestingly, not in the way he had originally sketched it with Fet's line »Kogda bozhestvennïy bezhal«.

42 The translation is partly inspired by that of Veronica Shenshin (1994) given in Emerson $2016^{\mathrm{a}}$, p. $72 \mathrm{f}$.

43 Medtner was, just like Rachmaninov, prompted by their mutual friend Marietta Shaginyan to set Pushkin's poem to music, and she would also receive the dedication of the Op. 29 songs. See Shaginyan 1957, p. 195.

44 Since the composition dates of the individual songs of the cycles Opp. 28 and 29 are hard to determine, it is not quite clear if the Muza song really precedes the use of the >Muzar motif in the Sonata-Ballade. Martyn 1995, pp. 97 and 103, suggests it be the other way round-but given the close vicinity, or even simultaneity, of the genesis of both works, the question which piece was finished earlier might not be relevant at all. 


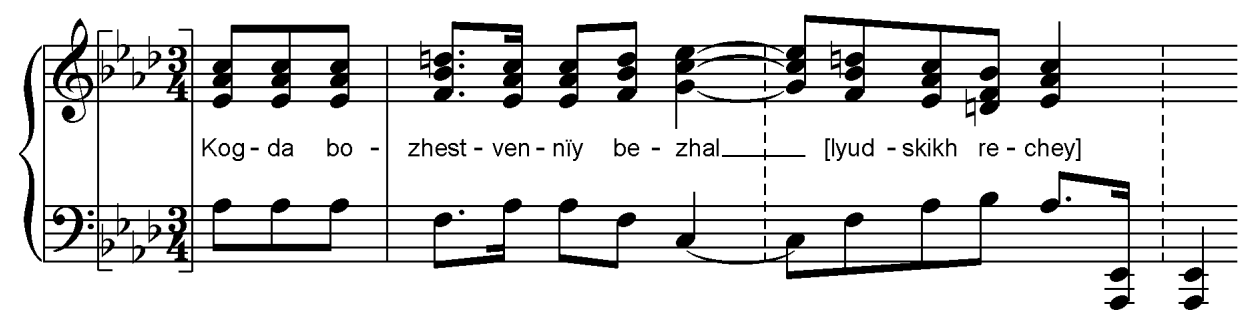

Example 3.6.12: Medtner, Sonata-Ballade, Op. 27, Fet sketch after Flamm 1995, p. 193

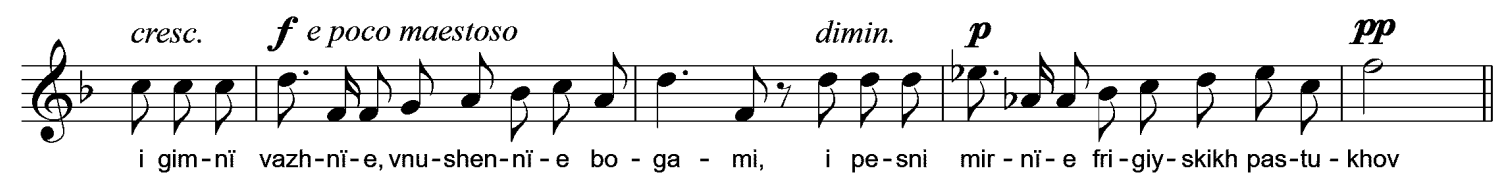

Example 3.6.13: Medtner, Muza, Op. 29 No. 1, mm. 11-14 (voice part)

In his handwritten conceptual notes to the Sonata-Ballade, however, Medtner again refers to Fet's poem - in particular to its last stanza which is concerned with Jesus's answer to Satan and the rejection of his offer. The composer directly links verses to certain passages of the music which would later form the $2^{\text {nd }}$ sonata movement, which can be understood as a paraphrase of Fet's line »i satana ischez« (»and Satan disappeared«), ${ }^{45}$ with its initial theme characterising the devil. ${ }^{46}$ Later, by the first appearance of the $>$ Muza motif within that movement (m. 37; see example 3.6.6), the devil's disappearance is depicted. Its continuation, a chordal realization of the motif marked sostenuto, pesante (m. 44ff.; see example 3.6.7), is connected to the words of Christ in Fet's poem »Pred bogom gospodom lish’ preklonyay koleni« (»Before God alone bow your knees «). ${ }^{47}$ One might even conclude that the reiteration of the >devil's themeく in the tonic major (m. 49) indicates that he has been overcome by Christ. The finale of the sonata presents, in Medtner's own words, a >variation Introduzione's topic, related to Fet's phrase $»$ i angelï prishli« (»and angels came «). ${ }^{48}$ Here the $\gg$ Muza motif is finally developed to a full cantilena, functioning as the movement's secondary theme. After many more reiterations within the movement's middle section, it culminates in the work's codetta, realised in a sparkling righthand figure which is combined with the $1^{\text {st }}$ movement's >ballade theme in the middle staff (m. 353ff.; see example 3.6.11). The sonata finally closes with an enthusiastic burst of the $>$ Muza< motif which sums up the

45 Dolinskaya 1966, p. 99 (again in Dolinskaya 2013, p. 119) quotes Medtner's handwritten notes to the sonata, which are preserved in the Moscow State Glinka Museum for Musical Culture, fonds 132, archive unity no. 56, p. 6. The corresponding lines are: »II chast' kak bï variatsiya otnosyashchayasya k slovam: I satana ischez«. See also Flamm 1995 , p. 438f.

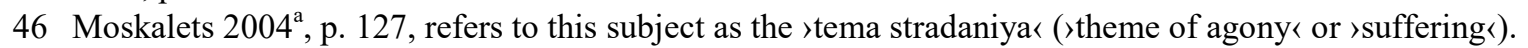

47 Swan 1967, p. 79, had already quoted this line with reference to the composer's oral transmission, but fails to clarify its origin in Fet's poetry. This background remained a bit blurred in writings of the following decades, and scholars tended to give only vague hints, mostly unaware of Medtner's sketches and handwritten notes, until the issue was finally put straight in Flamm 1995, pp. 194 and 438f. For an alternative translation of the Fet line, see the next but one footnote.

48 Dolinskaya 2013, p. 119: »III chast'—variatsiya, otnosyashchayasya k slovam: i angelï prishli«. The term >variation< must be understood here not only as a means of thematic transformation, applied to the >Muza< motif, but also as a metaphysical concept of staging an idea in different light. See also ibid., p. 120: »Osnovnoy kharakter Intermezzo [sic!] opedelyaet marshevaya postup' temï shestviya, razvïvayushcheysya v ryade variatsiy, liniya kotorikh zavershaetsya uzhe v finale.« 
work’s harmonic and motivic content, realised as a chordal pesante / allargando in shape of a $\mathrm{I}-\sharp \mathrm{IV}^{7}-\mathrm{V}^{7}-\mathrm{I}$ cadence. ${ }^{49}$ It hints back to the theological struggle of the $2^{\text {nd }}$ movement and, in using a prolonged halfdiminished seventh chord at the last but two position, simultaneously refers back to the sonata's very beginning where this harmony repeatedly alternates with the $\mathrm{F} \#$ major tonic. It might be even possible to regard the initial $>$ ballade theme $<$ as a broad ornamentation of the $>$ Muza $<$ motif, with its undulating contour containing every of its notes. ${ }^{50}$ However, all of the abovementioned quotes employ the $>$ Muza $<$ motif as heard in the Pushkin song, with a characteristic descending sixth, and do not refer to the smoother melodic outline of the Fet sketch.

Most interesting to the analyser are the versatile harmonic guises which are superimposed to the motif's rather simple melodic contour. The first three notes, repeating the same pitch, are confronted with differing chords on the fourth note, ascending a major second. These chords, in all their variety, share their unexpectedness and, in some cases, a distant tonal relation to the preceding harmony. A remarkable passage in this respect is the mentioned central episode from the sonata's $2^{\text {nd }}$ movement (see example 3.6.7), which features a progression of an $\mathrm{Eb}$ major triad and a half-diminished seventh chord based on $G \sharp$. Since the latter chord encompasses the triad of B minor, the succession of these two harmonies can be described, in the terminology of Neo-Riemannian Theory, as a ’hexatonic pole«—which means that the pitches of both chords belong to a symmetrical scale based on major thirds (with alternating minor thirds and halftones, defined as an array of pitches called a $>$ Konstrukt $<$ in Albert Simon's Tonfeld Theory).

The >Muzar motif and its derivations may be detected in others of Medtner's compositions as well. Bradley Emerson gives a detailed compilation of quotations occurring in a number of instrumental and vocal works and disseminates variants of the motif's contour. ${ }^{51}$ This broad range of derivations accepts nearly every instance of repeated notes followed by an ascending interval as a variant of the $>$ Muza< motif, which does not appear too convincing, given that the repetitive contour may be identified as a typical feature of Medtner's thematic invention in general. However, some passages in a number of his later works are of particular interest. Possibly by pure coincidence, a strikingly similar phrase is heard in the middle section of the Elegy, another Pushkin setting of 1924 (»Lyublyu vash sumrak neizvestnïy«), Op. 45 No. 1 (m. 42ff. and other passages in succession; see example 3.6.14). ${ }^{52}$

49 At the very end of her copy of the Sonata-Ballade (p. 36), Edna Iles wrote the line »Before the Lord alone, [only] one can kneel«, as if to demonstrate that the `Muza< motif finds its ultimate realisation here. It is likely that she followed Medtner's own words in this rendering of the Fet verse; with a minor deviance, the line is already quoted in Martyn 1995, p. 98. Thanks to Alexander Karpeyev and Bradley Emerson who provided me with a scan of Iles's copy, I am happy to give the exact translation here.

50 Both melodic contours emphasise the fifth and sixth scale degree before falling to the root, as exemplified by Emerson $2016^{\mathrm{a}}$, p. $38 \mathrm{f}$.

51 See Emerson $2016^{a}$, p. 11-34. The author identifies many of the alleged instances of the $>$ Muza motif in the topical context of either pastoral or elegy, and also claims a proximity to the >fate motif $<$ from Beethoven's $5^{\text {th }}$ Symphony.

52 The Tyutchev song Nash vek (Our Age), which was published together with the abovementioned Elegy as Op. 45 No. 4 (1924), suggests even another self-quotation. The words »Vpusti menya« (»Let me in«), forming the central expression of the poem, correspond to a musical phrase which, in its anacrusis, dotted rhythm and downward leap of a fifth or octave, distantly resembles the `Muza< motif. This observation I owe to Ekaterina Derzhavina. See also Flamm 1995, p. 196ff. 


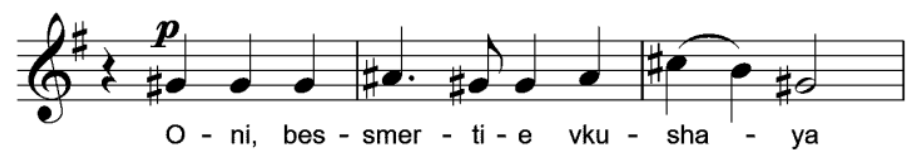

Example 3.6.14: Medtner, Elegy, Op. 45 No. 1, mm. 42-44 (voice part)

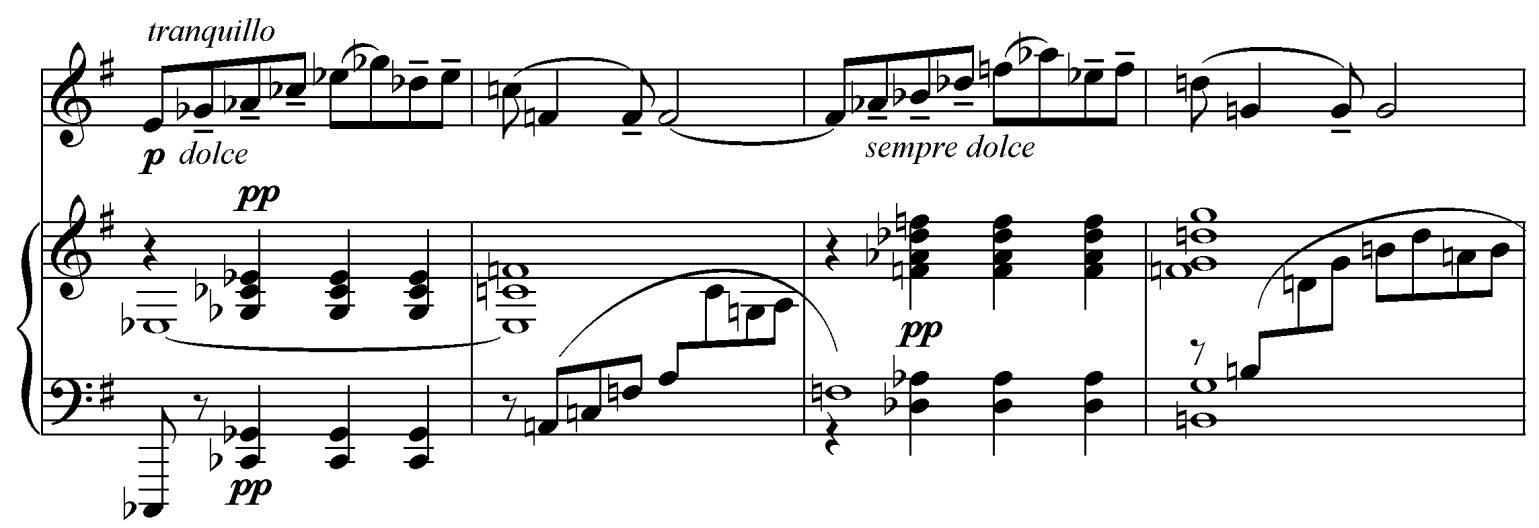

Example 3.6.15: Medtner, $2^{\text {nd }}$ Violin Sonata, Op. 44, $1^{\text {st }}$ mvt, exposition, mm. 16-19

The latter song was composed a decade after completing the Sonata-Ballade, shortly after Medtner's emigration from Russia, in direct proximity to the $2^{\text {nd }}$ Violin Sonata in G major, Op. 44 (1925). In the $1^{\text {st }}$ movement of this work, the composer introduces more reminiscences of the $>$ Muza motif, which is here reduced to its first four notes, appearing several times in a bewildering nonfunctional harmonisation during the movement's introduction (m. 16ff.; see example 3.6.15). Later, the same contour emerges in G minor within the secondary theme zone, now in the violin part, and in a mainly diatonic environment (m. 80ff). ${ }^{53}$ The rather anonymous contour of a twice-repeated note, followed by an ascending second, weakens the motif's referential quality, and detecting a derivation from the `Muza motif may seem insecure, if not questionable. Moreover, it is difficult to say whether the source of these four notes is the Fet sketch or the Pushkin song-the example suggests it be the former, as the melody proceeds in stepwise motion without any leaps. Another possible semantic connection to the Sonata-Ballade and Swan's »Erdenfrühling « association arises in the fact that, in Medtner's sketches, the primary theme of the violin sonata's final rondo is underlain with the words »Vesna idët« (»Spring is coming«), a motto taken from Fëdor Tyutchev’s poem Vesennie vodï (Waters of Spring). However, this movement lacks any direct quotes of the $>$ Muza motif.

More distinctly, the >Muza< motif is used in the C major Piano Quintet, Op. posth., Medtner's opus summum - a work which encapsulates his whole musical, aesthetic, and spiritual values, and in which »his artistic and religious convictions are finally united «. ${ }^{54}$ Its genesis spans a period of nearly 50 years until being finally completed in 1948. The hermeneutic implications of Fet's Kogda bozhestvennïy bezhal are of even higher relevance here due to the Quintet's explicitly religious content. As Medtner's sketches show, at least two of its three movements were originally inspired by Bible words, developing to a certain extent

53 There are more instances during the movement's development section; see Emerson $2016^{\mathrm{a}}$, p. $11 \mathrm{f}$. and $27 \mathrm{f}$.

54 Boyd 1980a , p. 25. 
within 1904-08. ${ }^{55}$ Part of the music which would later form the $1^{\text {st }}$ movement (Molto placido) was originally based on a blessing from Luke 6:21, »Blazhennïy alchushchie nïne, ibo nasitites' « (»Blessed are you who hunger now, for you will be satisfied«), also incorporating a transformation of the Gregorian Dies irae. In the final version of the Quintet, the linear version of the $>$ Muza< motif is introduced as an expressive secondary theme of the strings (m. 71ff.; see example 3.6.16), giving an exact reproduction of the melodic contour and the Lydian-mode harmonisation of the Fet sketch in the $1^{\text {st }}$ violin and cello parts, while the Dies irae figure sounds as a countersubject in the piano bass. Then, in a dense passage located at the centre of the Quintet's $1^{\text {st }}$ movement, both variants of the >Muza< motif, the linear one and the more expressive version as heard in the Muza song, seem to merge (m. 147ff.), before the movement closes with a hymnic culmination of the latter (m. 215ff.). Thus, while the preceding works quoting the $>$ Muza< motif made use of only one of its instances, the Piano Quintet finally unites and synthesises both.

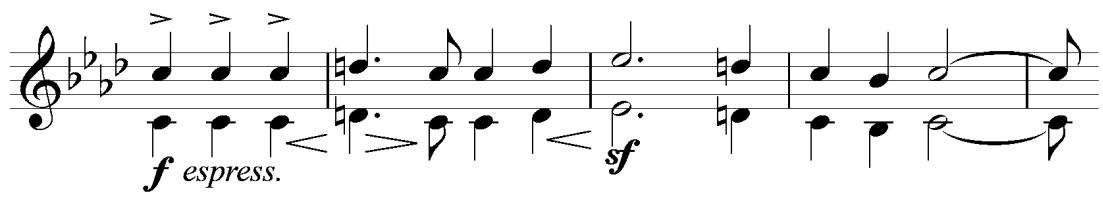

Example 3.6.16: Medtner, Piano Quintet, Op. posth., $1^{\text {st }} \mathrm{mvt}$, mm. $71-74$ ( $1^{\text {st }}$ violin and cello parts)

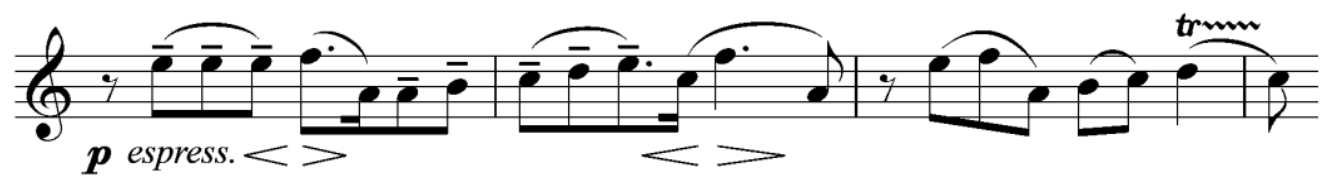

Example 3.6.17: Medtner, Piano Quintet, Op. posth., $2^{\text {nd }}$ mvt, mm. $41-44$ ( $1^{\text {st }}$ violin part $)$

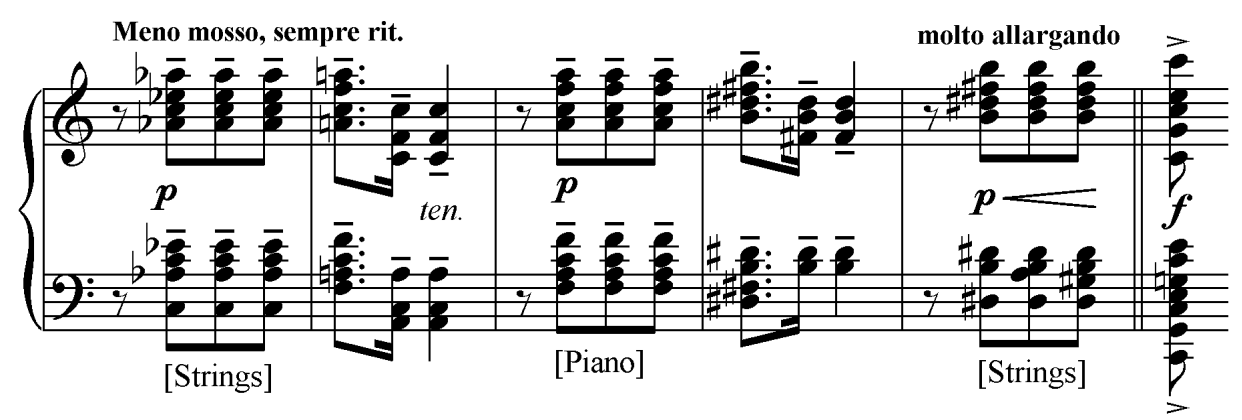

Example 3.6.18: Medtner, Piano Quintet, Op. posth., $2^{\text {nd }}$ mvt, mm. $68-72$

The drafts of the Quintet's $2^{\text {nd }}$ movement (Andantino con moto) were, on the other hand, inspired by three lines from Psalm 25:11 which Medtner had sketched for voice and piano during a very early stage of the work's genesis, and converted in the late 1940s to the Andantino's opening. This choral-like, stringed melody can still be sung on the verses of the penitential psalm »Radi imeni Tvoego, Gospodi, prosti sogreshenie moe, ibo veliko ono« (»For the sake of your name, Lord, forgive my iniquity, though it is great«) ${ }^{56}$ The

55 The approximate dates of the Quintet's genesis are given according to the examination of the sketches in Flamm 1995, p. 539f. Early drafts of the work, dating from c. 1904-05, were projected under the titles »Fantasy for String Quartet and Piano on Gospel texts« and »Theurgical, or liturgical, Sonata-Fantasy« (ibid., p. 541).

56 Ibid.; see also p. 542. The English translations of Psalm 25:11 and Luke 6:21 are given here in compliance to the text of the New International Version of the Holy Bible. The text underlay in the composer's manuscript was first 
$>$ Muza $<$ motif reappears as a violin cantilena during the middle section of the movement, again in the version of the Muza song, but transposed to A minor (m. 41ff.; see example 3.6.17). Among many further occurrences, one of the most remarkable is the transitional passage connecting the Quintet's $2^{\text {nd }}$ to its $3^{\text {rd }}$ movementthe motif repeatedly sounds in the upper voice, harmonised with a progression of $\mathrm{Ab}$ major, $\mathrm{F}$ major, and $\mathrm{B}$ major triads (m. 68ff; see example 3.6.18 and also chapter 2.4.2 for more thoughts on these harmonies). The quintet's final $3^{\text {rd }}$ movement, a metaphorical Osanna, is also reminiscent of the $>$ Muza (motif in many places, with its ascending second occasionally being altered to an ascending third (see m. 48f.). In addition, the musical topos of a hymn, maybe distantly derived from Pushkin's line $» 1$ gimnï vazhnïe« and certainly connected to the semantics of the $\mathrm{C}$ major tonality (see chapter 2.4.5), comes to clear expression in the finale's secondary theme, indicated Quasi Hymn (m. 346ff.). Moreover, the religious connotations derived from the Bible words incorporated in the sketches semantically link the work to the concept of >pokayanie< (repentance), a central idea of Christian spirituality, which appears not only significant for Fet's Kogda bozhestvennïy bezhal and the Sonata-Ballade, but also to another of Medtner's late compositions, the Two Elegies, Op. 59 (1940-41), the second of which the composer coined an selegy of repentance.$^{57}$ In its final appearance, the Piano Quintet not only appears as a sort of résumé to Medtner's whole œuvre for summarising musical material from every of his creative periods, but also due to its subliminal spiritual content which forms »a cross-movement programmatic layer resulting from the Bible words $«{ }^{58}$ thus being indicative of the composer's most personal convictions and beliefs.

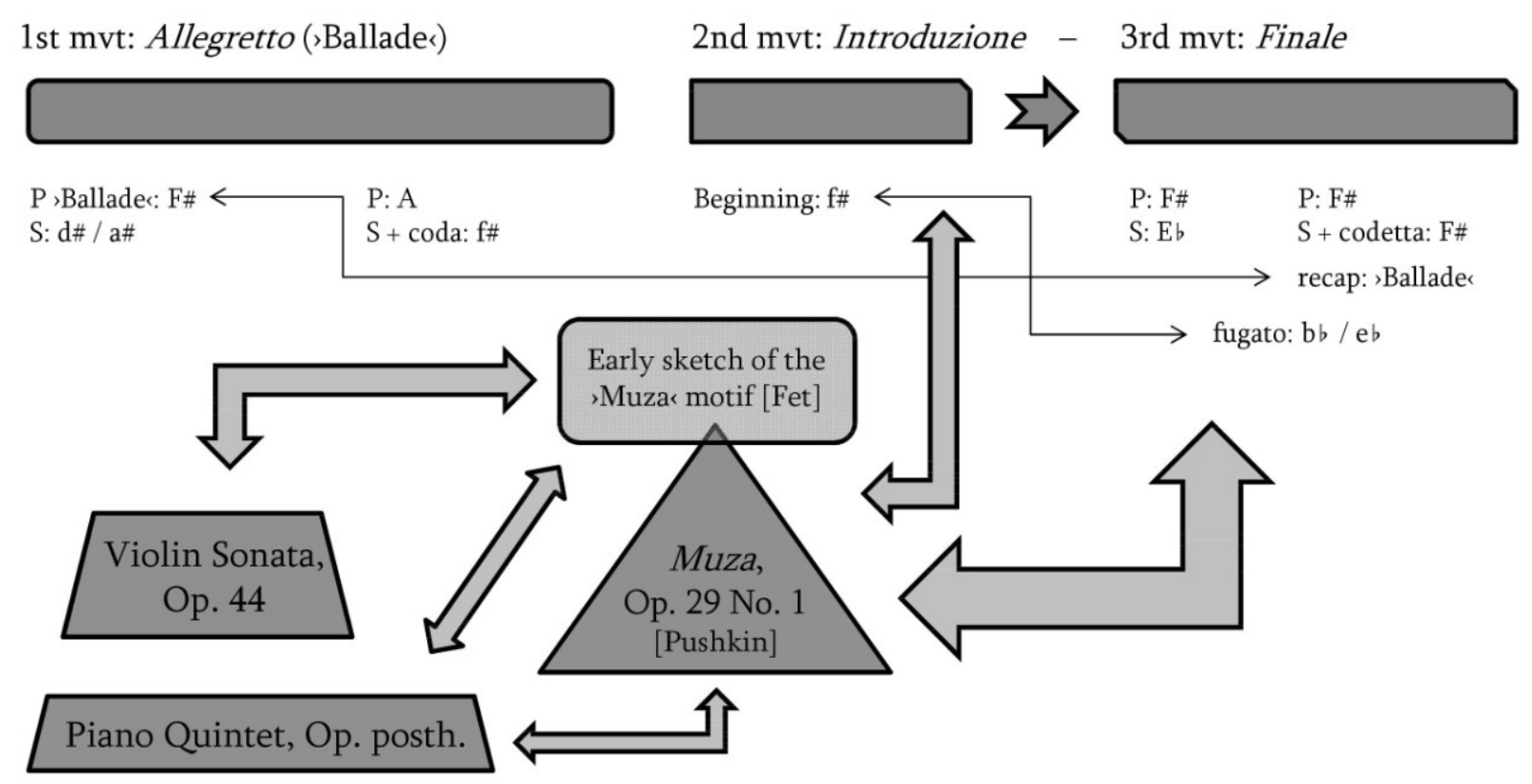

Figure 3.6.19: Intertextual relations between Medtner's Op. 27, Op. 29 No. 1, Op. 44, and Piano Quintet

revealed and commented in a somewhat pathetic tone by Klimov 1955, p. 209f., giving a translation according to the King James Bible.

57 See chapter 2.4.5 for more considerations on key semantics associated with grief, death, and penitence in Medtner.

58 My translation of Flamm 1995, p. 162: »Darüber hinaus läßt sich aber auch noch [...] eine satzübergreifende Programmatik erkennen, die aus den wechselnden Inhalten der Bibeltexte resultiert«. 


\subsubsection{CONCLUDING REMARKS}

Considering the numerous semantic implications caused by the so-called >Muza $<$ motif (an overview is given in figure 3.6.19), it may seem somewhat inappropriate to name that phrase after the Muza poem only. This label hints toward Pushkin, while its original inspiration by Fet's poetry and the descendence from a biblical context is neglected. Another possible, yet unintentional notion is the proximity to the title of Medtner's book Muza i moda (1935) in which he explicated his aesthetic worldview, and apparently was still so infatuated with Pushkin's Muza poem that he decided to use it as an epigraph for the first chapter of this publication. ${ }^{59}$ I suggest that, if the term is maintained, its use should be limited to occurrences in a secular context or directly related to Pushkin. For the more frequent usage in a distinctly religious environment, as in the Piano Quintet, the phrase might more suitably be referred to as a motif of >temptation $<$ or >overcoming $\triangleleft{ }^{60}$ However, one does not have to be aware of the mentioned implications to perform or analyse the Sonata-Ballade. The composition also works as a piece of absolute music due to its cyclic structure and teleology, aiming towards the finale's codetta. If we dare to submerge into its lower semantic layers, the sonata will prove to be a unique piece of Symbolist art, unfolding the most personal and idiosyncratic of its creator's aesthetic views to the recipient. It seems hardly possible to come closer to Medtner's artistic personality than here.

59 See Boyd $1980^{\text {a }}$, p. 23. However, the connection of the lyrics to the thoughts unfolded here, dealing with the general fundamentals of musical >language<, remains somewhat vague.

60 I have previously related to this thought in Bitzan $2016^{\mathrm{b}}, \mathrm{p} .11$. 


\subsection{EPILOGUE}

Having conducted the foregoing analyses with due in-depth observation, a final evaluation is, in order to take a step back from the detailed examinations of individual works, in need of a more conflating perspective. After the completion of the analyses, the question remains how the idea of the sonata (as a genre), as well as the multi-movement cycle and the sonata movement (as musical forms), could emerge as mandatory models for Medtner's musical thought in such an incommensurable way. It appears that the ssonata principle<, as adopted by the composer, does not only figure as an essential paradigm of music history, kept alive through his various approaches and formal experiments, but simply turns out as the most appropriate vehicle for expressing his creative thought. A sonata is considered the most comprehensive of all species of music, and the most concise at the same time. It poses a challenge to composers in providing a rigid framework which requires to be realised with maximum individual liberty. This demand, since it matched his artistic personality to choose the most firmly codified musical genre to articulate his imagination, made for its unique appeal to Medtner. Whereas sonatas and other instances of sonatnost' had formed the pinnacle of creative expression for his most influential predecessors, namely Beethoven, Schumann, and Brahms, these models would prove even more fundamental for Medtner. Rather than perceiving the ideal types of musical form as mere schemes, the notion of sonata form as a container to be filled with individual substance correlated most adequately with Medtner's attitude. At the same time, this choice of genre perfectly enabled him to demonstrate his aesthetic rootedness in the tradition of Austro-German music, literature, and philosophy.

Let us briefly refer back to the composer's claim, expressed in his book Muza i moda, that »a sonata that is built on senses that are not yet found, i.e., on [...] poly-tonality or a-tonality [...], is a sonata only in so far as it also sounds «. ${ }^{1}$ In Medtner's view, the >sonata principle< essentially required traditional tonality. He invariably attached its use to the genre's aesthetic preconditions, dating from its origins in the first half of the $18^{\text {th }}$ century - namely, the prevalence of diatonic harmony and motif-based construction - to be maintained even in the $20^{\text {th }}$ century. Otherwise, when applied to music which departed from these principles, the term >sonata would lose its original meaning. A thorough appreciation of Medtner's contributions to the genre is only possible in the light of this tough conviction. As a result, I may state that the sonataconceived as a species of instrumental music as well as a formal principle, and including all the aesthetic and dialectical implications associated with it—served the composer as an indispensable anchor point, as a principal embodiment of the artistic heritage he relied on throughout his creative life.

Yet the explanation of these backgrounds is insufficient to entirely grasp the versatile way of how Medtner approached the sonata genre. If, in a Hegelian sense, form should follow content and its specific demands, it would have been unsatisfactory for the composer to simply name his largest and most significant compositions >sonatas $\measuredangle$ and $>$ concertos $\measuredangle$. Another layer of meaning was needed, a means to express his intellectual and spiritual convictions before the chosen background of form aesthetics. This hermeneutic component

1 Medtner 1935, p. 51f., quoted after Swan's translation, p. 49; see also chapter 2.1.1. 
was provided by adding particular denominations further specifying the sonata category, which resulted in the conceptions of >genre sonatas $\triangleleft$ and \Symbolist sonatas (see chapter 2.5.3). By the incorporation of hybrid titles and subtitles, attributes, poetic mottos, or supplementary ascriptions, the idea of absolute music in Medtner gradually loses significance as it is transformed to a type of descriptive art with multifaceted identity. With hardly any exception, Medtner adjoined a narrative perspective to the compositions he named sonatas, charging the traditional genre with sublime meaning, and thus producing various intertexts, some of which emerge to the surface, whereas others stay behind the scenes. Thus, the titles of many of Medtner's works coalesce a traditional part (Sonata) with a peculiar suffix (-Skazka,-Ballade, -Reminiscenza), resulting in a number of unique and unmistakable conceptions of instrumental music.

By this means, Medtner's œuvre offers a compelling example to prove the agelessness of the >sonata principle<. The perspective of recipients who have regarded his music as conservative, non-contemporary, or even as a perpetual retrospect to conventional or even outdated aesthetics, overlooks the fact that the signifiers of tradition (such as the pre-established genres represented in his work) are continuously reinterpreted and inexhaustibly replenished with fresh content. Musical forms, understood as traditional resources and creative envelopes, withstand the risk of being conceived as pure schemes - and while schemes may age or even obsolesce, as Medtner wrote to the Swans, forms never do, given they are applied in his particular way. The sonata thus figures as a principle that rejuvenates itself when employed in a resourceful manner; and therefore it remains a topical concept of musical creation throughout the $20^{\text {th }}$ century and to this day. Accordingly, the research question posed at the outset of this study - and thus Medtner's own claim of the imperishability of the >sonata principle<- - has been successfully confirmed.

As a conclusion I will quote a work by the American poet Marc Cox (*1956), named Sonata, which may function as a sort of neo-Symbolist response to the conception of permeable, or >fluid ‘, genres as variously seen in artworks of the Russian Silver Age. Written exactly 90 years after Medtner had completed his first piano sonata, the poem metaphorically introduces a ninety-year-old »man by the sea«, symbolising a sphere which grows over time without aging — or, in the poet's words, »greys, then reddens « again. May Cox's poetry be read as a contemplation over Medtner's creative attitude, mapping his personal inspiration to sound as an autonomous agent (»the music plays the piano, which plays the man «); and may these associations and symbols serve as a transdisciplinary comment to the subject of this study. 


\section{Sonata}

At ninety, the piano plays him. $\quad$ leaving impressions in the keyboard

He's like a man by the sea that waves wash level

the wind knows it must wear down, cleansing its audience of shell halves,

sculpt to a profile, now glistening, now scoured dry.

then fill out again, And the house, the house just outside

billowing his sleeves and trouser legs

into a younger musculature.

Over and over, the music greys

then reddens, the part

in its hair shifting left to center

until those few blades of sea grass are all that's left to be

combed over the rocks, this sonata's frame,

it begs him to turn around

to pick his way back

along the stoney runner,

his hands stopping his ears.

But, at ninety, the music plays the piano,

which plays the man, who finally, fearlessly,

plays himself, which is the landscape,

and the thin fingers skitter, $\mid$ which is everything that ends.

$\operatorname{Marc} \operatorname{Cox}(1993)^{2}$

2 Published in Poetry Magazine, Vol. 164 (1994), No. 2, p. 70; cited here by kind permission of the author. I am quoting the following explanation from Cox's email, received on August 20, 2018: »I was [...] trying to metaphorically and sonically capture to experience of a pianist intensely involved in composition and performance. That is why I called [the poem] >Sonata<.« 


\section{Appendices}

\subsection{BIBLIOGRAPHY}

\section{Musical Sources ${ }^{1}$}

Medtner, Nikolai Karlovich $\left(1959^{\mathrm{a}}\right)$ : Sobranie sochineniy. Sochineniya dlya fortep'yano, Tom I, referenced as: Collected Edition, Vol. 1 (includes the Sonatas Op. 5, Op. 11 Nos. 1-3), edited by Aleksandr Fëdorovich Goedicke, Aleksandr Borisovich Goldenweiser, Georgy Vassilyevich Kirkor, Vasily Aleksandrovich Kiselëv, Konstantin Konstantinovich Sakva, Abram Vladimirovich Shatskes, and Vissarion Yakovlevich Shebalin, Moscow: Muzgiz.

$\left(1959^{b}\right)$ : Sobranie sochineniy. Sochineniya dlya fortep 'yano, Tom II, referenced as: Collected Edition, Vol. 2 (includes the Sonatas Op. 22, Op. 25 Nos. 1-2, Op. 27, Op. 30), ed. as above.

$\left(1960^{\mathrm{a}}\right)$ : Sobranie sochineniy. Sochineniya dlya fortep'yano, Tom III, referenced as: Collected Edition, Vol. 3 (includes the Sonatas Op. 38 No. 1, Op. 39 No. 5), ed. as above.

$\left(1960^{b}\right)$ : Sobranie sochineniy. Sochineniya dlya fortep'yano, Tom IV, referenced as: Collected Edition, Vol. 4 (includes the Sonatas Op. 53 Nos. 1-2, Op. 56), ed. as above.

\section{Writings $^{2}$}

Abraham, Gerald (1955): »Medtner and his Piano Music«, in: Holt (ed., 1955), pp. 86-92.

Acevedo, Clement (2018): Nikolai Medtner: A New Source for Sonata in F Minor, Op. 5, DMA dissertation: James Madison University, School of Music, Harrisonburg / Virginia.

Aleksandrov, Anatoly Nikolayevich (1979): »Nezabïvayemïe vstrechi« (»Unforgettable Encounters «), in: Blok, Vladimir Michailovich (ed.): A. N. Aleksandrov. Vospominaniya, stat'i, pis'ma, Moscow: Sovetskiy Kompozitor, pp. 62-74; extended version in: Apetyan (ed., 1981), pp. 94-104.

Alekseyev, Aleksandr Dmitrievich (1969): Russkaya fortepiannaya muzika. Konets XIX-nachala XX veka, Moscow: Nauka; chapter »Fortepiannoe tvorchestvo Metnera. Obshchaya ego kharakteristika, cherti fortepiannogo stilya. Skazki, sonati, kontserti« (pp. 247-295) transl. to German by Ernst Kuhn as: »Die Klaviermusik Nikolai Medtners und seine Konzerte für Klavier und Orchester«, in: Kuhn (ed., 2008 ), pp. 47-116; chapter »Fortepiannoe tvorchestvo Skryabina. Ego stilevïe chertï, Prelyudii, ètyudï i drugie sochineniya maloy formï. Poèmï, sonatï i kontsert« (pp. 186-246) partly transl. to German by Ernst Kuhn as: »Die Klaviermusik Alexander Skrjabins und sein Konzert für Klavier und Orchester«, in: Kuhn (ed., 2008 ), pp. 1-78.

— (1974): Sovetskaya fortepiannaya muzika 1917-1945, Moscow: Muzïka. (1982): Istoriya fortepiannogo iskusstva (The History of Pianistic Art), Vol. 3, Moscow: Muzika.

Alenskaya, Aminata (2003): »The Medtner Family and Russian Culture in the Silver Age«, proceedings of a Moscow workshop on April 23-26, 2002, in: Lettre du centre des études slaves, Paris, No. 2 / 2003. (2009): »Dukhovnoe savershchanie Nikolaya Metnera. >Muza i moda< v svete ponyatiy traditsionniy metafizicheskoy mïsli Vostoka« (»Medtner’s Spiritual Legacy«), in: Korolkova / Maslovskaya / Fedyakin (eds., 2009), pp. 170-199.

Alexander, Arthur (1951): »Nicholas Medtner. An Appreciation«, in: Tempo, New Series, No. 22, pp. 3-4. Almén, Byron (2008): A Theory of Musical Narrative, Bloomington / IN: Indiana University Press.

Anderson, Martin (1994): reviews of Medtner records, in: Tempo, New Series, No. 190, pp. 55-56 and 58-59.

Andreasen, Mogens Wenzel (2010): »Russian Bouquet«, liner notes to Alexander Vaulin's recording of Opp. 38 No. 1 and 56, transl. John Kendal / Alexander Vaulin, ClassCD 427, Frederiksberg: Classico, pp. 3-8.

Antcliffe, Herbert (1922): »Rachmaninoff is Apprehensive of Modernists - except Medtner«, in: The Christian Science Monitor, June 10, 1922, p. 16.

1 Other editions of Medtner's compositions are, where explicitly quoted, referenced directly in the footnotes.

2 Sources marked with an asterisk $\left(^{*}\right)$ could, despite the greatest reasonable effort, not be obtained in the course of my enquiries, and are thus considered unavailable to research. 
Apetyan, Zarui Apetovna (ed., 1957): Vospominaniya o Rakhmaninove (Memories of Rachmaninov), Vol. 2, Moscow ${ }^{5}$ 1988: Muzïka.

(ed., 1973): N. K. Metner. Pis'ma (Letters), Moscow: Sovetskiy Kompozitor.

(ed., 1981): N. K. Metner. Vospominaniya, stat'i, materialï (Memories, Essays, Materials), Moscow:

Sovetskiy Kompozitor.

Arensky, Anton Stepanovich (1894): Rukovodstvo k izucheniyu form instrumental'noy i vokal'noy muzïki

(Guide to the Study of Form of Instrumental and Vocal Music), Vol. 2: Gomofonicheskie formï,

Moscow: Yurgenson.

Arzamanov, Fëdor Georgievich (1963): S. I. Taneyev - prepodavatel' kursa muzikkal'nykh form (Taneyev: Teacher of a Class in Musical Form), Moscow: Muzgiz; $2^{\text {nd }}$ augmented edition, Moscow 1984: Muzika.

Asafiev, Boris Vladimirovich [Glebov, Igor] $\left(1930^{\mathrm{a}}\right)$ : Russkaya muzïka ot nachala XIX stoletiya, Leningrad: Academia; transl. to German by Ernst Kuhn as: Die Musik in Russland: von 1800 bis zur Oktoberrevolution 1917, musik konkret Vol. 9, Berlin 1998: Kuhn, pp. 325-373.

(1930) $)$ : Muzikal'naya forma kak protsess, Vol. 1, Moscow: Gosizdat Muzsektor; transl. to German by Ernst Kuhn as: Die musikalische Form als Prozeß, ed. by Eberhard Lippold / Dieter Lehmann, Berlin 1976: Verlag Neue Musik.

Austin, Michael (1952): »Nicolas Medtner«, in: Canon. Australian Journal of Music, Vol. 5, pp. 387-390.

Balser, Uwe (1995): »Nikolai Medtner«, liner notes to the author's recording of Op. 53 No. 1, CD 3-1787-2, Schwann: Koch International, pp. 2-4.

Barban, Eugene (1980): »In Praise of Medtner«, in: Clavier. Magazine for Pianists and Organists, Vol. 19, pp. 14-21.

(1989): »Metner, Nikolay Karlovich«, in: Dmitry Feofanov / Allan Benedict Ho (eds.), A Biographical Dictionary of Russian and Soviet Composers, New York: Greenwood Press, pp. 325-328.

Bartels, Ulrich (1995): »Alexander Scriabin: Der >fantastischeく Weg in die Einsätzigkeit«, in: Werner Keil (ed.): 1900: Musik zur Jahrhundertwende, Hildesheim: Olms, pp. 165-182.

Belsky, Svetlana (1995): »Svetlanov Plays Medtner«, liner notes to Evgeny Svetlanov's recording of Op. 11, Op. 25 No. 1, and Op. 38 No. 1, RD CD 10045, Moscow: Russian Disc, pp. 1-5.

Bely, Andrei [Bugayev, Boris Nikolayevich] (1902): Simfoniya (2-ya, dramaticheskaya), Moscow: Skorpion; transl. Roger Keys in: The Dramatic Symphony and The Forms of Art, Edinburgh 1986: Polygon Books, pp. 17-150.

(1903): »O teurgii«, in: Novy put', Vol. 9, pp. 100-123; transl. to German by Christoph Flamm as: »Über die Theurgie«, in: Flamm (1995), pp. 253-258.

_ (1910): »Snezhnïe arabeski. Muzika Metnera«, manuscript in: Russian State Archive of Literature and the Arts; ed. by Sergei Voronin in: Sovetskaya muzika, No. 3 / 1990, pp. 118-122; transl. to German by Christoph Flamm as »Schnee-Arabesken«, in: Flamm (1995), pp. 291-296.

_ (1933): Nachalo veka, Moscow: Gosizdat; reprinted Moscow 1990: Khudozhestvennaya Literatura.

Bely, Pëtr Sergeyevich (1977): »Kompozitorï XX veka: Nikolai Metner« (»Composers of the $20^{\text {th }}$ Century: Medtner«), in: Muzïkal'naya zhizn', No. 15 / 1977, pp. 15-16.

Belyayev, Viktor Mikhailovich (1915): Kratkoe izlozhenie ucheniya o kontrapunkte i ucheniya o muzïkal'nïkh formakh, Moscow: author's edition, pp. 43-48.

— (1927): »Analiz modyulatsiy v sonatakh Betkhovena S. I. Taneyeva«, in: Konstantin Alekseyevich Kuznetsnov (ed.): Russkaya kniga o Betkhovene. K stoletiyu so dnya smerti kompozitora, Moscow: Gosizdat Muzsektor, pp. 191-204.

Bertin, Benjamin (2018): Unifying Dionysus and Apollo. Nikolai Medtner's Synthesis of Russian and German Cultures in the Piano Sonatas Op. 25, D.Mus dissertation: Université de Montréal.

Biesold, Maria (1991): Sergej Rachmaninoff, 1873-1943: Zwischen Moskau und New York. Eine Künstlerbiographie, Berlin: Beltz / Quadriga.

Birnbach, Heinrich (1827): »Formlehre eines ersten Sonatensatzes im Durgeschlecht. Über die verschiedene Form grösserer Instrumentaltonstücke aller Art und deren Bearbeitung«, in: Berliner Allgemeine Musikalische Zeitung, Vol. 4, Nos. 34-37 and 45-46, pp. 269ff., 277ff., 285ff., 293ff., 362ff., and 369ff.

Bitzan, Wendelin (2012): »Klaviersonaten aus Russland. Komponisten und Werke des 19. und 20. Jahrhunderts: Ein Überblick«, in: Contrapunkt Magazine Vienna, No. 7, pp. 16-21.

(2014): »Die Vokalise im Schaffen russischer Komponisten. Zur Melodik des textlosen Gesangs bei Metner, Rachmaninov und Glièr«, in: Kreativitätsportal Musik, Fakultät Musik der Universität der Künste Berlin. 
$\left(2016^{\mathrm{a}}\right)$ : »Nikolaj Metners einsätzige Sonatenformen. Konzepte von Symmetrie und Balance in den Klaviersonaten Op. 11 und Op. 22«, in: Die Tonkunst. Magazin für klassische Musik und Musikwissenschaft, Vol. 10, No. 4 / 2016, pp. 451-458.

$\left(2016^{\mathrm{b}}\right)$ : »A Milestone of Symbolist Music. A Multi-Perspective Examination of Nikolai Medtner's Sonate-Ballade«, in: Problemy muzikal'noy nauki. Russian Journal of Academic Studies, Vol. 10, No. 3 / 2016, pp. 6-14.

— (2017): »Taneev, Skrjabin und das Orchester. Konzepte zyklisch-mehrsätziger Form an der Wende zum 20. Jahrhundert«, in: Musik \& Ästhetik, No. 84, pp. 60-77; shortened English version as: »Taneyev, Scriabin, and the Orchestra«, in: Journal of the Russian Society for Music Theory, Vol. 4, No. 1 / 2016, pp. 1-8.

(2018): »Sonatentheorien des Ostens. Zum Transfer einer mitteleuropäischen Formidee nach Russland und in die Sowjetunion bis 1945«, in: Journal of the German Society for Music Theory (ZGMTH), Vol. 15 / 2 (2018), pp. 23-43.

Billings, Lara (2014): Nikolai Karlovich Medtner's Settings of Fyodor Ivanovich Tutchev's Poems: A Performance and Pronunciation Guide, DMA dissertation: Florida State University.

Blok, Aleksandr Aleksandrovich (1918): »Intelligentsiya i revolyutsiya«, in: idem, Sobranie sochineniy, Vol. 6, Moscow 1962: Gosudarstvennoe izdatel'stvo khudozhestvennoy literaturï, pp. 9-20.

Blom, Eric (1954): »Medtner, Nikolay Karlovich«, in: Grove’s Dictionary of Music and Musicians, $5^{\text {th }}$ edition, Vol. 5, London: Macmillan, pp. 648-652.

Bloomquist, William Charles jr. (1993): The »Fairy Tales« of Nikolai Medtner, DMA dissertation: University of Texas, Austin.

Bolshakova, Natalia (2008): Georgy L'vovich Catoire: His Life and Music for Piano, With Special Emphasis on »Poem «, Second Sonata for Violin and Piano, Op. 20, DMA dissertation: University of North Texas.

Bondar, Lyudmila (2003): Nicolas Medtner: Composer, Pianist and Teacher, master thesis: Michigan State University.

Boyd, C. M. (1952): »Medtner Reconsidered«, in: Monthly Musical Record, Vol. 82, pp. 260-264.

Boyd, Malcolm (1965): »The Songs of Nicolas Medtner«, in: Music and Letters, Vol. 46, pp. 16-22. $\left(1980^{\mathrm{a}}\right)$ : »Metner and the Muse«, in: The Musical Times, Vol. 121, No. 1643, pp. 22-25. $\left(1980^{b}\right)$ : »Metner, Nikolay Karlovich«, in: The New Grove Dictionary of Music and Musicians, Vol. 12, London: Macmillan, pp. 219-221.

Braudo, Evgeny Maksimovich (1927): »Prokof'ev i Metner«, in: Sovetskoe iskusstvo, No. 3 / 1927, pp. 40-41.

Brower, Harriette (1925): »Medtner Finds Nothing but Discord in Ultra-Modern Music«, based on an interview with the composer, in: The Musician, No. 30, April 30, 1925, p. 11-12.

- (1926): Modern Masters of the Keyboard, New York: Stokes; reprinted New York 1969: Books for Libraries Press.

Brown, William H. (1943): »Nicolas Medtner«, in: The Gramophone, Vol. 21, September 1943, p. 50.

Bryantseva, Vera Nikolayevna (1962): Vtoraya fortep'yannaya sonata Rakhmaninova (Rachmaninov's Second Piano Sonata), Moscow: Muzgiz.

Calvocoressi, Michel Daniel (1944): A Survey of Russian Music, Middlesex: Penguin; reprinted Westport / CT 1974: Greenwood Press, pp. 82-87.

Campbell, Stuart (ed., 2003): Russians on Russian Music, 1880-1917: An Anthology, Cambridge: Cambridge University Press.

Caplin, William Earl (1998): Classical Form. A Theory of Formal Functions for the Instrumental Music of Haydn, Mozart, and Beethoven, Oxford: Oxford University Press, pp. 195-208.

Carpenter, Ellon DeGrief (1983): »The Contributions of Taneev, Catoire, Conus, Garbuzov, Mazel, and Tiulin«, in: Gordon Daniel McQuere (ed., 1983): Russian Theoretical Thought in Music, reprinted 2009: University of Rochester Press, pp. 253-378.

(1988): The Theory of Music in Russia and the Soviet Union, ca. 1650-1950, PhD dissertation: University of Pennsylvania.

Catoire, Georgy Lvovich (1936): Muzikal'naya forma (Musical Form), Vol. 2, eds. Dmitry Borisovich Kabalevsky / Lev Abramovich Mazel / Leonid Alekseyevich Polovinkin, Moscow: Muzgiz.

Catoire, Pëtr Georgievich (1967): »Erinnerungen an meinen Vater, den Komponisten Georgi Lwowitsch Catoire«, unpublished typoscript, transl. to German by Anna Zassimova, in: Zassimova (2011), pp. 29-58.

Catterall, Yvonne (1960): »Nicolas Medtner, the Man and his Music«, in: Makerere Journal, No. 4 / 1960, pp. 81-87. 
Chan, Wah Keung (2008): »Laurence Kayaleh \& Paul Stewart: The Sound of Medtner«, in: La Scena Musicale, Vol. 13, No. 6, March 2008, pp. 8-11.

Chernaya-Oh, Ekaterina (2008): The Skazki (Fairy Tales) of Nikolai Medtner: The Evolution and Characteristics of the Genre with Compositional and Performance Aspects, DMA dissertation: University of North Texas.

Chernova, Tatyana Yuryevna (2007): »)Khudozhestvennïy predmet $<$ i sonata Op. 25 No. 2 N. K. Metnera« (»The Artistic Object and Op. 25 No. 2«), in: Vyacheslav Vyacheslavovich Medushevsky (ed.): Metodologicheskaya funktsiya khristianskogo mirovozzreniya v muzikoznanii, Moscow Conservatory, pp. 51-86.

Choi, Hanna (2017): Documenting Developing Performance: Rethinking Nikolai Medtner at the Piano, PhD dissertation: Royal Conservatoire of Scotland / University of St Andrews.

Cinnamon, Howard (2013): »Classical Models, Sonata Theory, Equal Division of the Octave and Two Nineteenth-Century Symphonic Movements: Comparing Analytical Approaches«, in: Gamut, Vol. 6.1 / 2013, p. 45-93.

Clarke, Colin (2013): »Pianist Paul Stewart and the Road to Medtner«, in: Fanfare. The Magazine for Serious Record Collectors, Vol. 36, No. 6.

Cohn, Richard (1998): »Introduction to Neo-Riemannian Theory: A Survey and a Historical Perspective«, in: Journal of Music Theory, Vol. 42, No. 2 / 1998, pp. 167-180.

Collingwood, Lawrance (1955): »My Experience of Medtner's Music«, in: Holt (ed., 1955), pp. 141-145; reprinted as: »Moy mïsli o muzike Metnera«, in: Apetyan (ed., 1981), pp. 190-192.

Cone, Edward Toner (1968): Musical Form and Musical Performance, New York: Norton.

Covatta, Sister M. Annette Teresa (1965): The Piano Solo Music in Smaller Forms of Nicolas Medtner, DMA dissertation: School of Fine and Applied Arts, Boston University.

Craats, Jan van de (2001): »Nikolai Karlovich Medtner«, liner notes to Geoffrey Douglas Madge's recording of Op. 22, Op. 38 No. 1, and Op. 39 No. 5, BIS CD 1258, Åkersberga: BIS Records, pp. 4-8.

Crocker, Chris (2006-2013): medtner.org.uk, online resource comprising a catalogue of works, discography, variora of editions, list of publications, and concert lists. (2007-2010): »Medtner Editions«, list of all editions to have ever appeared in print; unpublished. (without year): »Medtner's Key Preferences«, published online at medtner.org.uk.

Czerny, Carl (1832): »Über die Formen und den Bau jedes Tonstückes«, translator's appendix in: Anton Reicha, Cours de composition musicale ou traité complet et raisonnée d'harmonie pratique, transl. as: Vollständiges Lehrbuch der musikalischen Composition, Vol. 1: Die Abhandlung von der praktischen Harmonie, Vienna: Diabelli, pp. 316-339; reprinted in: Musiktheorie, Vol. 1 (1986), pp. 261-276.

Czerny, Carl (1848): School of Practical Composition, transl. John Bishop, Vol. 1, London: Robert Cocks.

Delson, Viktor Yulievich (1961): Fortep'yannie sonatï Skryabina, Moscow: Muzgiz. (1962): »Muzïka Metnera«, in: Sovetskaya muzïka, No. 5 / 1962, pp. 103-104.

(1971): Skryabin. Ocherki zhizni i tvorchestva, partly transl. to German by Ernst Kuhn as: »Das Klavierschaffen Alexander Skrjabins«, in: Kuhn (ed., 2008 b), pp. 79-226.

Deppermann, Maria (1984): »Rußland um 1900. Reichtum und Krise einer Epoche im Umbruch«, in: Heinz-Klaus Metzger / Rainer Riehn (eds.), Aleksandr Skrjabin und die Skrjabinisten II, Musik-Konzepte Vol. 37 / 38, Munich: edition text + kritik, pp. 61-106.

Dittrich, Marie-Agnes (2011): Musikalische Formen. 20 Möglichkeiten, die man kennen sollte, Kassel: Bärenreiter.

Dolinskaya, Elena Borisovna (1966): Nikolai Metner. Monograficheskiy ocherk, Moscow: Muzika.

— (1981): »Nikolai Metner i Nikolai Myaskovskiy. K opïtu sravnitel'noy kharakteristiki« (»Medtner and Myaskovsky. Attempt of a Comparative Characterisation«), in: Sovetskaya muzika, No. 8 / 1981, pp. 71-78. (2013): Nikolai Metner, Moscow: Yurgenson / Muzika.

Donisch, Max (1928): review of a Medtner lieder recital in Berlin, in: Allgemeine musikalische Zeitung, November 2, 1928, p. 1182.

Drozdov, Anatoly Nikolayevich (1927): »N. K. Metner. K ego priezdu v SSSR «, in: Muzika i revolyutsiya, Vol. 4, pp. 18-21; transl. to German by Christoph Flamm as: »Zu Metners Ankunft in der UdSSR «, in: Flamm (1995), pp. 342-346.

Dubal, David (1989): The Art of the Piano. Its Performers, Literature, and Recordings, Pompton Plains / NJ ${ }^{3}$ 2004: Amadeus Press.

* Dubrovina, Miletta (2001): Nekotorïe osobennosti garmonicheskogo yazika N. K. Metnera (Some Features of Medtner's Harmonic Language), diploma thesis: Krasnoyarsk Academy of Music and Theatre. 
Eberle, Gottfried (2003, 2005, 2010, 2010, 2011): excerpts from program notes for the festival Rarities of Piano Music, introducing Medtner's sonatas Op. 25 Nos. 1-2, Op. 38 No. 1, Op. 39 No. 5, and Op. 53 No. 2, Husum: Stiftung Nordfriesland.

Eberlein, Dorothee (1978): Russische Musikanschauung um 1900, Studien zur Musikgeschichte des 19. Jahrhunderts Vol. 52, Regensburg: Gustav Bosse.

Eckardstein, Severin von (2007): »Zu den Werken«, liner notes to the author's recording of Op. 25 No. 2 and Op. 39 No. 5, MDG 6041465, Detmold: Dabringhaus und Grimm, pp. 16-18.

Edler, Arnfried (2004): »Sonaten oder Phantasien - was liegt am Namen?«, in: idem (ed.): Gattungen der Musik für Tasteninstrumente, Handbuch der musikalischen Gattungen Vol. 7, No. 3, Laaber: Laaber, pp. 35-81.

Eilerman, Susan Jane (1954): Nicolas Medtner, master thesis: College of Music, University of Cincinnati.

Elmore, Cenieth Catherine (1972): Some Stylistic Considerations in the Piano Sonatas of Nikolai Medtner, $\mathrm{PhD}$ dissertation: University of North Carolina, Chapel Hill.

Emerson, Bradley (2016 ${ }^{\mathrm{a}}$ ): Medtner's Sonata-Ballade: Interpreting its Dramatic Trajectory through Virtual Subjectivities, DMA dissertation: University of Texas at Austin.

- $\left(2016^{\mathrm{b}}\right)$ : $\gg$ Virtual Object and Reminiscing Agent in Nikolay Medtner's Sonata-Reminiscenza, Op. 38, No. 1«, in: Semiotics 2015: Virtual Identities, pp. 25-34.

Engel, Yuli Dmitrievich (1911): »Muzika N. Metnera«, in: Russkie vedomosti, March 11, 1911; transl. to German by Christoph Flamm as: »N. Metners Musik«, in: Flamm (1995), pp. 298-300.

Ewen, David (1934): Composers of Today. A Comprehensive and Critical Guide, New York: Wilson; revised version: European Composers Today. A Biographical and Critical Guide, New York 1954: Wilson.

- (1944): Ewen's Musical Masterworks. The Encyclopedia of Musical Masterpieces, New York ${ }^{2} 1958$ : Arco Publishing.

(1963): The Complete Book of $20^{\text {th }}$ Century Music, Englewood Cliffs / NJ: Prentice-Hall.

(1968): The World of Twentieth-Century Music, rev. Stephen J. Pettitt, London ${ }^{2} 1991$ : Robert Hale. (ed., 1969): Composers Since 1900. A Biographical and Critical Guide, New York: Wilson.

Faurot, Albert (1974): Concert Piano Repertoire. A Manual of Solo Literature for Artists and Performers, Metuchen / NJ: Scarecrow Press.

Fedyakin, Sergei Romanovich (2009): »Metner i ego vremya. Literaturno-muzikal'nïe parallelï« (»Medtner and his Time«), in: Korolkova / Maslovskaya / Fedyakin (eds., 2009), pp. 58-75.

Feofanov, Dmitry (ed., 1984): »Rare Masterpieces of Russian Piano Music«, introductory notes to an edition of Medtner's Op. 22, New York: Dover Publications, p. IX.

Flamm, Christoph (1995): Der russische Komponist Nikolaj Metner. Studien und Materialien, including a catalogue of works, discography, and bibliography, Studia Slavia Musicologia Vol. 5, Berlin: Kuhn. $\left(1995^{Z}\right)$ : Nikolaj Metner. Überlegungen zu den Ansätzen einer Wiederentdeckung«, in: Seidle (1995), pp. 11-18.

(1997): »Nikolai Medtner«, in: Annette Retinski / Klaus Stübler / Christine Wolf (eds.), Harenberg Kammermusikführer, Dortmund ${ }^{2}$ 1998: Harenberg Kommunikation, pp. 509-513.

(2002 ): »Nikolaj Metners Goethe-Vertonungen«, in: Hermann Jung (ed.): Eine Art Symbolik fürs Ohr. Johann Wolfgang von Goethe: Lyrik und Musik, Frankfurt am Main: Lang, pp. 183-203.

$\left(2002^{b}\right)$ : »Alexandrow: Klaviermusik«, liner notes to Hamish Milne's recordings of Aleksandrov's piano sonatas Opp. 18 and 19, CDA 67328, London: Hyperion Records, pp. 19-27.

(2003): »Nikolaj Medtner«, liner notes to recordings of Goethe songs by Caroline Vitale and Peter Baur, RS 051-0038, Udine: Real Sound, pp. 11-14.

(2004 $\left.{ }^{\mathrm{a}}\right)$ : »Die Rezeption Nikolaj Metners in der UdSSR «, in: Friedrich Geiger / Eckhard John (eds.): Musik zwischen Emigration und Stalinismus. Russische Komponisten in den 1930er und 1940er

Jahren, Stuttgart: Metzler, pp. 168-192.

- $\left(2004^{\mathrm{b}}\right)$ : »Metner (Familie)«, in: Die Musik in Geschichte und Gegenwart, $2^{\text {nd }}$ edition, Personenteil Vol. 12, Kassel: Bärenreiter, col. 102-105.

(2006): »Nikolaj Metner«, in: Hanns-Werner Heister / Walter-Wolfgang Sparrer (eds.): Komponisten der Gegenwart, $11^{\text {th }}$ and $19^{\text {th }}$ delivery $1997 / 2000$, Munich 1989ff.: edition text und kritik.

(2009): »Sem'ya Metnerov i kul'tura serebryanogo veka. Primechaniya k sonatam N. Metnera« (»The Medtner Family and Silver Age Culture. Annotations on Medtner’s Sonatas«), in: Korolkova / Maslovskaya / Fedyakin (eds., 2009), pp. 40-57.

(2013): »O znachenii emigratsii v tvorchestve N. K. Metnera« (»On the Meaning of Emigration for Medtner's Work«), in: Uchenie zapiski. Žurnal rossiyskoy akademii muzïki imeni Gnesinïk, No. 4 / 2013, pp. 10-13. 
(2015 $)$ : »Ideen des Klaviers in der Musik von Skrjabin, Rachmaninov, Metner und Prokof'ev«, in: Heinz von Loesch / Linde Großmann (eds.), Russische Schule der musikalischen Interpretation, Klang und Begriff Vol. 5, Mainz: Schott, pp. 123-136.

$\left(2015^{\mathrm{b}}\right)$ : »Ėmilij Metner as Music Critic. Preliminary Remarks«, in: Russian Literature Vol. 77, No. 4, pp. 613-630.

Frank, Jonathan (1958): »Rachmaninov and Medtner: A Comparison«, in: Musical Opinion, Vol. 81, p. 387.

Frolova, S. (1955): Fortepiannïe sonatï P. I. Chaykovskogo. Poyasnenie, Moscow: Muzgiz.

* Gabruk, S. (unknown year): Aspects of Style in Selected Piano Works of Nikolay Medtner, DMA dissertation: Michigan State University.

Gaditsky, Roman (2012): »Muzïka Nikolaya Metnera: mezhdu sovremennost'yu i vechnost'yu« (»Medtner's Music between Present Time and Eternity«), in: Otechestvo, No. 9 / 2012, pp. 19-22.

Gakkel', Leonid Evgen'evich (1976): Fortepiannaya muzika XX veka. Ocherki (Piano Music of the $20^{\text {th }}$ Century. Essays), Leningrad ${ }^{2}$ 1990: Sovetskiy Kompozitor.

Georgii, Walter (1941): Klaviermusik, Zürich ${ }^{5} 1976$ : Atlantis.

Genkina, Olga Aleksandrovna (2005): N. K. Metner. Sonata Op. 30 lya-minor, Saint Petersburg: Nauchno-metodicheskiy tsentr primorskogo rayona.

Gerstlé, Henry (1924): »The Piano Music of Nicolai Medtner«, in: The Musical Quarterly, Vol. 10, pp. 500-510.

Gilels, Emil Grigoryevich (1953): »O Metnere« (»On Medtner«), in: Sovetskaya muzïka, No. 12 / 1953, pp. 55-56.

Ginsburg, Lona Ruth (1961): The Piano Sonatas of Nikolai Medtner, master thesis: University of California.

Gjerdingen, Robert O. (2007): Music in the Galant Style. Being an Essay on Various Schemata Characteristic of Eighteenth-Century Music, Oxford: Oxford University Press.

Gnesin, Mikhail Fabianovich (1941): Nachal'nïy kurs prakticheskoy kompozitsii (Beginner's Course in Practical Composition), Moscow ${ }^{2} 1962$ : Muzgiz.

Gojowy, Detlef (1980): Neue sowjetische Musik der 20er Jahre, Regensburg: Laaber.

Goldenweiser, Aleksandr Borisovich (1923): review of Medtner's Opp. 34, 35, and 38, in: K novïm beregam, No. 1 / 1923, p. 59f.; transl. to German by Christoph Flamm, in: Flamm (1995), pp. 333-334.

— (1975): »Vospominaniya o N. K. Metnere« (»Memories of Medtner «), in: idem, O muzïkal'nom iskusstve, Moscow, p. 244ff.; reprinted in: Apetyan (ed., 1981), pp. 58-63.

Goldshtein, Mikhail (1973): »Nikolai Metner«, from the series »Russkie muzikal'nïe portreti« (»Russian Musical Portraits«), in: Russkaya mïsl', No. 2364, September $13^{\text {th }}, 1973$.

Golovinsky, Grigory L. (ed., 1956): G. E. Konyus: Stat'i, materiali, vospominaniya, Moscow: Muzika.

Gomez, Yannick (2018): Le langage musical de Nikolai Medtner. Aperçu à travers le thème de la Roussalka et une analyse de l'Improvisation en forme de variations op. 47, D.Mus dissertation: Université de Montréal.

Gordon, Stewart (1996): A History of Keyboard Literature. Music for the Piano and its Forerunners, New York: Schirmer Books.

Großmann, Linde (2008): »Das Übetagebuch von Nikolai Medtner«, in: Üben. Documentation 2006 / 2007 of the EPTA Section Germany, Düsseldorf: Staccato, pp. 48-60.

Gulinskaya, Soya Konstantinovna (1981): Nikolai Yakovlevich Myaskovskiy, Moscow: Muzïka; transl. to German by Ernst Kuhn as: Nikolai Jakowlewitsch Mjaskowski, Berlin 1985: Verlag Neue Musik.

Gurlitt, Wilibald (ed., 1961): »Medtner, Nikolaj Karlowitsch«, in: Riemann Musiklexikon. Personenteil L-Z, Mainz ${ }^{12}$ 1961: Schott, p. 185; supplement by Carl Dahlhaus (ed.): Riemann Musiklexikon. Ergänzungsband Personenteil L-Z, Mainz 1975: Schott, p.164.

Hackbridge Johnson, David (2011): »Rachmaninoff, Medtner, Scriabin, Liapunov«, liner notes to Chisato Kusonoki's recording of Op. 22, QTZ 2089, Bucks / UK: Quartz Music, pp. 3-6.

Hall, Albert (1939): »New Music - Piano«, in: The Musical Times, Vol. 80, pp. 352-360.

Hamilton, Michael (2017): German Blood Russian Birth: Nationality in the Solo Piano Music of Nikolai Medtner, master thesis: University of Liverpool.

Hanselmann, Jürg (1993): »Nicolai Medtner. Ausgewählte Klavierwerke«, liner notes to the author's recording of Op. 11 No. 3, Op. 25 No. 1, Op. 38 No. 1, and Op. 39 No. 5, CD 800.014, Kerpen: Prezioso / Adamek, pp. 5-8.

Hartmann, Thomas de (1956): »Sergeii Ivanovitch Taneieff«, in: Tempo, New Series, No. 39, pp. 8-11 / 13-15. Hartnett, Owen J. (2014): Comparing Russian Trends in the Piano Sonatas of Rachmaninoff and Medtner, DMA dissertation: Jacobs School of Music, Indiana University.

Hein, Hartmut (2006): »Medtner, Nikolaj Karlovič«, in: Christoph Kammertöns / Siegfried Mauser (eds.): Lexikon des Klaviers, Laaber: Laaber, pp. 501-502. 
Heinemann, Michael (1993): Liszt: Klaviersonate h-Moll, Meisterwerke der Musik Vol. 61, Munich: Fink. Henry, Leigh (1922): »Contemporaries: Nikolaus Medtner«, in: Musical Opinion, Vol. 44, December 1921, pp. 226-227; continuation in: Vol. 45, January 1922, pp. 318-320.

Hepokoski, James (2002): »Beyond the Sonata Principle«, in: Journal of the American Musicological Society, Vol. 55, pp. 91-154.

Hepokoski, James / Darcy, Warren (2006): Elements of Sonata Theory. Norms, Types, and Deformations in the Late-Eighteenth-Century Sonata, Oxford: Oxford University Press.

Hinson, Maurice (1987): Guide to the Pianist's Repertoire, Bloomington / IN ${ }^{3} 2000$ : Indiana University Press.

Hirschberg, Rudolf Walther (1931): »Nikolaus Medtner«, in: Signale für die musikalische Welt, Vol. 89, pp. 99-100.

Hollfelder, Peter (1999): Die Klaviermusik. Das große Standardwerk, Wilhelmshaven ${ }^{2}$ 1999: Noetzel.

Holt, Richard (1948 ): Medtner and his Music. A Tribute to a Great Russian Composer, ed. by Fred Smith, London: Rimington / Van Wyck.

$\left(1948^{\mathrm{b}}\right)$ : »Foreword, Analytical Notes and Translations«, liner notes to the $3^{\text {rd }}$ volume of the Medtner Society recordings of Opp. 33 and 39 No. 5, Middlesex: Gramophone / His Master's Voice, pp. 3-11. (1951): »Nicolas Medtner«, in: The Gramophone, Vol. 29, December 1951, pp. 149-150. (ed., 1955): Nicolas Medtner. A Tribute to his Art and Personality, London: Dennis Dobson.

Honeybourne, Duncan (2001): »Russian Piano Music in Deepest Warwickshire«, in: BMI Insight, No. 4, pp. 47-51.

Hou, Yi-Wen (2013): An Analysis and Interpretation of Sonata-Triad Op. 11 by Nikolai Medtner, $\mathrm{Fu}$ Yen Catholic University, Taiwan.

Howard, Leslie (1996): »Complete Piano Sonatas«, liner note to the author's recording of Anton Rubinstein's piano sonatas, CDD 22007, London: Hyperion Records, pp. 2-5.

Hsu, Iris (2019): Music as Cosmos. A Study of Medtner's Piano Sonata in G minor, Op. 22, Through the Lens of The Muse and the Fashion, DMA dissertation: Johns Hopkins University / Peabody Conservatory.

Hughes, Eric / Martyn, Barrie / Stonehill, Gerald (1978): »Medtner Recordings«, discography in: Recorded Sound, Vol. 70-71, pp. 794-805.

Hull, Arthur Eaglefield (1915): »The Pianoforte Sonatas of Scriabin«, in: The Musical Times,Vol. 57, No. 885, pp. 492-495; continuation in: No. 886, pp. 539-542.

Hull, Arthur Eaglefield (1916): »A Survey of the Pianoforte Works of Scriabin«, in: The Musical Quarterly, Vol. 2, pp. 601-614.

Iles, Edna (1978): »Medtner, Friend and Master«, in: Recorded Sound, No. 70-71, p. 791ff.; extended version as: »N. K. Metner - drug i uchitel'«, in: Apetyan (ed., 1981), pp. 165-175.

Ilyin, Ivan Aleksandrovich (1929): »Muzïka Metnera «, in: Russkiy kolokol, Vol. 7, pp. 11-23; transl. as: »A Study of Medtner«, in: Holt (ed., 1955), pp. 163-174.

(1932): »O muzike Metnera«, in: Vozrozhdenie, No. 2465, March 2, 1932; reprinted in: Yuri T. Lisitsa (ed.): I. A. Il'in. Sobranie sochineniy v desyati tomakh (Collected Works), Vol. 6/ 2, Moscow 1996: Russkaya Kniga, pp. 306-310.

(1943): »Nicolai Medtner, der Componist und Hellseher. Romantik und Klassizismus in der modernen russischen Musik«, lecture held by the author in Zurich, March 8, 1943; transl. to Russian by O. V. Koltypina as: »Nikolai Metner - kompozitor i providets (Romantizm i klassitsizm v sovremennoy russkoy muzike)«, in: Yuri T. Lisitsa (ed.): I. A. Il'in. Sobranie sochineniy v desyati tomakh, Vol. 6 / 3, Moscow 1997: Russkaya Kniga, pp. 497-520.

(1955): »Sonata Form in Medtner«, in: Holt (ed., 1955), pp. 180-188.

Indy, Vincent d' (1909): Cours de composition musicale, ed. by Auguste Sérieyx, Vol. 2 / 1, Paris: Durand. Isserlis, Julius (1955): »In Memory of Nicolas Medtner«, in: Holt (ed., 1955), pp. 157-158.

Istomin, Eugene (1998): »Introduction «, in: The Complete Piano Sonatas: Series I and II, reprint of the sonatas from the Soviet Collected Edition, Mineola / NY: Dover Publications, p. IX.

Ivry, Benjamin (2008): »Piano Rarities: Nikolai Medtner«, liner notes to Ekaterina Derzhavina's recording of Op. 11, Op. 38 No. 1, and Op. 39 No. 5, Phoenix 156, Cologne: Deutschlandradio Kultur, pp. 6-8.

Johnston, Blair Allen (2009): Harmony and Climax in the Late Works of Sergei Rachmaninoff, $\mathrm{PhD}$ dissertation: University of Michigan.

Kämper, Dietrich (1987): Die Klaviersonate nach Beethoven. Von Schubert bis Skrjabin, Darmstadt: Wissenschaftliche Buchgesellschaft. 
Kafarova, Saida (2003): An Introduction to Nikolai Medtner and Performance Analysis in Dialogue Form of his Works for Two Pianos: Russian Round Dance \& Knight Errant, DMA dissertation: University of Texas, Austin.

Kalendarev, Natalya (2005): Medtner: His Beliefs, Influences and Work, DMA dissertation: University of Washington.

Kang, Seo Hee (2014): A Performance and Pedagogical Guide to Selected Solo Piano Character Pieces of Nicolas Medtner, DMA dissertation: University of Illinois.

Karatygin, Vyacheslav Gavrilovich (1912): »Skryabin i molodïe moskovskie kompozitorï« (»Scriabin and the Young Muscovite Composers«), in: Apollon, No. 5 / 1912, pp. 25-38.

(1913): »Tretiy kamernïy kontsert Ziloti. Kontsert iz sochineniy Metnera«, review in: Rech', January 23, 1913; reprinted in: idem, Izbrannie stat'i (Collected Essays), ed. by L. O. Dansker, Moscow 1965: Muzika, pp. 56-59; transl. to German by Christoph Flamm as: »Drittes Ziloti-Kammerkonzert. Konzert aus Werken Metners«, in: Flamm (1995), pp. 305-308.

_ (1914): »Poslednie tendentsii v russkoy muzike«, in: Northern Notes, No. 6-7; reprinted in: idem, Izbrannïe stat'i, pp. 141-153; transl. Stuart Campbell as: »The Most Recent Trends in Russian Music«, in: Campbell (ed., 2003), pp. 224-233.

- (1918): »Metner«, in: Nash vek, Vol. 93, p. 191; reprinted in: idem, Zhizn', deyatel'nost', stat'i i materialï (Life, Influence, Essays, and Materials), Leningrad 1927: Academia; transl. to German by Christoph Flamm, in: Flamm (1995), p. 318.

Karpeyev, Aleksandr (2014): New Light on Nikolay Medtner as Pianist and Teacher. The Edna Iles Collection (EIMC) at the British Library, DMA dissertation: City University of London.

Kehler, George (ed., 1982): The Piano in Concert, Vol. 2: M-Z, Metuchen / NJ: Scarecrow Press.

Keldïsh, Yuri Vsevolodovich (1976): »Metner Nikolai Karlovich«, in: idem (ed.): Muzikkal'naya éntsiklopediya (Encyclopedia of Music), Moscow: Sovetskaya Ėntsiklopediya, Vol. 3, col. 564-567.

Keller, Charles William (1971): The Piano Sonatas of Nicolas Medtner, PhD dissertation: Ohio State University. Kelly, Terence (1988): The Songs of Nikolai Medtner, DMA dissertation: University of Maryland, College Park. Kholopov, Yuri Nikolayevich (1975): »Symmetrische Leitern in der Russischen Musik«, transl. to German by Detlef Gojowy, in: Die Musikforschung, Vol. 28, No. 4, pp. 379-407.

— (1990): »Die Klaviersonaten«, in: idem / Hermann Danuser / Mikhail Evgenyevich Tarakanov (eds.), Internationales Musikfestival Sergej Prokofjew und zeitgenössische Musik aus der Sowjetunion, Duisburg: Stadt Duisburg / Laaber Verlag, pp. 284-289.

Kim, Sungeun (2006): Nicholas Medtner's Piano Music with Special Emphasis on his Fairy Tales, DMA dissertation: Peabody Conservatory of Music, Johns Hopkins University, Baltimore.

Kinley, Sarah Louise (1970): A Performer's Analysis of Eight Piano Sonatas of Nicholas Medtner, master thesis: Jordan College of Music at Butler University, Indianapolis.

Kirnosova, Elena Nikolayevna (1995): »O tvorcheskom mïshlenii N. Metnera« (»On Medtner’s Creative Thinking «), in: Zilya Agzamovna Imamutdinova / Mark Genrikhovich Aranovsky (eds.): Muzïka. Issledovatel'skiy sbornik 1994, Moscow: Gosudarstvennyi Institut Iskusstvoznaniya, pp. 111-136.

- (1996): Metod tvorcheskoy rabotï N. K. Metnera i osobennosti ego khudozhestvennogo mïshleniya. Na materiale rukopisogo arkhiva kompozitora (Medtner's Method of Artistic Work), Candidate of the Arts dissertation: Federal Institute of the Arts, Moscow.

Klimov, Konstantin Evgenyevich (1955): »The Last Instrumental Composition: The Piano Quintet«, in: Holt (ed., 1955), pp. 201-210.

Koch, Heinrich Christoph (1793): Versuch einer Anleitung zur Composition, Vol. 3, Leipzig: Böhme.

Kollmann, Augustus Frederic (1799): An Essay on Practical Musical Composition, London: author's edition.

Konnov, Vladimir Petrovich $\left(2001^{\mathrm{a}}, 2001^{\mathrm{b}}\right)$ : »Iz istorii russkogo gëteanstva: Nikolai i Ėmiliy Metnerï«/ »Romansï N. K. Metnera na stikhi Gëte«; both articles in: Galina Viktorovna Yakusheva (ed.): Gëte $v$ russkoy kul'ture XX veka (Goethe in Russian Culture of the $20^{\text {th }}$ Century), Moscow ${ }^{2} 2004$ : Nauka, pp. 337-347 and 239-255.

Konsistorum, Natasha Mikhailovna (2004): Nikolai Karlovich Metner. Portret kompozitora, transl. to German by Christoph Flamm as: Der Komponist Nikolaj Medtner. Ein Porträt, Berlin: Henschel.

Kondratiev, Evgeny Andreyevich (2009): »Sistema muzïkal'nïkh smïslov Nikolaya Metnera« (»Medtner's System of Musical Sense«), in: Korolkova / Maslovskaya / Fedyakin (eds., 2009), pp. 28-35.

Korobov, Veniamin Andreyevich (1991): »Sonatnaya triada Metnera. Voprosï interpretatsii« (»Medtner's Sonata Triad. Questions of Interpretation«), in: Mikhail Georgievich Sokolov (ed.): Trudi kafedrï obshchego fortepiano po metodike, istorii i teorii ispolnitel'sva, Moscow Conservatory, pp. 111-131. 
Korolkova, Tatyana Aleksandrovna / Maslovskaya, Tatyana Yuryevna / Fedyakin, Sergei Romanovich (eds., 2009): Nikolai Metner. Voprosï biografii i tvorchestva (Questions of Medtner's Biography and Work), conference report, Library Fond »Russkoye Zarubezhe«: Materialï i issledovaniya, Vol. 10, Moscow: Russkiy Put'.

* Krivonos, O. (1999): »Fenomen vospominaniya i ego interpretatsiya $\mathrm{v}>$ Sonate-reminiscenze N. K. Metnera«, in: Kï̈vs'ke muzikoznavstvo. Sbornik statey, Vol. 2, Kiev Conservatory, pp. 79-96.

Kuhn, Ernst (ed., 2008 ): Einführung in die Klaviermusik von Nikolai Medtner, Studia Slavia Musicologia Vol. 42, Berlin: Kuhn. (ed., 2008 ): Einführung in die Klaviermusik von Alexander Skrjabin, Studia Slavia Musicologia Vol. 41, Berlin: Kuhn.

Kyuregyan, Tatyana Surenovna (2013): »»Muzïkal'naya formaく v Moskovskiy konservatorii«, in: Journal of the Russian Society for Music Theory, Vol. 7, No. 2/ 2013, pp. 187-193.

Laberge, Dominique (1955): »Homage to Medtner«, in: Holt (ed., 1955), pp. 146-151.

Laliberté, Alfred (1955): »The Spirit of Medtner«, in: Holt (ed., 1955), pp. 66-71.

Leonard, Richard Anthony (1956): A History of Russian Music, New York: Macmillan, reprinted Westport / CN 1977: Greenwood Press.

Lindlar, Heinrich (1960): »Medtner, Nikolai Karlowitsch«, in: Die Musik in Geschichte und Gegenwart, Vol. 8, Kassel: Bärenreiter, col. 1893-1894.

Lischke, André (2009): »Old Forms, New Masters«, liner notes to Anna Vinnitskaya’s recording of Op. 38 No. 1, transl. Charles Johnston, AM 177, Paris: Naïve Records, pp. 11-15.

Ljunggren, Magnus (1994): The Russian Mephisto. A Study of the Life and Work of Emilii Medtner, Acta Universitatis Stockholmiensis Vol. 27, Stockholm: Almqvist \& Wiksell. (2014): Poetry and Psychiatry. Essays on Early Twentieth-Century Russian Symbolist Culture, transl. Charles Rougle, Boston: Academic Studies Press.

Lobanova, Marina (2005): »Konsistorum, Natascha: Der Komponist Nikolaj Medtner«, review to Konsistorum (2004), in: das orchester No. 3 / 2005, p. 71.

Lockwood, Albert Lewis (1940): Notes on the Literature of the Piano, Ann Arbor: University of Michigan Press; reprinted New York 1968: Da Capo Press.

Loftis, Bobby Hughes (1970): The Piano Sonatas of Nicolai Medtner, PhD dissertation: University of West Virginia.

Longyear, Rey Morgan / Covington, Kate R. (1988): »Sources of the Three-Key Exposition«, in: Journal of Musicology, Vol. 6, pp. 448-470.

Lourié, Arthur (1932): »The Russian School«, in: The Musical Quarterly, Vol. 18, pp. 519-529.

Lu, Jenny (2019): Telling Tales. The Use of Byron Almén's Musical Narrative Theory as a Filter for a Performance of Medtner's Sonata-Skazka Op. 25 No. 1, master thesis: Monash University Melbourne.

Lyle, Watson (1931): »Medtner and his Music«, in: The Sackbut, Vol. 11, pp. 260-266; excerpts reprinted as: »Modern Composers. Nicolas Raslovitch [sic!] Medtner«, in: The Bookman, Vol. 82, pp. 297-298.

Lyle, Wilson (1985): A Dictionary of Pianists, London: Robert Hale, pp. 185-186.

Malikova, T. (1967): »Svoeobraznïe cherti garmonii Metnera« (»Original Features of Medtner's Harmony«), in: Yuri Nikolayevich Tyulin (ed.): Teoreticheskie problemï muziki XX veka. Sbornik statey (Theoretical Problems of $20^{\text {th }}$ Century Music), Vol. 1, Moscow: Muzika, pp. 280-305.

Mangsen, Sandra / Irving, John / Rink, John / Griffiths, Paul (2001): »Sonata«, in: The New Grove Dictionary of Music and Musicians, $2^{\text {nd }}$ edition, Vol. 23, London: Macmillan, pp. 671-687.

Margulis, Yura (2003): »Rachmaninoff, Prokofiev, Medtner, Stravinsky«, liner notes to the author's recording of Op. 22, AM 1362-2, Freiburg: Freiburger Musik Forum, pp. 10-13.

Marsrow, Amanda (2008): Contexts of Symbolist Music in Silver Age Russia, 1861-1917, master thesis: Southern Methodist University, Dallas.

Markson, Oliver H. (2017): A Study of Nikolai Medtner's Compositional Technique: Form and Narrative in Tales, DMA dissertation: City University of New York.

Martens, Frederick Herman (1919): »The Modern Russian Pianoforte Sonata«, based on an interview with Sergei Prokofiev, in: The Musical Quarterly, Vol. 5, pp. 357-363.

Martyn, Barrie (1995): Nicolas Medtner. His Life and Music, Aldershot and Brookfield: Scolar Press.

- (1998 $\left.{ }^{\mathrm{a}}\right)$ : »The Great Unknown«, in: International Piano Quarterly, Vol. 2, No. 5, pp. 8-13. $\left(1998^{\mathrm{b}}\right)$ : »The Complete Piano Sonatas«, liner notes to Marc-André Hamelin's recording of Medtner's piano sonatas, CDA 67221/4, London: Hyperion Records, pp. 2-8. 
(2001): »Medtner, Nicolas«, in: The New Grove Dictionary of Music and Musicians, $2^{\text {nd }}$ edition, Vol. 16, London: Macmillan, pp. 269-273.

(2002): »The Unknown Nicolas Medtner, Russian Pianist and Composer«, in: Clavier. Magazine for Pianists and Organists, Vol. 41, pp. 22-25.

Mattheson, Johann (1713): Das Neu-Eröffnete Orchestre, Hamburg: Schiller.

Maus, Fred Everett (1991): »Music as Narrative«, in: Indiana Theory Review, Vol. 12, No. 1, pp. 1-34.

Mauser, Siegfried (2004): »Expansion vs. Reduktion. Die Klaviersonate 1890-1920«, in: Arnfried Edler (ed.): Gattungen der Musik für Tasteninstrumente, Handbuch der musikalischen Gattungen Vol. 7, No. 3, Laaber: Laaber, pp. 81-116.

McBurney, Gerard (1993): »Composers in Person: Nicolas Medtner«, liner notes to the reissue of the Medtner Society recordings of skazki and songs, CDC 7 548392, EMI Records Ltd., pp. 5-8.

Medtner, Anna Mikhailovna (1955): »A Short Biography«, in: Holt (ed., 1955), pp. 17-21; extended version in Russian as: »O Nikolae Karloviche Metnere«, in: Apetyan (ed., 1981), pp. 36-45.

Medtner, Emil Karlovich [Vol'fing] (1912): »Russkaya muzika i muzïkal'naya gegemoniya « (»Russian Music and Musical Hegemony«), in: idem, Modernizm i muzika. Stat'i kriticheskie i polemicheskie (Modernism and Music. Critical and Polemic Essays), Moscow: Musaget, pp. 247-259.

Medtner, Nikolai Karlovich (1928): »On Inspiration. Opinions: Nicholas Medtner«, in: The Chesterian, No. 10, pp. 14-15; reprinted as: »Inspiration«, in: Holt (ed., 1955), p. 221.

(1933): »S. V. Rakhmaninov«, in: Rossiya i slavyanstvo, May 1, 1993; reprinted in: Apetyan (ed., 1957), pp. 347-351; transl. to German by Ernst Kuhn as: »Das Kostbare an Rachmaninow ist seine Imagination «, in: Wehrmeyer (ed., 2003), pp. 207-212.

(1935): Muza i moda. Zashchita osnov' muzïkal'nogo iskusstva, Paris: TAIR; reprinted by YMCA Press 1978; transl. Alfred Swan as: The Muse and the Fashion, Being a Defence of the Foundations of the Art of Music, Haverford / PA 1951: Haverford College Bookstore; excerpts from the book with an epilogue by Daniel Zhitomirsky in: Sovetskaya muzïka, No. 8/ 1981, pp. 78-87.

(1963): Povsednevnaya rabota pianista i kompozitora. Stranitsï iz zapisnïkh knizhek, compiled by Mariya Aleksandrovna Gurvich and Leopold Genrikhovich Lukomsky, Moscow 22011: Muzgiz; transl. Lyudmila Bondar as: The Daily Work of the Pianist and Composer, in: Bondar (2003), pp. 39-127; excerpts printed as: »Mïsli o rabote pianista«, in: Sovetskaya muzika, No. 11 / 1961, pp. 88-97.

Miller, Sydney (1941): »Medtner's Piano Music. An Appreciative Study«, in: The Musical Times, Vol. 82, No. 1184, pp. 361-363; continuation in: No. 1185, pp. 393-395.

Milne, Hamish (1980): »Nicolas Medtner: A Centenary Appraisal«, in: Music and Musicians, Vol. 28, pp. 20-23.

- (2003): »Medtner and the Muse«, inaugural lecture at London University, February 26, 2003.

Miranda, Christopher John (2016): Nikolai Medtner: Performing Imagination in his Sonata Reminiscenza, Op. 38 No. 1, DMA dissertation: Jacobs School of Music, Indiana University.

Mitchell, Rebecca (2015): Nietzsche's Orphans. Music, Metaphysics, and the Twilight of the Russian Empire, New Haven and London: Yale University Press.

Mochalova, L. D. (1962): Fortep'yannïe sonatï N. K. Metnera (Medtner's Piano Sonatas), diploma thesis: Moscow Conservatory.

Moldon, David (1976): A Bibliography of Russian Composers, London: White Lion.

Montagu-Nathan, Montagu (1916): An Introduction to Russian Music, Boston: Phillips.

(1917): Contemporary Russian Composers, London: Palmer \& Hayward.

(1918): A History of Russian Music, London: William Reeves.

* Morozova, Margarita Kirillovna (1991): »Moi vospominaniya«, in: Nashe nasledie, Vol. 24, No. 6, p. 107.

Morrison, Bryce (1998): »Blazing a Trail for Medtner«, in: International Piano Quarterly, Vol. 2, No. 5, pp. 14-20.

— (2010): »Complete Piano Sonatas \& Piano Works «, liner notes to the re-release of Hamish Milne's recordings of Medtner's piano sonatas, BC 9195, Leeuwarden: Brilliant Classics, pp. 2-14.

Moskalets, Yuliya Vladimirovna (2004ª): Russkaya fortepiannaya sonata rubezha XIX-XX stoletiy $v$ atmosfere khudozhestvennïk iskanniy epokhi (The Russian Piano Sonata in an Era of Artistic Search), Candidate of the Arts dissertation: Gnesins Academy Moscow.

$\left(2004^{\mathrm{b}}\right)$ : »Fortepiannaya muzïka N. K. Metnera v atmosfere khudozhestvennïkh iskaniy >serebryanogo veka«" (»Medtner's Piano Music in the Atmosphere of the `Silver Age« «), in: Vera Borisovna Valkova (ed.): Russkaya muzïkal'naya kul'tura: sovremennïe issledovaniya. Sbornik trudov, Moscow:

Gnesins Academy, pp. 107-126.

Mühlbach, Marc (1994): Russische Musikgeschichte im Überblick. Ein Handbuch, Berlin: Kuhn. 
Münch, Martin (2004): Die Klaviersonaten und späten Préludes Alexander Skrjabins, musicologia berolinensia Vol. 11, Berlin: Kuhn.

Mussky, Sergei Anatolyevich (2003): Samïe znamenitie: Kompozitorï Rossii (The Most Famous: Composers of Russia), Moscow: Vetche.

Mutylina, Evgeniya (2008): »Tvorchestvo N. K. Metnera v zerkale kritiki XX veka« (»Medtner's Work in the Light of $20^{\text {th }}$-Century Critic $\left.\ll\right)$, in: Tatyana Borisovna Sidneva / Elena Vladimirovna Pridanova (eds.), Aktual'nie problemï vysshego muzikal'nogo obrazovaniya. Sbornik statey, Vol. 10, Nizhny Novgorod Conservatory, pp. 80-88.

Myaskovsky, Nikolai Yakovlevich (1913): »N. K. Metner. Vpechatlenie ot ego tvorcheskogo oblika«, in: Muzïka, No. 119 / 1913, pp. 148-157; reprinted in: Apetyan (ed., 1981), pp. 22-28; transl. Stuart Campbell as: »Medtner. Impressions of his Creative Personality«, in: Campbell (ed., 2003), pp. 185-193.

Naroditskaya, Inna (2006): »Russian Rusalkas and Nationalism: Water, Power, and Women «, in: eadem / Linda Phyllis Austern: Music of the Sirens, Bloomington: Indiana University Press, pp. 216-249.

Nayko, Natalya Mikhailovna (1992): »N. K. Metner. Tvorcheskiy protsess i ego postizhenie (na materiale vïskazivvaniy kompozitora)« (»The Creative Process and its Understanding«), in: Galina Vladimirovna Grigoryeva (ed.): Muzikal'noe iskusstvo XX veka: Tvorcheskiy protsess, khudozhestvennie yavleniya, teoreticheskie kontseptsii. Sbornik nauchnïh trudov, Moscow Conservatory, pp. 3-16. (2012): Dialog s neosoznannïm neizvestnïm: Otrazhenie problem tvorcheskogo protsessa $v$ literaturnom nalsedii russkikh kompozitorov, Krasnoyarsk Academy of Music and Theatre.

Nelson, David $\left(1989^{\mathrm{a}}\right)$ : »Nikolai Karlovich Medtner«, liner notes to Ádám Fellegi’s recordings of a selection of Medtner's sonatas, 8.223268 / 8.223371 / 8.223372, Hong Kong 1989-91: Naxos, pp. 1-8. $\left(1989^{b}\right)$ : »Nikolai Miaskovsky«, liner notes to Endre Hegedüs's recordings of Myaskovsky's piano sonatas, 8.223156 / 8.223469, Hong Kong: Naxos 1989-1992, pp. 2-8.

Neuhaus, Heinrich [Neygauz, Genrikh Gustavovich] (1961): »Sovremennik Skryabina i Rakhmaninova« (»A Contemporary of Scriabin and Rachmaninov«), in: Sovetskaya muzïka, No. 11 / 1961, pp. 72-75; reprinted in: Apetyan (ed., 1981), pp. 31-35.

Neuwirth, Markus (2016): »Durch Nacht zum Licht (und zurück in die Nacht): Formstrategien, dramaturgische Funktionen und semantische Implikationen der Duraufhellung in Reprisen >klassischer Moll-Sonatenformen«, in: Hans-Joachim Hinrichsen / Stefan Keym (eds.), Dur vs. Moll - Zum semantischen Potential eines musikalischen Elementarkontrasts, Vienna: Böhlau. (in print)

Newman, Ernest (1915): »Medtner«, in: The Musical Times, Vol. 56, No. 863, pp. 9-11.

Newman, William Stein (1963): The Sonata in the Classic Era, Vol. 2 of A History of the Sonata Idea, Chapel Hill: University of North Carolina Press.

(1969): The Sonata since Beethoven, Vol. 3 of A History of the Sonata Idea, New York ${ }^{2}$ 1972: Norton.

Niemann, Walter (1905): »Neue Klaviersonaten«, in: Neue Zeitschrift für Musik, Vol. 72, No. 25, pp. 543-545. (1907): Das Klavierbuch. Geschichte der Klaviermusik und ihrer Meister bis zur Gegenwart, Leipzig ${ }^{2}$ 1910: Kahnt.

Ogdon, John (1972): »The Romantic Tradition«, in: Denis Matthews (ed.): Keyboard Music, Newton Abbot: David \& Charles / Penguin Books, pp. 209-258.

Orga, Ateş (1993): »Demidenko plays Medtner«, liner notes to Nikolai Demidenko’s recording of Op. 11 No. 2, Op. 38 No. 1, and Op. 39 No. 5, CDH 55315, London: Hyperion Records, pp. 2-3.

Orlova, Elena Mikhailovna (1982): Ocherki o russkikh kompozitorakh XIX-nachala XX veka, Moscow: Muzika.

Paperno, Dmitry (1998): Zapiski moskovskogo pianista; transl. as: Notes of a Moscow Pianist, Portland: Amadeus Press.

Pevzner, Irina (2013): Forgotten Russian Piano Music. The Sonatas of Anatoly Aleksandrov, DMA dissertation: University of South Carolina.

Pinsonneault, Bernard (1956): Nicolas Medtner, pianiste, compositeur, Montréal: Editions Beauchemin.

Pitts, James Lee (1999): Symmetrical Features of Medtner's Language: The Grozovaya Sonata, Op. 53 No. 2, DMA dissertation: University of North Texas.

Plaistow, Stephen (1976): liner notes to Malcolm Binns' recording of Opp. 27 and 53 No. 2, LP SHE 535, Pembury: Pearl.

Podporinova, Ekaterina Viktorovna (2007): Sonata v tvorchestve N. K. Metnera kak otrazhenie ideyno-khudozhestvennoy kontseptsii kompozitora, Candidate of the Arts dissertation: Kharkov University of the Arts. (2009): »Nikolai Metner: poisk utrachennoy garmonii« (»The Search for the Lost Harmony«), in: Musicus. Organ of the Saint Petersburg Conservatory, No. 3 / 2009, pp. 26-33. 
(2012): »Sonatï-skazki N. Metnera i An. Aleksandrova: v labirintakh muzïkal'nïkh form« (»The Sonati-Skazki Of Medtner and Aleksandrov: In the Labyrinth of Musical Forms«), in: Aspekti istorichnogo muzikoznavstva, No. 5 / 2012, pp. 243-257.

Pomazenkova, Mariya Sergeyevna (2009): »Otrazhenie muziki i vzglyadov na istusstvo N. Metnera v rabotakh russkogo filosofa I. Il'ina « (»The Description of Music and Views of Medtner's Art in Ilyin«), in: Vinokurova / Gokhfeld / Efimova / Kholodova (eds.), Iskusstvo glazami molodikh (Art through the Eyes of the Young), Krasnoyarsk Academy of Music and Theatre, pp. 319-323.

Ponomarchuk, Aleksandr [Burdin, Sasha] (2018): Tempo and Rhythmical Principles al rigore and flessibile in Selected Works by Nikolai Medtner: A Study and Recording, DMA dissertation: University of Iowa.

Postoutenko, Kirill Yur'evich (1994): »N. K. i Ė. K. Metnerï: paradoks natsional'noy samoidentifikatsii« (»N. and E. Medtner: The Paradox of National Self-Identification«), in: Opitï, Vol. 1, pp. 105-113.

Postovalova, Valentina Ilyinichna (2009): »A. F. Losev i N. K. Metner: dukhovnaya vstrecha v mire muzikal'nogo bïtiya« (»Losev and Medtner: An Artistic Encounter«), in: Korolkova / Maslovskaya / Fedyakin (eds., 2009), pp. 104-133.

Pott, Francis (2013): »Violin Sonatas Nos. 1 and 3«, liner notes to Chloë Hanslip's and Igor Tchetuev's recording of Opp. 21 and 57, CDA 67963, London: Hyperion Records, pp. 3-6.

Predvechnova, Ekaterina Olegovna (2017): »Semantika obraza-simvola vremeni v >Tragicheskoy sonate Op. 39 c-Moll Nikolaya Metnera« (»The Semantics of the Symbolic Image of Time«), in: Vestnik Tomskogo Gosudarstvennogo Universiteta, No. 26 / 2017, pp. 101-110.

Prokofiev, Grigory Petrovich (1913): »O Metnere« (»On Medtner«), in: Russkaya muzïkal'naya gazeta, Vol. 3, col. 65-70; transl. to German by Christoph Flamm, in: Flamm (1995), pp. 300-305.

Protopopov, Vladimir Vasilyevich $(1940,1947)$ : »O tematizme i melodike S. I. Taneeva« (»On Taneyev’s Thematicism and Melody«), in: Sovetskaya muzika, No. 7 / 1940, pp. 49-60; »Nekotorïe voprosï muzïkal'nogo stilya S. I. Taneeva« (»Some Questions on Taneyev’s Musical Style«), in: Sovetskaya muzika, No. 5 / 1947, pp. 42-52; both reprinted in: idem, Izbrannie issledovaniya i stat'i, ed. by Irina Andreyevna Bobykina, Moscow 1983: Sovetskiy Kompozitor, pp. 60-75 and 121-139.

_ (1987): Istoriya polifonii. Polifoniya v russkoy muzike XVII - nachala XX veka (History of Polyphony in Russian Music), Moscow: Muzïka.

(2010): Istoriya sonatnoy formï. Sonatnaya forma v russkoy muzike (History of Sonata Form in Russian Music), ed. by Tatyana Naumova Dubravskaya, Moscow: Muzika.

Prout, Ebenezer (1895): Applied Forms. A Sequel to Musical Form, $4^{\text {th }}$ edition, London: Augener \& Co. Pullman, Philip (2001): »From our Archive: Medtner«, in: Granta Magazine, No. 76: Music, p. 70ff.

Rakhlenko, Irina (2009): »Nikolai Metner i Edna Aylz. Tvorcheskie kontaktï« (»Medtner and Edna Iles: Creative Contacts«), in: Korolkova / Maslovskaya / Fedyakin (eds., 2009), pp. 28-35.

Ramey, Phillip (1977): »Piano Sonata in G minor, Op. 22«, liner notes to Emil Gilels’s recording, LP Y-34611, Moscow: Melodiya; re-released New York: Columbia Records.

Rattalino, Piero (2012): Guida alla musica pianistica, Varese: Zecchini.

Ratz, Erwin (1951): Einführung in die musikalische Formenlehre, Vienna ${ }^{3} 1973$ : Universal Edition.

Raybould, Clarence (1955): »A Monograph on Medtner«, in: Holt (ed., 1955), pp. 133-140.

Razgulyayev, Ruslan Aleksandrovich (2013 $)$ : »Sonata-vospominanie N. Metnera v aspekte formoobrazovaniya « (»Aspects of Formal Design in the Sonata-Reminiscenza«), in: Aktual'nie problemï vïsshego muzikalnogo obrazovaniya, No. 2 (28), pp. 22-25; extended version as: »Urovni formoobrazuyushchikh svyazey v Sonate-vospominanii N. Metnera«, published online at: Otkritïy tekst. $\left(2013^{\mathrm{b}}\right)$ : ») Muzïkalnïy kosmos〈 N. Metnera i istoriosofiya F. Tyutcheva« (»Medtner`s $>$ Musical Cosmos« and Tyutchev's Historiosophy«), in: Uchenie zapiski. Žurnal rossiyskoy akademii muzïki imeni Gnesinikh, No. 4 / 2013, pp. 21-30.

Redepenning, Dorothea (2008): Geschichte der russischen und der sowjetischen Musik, Vol. 2 / 1: Das 20. Jahrhundert, Laaber: Laaber.

Reicha, Anton (1814): Traité de la mélodie, Paris: Costallat; transl. to German by Carl Czerny as: Vollständiges Lehrbuch der musikalischen Composition, Vol. 2 (part 4), Vienna 1832: Diabelli. (1824): Traité de haute composition musicale, Vol. 2, Paris: Costallat; transl. to German by Carl Czerny as: Vollständiges Lehrbuch der musikalischen Composition, Vol. 4 (parts 8-10), Vienna 1832: Diabelli.

Réti, Rudolf (1951): The Thematic Process in Music, London ${ }^{2} 1961$ : Faber \& Faber.

Riemann, Hugo (1902): Grosse Kompositionslehre, Vol. 1: Der homophone Satz (Melodielehre und Harmonielehre), Berlin / Stuttgart: Spaemann. 
Riesemann, Oskar von [Rizeman] (1912): »Nikolai Metner«, in: Studiya. Zhurnal’ iskusstva i stsenï, No. 20, February 18, 1912, pp. 15-16.

— (1924): »Nikolai Medtner«, in: Rheinische Musik- und Theater-Zeitung, Vol. 25, pp. 375-376; transl. Bianca Karpeles, in: The Sackbut, Vol. 5, May 1925, pp. 302-304.

Rigbi, Elisheva (2013): »Musical Prose and Musical Narrativity in the Fin de Siècle«, in: Michael Leslie Klein / Nicholas Reyland (eds.): Music and Narrative since 1900, Bloomington: Indiana University Press, pp. 144-162.

Rimm, Robert (1999): »The Re-Discovered Russian«, in: Piano \& Keyboard, Vol. 7, Jan / Feb 2003, pp. 40-45.

- $\left(2003^{\mathrm{a}}\right)$ : The Composer-Pianists. Hamelin and The Eight, Amadeus Press: Cleckheaton. $\left(2003^{\mathrm{b}}\right)$ : Keyboard Music, in: Notes, Vol. 60, No. 1, September 2003, pp. $290 \mathrm{ff}$.

Rizzi, Nicolò (2018): »Narrative Traces and Medtner's Musical Speech. Memory Suggestions in the Three Cycles of Forgotten Melodies, Opp. 38-40«, paper in the conference Kul'turnoe prostranstvo Rossii: genezis i transformatsii, Saint Petersburg State Institute of Culture, April 6, 2018.

Roberts, Peter Deane (1993): Modernism in Russian Piano Music: Scriabin, Prokofiev, and their Russian Contemporaries, Bloomington: Indiana University Press.

Roitershtein, Mikhaèl Iosifovich (1966): »O edinstve sonatnogo-tsiklicheskoy formï u Chaykovskogo« (»On Unity in Tchaikovsky's Cyclic Sonata Form«), in: Vladimir Vasilyevich Protopopov (ed.): Voprosy muzikal'noy formï, Vol. 1, Moscow: Muzika, pp. 121-150.

Rom, Uri (2006): »Ein 〉Es-Dur-Gedanke`? Zum Zusammenhang von Motivik und Tonart bei Mozart«, in: Journal of the German Society for Music Theory (ZGMTH), Vol. 6 / 1 (2006), pp. 9-50.

Romansky, Stefan P. L. (1983): »Ein Weg zu Nicolai Medtner. Versuch einer Diskographie«, in: Rainer Klaas (ed.): Piano-Jahrbuch, Vol. 3, Recklinghausen: Piano-Verlag, pp. 125-133.

Rosen, Charles (1971): The Classical Style. Haydn, Mozart, Beethoven, $3^{\text {rd }}$ edition, New York 1997: Norton.

- (1980): Sonata Forms, revised edition, New York 1988: Norton, pp. 98-176.

Rousseau, Jean-Jacques (1765): »Sonate«, in: Denis Diderot / Jean Baptiste d'Alembert (ed.): Encyclopédie, ou Dictionnaire raisonné des sciences, des arts et des métiers, Vol. 15, Paris: Briasson et al., pp. 348ff.

Rowen, Ryan Isao (2015): Transcending Imagination; or, an Approach to Music and Symbolism during the Russian Silver Age, PhD dissertation: University of California, Los Angeles.

Rueger, Christoph [Rüger, Christof] (1979): Konzertbuch Klaviermusik, Leipzig: Deutscher Verlag für Musik. (1998): Harenberg Klaviermusikführer. 600 Werke vom Barock bis zur Gegenwart, Dortmund: Harenberg Kommunikation.

Sabaneyev, Leonid Leonidovich (1924): Istoriya russkoy muziki, Moscow: Rabotnik Prosveshcheniya, pp. 78-80; transl. to German by Oskar von Riesemann as: Geschichte der russischen Musik, Leipzig 1926: Breitkopf und Härtel; reprinted Hildesheim 1982: Georg Olms.

Sabaneyev, Leonid Leonidovich $\left(1927^{\mathrm{a}}\right)$ : Modern Russian Composers, transl. Judah Achilles Joffe, New York: International Publishers; reprinted Freeport / NY 1967: Books For Libraries Press. $\left(1927^{b}\right)$ : »Metner«, in: K novïm beregam muzikal'nogo iskusstva, No. 2 / 1923, pp. 21-23; transl. S. W. Pring as: »Two Critiques. II - Medtner«, in: Music and Letters, Vol. 8, pp. 328-334. (1928): »Nikolai Medtner«; transl. Pring, in: The Musical Times, Vol. 69, p. $209 f$.

(1929): »Medtner (Metner), Nicolas Razlovitch « [sic], in: Walter Willson Cobbett (ed.): Cyclopedic Survey of Chamber Music, Vol. 2: I-Z, Oxford ${ }^{2}$ 1963: Oxford University Press, p. 126f.

(1936): »N. K. Medtner«; transl. Pring, in: The Musical Times, Vol. 77, p. 313f.

(1955): »Medtner and his Age«, in: Holt (ed., 1955), pp. 77-85.

(1959): »N. K. Metner. K 80-letiyu ego rozhdeniya« (»To Medtner's $80^{\text {th }}$ Birthday«), in: Russkaya mïsl', 1959; reprinted in: idem, Vospominaniya o Rossii (Memories of Russia), ed. by Tatyana Yuryevna Maslovskaya, Moscow 2004: Klassika-XXI, pp. 81-86.

Sacre, Guy (1998): La musique de piano. Dictionnaire des compositeurs et des œuvres, Vol. 2, Paris: Laffont.

Salzer, Felix (1928): »Die Sonatenform bei Franz Schubert«, in: Studien zur Musikwissenschaft, Vol. 15, pp. 86-125.

Samin, Dmitry Konstantinovich (2001): Samïe znamenitie: Ėmigrantï Rossii (The Most Famous: Emigrants of Russia), Moscow: Vetche.

Sandelewski, Wiarosław (1988): »Medtner, Nikolaj Karlovič«, in: Alberto Basso (ed.): Dizionario enciclopedico universale della musica e dei musicisti, Le Biografie: Vol. 5, Turin: Unione Tipografico, pp. 4-5.

Sarest, Aleksandra (2014): Nikolai Medtner's First Piano Concerto: A Metrotectonic Analysis, DMA dissertation: City University of New York.

Sarkett, John A. (2014): Obscure Composers, Winnetka / IL: Sarkett Press. 
Scherek, Jeffreys (1950): »Nicholas Medtner«, in: Canon. Australian Journal of Music, Vol. 3, pp. 596-599. Schibli, Sigfried (1983): Alexander Skrjabin und seine Musik. Grenzüberschreitungen eines prometheischen Geistes, Munich and Zurich: Piper.

Schiwietz, Lucian (2009): »Lirika Geyne v kosmose Metnera. Nekotorïe zamechaniya k Op. 12 Nikolaya Metnera« (»Heine's Lyrics in Medtner's Cosmos. Some Notes on Op. 12«), in: Korolkova / Maslovskaya / Fedyakin (eds., 2009), pp. 93-103.

Schmidt-Beste, Thomas (2006): Die Sonate. Geschichte, Formen, Ästhetik, Bärenreiter Studienbücher Musik Vol. 5, Kassel: Bärenreiter; transl. as The Sonata, Cambridge 2011: Cambridge University Press.

Schoenberg, Arnold (1950): Style and Idea, New York: Philosophical Library.

- (1967): Fundamentals of Musical Composition, ed. by Gerald Strang and Leonard Stein, London 1970: Faber and Faber.

Schubart, Christian Friedrich Daniel (1806): Ideen zu einer Ästhetik der Tonkunst, Vienna: Degen.

Schumann, Otto (1952): Schumanns Klaviermusikbuch, Wilhelmshaven: Wilhelm Hübener.

Schwab, Alexander (2009): »Natsional'nïe chertï v tvorchestve N. Metnera. K probleme èpicheskogo opredeleniya« (»National Traits in Medtner's Work«), in: Korolkova / Maslovskaya / Fedyakin (eds., 2009), pp. 36-39.

Schwarz, Boris (1982): Musik und Musikleben in der Sowjetunion von 1917 bis zur Gegenwart, Vol. 1; transl. to German by Jeanette Zehnder-Reitinger, Wilhelmshaven: Heinrichshofen.

Segnitz, Eugen (1906): »Neue Klaviermusik«, in: Musikalisches Wochenblatt, Vol. 87, No. 3, p. 64.

Seidle, Peter (1995): »Nikolaj Medtner«. Dokumente, Diskographie, Katalog, catalogue for a Medtner exhibition at Husum Castle, Karlsruhe: Opus E / author's edition.

Semykin, Valery Grigoryevich (2017): Odnochastnaya fortepiannaya sonata XIX-pervoy treti XX stoletiya: kompozitsionno-dramaturgicheskie aspekti (The Single-Movement Piano Sonata of the $19^{\text {th }}$ and $20^{\text {th }}$ Centuries: Compositional and Dramaturgical Aspects), Candidate of the Arts dissertation: Gnesins Academy Moscow.

Seng-Quinn, Nellie (2016): The Motivic Economy in Medtner's Sonata romantica, DMA dissertation: City University of New York.

Shaginyan, Marietta Sergeyevna (1957): »Vospominaniya o S. V. Rakhmaninove« (»Memories of Rachmaninov«), in: Apetyan (ed., 1957), pp. 90-161; partly transl. to German by Ernst Kuhn as: Sergej Rachmaninow und Nikolai Medtner, in: Wehrmeyer (ed., 2003), pp. 191-206.

Shatskes, Abram Vladimirovich (1988): »Vospominaniya o Metnere pedagoge« (»Memories of the Pedagogue Medtner«), in: Mikhail Georgievich Sokolov (ed.): Pianistï rasskazïvayut, Vol. 3, Moscow: Sovetskiy Kompozitor, pp. 147-158.

Shevchenko, Tatyana Aleksandrovna (2017): Fortepiannïe sonatï N. K. Metnera v khudozhestvennom prostranstve evropeyskoy muzïki kontsa XIX - nachala XX stoletiy (Medtner's Piano Sonatas in the Artistic Space of European Music), Candidate of the Arts dissertation: Odessa National Music Academy. (2018): »Medtner's Piano Sonatas as Subject of Performing Interpretation (on the example of the Sonata-Reminiscenza, Op. 38 No. 1«, paper in the conference Kul'turnoe prostranstvo Rossii: genezis $i$ transformatsii, Saint Petersburg State Institute of Culture, April 6, 2018.

Shin, Haeshin (2018): Nikolai Medtner's Forgotten Melodies, op. 38: Sources, Analysis, and Interpretation, DMA dissertation: Boston University, College of Fine Arts.

Shneyerson, Grigory Mikhailovich (1956): »Novoe o Metnere« (»News about Medtner«), in: Sovetskaya muzika, No. 7 / 1956, pp. 139-143.

Shtember, Nikolai Viktorovich (1981): »Iz vospominaniy o N. K. Metnere« (»From the Memories of Medtner«), in: Apetyan (ed., 1981), pp. 82-93.

* Shtrom, A. (2004): »Dve >Muzï<. O romansakh N. Metnera, soch. 29 No. 1 i S. Rakhmaninova, soch. 34 No. 1 na stikhotvorenie A. Pushkina >Muza«« (»Two >Muses«. On Medtner’s and Rachmaninov's Romances on Pushkin's Poem >Muza««), in: Muzikal'naya akademia, Vol. 12, p. 127-131.

Shvets, Nikolai Antonovich (2009): »Poėziya Pushkina v khudozhestvennïkh vozzreniyakh i tvorchestve Nikolaya Metnera« (»Pushkin's Poetry in Medtner's Work and Artistic Views«), in: Korolkova / Maslovskaya / Fedyakin (eds., 2009), pp. 76-92.

Sitsky, Larry (1994): Music of the Repressed Russian Avant-Garde, 1900-1929, Westport / CN: Greenwood. Skalkina, Marina Vladimirovna (2004): »Nikolai Metner. Zhizn’ v tvorchestve« (»Medtner. His Life through his Work«), in: Yuzhno-rossiyskiy muzïkal'nüy al'manakh, Vol. 1, Rostov-on-the-Don Conservatory, pp. $155-159$. 
_ (2009): »Tema i eë razvitie v fortepiannïkh sonatakh N. K. Metnera« (»The Theme and its Development in Medtner's Piano Sonatas«), in: Evgeniya Romanovna Skurko / Evgeniya Ivanovna Chigareva (eds.), Zhizn' muziki: k 100-letiyu so dnya rozhdeniya V. P. Bobrovskogo, Moscow Conservatory, pp. 209-214.

Skvorak, David John (2003): Thematic Unity in Nicolas Medtner's Works for Piano: Skazki, Sonatas, and Piano Quintet, DMA dissertation: University of Cincinnati.

Smith, Gregory Michael (2003): Performance Practice Issues in Russian Piano Music, master thesis: University of Newcastle.

Sokolov, Oleg Vladimirovich (1968): »O sonatnosti v proizvedeniyakh Metnera«, in: Sergei Sergeyevich Skrebkov (ed.): Voprosï teorii muzïki. Sbornik statey, Vol. 1, Moscow: Muzïka, pp. 140-166; partly transl. to German by Ernst Kuhn as: »Die Sonatenform in Nikolai Medtners Klaviermusik und ihre vielfältigen Ausprägungen «, in: Kuhn (ed., 2008 a), pp. 161-192.

Sorabji, Kaikhosru Shapurji (1932): Around Music, London: Unicorn Press. (1955): »The Greatness of Medtner«, in: Holt (ed., 1955), pp. 122-132.

Sorokina, Elena Gennadievna (1976): »Fortepiannïe sonatï S. V. Rakhmaninova« (»Rachmaninov's Sonatas«), in: Aleksey Ivanovich Kandinsky (ed)., Iz istorii russkoy i sovetskoy muziki, Vol. 2, Moscow: Muzïka, pp. 146-180.

Sposobin, Igor Vladimirovich (1947): Muzikal'naya forma. Uchebnik obshchego kurs analiza, revised edition, Moscow 2002: Muzika.

Spring, Michael (1998): »Medtner on Record. The Complete Discography of Commercial Piano Recordings«, in: International Piano Quarterly, Vol. 2, No. 5, pp. 22-31.

Staples, James Gwynn (1972): Six Lesser-Known Piano Quintets of the Twentieth Century, DMA dissertation: Eastman School of Music, University of Rochester.

Steger, Hanns (1979): Der Weg der Klaviersonate bei Alexander Skrjabin, Munich: Wollenweber.

Stein, Leon (1962): Structure and Style. The Study and Analysis of Musical Forms, Princeton / NJ: Summy Birchard.

Stewart, Paul (2012): »Complete Piano Sonatas Vol. 1«, liner notes to the author's recording of Opp. 5 and 38 No. 1, GP 617, Hong Kong: Naxos, pp. 5-9.

(2016): »Complete Piano Sonatas Vol. 2«, liner notes to the author's recording of Op. 11, Op. 25 No. 1, and Op. 56, GP 618, Hong Kong: Naxos, pp. 4-9.

Stöhr, Richard (1911): Musikalische Formenlehre, Leipzig: Siegel; rev. by Hans Gál and Alfred Orel as: Formenlehre der Musik, Halle 1950: Mitteldeutscher Verlag.

Strikovskaya, Elena Evseyevna (2017): »Nikolai Metner. Vse sonatï dlya fortepiano. Tsikl iz 2-kh vecherov«, review of two concerts in the Rachmaninov Hall of the Moscow Conservatory, April 2017; transl. by Alexander Grusenberg as »Nikolai Medtner. The 14 Piano Sonatas in Two Evening Recitals«, in: Piano Journal, periodical of the European Piano Teachers Association (EPTA), No. 112 / 2017, pp. 5-7.

Surace, Ronald Dominic (1973): The Solo Piano Music of Nicolas Medtner, DMA dissertation: University of Cincinnati.

Swan, Alfred Julius (1922): »Medtner«, in: The Musical Times, Vol. 63, pp. 616-619.

- $\left(1927^{\mathrm{a}}\right)$ : »Medtner and the Music of our Time«, in: Music and Letters, Vol. 8, pp. 46-54; reprinted in: Holt (ed., 1955), pp. 28-37. $\left(1927^{b}\right)$ : »The Present State of Russian Music«, in: The Musical Quarterly, Vol. 13, pp. 29-38. (1928): »Nicholas Medtner«, in: The Chesterian, Vol. 10, December 1928, pp. 77-81.

(1944), co-authored with Ekaterina Swan: »Rachmaninoff. Personal Reminiscences«, in: The Musical Quarterly, Vol. 30, pp. 1-19 and 174-191; translated to Russian as: »Vospominaniya o S. V. Rakhmaninove« (»Memories of Rachmaninov«), in: Apetyan (ed., 1957), pp. 184-215.

- (1967): »Das Leben Nikolai Medtners. Nach Unterlagen des Familienarchivs und unveröffentlichten Dokumenten«, in: Die Musik des Ostens, Vol. 4, pp. 65-116.

(1969): memorial essay, in: idem / Yuri Nikolayevich Tyulin / Panteleymon Ivanovich Vasilyev, »Iz vospominaniy o N. K. Metnere« (»From the Memories of Medtner«), in: Sovetskaya muzika, No. 7 / 1972, pp. 117-124; translated to Russian as: »Moi vstrechi s istinnïm khudozhnikom« (»My Encounters with a Real Artist«), in: Apetyan (ed., 1981), pp. 142-153.

Takaku, Satoru (2003): »Preface«, revision report to an edition of the $1^{\text {st }}$ cycle of Forgotten Melodies, Op. 38, Tokyo: Zen-On Music Company, pp. 22-26.

(2004): »Sonata Minacciosa«, liner notes to Masahiro Kawakami’s recording of Opp. 11 and 53 No. 2, HCC-2016, Tokyo: Harmony Limited. 
Takenouchi, Hiroaki (2004): Piano Sonatas by Nikolay Medtner: A Performer's Perspective, master thesis: Royal College of Music, London.

Tarasova, Evgeniya (2009): »Ivan Il'in o Nikolae Metnere (na materiale statey i pisem)« (»Ilyin on Medtner«), in: Vestnik rossiskoy akademii imeni Gnesinikh, No. 2 \& 2009, pp. 28-38.

Taruskin, Richard (1980): »The Piano Music of Nikolai Medtner«, liner notes to Antony Rollé's recording of Medtner's Op. 53 No. 2, LP SR 9026, New York: Finnadar.

- (1997): Defining Russia Musically. Historical and Hermeneutical Essays, Princeton and Oxford: Princeton University Press.

Taube, Artur (1971): »Sylwetki słynnych rosyjskich pianistów-pedagogów«. Mikołaj Medtner, in: Ruch Muzyczny, Vol. 15, No. 19, pp. 14-16.

Tauscheck, Jonathan Paul (2012): A Performance Guide to Two Fairy Tales of Nickolai [sic!] Medtner, DMA dissertation: University of Iowa.

Teichmüller, Robert / Herrmann, Kurt $(1927,1934)$ : Internationale moderne Klaviermusik. Ein Wegweiser und Berater, Leipzig and Zurich 1927: Hug; continued as: Kurt Hermann (ed.): Die Klaviermusik der letzten Jahre, published as an appendix to the former, Leipzig and Zurich 1934: Hug.

Terlikova, Liudmila Evgenievna (1993): »Ispolnitel'skoe voploshchenie fakturï v fortepiannïkh sonatakh Metnera « (»Performative Aspects of Texture in Medtner's Piano Sonatas«), in: Natalya Nikolayevna Simonova (ed.): Proizvedeniya otechestvennoy i zarubezhnoy klassiki v repertuare studentov vuza. Voprosï stilya i ispolnitel'skoy interpretatsii, Rostov-on-the-Don Conservatory, pp. 72-87.

Thiessen, Karl (1909): »Neue russische Klaviermusik«, in: Signale für die musikalische Welt, Vol. 67, pp. 896-897.

Tideböhl, Ellen von (1913): »Modern Masters in Russia«, in: The Etude Magazine, March 1913.

- (1916): »Bach and Beethoven Not Excluded from Programs in Moscow: Nikolai Medtner, a Gifted Composer«, in: Musical Courier, Vol. 72, No. 19, May 11, 1916, pp. 56-57.

Tozer, Geoffrey (1998): »Biography« / »Performance Notes«, in: The Complete Piano Sonatas: Series I and II, reprint of the sonatas from the Soviet Collected Edition, Mineola / NY: Dover Publications, pp. X-XIII. (1999): »Piano Sonatas \& Forgotten Melodies«, liner notes to the author's complete recording of Medtner's piano sonatas, Chan 9723-(4), Colchester: Chandos Records, pp. 8-18.

Truscott, Harold (1956): »Nicolas Medtner«, in: The Chesterian, Vol. 31, Summer 1956, pp. 1-9. (1961): »Medtner's Sonata in G minor, Op. 22«, in: The Music Review, Vol. 22, pp. 112-123.

Tumanina, Nadezhda Vasilyevna (1960): Istoriya russkoy muziki, Vol. 3, Moscow: Muzgiz.

Türk, Daniel Gottlob (1789): Klavierschule, oder Anweisung zum Klavierspielen, Leipzig and Halle: Schwickert.

Tyulin, Yuri Nikolayevich (1972): memorial essay, in: idem / Alfred Julius Swan / Panteleymon Ivanovich Vasilyev, »Iz vospominaniy o N. K. Metnere« (»From the Memories of Medtner«), in: Sovetskaya muzika, No. 7 / 1972, pp. 113-117; extended Russian version as: »Vstrechi s N. K. Metnerom« (»Encounters with Medtner«), in: Apetyan (ed., 1981), pp. 110-117.

Uhl, Nathan (2017): The Opus 41 Vocalises of Nikolai Medtner: Background, Analysis, and Performer's Guide, DMA dissertation: Arizona State University.

* Urban, Erich (1922): »Compositionen von Nikolaus Medtner«, in: Berliner Zeitung, April 11, 1922.

Vande Moortele, Steven (2009): Two-Dimensional Sonata Form, Leuven: Leuven University Press.

Vasilyev, Panteleymon Ivanovich (1959): »N. K. Metner«, preface in: Collected Edition, Vol. 1 (1959 $\left.{ }^{\mathrm{a}}\right)$.

- (1962): Fortep 'yannïe sonatï Metnera, Moscow: Muzgiz; transl. to German by Ernst Kuhn as: »Die Klaviersonaten Nikolai Medtners«, in: Kuhn (ed., 2008ª), pp. 117-160.

_ (1963): »Zapisnie knizhki Metnera«, introduction and appendix to Medtner (1963); transl. Lyudmila Bondar as »Medtner's Notebooks«, in: Bondar (2003), pp. 25-38.

— (1972): memorial essay, in: idem / Yuri Nikolayevich Tyulin / Alfred Julius Swan, »Iz vospominaniya o N. K. Metnere« (»From the Memories of Medtner«), in: Sovetskaya muzika, No. 7 / 1972, pp. 124-126; extended Russian version as: »O moem uchitele i druge« (»About my Teacher and Friend«), in: Apetyan (ed., 1981), pp. 71-81.

Vasyutinskaya, Evgeniya Aleksandrovna (2014): N. K. Metner: lichnost', vzglyadï, stil'. Ispolnenie muzïki Metnera: analiticheskie ètyudi (Personality, Views, Style. Analytic Studies), Saint Petersburg: Kompozitor.

Voroshilova, Vera Aleksandrovna (2004): »Metodicheskie aspektï interpretatsii sonatï N. K. Metnera g-moll soch. 22« (»Methodical Aspects of the Interpretation of Medtner's G minor Sonata«), in: Aktual'nie problemï vïsshego muzikal'nogo obrazovaniya. Sbornik statey, Vol. 6, Nizhny Novgorod Conservatory, pp. 78-82.

Walther, Johann Gottfried (1732): Musicalisches Lexicon oder Musicalische Bibliotec, Leipzig: Deer. 
Wehrmeyer, Andreas (1991): Studien zum russischen Musikdenken um 1920, Frankfurt am Main: Peter Lang, Europäische Hochschulschriften Series XXXVI, Vol. 67. (ed., 1996): Sergej Taneev - Musikgelehrter und Komponist. Materialien zu Leben und Werk, Studia Slavia Musicologia Vol. 3, Berlin: Kuhn.

- (2000): Sergej Rachmaninow, Rowohlts Monographien, Reinbek ${ }^{2} 2006$ : Rowohlt.

— (ed., 2003): Rachmaninow aus der Nähe. Erinnerungen und kritische Würdigungen von Zeitgenossen, musik konkret Vol. 13, Berlin: Kuhn.

Weinberg, Jacob (1958): »Sergei Ivanovitch Taneiev«, in: The Musical Quarterly, Vol. 44, pp. 19-31.

Westfall, David Charles (2008): Three One-Movement Sonatas of the Russian Silver-Age: A Comparative Study, DMA dissertation: University of Hartford, Connecticut.

Wier, Albert Ernest (1940): The Piano: Its History, Makers, Players and Music, New York: Longmans, Green \& Co.

Wodarski, Alicia (2013): Nikolai Medtner's Fairy Tales as Shakespearean Adaptation, honors thesis: Bowling Green State University, Ohio.

Wolf, Henry Samuel (1957): The Twentieth Century Piano Sonata, PhD dissertation: Boston University. Wolters, Klaus (1967): Handbuch der Klavierliteratur. Klaviermusik zu zwei Händen, Zürich ${ }^{2}$ 1977: Atlantis. Yagodkina, T. I. (1959): Sonata Metnera g-Moll soch. 22, diploma thesis: Moscow Conservatory.

Yakovlev, Vasily Vasilyevich (1927): »Nikolai Karlovich Metner« / »Nikolaj Medtner«, bilingual essay in: Biografii sovremennïh russkikh kompozitorov / Biographien russischer Komponisten, Moscow: Muzgiz, pp. 22-34; German text reprinted in: Flamm (1995), pp. 337-340.

Yasser, Iosif Samuilovich (1924): »Carrying Classicism into the Futurist Camp, Nicholas Medtner Comes to Win New Worlds«, in: Musical America, November 8, 1924, pp. 5 and 24; with an addendum »Russian Composer Disclaims Modernism«, signed by 〉H. M.<, ibid., p. 24. (1955): »The Art of Nicolas Medtner«, in: Holt (ed., 1955), pp. 46-65; reprinted as: »Iskusstvo Nikolaya Metnera«, in: Apetyan (ed., 1981), pp. 198-210.

Yeh, Huey-Jing (2008): A Research and Interpretation of Piano Sonata »Reminiscenza« by Nikolai Medtner, master thesis: Soochow University Suzhou, China.

Zassimova, Anna (2011): Georges Catoire. Seine Musik, sein Leben, seine Ausstrahlung, Studia Slavia Musicologia Vol. 49, Berlin: Kuhn.

Zenkin, Konstantin Vladimirovich (2003): »Nikolai Metner v muzikal'nom mire svoego vremini« (»Medtner in the Musical World of his Time«), in: idem / Konstantin Anatolyevich Zhabinsky (eds.), Muzika v prostranstve kul 'turï. Izbrannïe stat'i, Vol. 2, Rostov-on-the-Don: Kniga, pp. 191-207; reprinted in: Korolkova / Maslovskaya / Fedyakin (eds., 2009), pp. 9-27.

Zetel, Isaak Zusmanovich (1969): »Snova zvuchit muzïka Metnera« (»Medtner’s Music Sounds Anew«), in: Aleksandr Aleksandrovich Nikolayev (ed.): Voprosy muzikal'no-ispolnitel'skogo iskusstva (Questions of Musical-Dramatical Art), Vol. 5, Moscow: Muzika, pp. 330-342.

(1981): N. K. Metner - pianist. Tvorchestvo, ispolnitel'stvo, pedagogika, Moscow: Muzïka; transl. to German by Kerstin True-Biletzki as: N. K. Medtner-der Pianist. Sein kompositorisches Schaffen, seine Interpretationskunst und Pädagogik, eds. Lucian Schiwietz / Hans-Jürgen Winterhoff, Sinzig 2003: Studio Verlag / Edition IME.

Zhitomirsky, Daniel Vladimirovich (1960): Russkie kompozitori kontsa XIX i nachala XX veka (Late-19 $9^{\text {th }}$ Century and Early-20 ${ }^{\text {th }}$-Century Russian Composers), Moscow: Sovetskiy Kompozitor, pp. 54-55. (1981): »N. K. Metner. Zametki o stile«, in: idem, Izbrannie stat'i, Moscow: Sovetskiy Kompozitor, pp. 283-329; transl. to German by Ernst Kuhn as: »Über Nikolai Medtner und seine Musik«, in: Kuhn (ed., 2008), pp. 1-45.

Zilberkant, Eduard (1996): Anton Rubinstein and the Nineteenth-Century Piano Sonata, DMA dissertation: Temple University, Philadelphia.

Zuk, Patrick (2009): »Medtner«, in: Nineteenth-Century Music Review, Vol. 6, No. 2, pp. 169-172. (2013): »Musical Modernism in the Mirror of the Myaskovsky-Prokof' ev Correspondence«, in: Christoph Flamm / Henry Keazor / Roland Martin (eds.), Russian Émigré Culture: Conservatism or Evolution?, Newcastle upon Tyne: Cambridge Scholars, pp. 229-244. 


\subsection{AnNOtated List of Publications}

\section{Primary Sources}

$\begin{array}{lll}\text { Apetyan 1973 } & \text { ru } & \text { Soviet edition of Medtner's letters } \\ \text { Medtner 1928 } & \text { en } & \text { On the source and character of musical inspiration } \\ \text { Medtner 1933 } & \text { ru, de } & \text { Appreciation of Rachmaninov as composer, pianist, and conductor to his 60th birthday } \\ \text { Medtner 1935 } & \text { ru, en } & \text { Artistic creed, including thoughts on form, melody, harmony, dissonance, modernism } \\ \text { Medtner 1963 } & \text { ru, en } & \text { Ideals of creative work, instruction at the piano; performance notes on some sonatas }\end{array}$

\subsubsection{The SonAtas: ANALysis AND Musical COMMENT}

Alekseyev 1969 ru, de Examination of piano works; covers Op. 11, Op. 22, Op. 25, Op. 27, nothing on later

Bertin 2018

Bitzan $2016^{\mathrm{a}}$

Bitzan $2016^{\mathrm{b}}$

Dolinskaya 1966

Dolinskaya 2013

Elmore 1972

Emerson 2016 ${ }^{\mathrm{a}}$

Emerson $2016^{\mathrm{b}}$

Flamm 1995

Genkina 2005

Ginsburg 1961

Keller 1971

Kinley 1970

Loftis 1970

Malikova 1967

Martyn 1995

Miranda 2016

Mochalova 1962

Moskalets 2004 ${ }^{\mathrm{a}} \quad \mathrm{ru}$

Moskalets 2004 ${ }^{\mathrm{b}} \quad \mathrm{ru}$

Pitts 1999

Podporinova 2007

en

Podporinova 2009 ru

Protopopov 1987 ru

Protopopov $2010 \quad \mathrm{ru}$

Razgulyayev $2013^{\mathrm{a}}$ ru

Seng-Quinn 2016 en

Semykin $2017 \quad$ ru

Skvorak 2003

Smith 2003

Sokolov 1968

Surace 1973 sonatas; examples from Op. 11 / 2, Op. 22, Op. 25 / 1, Op. 27, Op. 38 / 1; some autographs Discussion of Dionysic and Apollonian aspects, analysis of Op. 25 Nos. 1 and 2 On tonal symmetry and architectural balance, notes on Op. 11 Nos. 1 and 3, and Op. 22 Analysis of Op. 27, genesis of the `Muza< motif, intertextual and hermeneutic aspects Comments on most of the sonatas, analytical aspects in Op. 22, Op. 27, Op. 38/1, further comments and examples from Op. 5, Op. 11 / 2, Op. 25 / 2, Op. 53 / 1, Op. 56 Enhanced version of 1966, now including Op. 30, Op. 39/5, and extended introduction Comparative analysis of all sonatas, arranged by parameters; includes chord statistics Extensive study of Op. 27, incorporating analytical, narrative, and metaphysical aspects Analysis of Op. 38 / 1 from a hermeneutic perspective, comment on form; mentions Op. 5 Short but comprehensive analyses of Op. 5, Op. 11 / 2, Op. 22, Op. 25 / 2, Op. 38 / 1, and Op. 39 / 5; discussion of Op. 27; example from Op. 53 / 2; elaborations on harmony Analysis of Op. 30, possible text underlay of secondary theme; mentions Op. 25 / 2 Analyses of all sonatas but Op. 56; summary of style and form Examinations of all sonatas; thoughts on sonata form and compositional techniques Discussion of Op. 5, Op. 22, Op. 25, Op. 27, Op. 30, Op. 53 / 1, Op. 56; performer's view Comparative analysis of all sonatas, arranged by parameters; many charts and statistics Features of harmony and cadences; refers to Op. 5, Op. 11 / 3, Op. 22, Op. 27, Op. 53 Biography, includes selected analytical aspects, examples from all sonatas but Op. 11 / 1 Performance-based analysis of Op. 38 / 1, many imaginative remarks Thesis examining Medtner's sonata œuvre, many general thoughts, examples from Op. 5, Op. 11 / 3, Op. 22, Op. 27, Op. 30, Op. 39 / 5, Op. 53 / 2

Sonata history in Russia, problems of the genre, sonatas by Glazunov, Rachmaninov, Myaskovsky; discusses Op. 11 / 1, Op. 22, Op. 25 / 2, Op. 27, Op. 30, Op. 38 / 1, Op. 39 / 5 Analytic comment on Op. 22, Op. 25; examples from Op. 27, Op. 38 / 1; notes on Op. 39 / 5 Analysis of Op. 53 / 2; aspects of symmetry in Op. 5, Op. 25 / 2, Op. 27, Op. 30, Op. 39 / 5

ua, ru Extended analysis of Op. 5; thoughts on philosophical background of Op. 11; notes on most other sonatas; comments on hybrid genre and possible programmatic content Aspects of triadity and symmetry, examples from Op. 5, Op. 11, Op. 27, Op. 38 / 1 On polyphony in Medtner; examples from Op. 5, Op. 11 / 1, Op. 27, Op. 53 / 2 On sonata form in Medtner; examples from Op. 5, Op. 11, Op. 25/1; notes on Op. 27 Aspects of shape and analysis of form-building relationships in Op. 38 / 1 Thorough examination of Op. 53 / 1, including detailed motivic analyses Single-movement sonatas of the $19^{\text {th }}$ century and in Russian music of the early $20^{\text {th }}$ century; notes on Op. 11, Op. 22, Op. 30, Op. 38 / 1, Op. 39 / 5, Op. 53 / 2

en On thematic unity in Medtner's piano works; short analyses of Op. 22, Op. 25 / 1 en Analysis of Op. 22, focusing on performance aspects; notes on other Russian piano sonatas ru, de Flexibility of sonata forms; examples from Op. 11, Op. 22, Op. 25/1, Op. 38/1, Op. 53/ 1 en Analysis of main themes, examples from Op. 5, Op. 11, Op. $38 / 1$, Op. 39/5, Op. $53 / 2$ 
Takenouchi 2004 en

Truscott 1961 en

Tumanina 1960 ru

Vasilyev 1962 ru, de

Vasyutinskaya 2014 ru

Westfall 2008 en

Yagodkina 1959 ru

Yeh 2008

Zetel 1981
Thematic interrelation in Op. 11, further analytic aspects in Opp. $25 / 2$ and $53 / 2$ Notes on single-movement forms, narrative analysis of Op. 22 with many examples Chapter on Medtner's piano music, discussing Opp. 22 and 25 / 1, many examples

Compact monograph on the sonatas with brief analytic comments on every work and movement, examples from all sonatas except Op. $11 / 1$

Analyses of Op. 22, Op. 38 / 1, Op. 39 / 5 from performer's perspective, many examples Analysis of Op. 38 / 1 in comparison to Scriabin's Op. 53 and Prokofiev's Op. 28 Extended analysis of Op. 22, comments on Op. 11, Op. 25 / 2, Op. 38 / 1, many examples Master thesis on the analysis and performance of Op. $38 / 1$

ru, de Biography, elaborates on stylistic questions, performance, and teaching; notes on Op. 22, Op. 25, Op. 30, Op. 38 / 1, Op. 53, Op. 56; examples also from Op. 5, Op. 27

\subsubsection{The Sonatas: Genesis, Reception, Reviews, Critics, Aesthetic Comment}

\begin{tabular}{|c|c|c|}
\hline Alekseyev 1982 & $\mathrm{ru}$ & ef discussion of Medtner's piano œuvre; notes on Op. 11 / 2, Op. 22, Op. 27, Op. 38 / 1 \\
\hline Anderson 1994 & en & ecord reviews, with short notes on Opp. 38 / 1 and $39 / 5$ \\
\hline Andreasen 2010 & en, de & Liner notes to Vaulin's recording, short imaginative comment on Opp. 38 / 1 and 56 \\
\hline Asafiev $1930^{\mathrm{a}}$ & ru, de & Notes on Medtner's use of sonata form, very brief comment on Opp. 22 and 25 \\
\hline Balser 1995 & de, en & Liner notes to the author's recording, short biography, comment on Op. 53 / 1 \\
\hline Barban 1980 & en & General discussion of style and reception, examples from Opp. 11 / 1 and 39 / 5 \\
\hline Belsky 1995 & en & Liner notes to Svetlanov's recording, comments on Op. 11, Op. 25 / 1, Op. 38 / 1 \\
\hline Bitzan 2012 & de & Notes on piano sonatas by Russian and Soviet composers, brief analysis of Op. 22 \\
\hline Boyd 1952 & en & Obituary, mentions sonatas Opp. 25 / 2 and 56, example from Op. 22 \\
\hline Boyd $1980^{\mathrm{a}}$ & en & On the use of the Muza motif, examples from Op. 27, does not refer to Op. 44 \\
\hline Chernova 2007 & $\mathrm{ru}$ & Ilyin's term >artistic subject $<$ as applied to Op. 25 / 2; contemporary critiques, examples \\
\hline Clarke 2013 & en & On Paul Stewart's approach to Medtner; comment on Op. 25 / 2, Op. 38 / 1, and Sonatina \\
\hline Craats 2001 & en, de & Liner notes to Madge's recording, descriptive notes on Op. 22, Op. 38 / 1, Op. 39 / 5 \\
\hline Dubal 1989 & en & Encyclopedic article on Medtner, short comments on all sonatas \\
\hline $2003-11$ & de & tival program notes on Op. 25 / 1, Op. 25 / 2, Op. 38 / 1, Op. 39 / 5, Op. 53 / 2 \\
\hline Eckardstein 2007 & de, en & s to the author's recording, brief comment on Opp. 25 / 2 and 39 / 5 \\
\hline Eilerman 1954 & en & Biography, personality, appreciation of style; short analysis of Op. 38 / 1 \\
\hline Feofanov 1981 & en & Introduction to an edition of Russian piano works, short comment on Op. 22 \\
\hline Flamm 1995 & de & Comprehensive catalogue of works, information on genesis of all sonatas, concert list \\
\hline Flamm $1995^{z}$ & de & Reception and renaissance; notes on Op. 25 / 2, Op. 53 / 2, example from Op. 56 \\
\hline 2006 & de & Biography, essay on style, ae \\
\hline 2009 & $\mathrm{u}$ & 5, Op. 11 / 2, Op. 25 / 2, Op. 27, Op. 53 / 2 \\
\hline 2015 & e & Cantability, percussiveness, expansion in Medtner; notes on Op. 25 / 1, Op. 25 / 2, Op. 27 \\
\hline Gerstlé 1924 & en & Examination of early piano works, comment on early sonatas from Op. 5 to Op. 30 \\
\hline Goldenweiser 1923 & ru, de & Contemporary review of Op. $38 / 1$, discussing the work's thematic structure \\
\hline Hackbridge 2011 & en & Liner notes to Kusunoki's recording, description and interpretative history of Op. 22 \\
\hline Hall 1939 & en & Contemporary review of Op. 56 , commenting on the work's delicacy \\
\hline Hamilton 2017 & en & On Russian nationality, comments on many sonatas, details on Op. 5, Op. 39, Op. 53 / 1 \\
\hline Hanselmann 1993 & de & Liner notes to the author's recording, notes on Op. $11 / 3$, Op. $25 / 1$, Op. $38 / 1$, Op. $39 / 5$ \\
\hline Hartnett 2014 & en & Russianness in sonatas; covers Op. 5, Op. 22, Op. 25, Op. 27, Op. 38 / 1, Op. 53, Op. 56 \\
\hline Henr & en & Philosophical thoughts, mentions Op. 5, Op. 11, Op. 27, example from Op. 25 / 2 \\
\hline Holt $1948^{\mathrm{a}}$ & en & Extended essay on Medtner's music, mentions sonatas Op. 22, Op. 27, Op. 39 / 5 \\
\hline Ilyin 1943 & de, ru & Praise of Medtner's vision and literary inspiration; mentions Opp. 25 / 1 and 39 / 5 \\
\hline Ilyin 1951 & en & Overview of artistic preconditions; emotional and picturesque interpretation of Op. 5 \\
\hline Kalendarev 2005 & en & Short notes on most of the sonatas, examples from Op. 22 , Op. 25 / 2, Op. 27 , Op. 38 / 1 \\
\hline Karatygin 1913 & ru, de & Offensive review of a Medtner recital, mentioning Opp. 22 and 25 / 2 \\
\hline Karpeyev 2014 & en & On Edna Iles and interpretative questions, examples from Op. 39 / 5, Op. 53 / 1, Op. 56 \\
\hline Konsistorum 2004 & de & Brief introductory notes to Op. 11 / 2, Op. 25 / 1, Op. 38 / 1 \\
\hline Korobov 1991 & $\mathrm{u}$ & On the interpretation of Sonata Triad Op. 11 in the context of Goethe's lyrics \\
\hline
\end{tabular}


Laberge 1955

Lischke 2009

Lockwood 1940

Lyle Watson 1931

Margulis 2003

Marsrow 2008

Martens 1919

Martyn 1995

Martyn $1998^{\mathrm{b}}$

Mauser 2004

Montagu 1917

Morrison 2010

Nelson $1989^{\mathrm{a}}$

Newman E 1915

Newman W 1969

Niemann 1905

Orga 1993

Pinsonneault 1956

Plaistow 1976

Podporinova 2012

Postovalova 2009

Predvechnova 2017

Pullman 2001

Ramey 1977

Rimm 1999

Rimm 2003 ${ }^{\mathrm{a}}$

Rizzi 2018

Rowen 2015

Rueger 1979

Sacre 1998

Segnitz 1906

Shevchenko 2017

Shevchenko 2018

Skalkina 2009

Sorabji 1932

Stewart 2012

Strikovskaya 2017

Taruskin 1980

Takaku 2003

Takaku 2004

Terlikova 1993

Thiessen 1909

Tozer 1998

Tozer 1999

Vasilyev 1963

Wier 1940

Wolf 1957

Yasser 1955

Yasser 1981

Zhitomirsky 1981 en

fr, en

en

en

de, en

en

en

en

en

de

en

en

en

en

en

de

en, de fr

en

$\mathrm{ru}$

$\mathrm{ru}$

$\mathrm{ru}$

en

en

en

en

en

en

de

fr

de

ru

en

$\mathrm{ru}$

en

en, de

$\mathrm{ru}$

en

en

en, jp

$\mathrm{ru}$

de

en

en, de

$\mathrm{ru}$, en

en

en

en

ru

ru, de
Significance of Medtner's œuvre, associative thoughts on Opp. 11 and 27

Liner notes to Vinnitskaya's recording, introductory notes to Op. 38 / 1

Annotated list of piano works, including comment on Op. 22, Op. 25 / 2, Op. 27, Op. 30

Impressions based on an interview with Medtner, list of piano works, note on Op. 5

Liner notes to the author's recording, associative remarks on Op. 22

Silver Age and Symbolism in music; mentions Op. 5, Op. 11, Op. 25, Op. 27

Short remarks on the first ten sonatas, in particular Op. 11, Op. 25, Op. 27

Discussion of all sonatas, their contexts, and circumstance of genesis; includes autographs

Liner notes to Hamelin's recording, short introductions to all sonatas

Rough summary of sonatas, comment on Op. 27, mentions Opp. 5 and 56

On Brahmsian style and major piano works, comment on Op. 5, Op. 11, Op. 25 / 1

Liner notes to Milne's recording; introductions to all sonatas but Opp. 38 / 1 and 56

Liner notes to Fellegi's recording; notes on Op. 5, Op. 11, Op. 22, Op. 25, Op. 27, Op. 56

Questions of craftsmanship and style, discusses Op. 5, Op. 11, Op. 22, Op. 25 / 2, Op. 27

Overview and table of sonatas, comment on style and variety of forms, short remarks

on Op. 22, Op. 25 / 2, Op. 38 / 1, Op. 39 / 5, Op. 53 / 1, example from Op. 25 / 1

Contemporary review of Op. 5, somewhat contemptuous

Liner notes to Demidenko's recording, short notes on Op. 11 / 2, Op. 38 / 1, Op. 39 / 5

Glorifying biography, including a work list; comment on Op. 11, Op. 22, Op. 25 / 2 ,

Op. 27; examples from Op. 5, Op. 39 / 5; quotes Marcel Dupré on Op. 53

Liner notes to Malcolm Binns' recording of Opp. 27 and 53 /2, short analytic text

On the relationship of Op. 25 / 1 and Aleksandrov's Sonata-Skazka, Op. 90

Medtner's music in context of Losev's philosophy, including a typology of Op. 25 / 1

On the semantics of time and symbolic imagery in Op. 39 / 5

Emotional comment on listening to music, mentions Op. 5, Op. 25, Op. 38 / 1, Op. 56

Liner notes to Gilels's recording; short biography, introduction to Op. 22

Excerpts from a Hamelin interview, notes on Op. 22, examples from Opp. 25 / 2 and 38 / 1

Essay on Medtner and Rachmaninov, many biographical details; mentions Opp. 5 and 56;

remarks on Op. 25 / 2, Op. 38 / 1, Op. 53, Op. 56; quotes Stephen Hough on Op. 22

On narrativity and personal memory in the Forgotten Melodies, Opp. 38, 39, and 40

Music and Russian Symbolism; narrative aspects in Op. 5, Op. 38 / 1, and other works

Short paragraph on biography and works; introduction to Op. 22

Notes on pianistic style; brief guide to all sonatas, particularly Opp. 25 / 2 and 27

Mediocre contemporary review of Op. 5, appreciating the $1^{\text {st }}$ and $3^{\text {rd }}$ movements

Contextualisation of the sonatas in European music at the turn of the $20^{\text {th }}$ century

Discussion of Op. 38 / 1 from a performer's perspective, graphs of performance indications

On thematic development, refers to sonatas Op. 5, Op. 11, Op. 22, Op. 27, Op. 39, Op. 56

Appreciative comment on Op. 22, Op. 25 / 2, Op. 27, Op. 30

Liner notes to the author's recording; extended notes on Op. 5, Op. 38 / 1, and Sonatina

Review of Moscow concerts, notes on Op. 39 / 5, thoughts on >himmlische Längen

Liner notes to Rollé's recording of Op. 53 / 2, comment on genesis and context

Revisionary notes on Op. 38, providing information on sources and genesis

Liner notes to Kawakami's recording of Opp. 11 and 53 /2, short text on both works

On interpretive aspects of the textures of Op. 11, performer's perspective

Contemporary review of Op. $11 / 1$, not particularly enthusiastic

Biographical essay with short but imaginative notes on all sonatas

Biography, differing from 1998; introduction with personal thoughts on all sonatas

Preface to Medtner 1963, discusses his skills as a performer and teacher; mentions Op. 5

Short account of piano music, comment on Op. 11 / 2, Op. 22, Op. 25 / 2, Op. 27, Op. 30

Extensive chapter on Russian piano sonatas; comment on Op. 5, Op. 11, Op. 25 / 2

Overview of Medtner's œuvre, stylistic aspects, examination of skazki and melodic

similarities to folk song; analysis of Op. 14 / 2, example from Op. 22

On melody in skazki and other works, referring to similar examples as Yasser 1955

Aesthetic environment, rejection of modernism; notes on Op. 22, Op. 38 / 1, Op. 56 


\subsubsection{General Issues: Biography, Style, Evaluations, Appreciations, Memories}

\begin{tabular}{|c|c|c|}
\hline Abraham 1955 & en & Biographical notes, overview of major piano works, not focusing on sonatas \\
\hline Aleksandrov 1979 & $\mathrm{ru}$ & Influence on Aleksandrov's works, mentions Op. 11, Beethoven and Schumann \\
\hline Alenskaya 2009 & ru & Tradition and modernism in East and West, Muza i moda as opposed to René Guénon \\
\hline Alexander 1951 & en & Brief notes on Medtner's style, mentions sonatas Op. 5, Op. 11, Op. 25 / 2 \\
\hline Antcliffe 1922 & en & Rachmaninov's view of Medtner as expressed in an interview \\
\hline Austin 1952 & en & Obituary, comments on style of composition, nothing on particular works \\
\hline Bely Andrei 1903 & ru, de & Thoughts on Op. 1 and Medtner's aesthetic thought, philosophical perspective \\
\hline Bely Andrei 1910 & ru, de & Picturesque characterisation of person and œuvre, many quotes \\
\hline Bely Andrei 1933 & ru & Essay on Emil Medtner, many memories, account of Nikolai performing his Op. 5 \\
\hline Bely Pëtr 1977 & $\mathrm{ru}$ & General thoughts on biography and œuvre, mentions Opp. 22 and 25 / 2 \\
\hline Borodin 2015 & de & On the Romantic aesthetics of Soviet pianistic art, with some references to Medtner \\
\hline Braudo 1927 & $\mathrm{ru}$ & Brief essay on the relationship between Medtner and Prokofiev, no details on works \\
\hline Brower 1925 & en & Medtner's aesthetic position, based on an interview with the composer \\
\hline Brower 1926 & en & Biographical article, notes on style, relationship to other modern composers \\
\hline Brown 1943 & en & Short paragraph on artistic individuality, mentions Opp. 22 and 25 / 2 \\
\hline Calvocoressi 1944 & en & Brief comments on style, nothing on particular works, emphasises German descent \\
\hline Catterall 1960 & en & Biographical essay, notes on Concerto Op. 50, mentions Op. 39 / 5 \\
\hline Collingwood 1955 & en, ru & Short discussion of a number of works, mentions Opp. 22 and 25 / 2 \\
\hline Delson 1962 & $\mathrm{ru}$ & Brief retrospective on performers and concerts of Medtner's music \\
\hline Dolinskaya 1981 & $\mathrm{ru}$ & Confrontation of Medtner and Myaskovsky, mentions Op. 11 / 2, Op. 25 / 1, Op. 38 / 1 \\
\hline Drozdov 1927 & ru, de & Stylistic and emotional aspects of Medtner's music, mentions Opp. 5 and 11 / 1 \\
\hline Eberlein 1978 & de & Discussion of aesthetic position, epithet \Russian Brahms`, modernism, Emil Medtner \\
\hline Engel 1911 & ru, de & Notes on Medtner's style and preferred genres, mentions Opp. 22 and 25 / 1 \\
\hline Fedyakin 2009 & $\mathrm{ru}$ & On parallels between music and literature, mentions Opp. 38 / 1 and 39 / 5 \\
\hline Flamm 1995 & de & $\begin{array}{l}\text { Family background, deep insights to artistic and aesthetic sphere; relationship to Emil } \\
\text { Medtner and Andrei Bely; inspiration through literature; summary of Muza i moda }\end{array}$ \\
\hline Flamm $2004^{\mathrm{a}}$ & de & Reception in the USSR, ban and renaissance, notes on Op. 22, influence on Aleksandrov \\
\hline Flamm 2013 & ru & Role of Medtner's emigration, likeliness of stylistic changes; mentions Op. 30, 38, 39 \\
\hline Frank 1958 & en & Comparison of Medtner's and Rachmaninov's styles, nothing on the sonatas \\
\hline Gaditsky 2012 & $\mathrm{ru}$ & Article on Medtner's influences, contemporary perspectives, thoughts from Muza i moda \\
\hline Gilels 1953 & $\mathrm{ru}$ & Appreciation of piano works, comment on Op. 22, mentions Opp. 11 / 2 and 27 \\
\hline Goldenweiser 1975 & $\mathrm{ru}$ & Memorial article, refers to Beethoven's piano sonatas \\
\hline Goldshtein 1973 & $\mathrm{ru}$ & Biographical portrait, notes on education, concert activity, travels, and emigration \\
\hline Großmann 2008 & de & On Medtner's documentation of his practising and his philosophy of piano playing \\
\hline Hirschberg 1931 & de & Essay on biography and style, anti-modernism, no particular comment on works \\
\hline Holt $1948^{\mathrm{b}}$ & en & Liner notes to Medtner Society recordings, notes and examples from Op. 39 / 5 \\
\hline Holt 1951 & en & Obituary, appraisal of the qualities of Medtner's music, no specific comment on music \\
\hline Honeybourne 2001 & en & Article on Edna Iles, attitude towards Medtner, no specific comment on music \\
\hline Iles 1978 & en, ru & Personal memories of Medtner, artistic creed, mentions Op. 27, Op. 39 / 5, Op. 53 \\
\hline Ilyin 1929 & ru, en & Characterisation and appraisal of Medtner's music, thoughts on sonata forms \\
\hline Ilyin 1932 & $\mathrm{ru}$ & On Medtner's stay and recitals in Paris, mentions Op. 25 / 2 \\
\hline Istomin 1998 & en & On the sonatas' history of edition and role in recital programmes, mentions Op. 22 \\
\hline Kalendarev 2005 & en & Aesthetic background, relationship to Russian art, biographical essay \\
\hline Karatygin 1912 & $\mathrm{ru}$ & General article on contemporary Russian composers, comments on Medtner's style \\
\hline Karatygin 1914 & ru, en & Discussion of contemporary Russian music, short passage on Medtner \\
\hline Karatygin 1918 & ru, de & Offensive review of a Medtner recital, detesting his intellectuality \\
\hline Kirnosova 1995 & $\mathrm{ru}$ & On creative thinking and the role of sketches; mentions Op. 5, example from Op. $11 / 3$ \\
\hline Kirnosova 1996 & $\mathrm{ru}$ & Thesis on Medtner's artistic thought and working process; mentions Op. 25 / 2 \\
\hline Kondratiev 2009 & $\mathrm{ru}$ & On Medtner's musical sense; quotes Ilyin, Spengler, Weidlé, and other philosophers \\
\hline Konnov $2001^{\text {a }}$ & $\mathrm{ru}$ & Essay on Nikolai and Emil Medtner's Goetheanism, reference to Steiner and Jung \\
\hline Konsistorum 2004 & de & Biography, artistic views and backgrounds, anecdotes, attitude towards sonata form \\
\hline Kuhn 2008 & de & Medtner's artistic profile and identity, notes on research; includes a work list \\
\hline
\end{tabular}


Leonard 1956

Ljunggren 1994

Lobanova 2005

Lourié 1932

Martyn 1995

Martyn $1998^{a}$

Martyn 2002

McBurney 1993

Medtner Anna 1981 r

Medtner Emil 1912 ru

Miller 1941 en

Milne 1980 en

Milne 2003 en

Mitchell 2015 en

Montagu 1918 en

Morrison 1998 en

Mühlbach 1994 de

Mussky $2003 \quad$ ru

Mutylina $2008 \quad$ ru

Myaskovsky 1913 ru, en

Nayko 1992 ru

Nayko 2012 ru

Neuhaus 1961 ru

Ogdon 1972 en

Orlova 1982 ru

Paperno 1998 en

Pinsonneault 1956 fr

Pomazenkova 2009 ru

Postoutenko 2004 ru

Prokofiev 1913 ru, de

Rakhlenko 2009 ru

Raybould 1955 en

Razgulyayev $2013^{\mathrm{b}} \mathrm{ru}$

Redepenning 2008 de

Riesemann 1912

Riesemann 1925

Sabaneyev 1924

Sabaneyev $1927^{\mathrm{a}}$

Sabaneyev $1927^{\mathrm{b}}$

Sabaneyev 1928

Sabaneyev 1936

Sabaneyev 1955

Sabaneyev 2004

Samin 2001

Scherek 1950

Schwab 2009

Schwarz 1982

Seidle 1995

Shaginyan 1957

Shatskes 1988

Shneyerson 1956

Shtember 1981

Skalkina 2004

Sorabji 1932

$\mathrm{ru}$, en

$\mathrm{ru}$, en

ru, en

ru, en

en

$\mathrm{ru}$

$\mathrm{ru}$

en

ru

de

de

ru, de

ru

ru

ru

ru

en
Short chapter with biographical notes, relationship to Brahms, mentions Op. 53 / 1

Biography of Emil Medtner, many insights to his relationships with Nikolai and Anna

Critical review of Konsistorum 2004, notes on Emil Medtner's anti-Semitism

Medtner's aesthetic position and German heritage, no specific comment on music

Extensive and detailed biography, insights to personal and familial connections

Article on Medtner's image and lack of popularity; mentions Opp. 22 and 25 / 1

Biographical essay, focuses on teaching activity, mentions Opp. 5 and 25 / 2

Short introduction to Medtner's music, influences, and philosophy

Memories, many biographical details, refers to Op. 25 / 2, Op. 27, Op. 53 / 2

Remarks on music and modernism, associating his brother with >German style

Medtner's style and importance as a piano composer, example from Op. 25 / 1

Appreciative biographical essay on the occasion of Medtner's centenary, mentions Op. 25 / 2

On the Medtner renaissance and his philosophical thought, nothing on the sonatas

Portrait of the Medtners' philosophical and metaphysical attitude; example from Op. 38 / 1

Short biographical account, notes on a selection of works, mentions Op. 5

Notes on recordings by Demidenko, Moiseivich, Hamelin et al., mentions Op. 25 / 2

Chapter on Medtner's biography and major works, no reference to sonatas

Biographical article with contemporary critiques, mentions Op. 11, Op. 25 / 2, Op. 53

Opinions of contemporary critics, including Karatygin, Sabaneyev, and Myaskovsky

Appreciation and defence of Medtner, mentions Op. 5, Op. 22, Op. 25 / 2

Thoughts on creativity and the process of composition, notes by Anna Medtner

On Medtner's working process, balance of contemplation and action, nothing on the music

Relationship to Beethoven, Chopin, Rachmaninov, Scriabin, Aleksandrov; mentions Op. 22

Short passage on Medtner with only slight references to sonatas

Biography and influences in Russia and the Soviet Union; mentions Opp. 11 and 25 / 2

Autobiographical notes, encounters with Medtner's music, quoting Emil Gilels on Op. 22

Biographical notes, comment on education and interpretive views; many quotations

On the reception of Medtner in the writings of Ivan Ilyin, nothing on particular works

Essay on national self-perception of Emil and Nikolai Medtner, based on Bely's letters

Appreciative article on Medtner's early works, discusses Op. 11, Op. 22, Op. 25 / 2

Essay on Medtner and Edna Iles, discussing Medtner's annotations to Op. 39 / 5

Appraisal of the qualities of Medtner's music, mentions Opp. 25 / 1 and 30

On Tyutchev's historiosophy and Medtner's concept of >artistic paradise

Aesthetic background, Silver Age, Symbolism in literature; brief passage on Medtner

Short essay on Medtner, no reference to particular works apart from Op. 25 / 2

ru, en Account of Medtner's originality, possible reasons for neglection, selected works

$\mathrm{ru}$, de Notes on the retrospective and delicate style of Medtner's music
Essay discussing Medtner's German heritage, influence of Brahms, nothing on sonatas

Appreciation, notes on musical depth and spiritual attitude, parallels to Reger

Discussions of style and artistic rank, with only brief reference to sonatas

Appreciation, attitude towards modernism, discussion of Medtner's lack of success

Obituary, notes on Medtner's ascetic nature and some features of his music

On Medtner's style and Russianness, relationship to other composers, nothing on music

Thoughts on Medtner as an emigrant, relationship to Rachmaninov, mentions Op. 22

Short essay with remarks on originality, appreciation of Op. $41 / 1$

Short essay on national traits in Medtner's personality, Germanness and Russianness

On artistic life before the Russian revolution, only marginal reference to Medtner

Documentation of a Medtner exhibition; notes on biography and discography, facsimiles

Memories of Rachmaninov and the Medtner family, mentions Opp. 25 / 2 and 27

Acknowledgment of Medtner as a teacher and pianist, mentions recitals with Op. 27

Review of Holt's memorial volume of 1955

Memories of a former student, comment on Medtner's appreciation of his Op. 27

Philosophical background, notes on Muza i moda and on writings by Emil Medtner

Essay on Medtner's style and mastership, notes on a number of compositions 


\begin{tabular}{|c|c|c|}
\hline Sorabji 1955 & en & Thoughts on Medtner's works, appraisal of Op. 25 / 2, mentions Op. 22, Op. 39 / 5, Op. 53 \\
\hline Swan 1922 & en & Introduction to Medtner's works and their qualities, examples from Opp. 11 / 3 and 27 \\
\hline Swan $1927^{\mathrm{a}}$ & en & Notes on style and aspects of musical form and polyphony; mentions Op. 22 \\
\hline Swan $1927^{\mathrm{b}}$ & en & Essay on Russian composers; reference to Medtner's conservativism, mentions Op. 30 \\
\hline Swan 1928 & en & Discussion of Medtner's artistic creed, appeal to the public, traits of some of his works \\
\hline Swan 1944 & en & Memories of Rachmaninov, including many references to Medtner \\
\hline Swan 1967 & de & Biography, focusing on familial relationships and journeys; examples from Opp. 5 and. 27 \\
\hline Swan 1972 & $\mathrm{ru}$ & Memorial article, including many personal memories; mentions Op. 22 \\
\hline Tarasova 2009 & $\mathrm{ru}$ & On the relationship between Medtner and Ivan Ilyin, mentions Opp. 25 / 2 and 38 / 1 \\
\hline Taube 1971 & $\mathrm{pl}$ & On Medtner as a pianist and teacher, account of his recitals, mentions Op. 11 / 2 \\
\hline Tideböhl 1913 & en & Short biographical paragraph, somewhat superficial, nothing on the sonatas \\
\hline Tideböhl 1916 & en & Introduction to Medtner's person and musical style, review of two recitals \\
\hline Truscott 1956 & en & Notes on musical style, differences to Rachmaninov, mentions Op. 22, Op. 25 / 2, Op. 27 \\
\hline Tyulin 1972 & $\mathrm{ru}$ & Memorial essay, includes an example from Op. 5, refers to Op. 22 \\
\hline Vasilyev 1959 & $\mathrm{ru}$ & Preface to Collected Edition; biographical notes, mentions Op. 22, Op. 27, Op. 30, Op. 53 / 2 \\
\hline Vasilyev 1972 & $\mathrm{ru}$ & Memorial article, mentions Beethoven's sonatas and Op. 25 / 2, Op. 30, Op. 53 \\
\hline Vasyutinskaya 2014 & $\mathrm{ru}$ & General issues of biography and style, synopses of Muza i Moda and The Daily Work \\
\hline Yakovlev 1927 & ru, de & Early biographical essay on Medtner, no reference to particular works \\
\hline Yasser 1924 & en & On Medtner's attitude towards modernism and musical form; resemblance to Brahms \\
\hline Zenkin 2003 & ru & Study of Medtner's interaction with contemporary musicians, attitude towards modernism \\
\hline Zetel 1969 & ru & Essay on the role of Medtner's works in the piano repertoire, mentions Gilels and Op. 22 \\
\hline Zhitomirsky 1960 & $\mathrm{ru}$ & Guide to Russian composers, including a short paragraph on Medtner and his music \\
\hline Zuk 2009 & en & Biographical notes, reception of Medtner's music; review of Milne's Skazki recording \\
\hline Zuk 2013 & en & On the correspondence between Myaskovsky and Prokofiev, few mentions of Medtner \\
\hline
\end{tabular}

\subsubsection{ENCYCLOPEDIC TEXTS, WORK LISTS, DisCOGRAPHY, BIBLIOGRAPHY}

\begin{tabular}{|c|c|c|}
\hline Barban 1989 & en & Short biography and bibliography, mentions sonatas Opp. 27 / 2 and 39 / 5 \\
\hline Blom 1954 & en & Grove article with short biography and work list, mentions Op. 11, Op. 25, Op. 27 \\
\hline Bondar 2003 & en & Biography, notes on aesthetic principles, religious beliefs, and activity as a pianist \\
\hline Boyd $1980^{b}$ & en & New Grove article ( $1^{\text {st }}$ edition) with brief work list and bibliography \\
\hline Crocker (no year) & en & Statistics of the keys of Medtner's compositions \\
\hline Ewen 1934 & en & Biographical article, quoting Swan, Sabaneyev and Newman; nothing on sonatas \\
\hline Ewen 1944 & en & Very brief overview of compositions, referring mainly to skazki and songs \\
\hline Ewen 1963 & en & Short biographical text with references to smaller forms, nothing on sonatas \\
\hline Ewen 1968 & en & Biographical aspects and notes on smaller forms, particularly skazki, and Concerto Op. 33 \\
\hline Ewen 1969 & en & Biography, with some references to other authors and incomplete work list \\
\hline Faurot 1974 & en & Very short notes on major solo piano works, appreciations of Opp. 22 and 27 \\
\hline Flamm $2004^{\mathrm{b}}$ & de & $M G G$ article ( $2^{\text {nd }}$ edition) with essay on biography and style, work list, selected bibliography \\
\hline Flamm 2006 & de & Chronological catalogue of works, includes recent bibliography and discography \\
\hline Georgii 1976 & de & Brief evaluation of piano works, comments on Op. 5, Op. 22, Op. 25 / 1, Op. 53 / 2 \\
\hline Gordon 1996 & en & Brief article within a summary of Russian keyboard music, list of sonatas \\
\hline Gurlitt 1961 & de & Short encyclopedic article with work list and selected bibliography \\
\hline Hein 2006 & de & Short but comprehensive article, work list, some notes on sonatas including Op. 5 \\
\hline Hinson 1987 & en & Encyclopedic article, very short notes on all sonatas but Opp. 53 / 2 and 56 \\
\hline Hollfelder 1999 & de & Very short biographical article with work list and selected bibliography \\
\hline Hughes et al. 1978 & en & Comprehensive discography of Medtner's works, notes on Medtner as pianist \\
\hline Kehler 1982 & en & Small selection of Medtner's recital programmes \\
\hline Keldïsh 1976 & $\mathrm{ru}$ & Biographical article, brief discussion of sonatas, mentions Op. 5, Op. 25 / 2, Op. 53 / 2 \\
\hline Lindlar 1960 & de & $M G G$ article ( $1^{\text {st }}$ edition) with short biography and notes on style, incomplete work list \\
\hline Lyle Wilson 1985 & en & Short biography focusing on Medtner as a pianist, sonatas not mentioned \\
\hline Martyn 2001 & en & New Grove article ( $2^{\text {nd }}$ edition) with biography, work list, bibliography; mentions Op. 25 / 2 \\
\hline Moldon 1976 & en & Selected bibliography, including some journal articles; by no means complete \\
\hline
\end{tabular}




$\begin{array}{ll}\text { Montagu 1916 } & \text { en } \\ \text { Niemann 1907 } & \text { de } \\ \text { Rattalino 2012 } & \text { it } \\ \text { Rimm 2003 } & \text { en } \\ \text { Romansky 1983 } & \text { de } \\ \text { Rueger 1998 } & \text { de } \\ \text { Sandelewski 1988 } & \text { it } \\ \text { Sarkett 2014 } & \text { en } \\ \text { Schumann 1952 } & \text { de } \\ \text { Spring 1998 } & \text { en } \\ \text { Teichmüller 1927 } & \text { de } \\ \text { Wolters 1967 } & \text { de }\end{array}$

Very brief paragraph concerning stylistic relationships to other music Contemptuous article on Slavic piano music, mentioning Medtner only randomly Encyclopedic article on major works, notes on Op. 22, Op. 38 / 1, Op. 39 / 5, Op. 53, Op. 56 Review of the Dover editions of Medtner's piano music; notes on Op. 38 / 1

Selected discography and biographical notes; examples from Opp. 38 / 1 and 39 / 5 Biographical article with brief reference to sonatas; list of piano compositions Short account of biography and style, work list, selected bibliography Brief notes on most of the sonatas, not very elaborated, from a listener's perspective Very short article in lofty tone, mentions Op. 5, Op. 22, Op. 25 / 1, Op. 53 / 2 So-far-complete discography of commercial piano recordings Article with few estimating words on Op. 5, Op. $11 / 2$, Op. 22, Op. 25, Op. 30, Op. 53 / 2 Notes on selected piano works, mentions Op. 5, Op. 38 / 1, Op. 39 / 5, Op. 53

\subsubsection{Writings DisCusSing OTHERS OF MEDTNER's OR OTHER COMPOSERS’ WORKS}

Alekseyev 1969 ru

Alekseyev 1974 ru

Arzamanov 1963 ru

Bartels 1995

Biesold 1991

Billings 2014

Bitzan 2014

Bitzan 2017

Bloomquist 1993

Bolshakova 2008

Boyd 1965

Bryantseva 1962

Chan 2008

Chernaya-Oh 2008

Covatta 1965

Delson 1961

Delson 1971

Deppermann 1984

Flamm 1997

Flamm 2002 ${ }^{\mathrm{a}}$

Flamm 2002 ${ }^{\text {b }}$

Flamm 2003

Frolova 1955

Gakkel 1976

Gojowy 1980

Golovinsky 1965

Gulinskaya 1981

Hartmann 1956

Howard 1996

Hull 1915

Hull 1916

Kämper 1987

Kafarova 2003 u

Discussion of sonatas by Tchaikovsky, Glazunov, Rachmaninov, Scriabin, Myaskovsky, Stanchinsky, Prokofiev and others, also including smaller works, many examples

Notes on and examples from sonatas by Myaskovsky, Aleksandrov, Feinberg, and others de On the development of single-movement sonata form in Scriabin's œuvre

de Rachmaninov biography, many references to Medtner, mutual dedication of concertos en On Medtner's Tyutchev songs, unambitious performer's perspective, including translations de Study of vocalises by Rachmaninov, Medtner, and Glière, examining interval smoothness de, en On cyclic form in Taneyev's C minor Symphony, Scriabin's $2^{\text {nd }}$ Symphony, and other works en Thesis on skazki, including a general chapter on Russian piano music en Thesis on Georgy Catoire's music, mentioning Medtner only marginally

en Essay on Medtner's vocal music, mentions Opp. 22 and 41 / 1

ru Analysis of Rachmaninov's $2^{\text {nd }}$ Piano Sonata, Op. 36

en, fr Article on Stewart and Kayaleh performing Medtner's violin sonatas; biographical notes en Thesis on skazki, including a chapter on form and harmony, many references to sonatas en Thesis on skazki and other smaller piano works, mentions Op. 5, Op. 38 / 1, Op. 39 / 5

ru Short study of all of Scriabin's piano sonatas

ru Chapter from a Scriabin monograph, dedicated to his piano music

de Aesthetic environment, Silver Age, Symbolist philosophy and literature; nothing on Medtner

de Article on chamber music, detailed notes on Op. 21, Op. 44, Op. 57, and piano quintet

de On the Medtners' relationship to Goethe; notes on Opp. 6, 15, 18, 46, and vocalises

de, en Liner notes to recordings of Aleksandrov's piano sonatas Opp. 18 and 19

de Liner notes to recordings of Medtner's songs; family background, Goethe and other poets

ru Short study on Tchaikovsky's piano sonatas

ru Essay on piano works by Rachmaninov, including few references to Medtner

de Nuanced examination of Soviet music from the 1920s; notes on sonatas and other works by Myaskovsky, Aleksandrov, Feinberg, Melkikh, Gnesin, Shaporin; short portraits of Roslavets, Lourié, Protopopov, Obukhov, Evseyev, Polovinkin, Lyatoshinsky, Polovinkin, Shaporin, Prokofiev, Shcherbachev, Shebalin, Shostakovich. and others $\mathrm{ru}$ ru, de en en en en de Collection of essays by and memories of Georgy Conus, few references to Medtner Myaskovsky biography, with very few comments on his piano sonatas On Taneyev's biography and work, thoughts on sonata form, personal memories of the author Liner notes to the author's recording of Anton Rubinstein's piano sonatas Short descriptive notes on Scriabin's sonatas, examples from Op. 6, Op. 19, Op. 23, Op. 30 Overview on Scriabin's piano works, notes on and examples from sonatas Opp. 6 and 19 Discussion of sonatas by Rubinstein, Tchaikovsky, and Glazunov, separate chapter on Scriabin with examples from Op. 6, Op. 23, Op. 30, Op. 53, Op. 64, Op. 68, Op. 70 
Kang $2014 \quad$ en

Kim 2006

Kelly 1988 en

Kholopov $1990 \quad$ ru

Konnov 2001 ${ }^{\text {b }}$ ru

Markson 2017 en

Münch 2004 de

Nelson $1989^{\mathrm{b}}$ en

Pevzner 2013 en

Pott 2013 en

Protopopov $1940 \quad \mathrm{ru}$

Protopopov 1947 ru

Protopopov 2010 ru

Roberts 1993 en

Roitershtein 1966 ru

Sabaneyev 1929 en

Sarest 2014 en

Schibli 1983 de

Schiwietz 2009 ru

Shvets 2009 ru

Sitsky 1994 en

Sorokina 1976 ru

Staples 1972 en

Steger 1979 de

Tauscheck 2012 en

Wehrmeyer 2000 de

Weinberg 1958 en

Wodarski 2013 en

Uhl 2017 en

Zassimova 2011 de

Zilberkant 1996 en
Performance guide to Medtner's skazki, Stimmungsbilder, and other character pieces Thesis focusing on skazki, discusses sonata form in Opp. 8 / 2 and 14 / 2

Thesis on Medtner's songs, including thoughts on style, musical form, and sonatas Essay on Prokofiev's piano sonatas, many analytic details, no musical examples Essay on Medtner's songs and settings of Goethe poems, mentions Opp. 11 and $38 / 1$ Study of Medtner's compositional technique, focusing on skazki Diffuse thoughts on Scriabin's sonatas and the concept of single-movement form Liner notes to Hegedüs's recordings of Myaskovsky's piano sonatas Study on Aleksandrov's piano sonatas, including thoughts on Medtner's influence Liner notes to violin sonatas Opp. 21 and 57, thoughts on epithet >Russian Brahms< On thematism, melody, and chromatic scales in the compositions of Taneyev Stylistic questions concerning Taneyev's œuvre, comparisons to Tchaikovsky Study of sonata form in Russian music with chapters on Taneyev, Arensky, Catoire; examples from Balakirev, Tchaikovsky, Glazunov, Rachmaninov, Scriabin, Myaskovsky Discussion of sonatas by Mosolov and Scriabin, no reference to Medtner On tonality and cyclic form in Tchaikovsky's major instrumental works Encyclopedic article on chamber music, notes on Op. 21, Op. 41 / 1, Op. 44, piano quintet Thesis including a metrotechtonic analysis of Concerto, Op. 33; some notes on sonatas Development of the sonata genre in Scriabin, examples from Op. 19, Op. 30, Op. 53 etc. Essay on the use of Heine's lyrics in Medtner, examination of songs Op. 12 On the relevance of Pushkin's poetry in Medtner's songs, no reference to sonatas Several chapters on Russian avant-garde composers such as Rebikov, Stanchinsky, Polovinkin, Lyatoshinsky, Feinberg, Aleksandrov, Krein, Tcherepnin, Sabaneyev et al. Analyses of Rachmaninov's Piano Sonatas, Opp. 28 and 36 On piano quintets of the $20^{\text {th }}$ century, including an analysis of Medtner's C major Quintet Introduction to Scriabin's musical language, analyses of sonatas Op. 23, Op. 53, Op. 70 Thesis discussing aspects of performance of the Skazki Opp. 8 / 2 and 14 / 2 Rachmaninov biography, including some references to Medtner Essay on Taneyev and his teaching methods in counterpoint; includes a short work list Thoughts on descriptive and narrative music, discusses Skazki Opp. 14 / 1 and 35 / 4 On Medtner's vocalise compositions, including an extended analysis of Op. 41 / 1 Catoire biography, including a short chapter on relationship between Catoire and Medtner On Rubinstein's sonatas and the evolution of the genre during the $19^{\text {th }}$ century 


\subsection{INDEX OF NAMES}

Aleksandrov, Anatoly Nikolayevich................ $8,30^{\mathrm{fn}}, 33^{\mathrm{fn}}, 38 \mathrm{f} ., 43,49,83,103^{\mathrm{fn}}, 165,172,178^{\mathrm{fn}}, 180^{\mathrm{fn}}, 200^{\mathrm{fn}}, 208,228$

Arensky, Anton Stepanovich....

Asafiev, Boris Vladimirovich

$8,11,37-40,49,51,63,66 \mathrm{f} ., 131^{\mathrm{fn}}, 137^{\mathrm{fn}}, 139,171^{\mathrm{fn}}, 177$

Bach, Carl Philipp Emanuel. $.53^{\text {fn }}, 54,66 f f ., 78,79^{\mathrm{fn}}, 85^{\mathrm{fn}}, 124,165^{\mathrm{fn}}, 188,244$

Bach, Johann Sebastian

$36,78,120,142^{\text {fn }}, 148,239^{\text {fn }}$

Balakirev, Mily Alekseyevich 19,37 ff., $44,46,50,54,131^{\text {fn }}, 139^{\text {fn }}$

Beethoven, Ludwig van.

8 , 15 f., $16^{\text {fn }}, 18,28 \mathrm{ff}$., 33,35 f., $53^{\text {fn }}, 61,64 f f ., 66 f^{\text {fn }}, 69^{\text {fn }}, 74,77-82,84,87 \mathrm{ff} ., 102$, $111^{\text {fn }}, 121$ ff., 127,136 f., $143^{\text {fn }}, 144,145^{\text {fn }}, 147$ f., $154,157^{\text {fn }}, 160,162^{\text {fn }}, 163-166,171^{\text {fn }}$, $173,177 f^{\text {fn }}, 179,186^{\text {fn }}, 189,198^{\text {fn }}, 209,222$ f., $224 f^{\text {fn }}, 231,232^{\text {fn }}, 246,262^{\text {fn }}, 266$

Bely, Andrei. $17,18^{\text {ff }}, 20^{\text {ff }}, 22$ ff., $118,127,144,159,229,231$

Belyayev, Mitrofan Petrovich $6,12,40,136,139$

Benjamin, Anton J. $.6,160 \mathrm{ff}$.

Berg, Alban $32,83^{\text {fn }}, 193$

Berlioz, Hector 33 f., $53^{\text {fn }}, 88,227$

Blok, Aleksandr Aleksandrovich $22,118,127,195^{\mathrm{fn}}, 228 \mathrm{ff}$.

Blumenfeld, Feliks Mikhailovich $. .30^{\text {fn }}, 38 \mathrm{ff} ., 48,189^{\mathrm{fn}}, 222$

Borodin, Aleksandr Porfiryevich $18,39,50,52,131^{\text {fn }}, 253$

Brahms, Johannes $. .8,15-18,35 f ., 53^{\text {fn }}, 74,78 f$ f. $82,88,102,114,124,136 f$., $140,143^{\text {fn }}, 147,164,166^{\text {fn }}, 171^{\text {fn }}, 178^{\text {fn }}, 185 f^{\text {fn }}, 189^{\text {fn }}$

Bratenshi, Andrei Mikhailovich $75,160,162,172^{\text {fin }}, 177$

Bratenshi, Anna Mikhailovna — see Medtner, Anna Mikhailovna

Bruckner, Anton $36,65^{\text {fn }}$

Bryusov, Valery Yakovlevich. $20^{\text {fn }}, 22,24$

Bugayev, Boris Nikolayevich — see Bely, Andrei

Caplin, William Earl. $62,70,101,134,155^{\text {fn }}$

Catoire, Georgy Lvovich

Chopin, Fryderyk. 38f., 51f., 66f., 75, 83, 85 fn $137,139,162,166^{\mathrm{fn}}, 185,205$ $18^{\mathrm{fn}}, 31,40,47,81 \mathrm{f} ., 92,110,114,116,121^{\mathrm{fn}}, 122,124,137^{\mathrm{fn}}, 143^{\mathrm{fn}}$, $151,180^{\text {fn }}, 186^{\text {fn }}, 192,204,213,221,222^{\text {fn }}, 231,232^{\text {fn }}, 247$ f., 251

Čiurlionis, Mikalojus Konstantinas 22f., 132

Clementi, Muzio $86,163,186^{\mathrm{fn}}, 198^{\mathrm{fn}}$

Conus, Georgy Ėduardovich $38,63^{\text {fn }}, 66 f ., 122^{\text {fn }}, 206$

Conus, Lev Ėduardovich $51,75 f$

Czerny, Carl.

Derzhavina, Ekaterina Vladimirovna $30,57,59 f ., 166^{\mathrm{fn}}, 168^{\mathrm{fn}}$

Dupré, Marcel 6 ., $166,171,178,262^{\text {fn }}$

Dvořák, Antonín 131,288

Eichendorff, Joseph von $86,131^{\mathrm{fn}}, 160,186^{\mathrm{fn}}, 232^{\mathrm{fn}}$

Engel, Yuli Dmitrievich. . 4,20

Fauré, Gabriel $187,213^{\text {fn }}$

Feinberg, Samuil Evgenyevich.

61,247

Fet, Afanasy Afanasievich

Franck, César $8,33^{\text {fn }}, 41$ f., 83,222

Gilels, Emil Grigoryevich

Glazunov, Aleksandr Konstantinovich

Glebov, Igor - see Asafiev, Boris Vladimirovich

Glinka, Mikhail Ivanovich $37,50,186,221,247,260^{\text {fn }}$

Gnesin, Mikhail Fabianovich. $182,247^{\mathrm{fn}}$

Goedicke, Aleksandr Fëdorovich $6,11,17,75 f$., $137,186^{\text {fn }}, 205,207$

Goethe, Johann Wolfgang von. 4, 20, 114f., 120f., 221, 248, 257-265 33 ff., 51,88 f., $137^{\text {fn }}, 148,205,257$ .. $7,185,189$ $8,15 f ., 18^{\text {fn }}, 37-40,42,50,51^{\text {fn }}, 53$ f., $139^{\text {fn }}, 140,209^{\text {fn }}, 232^{\text {fn }}, 247^{\text {fn }}$ Goldenweiser, Aleksandr Borisovich 4, 17, 19f., 49 $9^{\text {fn }}, 76,90 f ., 99 f f ., 109,116 f ., 120 f ., 126$, 129f., $132^{\text {fn }}, 161,162^{\text {fn }}, 171$ f., 178,183 f., $226,258^{\text {fn }}$ Grieg, Edvard...... $6,30^{\mathrm{fn}}, 33^{\mathrm{fn}}, 51,78$ $82,124,186^{\text {fn }}, 209^{\text {fn }}, 232^{\text {fn }}, 247$ 
Hamelin, Marc-André

$.6,136,166,171,178,185,207,220,222,246$

Haydn, Joseph $28,30,36,61,85,122,166^{\mathrm{fn}}, 186^{\mathrm{fn}}, 198^{\mathrm{fn}}, 209,232^{\mathrm{fn}}$

Hegel, Georg Wilhelm Friedrich

184,266

Heine, Heinrich. $20,49^{\mathrm{fn}}, 131^{\mathrm{fn}}$

Hepokoski, James $45^{\mathrm{fn}}, 61^{\mathrm{fn}}, 62,70,134 \mathrm{f} ., 156,164,165^{\mathrm{fn}}, 170^{\mathrm{fn}}, 190 \mathrm{ff}^{\mathrm{fn}}, 204^{\mathrm{fn}}, 210,250^{\mathrm{fn}}, 251$

Iles, Edna $7,28^{\mathrm{fn}}, 185,207,246,254^{\mathrm{fn}}, 258,261^{\mathrm{fn}}$

Ilyin, Ivan Aleksandrovich $24,78 \mathrm{f} ., 79^{\mathrm{fn}}, 136^{\mathrm{fn}}, 140,142^{\mathrm{fn}}, 148^{\mathrm{fn}}, 150,152^{\mathrm{fn}}, 158^{\mathrm{fn}}, 159,220^{\mathrm{fn}}, 221$

Indy, Vincent d' $33 \mathrm{f}, \mathrm{6}, \mathrm{1}, 88,194,232^{\mathrm{fn}}$

Ippolitov-Ivanov, Mikhail Mikhailovich $38,63^{\mathrm{fn}}, 131^{\mathrm{fn}}, 187$

Karatygin, Vyacheslav Gavrilovich 14f., 187f., 221, $222^{\mathrm{fn}}$

Katuar, Georgy Lvovich — see Catoire, Georgy Lvovich

Kholopov, Yuri Nikolayevich. $48^{\mathrm{fn}}, 68,97^{\mathrm{fn}}, 160^{\mathrm{fn}}, 252^{\mathrm{fn}}$

Koch, Heinrich Christoph.... $.28,57 \mathrm{ff}$

Konyus, Georgy Ėduardovich — see Conus, Georgy Ėduardovich

Konyus, Lev Ėduardovich — see Conus, Lev Ėduardovich

Kusevitsky, Sergei Aleksandrovich

$13,187,221$

Lermontov, Mikhail Yuryevich 19f., $93^{\mathrm{fn}}, 99^{\mathrm{fn}}, 120,126,129 \mathrm{ff} ., 132^{\mathrm{fn}}, 230,232,247$

Liszt, Franz

Lyadov, Anatoly Konstantinovich $8,11^{\mathrm{fn}}, 29,31-34,40,45 \mathrm{f} ., 50,52,54 \mathrm{f} ., 61^{\mathrm{fn}}, 67,77 \mathrm{f} ., 84,88,92,97$ $106,138,148,171^{\mathrm{fn}}, 183,185 \mathrm{f}, 193^{\mathrm{fn}}, 200,217^{\mathrm{fn}}, 223,225 \mathrm{f} ., 230$

Lyapunov, Sergei Mikhailovich $18^{\mathrm{fn}}, 19,38,55,139^{\mathrm{fn}}, 247$

Marx, Adolf Bernhard 32 , 38ff., $45 \mathrm{f} ., 84$

Mattheson, Johann $57,60 f ., 63,64 f^{f n}$

Medtner, Aleksandr Karlovich (brother) $27,58,118$

Medtner, Aleksandra Karlovna (mother) 51,205

Medtner, Anna Mikhailovna (wife) 11f., 17,75

Medtner, Emil Karlovich (brother) Medtner, Karl Karlovich (brother). $6,12 \mathrm{f}, 17,75 \mathrm{f} ., 78^{\mathrm{fn}}, 116^{\mathrm{fn}}, 123^{\mathrm{fn}}, 131^{\mathrm{fn}}, 143-146,155$,
$158 \mathrm{f} ., 162,182,184^{\mathrm{fn}}, 187,208^{\mathrm{fn}}, 221^{\mathrm{fn}}, 244,246,254$ Medtner, Karl Petrovich (father). 11f., 16ff., 24, 74, 76, $119^{\mathrm{fn}}, 125,136^{\mathrm{fn}}, 139^{\mathrm{fn}}, 143 \mathrm{f} ., 158 \mathrm{f} ., 178,184,220^{\mathrm{fn}}, 225^{\mathrm{fn}}, 246$ .. 11,17

Mendelssohn Bartholdy, Felix 30f., 34, 36, 50, 122, 124, 160, $171^{\mathrm{fn}}, 186^{\mathrm{fn}}, 198^{\mathrm{fn}}, 232^{\mathrm{fn}}, 236$

Milne, Hamish $7,16^{\mathrm{fn}}, 19,136,166,171,178,185,207,220,222,231,246$

Mozart, Wolfgang Amadé $28,30,36,122,145^{\mathrm{fn}}, 178,186^{\mathrm{fn}}, 192,203^{\mathrm{fn}}, 232^{\mathrm{fn}}$

Mussorgsky, Modest Petrovich. $18,35,39,44,51,97,208^{\mathrm{fn}}, 227 \mathrm{f}$. Myaskovsky, Nikolai Yakovlevich......8, 35, 37ff., 42f., 46, 54, 84, 140, 165, $171^{\mathrm{fn}}, 188,209^{\mathrm{fn}}, 221,225,228,244,247^{\mathrm{fn}}$ Newman, William Stein $28^{\mathrm{fn}}, 32^{\mathrm{fn}}, 37^{\mathrm{fn}}, 43^{\mathrm{fn}}, 46^{\mathrm{fn}}, 50^{\mathrm{fn}}, 62,70,79,83^{\mathrm{fn}}, 140,183^{\mathrm{fn}}, 217^{\mathrm{fn}}$

Nietzsche, Friedrich $18,20 f ., 119^{\mathrm{fn}}$

Prokofiev, Grigory Petrovich. 15,221

Prokofiev, Sergei Sergeyevich $.4,8,33^{\text {fn }}, 38 f$ f., 42, 48f., 55, 74, 80, 83f., $124^{\text {fn }}, 137$, $160^{\mathrm{fn}}, 165,166^{\mathrm{fn}}, 175^{\mathrm{fn}}, 189,201^{\mathrm{fn}}, 211^{\mathrm{fn}}, 221^{\mathrm{fn}}, 225$

Protopopov, Sergei Vladimirovich $33^{\mathrm{fn}}, 42$

Protopopov, Vladimir Vasilyevich $28^{\mathrm{fn}}, 37^{\mathrm{fn}}, 51^{\mathrm{fn}}, 64,65^{\mathrm{fn}}, 68,103^{\mathrm{fn}}, 106,138^{\mathrm{fn}}$, $141,146 f^{\mathrm{fn}}, 165^{\mathrm{fn}}, 176^{\mathrm{fn}}, 185^{\mathrm{fn}}, 210^{\mathrm{fn}}, 253,256^{\mathrm{fn}}$ $60^{\mathrm{fn}}, 61,63,162 \mathrm{f} ., 165^{\mathrm{fn}}$

Prout, Ebenezer. 4, 19f., 46, 94, 101, 113, 119, 127, 129, 131 fn $177,247,257-262,264 f$.

Pushkin, Aleksandr Sergeyevich

Rachmaninov, Sergei Vasilyevich $.5,8,13,16^{\mathrm{fn}}, 31,38-41,47,51,53 \mathrm{f} ., 64^{\mathrm{fn}}, 75 \mathrm{f} ., 92 \mathrm{f} ., 100,103$, $116,119,136,138^{\mathrm{fn}}, 143,152,158,171^{\mathrm{fn}}, 176^{\mathrm{fn}}, 177,186^{\mathrm{fn}}, 189$, $193^{\mathrm{fn}}, 195,202,212^{\mathrm{fn}}, 213 \mathrm{ff} ., 220 \mathrm{f} ., 226,230,232 \mathrm{f}^{\mathrm{fn}}, 258 \mathrm{f}$.

Reger, Max $18,35,70^{\mathrm{fn}}, 88,106,160$

Reicha, Anton $57-60,70$

Rheinberger, Josef Gabriel $29,34,79 \mathrm{f}$.

Riemann, Hugo $60 \mathrm{f} ., 63 \mathrm{f} ., 66,162^{\mathrm{fn}}, 252^{\mathrm{fn}}$
$4,63,97,124,139^{\mathrm{fn}}, 232^{\mathrm{fn}}$

Rimsky-Korsakov, Nikolai Andreyevich. Rosen, Charles $27^{\mathrm{fn}}, 56,59,62,69^{\mathrm{fn}}, 70$ 
Rubinstein, Anton Grigoryevich. $8,37,39,50 f ., 131^{\mathrm{fn}}, 148$

Rubinstein, Nikolai Grigoryevich 37,64

Sabaneyev, Leonid Leonidovich. $14,24,78,222,244$

Saint-Saëns, Camille $31,34 f ., 61,88$

Schenker, Heinrich $61 \mathrm{f} ., 69^{\mathrm{fn}}, 135,142 \mathrm{f}$.

Schoenberg, Arnold $13^{\mathrm{fn}}, 32,35,60 \mathrm{ff} ., 65^{\mathrm{fn}}, 70^{\mathrm{fn}}, 101,102^{\mathrm{fn}}, 134,155,193$

Schubert, Franz

Schumann, Robert. $.29 \mathrm{ff} ., 33,35,69^{\mathrm{fn}}, 74,81,88,114,122,148,164,166^{\mathrm{fn}}, 171^{\mathrm{fn}}, 178^{\mathrm{fn}}, 192,203^{\mathrm{fn}}$ $8,15,18,30 f ., 34 \mathrm{ff} ., 50,53^{\mathrm{fn}}, 74,82,86,88,102,124^{\mathrm{fn}}, 136 \mathrm{ff}$., $140,143 \mathrm{ff} ., 147^{\mathrm{fn}}, 159 \mathrm{f} ., 164,178,186^{\mathrm{fn}}, 189,226,236,255,266$

Scriabin, Aleksandr Nikolayevich $4,8-11,23 \mathrm{f} ., 30^{\mathrm{fn}}, 31,33^{\mathrm{fn}}, 35,37-41,43,45,47,49,52 \mathrm{f}^{\mathrm{fn}}, 64^{\mathrm{fn}}, 67$, $74,77^{\mathrm{fn}}, 83,92,97,100,103,117,119,127,132,137 \mathrm{f} ., 148^{\mathrm{fn}}, 165 \mathrm{f}^{\mathrm{fn}}$, $172,180^{\mathrm{fn}}, 185^{\mathrm{fn}}, 188,195,208 \mathrm{f}^{\mathrm{fn}}, 225-228,244,246,257,258^{\mathrm{fn}}$

Shaginyan, Marietta Sergeyevna $125^{\mathrm{fn}}, 220^{\mathrm{fn}}, 259^{\mathrm{fn}}$

Shakespeare, William 31, 129, 230

Shostakovich, Dmitry Dmitrievich $43,137,142^{\mathrm{fn}}, 193^{\mathrm{fn}}$

Shtember, Nikolai Viktorovich.... 28,253

Sorabji, Kaikhosru Shapurji. $188,220^{\mathrm{fn}}, 222,244,247$

Sposobin, Igor Vladimirovich. 67, 189

Stanchinsky, Aleksei Vladimirovich $8,37 \mathrm{ff} ., 41,47$

Swan, Alfred Julius $3,5,12 \mathrm{f}^{\mathrm{fn}}, 47^{\mathrm{fn}}, 71^{\mathrm{fn}}, 78^{\mathrm{fn}}, 81,95^{\mathrm{fn}}, 123^{\mathrm{fn}}, 131^{\mathrm{fn}}, 136^{\mathrm{fn}}, 143^{\mathrm{fn}}$, 158f., $181^{\mathrm{fn}}, 184^{\mathrm{fn}}, 188^{\mathrm{fn}}, 221^{\mathrm{fn}}, 248,256^{\mathrm{fn}}, 257 \mathrm{ff} ., 262,266^{\mathrm{fn}}, 267$

Szymanowski, Karol. $32,36,51,106,225$

Taneyev, Sergei Ivanovich ......8, 11, 15f., 37-41, 49f., 52f., 64-67, 78, 103f., $124^{\mathrm{fn}}, 136,138 \mathrm{f} ., 164,168^{\mathrm{fn}}, 185^{\mathrm{fn}}, 206^{\mathrm{fn}}, 209^{\mathrm{fn}}$ Tchaikovsky, Pëtr Ilyich $8,10,19,21,29,31,35,37 \mathrm{ff} ., 43,45,50 \mathrm{ff} ., 53^{\mathrm{fn}}, 63,82^{\mathrm{fn}}, 97,131^{\mathrm{fn}}, 137^{\mathrm{fn}}, 139$, $144,156,158,164,176^{\mathrm{fn}}, 177,186^{\mathrm{fn}}, 189 \mathrm{f} ., 196^{\mathrm{fn}}, 209^{\mathrm{fn}}, 215^{\mathrm{fn}}, 232^{\mathrm{fn}}, 241,249$

Tozer, Geoffrey $6,7^{\mathrm{fn}}, 103^{\mathrm{fn}}, 136,140,166,171,178,184^{\mathrm{fn}}, 185,194,207,209^{\mathrm{fn}}, 215^{\mathrm{fn}}, 218,220,222 \mathrm{f} ., 232^{\mathrm{fn}}, 246$ Tyulin, Yuri Nikolayevich $140,141 \mathrm{f}^{\mathrm{fn}}, 150^{\mathrm{fn}}$

Tyutchev, Fëdor Ivanovich ............... 4, 19f., 75, 101, 115, 117, 119ff., 127, 129, 220f., 225ff., 229ff., 232 ${ }^{\mathrm{fn}}$, 234, 244, 262 Vasilyev, Panteleymon Ivanovich $5,28,78^{\mathrm{fn}}, 84,108^{\mathrm{fn}}, 116^{\mathrm{fn}}, 142^{\mathrm{fn}}, 147^{\mathrm{fn}}, 175^{\mathrm{fn}}, 193,194^{\mathrm{fn}}$, 197f. ${ }^{\mathrm{fn}}, 201^{\mathrm{fn}}, 203^{\mathrm{fn}}, 213,215^{\mathrm{fn}}, 219^{\mathrm{fn}}, 227,242^{\mathrm{fn}}, 244^{\mathrm{fn}}, 256 \mathrm{f}^{\mathrm{fn}}$

Wadiyar, Jaya Chamaraja ..... $, 13,76,222$

Wagner, Richard 17f., 34, 91, 119, 148, 192, 205

Yasser, Iosif Samuilovich.... $15^{\mathrm{fn}}, 19,93^{\mathrm{fn}}, 196$

Yavorsky, Boleslav Leopoldovich. $66,97^{\mathrm{fn}}, 252^{\mathrm{fn}}$

Ysaÿe, Eugène $32,225,247^{\mathrm{fn}}$

Yurgenson, Pëtr Ivanovich $.6,13,139,161,166,171,174,178$ 


\subsection{INDEX OF MEDTNER's COMPOSITIONS}

Op. 1

Op. $1^{\text {bis }}$

Op. 2

Op. 3

Op. 4

Op. 5

Op. 6

Op. 7

Op. 8

Op. 9

Op. 10

Op. 11

Op. 12

Op. 13

Op. 14

Op. 15

Op. 16

Op. 17

Op. 18

Op. 19 (a)

Op. 20

Op. 21

Op. 22

Op. 23

Op. 24

Op. $25 / 1$

Op. 25 / 2 Piano Sonata in E minor

Op. 26

Op. 27

Op. 28

Op. 29

Op. 30

Op. 31

Op. 32

Op. 33

Op. 34

Op. 35

Op. 36

Op. 37

Op. 38

Op. 39

Four Skazki for piano

Sonata-Ballade in $\mathrm{F} \#$ major for piano

Seven Poems (Fet, Bryusov, Tyutchev)

Seven Poems (Pushkin)

Piano Sonata in A minor

Three Pieces for piano.

Six Poems (Pushkin)

Piano Concerto in $\mathrm{C}$ minor.

Four Skazki for piano

Four Skazki for piano

Six Poems (Pushkin)

Five Poems (Tyutchev, Fet)

Forgotten Melodies for piano, $1^{\text {st }}$ cycle

$4,6,31^{\text {fn }}, 48,51,55,62,67,75,77 f .83 f f ., 87,94 f, 97,99,101,110$

$116,127,133,164 \mathrm{f} ., 169,175^{\text {fn }}, 185-207,219,227^{\text {fn }}, 233,245$

94, 122f., 209

20, 114f., 120f., 207, 221

$7,9,71,75,77 f ., 87,89^{\text {fn }}, 92,94,96,108,114$,

$121,125 \mathrm{f} ., 133,171^{\mathrm{fn}}, 207-221,232,256,267$ 4, 20, 75, 77f., 83, 89, 91 ${ }^{\text {fn }}, 93$ f., 97, 99, 101, 103, 105,

108, 111f., 116, 119, 127, 133, 158, 187, 207, 220-245, 247

$6,101 \mathrm{f} ., 123,125,206^{\mathrm{fn}}, 208$

7, 9, 20, 75, 77f., 87, 89, 94, 96ff., 100f., 106, 108, 111,

121, 125f., 133, 158, $171^{\text {fn }}, 193,221$ f., 246-265, 267

..19f., $120 \mathrm{f} ., 259^{\mathrm{fn}}$

$.20,94,177^{\mathrm{fn}}, 247,257-260,264$

$.6^{\mathrm{fn}}, 7,13,54,75,77$ f., 83 f., $87,96 \mathrm{f} ., 118,127,160^{\mathrm{fn}}$ $47,96,101,123,125,131,253^{\text {fn }}$ 19 f., $116,127^{\text {fn }}$

$53,75,77 f ., 84 f ., 89,101,103 f f ., 121,201,206^{\text {fn }}, 209,244^{\text {fn }}$ $.85^{\text {fn }}, 96 \mathrm{ff} ., 101,102^{\text {fn }}, 123,125,129,132,175,230$

$104,116,123,125,129,208,230$

$20,93,119$ $20,93,120,230 f$.

4, 6f., 9, 35, 71, 75, 77f., 83, 89, 91, 96, 100f., 109, 123, 127f., 145, 255 ff, 267 ...4, 7, 9, 71, 75, 77f., 83, 86f., 89f., 93ff., $97^{\text {fn }}, 106,121,127$ f., 209, 226 $18^{\text {fn }}, 71,92^{\text {fn }}, 123$

Op. $40 \quad$ Forgotten Melodies for piano, $3^{\text {rd }}$ cycle

Op. 41 / 1 Sonata-Vocalise in C major

Op. 41 / 2 Suite-Vocalise in F minor.
.. 4, 9, 20, 76f., 83, 90, 93, 95, 101, 106, 109,119, 178, $198^{\text {fn }}, 246^{\text {fn }}, 248^{\text {fn }}$ $20,74,76,90^{\mathrm{fn}}, 93,130,132^{\mathrm{fn}}$ 
Op. 42

Op. 43

Op. 44

Op. 45

Op. 46

Op. 47

Op. 48

Op. 49

Op. 50

Op. 51

Op. 52

Op. $53 / 1$

Op. $53 / 2$

Op. 54

Op. 55

Op. 56

Op. 57

Op. 58

Op. 59

Op. $59^{\text {bis }}$

Op. 60

Op. 61

WoO 1

WoO 2

WoO 3

WoO 5
Three Skazki for piano.

$18,19^{\mathrm{fn}}, 20 \mathrm{f} ., 96,104,125,129,208 \mathrm{f}$.

Two Canzonas with Dances for violin and piano.

Violin Sonata in G major

Four Songs (Pushkin, Tyutchev) $91,123,129 \mathrm{f}$.

Seven Songs (Goethe, Eichendorff, Chamisso) 19, 76f., 90, 93, 101, 131, 207 fn $247,262,264$

Improvisation in $\mathrm{F} \#$ minor for piano $20,121,177^{\mathrm{fn}}, 261 \mathrm{f}$.

Two Skazki for piano

Three Hymns in Praise of Toil for piano

$20,90^{\mathrm{fn}}$

Piano Concerto in $\mathrm{C}$ minor

Six Skazki for piano

Seven Songs (Pushkin).

Sonata romantica in $\mathrm{B} b$ minor for piano

Grozovaya Sonata in F minor for piano

Eight Romantic Sketches for the Youth for piano

Theme and Variations in $\mathrm{C} \#$ minor for piano

Sonata-Idyll in G major for piano

Sonata epica in E minor for violin and piano

Two Pieces for two pianos.

Two Elegies for piano

Polden' (Tyutchev)

Piano Concerto (Ballade) in E minor

19, 76ff., 96, 97 fn $, 109,112$

$7,9,44^{\mathrm{fn}}, 71,76 \mathrm{f} ., 87,89,127 \mathrm{f} ., 137,145^{\mathrm{fn}}, 219$

.. 4, 7, 9, 76f., 81, 83, 86f., 95, 106f., 118, 121, 127, 231

$.15^{\mathrm{fn}}, 101,117,119,122,125,129 \mathrm{ff} ., 208,211$ $15^{\mathrm{fn}}, 101,131$

. 6f., 9, $15^{\mathrm{fn}}, 76 \mathrm{ff} ., 89^{\mathrm{fn}}, 90,104,125-128,171^{\mathrm{fn}}, 206,246^{\mathrm{fn}}$

...9, 76f., 93, 98, 100, 107, 111, 114, 119, 127, 136 ${ }^{\mathrm{fn}}, 232,244$

$19,107,130$

$85,91,117 \mathrm{f} ., 120^{\mathrm{fn}}, 121,125,177,264$

101,117

Seven Posthumous Songs (Eichendorff, Pushkin, Lermontov, Tyutchev) $20,93,101,117,129^{\mathrm{fn}}$

Two Cadenzas to Beethoven's $4^{\text {th }}$ Piano Concerto 82

Etude in $\mathrm{C}$ minor for piano 122

Skazka in D minor for piano 116,125

Piano Quintet in C major $4,24,31,74-77,93,96,101,107,111,119,178,247,257^{\mathrm{fn}}, 262-265$ 


\subsection{INDEX OF FiguRES AND MUSICAL EXAMPLES}

Figure 0.1

Figure 0.2

Figure 0.3

Figure 1.1

Figure 1.15

Figure 1.16

Figure 2.5.1

Figure 3.0.1

Figure 3.0.2

Figure 3.2.1

Figure 3.2.2

Figure 3.2.3

Figure 3.3.2

Figure 3.3.13

Figure 3.4.8

Figure 3.5.1

Figure 3.6.0

Figure 3.6.19

Table 1

Table 2

Example 1.2

Example 1.3

Example 1.4

Example 1.5

Example 1.6

Example 1.7

Example 1.8

Example 1.9

Example 1.10

Example 1.11

Example 1.12

Example 1.13

Example 1.14

Example 2.1.1

Example 2.1.2

Example 2.1.3

Example 2.1.4

Example 2.1.5

Example 2.1.6

Example 2.2.1

Example 2.2.2

Example 2.2.3

Example 2.2.4

Example 2.2.5

Example 2.2.6

Example 2.2.7

Example 2.2.8

Example 2.2.9
Medtner, Sonata, Op. 5, first edition (Belyayev 1904), pp. 1-2 12

Bely, Simfoniya 2-ya, dramaticheskaya (Second >Dramatic Symphony), beginning of $1^{\text {st }}$ part ............23

Čiurlionis, Žvaigždžiu sonata (Stellar Sonata), Allegro and Andante ............................................... 23

Medtner's recording of Beethoven's Sonata, Op. 57 (RCA Victor 1930) ........................................ 29

Reicha's scheme of sonata form (grande coupe binaire) ................................................................ 58

Taneyev's scheme of the development section, according to Arzamanov...................................... 65

Intersections of the sonata and skazka genres in Medtner ........................................................... 126

Schematic graphs of the period and sentence theme structure .................................................... 134

Hepokoski and Darcy, generic layout of sonata form .......................................................... 135

Medtner, Sonata, Op. 11 No. 1, layout of tonal regions ............................................................. 170

Medtner, Sonata-Elegy, Op. 11 No. 2, layout of tonal regions ................................................... 170

Medtner, Sonata, Op. 11 No. 3, layout of tonal regions ........................................................ 170

Medtner, Sonata, Op. 22, layout of tonal regions .......................................................................... 191

Medtner, Sonata, Op. 22, numeric metrotechtonic graph ........................................................... 206

Medtner, Sonata-Skazka, Op. 25 No. 1, mirror scheme of theme entries after Moskalets.............. 219

Medtner, Sonata, Op. 25 No. 2, structural graph with arch-like and elliptic shapes....................... 224

Medtner, Sonata-Ballade, Op. 27, $1^{\text {st }}$ mvt, mirror scheme of theme entries after Podporinova.......... 249

Intertextual relations between Medtner's Op. 27, Op. 29 No. 1, Op. 44, and Piano Quintet ........... 264

Comparison of sonata terminology in writings of European authors........................................... 57

Classification of fundamental progressions of fifths 113

Beethoven, Piano Sonata, Op. 13, $1^{\text {st }}$ mvt, mm. 52-56 // $3^{\text {rd }}$ mvt, mm. 1-2 ….............................. 35

Brahms, Piano Sonata, Op. 2, $2^{\text {nd }}$ mvt, mm. 1-5 // $3^{\text {rd }}$ mvt, mm. 1-2 .............................................. 36

Glazunov, $1^{\text {st }}$ Piano Sonata, Op. 74, $1^{\text {st }}$ mvt, mm. 7-10 //

Rachmaninov, $2^{\text {nd }}$ Piano Sonata, Op. 36, $1^{\text {st }}$ mvt, mm. 1-3 ….................................................... 40

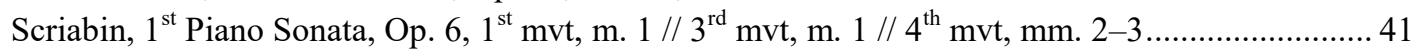

Myaskovsky, $2^{\text {nd }}$ Piano Sonata, Op. 13, mm. 23-26//

Feinberg, $1^{\text {st }}$ Piano Sonata, Op. 1, mm. 1-4 ............................................................................... 42

Balakirev, Piano Sonata, 1905 version, $1^{\text {st }}$ mvt, mm. 1-12 ..................................................... 44

Lyapunov, Piano Sonata, Op. 27, mm. 1-4 // mm. 52-55 // mm. 360-365 .................................. 46

Myaskovsky, $1^{\text {st }}$ Piano Sonata, Op. 6, $1^{\text {st }} \mathrm{mvt}$, mm. 1-5 // $4^{\text {th }} \mathrm{mvt}$, mm. 219-222 ........................ 46

Prokofiev, $3^{\text {rd }}$ Piano Sonata, Op. 28, mm. 58-61 // mm. 199-202 .................................................. 49

Tchaikovsky, Piano Trio, Op. 50, $2^{\text {nd }} \mathrm{mvt}$, mm. 1-6// $10^{\text {th }}$ var, mm. 1-4// final var, mm. 2-5 ...... 52

Catoire, $2^{\text {nd }}$ Violin Sonata, Op. 20, mm. 8-11 / mm. 302-304 // mm. 327-330 .............................. 52

Taneyev, Symphony, Op. 12, $1^{\text {st }} \mathrm{mvt}$, mm. 57-69 // $4^{\text {th }}$ mvt, mm. 299-304 .................................. 53

Rimsky-Korsakov, Piano Concerto, Op. 30, mm. 1-2 // mm. 6-9 // mm. 150-154 ........................ 54

Medtner, Skazka, Op. 8 No. 2, mm. 58-59 // mm. 140-142 .......................................................... 85

Medtner, Sonata tragica, Op. 39 No. 5, mm. 1-5 // mm. 53-59 .................................................... 86

Medtner, Grozovaya Sonata, Op. 53 No. 2, mm. 1-4 // mm. 54-55 .............................................. 86

Medtner, $1^{\text {st }}$ Piano Concerto, Op. 33, mm. 4-9 // mm. 262-269 ....................................................... 89

Medtner, Canzona matinata, Op. 39 No. 4, mm. 37-40 ................................................................. 90

Medtner, Elegy, Op. 59 No. 1, mm. 1-3 // Elegy, Op. 59 No. 2, mm. 1-3...................................... 91

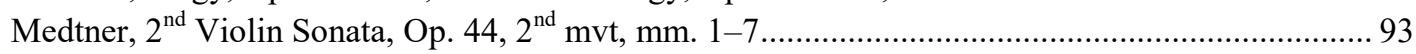

Medtner, Grozovaya Sonata, Op. 53 No. 2, exposition, mm. 67-69 ............................................. 95

Medtner, Sonata-Reminiscenza, Op. 38 No. 1, exposition, mm. 17-23 ........................................ 96

Medtner, Piano Quintet, Op. posth., $1^{\text {st }}$ mvt, mm. 13-22 ............................................................ 96

Medtner, Skazka, Op. 34 No. 1, final section, mm. 149-156......................................................... 96

Medtner, Sonata-Ballade, Op. 27, $1^{\text {st }}$ mvt, development, mm. 126-128....................................... 97

Medtner, Skazka, Op. 34 No. 1, introduction, mm. 1-7................................................................. 98

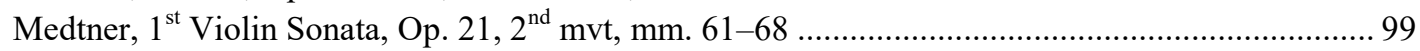

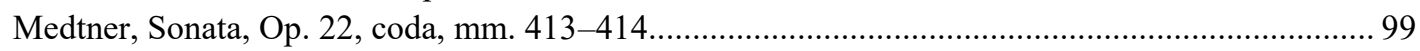


Example 2.2.10

Example 2.2.11

Example 2.2.12

Example 2.3.1

Example 2.3.2

Example 2.3.3

Example 2.3.4

Example 2.3.5

Example 2.4.1

Example 2.4.2

Example 2.4.3

Example 2.4.4

Example 2.4.5

Example 2.4.6

Example 2.4.7

Example 2.4.8

Example 2.4.9

Example 2.4.10

Example 2.4.11

Example 2.4.12

Example 2.5.2

Example 2.5.3

Example 2.5.4

Example 2.5.5

Example 2.5.6

Example 3.1.1

Example 3.1.2

Example 3.1.3

Example 3.1.4

Example 3.1.5

Example 3.1.6

Example 3.1.7

Example 3.1.8

Example 3.1.9

Example 3.1.10

Example 3.1.11

Example 3.1.12

Example 3.2.11

Example 3.2.12

Example 3.2.13

Example 3.2.14

Example 3.2.20

Example 3.2.21

Example 3.2.22

Example 3.2.23

Example 3.2.24

Example 3.2.25

Example 3.2.31

Example 3.2.32

Example 3.2.33

Example 3.2.34
Medtner, Meeresstille, Op. 15 No. 7, mm. 1-2. 100

Medtner, Danza silvestra, Op. 38 No. 7, mm. 113-116 ................................................................ 100

Medtner, Skazka, Op. 26 No. 3, mm. 1-16 .................................................................................... 102

Medtner, Piano Concerto, Op. 33, $1^{\text {st }}$ subdivision, mm. 157-159 ................................................. 104

Medtner, Piano Concerto, Op. 33, $3^{\text {rd }}$ subdivision, mm. 533-538 ….......................................... 105

Medtner, Sonata, Op. 25 No. 2, $2^{\text {nd }}$ subdivision, mm. 311-318 ….............................................. 105

Medtner, Grozovaya Sonata, Op. 53 No. 2, development, mm. 210-215 …................................... 107

Medtner, Skazka, Op. 14 No. 2, mm. 105-108 ….......................................................................... 108

Medtner, Skazka, Op. 20 No. 2, mm. 1-4 …............................................................................... 110

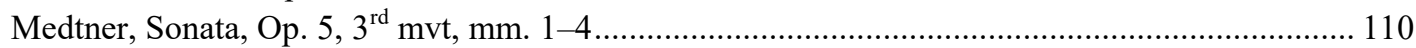

Medtner, Sonata, Op. 25 No. 2, $2^{\text {nd }}$ subdivision, mm. 604-607 .................................................... 112

Medtner, Piano Concerto, Op. 60, $1^{\text {st }}$ subdivision, mm. 170-185 .................................................. 112

Medtner, Sonata-Skazka, Op. 25 No. 1, $2^{\text {nd }}$ movement, mm. 47-51 …........................................... 114

Medtner, Skazka, Op. 9 No. 2, mm. 85-90 .............................................................................. 115

Medtner, Sumerki, Op. 24 No. 4, mm. 29-33 ............................................................................. 115

Medtner, Wandrers Nachtlied I, Op. 15 No. 1, mm. 17-19..................................................... 117

Medtner, Skazka, Op. 51 No. 5, mm. 124-128 ................................................................... 117

Medtner, Elegy, Op. 59 No. 1, mm. 107-108 // Elegy, Op. 59 No. 2, mm. 107-108................... 118

Medtner, Sonata, Op. 30, mm. 609-610// Grozovaya Sonata, Op. 53 No. 2, mm. 446-447......... 118

Medtner, Den i noch', Op. 24 No. 1, mm. 59-68 // Bessonnitsa, Op. 37 No. 1, mm. 61-64 „........ 120

Medtner, Idyll, Op. 7 No. 1, mm. 1-2 // Sonata, Op. 56, $1^{\text {st }}$ movement, mm. 9-12 ….................. 127

Medtner, Romanza, Op. 39 No. 2, mm. 42-46 // Sonata, Op. 53 No. 1, $1^{\text {st }} \mathrm{mvt}$, mm. 1-2 ............... 128

Medtner, Canzonas with Dances, Op. 43 No. 2, mm. 5-8 // Skazka, Op. 48 No. 1, mm. 1-4........ 130

Medtner, Hymn Before Work, Op. 49 No. 1, mm. 5-6 // Prelude, Op. 54 No. 7, mm. 5-6 ............ 131

Medtner, Rusalka, Op. 2 No. 1, mm. 13-14 // Improvisation, Op. 47, mm. 1-2 .......................... 132

Medtner, Sonata, Op. 5, table of motives..................................................................................... 142

Medtner, Sonata, Op. 5, $1^{\text {st }}$ mvt, mm. 35-38,

confronted with themes by Clara Wieck, Robert Schumann, and Ludwig van Beethoven ............ 144

Medtner, Sonata, Op. 5, $1^{\text {st }}$ mvt, development, mm. 85-90 ................................................... 146

Medtner, Sonata, Op. 5, $1^{\text {st }}$ mvt, coda, mm. 199-206.......................................................... 147

Medtner, Sonata, Op. 5, $2^{\text {nd }}$ mvt, beginning, mm. 1-8 …........................................................... 149

Medtner, Sonata, Op. 5, $2^{\text {nd }}$ mvt, mm. 95-97 // mm. 128-129 .................................................... 150

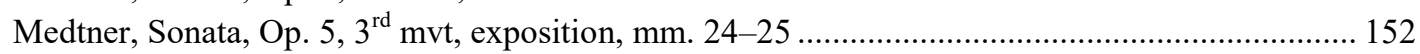

Medtner, Sonata, Op. 5, $3^{\text {rd }}$ mvt, exposition, mm. 30-33 .......................................................... 152

Medtner, Sonata, Op. 5, $3^{\text {rd }}$ mvt, recapitulation, mm. 56-57 ...................................................... 153

Medtner, Sonata, Op. 5, $4^{\text {th }}$ mvt, exposition, mm. 33-40 ............................................................ 155

Medtner, Sonata, Op. 5, $4^{\text {th }}$ mvt, development, mm. 149-154 …................................................ 155

Medtner, Sonata, Op. 5, $4^{\text {th }}$ mvt, recapitulation, mm. 279-287 …............................................... 157

Medtner, Sonata, Op. 11 No. 1, exposition, mm. 1-4 ................................................................ 168

Medtner, Sonata, Op. 11 No. 1, exposition, mm. 37-40 ............................................................. 169

Medtner, Sonata, Op. 11 No. 1, recapitulation, mm. 187-190 …............................................... 169

Medtner, Sonata, Op. 11 No. 1, exposition: mm. 48-49 // development: mm. 107-108............... 169

Medtner, Sonata-Elegy, Op. 11 No. 2, exposition, mm. 1-2, confronted with other works:

Medtner, An die Türen will ich schleichen, Op. 15 No. 2, mm. 1-3 //

Scriabin, Fantasy, Op. 28, mm. 1-4 // Aleksandrov, Piano Sonata, Op. 12, mm. 1-4 .................. 172

Medtner, Sonata-Elegy, Op. 11 No. 2, exposition, mm. 1-4 ........................................................ 174

Medtner, Sonata-Elegy, Op. 11 No. 2, exposition, mm. 25-28 ..................................................... 174

Medtner, Sonata-Elegy, Op. 11 No. 2, recapitulation, mm. 51-53 ............................................... 175

Medtner, Sonata-Elegy, Op. 11 No. 2, recapitulation, mm. 71-74 ................................................ 176

Medtner, Sonata-Elegy, Op. 11 No. 2, development, m. 41 // coda, mm. 79-80 .......................... 177

Medtner, Sonata, Op. 11 No. 3, exposition, mm. 1-8 …................................................................ 180

Medtner, Sonata, Op. 11 No. 3, exposition, mm. 32-36................................................................ 181

Medtner, Sonata, Op. 11 No. 3, recapitulation, mm. 158-162 ….................................................... 181

Medtner, Sonata, Op. 11 No. 3, development, mm. 91-95 …........................................................ 182 
Example 3.3.1

Example 3.3.3

Example 3.3.4

Example 3.3.5

Example 3.3.6

Example 3.3.7

Example 3.3.8

Example 3.3.9

Example 3.3.10

Example 3.3.11

Example 3.3.12

Example 3.4.1

Example 3.4.2

Example 3.4.3

Example 3.4.4

Example 3.4.5

Example 3.4.6

Example 3.4.7

Example 3.5.2

Example 3.5.3

Example 3.5.4

Example 3.5.5

Example 3.5.6

Example 3.5.7

Example 3.5.8

Example 3.5.9

Example 3.5.10

Example 3.5.11

Example 3.5.12

Example 3.5.13

Example 3.5.14

Example 3.6.1

Example 3.6.2

Example 3.6.3

Example 3.6.4

Example 3.6.5

Example 3.6.6

Example 3.6.7

Example 3.6.8

Example 3.6.9

Example 3.6.10

Example 3.6.11

Example 3.6.12

Example 3.6.13

Example 3.6.14

Example 3.6.15

Example 3.6.16

Example 3.6.17

Example 3.6.18

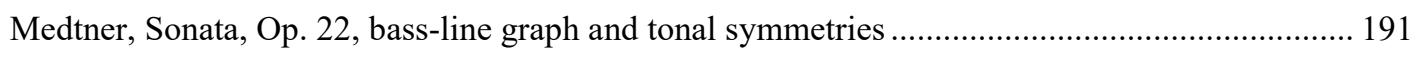

Medtner, Sonata, Op. 22, exposition, mm. 1-8 ............................................................................. 196

Medtner, Sonata, Op. 22, exposition, mm. 13-31 ........................................................................ 197

Medtner, Sonata, Op. 22, exposition, mm. 9-11// mm. 37-38 // mm. 46-47 // mm. 60-63.......... 197

Medtner, Sonata, Op. 22, exposition, mm. 95-98 …..................................................................... 199

Medtner, Sonata, Op. 22, recapitulation, mm. 328-331 ............................................................. 199

Medtner, Sonata, Op. 22, exposition, mm. 131-133 ................................................................... 200

Medtner, Sonata, Op. 22, Interludium, mm. 197-198 // mm. 201-202 .......................................... 202

Medtner, Sonata, Op. 22, recapitulation, mm. 262-266 …........................................................... 203

Medtner, Sonata, Op. 22, coda, mm. 405-408 ............................................................................ 204

Medtner, Sonata, Op. 22, Interludium, mm. 245-248 // coda, mm. 403-404............................... 205

Medtner, Sonata-Skazka, Op. 25 No. 1, $1^{\text {st }}$ mvt, $1^{\text {st }}$ exposition, mm. 1-4 ...................................... 211

Medtner, Sonata-Skazka, Op. 25 No. 1, $1^{\text {st }}$ mvt, $1^{\text {st }}$ exposition, mm. 9-11//

Medtner, Vögleins Märchen, Op. 54 No. 2, mm. 1-4 ................................................................ 211

Medtner, Sonata-Skazka, Op. 25 No. 1, $1^{\text {st }}$ mvt, $1^{\text {st }}$ exposition, mm. 45-46................................ 212

Medtner, Sonata-Skazka, Op. 25 No. 1, $2^{\text {nd }}$ mvt, mm. 1-4 //

Rachmaninov, Paganini Rhapsody, Op. 43, $18^{\text {th }}$ variation, mm. 3-6 .......................................... 214

Medtner, Sonata-Skazka, Op. 25 No. 1, $3^{\text {rd }}$ mvt, mm. 1-6 .......................................................... 216

Medtner, Sonata-Skazka, Op. 25 No. 1, $3^{\text {rd }}$ mvt, mm. 25-28 ....................................................... 216

Medtner, Sonata-Skazka, Op. 25 No. 1, $3^{\text {rd }}$ mvt, mm. 46-47 // mm. 50-51 ................................ 218

Mussorgsky, Pictures at an Exhibition: Samuel Goldenberg and Schmuyle, mm. 28-29 //

Scriabin, Sonata, Op. 6, $4^{\text {th }}$ mvt, m. $71 / /$ Medtner, Sonata, Op. 25 No. $2,1^{\text {st }}$ subdivision, m. 1 .... 228

Aleksandrov, Sonata-Skazka, Op. 4, mm. 1-5 // Medtner, Skazka, Op. 8 No. 2, mm. 5-8 ........... 228

Medtner, Sonata, Op. 25 No. 2, $1^{\text {st }}$ subdivision, mm. 2-5 .......................................................... 234

Medtner, Sonata, Op. 25 No. 2, $1^{\text {st }}$ subdivision, exposition, mm. 40-42 ..................................... 235

Medtner, Sonata, Op. 25 No. 2, $1^{\text {st }}$ subdivision, exposition, mm. 80-84 ................................... 235

Medtner, Sonata, Op. 25 No. 2, $1^{\text {st }}$ subdivision, recapitulation, mm. 181-182 …...................... 236

Medtner, Sonata, Op. 25 No. 2, $1^{\text {st }}$ subdivision, mm. 241-242 …................................................. 238

Medtner, Sonata, Op. 25 No. 2, $2^{\text {nd }}$ subdivision, mm. 270-274 .................................................. 239

Medtner, Sonata, Op. 25 No. 2, $2^{\text {nd }}$ subdivision, exposition, mm. 285-290 ................................ 240

Medtner, Sonata, Op. 25 No. 2, $2^{\text {nd }}$ subdivision, mm. 325-326 // mm. 332-333// mm. 434-435.. 241

Medtner, Sonata, Op. 25 No. 2, $2^{\text {nd }}$ subdivision, mm. 561-564 .................................................... 242

Medtner, Sonata, Op. 25 No. 2, $2^{\text {nd }}$ subdivision, mm. 577-582 …................................................ 243

Medtner, Sonata, Op. 25 No. 2, $2^{\text {nd }}$ subdivision, mm. 631-633 .................................................... 243

Medtner, Sonata-Ballade, Op. 27, $1^{\text {st }}$ mvt, exposition, mm. 19-20............................................. 250

Medtner, Sonata-Ballade, Op. 27, $1^{\text {st }}$ mvt, exposition, mm. 35-36 // m. 44................................ 250

Medtner, Sonata-Ballade, Op. 27, $1^{\text {st }}$ mvt, recapitulation, mm. 150-153...................................... 251

Medtner, Sonata-Ballade, Op. 27, $1^{\text {st }}$ mvt, m. 231 // Chopin, Barcarolle, Op. 60, m. 93 ............... 251

Medtner, Sonata-Ballade, Op. 27, $1^{\text {st }}$ mvt, mm. 293-297 // $2^{\text {nd }}$ mvt, mm. 1-2 ............................ 252

Medtner, Sonata-Ballade, Op. 27, $2^{\text {nd }}$ mvt, m. 37-38 ................................................................. 254

Medtner, Sonata-Ballade, Op. 27, $2^{\text {nd }}$ mvt, mm. 44-49 …........................................................... 254

Medtner, Sonata-Ballade, Op. 27, $3^{\text {rd }}$ mvt, exposition, mm. 48-51 ............................................... 255

Medtner, Sonata-Ballade, Op. 27, $3^{\text {rd }}$ mvt, recapitulation, mm. 314-318 ….................................. 255

Medtner, Sonata-Ballade, Op. 27, $3^{\text {rd }}$ mvt, development, mm. 130-137

Medtner, Sonata-Ballade, Op. 27, $3^{\text {rd }}$ mvt, codetta, mm. 353-356

Medtner, Sonata-Ballade, Op. 27, Fet sketch after Flamm ............................................................ 260

Medtner, Muza, Op. 29 No. 1, mm. 11-14 ..................................................................................... 260

Medtner, Elegy, Op. 45 No. 1, mm. 42-44 .................................................................................. 261

Medtner, $2^{\text {nd }}$ Violin Sonata, Op. 44, $1^{\text {st }}$ mvt, exposition, mm. 16-19 ............................................. 261

Medtner, Piano Quintet, Op. posth., $1^{\text {st }}$ mvt, mm. 71-74 .............................................................. 262

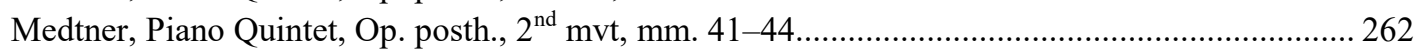

Medtner, Piano Quintet, Op. posth., $2^{\text {nd }}$ mvt, mm. 68-72.......................................................... 263 


\begin{abstract}
The sonata output of Nikolai Karlovich Medtner (1880-1951), spanning eighteen compositions, can be regarded as essential within the composer's œuvre. Like his contemporaries Aleksandr Scriabin and Sergei Prokofiev, Medtner dealt with sonata form lifelong and, along with them, cast the genre from the 19th into the 20th century. However, his compositions never received as much attention as those of his famous compatriots so far. Medtner's piano works, although more frequently considered by performers in the past two decades, have been lacking a thorough appreciation in the domains of musicology and musical analysis. Instead, Medtner has been repeatedly referred to as a restorer of the formal paradigms of Classicism, and as a conservative figure in times of ongoing stylistic changes, especially on the field of sonata form. This point of view may prevent us from approving of Medtner's most flexible and innovative way of handling this traditional genre.

While composing largely autodidactical, Medtner attained a series of individual strategies in employing sonata form. Incorporating in his music a remarkable variety of outlines and conceptions of musical form, he turned to single-movement sonata form quite early in his career (in the Sonata Triad, Op. 11). Later, he would explore other creative solutions rather independent from the Classical model - that is, to implement sonata movements in cycles of character pieces (Forgotten Melodies, Opp. 38 and 39), to develop formal hybrids ranging between one-piece and multi-sectional layouts (Op. 22, Op. 53 No. 2), and to extend singlemovement sonata form to an integrative unit of symphonic dimensions (Op. 25 No. 2). Besides his fourteen piano sonatas, Medtner created three violin sonatas, a Sonate-Vocalise for voice and piano, and a piano quintet, as well as three piano concertos. Many of these concisely-built works, proving the composer's command of formal and contrapuntal refinement throughout, bear a descriptive attribute or subtitle. This feature allows for a possible perception of Medtner's music as Symbolist art, enriched with poetic, metaphysical, or spiritual aspects which point beyond the music.

This dissertation approaches Medtner's early piano sonatas in the context of genre history, confronts them with other composers' works, and discusses them from various analytic perspectives. A special goal is to consider the pieces in the aesthetic environment of their time, and to regard them as peculiar instances of the ssonata principle<, an ageless conception of musical form. The study is subdivided in three large parts, the first of which presents a summary of sonata composition before Medtner, working out stylistic features and lines of tradition among Western European and Russian composers as well as the genre's reflection in music theory and scholarship of the $19^{\text {th }}$ and $20^{\text {th }}$ centuries. The second part concentrates on Medtner's musical language and its characteristic features. Separate chapters are dedicated to his application of sonata form, to melody, rhythm, counterpoint, and harmony. Finally, the third and most comprehensive part provides detailed examinations of eight of Medtner's piano sonatas, including aspects of their genesis and reception, and employing recent methods of musical analysis.
\end{abstract}

